UNIVERSIDADE DE SÃO PAULO

ESCOLA DE ENGENHARIA DE SÃO CARLOS

DEPARTAMENTO DE ENGENHARIA DE ESTRUTURAS

YURY OURIQUES RODRIGUES

ANÁLISE NUMÉRICA E EXPERIMENTAL DO COMPORTAMENTO DA INTERFACE AÇO-CONCRETO DE LAJES MISTAS 



\section{ANÁLISE NUMÉRICA E EXPERIMENTAL DO COMPORTAMENTO DA INTERFACE AÇO-CONCRETO DE LAJES MISTAS}

\section{VERSÃO CORRIGIDA}

A versão original encontra-se na Escola de Engenharia de São Carlos

Dissertação apresentada ao Programa de PósGraduação em Engenharia Civil (Engenharia de Estruturas) da Escola de Engenharia de São Carlos da Universidade de São Paulo para obtenção do título de Mestre em Ciências.

Área de Concentração: Estruturas

Orientadora: Profa. Dra. Ana Lúcia Homce de Cresce El Debs. 


\section{AUTORIZO A REPRODUCÃO TOTAL OU PARCIAL DESTE TRABALHO, POR QUALQUER MEIO CONVENCIONAL OU ELETRÔNICO, PARA FINS DE ESTUDO E PESQUISA, DESDE QUE CITADA A FONTE.}

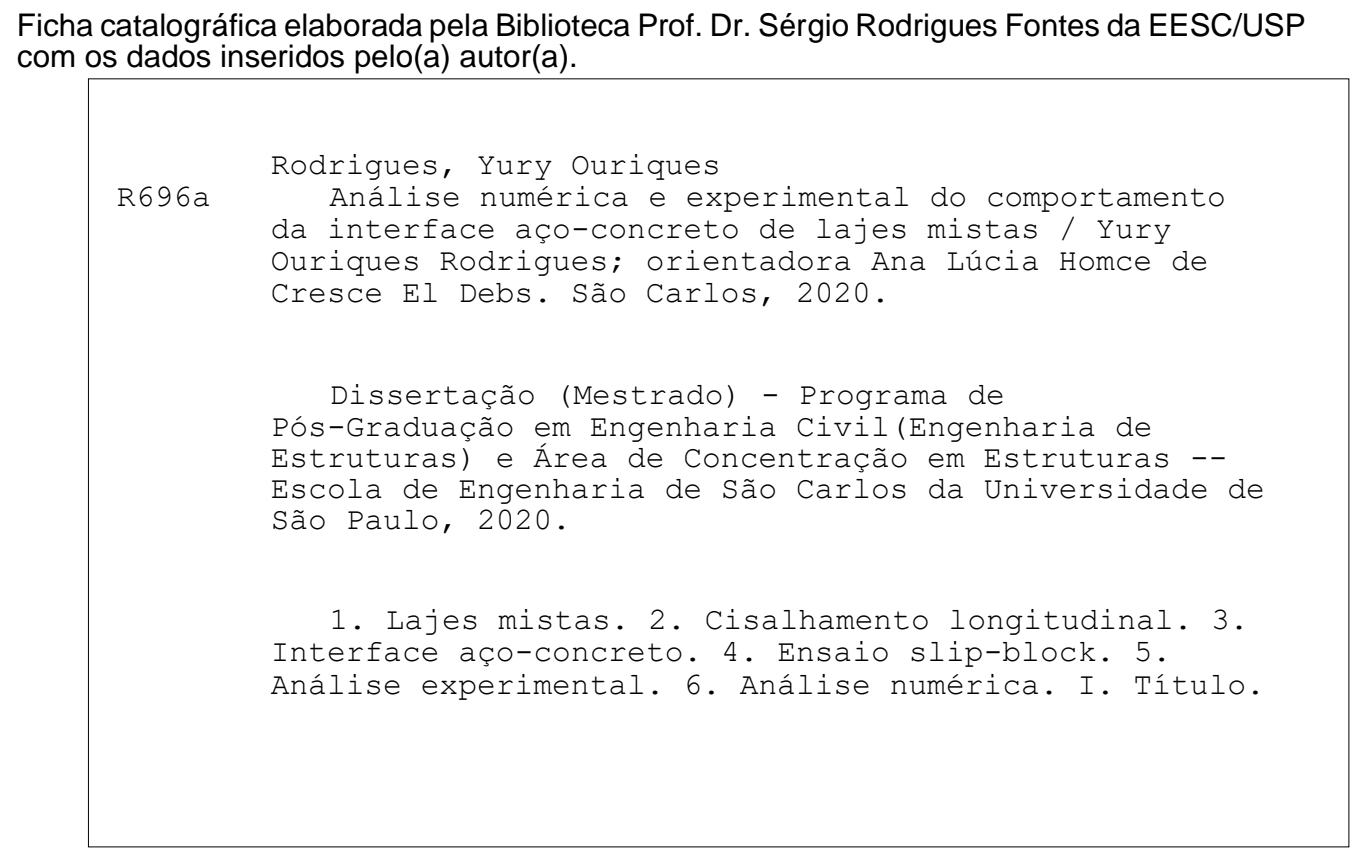




\section{FOLHA DE JULGAMENTO}

Candidato: Bacharel YURY OURIQUES RODRIGUES.

Título da dissertação: "Análise numérica e experimental do comportamento da interface aço-concreto de lajes mistas".

Data da defesa: $24 / 03 / 2020$

Comissão Julgadora

Resultado

Prof. Associado Ricardo Carrazedo

A PROVADO

(Orientador Designado)

(Escola de Engenharia de São Carlos - EESC/USP)

Profa. Dra. Silvana De Nardin

APROVADO

(Universidade Federal de São Carlos/UFSCar)

Prof. Dr. Pedro Colmar Gonçalves da Silva Vellasco

APROVADO

(Universidade do Estado do Rio de Janeiro/UERJ)

Coordenador do Programa de Pós-Graduação em Engenharia Civil

(Engenharia de Estruturas):

Prof. Associado Vladimir Guilherme Haach

Presidente da Comissão de Pós-Graduação:

Prof. Titular Murilo Araujo Romero 



\section{AGRADECIMENTOS}

À Deus, primeiramente, pelo dom da vida, por todo amor, pelas oportunidades me conferidas e por ser sempre meu guia.

Aos meus pais, Luis Rodrigues e Isa Ouriques, pelo amor, apoio e instruções, fundamentais para definição dos meus valores e construção do meu caráter. Obrigado por todo esforço, incentivo e presença, mesmo à distância.

Aos meus irmãos, Ytalo e Ygor, pelo incentivo, conselhos, carinho e parceria no desenvolvimento dos meus sonhos.

À minha orientadora, profa. Dra. Ana Lúcia H. C. El Debs, pelas instruções, apoio e prontidão. Sou grato por toda ajuda e pela orientação técnica-científica e pessoal.

Aos professores e funcionários do Departamento de Engenharia de Estruturas (SET) da EESC-USP, que de maneira direta ou indireta contribuíram no desenvolvimento deste trabalho.

Agradeço especialmente aos professores Dr. Maximiliano Malite e Dr. Vladimir G. Haach, pelo apoio e contribuições no exame de qualificação e durante a pesquisa, assim como à profa. Dra. Marcela N. Kataoka pela atenção. Sou grato ao prof. Dr. Rogério P. Ribeiro pelo apoio para a realização dos ensaios no Laboratório de Mecânica das Rochas.

Aos técnicos do Laboratório de Estruturas (Departamento de Engenharia de Estruturas), do Laboratório de Mecânica das Rochas (Departamento de Geotecnia), do Laboratório de Propriedades Mecânicas (Departamento de Engenharia de Materiais) e da Oficina Mecânica da EESC-USP, pelo apoio, instruções e ajuda na preparação e realização dos ensaios experimentais.

Aos colegas e amigos pelo carinho, apoio e ajuda ao longo dessa fase de minha vida.

À MODULAR Sistema Construtivo pela doação das fôrmas de aço das lajes mistas.

Ao apoio da Coordenação de Aperfeiçoamento de Pessoal de Nível Superior (CAPES) - Código de Financiamento 001.

À Escola de Engenharia de São Carlos da Universidade de São Paulo (EESC-USP), prezada instituição que promoveu minha formação acadêmica. 

O valor de uma ideia está no uso que se faz dela.

Thomas Edison 



\section{RESUMO}

RODRIGUES, Y. O. Análise numérica e experimental do comportamento da interface açoconcreto de lajes mistas. 2020. 280p. Dissertação (Mestrado em Ciências - Engenharia Civil (Engenharia de Estruturas)) - Escola de Engenharia de São Carlos, Universidade de São Paulo, São Carlos, 2020.

Dentre os possíveis modos de ruptura de lajes mistas, a falha por cisalhamento longitudinal da interface aço-concreto é o mais dominante. Para cada tipo de fôrma de aço os métodos normativos requerem a avaliação experimental da capacidade resistente ao cisalhamento longitudinal por meio de uma série de ensaios de protótipos em escala real. Esse procedimento torna onerosa e demorada a caracterização de lajes mistas, além de não permitirem a análise específica de todas as variáveis envolvidas. Diante disso, o presente trabalho consiste em um estudo numérico e experimental da interface aço-concreto de uma laje mista, com ênfase na aplicação do ensaio de modelos de pequenas dimensões denominado slip-block. A análise experimental contemplou a realização de quatro ensaios slip-block e de dois ensaios flexão de lajes mistas em escala real. Desenvolveu-se uma nova metodologia para caracterização qualitativa e quantitativa da interface, que empregou o ensaio slip-block e permitiu correlacionar seu comportamento de acordo com a configuração da fôrma de aço. Além disso, foi possível correlacionar os resultados fornecidos por essa metodologia com os obtidos por meio do ensaio de flexão. A análise numérica utilizou o pacote computacional DIANA ${ }^{\circledR}$ e consistiu na simulação dos dois tipos de ensaios realizados, em que o modelo da interface açoconcreto foi configurado utilizando os parâmetros experimentais provenientes da metodologia proposta. No caso do modelo numérico do ensaio slip-block, o emprego direto desses parâmetros resultou em um modelo representativo com excelente precisão. Uma estratégia para simulação do ensaio de flexão da laje mista foi desenvolvida para aplicar esses parâmetros de modo a contemplar os efeitos da flexão e da assimetria longitudinal da fôrma de aço utilizada, que resultou em um modelo numérico consistente e representativo. A análise paramétrica realizada sobre a espessura da capa de concreto, a espessura da fôrma de aço, o comprimento efetivo da laje mista e a resistência ao escoamento do aço permitiu verificar como cada uma dessas variáveis influencia o comportamento estrutural da laje. Concluiu-se que a metodologia desenvolvida para caracterização da interface aço-concreto de lajes mistas é consistente, possui baixo custo, pode ser utilizada para o desenvolvimento de fôrmas de aço e, aliada à estratégia de simulação numérica proposta, permite um indicativo do comportamento de lajes mistas.

Palavras-chave: Lajes mistas. Cisalhamento longitudinal. Interface aço-concreto. Ensaio slipblock. Análise experimental. Análise numérica. 



\begin{abstract}
RODRIGUES, Y. O. Numerical and experimental analysis of the steel-concrete interface behavior of composite slabs. 2020. 280p. Dissertation (M. Sc. in Civil Engineering (Structural Engineering)) - São Carlos School of Engineering, University of São Paulo, São Carlos, 2020.

The longitudinal shear failure in the steel-concrete interface is the most common type of rupture in the composite slabs. The experimental assessment of the longitudinal shear resistance involves normative proceedings for each type of steel sheeting that require a series of full-scale tests. It makes the composite slabs characterization costly and time-consuming. In addition, to do not allow the specific analysis of all the variables involved. In this context, the present work consists of numerical and experimental study of the steel-concrete interface of a composite slab, with an emphasis on the application of the small-scale test called slip-block. The experimental analysis included the performance of four slip-block tests and two full-scale bending tests of composite slabs. A new methodology was developed for qualitative and quantitative characterization of the interface. The slip-block test allowed correlating its behaviour according to the geometry of the steel sheeting. Such methodology also provided the correlation of the results with those obtained in the full-scale bending tests. The numerical analysis of the two experimental tests was performed with the DIANA ${ }^{\circledR}$ computational package. The configuration of the parameters related to the steel-concrete interface were resulted from the experimental tests. In the numerical model of a slip-block test such procedure resulted in an adequate representative model with satisfactory accuracy. A strategy was developed for simulating the full-scale bedding test of the composite slab to apply these parameters to contemplate the effects of bending and the longitudinal asymmetry of the steel sheeting. The results of the numerical model were consistent and representative. The parametric analysis carried out taken into account the variation of the thickness of the concrete and the steel sheeting, besides the effective length of the composite slab and the steel yield stress. Such parametric study allowed verifying the influences of each parameter in the structural behaviour of the slab. Finally, it was concluded that the methodology developed to characterize the steel-concrete interface of composite slabs is consistent and has a low cost. Therefore, it can be used in the development stage of steel sheeting. In addition, this new methodology aligned with the proposed numerical simulation strategy provides an adequate knowledgement of the behaviour of the composite steel-concrete slabs.
\end{abstract}

Keywords: Composite slabs. Longitudinal shear. Steel-concrete interface. Slip-block test. Experimental analysis. Numerical analysis. 



\section{LISTA DE FIGURAS}

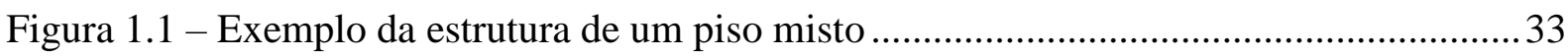

Figura 1.2 - Diferença entre vigas de aço e concreto com ação mista e sem ação mista..........34

Figura 1.3 - Tipologias de lajes mistas de aço e concreto ..................................................... 35

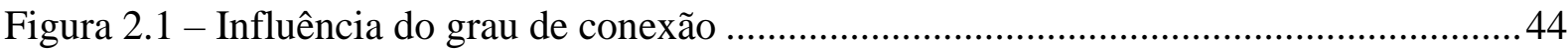

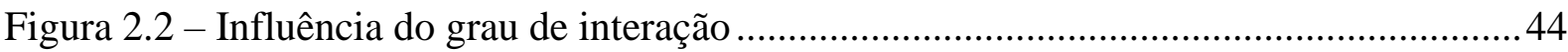

Figura 2.3 - Distribuição das deformações de acordo com o tipo de interação ........................ 44

Figura 2.4 - Sistemas de conexão de cisalhamento em lajes mistas ...................................... 47

Figura 2.5 - Forma genérica de nervura considerada por Burnet e Oehlers (2001)................51

Figura 2.6 - Distribuição das forças de travamento na laje mista de acordo com o tipo de

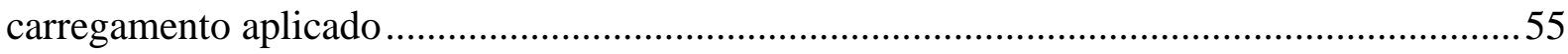

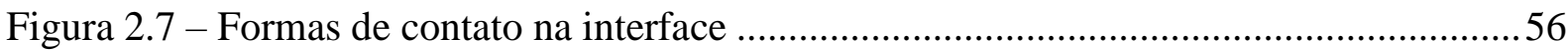

Figura 2.8 - Forças de contato na superfície das mossas .......................................................57

Figura 2.9 - Configuração da seção transversal da laje mista com fôrma de perfil reentrante 57 Figura 2.10 - Seções transversais das lajes ensaiadas por Waldmann, May e Thapa (2017) ..58 Figura 2.11 - Configuração da seção transversal da laje mista com fôrma de perfil trapezoidal

Figura 2.12 - Desempenho da fôrma de aço de perfil trapezoidal em uma laje mista submetida ao ensaio de flexão de quatro pontos

Figura 2.13 - Influência da geometria das mossas sobre a separação vertical.........................60

Figura 2.14 - Esquema do mecanismo de resistência ao deslizamento longitudinal ...............61

Figura 2.15 - Deslizamento longitudinal correspondente à carga máxima $(d)$........................62

Figura 3.1 - Esquema de ensaio de flexão a quatro pontos para lajes mistas .........................65

Figura 3.2 - Modos de ruptura em lajes mistas submetidas ao ensaio de flexão ......................67

Figura 3.3 - Curvas experimentais da carga normalizada versus deslocamento vertical no meio do vão para lajes que falharam à flexão e ao cisalhamento longitudinal 69

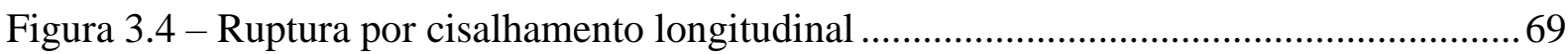

Figura 3.5 - Características do "segundo estágio do comportamento ......................................72

Figura 3.6 - Ondulações nas ondas altas da fôrma de aço no "estágio final de comportamento" . .73

Figura 3.7 - Gráfico típico da Força $(F)$ versus Flecha $(\delta)$ para lajes mistas.......................... 75

Figura 4.1 - Esquema do ensaio push-out proposto por Schuster (1970) ............................... 78

Figura 4.2 - Esquema do ensaio pull-out proposto por Plooksawasdi (1977) ........................ 78 
Figura 4.3 - Esquema de ensaio push-out proposto por Skart (1978) .................................. 79

Figura 4.4 - Esquema de ensaio push-out proposto por Jolly e Zubair (1978) ....................... 80

Figura 4.5 - Esquema do ensaio pull-out proposto por Daniels (1988) ................................. 81

Figura 4.6 - Gráfico da tensão de cisalhamento versus o deslizamento para o ensaio pull-out

Figura 4.7 - Esquema do ensaio push-off proposto por Daniels, O'Leary e Crisinel (1990).. 83

Figura 4.8 - Esquema de ensaio slip-block proposto por Patrick e Poh (1990) ...................... 85

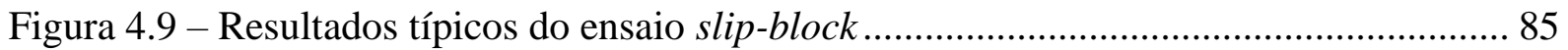

Figura 4.10 - Ensaio de deslizamento proposto por Holomek, Bajer e Vilda (2016) ............. 88

Figura 4.11 - Ensaio de deslizamento realizado por Yi et al. (2018) .................................... 89

Figura 4.12 - Gráfico típico da força resistente ao cisalhamento versus deslizamento do ensaio slip-block sob força vertical nula ou constante realizado por Yi et al. (2018)........................ 90

Figura 4.13 - Esquema de ensaio push-out proposto por Airumyan et al. (1990)................... 91

Figura 4.14 - Esquema de ensaio proposto por An (1993) .................................................. 92

Figura 4.15 - Esquema de ensaio proposto por Veljkovic (1996) ........................................ 93

Figura 4.16 - Esquema de ensaio push-out proposto por Burnet (1998)............................... 94

Figura 4.17 - Esquema de ensaio push-out proposto por Tremblay et al. (2002) .................. 95

Figura 4.18 - Esquema do ensaio de flexão elementar proposto por Abdullah (2004) ........... 96

Figura 4.19 - Gráfico da tensão de cisalhamento longitudinal versus deslizamento para os

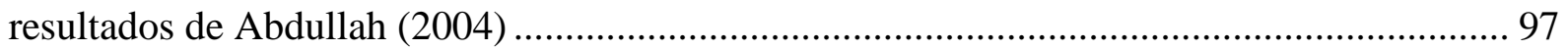

Figura 4.20 - Esquema do ensaio push-out proposto por Fontes (2016)............................... 98

Figura 4.21 - Efeito da fixação da fôrma de aço em lajes mistas com fôrma trapezoidal..... 100

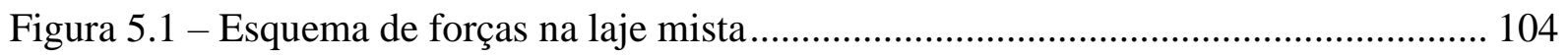

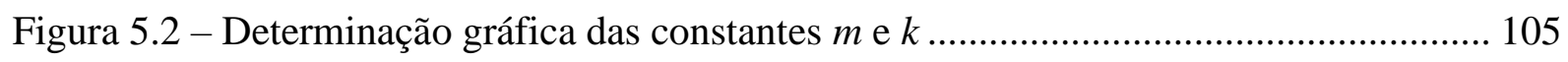

Figura 5.3 - Linha de regressão linear e linha reduzida de regressão linear ......................... 106

Figura 5.4 - Distribuição de tensões de momento fletor positivo em uma seção qualquer da laje mista empregando o Método da Interação Parcial ................................................................. 110

Figura 5.5 - Características da seção transversal da laje mista genérica utilizada no Método da

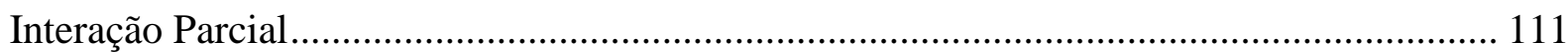

Figura 5.6 - Forças atuantes num segmento de laje mista................................................ 111

Figura 5.7 - Determinação gráfica do grau de interação parcial ao cisalhamento ( $)$ dos

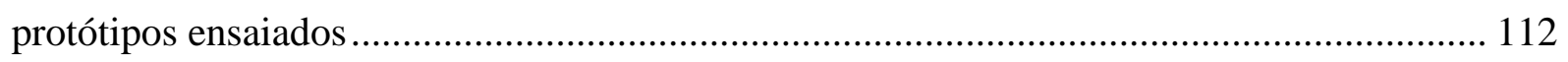

Figura 5.8 - Curva típica $M_{\mathrm{Rd}}$ versus $L_{\mathrm{x}}$ para Método da Interação Parcial .......................... 114

Figura 6.1 - Perfil MODULAR DECK - MD 55 ................................................................ 115 
Figura 6.2 - Configuração das mossas da fôrma MODULAR DECK - MD 55 116

Figura 6.3 - Laje mista objeto do estudo

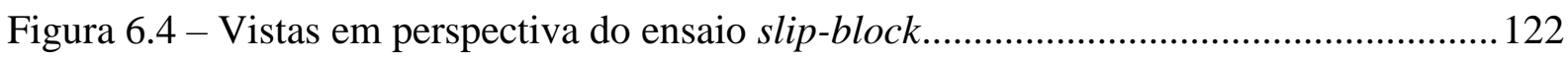

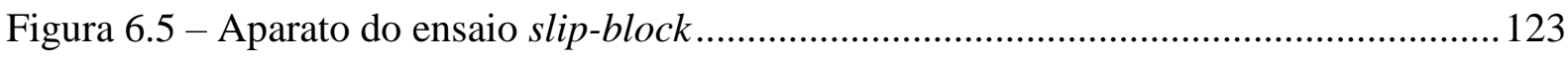

Figura 6.6 - Equipamento do ensaio slip-block ........................................................... 125

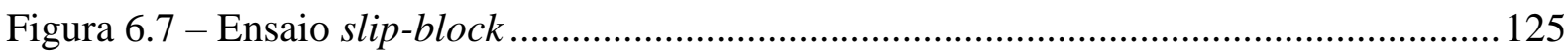

Figura 6.8 - Gráfico generalizado da Força horizontal $\left(F_{\mathrm{H}}\right)$ versus Deslizamento $(s) \ldots \ldots \ldots . . .128$

Figura 6.9 - Gráfico da Força horizontal $\left(F_{\mathrm{H}}\right)$ versus Deslizamento $(s)$ sob Força vertical $\left(F_{\mathrm{V}}\right)$ constante

Figura 6.10 - Gráfico típico da Força horizontal $\left(F_{\mathrm{H}}\right)$ versus Deslizamento $(s)$ dos protótipos

Figura 6.11 - Comportamento da interface aço-concreto de um trecho do protótipo do ensaio slip-block

Figura 6.12 - Pressão exercida pela fôrma de aço sobre o concreto

Figura 6.13 - Comportamento da interface aço-concreto durante o ensaio slip-block

Figura 6.14 - Situação do concreto e da fôrma de aço após a realização do ensaio

Figura 6.15 - Gráfico da Força horizontal $\left(F_{\mathrm{H}}\right)$ versus Força vertical $\left(F_{\mathrm{V}}\right)$ para $s=2,5 \mathrm{~mm} 136$

Figura 6.16 - Gráfico do Coeficiente de atrito $(\mu)$ e da Tensão mecânica resistente $\left(\tau_{\mathrm{m}}\right)$ versus

Deslizamento $(s)$

Figura 6.17 - Processo de deslizamento do concreto em relação à mossa da fôrma de aço .. 138

Figura 6.18 - Gráfico da Força horizontal $\left(F_{\mathrm{H}}\right)$ versus Deslizamento $(s)$ sob Força vertical $\left(F_{\mathrm{V}}\right)$ variável

Figura 6.19 - Gráfico de $F_{\mathrm{H}}$ versus s sob $F_{\mathrm{V}}$ constante e sob $F_{\mathrm{V}}$ variável 142

Figura 6.20 - Gráfico da Força horizontal $\left(F_{\mathrm{H}}\right)$ versus Força vertical $\left(F_{\mathrm{V}}\right)$ correspondente ao $1^{\circ}$ Ciclo de carregamento 144

Figura 6.21 - Seção transversal dos protótipos do ensaio de flexão ..... 147

Figura 6.22 - Esquema do ensaio de flexão

Figura 6.23 - Ensaio de flexão da laje mista 150

Figura 6.24 - Gráfico da Força $(F)$ versus Deslocamento vertical no meio do vão $(\delta)$ das Lajes 1 e 2

Figura 6.25 - Deslizamento e separação vertical na região da fissura principal (Laje 2) ...... 153

Figura 6.26 - Deformação da nervura na extremidade que deslizou (Laje 2). 153

Figura 6.27 - Deslizamento e separação vertical ao longo do vão de cisalhamento (Laje 1) 154 Figura 6.28 - Influência da orientação das mossas sobre a resistência da ligação mecânica 154 
Figura 6.29 - Gráficos da Força versus Deslocamento vertical nos três pontos de medição 155 Figura 6.30 - Laje 1 após a realização do ensaio de flexão

Figura 6.31 - Ondulações na parte comprimida da fôrma de aço no final do ensaio (Laje 1)

Figura 6.32 - Resultados referentes ao deslizamento e às deformações do aço e do concreto da Laje 1

Figura 6.33 - Resultados referentes ao deslizamento e à deformação do aço e do concreto da Laje 2.

Figura 7.1 - Gráfico da tensão de cisalhamento versus deslizamento - Abdullah (2004) .... 175

Figura 7.2 - Seção transversal da fôrma de aço linearizada .............................................. 178

Figura 7.3 - Elementos finitos utilizados na simulação numérica...................................... 179

Figura 7.4 - Comportamento do concreto adotado no modelo numérico............................. 182

Figura 7.5 - Comportamento do aço adotado no modelo numérico .................................... 182

Figura 7.6 - Características do elemento finito de interface............................................... 183

Figura 7.7 - Estrutura do modelo numérico do ensaio slip-block ....................................... 186

Figura 7.8 - Condições de contorno do modelo numérico do ensaio slip-block ................... 190

Figura 7.9 - Gráfico de $F_{\mathrm{H}}$ versus $s$ - teste de malha do modelo numérico do ensaio slip-block 191

Figura 7.10 - Gráfico de $F_{\mathrm{H}}$ versus $s$ do modelo numérico do ensaio slip-block - análise de $k_{t}$ para $k_{n}=10 \mathrm{~N} / \mathrm{mm}^{3}$

Figura 7.11 - Gráfico de $F_{\mathrm{H}}$ versus $s$ do modelo numérico do ensaio slip-block - análise de $k_{n}$ $\operatorname{com} k_{t}=10 \mathrm{~N} / \mathrm{mm}^{3}$

Figura 7.12 - Gráfico de $F_{\mathrm{H}}$ versus $s$ do modelo numérico do ensaio slip-block - análise de $\mu$

Figura 7.13 - Gráfico de $F_{\mathrm{H}}$ versus $s$ do modelo numérico do ensaio slip-block - análise de $c$

Figura 7.14 - Curvas de entrada para o Hardening do modelo Coulomb Friction .... 196

Figura 7.15 - Gráfico de $F_{\mathrm{H}}$ versus $s$ do modelo numérico validado do ensaio slip-blockcomparação com os resultados experimentais

Figura 7.16 - Tensões principais na capa de concreto - modelo numérico do ensaio slip-block

Figura 7.17 - Deformações principais na capa de concreto - modelo numérico do ensaio ... 200 Figura 7.18 - Tensões e deformações da fôrma de aço - modelo numérico do ensaio slip-block 
Figura 7.19 - Tensão de cisalhamento na interface - modelo numérico do ensaio slip-block201 Figura 7.20 - Geometria e simetria considerada para o modelo numérico inicial da laje mista

Figura 7.21 - Estrutura do modelo numérico inicial do ensaio de flexão da laje mista 204

Figura 7.22 - Condições de contorno e carregamento modelo numérico inicial do ensaio de flexão da laje mista 206

Figura 7.23 - Gráfico de $F$ versus $\delta$ do teste de malha do modelo numérico inicial do ensaio de flexão 208

Figura 7.24 - Gráfico de $F$ versus $\delta$ do modelo numérico inicial da laje mista utilizando interface com comportamento elástico linear - análise de $k_{t}$ com $k_{n}=10 \mathrm{~N} / \mathrm{mm}^{3}$

Figura 7.25 - Largura de fissura no concreto do modelo numérico inicial da laje mista com $k_{t}=k_{n}=10 \mathrm{~N} / \mathrm{mm}^{3}$ imediatamente após a abertura da fissura principal (interface com comportamento elástico linear)

Figura 7.26 - Distribuição das tensões principais no concreto do modelo numérico inicial com $k_{t}=k_{n}=10 \mathrm{~N} / \mathrm{mm}^{3}$ quando $\delta=60 \mathrm{~mm}$ (interface com comportamento elástico linear)

Figura 7.27 - Distribuição das tensões principais na fôrma de aço do modelo numérico inicial com $k_{t}=k_{n}=10 \mathrm{~N} / \mathrm{mm}^{3}$ quando $\delta=60 \mathrm{~mm}$ (interface com comportamento elástico linear) 211 Figura 7.28 - Gráfico de $F$ versus $\delta$ do modelo numérico inicial da laje mista utilizando interface com comportamento elástico linear - análise de $k_{n}$ com $k_{t}=1 \mathrm{~N} / \mathrm{mm}^{3}$ e com $k_{t}=100 \mathrm{~N} / \mathrm{mm}^{3}$

Figura 7.29 - Gráfico de $F$ versus $\delta$ do modelo numérico inicial da laje mista utilizando o modelo de interface Coulomb Friction - análise de $k_{t}$ com $k_{n}=1 \mathrm{~N} / \mathrm{mm}^{3}$ e $k_{n}=100 \mathrm{~N} / \mathrm{mm}^{3}$

Figura 7.30 - Largura de fissura no concreto do modelo numérico inicial da laje mista com $k_{n}=$ $1 \mathrm{~N} / \mathrm{mm}^{3}$ e $k_{t}=25 \mathrm{~N} / \mathrm{mm}^{3}$ imediatamente após a abertura da segunda fissura (modelo de interface Coulomb Friction) 214

Figura 7.31 - Distribuição das tensões principais no concreto do modelo numérico com $k_{t}=k_{n}=$ $10 \mathrm{~N} / \mathrm{mm}^{3}$ (modelo de interface Coulomb Friction) 215

Figura 7.32 - Distribuição das tensões principais na fôrma de aço do modelo numérico com $k_{t}=k_{n}=10 \mathrm{~N} / \mathrm{mm}^{3}$ (modelo de interface Coulomb Friction)

Figura 7.33 - Gráfico de $F$ versus $\delta$ do modelo numérico inicial da laje mista utilizando o modelo de interface Coulomb Friction - análise de $k_{n} \operatorname{com} k_{t}=1 \mathrm{~N} / \mathrm{mm}^{3}$ e $k_{t}=100 \mathrm{~N} / \mathrm{mm}^{3} 216$ Figura 7.34 - Distribuição das tensões da interface do modelo numérico inicial com $k_{t}=k_{n}=10 \mathrm{~N} / \mathrm{mm}^{3}$ (modelo de interface Coulomb Friction) 
Figura 7.35 - Gráfico de $F$ versus $\delta$ do modelo numérico inicial da laje mista com interface linear - análise de $\mu$ 218

Figura 7.36 - Gráfico de $F$ versus $\delta$ do modelo numérico inicial da laje mista com interface linear - análise de $c$

Figura 7.37 - Gráfico de $F$ versus $\delta$ do modelo numérico inicial da laje mista com os parâmetros de interface do modelo numérico do ensaio slip-block

Figura 7.38 - Gráfico de $F$ versus $s$ do modelo numérico inicial da laje mista com os parâmetros de interface do modelo numérico do ensaio slip-block. 221 Figura 7.39 - Tensões principais no concreto do modelo numérico inicial da laje mista com os parâmetros de interface do modelo numérico do ensaio slip-block.

Figura 7.40 - Tensões principais na fôrma de aço do modelo numérico inicial da laje mista com os parâmetros de interface do modelo numérico do ensaio slip-block 223 Figura 7.41 - Distribuição das tensões na interface do modelo numérico inicial da laje mista com os parâmetros de interface do modelo numérico do ensaio slip-block. 224 Figura 7.42 - Largura de fissura no concreto do modelo numérico da laje mista com os parâmetros de interface do modelo numérico do ensaio slip-block .

Figura 7.43 - Gráficos genéricos da tensão de cisalhamento versus o deslizamento dos ensaios da laje mista e do slip-block...... 225

Figura 7.44 - Gráfico da Coesão $(c)$ versus Deslizamento $(s)$ reconsiderado para o Hardening do modelo numérico de interface da laje mista. 226 Figura 7.45 - Gráfico de $F$ versus $\delta$ do modelo numérico inicial da laje mista com os parâmetros de interface do modelo numérico do ensaio slip-block reconsiderados 227 Figura 7.46 - Gráfico de $F$ versus $s$ do modelo numérico inicial da laje mista com os parâmetros de interface do modelo numérico do ensaio slip-block reconsiderados 227 Figura 7.47 - Representação dos sentidos mais e menos resistentes do chaveamento promovido pelas mossas da fôrma de aço ..... .229

Figura 7.48 - Situações simulada e real da laje mista após o ensaio de flexão ...................... 230 Figura 7.49 - Gráfico de $F_{\mathrm{H}}$ versus $s$ obtido por Cheng, Yang e Davison (1994).................. 231 Figura 7.50 - Gráfico da Coesão (c) versus Deslizamento ( $s$ ) do Hardening do modelo numérico definitivo da interface da laje mista.

Figura 7.51 - Geometria considerada para o modelo numérico definitivo da laje mista ...... 234

Figura 7.52 - Estrutura do modelo numérico do ensaio de flexão da laje mista .....

Figura 7.53 - Condições de contorno e carregamento do modelo definitivo do ensaio de flexão da laje mista 236 
Figura 7.54 - Largura de fissura no concreto do modelo numérico definitivo da laje mista após o ensaio

Figura 7.55 - Protótipo Laje 1 após a realização do ensaio de flexão

Figura 7.56 - Gráfico de $F$ versus $\delta$ do modelo numérico definitivo da laje mista - Laje 1.238

Figura 7.57 - Gráfico de $F$ versus $s$ do modelo numérico definitivo da laje mista - Laje 1..238

Figura 7.58 - Gráficos da Força versus Deslocamento vertical das seções localizadas abaixo do carregamento aplicado - modelo numérico definitivo - Laje 1

Figura 7.59 - Tensões principais no concreto do modelo numérico definitivo - Laje 1

Figura 7.60 - Tensões principais na fôrma de aço do modelo numérico definitivo - Laje 1242

Figura 7.61 - Ondulações na parte comprimida da fôrma de aço após o ensaio

Figura 7.62 - Distribuição das tensões normais e de cisalhamento na interface do modelo numérico definitivo - Laje 1 243

Figura 7.63 - Gráfico de $F$ versus $\varepsilon$ do modelo numérico definitivo da laje mista - Laje 1..245

Figura 7.64 - Gráfico de $F$ versus $\delta$ do modelo numérico definitivo da laje mista - Laje 2.246

Figura 7.65 - Gráfico de $F$ versus $s$ do modelo numérico definitivo da laje mista - Laje 2..246

Figura 7.66 - Gráfico da Força versus Deslocamento vertical das seções localizadas abaixo do carregamento aplicado - Laje 2 .....

Figura 7.67 - Análise paramétrica - Espessura da capa de concreto $(h)$.............................248

Figura 7.68 - Análise paramétrica - Espessura da fôrma de aço $\left(t_{\mathrm{s}}\right)$..................................249

Figura 7.69 - Análise paramétrica - Comprimento efetivo da laje mista $\left(L_{\mathrm{ef}}\right)$.....................251

Figura 7.70 - Análise paramétrica - Resistência ao escoamento do aço da fôrma $\left(f_{\mathrm{y}}\right) \ldots \ldots . . . .252$

Figura B.1 - Posicionamento dos extensômetros no concreto ..............................................273

Figura B.2 - Posicionamento dos extensômetros na fôrma de aço .......................................273

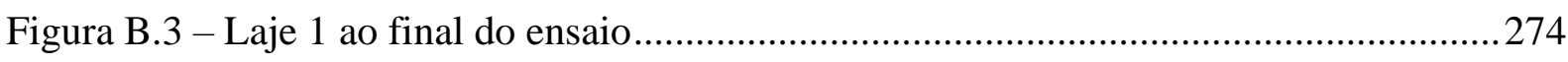

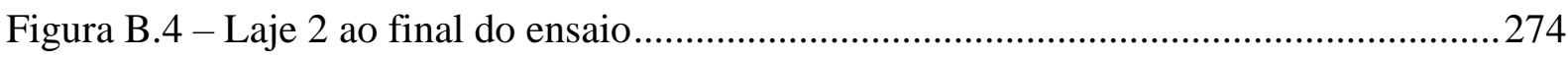

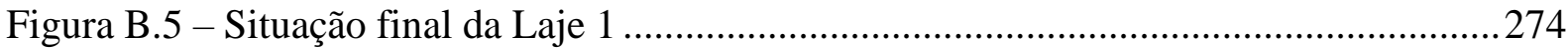

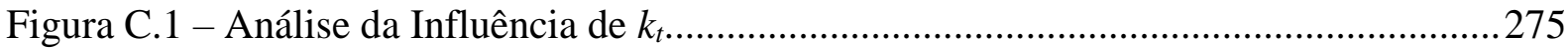

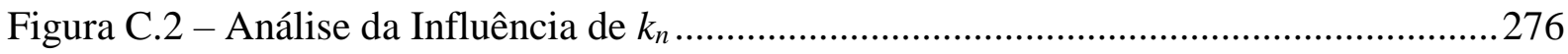

Figura D.1 - Análise da Influência de $k_{t}$ - Interface de comportamento elástico ..................277

Figura D.2 - Análise da Influência de $k_{n}$ - Interface de comportamento elástico .................278

Figura D.3 - Análise da Influência de $k_{t}$ - Modelo de interface Coulomb Friction ..............279

Figura D.4 - Análise da Influência de $k_{n}$ - Modelo de interface Coulomb Friction..............280 



\section{LISTA DE TABELAS}

Tabela 5.1 - Forças resistentes associadas ao cisalhamento longitudinal e seus coeficientes de ponderação para a obtenção dos valores de projeto

Tabela 6.1 - Resistência à compressão do concreto segundo os respectivos protótipos .......118

Tabela 6.2 - Resistência à tração do concreto segundo os respectivos protótipos................. 118

Tabela 6.3 - Módulo de elasticidade do concreto segundo os respectivos protótipos ...........119

Tabela 6.4 - Propriedades mecânicas do aço constituinte da fôrma MODULAR MD 55.....120

Tabela 6.5 - Configuração do carregamento aplicado em cada ensaio slip-block ................. 121

Tabela 6.6 - Peso de alguns componentes do aparato do ensaio slip-block.......................... 126

Tabela 6.7 - Sequência de carregamento do slip-block sob força vertical variável ................128

Tabela 6.8 - Valores de $F_{\mathrm{H}}$ de acordo com a curva típica da Figura $6.10 \ldots \ldots \ldots \ldots \ldots \ldots \ldots \ldots \ldots . . . . . . . . . . . . . .130$

Tabela 6.9 - Resultados de $\mu$ e $\tau_{\mathrm{m}}$ obtidos por meio dos ensaios com $F_{\mathrm{V}}$ constante.............. 137

Tabela 6.10 - Resultados de $\mu$ e $\tau_{\mathrm{m}}$ obtidos por meio do ensaio com $F_{\mathrm{V}}$ variável ................. 144

Tabela 6.11 - Resultados obtidos por meio dos ensaios com $F_{\mathrm{V}}$ constante e com $F_{\mathrm{V}}$ variável 145

Tabela 6.12 - Resultados obtidos por meio dos ensaios de flexão......................................151

Tabela 6.13 - Avaliação da capacidade resistente dos protótipos do ensaio de flexão...........160

Tabela 7.1 - Síntese das considerações realizadas nos trabalhos numéricos referenciados... 171

Tabela 7.2 - Parâmetros do concreto do modelo numérico do ensaio slip-block .................. 187

Tabela 7.3 - Parâmetros do aço do modelo numérico do ensaio slip-block........................... 187

Tabela 7.4 - Parâmetros da interface aço-concreto do modelo numérico do ensaio slip-block

Tabela 7.5 - Características de cada modelo da análise da malha do ensaio slip-block ........191

Tabela 7.6 - Relação entre os valores numéricos e experimentais do ensaio slip-block .......198

Tabela 7.7 - Parâmetros do concreto do modelo numérico do ensaio de flexão da laje mista

Tabela 7.8 - Parâmetros do aço do modelo numérico do ensaio de flexão da laje mista ...... 205

Tabela 7.9 - Características de cada modelo da análise da malha do ensaio da laje mista....207 
Tabela 7.10 - Relação entre os valores numéricos e experimentais do modelo inicial da laje mista com os parâmetros de interface do modelo numérico do ensaio slip-block

Tabela 7.11 - Parâmetros da interface aço-concreto do modelo numérico definitivo da laje mista

Tabela 7.12 - Quantidade de elementos utilizados no modelo numérico definitivo da laje mista

Tabela 7.13 - Relação entre os valores numéricos e experimentais do modelo definitivo da laje mista 239

Tabela 7.14 - Análise paramétrica - Espessura da capa de concreto $(h)$ 248

Tabela 7.15 - Análise paramétrica - Espessura da fôrma de aço $\left(t_{\mathrm{s}}\right)$ 250

Tabela 7.16 - Análise paramétrica - Comprimento efetivo da laje mista $\left(L_{\mathrm{ef}}\right)$ 251

Tabela 7.17 - Análise paramétrica - Tensão de escoamento do aço da fôrma $\left(f_{\mathrm{y}}\right)$ 252

Tabela A.1 $-F_{\mathrm{H}}$ e $F_{\mathrm{V}}$ de acordo com $s$ - ensaio slip-block com $F_{\mathrm{V}}$ constante 271

Tabela A.2 $-F_{\mathrm{H}}$ e $F_{\mathrm{V}}$ de acordo com o ciclo - ensaio slip-block com $F_{\mathrm{V}}$ variável. 272 


\section{LISTA DE SÍMBOLOS E ABREVIATURAS}

\begin{tabular}{|c|c|}
\hline$a$ & Profundidade da linha neutra do concreto \\
\hline$A_{\mathrm{p}}$ & Área da seção transversal da fôrma de aço \\
\hline$b$ & Largura da laje mista ou do seu protótipo \\
\hline$c$ & Coesão da interface do modelo Coulomb Friction \\
\hline$d_{\mathrm{p}}$ & Distância entre a face superior da laje e o centro de gravidade da fôrma \\
\hline$e$ & Distância do centro geométrico da área efetiva da fôrma à sua face inferior \\
\hline$e_{\mathrm{p}}$ & Distância da linha neutra de plastificação da seção da fôrma à sua face inferior \\
\hline$E_{\mathrm{a}}$ & Módulo de elasticidade do aço \\
\hline$E_{\mathrm{c}}$ & Módulo de elasticidade do concreto \\
\hline$E_{\mathrm{c}, \mathrm{m}}$ & Módulo de elasticidade médio do concreto \\
\hline$f_{\mathrm{c}}$ & Resistência à compressão do concreto \\
\hline$f_{\mathrm{cd}}$ & Resistência à compressão de projeto do concreto \\
\hline$f_{\mathrm{ck}}$ & Resistência característica à compressão do concreto, aos 28 dias \\
\hline$f_{\mathrm{c}, \mathrm{m}}$ & Resistência média à compressão do concreto \\
\hline$f_{\mathrm{ct}}$ & Resistência à tração direta do concreto \\
\hline$f_{\mathrm{ct}, \mathrm{f}}$ & Resistência à tração na flexão do concreto \\
\hline$f_{\mathrm{ct}, \mathrm{m}}$ & Resistência média à tração direta do concreto \\
\hline$f_{\mathrm{u}}$ & Resistência à ruptura do aço \\
\hline$f_{\mathrm{y}}$ & Resistência ao escoamento do aço \\
\hline$f_{\mathrm{y}, \mathrm{Fd}}$ & Resistência de projeto ao escoamento do aço da fôrma \\
\hline$F_{\text {des }}$ & Força de início do deslizamento de extremidade da laje mista \\
\hline$F_{\mathrm{H}}$ & Força horizontal no ensaio slip-block \\
\hline$F_{\text {H,máx }}$ & Força horizontal máxima no ensaio slip-block \\
\hline$F_{\mathrm{H}, \mathrm{ret}}$ & Força horizontal de retomada de resistência após a ruptura da ligação química \\
\hline$F_{\mathrm{H}, \text { rup }}$ & Força horizontal referente à ruptura da ligação química \\
\hline$F_{\mathrm{m}}$ & Força mecânica resistente devido ao intertravamento promovido pelas mossas \\
\hline$F_{\text {máx }}$ & Força máxima resistente da laje mista no ensaio de flexão \\
\hline$F_{\text {ret }}$ & Força referente à retomada de resistência após o início do deslizamento relativo \\
\hline$F_{\mathrm{V}}$ & Força vertical no ensaio slip-block \\
\hline$G_{\mathrm{c}}$ & Energia de fratura do concreto à compressão \\
\hline$G_{\mathrm{f}}$ & Energia de fratura do concreto à tração \\
\hline$h_{\mathrm{t}}$ & Altura total da laje mista \\
\hline
\end{tabular}




\begin{tabular}{|c|c|}
\hline$k_{n}$ & Rigidez normal da interface \\
\hline$k_{t}$ & Rigidez tangencial da interface \\
\hline$L$ & Comprimento total da laje mista \\
\hline$L_{\mathrm{f}}$ & Comprimento efetivo da laje mista \\
\hline$L_{\mathrm{s}}$ & Comprimento (ou vão) de cisalhamento da laje mista \\
\hline$L_{0}$ & Comprimento em balanço da laje mista \\
\hline$M_{\mathrm{pa}}$ & Momento fletor que causa a plastificação da fôrma de aço \\
\hline$M_{\mathrm{pr}}$ & Momento fletor de plastificação da fôrma de aço reduzido devido à presença de $N_{\mathrm{a}}$ \\
\hline$M_{\mathrm{R}}$ & Momento fletor máximo resistente previsto da laje mista sob interação total \\
\hline$M_{\mathrm{Rd}}$ & Momento fletor resistente de projeto da laje mista sob interação parcial \\
\hline$M_{\text {test }}$ & Momento fletor resistente ao cisalhamento longitudinal obtido \\
\hline$M_{\mathrm{sd}}$ & Momento fletor solicitante de projeto da laje mista \\
\hline$N_{\mathrm{a}}$ & Força resultante atuante na seção transversal da fôrma de aço \\
\hline$N_{\mathrm{c}}$ & Força resultante na seção transversal do concreto \\
\hline$N_{\mathrm{cf}}$ & Força resultante na seção transversal do concreto na situação de interação completa \\
\hline$N_{\mathrm{pa}}$ & Força normal que causa a plastificação da fôrma de aço \\
\hline$R$ & Reação de apoio da laje mista no ensaio de flexão \\
\hline$s$ & Deslizamento relativo entre a fôrma de aço e o concreto \\
\hline$t_{\mathrm{n}}$ & Espessura nominal da fôrma de aço \\
\hline$t_{\mathrm{s}}$ & Espessura de cálculo da fôrma de aço \\
\hline$t_{n}$ & Tensão normal à interface do modelo numérico \\
\hline$t_{t}$ & Tensão tangencial à interface do modelo numérico \\
\hline$V_{\mathrm{Rd}}$ & Esforço cortante último de projeto da laje mista \\
\hline$V_{\mathrm{u}}$ & Esforço cortante último associado ao cisalhamento longitudinal da laje mista \\
\hline$y$ & Distância entre os vetores das forças $N_{\mathrm{c}}$ e $N_{\mathrm{a}}$ \\
\hline$\mu$ & Coeficiente de atrito entre o aço e o concreto \\
\hline$\tau$ & Tensão de cisalhamento na interface aço-concreto \\
\hline$\tau_{\mathrm{m}}$ & Tensão mecânica média resistente ao cisalhamento da interface aço concreto \\
\hline$\tau_{\mathrm{u}, \mathrm{Rd}}$ & Tensão média resistente de projeto ao cisalhamento longitudinal da laje mista \\
\hline$\rho$ & Taxa de aço da armadura da laje mista \\
\hline$\eta$ & Grau de interação entre o aço e o concreto da laje mista \\
\hline$\delta$ & Deslocamento vertical no meio do vão da laje mista \\
\hline$\delta_{\mathrm{des}}$ & Deslocamento vertical correspondente à $F_{\text {des }}$ \\
\hline
\end{tabular}


$\delta_{\text {máx }} \quad$ Deslocamento vertical correspondente à $F_{\text {máx }}$

$\beta \quad$ Coeficiente de retenção ao cisalhamento do concreto

$\phi \quad$ Ângulo de atrito

$\psi \quad$ Ângulo de dilatância

$\kappa \quad$ Parâmetro interno do modelo de interface referente ao deslizamento irreversível

$v_{\mathrm{a}} \quad$ Coeficiente de Poisson do aço

$v_{\mathrm{c}} \quad$ Coeficiente de Poisson do concreto

ABNT Associação Brasileira de Normas Técnicas

ANSI American National Sandards Institute

AS Australian Standard

ASCE Society of Civil Engineers

ASTM American Society for Testing and Materials

CEB Comité Euro-International du Béton

$\mathrm{CP} \quad$ Corpo de prova

CSSBI Canadian Sheet Steel Building Institute

EESC Escola de Engenharia de São Carlos

FIP Fédération Internationale de la Précontrainte

NZS New Zealand Standard

USP Universidade de São Paulo 



\section{SUMÁRIO}

CAPÍTULO 1 - INTRODUÇÃO .................................................................................................33

1.1 Estruturas Mistas de Aço e Concreto .........................................................................33

1.2 Lajes Mistas de Aço e Concreto ............................................................................................................35

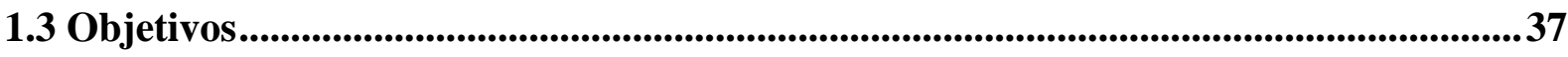

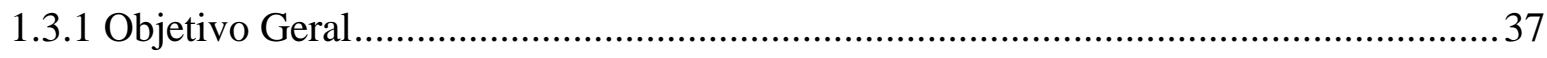

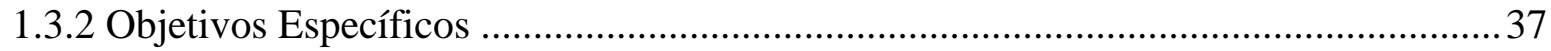

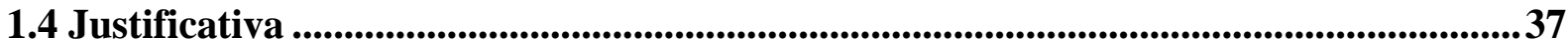

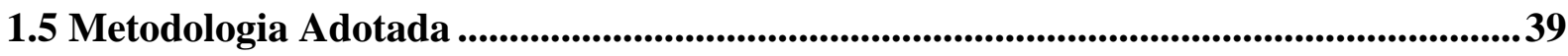

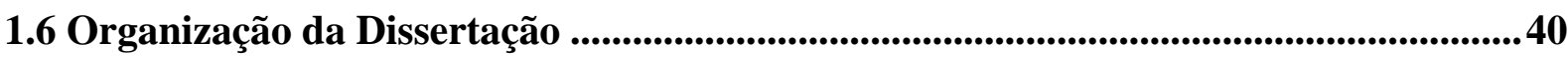

CAPÍTULO 2 - A INTERFACE AÇO-CONCRETO DE LAJES MISTAS.....................43

2.1 Ligação Aço-Concreto ........................................................................................................43

2.2 Transferência de Cisalhamento..................................................................................................45

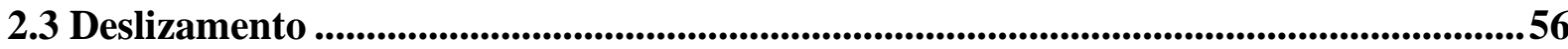

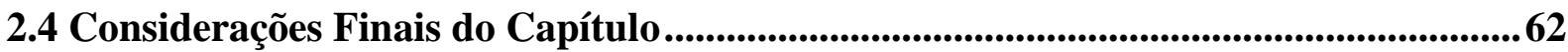

CAPÍTULO 3 - COMPORTAMENTO E CLASSIFICAÇÃO DAS LAJES MISTAS ... 65

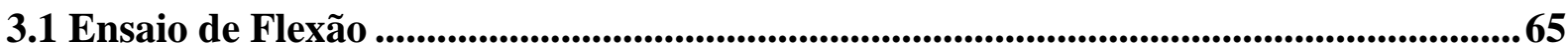

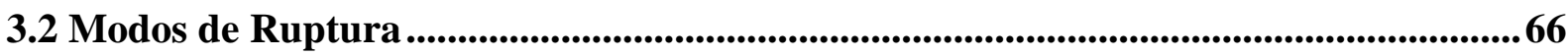

3.3 Comportamento das Lajes Mistas ............................................................................................... 71

3.4 Classificação do Comportamento das Lajes Mistas ........................................................74

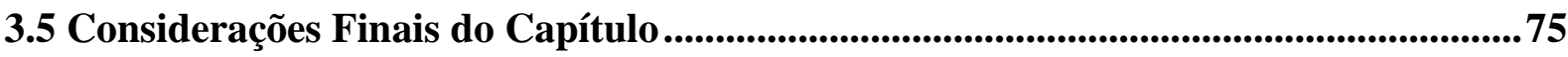

CAPÍtulo 4 - MODELOS DE PEQUENAS DIMENSÕES PARA ANÁliSE DA INTERFACE AÇO-CONCRETO ..................................................................................................... 77

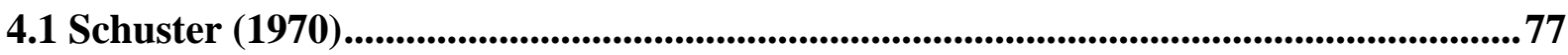

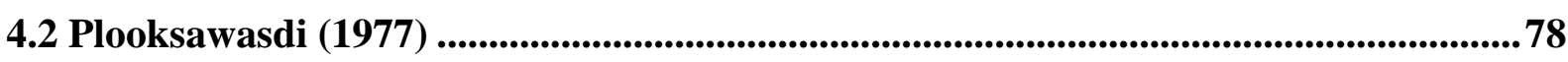

4.3 Stark (1978) .................................................................................................................................... 79

4.4 Jolly e Zubair (1978).......................................................................................................................... 79

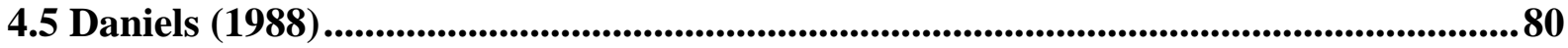

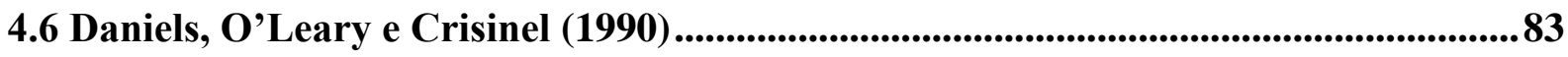

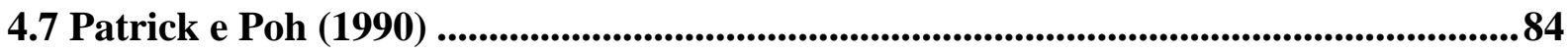




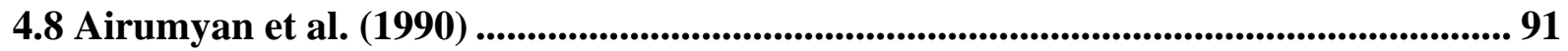

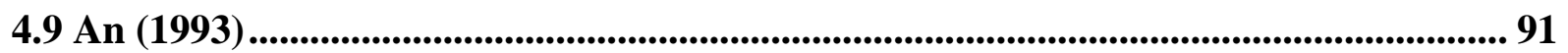

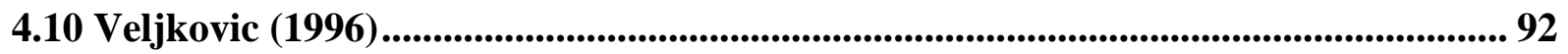

4.11 Burnet (1998) ........................................................................................................................................ 94

4.12 Tremblay et al. (2002) ......................................................................................................... 95

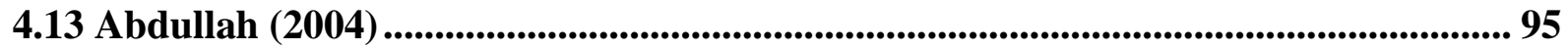

4.14 Fontes (2016)

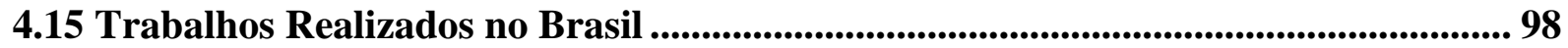

4.16 Considerações Finais do Capítulo ........................................................................................... 100

CAPÍTULO 5 - MÉTODOS ANALÍTICOS - RESISTÊNCIA AO CISALHAMENTO

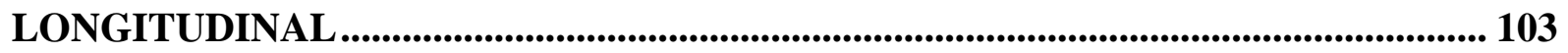

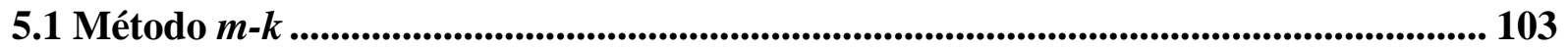

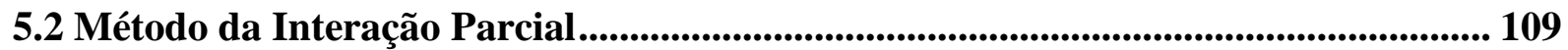

5.3 Considerações Finais do Capítulo .................................................................................. 114

CAPÍTULO 6 - ANÁLISE EXPERIMENTAL .............................................................................. 115

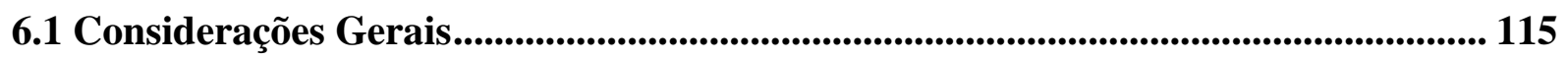

6.2 Propriedades dos Materiais............................................................................................................ 117

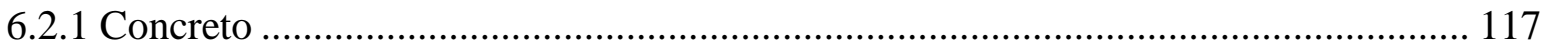

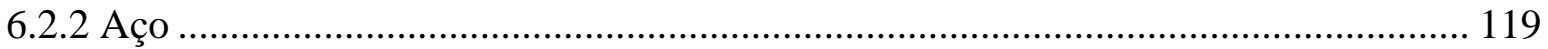

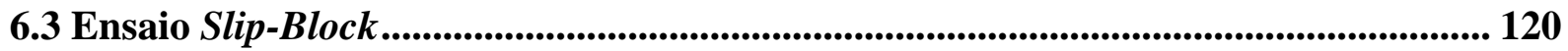

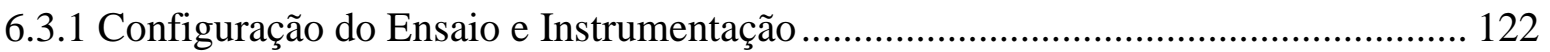

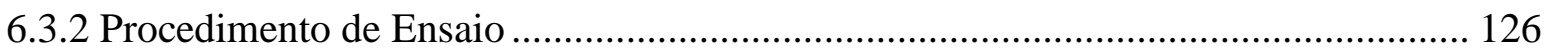

6.3.2.1 Carregamento Vertical Constante ao Longo do Ensaio...................................... 126

6.3.2.2 Carregamento Vertical Variável ao Longo do Ensaio ........................................ 126

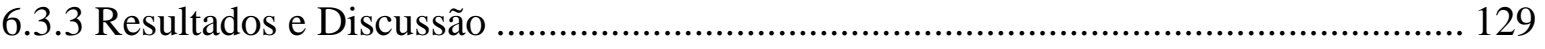

6.3.3.1 Carregamento Vertical Constante ao Longo do Ensaio...................................... 129

6.3.3.2 Carregamento Vertical Variável ao Longo do Ensaio ....................................... 140

6.3.3.3 Comparação das Metodologias e Considerações sobre o Ensaio Slip-Block ..... 145

6.4 Ensaio de Flexão.................................................................................................... 147

6.4.1 Configuração e Procedimento de Ensaio................................................................. 148

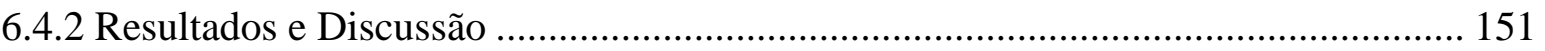

6.5 Considerações Finais do Capítulo ........................................................................................ 161 
7.1 Emprego do MEF em Lajes Mistas ............................................................................................164

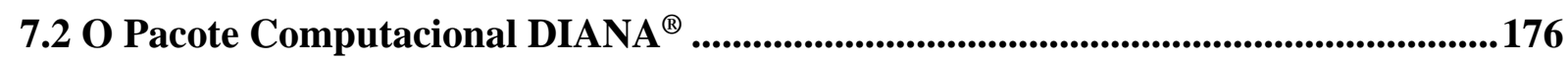

7.3 Aspectos da Simulação Numérica ..........................................................................177

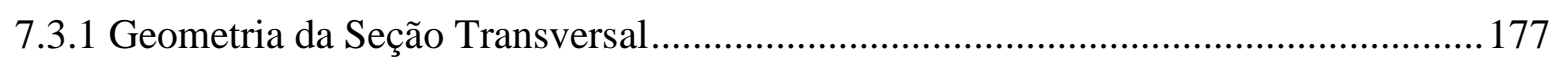

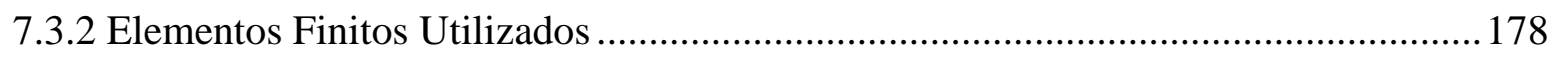

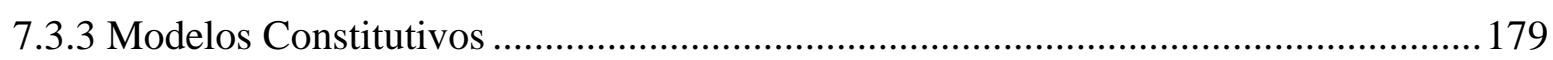

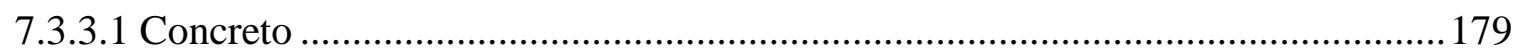

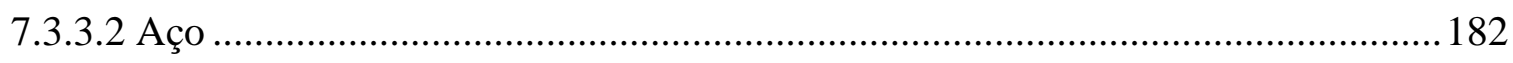

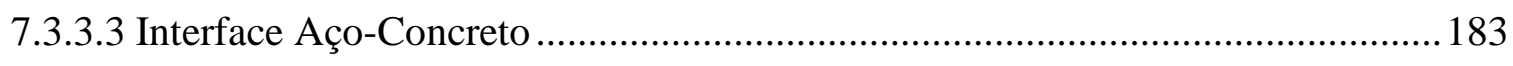

7.4 Análise Numérica do Ensaio Slip-Block ...........................................................186

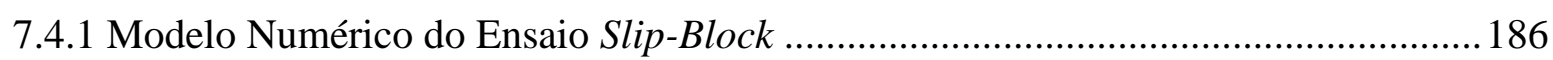

7.4.1.1 Estrutura do Modelo e Propriedades dos Materiais ............................................ 186

7.4.1.2 Condições de Contorno e Carregamento............................................................ 189

7.4.1.3 Estratégia de Solução e Critério de Convergência .............................................. 190

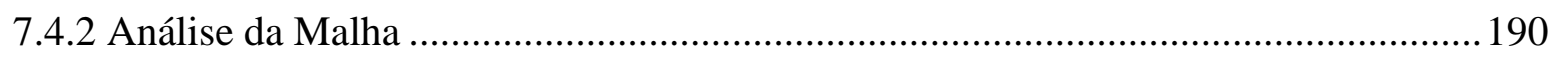

7.4.3 Análise de Sensibilidade do Modelo de Interface................................................... 192

7.4.4 Validação do Modelo Numérico do Ensaio Slip-Block ...........................................196

7.5 Análise Numérica da Laje Mista .............................................................................................202

7.5.1 Análise do Modelo de Interface sobre o Comportamento da Laje Mista .................203

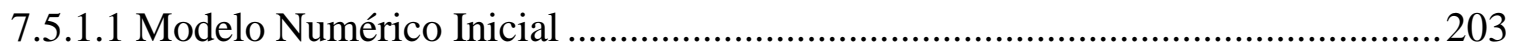

7.5.1.1.1 Estrutura do Modelo e Propriedades dos Materiais .....................................204

7.5.1.1.2 Condições de Contorno e Carregamento ......................................................206

7.5.1.1.3 Estratégia de Solução e Critério de Convergência .......................................207

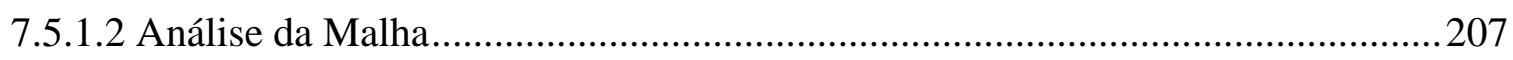

7.5.1.3 Análise de Sensibilidade do Modelo de Interface .............................................209

7.5.1.4 Aplicação Direta dos Parâmetros de Interface Obtidos no Ensaio Slip-Block....220

7.5.1.5 Reavaliação dos Parâmetros de Interface Obtidos no Ensaio Slip-Block ............225

7.5.2 Estratégia para Simulação da Interface Aço-Concreto da Laje Mista .......................228

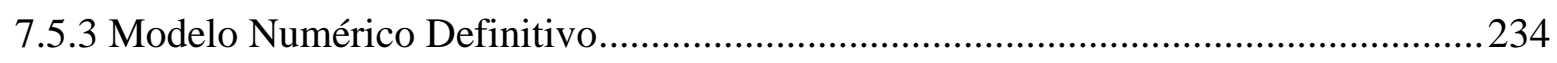

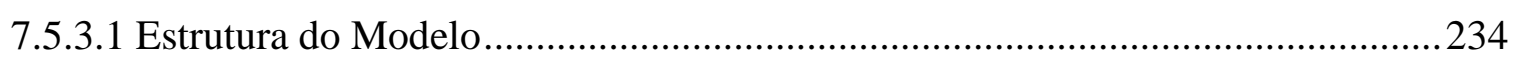

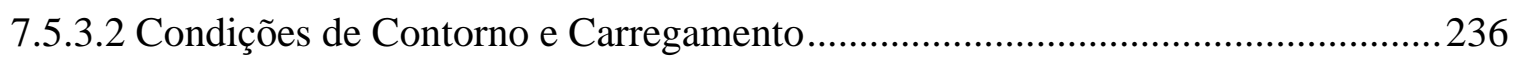

7.5.4 Validação do Modelo Numérico Definitivo .......................................................... 237 


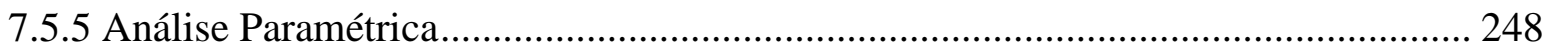

7.5.5.1 Espessura da Capa de Concreto .................................................................... 248

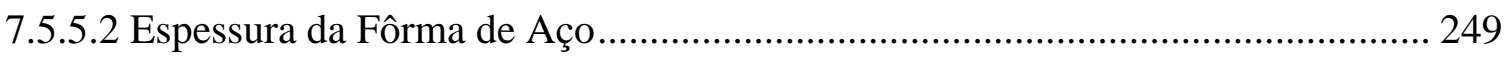

7.5.5.3 Comprimento Efetivo da Laje Mista .......................................................... 250

7.5.5.4 Resistência ao Escoamento do Aço .................................................................. 252

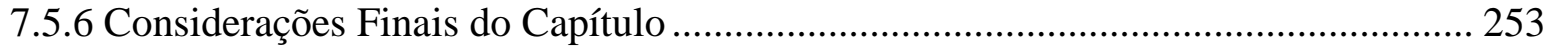

CAPÍTULO 8 - CONCLUSÕES E SUGESTÕES ........................................................... 255

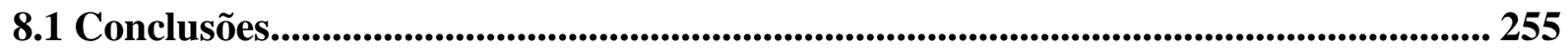

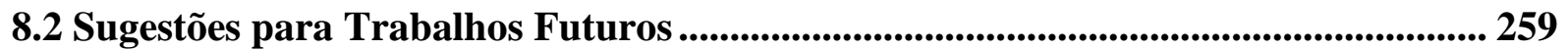

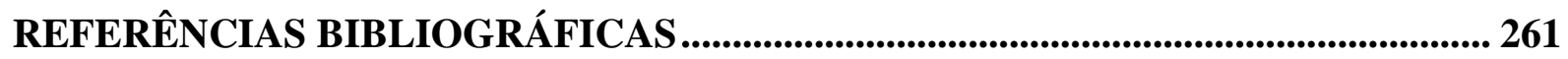

APÊNDICE A - RESULTADOS EXPERIMENTAIS DO ENSAIO SLIP-BLOCK .... 271

A.1 Força Vertical Constante ao Longo do Ensaio ............................................................. 271

A.2 Força Vertical Variável ao Longo do Ensaio......................................................................... 272

APÊNDICE B - RELATÓRIO FOTOGRÁFICO DO ENSAIO DE FLEXÃO............. 273

APÊNDICE C - RESULTADOS NUMÉRICOS DO MODELO DO ENSAIO SLIP-

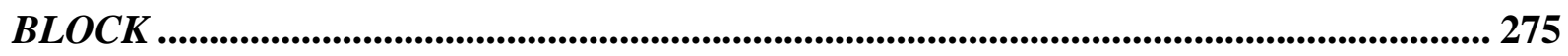

APÊNDICE D - RESULTADOS NUMÉRICOS DO MODELO INICIAL DA LAJE

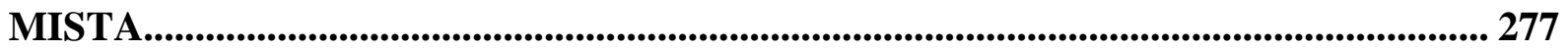

D.1 Modelo de Interface de Comportamento Elástico Linear ......................................... 277

D.2 Modelo de Interface Coulomb Friction ................................................................. 279 


\section{CAPÍTULO 1 - INTRODUÇÃO}

O tema do presente trabalho é apresentado neste capítulo com o objetivo de descrever as considerações gerais sobre as estruturas mistas e as lajes mistas de aço e concreto, assim como a inserção e objetivos da pesquisa no cenário atual. Em seguida são apresentadas as justificativas, a metodologia adotada e a organização desta dissertação.

\subsection{Estruturas Mistas de Aço e Concreto}

O desenvolvimento e aprimoramento de métodos construtivos para promover o melhor aproveitamento dos materiais constituintes, assim como maior segurança, economia e sustentabilidade, são objetivos constantes da Engenharia Civil de um modo geral. Os projetos estruturais exigem cada vez mais soluções capazes de atender determinadas exigências de arquitetura, prazo, durabilidade e resistência, entre outras. Neste aspecto, destacam-se as soluções promovidas pelos sistemas estruturais mistos de aço e concreto, caracterizados por empregar elementos formados por estes dois materiais.

$\mathrm{O}$ uso crescente desses sistemas se deve à capacidade de promoverem determinadas soluções diante das exigências requeridas tanto de projeto quanto de execução, como redução do peso total da estrutura, grandes vãos livres, praticidade, maior velocidade de execução e redução do desperdício. A Figura 1.1 apresenta o exemplo da estrutura de um piso misto, no qual a laje e as vigas apresentam ação mista entre o aço e o concreto.

Figura 1.1 - Exemplo da estrutura de um piso misto

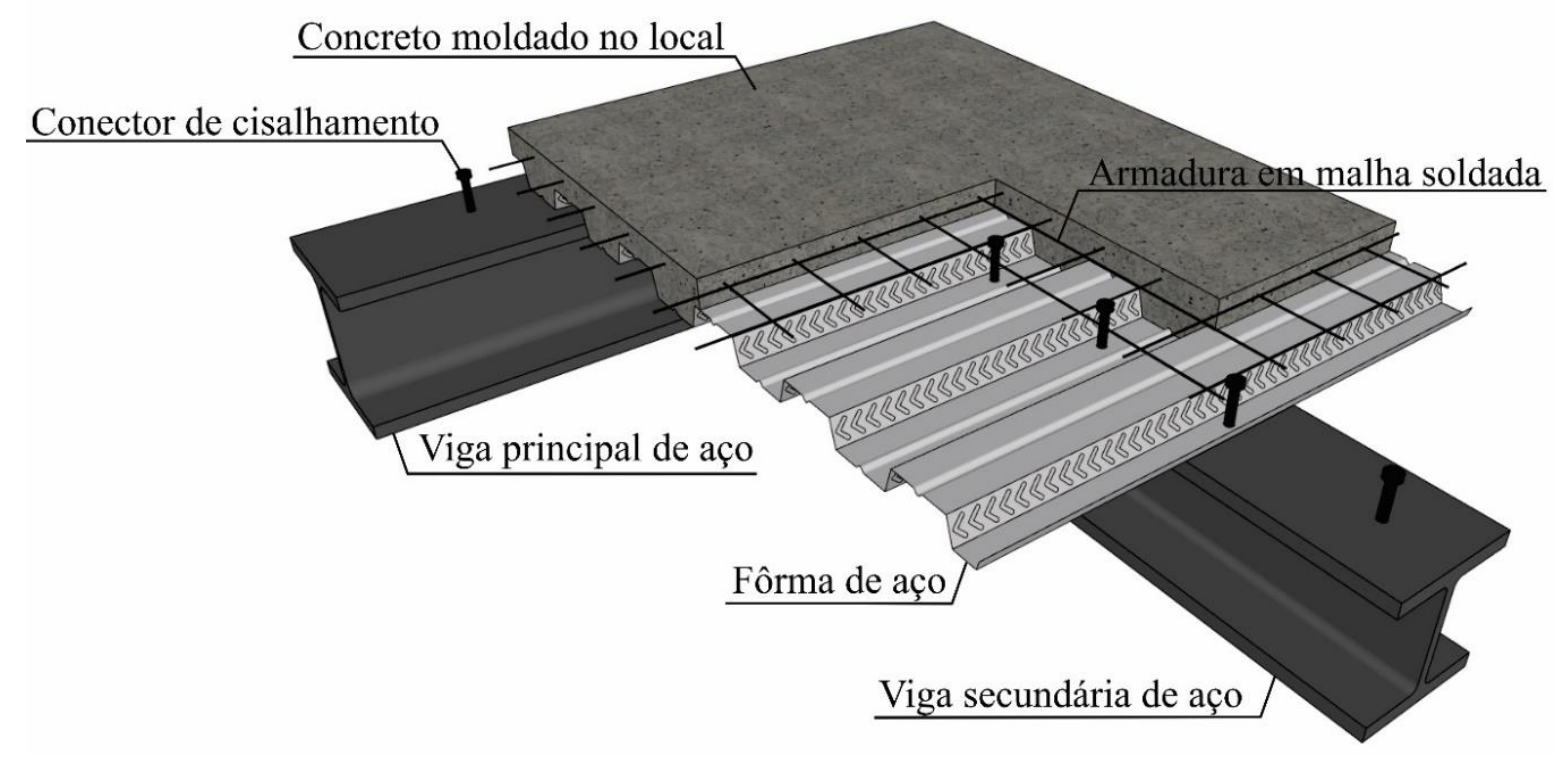

Fonte: Autoria própria 
Para que a estrutura seja considerada mista, seus materiais constituintes devem trabalhar de maneira solidária, ou seja, trabalharem em conjunto para resistir aos esforços solicitantes. A distribuição dos esforços entre os materiais é função das suas propriedades mecânicas e da interação existente entre eles.

No caso da estrutura mista composta por aço e concreto, a interação entre o perfil de aço e o concreto pode ocorrer por meios mecânicos (conectores, mossas, ressaltos, etc.), por atrito, por simples aderência e por repartição de cargas. Sendo assim, essa interação depende de como os materiais estão interligados e da eficiência que essas ligações apresentam para transmitir esforços de cisalhamento de um material ao outro. A Figura 1.2 ilustra a diferença entre uma viga de aço e concreto sem ação mista (a) e com ação mista (b).

Figura 1.2 - Diferença entre vigas de aço e concreto com ação mista e sem ação mista
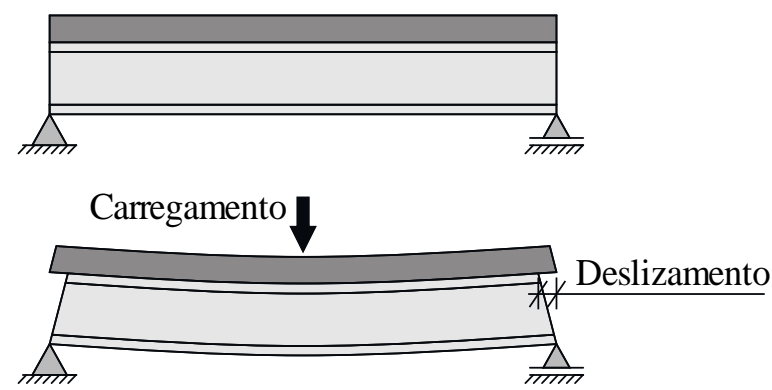

Tensão de

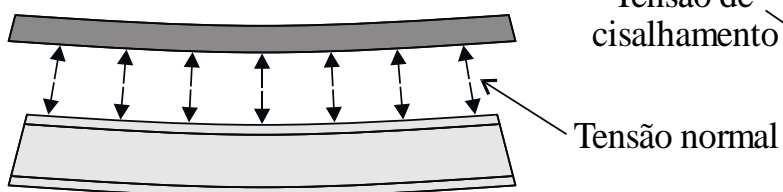

(a) Viga sem ação mista
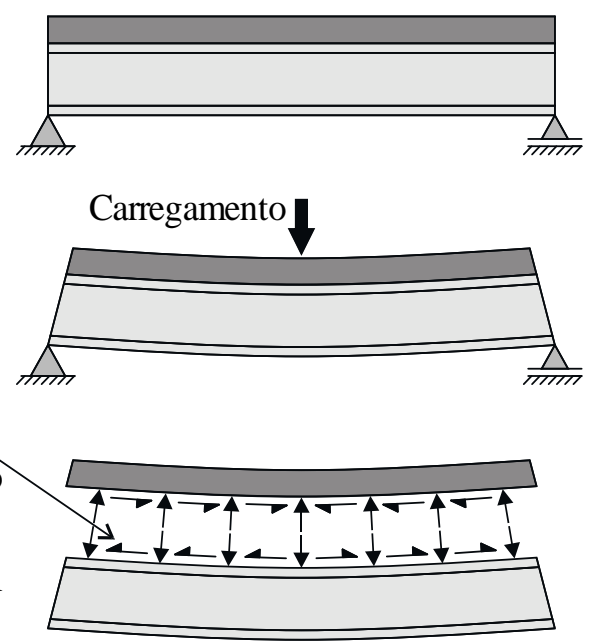

(b) Viga com ação mista

Fonte: Autoria própria

$\mathrm{Na}$ ausência de qualquer ligação na interface aço-concreto, os dois componentes se deformam de modo independente, o que acarreta na existência de deslizamento relativo entre eles (Figura 1.2 (a)). Considerando que o aço e o concreto estejam interligados de alguma forma entre si e que esta ligação possua resistência suficiente para resistir ao fluxo de cisalhamento gerado na interface, os dois componentes se deformam como um único elemento, o que caracteriza a ação mista (Figura 1.2 (b)).

A correta análise dos fenômenos que ocorrem na interface aço-concreto e os fatores que influenciam a ligação entre estes materiais é fundamental para melhorar a eficiência da ação mista da estrutura e, consequentemente, aprimorar seu desempenho. Com isso é possível gerar benefícios de ordem técnica, econômica e sustentável. 


\subsection{Lajes Mistas de Aço e Concreto}

Lajes mistas de aço e concreto são aquelas em que a fôrma de aço incorporada faz parte do seu sistema estrutural, funcionando, antes da cura do concreto, como suporte das ações permanentes e sobrecargas de construção e, depois da cura, como parte ou toda armadura de tração da laje. Dentre outras vantagens desse tipo de laje, destacam-se: dispensa de fôrmas de moldagem, possibilidade de dispensar escoramentos, facilidade de instalação, maior velocidade construtiva, redução ou mesmo eliminação da armadura de tração na região de momentos fletores positivos e redução de desperdício de material. Como desvantagens tem-se a necessidade da utilização de forros suspensos, devido a razões estéticas, e a necessidade de maior quantidade de vigas secundárias devido à limitação dos vãos antes da cura do concreto, caso não se utilize escoramento e/ou fôrmas de grande altura.

A Figura 1.3 ilustra alguns exemplos de lajes mistas com fôrma de aço incorporada. Os perfis das fôrmas das lajes mistas das Figura 1.3 (a) e (b) são chamados reentrantes, os das Figura 1.3 (c) e (d) são chamados trapezoidais e o da Figura 1.3 (e) é dito em forma de L ou reentrante $\mathrm{L}$.

Figura 1.3 - Tipologias de lajes mistas de aço e concreto
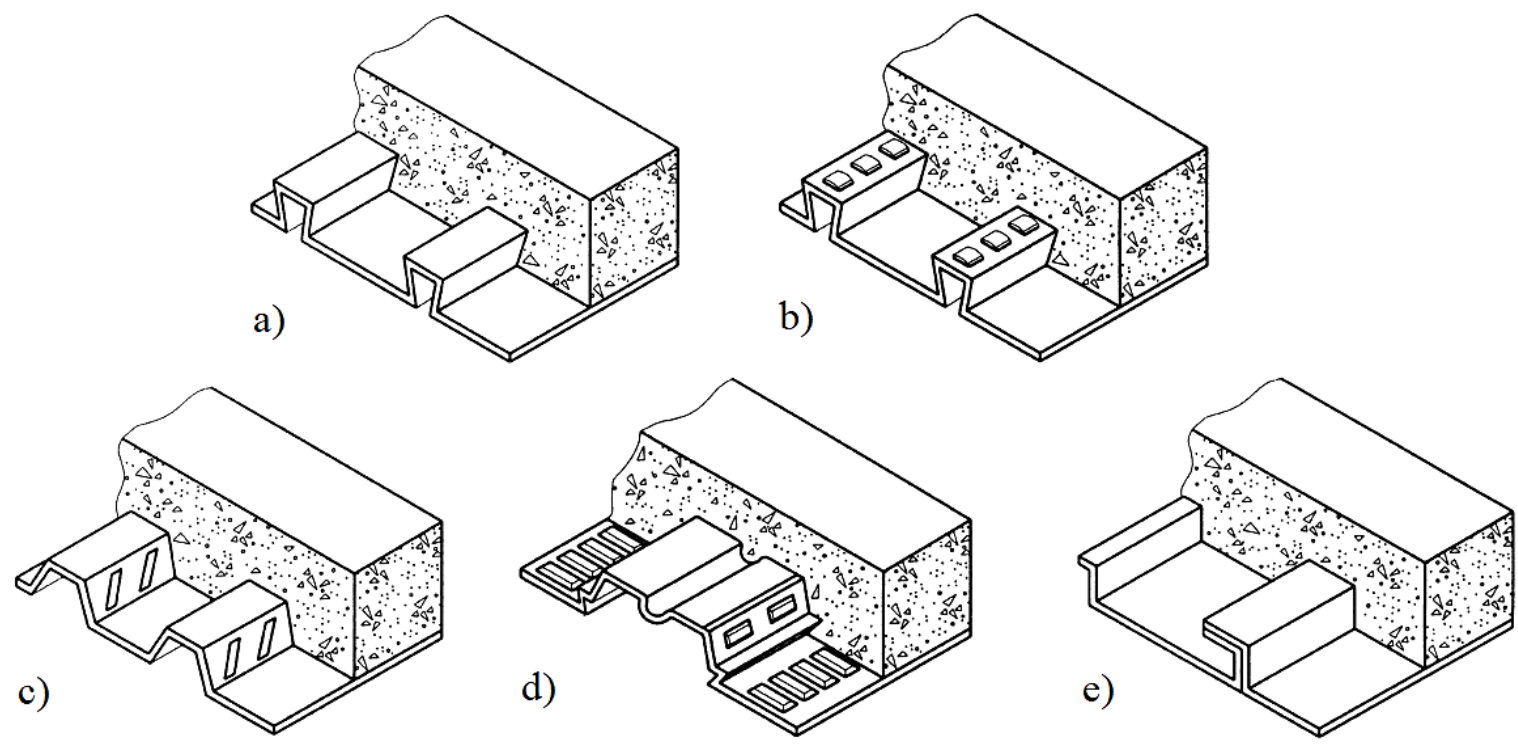

Fonte: Adaptado de BS 5950-4:1994

Os possíveis modos de ruptura de lajes mistas são: por flexão, cisalhamento vertical, cisalhamento longitudinal e punção. Entretanto, o estado limite de ruptura por cisalhamento longitudinal é o que mais frequentemente é atingido e está relacionado com a resistência da interface aço-concreto. Em geral, a limitação dos deslocamentos e a resistência da interface aço-concreto são os fatores mais restritivos no dimensionamento de lajes mistas. 
A ligação entre o aço e o concreto em lajes mistas é geralmente promovida pela adesão, intertravamento mecânico, atrito e conectores de cisalhamento (quando presentes). Mossas prensadas na fôrma metálica são dispositivos de conexão de cisalhamento eficientes e muito empregados, conforme ilustrado na Figura 1.3 (b), (c) e (d). No entanto, essas mossas são projetadas especificamente para cada tipo de fôrma e dependentes do fabricante, o que dificulta a previsão teórica do comportamento da ligação aço-concreto ao cisalhamento, pois depende de vários parâmetros inter-relacionados, como a geometria e localização das mossas, assim como da geometria e rigidez da própria fôrma de aço. Diante disto, a resistência da interface aço-concreto de lajes mistas é avaliada por meio de ensaios experimentais necessariamente realizados para cada tipo de fôrma.

Os métodos de cálculo normatizados para a determinação da resistência ao cisalhamento longitudinal de lajes mistas são semi-empíricos, cujos parâmetros empregados são obtidos por meio de ensaios de flexão normatizados que utilizam protótipos em escala real. O método denominado internacionalmente de Método $m$ - $k$ é aplicado tanto para lajes de comportamento frágil quanto para lajes de comportamento dúctil. O Método da Interação Parcial é aplicado apenas para lajes cujo comportamento é considerado dúctil.

A necessidade de realização de ensaios empregando um conjunto de protótipos em escala real torna onerosa e demorada a utilização dos métodos normatizados para a caracterização das lajes mistas em cada caso quando objetiva-se desenvolver novos modelos ou estudar a eficácia de fôrmas metálicas. Além disso, nem todos os parâmetros que influenciam o comportamento da interface aço-concreto são efetivamente avaliados nestes ensaios de flexão.

Nas últimas quatro décadas alguns autores propuseram ensaios que utilizam protótipos de pequenas dimensões com o objetivo de melhor investigar o comportamento da interface e empregar os resultados experimentais em métodos teóricos para a determinação da resistência ao cisalhamento longitudinal de lajes mistas. Tais ensaios também já foram utilizados com o objetivo de extrair parâmetros para modelar o comportamento da interface aço-concreto em simulações numéricas que empregaram o Método dos Elementos Finitos (MEF) para avaliar a resistência da laje mista e o seu comportamento estrutural, complementando, assim, as análises teóricas e experimentais.

Entretanto, devido à complexidade do comportamento da interface aço-concreto de lajes mistas e da variabilidade de fôrmas disponíveis, ainda são necessários estudos para avaliar a empregabilidade dos resultados fornecidos pelos ensaios de modelos de pequenas dimensões devido às suas limitações, uma vez que estes ensaios são incapazes de simular todos os fenômenos que ocorrem simultaneamente na interface de uma laje mista sob flexão. 


\subsection{Objetivos}

\subsubsection{Objetivo Geral}

O objetivo geral do presente trabalho consiste em analisar o comportamento da interface aço-concreto de lajes mistas.

\subsubsection{Objetivos Específicos}

Os objetivos específicos são:

- Verificar a aplicabilidade do ensaio de pequenas dimensões slip-block para a análise do comportamento da interface aço-concreto quanto ao cisalhamento longitudinal;

- Desenvolver uma nova metodologia para a caracterização da interface aço-concreto por meio do ensaio slip-block realizado sob carregamento vertical constante;

- Analisar e classificar experimentalmente o comportamento da laje mista submetida ao ensaio de flexão;

- Desenvolver uma metodologia para empregar os resultados obtidos do ensaio slip-block na modelagem numérica da interface aço-concreto da laje mista;

- Elaborar um modelo numérico de interface representativo por meio da simulação numérica dos ensaios slip-block e de flexão;

- Realizar uma análise paramétrica do modelo numérico validado da laje mista estudada.

\subsection{Justificativa}

Uma vez que o cisalhamento longitudinal é o fenômeno que frequentemente governa a capacidade resistente das lajes mistas de aço e concreto, sua correta avaliação qualitativa e quantitativa é importante a fim de promover segurança e otimização estrutural. Além disso, devido à complexidade do comportamento da interface aço-concreto e sabendo que geralmente a carga máxima que determina o estado limite último de cisalhamento longitudinal é consideravelmente inferior àquela que determina o estado limite último à flexão, estudos para avaliar efetivamente o comportamento da interface são necessários a fim de proporcionar melhor aproveitamento da ação mista da laje, assim como desenvolver novos métodos e tecnologias que otimizem tal estrutura.

Alguns trabalhos mais recentes presentes na literatura técnica têm abordado o emprego de novos materiais em lajes mistas, porém não se concentraram em aprofundar o conhecimento 
existente sobre os fenômenos presentes na interface aço-concreto. Contudo, como a resistência da interface determina a capacidade última das lajes mistas na grande maioria dos casos, o emprego de outros tipos de concreto ou de aço não promove um impacto considerável sobre a resistência e o comportamento da laje mista, se nenhum aperfeiçoamento na ligação açoconcreto for realizado.

Neste aspecto se destacam os ensaios de modelos de pequenas dimensões, que podem fornecer resultados interessantes sobre a interface aço-concreto e possibilitar a compreensão de determinados fenômenos físicos que não são explicitamente verificados no ensaio de flexão em escala real, mas que se desenvolvem nas lajes mistas. Além disso, a necessidade de realização de ensaios de flexão em escala real para a obtenção de parâmetros a serem utilizados nos métodos de cálculo normatizados, como já mencionado, é um fato que torna onerosa e longa a caracterização da interface aço-concreto das lajes mistas, pois cada tipo de fôrma deve ser avaliado separadamente por meio de uma série desses ensaios.

Sendo assim, a aplicação de ensaios de dimensões menores, que analisem eminentemente o comportamento da interface, aliados a métodos analíticos e/ou numéricos, são soluções plausíveis de serem empregadas para melhorar o entendimento dos fenômenos que ocorrem no elemento estrutural e auxiliar o desenvolvimento de novas fôrmas de aço, mobilizando menos recursos.

Alguns ensaios para avaliar o cisalhamento longitudinal que constam na literatura técnica são do tipo pull-out, push-out, push-off e slip-block, que consistem basicamente em promover o deslizamento do concreto em relação à fôrma de aço ou vice-versa, conforme o caso. Adicionalmente, novas metodologias de ensaio foram desenvolvidas recentemente por meio da adaptação de ensaios existentes. Todos foram projetados para investigar o comportamento e a resistência da interface aço-concreto, além de extrair parâmetros a serem utilizados em métodos analíticos e/ou em simulações numéricas.

Devido ao arranjo desses ensaios, não é considerado o efeito da curvatura e da separação vertical que ocorrem em lajes mistas submetidas à flexão e que interfere na resistência ao cisalhamento longitudinal. Entretanto, modelos analíticos e numéricos que empregam parâmetros extraídos dos ensaios de modelos de pequenas dimensões têm apresentado boas concordâncias com os resultados provenientes dos ensaios em escala real, indicando que os modelos de dimensões reduzidas são aplicáveis e devem ser melhor explorados.

A análise numérica de estruturas, em geral, auxilia no entendimento do comportamento estrutural e permite avaliar a interferência de demais parâmetros e características que podem 
ser modificados na análise sem grandes custos e dificuldades, quando comparada à uma análise experimental.

No caso da simulação numérica de lajes mistas, a maior dificuldade consiste na modelagem da interface aço-concreto devido à complexidade do seu comportamento e da variabilidade de tipologias de fôrmas de aço existentes. Diante disso, geralmente recorre-se à resultados experimentais para obter determinados parâmetros a serem empregados no modelo numérico da interface. Tais parâmetros são obtidos por meio de ensaios de flexão em escala real ou ensaios de modelos de pequenas dimensões.

A análise numérica se torna, portanto, uma ferramenta relevante para investigar o comportamento das lajes mistas, sobretudo da interface aço-concreto, pois é possível complementar a análise experimental e reduzir a necessidade da realização de ensaios de flexão em escala real quando o objetivo é a análise prévia para o desenvolvimento de um novo tipo de fôrma ou a inclusão de um novo componente.

$\mathrm{O}$ presente trabalho consiste num estudo que empregou análises experimentais e numéricas com a finalidade de avaliar o comportamento da interface aço-concreto de uma laje mista utilizando ensaios de modelos de pequenas dimensões. A análise experimental consistiu na investigação do comportamento da interface aço-concreto por meio da realização do ensaio de cisalhamento denominado slip-block e do ensaio de flexão a quatro pontos, preconizado pelas normas vigentes. A análise numérica consistiu na simulação desses dois tipos de ensaios, empregando um modelo de interface que utiliza os parâmetros obtidos experimentalmente por meio do ensaio slip-block. Dessa forma, desenvolveu-se uma metodologia que aplica os resultados oriundos do ensaio slip-block para a modelagem da interface aço-concreto, promovendo a simulação do comportamento estrutural da laje mista.

\subsection{Metodologia Adotada}

A metodologia de pesquisa adotada neste trabalho consiste numa fundamentação teórica acerca do tema abordado e em análises experimentais e numéricas desenvolvidas para atingir os objetivos estabelecidos.

A fundamentação teórica estabelece o conhecimento científico já desenvolvido acerca do comportamento estrutural das lajes mistas e dos fenômenos que ocorrem na interface açoconcreto, sendo apresentadas as principais pesquisas até então realizadas e presentes na literatura. Também são abordados os tipos de ensaios experimentais que constam na literatura técnica para a análise da interface de lajes mistas, assim como os métodos analíticos normativos. 
A análise experimental consistiu na realização de quatro ensaios de cisalhamento slipblock e dois ensaios de flexão em escala real da laje mista. Um dos modelos do ensaio slipblock foi ensaiado seguindo a metodologia desenvolvida pelos autores do ensaio, enquanto que os outros três foram ensaiados sob força confinante constante, porém com magnitudes diferentes aplicadas em cada modelo. Por meio dos ensaios slip-block sob força confinante constante, definiu-se o comportamento da interface aço-concreto ao cisalhamento direto e desenvolveu-se uma metodologia para a definição dos parâmetros da interface com base nos resultados experimentais.

Os ensaios em escala real permitiram definir o comportamento estrutural da laje mista, caracterizá-la segundo as prescrições normativas vigentes, correlacionar o comportamento da interface sob flexão com o observado no ensaio slip-block e fornecer modelos que serviram de referência para a simulação numérica realizada.

A análise numérica empregando elementos finitos foi realizada utilizando como ferramenta o pacote computacional de análise estrutural DIANA ${ }^{\circledR}$, versão 9.6, que emprega o Método dos Elementos Finitos (MEF). Simulou-se o ensaio slip-block e o ensaio de flexão utilizando um modelo de interface que empregou os parâmetros obtidos por meio da metodologia desenvolvida, que utilizou resultados experimentais do ensaio slip-block. Dessa forma, analisou-se a influência de cada parâmetro do modelo de interface sobre o comportamento dos modelos simulados e realizou-se suas respectivas validações com base nos resultados dos protótipos experimentais. Por fim, realizou-se uma análise paramétrica do modelo da laje mista do ensaio de flexão para analisar a influência do comprimento de cisalhamento da laje, da espessura da capa de concreto, da espessura da fôrma de aço e da resistência ao escoamento do aço da fôrma.

\subsection{Organização da Dissertação}

Esta dissertação está estruturada em 8 capítulos, organizados de modo a melhor apresentar o desenvolvimento do trabalho realizado. Neste capítulo são apresentados o contexto e a motivação do trabalho, expondo as definições e características das estruturas mistas e das lajes mistas. Além disso, apresenta-se a justificativa do estudo sobre o comportamento da interface aço-concreto de lajes mistas, além dos objetivos e da metodologia da pesquisa.

O Capítulo 2 descreve os fenômenos que se desenvolvem na interface aço-concreto de lajes mistas, expondo informações importantes obtidas da literatura técnica e fundamentando o estudo realizado. 
O Capítulo 3 explica o comportamento e a classificação das lajes mistas quando submetidas ao ensaio de flexão normatizado. Dessa forma, é feita uma correlação dos fenômenos descritos no Capítulo 2 com o comportamento observado durante o ensaio, assim como são apresentados os possíveis modos de ruptura.

No Capítulo 4 são apresentados os ensaios de modelos de pequenas dimensões, presentes na literatura, desenvolvidos para analisar e caracterizar a interface aço-concreto de lajes mistas. Estes ensaios estão organizados em ordem cronológica e de acordo com o respectivo autor. Também são ressaltadas algumas considerações sobre esses ensaios. Além disso, cita-se as pesquisas realizadas no Brasil envolvendo lajes mistas.

O Capítulo 5 descreve os métodos de cálculo normatizados para determinação da resistência ao cisalhamento longitudinal de lajes mistas, que são constantemente mencionados ao longo da dissertação. Adicionalmente, realizou-se uma comparação das considerações preconizadas pelas principais normas nacional e internacionais.

A análise experimental é apresentada no Capítulo 6. Descreve-se a laje mista estudada, a caracterização dos materiais empregados e os procedimentos adotados nos ensaios slip-block e de flexão. A nova metodologia para obtenção de parâmetros por meio do ensaio slip-block é descrita. Os resultados experimentais são apresentados e discutidos, assim como são correlacionados com os fenômenos descritos nos Capítulos 2 e 3.

O Capítulo 7 descreve a análise numérica desenvolvida. Inicialmente é realizada uma revisão bibliográfica, com ênfase nas técnicas de modelagem, de trabalhos recentes da literatura técnica que realizaram simulações numéricas de lajes mistas empregando o MEF. São apresentados o pacote computacional utilizado e os aspectos da simulação numérica realizada neste trabalho. As análises numéricas do ensaio slip-block e do ensaio de flexão são apresentadas, descrevendo a metodologia utilizada. Em cada caso os resultados numéricos são discutidos e comparados aos experimentais. Por fim, realizou-se a análise paramétrica do modelo numérico validado.

No Capítulo 8, finalmente, são apresentadas as conclusões do trabalho, considerando os resultados das análises numérica e experimental realizadas, assim como as metodologias utilizadas. Algumas sugestões para pesquisas futuras também são mencionadas. 



\section{CAPÍTULO 2 - A INTERFACE AÇO-CONCRETO DE LAJES MISTAS}

A compreensão dos fenômenos que ocorrem na interface de lajes mistas de aço e concreto é fundamental para o desenvolvimento do trabalho científico em estruturas mistas. Neste capítulo são apresentadas informações relevantes da literatura técnica sobre a interface aço-concreto no que diz respeito à ligação, transferência de cisalhamento e mecanismos de deslizamento entre os dois materiais.

\subsection{Ligação Aço-Concreto}

No estudo da interface aço-concreto de uma estrutura mista é importante a distinção dos conceitos de conexão e interação. Segundo Calado e Santos (2010):

- A conexão é definida como o sistema utilizado para garantir que os materiais trabalhem solidariamente e está diretamente relacionada com a força longitudinal resistente da interface;

- A interação caracteriza o elemento estrutural quanto ao deslocamento relativo entre os materiais.

O Eurocode 4: 2004 cita que um comprimento de uma laje mista tem conexão de cisalhamento total quando o aumento na resistência da conexão longitudinal de cisalhamento não aumentaria a resistência à flexão do elemento. Caso contrário, a conexão de cisalhamento é considerada parcial.

A interação e a conexão são dependentes uma da outra, uma vez que um elemento estrutural com elevado grau de conexão apresenta resistência ao cisalhamento longitudinal para garantir que a ruptura não ocorra devido ao deslizamento entre os materiais. Contudo, o deslizamento está relacionado também com a rigidez do sistema de conexão, pois este pode ser suficientemente resistente, porém consideravelmente dúctil, gerando deslizamentos relativos.

Uma vez que um elemento estrutural misto composto por aço e concreto é formado pela interligação destes materiais, seu comportamento solidário é garantido pela resistência da conexão existente entre eles e ocorre sob interação total, ou seja, sem a ocorrência de deslizamento relativos. Por outro lado, um elemento composto por dois ou mais materiais com conexão nula (desprezando a ligação química entre os materiais) não possui comportamento solidário e os materiais resistem ao esforço solicitante de maneira independente, verificando-se deslizamentos relativos entre eles, o que caracteriza a interação nula. 
Um elemento estrutural misto com conexão parcial promove, também, interação parcial. Sendo assim, de acordo com Fontes (2016), espera-se que a ruptura deste elemento ocorra devido a falha da conexão, permitindo deslizamento entre os materiais, que são parcialmente explorados à flexão neste caso. A Figura 2.1 e a Figura 2.2 ilustram as diferenças relativas aos graus de conexão e de interação entre os materiais constituintes de uma estrutura mista de aço e concreto. A Figura 2.3 destaca a configuração das deformações para cada caso apresentado na Figura 2.2, sendo $\varepsilon_{\text {concreto }}$ e $\varepsilon_{\text {aço }}$ as deformações do concreto e do aço, respectivamente.

Figura 2.1 - Influência do grau de conexão

Conexão nula

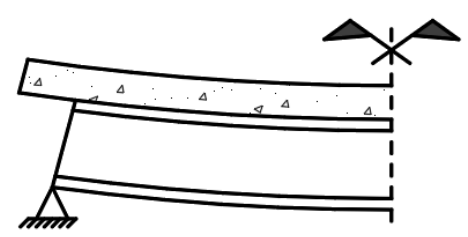

Conexão parcial

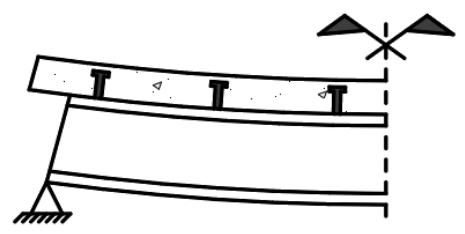

Conexão total

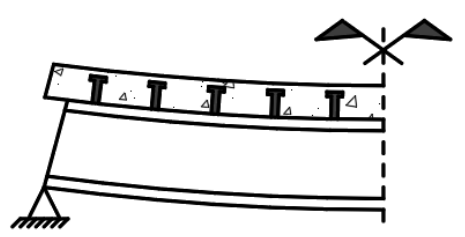

Fonte: Adaptado de CALADO; SANTOS, 2010

Figura 2.2 - Influência do grau de interação

Interação nula

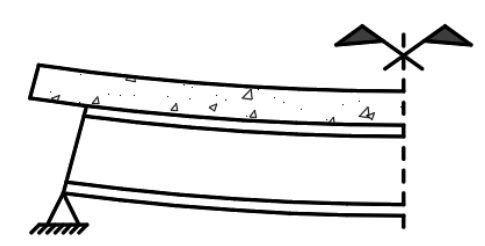

Interação parcial

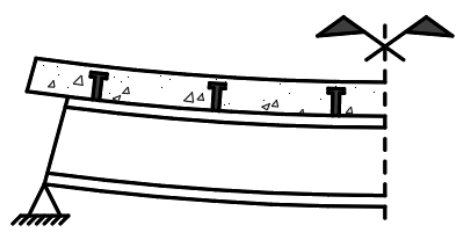

Interação total

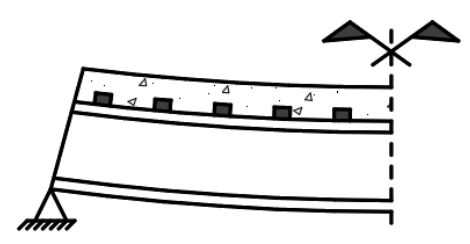

Fonte: Adaptado de CALADO; SANTOS, 2010

Figura 2.3 - Distribuição das deformações de acordo com o tipo de interação

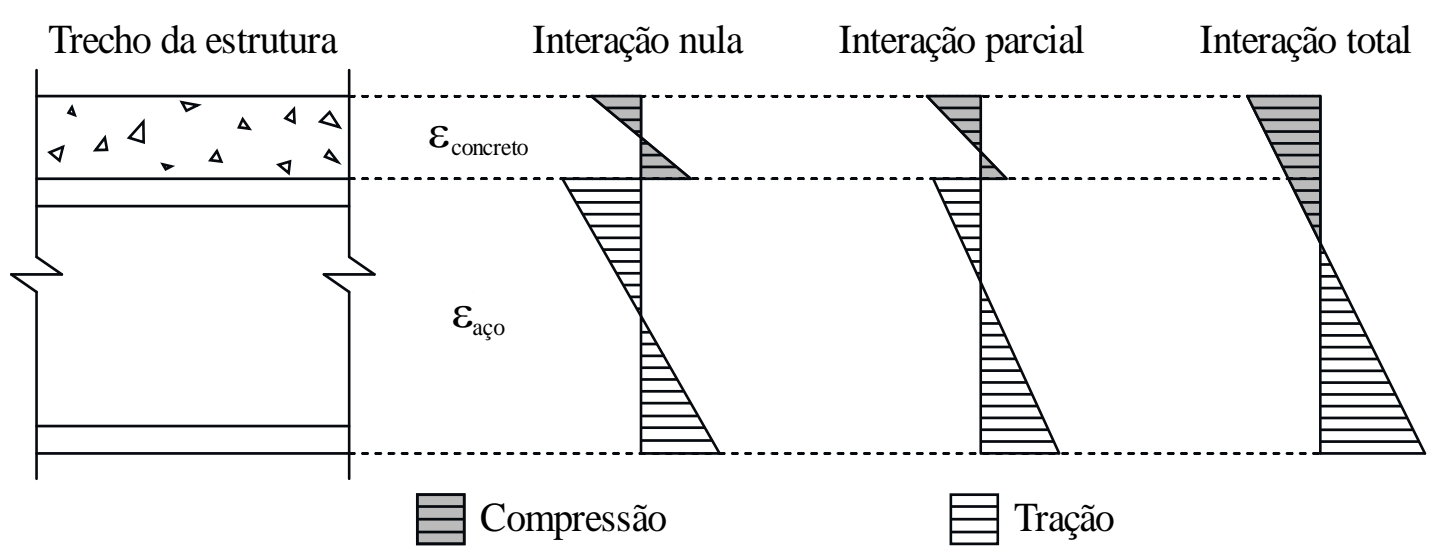

Fonte: Autoria própria 
Para elementos mistos de aço e concreto o comportamento da interface e a interação parcial tem uma relação estreita entre si. Portanto, é ideal que o comportamento das estruturas mistas seja próximo da conexão total, garantindo que os materiais trabalhem em conjunto, e que ocorra interação total ou elevada entre eles, possibilitando aproveitar a associação dos materiais de uma forma mais eficiente.

Se os dispositivos de conexão tiverem a capacidade de resistir às forças de cisalhamento que ocorrem na interface, o elemento estrutural misto atingirá sua capacidade máxima mantendo-se em conexão total. Caso contrário, se os conectores forem insuficientes para resistir à força de cisalhamento, então a capacidade estrutural do elemento estará limitada pela resistência da conexão entre os materiais e o elemento estará em conexão parcial.

Devido à deformabilidade dos conectores, quando o elemento estrutural é solicitado à flexão, verificar-se-ão deslocamentos relativos entre os materiais, influenciando a rigidez e a deformação do elemento estrutural (FONTES, 2016, p. 11). Se os conectores forem resistentes e flexíveis, o elemento estrutural atinge a sua capacidade máxima sob interação parcial. Todavia, se os conectores forem rígidos, sendo suas deformações desprezíveis, a capacidade máxima do elemento estrutural é atingida sob interação total.

\subsection{Transferência de Cisalhamento}

O desenvolvimento de uma fôrma de aço para uma laje mista deve considerar a conexão entre a fôrma e o concreto circundante de modo a melhorar a ligação aço-concreto, assim como a capacidade de suportar o concreto fresco e demais carregamentos durante a fase de construção. O desempenho da ligação aço-concreto depende dos mecanismos de transferência de cisalhamento longitudinal.

A ligação química, a ligação por atrito e a ligação mecânica são os principais mecanismos de transferência de cisalhamento entre a fôrma de aço e o concreto em lajes mistas, contribuindo, portanto, na resistência ao cisalhamento da interface.

A ligação química (chemical bond) é considerada a ligação resultante da aderência química da pasta de cimento à chapa de aço. Essa ligação ocorre apenas quando existe interação total entre ambos os materiais. Inicialmente o cisalhamento longitudinal é transferido através da interface aço-concreto por meio da ligação química. Quando essa ligação é quebrada, o deslizamento relativo é iniciado e a resistência da ligação química torna-se nula e não retorna a existir. 
Apesar de poder alcançar valores significativos, a magnitude da ligação química é fortemente influenciada pelas condições da superfície da fôrma de aço durante a concretagem e pode ser danificada na ocorrência de carregamento repetitivo. Além disso, possui natureza frágil, uma vez que se rompe de maneira repentina numa fase inicial de carregamento. Logo, a contribuição da ligação química sobre a resistência da interface é comumente desprezada.

Neste contexto é importante destacar que Burnet e Oehlers (2001) realizaram uma pesquisa experimental empregando um tipo de ensaio de deslizamento chamado push-test e verificaram que a resistência da ligação química é função da geometria da nervura e, portanto, não é predominantemente uma propriedade adesiva, como é usualmente assumida, mas principalmente uma propriedade mecânica relacionada com a ação de descascamento do concreto.

A ligação por atrito (frictional bond) ocorre devido a existência de rugosidades nas superfícies dos materiais e se manifesta quando há tendência de deslizamento relativo entre o aço e o concreto. Está relacionada com as pressões internas desenvolvidas na interface, de modo que quanto maiores essas pressões, maior a parcela de resistência ao cisalhamento proveniente da ligação por atrito. Nesse aspecto, Chen e Shi (2011) afirmam que a ligação por atrito é diretamente proporcional à força normal atuante perpendicularmente à interface aço-concreto. Sendo assim, essa ligação é afetada pelo peso próprio da laje e pela sobrecarga, tornando-se mais significativa na região onde forças transversais à interface são aplicadas, principalmente nas regiões de apoio.

Ferrer, Marimon e Crisinel (2006) afirmam que várias razões podem influenciar o coeficiente de atrito da interface aço-concreto de lajes mistas (o que consequentemente interfere na ligação por atrito da interface), como tipo do cimento, dosagem do concreto, tipo e dimensões dos agregados, processos de cura e conformação, nível de umidade, entre outros. Contudo, com base nos resultados experimentais obtidos por meio de ensaios de deslizamento do tipo pull-out, os autores afirmaram que o acabamento da superfície da fôrma de aço é um fator crucial que influencia o coeficiente de atrito da interface.

Adicionalmente, Fontes (2016) descreve que quando o concreto é submetido a um esforço, deforma-se sendo encurtado segundo um eixo e expandido segundo eixos ortogonais devido ao efeito de Poisson, gerando, assim, tensões normais à interface aço-concreto que aumentam a ligação por atrito.

A ligação mecânica (mechanical bond) existe devido ao intertravamento físico entre a fôrma de aço e o concreto proporcionado pelos relevos presentes na superfície da fôrma de aço, como mossas e indentações. Esse mecanismo de transferência de cisalhamento mobiliza forças 
localizadas que promovem resistência ao deslizamento relativo entre os materiais e melhora sua conexão.

As principais vantagens das mossas e indentações são a facilidade e a velocidade com que podem ser produzidas, uma vez que são executadas por meio de prensagem da chapa de aço, que posteriormente é dobrada para se obter o perfil desejado.

Uma vez que a ligação química é negligenciada, as ligações por atrito e mecânica são mais relevantes na transferência de cisalhamento longitudinal, sendo essa última a que confere a maior parcela de resistência à interface, em geral. Contudo, a resistência de cada solução é variável de acordo com o sistema de conexão utilizado. Logo, a resistência da interface de cada solução é avaliada por meio de ensaios experimentais devido à variabilidade existente de mossas e à complexidade do comportamento da interface aço-concreto de lajes mistas.

Tanto a ligação por atrito quanto a ligação mecânica tratam de irregularidades na superfície dos materiais, porém a primeira em escala microscópica e a segunda em escala macroscópica. O intertravamento físico entre a fôrma de aço e o concreto é desenvolvido como resultado da ação conjunta da curvatura proveniente da flexão da fôrma de aço, do atrito entre esta e o concreto (devido à rugosidade da superfície) e do travamento promovido pelas mossas. A Figura 2.4 destaca alguns sistemas de conexão de cisalhamento comumente empregados em lajes mistas.

Figura 2.4 - Sistemas de conexão de cisalhamento em lajes mistas
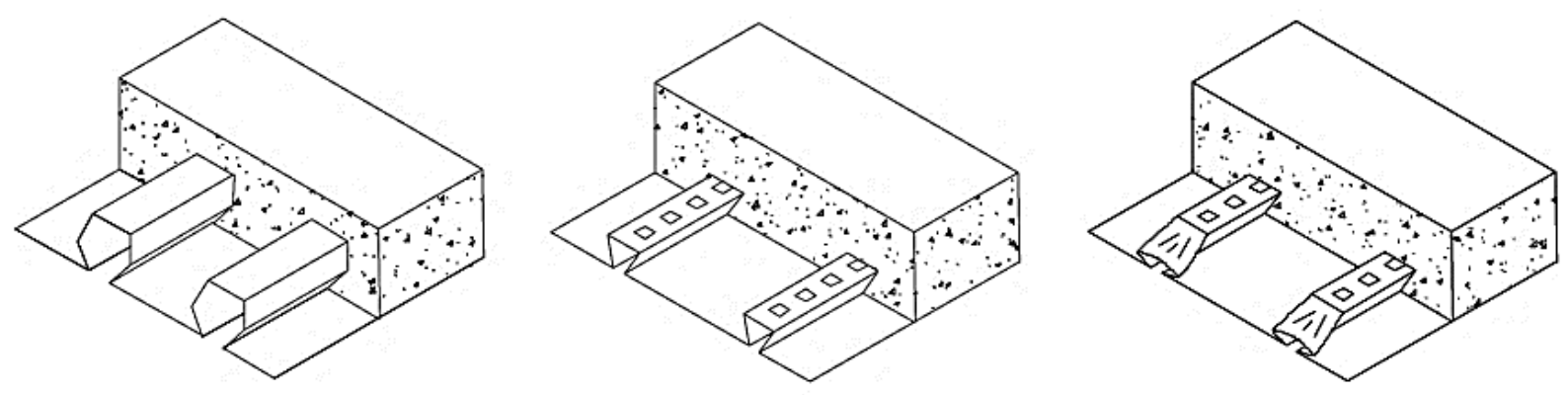

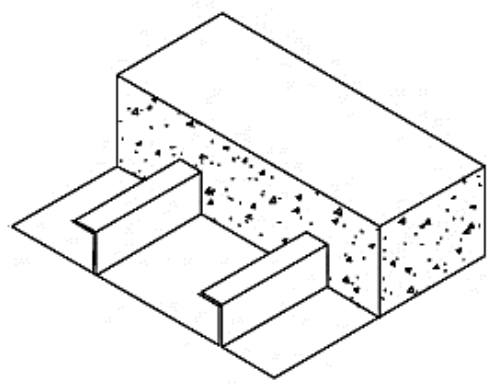

a) Ligação por atrito

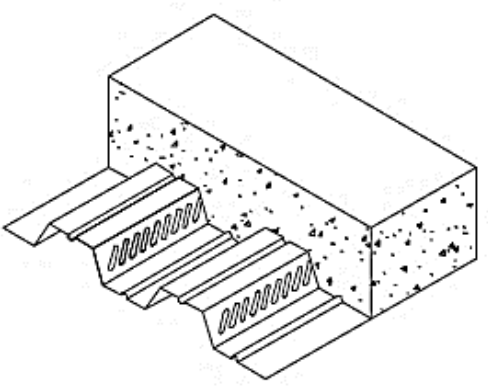

(b) Ligação mecânica

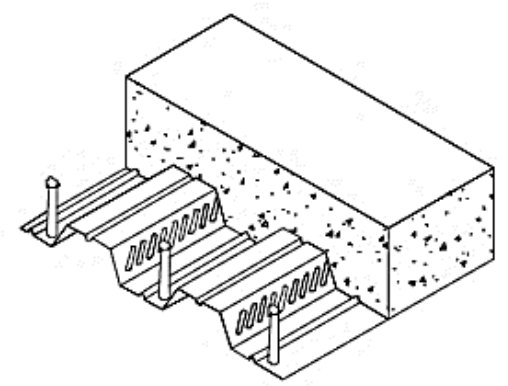

(c) Ligação mecânica e ancoragem de extremidade

Fonte: Adaptado de ABDULLAH, 2004 
O correto conhecimento sobre a transferência do cisalhamento longitudinal entre a fôrma de aço e o concreto por meio dos elementos conectores de cisalhamento é de grande importância para o desenvolvimento de novas configurações de fôrmas de aço, pois isso afeta significativamente a capacidade resistente das lajes mistas.

A ABNT NBR 8800: 2008 e o Eurocode 4: 2004, assim como outras normas, não permitem a consideração efetiva da ligação química entre o aço e o concreto. A norma brasileira estabelece que a transmissão de cisalhamento para garantir o comportamento misto deve ser efetuada por meio de ligação mecânica (empregando mossas) nas fôrmas de aço trapezoidais e por meio de ligação por atrito (devido ao confinamento do concreto) nas fôrmas de aço reentrantes, conforme ilustrado a Figura 2.4 (b), porém permite o uso de outros meios para garantir o comportamento misto.

As ancoragens de extremidade são outros sistemas mecânicos empregados, como o uso de conectores tipo stud (ou por outro tipo de dispositivo de ligação entre o concreto e a fôrma de aço) e obtidos por meio da deformação das nervuras na extremidade da fôrma, conforme ilustrado na Figura 2.4 (c). O primeiro caso se aplica às fôrmas trapezoidais e reentrantes, enquanto o segundo caso se aplica apenas às fôrmas reentrantes.

Em relação às ancoragens de extremidade que empregam conectores tipo pino de cabeça (stud bolt), Chen e Shi (2011) citam que, para permitir uma ancoragem de extremidade efetiva, é o deslizamento da ligação de cisalhamento em vez da resistência dos studs ancorados que governam a contribuição dos conectores de extremidade à resistência ao cisalhamento das lajes mistas. Eshwari et al. (2017) destacam que o emprego de conectores de cisalhamento possui muitas vantagens como o custo-benefício, confiabilidade e desempenho seguro sob tensões estáticas e dinâmicas, alta ductilidade e melhor capacidade resistente à flexão da laje mista.

Nos trabalhos experimentais realizados por Bode e Minas (1997), Chen (2003), Chen, Shi e Qiu (2011), Rana, Uy e Mirza (2015) e Eshwari et al. (2017) constatou-se que o emprego de conectores de extremidade do tipo stud em lajes mistas sob flexão promoveu comportamento dúctil e aumento na capacidade resistente. Além disso, em alguns casos se observou aumento da rigidez do elemento estrutural.

De acordo com Rana, Uy e Mirza (2015), a ancoragem de extremidade é geralmente mais flexível que o comportamento relativamente frágil da interface aço-concreto, o que torna possível que a resistência da ancoragem de extremidade não seja totalmente mobilizada quando a resistência última ao cisalhamento longitudinal é atingida. 
A resistência da interface ao cisalhamento longitudinal, segundo Abdullah e Easterling (2009), depende de muitos fatores, entre os quais incluem a forma do perfil da fôrma de aço, tipo e frequência de mossas, espessura da chapa de aço, configuração do carregamento, comprimento do vão de cisalhamento, espessura do concreto, tensão na fôrma de aço, atrito de apoio, travamento natural devido à curvatura sob flexão e tipo de ancoragem de extremidade. Além disso, o comportamento da interface também é influenciado pelas condições de construção como: temperatura do concreto fresco, tipo de aço, umidade relativa do ambiente, processo de cura do concreto, natureza e forma dos agregados.

No que se refere à influência do processo de fabricação da fôrma de aço sobre o comportamento da laje mista, Veljkovic (1996) estudou o efeito da laminação a frio sobre as propriedades do material da fôrma de aço. Segundo o autor, esse efeito deve ser considerado nas dobras da fôrma de aço e na parte ondulada da alma (onde as mossas estão localizadas). Os efeitos do dobramento dependem da magnitude das deformações plásticas causadas no processo de formação e incluem o aumento das resistências ao escoamento e última, perda do patamar de escoamento e redução da ductilidade. As mossas reduzem consideravelmente a rigidez axial da região ondulada, pois as deformações de flexão são somadas às deformações oriundas do achatamento das mossas, segundo o autor.

Veljkovic (1996) também estudou os efeitos das deformações da fôrma de aço sobre a transferência de cisalhamento na interface aço-concreto por meio de ensaios de modelos de pequenas dimensões, principalmente o tension push-test, apresentado na seção 4.10. O autor constatou que a presença de grandes deformações na chapa de aço constituinte da fôrma, assumindo a ocorrência de deslizamento relativo, causa uma redução do intertravamento mecânico para fôrmas com mossas. A magnitude desta redução depende do nível de deformação e da magnitude do deslizamento. Na fôrma analisada por Veljkovic (1994), as mossas existentes (em forma de V) nas almas dos perfis reduziram a tensão de escoamento efetiva e o módulo de elasticidade a $47 \%$ dos valores originais da chapa plana de aço.

Ferrer (2005) realizou um intenso estudo experimental e numérico sobre a interação entre o aço e o concreto em lajes mistas. Foram realizados ensaios de flexão e do tipo pull-out (seção 4.5). Comprovou-se tanto nos modelos numéricos como nos ensaios de flexão instrumentados com extensômetros, que, a partir do primeiro deslizamento, a interação entre a fôrma de aço e o concreto provocou deformações no aço que excederam bastante o limite elástico, limitando a resistência ao cisalhamento. Segundo o autor, essas deformações são tipicamente associadas a dois fenômenos diferentes: a flexão transversal da fôrma de aço e o efeito cúpula nas mossas. 
O efeito da flexão transversal é explicado na seção 2.3. O chamado efeito de cúpula, por sua vez, está relacionado com a geração de tensões de membrana compressivas no topo da mossa e tração na base de seu entorno, podendo exceder a força de escoamento do aço, tendendo a causar um esmagamento da indentação no concreto.

Com relação à tensão de escoamento do aço, Hicks, Pennington e Jones (2014) realizaram um estudo experimental que avaliou a resistência ao cisalhamento longitudinal de lajes mistas empregando dois tipos de perfis trapezoidais, em que o único parâmetro variado foi a resistência ao escoamento do aço da fôrma. O comportamento ao cisalhamento longitudinal foi classificado como dúctil e o Método da Interação Parcial foi aplicado para determinar sua resistência. Diante dos valores fornecidos por esse método, verificou-se que as lajes mistas empregando a fôrma de aço de maior resistência ao escoamento apresentaram menor resistência ao cisalhamento longitudinal. Isso conflita com o requerimento do item B.3.1(4) do Eurocode:2004 para uma investigação reduzida, em que se emprega os resultados de lajes com fôrma de aço de menor tensão ao escoamento para a determinação da resistência ao cisalhamento longitudinal de lajes com fôrmas de aço de tensão de escoamento superior.

Em se tratando de modificações na fôrma de aço, a ligação aço-concreto pode ser melhorada por meio do tipo de aço, tratamento superficial, configuração das mossas e presença de ancoragens de extremidade. Além disso, como descrito na seção anterior, o comportamento estrutural do elemento é influenciado pela resistência e a rigidez da conexão existente entre o aço e o concreto. Neste aspecto, Venkat e Upadhyay (2008) citam que o intertravamento mecânico é parcialmente dependente da rigidez local da fôrma de aço e, portanto, as mossas estão melhor situadas próximas às seções mais rígidas do perfil.

Cheng, Yam e Davison (1994) realizaram um estudo experimental envolvendo dois tipos de fôrmas com o objetivo de avaliar os parâmetros que influenciam significativamente a resistência ao cisalhamento da ligação aço-concreto e as características das lajes mistas. Os ensaios realizados foram o de flexão a quatro pontos e ensaio do tipo pull-out. Avaliou-se a influência do comprimento de cisalhamento, do tipo de mossas e indentações, da posição do perfil, da altura das mossas, da direção de arrancamento relativa às mossas e do revestimento superficial. Os resultados indicaram que a resistência ao cisalhamento aumentou significativamente com o aumento da altura das mossas, sendo este considerado o fator dominante sobre o comportamento das lajes mistas. Para o tipo de mossa investigada (em forma de V), verificou-se a ruptura da ligação de cisalhamento na direção fraca do chaveamento. Constatou-se que o revestimento superficial também influenciou a ligação química da interface aço-concreto. 
Makelainen e Sun (1999) realizaram um estudo experimental empregando ensaios de deslizamento semelhante ao slip-block para avaliar a influência de algumas características da geometria da fôrma de aço. Os resultados dos ensaios indicaram que a resistência ao cisalhamento longitudinal das amostras foi significativamente afetada pela altura das mossas. O comprimento das mossas também influenciou a resistência ao cisalhamento, de modo que quanto maior o comprimento, maior a resistência. Todavia, quando as mossas possuíam um certo comprimento, a influência do seu aumento não foi significativa. Os autores também concluíram que a espessura da fôrma de aço teve um efeito significativo na rigidez dos modelos ensaiados.

No trabalho experimental desenvolvido por Burnet e Oehlers (2001) foi realizada uma análise paramétrica que avaliou a influência da geometria, mossas, espessura da fôrma e preparação da superfície. Foram analisadas fôrmas com perfis dos tipos trapezoidal e reentrantes (ambas com e sem a presença de mossas), de modo que os autores consideraram esses dois perfis como fazendo parte de uma família genérica a qual a largura da mesa superior $\left(b_{\mathrm{f}}\right)$ e a altura do perfil $(h)$ são mantidas constantes enquanto a abertura da nervura $\left(b_{\mathrm{r}}\right)$ era variável, conforme ilustra a Figura 2.5.

Figura 2.5 - Forma genérica de nervura considerada por Burnet e Oehlers (2001)

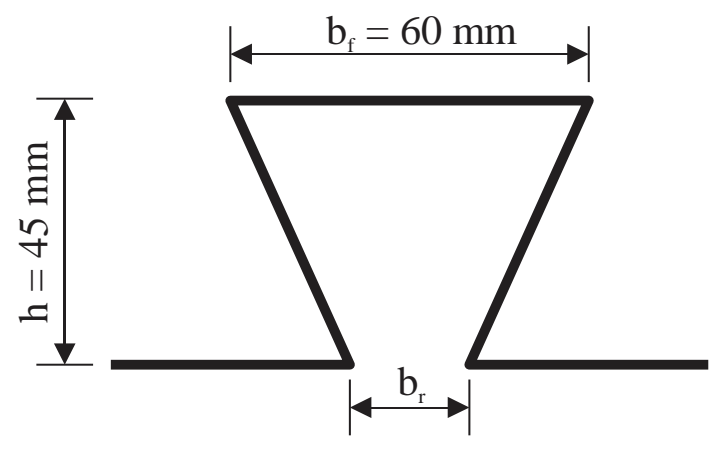

Fonte: Adaptado de BURNET; OEHLERS, 2001

Diante dos resultados, Burnet e Oehlers (2001) verificaram que a inclusão das mossas promoveu resistência residual após a quebra da ligação química. Além disso, os autores citam que o deslizamento referente à capacidade máxima de cisalhamento é função da geometria da mossa. Verificou-se que as mossas têm um efeito relativamente menor em amostras com pequenos valores de $b_{\mathrm{r}} / b_{\mathrm{f}}$, como ocorre em fôrmas reentrantes, mas que têm efeitos substanciais em amostras com grandes valores de $b_{\mathrm{r}} / b_{\mathrm{f}}$, como ocorre em fôrmas trapezoidais. $\mathrm{O}$ aumento da espessura aumentou significativamente a resistência da interface para todos os valores do parâmetro de forma $b_{\mathrm{r}} / b_{\mathrm{f}}$. A aplicação de um agente antiaderente às fôrmas com mossas não só destruiu a ligação química, mas também reduziu substancialmente a ligação de intertravamento. 
Tremblay et al. (2002) realizaram um estudo experimental por meio de ensaios de flexão em escala real e ensaios de modelos de pequenas dimensões de um tipo de push-out para avaliar a capacidade resistente da ligação aço-concreto de lajes mistas. Os autores verificaram a influência da espessura da chapa da fôrma de aço, a classe do aço, o revestimento superficial, a idade de cura do concreto e a presença de condutos elétricos na laje. As lajes com fôrmas de aço mais espessas apresentaram maior capacidade resistente, o que foi explicado pelo fato da maior rigidez das mossas à deformação, que implica em melhorias na ligação aço-concreto e em maior resistência à separação vertical, segundo os autores. Verificou-se que a ligação química é afetada pelas condições da superfície e que a presença de condutos elétricos tem impacto negativo sobre a capacidade resistente para lajes com vãos de cisalhamento curtos.

Ferrer, Marimon e Crisinel (2006) realizaram um estudo numérico empregando modelos formados por elementos finitos com o objetivo de avaliar a dependência do mecanismo de resistência ao cisalhamento em relação aos parâmetros geométricos de projeto. O concreto foi modelado como uma superfície rígida. Tais modelos foram validados utilizando os resultados de ensaios de deslizamento do tipo pull-out e de ensaios de flexão. Posteriormente fez-se uma análise paramétrica para avaliar a influência de cada característica considerada. Os autores concluíram o seguinte:

- Verificou-se uma dependência linear entre a resistência ao cisalhamento e coeficiente de atrito entre o aço e o concreto;

- Para todas as formas de perfis (trapezoidais e reentrantes), observou-se que o movimento de deslizamento entre a fôrma de aço e concreto produz forças de interação localizadas apenas nas extremidades das mossas, porque a fôrma de aço flete enquanto o concreto permanece reto.

- As extremidades de mossas longas, bem como as mossas pontuais, estão melhor localizadas perto das arestas do perfil e as mossas longas são melhores que as curtas, porque suas extremidades são forçadas a ficarem próximas das arestas, promovendo, também, maior inércia para resistir à flexão transversal;

- O declive da mossa mostrou-se ser o parâmetro mais significativo que afeta a resistência ao cisalhamento, pois variações de poucos graus causam grandes variações de resistência ao cisalhamento. No entanto, a melhoria da resistência ao cisalhamento é sempre alcançada em detrimento da ductilidade e a falha de descascamento do concreto limita esse parâmetro.

- Pode ser assumido que a resistência ao cisalhamento depende linearmente da espessura da chapa dentro da faixa usual de espessura, apesar de sua real dependência ser 
quadrática, mas perdendo parte da força real quando extrapolando resultados para valores de espessura maiores do que os testados;

- Foi encontrada dependência linear entre a resistência ao cisalhamento longitudinal e a altura da mossa, porém quando o aço está escoando através de toda a espessura da chapa, nenhuma melhoria de resistência é alcançada ao se aumentar a altura da mossa;

- A direção alternada de uma mossa para a próxima (para dentro/para fora) reduziu a dependência da resistência ao cisalhamento da direção de inclinação e, além disso, a rigidez à flexão transversal é melhorada, pois a inércia é aumentada.

No estudo experimental e numérico realizado por Abdullah e Eastering (2009), os autores verificaram que a ligação de cisalhamento das lajes mistas sob flexão variou de acordo com a esbeltez da laje, definida como o comprimento do vão de cisalhamento $\left(L_{\mathrm{s}}\right)$ do ensaio de flexão dividido pela altura da laje $(h)$, o que influenciou sua resistência e o seu comportamento.

Nos trabalhos experimentais desenvolvidos por Cifuentes e Medina (2013) e Waldmann, May e Thapa (2017), que realizaram ensaios de flexão, avaliou-se a influência da espessura da fôrma de aço, dentre outros aspectos. Em ambos os trabalhos, verificou-se que a espessura da fôrma de aço influenciou consideravelmente a resistência ao cisalhamento longitudinal, uma vez que esta aumentou com o acréscimo da espessura da chapa de aço, especialmente para as amostras de vãos longos. Quanto maior a espessura da fôrma, maior a rigidez de flexão, o que promove maior ligação entre o concreto e a fôrma de aço.

A densidade, resistência e idade de cura do concreto podem influenciar o desempenho da laje mista, segundo Abdullah (2004). Na literatura técnica, entretanto, verificam-se divergências sobre a influência da resistência do concreto sobre o desempenho das lajes mistas.

No estudo realizado por Tremlbay et al. (2002) verificou-se que, em geral, a resistência ao cisalhamento longitudinal das lajes mistas ensaiadas não foi influenciada pela resistência do concreto.

Yi et al. (2018) realizaram um estudo experimental empregando ensaios de deslizamento do tipo slip-block com lajes mistas de perfil reentrante utilizando o concreto convencional e o concreto com borracha triturada (crumb rubber concrete). Os resultados revelaram claramente que a resistência à compressão do concreto não afetou a resistência ao cisalhamento longitudinal da interface. Além disso, o protótipo feito de concreto com borracha triturada mostrou uma resistência de pico inicial maior associada a um maior deslizamento em comparação com a do protótipo feito com concreto simples. Os autores concluíram também que a ligação por atrito entre a fôrma e o concreto não é a parte crucial na resistência ao cisalhamento longitudinal. 
Ferrer (2005) verificou, por meio de ensaios realizados em diferentes laboratórios, que a resistência do concreto tem uma influência significativa sobre a resistência ao deslizamento, uma vez que a formação das ranhuras depende da erosão da superfície no trajeto de contato das extremidades das mossas. Além disso, Ferrer, Marimon e Crisinel (2006) afirmam que existe uma relação significante entre a resistência à compressão do concreto e as resistências ao cisalhamento determinadas por meio de ensaios do tipo pull-out, uma vez que as amostras fabricadas com concreto de maior resistência à compressão mostraram resistências maiores.

No trabalho realizado por Rana, Uy e Mirza (2015) verificou-se por meio da análise numérica que o efeito da resistência do concreto foi significante sobre o comportamento da curva da carga versus deslocamento vertical das lajes mistas avaliadas.

Em termos de projeto, considera-se o carregamento uniformemente distribuído sobre as lajes. Entretanto, as normas vigentes preconizam o ensaio de flexão a quatro pontos para a caracterização das lajes mistas quanto ao cisalhamento longitudinal. Diante disto, Soltanalipour et al. (2020) realizaram um trabalho experimental e numérico que compara os resultados destas duas configurações de carregamento.

As forças de contato existem nas três direções da interface (longitudinal, vertical e transversal). Com relação ao travamento vertical promovido pela interface aço-concreto, Soltanalipour et al. (2020) consideram que o travamento é positivo quando as forças verticais atuantes na interface são oriundas da situação em que o concreto é empurrado contra a fôrma de aço. A situação contrária, ou seja, quando o concreto tende a se afastar da fôrma de aço, é definida como travamento negativo. Ambas as situações contribuem para o aumento do efeito do atrito e, consequentemente, aumentam a resistência ao cisalhamento longitudinal.

No caso do ensaio de flexão a quatro pontos, segundo Soltanalipour et al. (2020), o carregamento aplicado é parcialmente transmitido à fôrma de aço localizada sob as regiões carregadas e resistido por ela devido à sua rigidez à flexão. Sendo assim, na região de apoio, o restante da força de cisalhamento transferida pelo concreto é transmitido para a fôrma de aço e para o apoio, equilibrando a força de reação total. Por outro lado, no ensaio com carregamento uniforme, a pressão aplicada é transferida progressivamente pela interface ao longo de todo o comprimento do vão.

Os resultados obtidos por Soltanalipour et al. (2020) indicaram que, no caso das lajes submetidas ao ensaio de flexão a quatro pontos, as forças de travamento positivo existem na região onde o carregamento externo é aplicado e na região de apoio. Já as forças de travamento negativo se desenvolveriam entre a fissura e o apoio, assim como entre fissuras no concreto, pois o concreto tende a permanecer quase reto enquanto a fôrma de aço se curva. 
No caso do ensaio com carregamento uniforme, Soltanalipour et al. (2020) explicam que as forças de travamento positivo estão presentes devido à transferência uniforme do carregamento, porém as forças de travamento negativo não se desenvolvem. A Figura 2.6 apresenta a distribuição das forças de travamento, segundo Soltanalipour et al. (2020), de acordo com o tipo de carregamento aplicado: concentrado ou distribuído.

Figura 2.6 - Distribuição das forças de travamento na laje mista de acordo com o tipo de carregamento aplicado

$\uparrow$ Força de travamento positivo $\quad \downarrow$ Força de travamento negativo

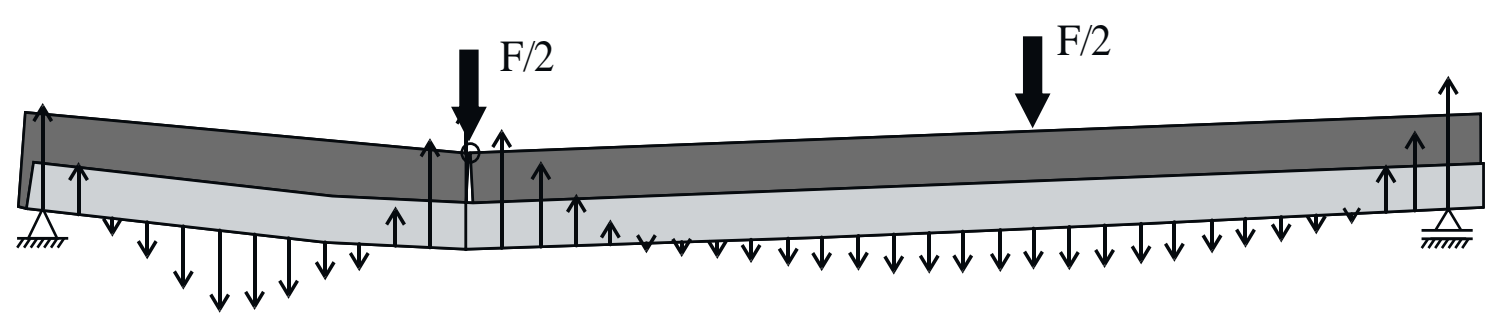

a) Carregamento do ensaio de flexão a quatro pontos

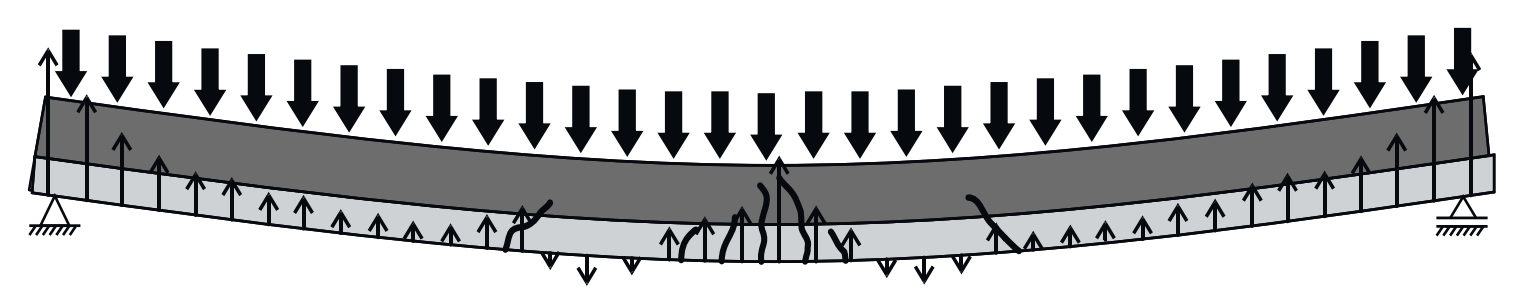

b) Carregamento uniformemente distribuído

Fonte: Adaptado de SOLTANALIPOUR et al., 2020

O travamento negativo em lajes com fôrma de perfil de reentrante pode ser considerável, devido à extensa superfície de contato e às grandes capacidades de retenção, razão pela qual a maior resistência ao cisalhamento dos perfis reentrantes convencionais em relação aos trapezoidais, de acordo com Soltanalipour et al. (2020).

Percebe-se, portanto, que a transferência de cisalhamento na interface aço-concreto em lajes mistas é um fenômeno complexo e variável de acordo com sua configuração, o que dificulta a elaboração de soluções analíticas para o problema. Entretanto, diante dos resultados e conclusões obtidas das pesquisas aqui descritas, nota-se convergência sobre a influência de alguns aspectos, como a espessura da chapa de aço da fôrma, a forma do perfil e a altura e comprimento das mossas. Estes aspectos influenciam a rigidez à flexão local e, consequentemente, o confinamento do concreto (influenciando a ligação por atrito) e a separação entre os dois materiais (influenciando as ligações mecânica e por atrito), assim como influencia a distribuição dos esforços na interface, conforme explicado a seguir. 


\subsection{Deslizamento}

A forma com que o aço e o concreto estão ligados, ou seja, interagem e transmitem esforços entre si, define o comportamento e a eficiência das lajes mistas. O mecanismo de deslizamento está estritamente relacionado com o mecanismo de transferência de cisalhamento, uma vez que a forma como os esforços são transmitidos na interface aço-concreto influencia a deformação e os deslocamentos dos dois materiais. Por outro lado, mediante a ocorrência dessas deformações e deslocamentos, a configuração dos esforços atuantes na interface muda.

Numa laje mista carregada, segundo Chen e Shi (2011), existem três estados para pontos arbitrários da interface aço-concreto, descritos a seguir: adesão, deslizamento e separação, conforme ilustrado na Figura 2.7. É definido que o contato de adesão é o estado quando a fôrma de aço e o concreto são contínuos em deslocamento em todas as direções. O deslizamento é o estado quando o deslocamento relativo da posição entre a fôrma de aço e o concreto aparece somente na direção tangencial. A separação é o estado em que os deslocamentos relativos ocorrem em direção arbitrária.

Figura 2.7 - Formas de contato na interface

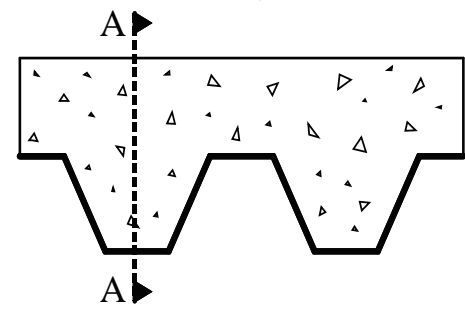

Seção transversal da laje mista

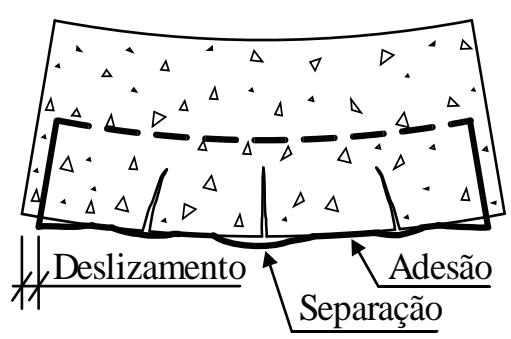

Corte A-A (Pequeno trecho)

Fonte: Adaptado de CHEN; SHI, 2011

Quando o esforço solicitante de cisalhamento é maior do que o esforço resistente das ligações química e por atrito, o deslizamento relativo é iniciado entre a fôrma de aço e o concreto. Chen e Shi (2011) afirmam que o deslizamento não é uniformemente distribuído ao longo de todo o comprimento de uma laje mista simplesmente apoiada, diminuindo gradualmente desde as extremidades até o meio do vão.

A presença de mossas na fôrma de aço contribui para resistir ao deslizamento relativo entre o aço e o concreto. Nesse caso, forças de contato $\left(F_{c}\right)$ se desenvolvem na interface açoconcreto das mossas e contribuem para a flexão local da fôrma de aço devido a sua espessura limitada. Para que o deslizamento ocorra, a indentação no concreto deve transpassar a mossa, o que, juntamente com a deformação da fôrma, causa a separação entre os dois materiais. A Figura 2.8 ilustra estes fenômenos num trecho da interface que contém mossas. 
Figura 2.8 - Forças de contato na superfície das mossas

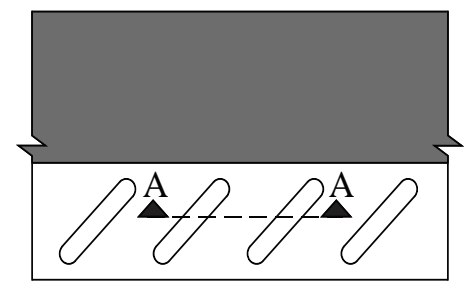

Trecho da Laje Mista

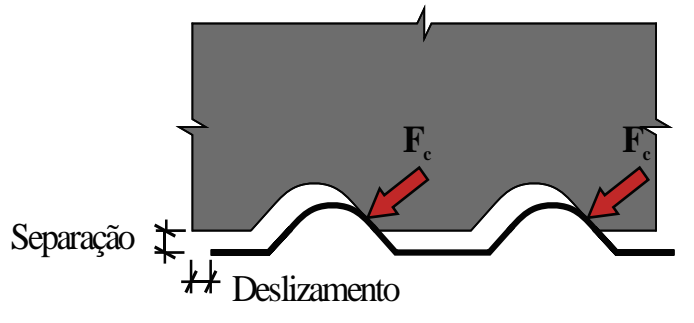

Corte A-A ampliado

Fonte: Autoria própria

A fim de desenvolver resistência ao cisalhamento, a fôrma de aço deve ser capaz de resistir a essas forças de contato e promover o equilíbrio de forças na interface. Sendo assim, a conexão deve ser capaz de resistir às forças que tendem a empurrar as mossas para fora do concreto.

As forças longitudinais de cisalhamento em fôrmas de perfil reentrante são resistidas pelo concreto localizado em torno das mossas. Dessa forma, o deslizamento entre as duas superfícies da interface só é possível se a fôrma se mover em relação ao concreto. Esse movimento é resistido pela nervura da fôrma, que está confinada e tende a resistir à deformação induzida pelas forças longitudinais de cisalhamento. Essa resistência à deformação da nervura da fôrma induz forças normais na interface que podem ser descritas como forças passivas, segundo Burnet (1998), pois não dependem diretamente de cargas aplicadas externamente.

Esse fenômeno causa a flexão local da fôrma de aço, o que reduz o efeito de travamento das mossas e, consequentemente, a resistência ao cisalhamento longitudinal. Dessa forma, a estabilidade global da laje mista é comprometida. A Figura 2.9 ilustra a configuração da seção transversal de uma laje mista com fôrma de perfil reentrante referente aos trechos sem e com reação de apoio.

Figura 2.9 - Configuração da seção transversal da laje mista com fôrma de perfil reentrante

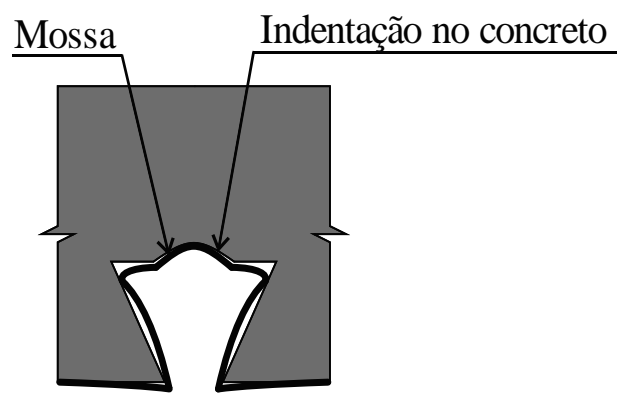

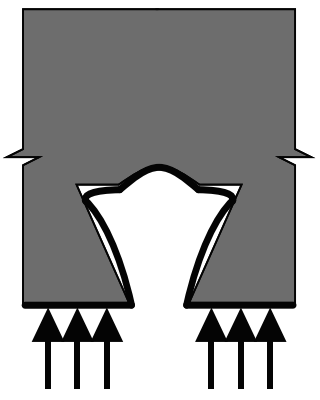

(b) Trecho com reação de apoio

Fonte: Autoria própria 
Nas lajes mistas com fôrmas de perfil reentrante, a forma do próprio perfil evita consideravelmente a elevação do bloco de concreto, conforme se observa na Figura 2.9. As forças de contato presentes na interface aço-concreto proporcionam o equilíbrio com as forças que atuam nas mossas. De acordo com Schuurman e Stark (2002), a presença da reação de apoio dificilmente influencia a resposta deste tipo de fôrma de aço, conforme ilustrado na Figura 2.9.

Waldmann, May e Thapa (2017) desenvolveram um trabalho experimental empregando concreto leve com lascas de madeira em lajes mistas com fôrmas de aço de perfil reentrante. $\mathrm{O}$ objetivo do trabalho foi analisar a capacidade resistente e a ação mista dessas lajes. Dois tipos de fôrmas foram avaliados: tipo A (com mossas apenas na mesa superior do perfil) e tipo B (com mossas na mesa superior e nas almas do perfil). Para cada tipo de fôrma, analisou-se duas espessuras da chapa de aço: 0,75 $\mathrm{mm}$ e 1,00 mm. A fim de investigar as diferenças entre os tipos de perfil e sua influência sobre o comportamento, as diferentes lajes mistas foram cortadas após o ensaio para revelar suas seções transversais e alguns comportamentos interessantes foram identificados, conforme ilustra a Figura 2.10.

Figura 2.10 - Seções transversais das lajes ensaiadas por Waldmann, May e Thapa (2017)

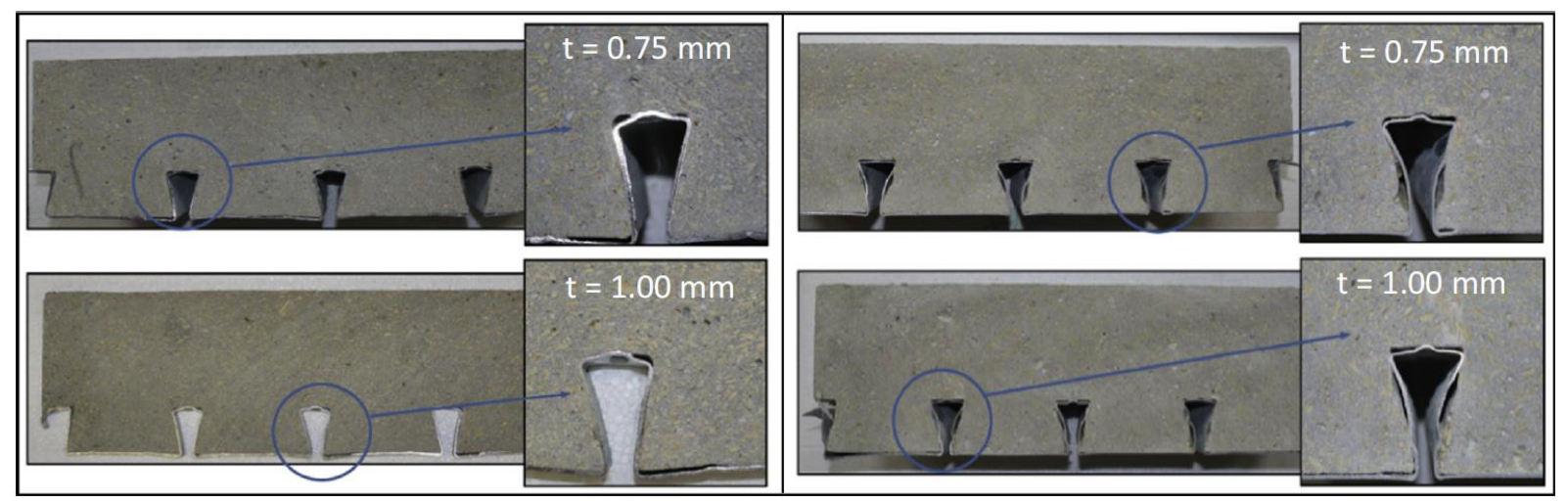

a) Laje com fôrma do tipo $\mathrm{A}$

(b) Laje com fôrma do tipo B

Fonte: WALDMANN; MAY; THAPA, 2017

Os fenômenos descritos anteriormente são claramente ilustrados nas fotografias da Figura 2.10. Quando o deslizamento ocorreu, a mesa superior foi comprimida e se separou do concreto em todos os casos. No caso da laje com fôrma do tipo A, devido às forças de contato desenvolvidas na interface, a alma do perfil foi pressionada contra o concreto, transferindo inteiramente as tensões resultantes do contato e do atrito. Já no caso das lajes com fôrma do tipo B, devido a presença de mossas nas almas do perfil, ocorre a flexão local das almas, uma vez que a indentação no concreto tende a transpassar a mossa. Sendo assim, nenhum contato completo pode ser estabelecido nessas regiões, comprometendo a transferência das tensões de contato e atrito, o que diminui o efeito de intertravamento. 
No caso das lajes mistas com fôrma de perfil trapezoidal, a configuração de esforços de contato tende a causar maior separação, pois o formato da nervura não confina o concreto, embora algumas forças passivas possam ser induzidas devido à forma das mossas. A esse fato se atribui o termo "separação vertical" entre o concreto e a fôrma de aço. A Figura 2.11 ilustra a configuração da seção transversal para os trechos com e sem reação de apoio.

Figura 2.11 - Configuração da seção transversal da laje mista com fôrma de perfil trapezoidal

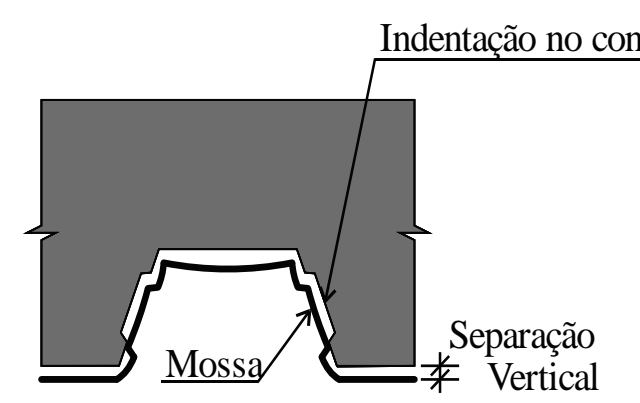

a) Trecho sem reação de apoio

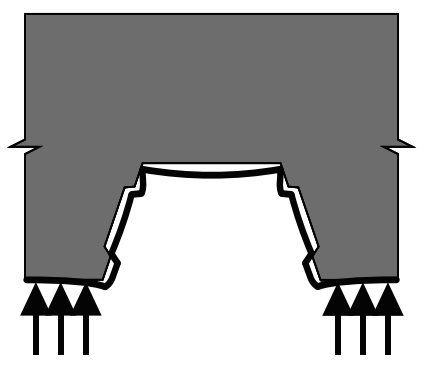

(b) Trecho com reação de apoio

Fonte: Autoria própria

A presença da reação de apoio influencia bastante a resposta da fôrma de aço de perfil trapezoidal, conforme ilustra a Figura 2.11, pois reduz o efeito da separação vertical na região de apoio da laje. É importante destacar que, independentemente do tipo de fôrma de aço, as forças normais à interface desenvolvidas devido à resistência da fôrma à deformação e devido a presença das reações de apoio aumentam a ligação por atrito e, consequentemente, contribuem para a resistência ao cisalhamento longitudinal.

A Figura 2.12 ilustra o comportamento da interface aço-concreto no caso de uma laje mista com fôrma de perfil trapezoidal submetida ao ensaio de flexão a quatro pontos, que é o ensaio preconizado pelas normas vigentes para a determinação da resistência ao cisalhamento longitudinal de lajes mistas.

Devido à resposta diferente da fôrma de aço em cada uma das regiões ilustradas (I e II) na Figura 2.12, a resistência ao cisalhamento longitudinal não é constante ao longo do comprimento de cisalhamento $\left(L_{\mathrm{s}}\right)$. Na região I a presença da reação de apoio restringe a separação vertical, confinando a interface e proporcionando maior resistência ao cisalhamento longitudinal. Na região II não há forças externas transversais à interface, então o fenômeno da separação vertical é passível de ocorrer. Entre as regiões I e II existe uma região de transição (I/II) em que a separação vertical passa de restrita para irrestrita e é suavizada devido à rigidez da fôrma de aço, segundo Schuurman e Stark (2002). Neste aspecto, Cifuentes e Medina (2013) destacam em seu trabalho a influência da espessura da fôrma de aço sobre a sua rigidez. 
Figura 2.12 - Desempenho da fôrma de aço de perfil trapezoidal em uma laje mista submetida ao ensaio de flexão de quatro pontos
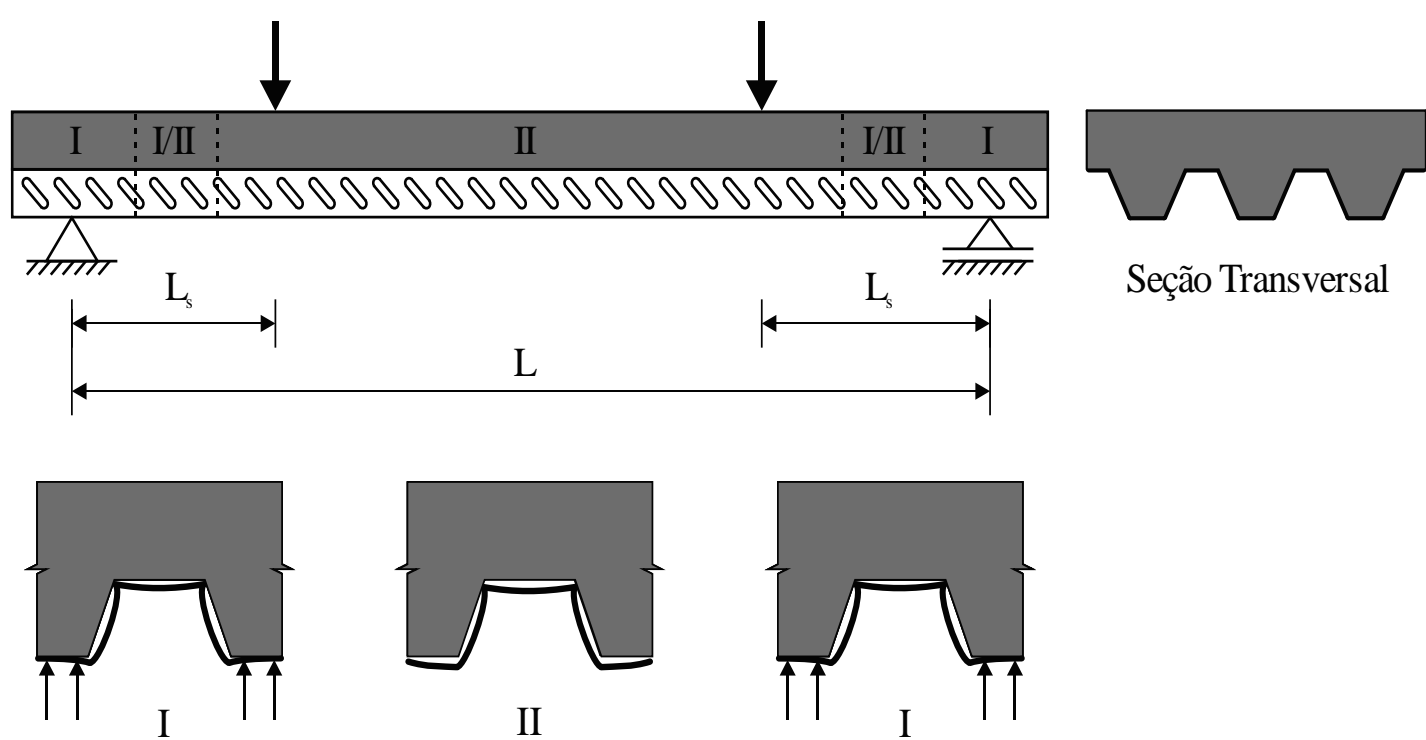

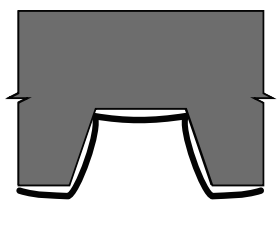

II

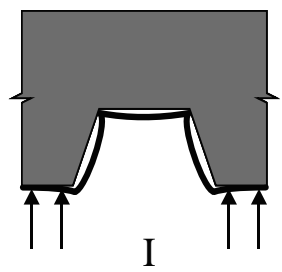

Fonte: Adaptado de SCHUURMAN; STARK, 2002

Ferrer, Marimon e Crisinel (2006) também citam que no caso das lajes mistas com fôrma de perfil trapezoidal, as componentes horizontais das forças de contato são internamente auto balanceadas graças à simetria natural das nervuras lado a lado, porém as componentes verticais devem ser equilibradas internamente pela existência de um ângulo de retenção mínimo para evitar a separação vertical de ambos os materiais, conforme ilustra a Figura 2.13.

Figura 2.13 - Influência da geometria das mossas sobre a separação vertical

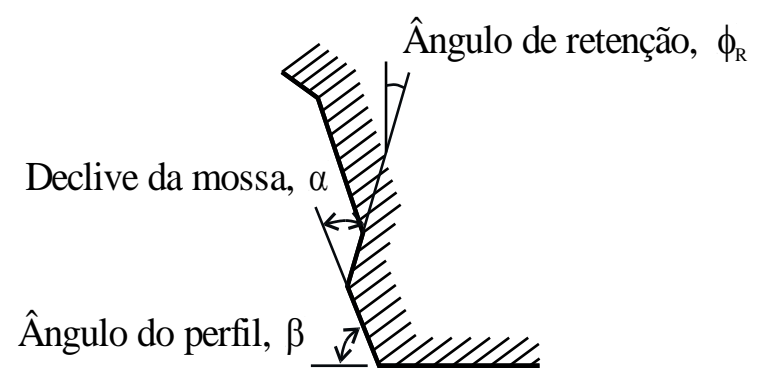

(a) Ângulo de retenção

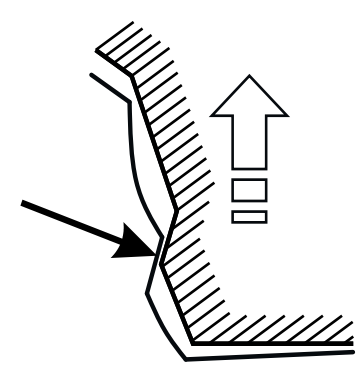

(b) Destacamento vertical devido a flexão local da fôrma

Fonte: adaptado de FERRER; MARIMON; CRISINEL, 2006

A própria forma das nervuras das fôrmas de perfis reentrantes garante a existência do ângulo de retenção vertical e, consequentemente, o equilíbrio interno das forças verticais, de acordo com Ferrer, Marimon e Crisinel (2006). No entanto, os perfis de nervuras abertas devem fornecer um ângulo de retenção mínimo por meio de mossas, como ilustrado na Figura 2.13, 
para possibilitar o equilíbrio interno das forças verticais. Caso contrário, essas forças verticais só podem ser equilibradas pelo próprio peso do concreto. Esses mesmos aspectos foram verificados nos estudos realizados por Burnet e Oehlers (2001) e por Schuurman e Stark (2002). Portanto, a resistência à essa separação vertical é obtida pela adoção de uma configuração adequada para o perfil da fôrma, assim como de mossas com formato e localização adequados.

Chen, Shi e Qiu (2011) afirmam, com base em seu estudo experimental, que a ancoragem de extremidade pode restringir a separação e o deslizamento entre a fôrma de aço e o concreto, de modo que tanto a carga referente ao início do deslizamento quanto a carga máxima das lajes mistas aumentam consideravelmente.

A ocorrência da flexão local da seção transversal da fôrma devido a configuração de esforços descrita acima induz a concentração de tensões nas extremidades das mossas, conforme ilustra a Figura 2.14. Como descrito na seção anterior, o estudo realizado por Ferrer, Marimon e Crisinel (2006) mostrou que para todos os perfis analisados o movimento de deslizamento entre a fôrma de aço e o concreto produz forças de interação localizadas apenas nas extremidades da mossa, justamente porque a fôrma de aço flete localmente enquanto o concreto permanece alinhado.

Figura 2.14 - Esquema do mecanismo de resistência ao deslizamento longitudinal

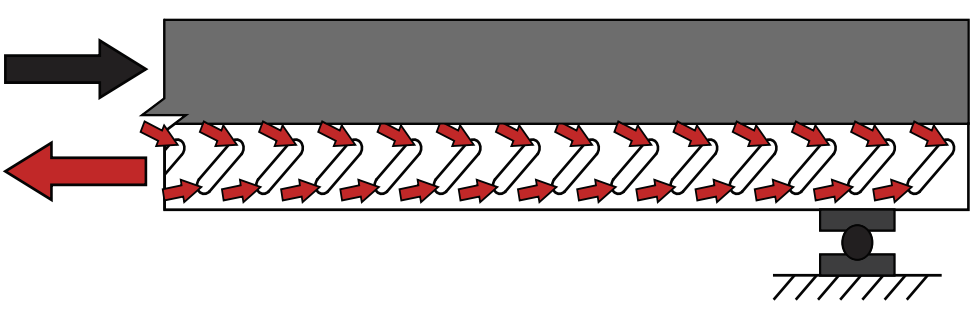

Vista Longitudinal da Laje Mista

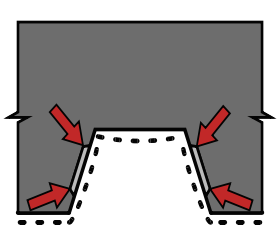

Seção Transversal

Fonte: Adaptado de FERRER; MARIMON; CRISINEL, 2006

Ferrer (2005) verificou que nas lajes mistas com fôrmas de perfil trapezoidal ensaiadas em seu trabalho, a queda da capacidade resistente sempre foi devido à perda total da capacidade de retenção vertical do concreto. Além disso, o autor observou que quando o deslizamento longitudinal é necessário para desalojar completamente as mossas de suas posições iniciais (isso significará, em qualquer caso, uma flexão transversal da fôrma), não há, nos perfis trapezoidais, qualquer interferência entre os dois elementos que impeça a separação vertical. Dessa forma, o valor do dito deslizamento $d$ é sempre, para cada configuração de fôrma de aço, a magnitude da projeção longitudinal das inclinações das mossas, como mostrado na Figura 2.15. 
Figura 2.15 - Deslizamento longitudinal correspondente à carga máxima $(d)$

Fonte: FERRER, 2005

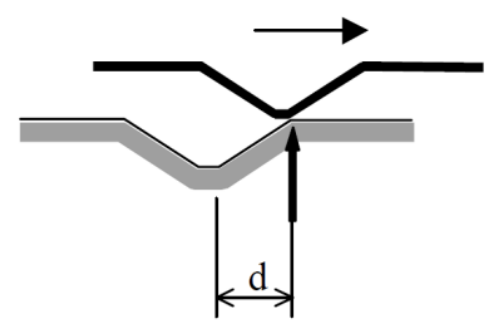

O fenômeno da flexão local e, consequentemente, a separação vertical estão relacionados principalmente com a espessura da fôrma de aço e com a configuração das mossas (formato, inclinação e espaçamento). As mossas contribuem para a resistência à flexão local por sua resistência em se curvar para fora do plano da chapa de aço. Dessa forma, a rigidez de flexão local na área das mossas depende do comprimento, largura ou profundidade da mossa, uma vez que o momento de inércia se torna maior se qualquer uma dessas propriedades for aumentada. Sendo assim, as forças de interação desenvolvidas durante o deslizamento, pelo efeito de travamento das mossas, também são aumentadas.

O momento de inércia da fôrma, assim a sua rigidez à flexão local, aumenta à medida que o espaçamento das mossas (comprimento do padrão) diminui, e assim as forças desenvolvidas pelo efeito de cunha de relevos para deformar a chapa também aumentam (FERRER; MARIMON; CRISINEL, 2006, p. 1.269). Entretanto, quando as indentações no concreto estão muito próximas uma da outra, um descascamento local do concreto também pode ocorrer, segundo Holomek et al. (2014).

\subsection{Considerações Finais do Capítulo}

É notável a complexidade dos fenômenos de transferência de esforços e de deslizamento que existem na interface aço-concreto das lajes mistas. Apesar do conhecimento já desenvolvido a respeito desses fenômenos, ainda são necessários estudos que melhor evidenciem a influência e participação de cada propriedade sobre o comportamento local e global da estrutura, principalmente devido à grande variabilidade de fôrmas de aço existentes.

Os ensaios de modelos de pequenas dimensões que consistem no cisalhamento da interface aço-concreto de lajes mistas permitem analisar mais efetivamente alguns dos fenômenos aqui descritos e avaliar a influência de cada propriedade envolvida na análise. Dependendo do tipo de ensaio, é possível verificar a influência da reação de apoio sobre o comportamento da interface e determinar a participação das ligações mecânicas e por atrito. 
Por meio de simulações numéricas adequadas pode-se, adicionalmente, analisar os fenômenos existentes na transferência de cisalhamento e verificar o impacto de cada propriedade sobre o comportamento local e global do elemento estrutural.

Diante disso, o emprego dos ensaios de modelos de pequenas dimensões para fornecer parâmetros da interface aço-concreto para a simulações numéricas torna-se uma opção pertinente para a compreensão da fenomenologia existente e auxilia, portanto, o desenvolvimento de uma ligação mais eficaz entre os dois materiais da laje mista. Com isso é possível investigar as causas e impactos de cada propriedade e desenvolver fôrmas mais eficientes, gerando benefícios de ordem técnica, econômica e sustentável para a indústria da Construção Civil com uso de estruturas mistas. 



\section{CAPÍTULO 3 - COMPORTAMENTO E CLASSIFICAÇÃO DAS LAJES MISTAS}

A realização do ensaio de flexão de uma laje mista até atingir o seu colapso permite definir o seu modo de ruptura, sua capacidade resistente última, analisar seu comportamento e avaliar alguns mecanismos que se desenvolvem na interface aço-concreto. Além disso, o ensaio permite classificar a laje mista quanto ao seu comportamento.

Este capítulo apresenta o ensaio de flexão preconizado pelas normas Eurocode 4: 2004, ANSI/ASCE 3-91:1992, CSSBI S3: 2017 e a AS/NZS 2327: 2017. Também são descritos os possíveis modos de ruptura das lajes mistas submetidas a este ensaio, o comportamento geral das lajes com modo de ruptura devido ao cisalhamento longitudinal e a sua classificação.

\subsection{Ensaio de Flexão}

O ensaio de flexão adotado pelas normas citadas consiste em submeter a laje mista em escala real à flexão a quatro pontos por meio de um carregamento simétrico, conforme ilustra a Figura 3.1, sendo $L_{\mathrm{s}}$ chamado de comprimento de cisalhamento (ou vão de cisalhamento) e $L_{\text {ef }}$ o comprimento efetivo (ou vão efetivo). Diante dos resultados obtidos por meio desse tipo de ensaio é possível definir a resistência ao cisalhamento longitudinal de lajes mistas empregando o Método $m-k$ e o Método da Interação Parcial.

Figura 3.1 - Esquema de ensaio de flexão a quatro pontos para lajes mistas

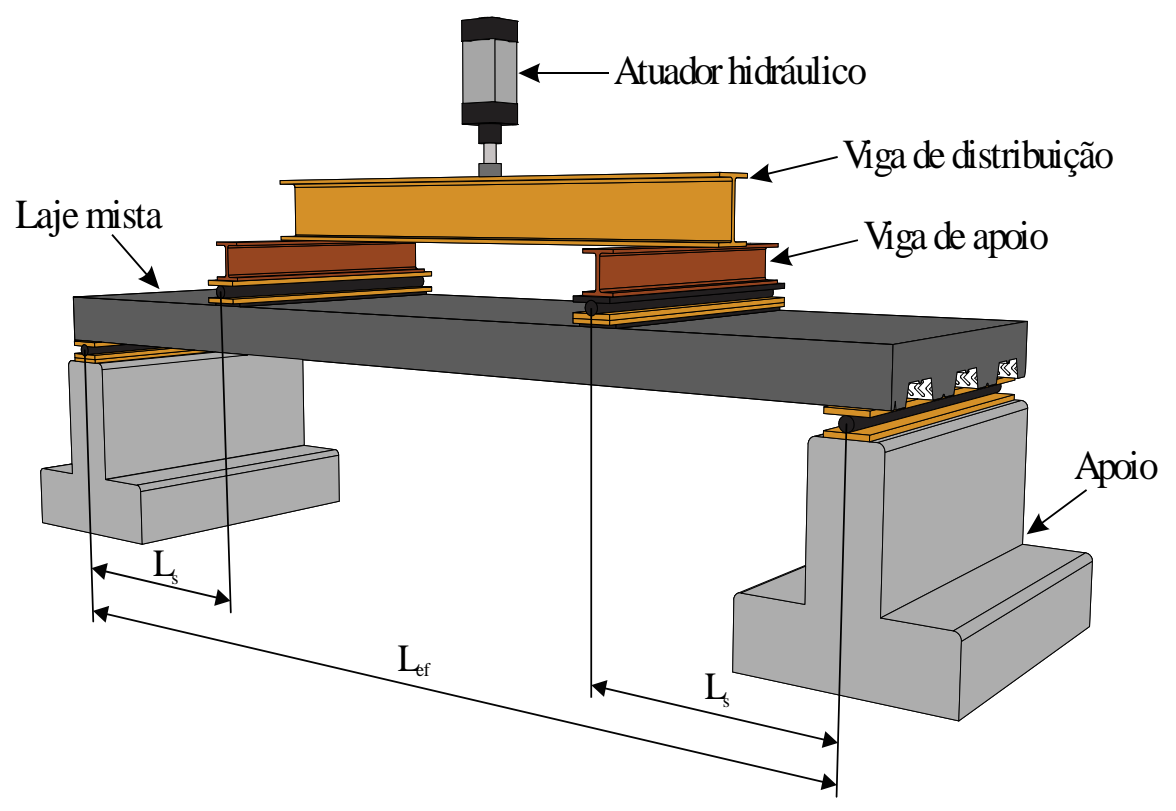

Fonte: Autoria própria 
As variáveis a serem investigadas neste ensaio incluem a espessura e o tipo de chapa de aço, o tipo de aço, o revestimento da chapa de aço, a densidade e a classe do concreto, a espessura da laje e o comprimento de cisalhamento.

O Eurocode 4: 2004 e a AS/NZS 2327: 2017 recomendam a colocação de indutores de fissuras na zona de tração das lajes sob o carregamento aplicado com o objetivo de melhor definir o comprimento de cisalhamento, assim como de eliminar a resistência à tração do concreto. As demais normas aqui referenciadas não prescrevem o uso desse dispositivo.

O procedimento de carregamento recomendado pelo Eurocode 4: 2004 e a AS/NZS 2327: 2017 consiste em duas etapas. Inicialmente a laje é submetida a um carregamento cíclico, cujo objetivo é eliminar a ligação química existente na interface aço-concreto. Posteriormente é aplicado um carregamento estático crescente até a ruptura da laje. As normas ANSI/ASCE 391:1992 e CSSBI S3: 2017 não prescrevem a realização do carregamento cíclico previamente.

Neste aspecto, cabe destacar que os trabalhos realizados por Bode e Minas (1997), Marimuthu et al. (2007) e Cifuentes e Medina (2013) avaliaram a influência da carga cíclica aplicada antes da realização do ensaio com carregamento estático até a ruptura. Em todos estes trabalhos concluiu-se que o valor de carga máxima não foi influenciado pelo ensaio cíclico prévio. Bode e Minas (1997) constataram, também, que o deslocamento vertical no meio do vão e o deslizamento de extremidade correspondente referentes à carga máxima são independentes do número de ciclos de carga aplicados. Entretanto, Cifuentes e Medina (2013) verificaram que o efeito do ensaio cíclico influenciou apenas o deslocamento vertical no meio do vão no ensaio estático, uma vez que as lajes sem aplicação prévia de carregamento cíclico atingiram maiores deslocamentos verticais no meio do vão para a carga última.

As dimensões do protótipo a ser ensaiado são estabelecidas para que o colapso ocorra sempre por cisalhamento longitudinal, caracterizado pelo aparecimento de uma fissura maior sob as regiões de aplicação de carga e pelo deslizamento relativo de grande proporção entre a fôrma e o concreto, conforme apresentado detalhadamente a seguir.

\subsection{Modos de Ruptura}

O dimensionamento de lajes mistas envolve a análise do sistema tanto na fase de construção (fôrma trabalhando isoladamente para sustentar o peso do concreto fresco e a sobrecarga de construção) quanto na fase final ou mista (após a resistência do concreto ter atingido $0,75 f_{c k}$ ). Nessa última fase todos os estados limites devem ser verificados para garantir a segurança estrutural da laje mista. 
Os modos de colapso que podem ocorrer numa laje mista são: flexão, cisalhamento vertical, cisalhamento longitudinal e punção. Dentre esses modos, o estado limite de ruptura por cisalhamento longitudinal é o que ocorre com mais frequência.

$\mathrm{Na}$ fase mista, os estados limites últimos considerados para lajes mistas de aço e concreto são baseados nos possíveis modos de colapso, cujas seções críticas estão ilustradas na Figura 3.2 (a) (seções $a-a, b-b$ e $c-c$ ), que representa um esquema simples do ensaio normatizado apresentado na seção anterior.

Figura 3.2 - Modos de ruptura em lajes mistas submetidas ao ensaio de flexão

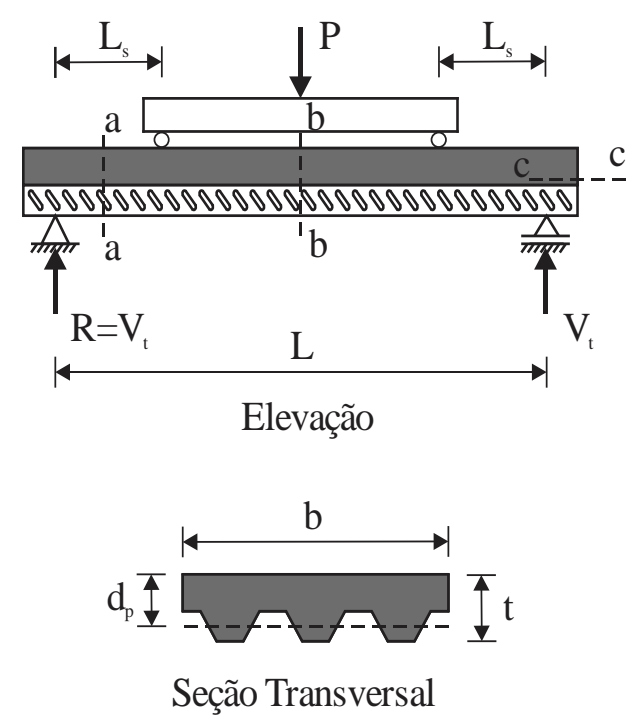

(a) Elevação e seção transversal da laje mista sob ensaio de flexão

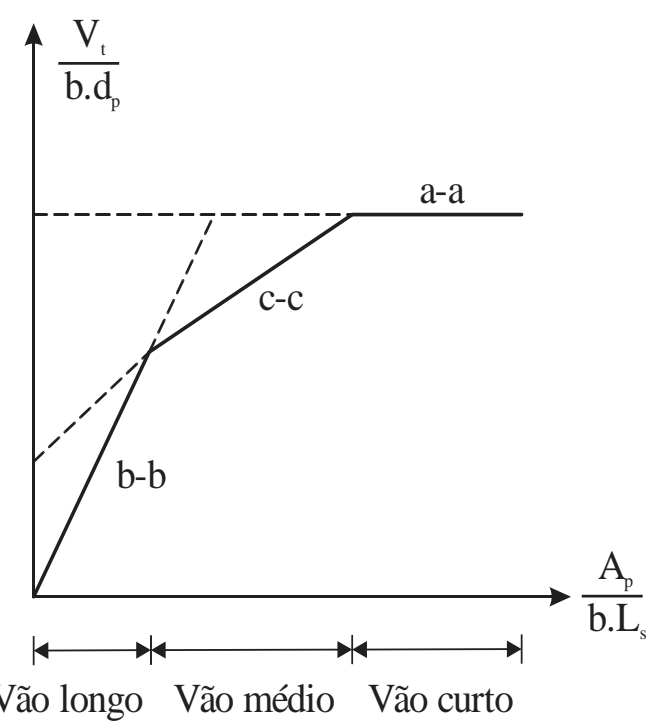

(b) Gráfico da tensão de cisalhamento nominal versus esbeltes invertida da laje

Fonte: Adaptado de GHOLAMHOSEINI et al., 2014

Os estados limites que devem ser verificados são:

- Seção crítica $a$ - $a$ - cisalhamento vertical. Pode ser crítico nos casos em que as lajes são espessas e possuem comprimento curto, sujeitas a carregamentos elevados;

- Seção crítica $b-b$ - flexão. Pressupõe-se interação total entre a fôrma e o concreto e pode ser crítico se o vão de cisalhamento $\left(L_{\mathrm{s}}\right)$ for suficientemente grande para garantir uma alta resistência ao deslizamento longitudinal;

- Seção crítica $c-c$ - cisalhamento longitudinal. A carga máxima suportada pela laje é determinada pela resistência ao cisalhamento da ligação aço-concreto na interface e, evidentemente, não se atinge o momento fletor resistente da seção crítica $b$ - $b$. Caracteriza-se como ação mista de interação parcial, sendo geralmente o estado limite crítico de lajes mistas; 
- Punção - Não está apresentado na Figura 3.2 . Pode ser crítico se o perímetro da área carregada e a espessura da laje forem pequenos e se a carga for muito elevada.

Os modos de falha descritos estão expostos graficamente na Figura 3.2 (b), por meio do gráfico que relaciona a tensão de cisalhamento nominal $\left(V_{\mathrm{t}} / b \cdot d_{\mathrm{p}}\right)$ e a esbeltes reduzida da laje mista $\left(A_{\mathrm{p}} / b \cdot L_{\mathrm{s}}\right)$, onde $V_{\mathrm{t}}$ é a reação de apoio, $A_{\mathrm{p}}$ é a área da seção transversal da fôrma de aço, $b$ é a largura da laje, $d_{\mathrm{p}}$ é a altura efetiva da laje e $L_{\mathrm{s}}$ é o comprimento de cisalhamento. Nesse gráfico os trechos $a-a, b-b$ e $c$-c são referentes aos modos de ruptura por flexão na região de momento máximo, por cisalhamento longitudinal e por cisalhamento vertical, respectivamente.

Abdullah (2004) destaca que a ruptura por flexão não é um critério de projeto dominante, porque a interação entre o aço e o concreto geralmente é incompleta e o comprimento da laje é sempre limitado pelo estado limite de serviço (deslocamento vertical). Para que a ruptura por cisalhamento vertical seja dominante, o autor cita que a laje tem que ser muito curta e espessa com uma alta carga concentrada perto dos apoios, o que não é comum na prática de construção e, portanto, não tem sido objeto de muitas pesquisas, sendo seu efeito normalmente ignorado no projeto.

O modo de ruptura por flexão é atingido se a resistência à flexão da laje mista for atingida, o que só é possível se a resistência ao cisalhamento longitudinal for suficiente para garantir a ligação aço-concreto e causar o escoamento de toda a seção transversal da fôrma de aço. Esse modo de ruptura pode ser atingido por lajes que possuem grandes comprimentos de cisalhamento, conforme se observa no gráfico da Figura 3.2 (b). Entretanto, a resistência à flexão dessas lajes é atingida acompanhada de grandes rotações e deslocamentos verticais. A Figura 3.3 ilustra o gráfico da carga normalizada (carga aplicada/carga de plastificação da seção) versus deslocamento vertical no meio do vão obtido experimentalmente por Veljkovic (1996), apresentando a diferença do comportamento de uma laje mista que falhou à flexão e outra que falhou devido ao cisalhamento longitudinal.

É importante ressaltar que, para o modo de ruptura por flexão a carga máxima suportada pode ser atingida com a ocorrência de deslizamento do concreto em relação à fôrma de aço, ou seja, sob interação parcial. Além disso, a carga última que resulta na falha por cisalhamento longitudinal está geralmente distante da resistência última à flexão ou da resistência ao cisalhamento vertical das lajes mistas. Portanto, na grande maioria dos casos a resistência ao cisalhamento longitudinal governa o comportamento das lajes mistas e, consequentemente, seu dimensionamento. 
Figura 3.3 - Curvas experimentais da carga normalizada versus deslocamento vertical no meio do vão para lajes que falharam à flexão e ao cisalhamento longitudinal

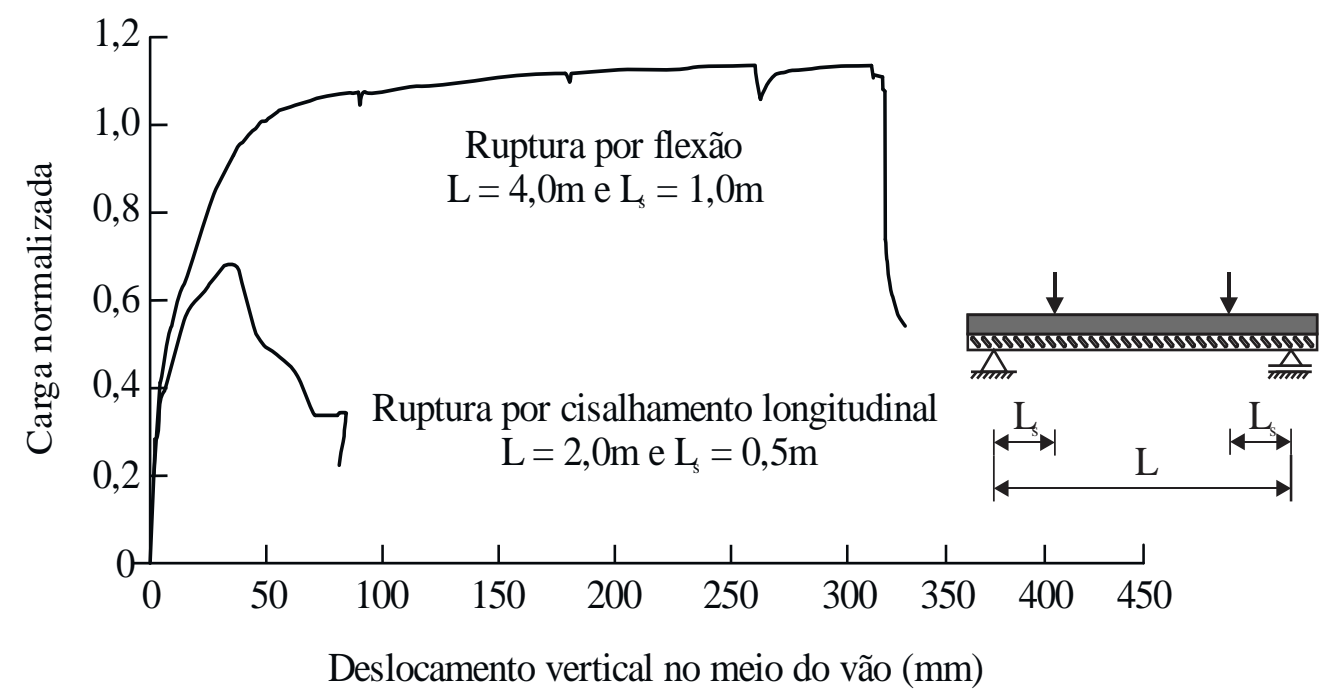

Fonte: Adaptado de VELJKOVIC, 1996

O modo de ruptura por cisalhamento longitudinal é caracterizado pelo desenvolvimento de uma fissura aproximadamente diagonal, dentro do vão de cisalhamento do concreto, sob ou perto de uma das cargas concentradas no instante imediatamente antes da ruptura, seguida por um deslizamento da extremidade observável entre a fôrma de aço e o concreto, conforme ilustrado na Figura 3.4.

Figura 3.4 - Ruptura por cisalhamento longitudinal

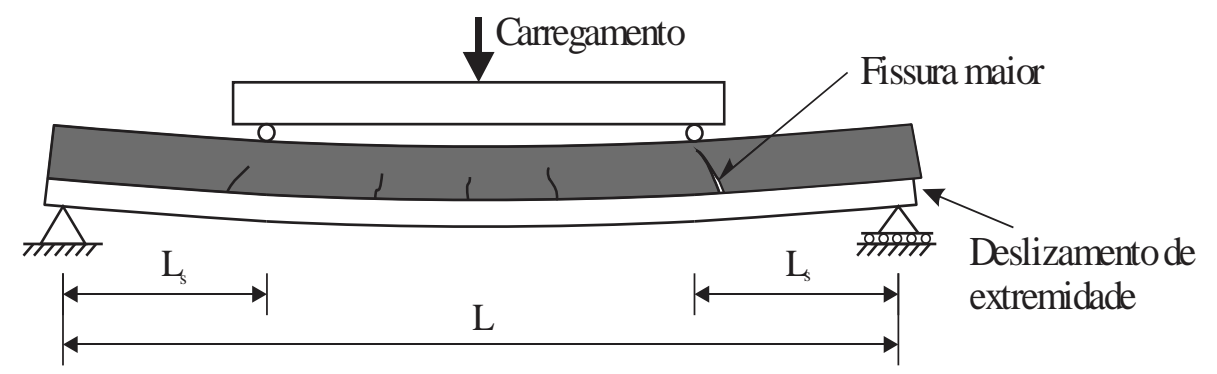

Fonte: Adaptado de ABDULLAH, 2004

A ruptura por cisalhamento longitudinal ocorre quando a resistência dos sistemas de retenção de deslizamento (mossas, atrito e ancoragens de extremidade) é excedida. Ferrer (2005) cita que essa ruptura pode ocorrer devido à quatro fenômenos fundamentais:

- Falha por liberação longitudinal da fôrma: as mossas transformam os esforços cisalhantes longitudinais em esforços transversais à chapa, provocando a flexão transversal da fôrma e desalojando o concreto das mossas, o que acarreta no deslizamento longitudinal; 
- Falha por separação vertical: é o modo de falha mais ocorrente em fôrmas trapezoidais, pois a presença das mossas é o que resiste à separação vertical e, quando ocorre a flexão transversal da chapa, o movimento relativo entre a fôrma e o concreto é liberado, acarretando na queda da resistência ao cisalhamento longitudinal;

- Falha por ruptura do concreto: no caso de alta resistência dos dois modos de falha anteriores, isso poderia levar à ruptura do concreto por tração vertical na base das nervuras de perfis trapezoidais, cisalhamento longitudinal nas bases das nervuras de perfis reentrantes, cisalhamento do concreto na base das mossas, descascamento do concreto em torno das mossas e compressão local nas zonas de contato;

- Falha por esmagamento das mossas: dependendo do formato das mossas, pode haver uma força de interação cuja componente perpendicular à fôrma pode atingir intensidades altas e esmagar as mossas.

Com relação à influência do comprimento de cisalhamento $\left(L_{\mathrm{s}}\right)$, destacam-se os trabalhos realizados por Chen e Shi (2011) e Gholamhoseini et al. (2014).

Chen e Shi (2011) realizaram um estudo numérico de lajes mistas utilizando resultados experimentais de ensaios do tipo pull-out e de flexão a quatro pontos, efetuando uma análise paramétrica sobre o comprimento de cisalhamento, porém mantendo o mesmo comprimento da laje. Verificou-se que a maior parte da ligação de cisalhamento existia na região do comprimento de cisalhamento da laje submetida a flexão, enquanto a resistência da ligação de cisalhamento também se desenvolvia na região de flexão pura. Além disso, os autores concluíram que é provável que a força máxima de cisalhamento longitudinal possível seja uma propriedade inerente a cada laje mista específica, na medida em que os perfis de aço e o concreto são os mesmos, sendo influenciada inversamente pelo comprimento de cisalhamento.

Gholamhoseini et al. (2014) realizaram um trabalho experimental empregando o ensaio de flexão até a ruptura de lajes mistas utilizando quatro tipos de fôrmas que são amplamente empregadas na Austrália. Os ensaios foram realizados para comprimentos de cisalhamento iguais a um quarto e um sexto do comprimento da laje. Foi alcançada resistência significativa à flexão após a fissuração em todas as lajes, mas em todas elas a resistência máxima à flexão foi controlada pelo deslizamento na interface aço-concreto no comprimento de cisalhamento. Sendo assim, a resistência à flexão das lajes nunca foi atingida. A tensão de cisalhamento última para cada tipo de laje ensaiada para o comprimento de cisalhamento de $L / 6$ foi maior do que a obtida quando o comprimento de cisalhamento foi $L / 4$. Observa-se, portanto, que a laje com menor comprimento de cisalhamento proporcionou maior resistência, assim como foi observado por Chen e Shi (2011). 
Chen, Shi e Qiu (2011) concluíram em seu trabalho que a tensão de cisalhamento longitudinal não se distribui simplesmente de maneira uniforme sobre o vão de cisalhamento, sendo a maior tensão localizada na região próxima à aplicação do carregamento. Além disso, é muito menor dentro da região de flexão pura, de modo que a tensão de cisalhamento dentro do vão de cisalhamento é maior e desempenha a maior contribuição para a resistência ao cisalhamento longitudinal de uma laje mista.

Embora exista a possibilidade de ocorrência de um dos três modos de colapso descritos, o objetivo do ensaio de flexão é obter dados para determinar a resistência ao cisalhamento longitudinal da laje mista por meio dos métodos de cálculo semi-empíricos. A ABNT NBR 8800: 2008 permite o emprego do Método $m-k$ e do Método da Interação Parcial. Para o primeiro, a norma brasileira faz referência direta ao uso do Eurocode 4: 2004 ou CSSBI S2: 2008 ou ANSI/ASCE 3-91: 1992. Para o segundo, faz referência apenas ao Eurocode 4: 2004. A NBR 14323: 2013 recomenda o procedimento realizado para a determinação dos coeficientes $m$ e $k$ conforme Eurocode 4: 2004 ou outras especificações estrangeiras.

\subsection{Comportamento das Lajes Mistas}

Uma vez que o ensaio de flexão apresentado na Figura 3.1 deve ser planejado para que a ruptura da laje ocorra por cisalhamento longitudinal, as lajes mistas possuem, em geral, um comportamento semelhante no decorrer do ensaio.

Mediante o carregamento aplicado, os mecanismos de transferência de cisalhamento, apresentados no Capítulo 2, são ativados. Inicialmente o carregamento é suportado pelo aço e pelo concreto, que se deslocam juntos, de forma que a transferência de cisalhamento na interface acontece sob interação total. Quando não se aplica carregamento cíclico prévio, é notada a ruptura da ligação química, caracterizada por estalos ouvidos no início do ensaio.

Com o aumento de carregamento, devido à diferença de rigidez entre a fôrma de aço e a capa de concreto, desenvolvem-se os mecanismos de deslizamento descritos no Capítulo 2, principalmente a flexão local da fôrma de aço e a separação vertical entre os materiais na região em que o carregamento é aplicado, promovendo a perda da ação mista neste local. Dessa forma, só o concreto suporta o carregamento adicional. Aumentando-se ainda mais o carregamento, ocorre maior separação vertical, implicando em maior parcela suportada pelo concreto e cada vez menos ação mista na região. Esse processo, é considerado o "primeiro estágio de comportamento", de acordo com Grossi (2016). 
Chen e Shi (2011) destacam que quando a carga de uma laje que é transferida para o concreto excede sua resistência à tração, o concreto iniciará a fissuração e resultará no intertravamento mecânico devido, principalmente, às mossas da fôrma de aço, para manter o concreto e a fôrma de aço unidos.

O "segundo estágio de comportamento" se inicia quando, sob um ponto de aplicação do carregamento (este, de valor $F_{d e s}$ ), ou sob ambos, fissuras começam a surgir (GROSSI, 2016, p. 41), conforme ilustra a Figura 3.5 (a). Quase que imediatamente, em um dos comprimentos de cisalhamento (ou em ambos) inicia-se o deslizamento relativo entre o aço e o concreto, decorrente da contínua perda de ação mista em todo esse comprimento (ou comprimentos), que naturalmente gera deslizamento relativo de extremidade entre os dois materiais, conforme ilustra a Figura 3.5 (b).

Segundo Grossi (2016), negligenciando o efeito localizado de separação vertical da interface na região de aplicação do carregamento, pode-se dizer que esse deslizamento relativo, e consequentemente o "segundo estágio de comportamento" e a força $F_{\text {des }}$, explicitam a fronteira da passagem do regime de interação completa para o de interação parcial em todo o seu comprimento (ou comprimentos) de cisalhamento, conduzindo à grande perda de rigidez do sistema como um todo.

Figura 3.5 - Características do "segundo estágio do comportamento

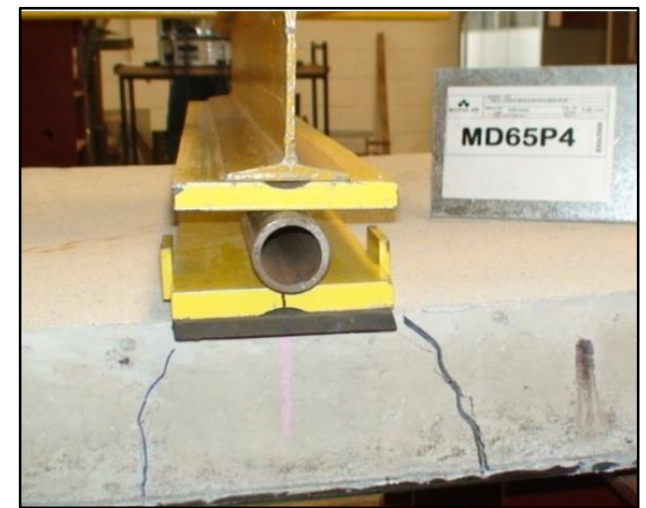

(a) Aspecto típico da fissura do "segundo estágio de comportamento"

Fonte: GROSSI, 2016

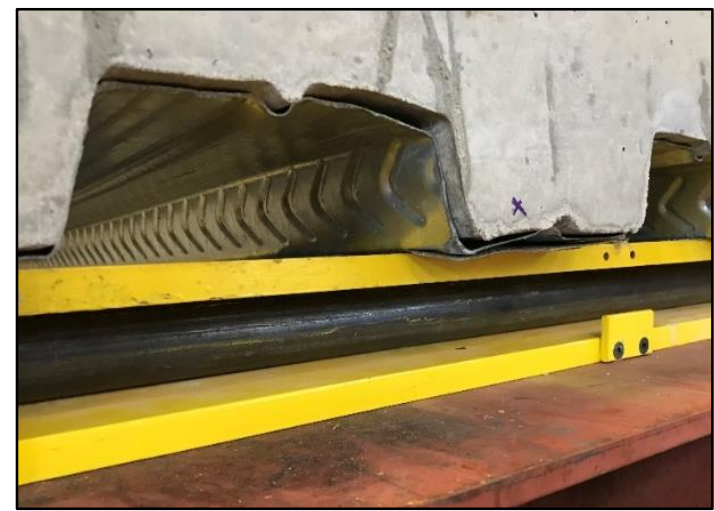

(b) Deslizamento relativo de extremidade entre o concreto e a fôrma de aço

Fonte: Autoria própria

Veljkovic (1996) destaca que após o surgimento da fissura principal sob um dos pontos de aplicação do carregamento, o concreto localizado entre a extremidade da laje e essa fissura começa a deslizar sobre a fôrma de aço, sendo esta parte da laje mobilizada pelo cisalhamento longitudinal. $\mathrm{O}$ autor afirma que o deslizamento é maior na posição da fissura principal e diminui em direção à extremidade da laje, o que é contrário às previsões das teorias baseadas no comportamento contínuo do material. 
Uma característica importante, citada por Chen, Shi e Qiu (2011), é que antes da fissuração no concreto, a tensão de cisalhamento existe apenas na região do comprimento de cisalhamento e nenhuma tensão de cisalhamento ocorre na região do comprimento central, que está sob flexão pura. Após a fissuração do concreto do comprimento central, tensões de cisalhamento longitudinal se desenvolvem nessa região, pois haveria um pequeno deslizamento relativo entre o concreto e o aço e uma deformação discreta ocorre no concreto adjacente às fissuras, o que contribui para a existência da tensão de cisalhamento na interface.

Na sequência do ensaio alcança-se o chamado "estágio final de comportamento", em que a laje mista não suporta mais acréscimos de carregamento, ou seja, a estrutura atinge sua ruína. A configuração desse estágio é caracterizada pela formação de um mecanismo plástico em uma seção qualquer situada na região de momento máximo (comprimento entre os carregamentos aplicados), tornando o sistema hipostático. De acordo com Grossi (2016), esse mecanismo pode ser formado por uma das seguintes condições: (a) plastificação do aço, ruptura do concreto ou ambos; (b) ondulações da parte comprimida da fôrma de aço (ondas altas). A Figura 3.6 ilustra este último caso.

Figura 3.6 - Ondulações nas ondas altas da fôrma de aço no "estágio final de comportamento"

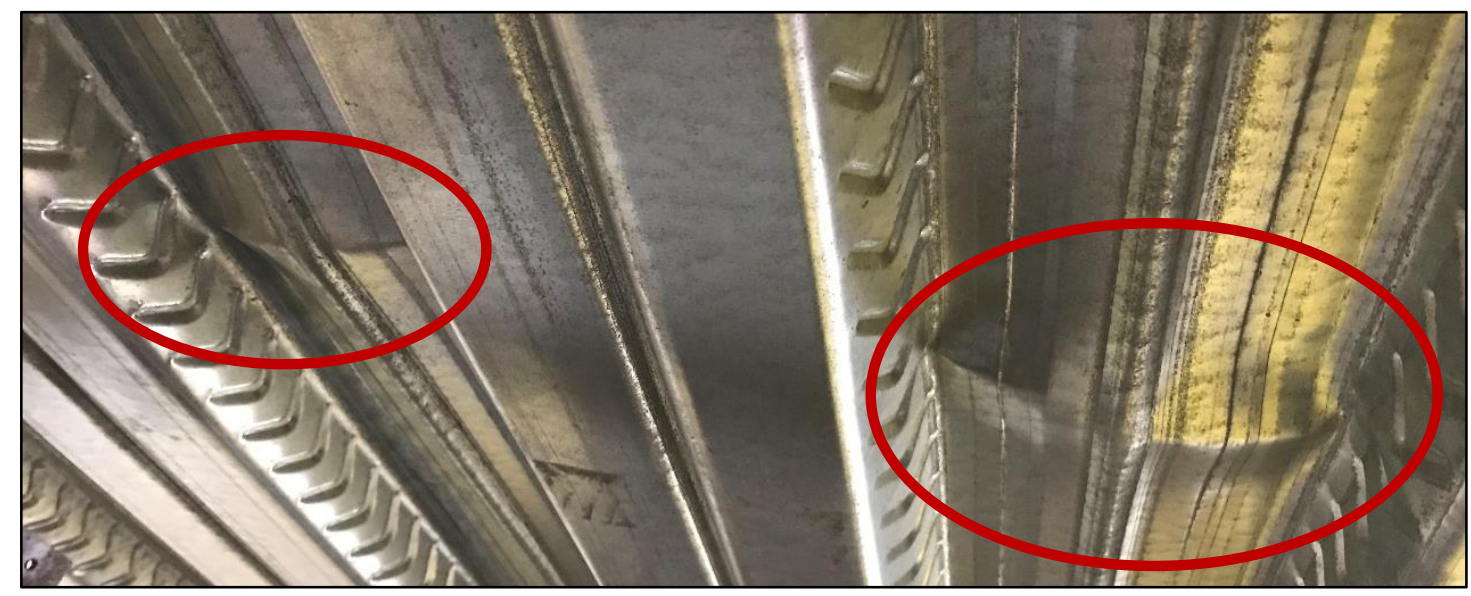

Fonte: Autoria própria

Chen, Shi e Qiu (2011) observaram em seus ensaios que, antes do início do deslizamento, todo o perfil de aço está tracionado e, após o início do deslizamento, algumas partes da mesa superior do perfil de aço passaram a ser comprimidas devido à separação localizada na interface, enquanto a mesa inferior e a maior parte da alma de fôrma de aço ainda se mantinham tracionadas. Esse fenômeno também foi observado nos modelos analisados no presente trabalho. 


\subsection{Classificação do Comportamento das Lajes Mistas}

Sendo o cisalhamento longitudinal o estado limite último de lajes mistas submetidas ao ensaio descrito na seção 3.1, sua resposta estrutural pode ser classificada como dúctil ou frágil. Essa classificação torna-se importante pelo fato de que há métodos analíticos cujo emprego é restrito a apenas um dos tipos ou que apresentam diferentes considerações para cada comportamento.

O comportamento dúctil de uma laje mista é caracterizado pelo Eurocode 4: 2004 e pela AS/NZS 2327: 2017 quando a carga última alcançada pelo sistema $\left(F_{\text {máx }}\right)$ supera em pelo menos $10 \%$ o valor da carga no momento em que o deslizamento entre o aço e o concreto atingir $0,1 \mathrm{~mm}\left(F_{\text {des }}\right)$. Caso contrário, a laje mista é considerada frágil. As duas normas prescrevem que $F_{\text {máx }}$ deve ser o menor valor entre a maior força aplicada durante o experimento e a força aplicada correspondente à flecha $L / 50$.

No caso das lajes mistas frágeis, no instante do deslizamento relativo entre o aço e o concreto ("segundo estágio de comportamento"; força $F_{\text {des}}$ ), verificado por grande perda de rigidez da laje, de modo que a laje não mais suporta acréscimos de carregamento superiores a $F_{\text {des. }}$ Contrariamente, as lajes mistas dúcteis ainda apresentam capacidade para suportar considerável acréscimo de carregamento mesmo após alcançar o "segundo estágio de comportamento", em que há grande perda de rigidez do elemento estrutural.

Para as lajes mistas frágeis o carregamento necessário para romper a condição de interação completa do elemento é, geralmente, superior àquele para atingir a resistência máxima em interação parcial. Já para as lajes dúcteis a maior força alcançada durante o ensaio $\left(F_{\text {máx }}\right)$ é considerada a do instante do "estágio final de comportamento", que ocorre sob interação parcial. A Figura 3.7 ilustra os gráficos dos comportamentos típicos da Força $(F)$ versus Deslocamento vertical no meio do vão (ou flecha) $(\delta$ ) para lajes mistas dúcteis e frágeis submetidas ao ensaio de flexão com controle de deslocamento.

Grossi (2016) destaca que as lajes mistas frágeis apresentam pouca capacidade de rotação, enquanto as lajes mistas dúcteis apresentam elevada capacidade de rotação. Dessa forma, segundo o autor, a ruptura de lajes mistas frágeis ocorre estando o aço e o concreto com valores de deformação muito inferiores ao de plastificação total, enquanto que a ruptura das lajes mistas dúcteis é atingida com os dois materiais sob deformações próximas da condição de plastificação total. 
Figura 3.7 - Gráfico típico da Força $(F)$ versus Flecha $(\delta)$ para lajes mistas

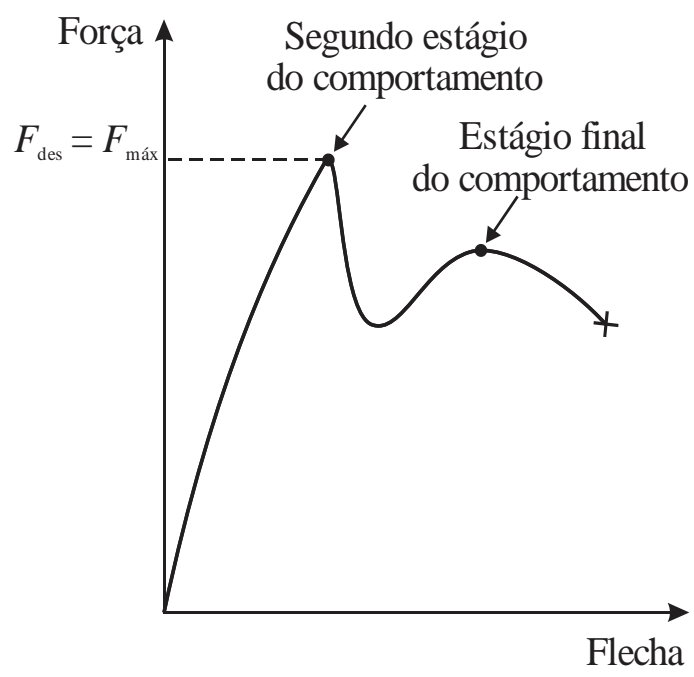

(a) Laje mista considerada frágil

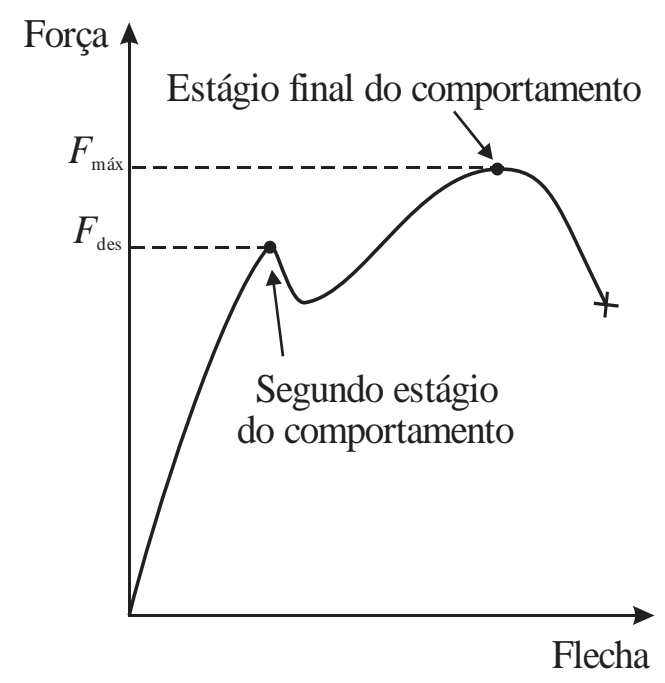

(b) Laje mista considerada dúctil

Fonte: Adaptado de GROSSI, 2016

As mossas presentes na superfície da fôrma de aço têm a função de promover resistência ao cisalhamento longitudinal da interface aço-concreto, porém é desejável que elas não possuam resistência suficiente para fazer com que as lajes apresentem comportamento frágil, pois, como visto no capítulo anterior, a rigidez da conexão existente na interface influencia o comportamento global da laje.

Nesse contexto, Ferrer (2005) cita que a rigidez excessiva do sistema de intertravamento da fôrma pode causar concentração de tensão em uma pequena área e provocar uma ruptura frágil do concreto por cisalhamento ou descascamento e, portanto, uma ruptura sequencial (não simultânea) dos dispositivos de intertravamento mecânico, resultando numa resistência mínima de toda a laje mista.

Diante disso, para que a laje mista possua uma ligação aço-concreto eficiente, o sistema de intertravamento entre esses dois materiais deve evitar o deslizamento apresentando a deformabilidade necessária para que o esforço cisalhante seja distribuído convenientemente antes que ocorra a ruptura do concreto localizado nas imediações da interface.

\subsection{Considerações Finais do Capítulo}

Diante do comportamento descrito para uma laje mista submetida ao ensaio de flexão a quatro pontos, nota-se claramente a ação dos mecanismos de transferência de cisalhamento e de deslizamento sobre o desempenho do elemento estrutural. 
Apesar de ser um ensaio relativamente simples, a sua realização é trabalhosa e onerosa, principalmente quando se trata de um estudo prévio para o desenvolvimento de um tipo de fôrma de aço, uma vez que é necessário realizar uma quantidade significativa de ensaios para avaliar cada propriedade que influencia no comportamento estrutural do elemento. Além disso, apenas a realização desse ensaio não esclarece totalmente os fenômenos físicos que se desenvolvem na interface aço-concreto e que são importantes para avaliar a resistência ao cisalhamento longitudinal promovido pela fôrma de aço.

Diante disso, vários ensaios para analisar o comportamento da interface foram propostos, conforme apresenta o capítulo seguinte (Capítulo 4). A principal característica desses ensaios é o tamanho pequeno de seus modelos, pois um pequeno trecho do elemento estrutural é ensaiado. Dessa forma, pode-se estudar precisamente a interface aço-concreto de lajes mistas, caracterizando seu comportamento e sua resistência, com menor custo quando comparado aos ensaios de flexão em escala real. 


\section{CAPÍTULO 4 - MODELOS DE PEQUENAS DIMENSÕES PARA ANÁLISE DA INTERFACE AÇO-CONCRETO}

Os fabricantes de fôrmas de aço fornecem tabelas para que os engenheiros desenvolvam o projeto de lajes mistas. Tais tabelas são obtidas por meio dos resultados fornecidos pelos métodos normativos, que necessitam da realização de ensaios de flexão em escala real para a caracterização e avaliação do comportamento dessas lajes. Sendo assim, projetistas e fabricantes que pretendem avaliar o desempenho da laje com uma nova configuração para a fôrma de aço precisam necessariamente realizar uma série de ensaios em escala real para verificar sua capacidade resistente, uma vez que não existem métodos de cálculo puramente analíticos para determinar a capacidade resistente ao cisalhamento longitudinal de lajes mistas.

Em contrapartida, alguns pesquisadores desenvolveram outros ensaios com modelos de pequenas dimensões objetivando analisar o comportamento de lajes mistas (especificamente da interface aço-concreto), investigar a influência de cada propriedade e desenvolver metodologias teóricas alternativas para caracterização e determinação do comportamento e da capacidade resistente dessas lajes, assim como utilizar os resultados obtidos para modelar numericamente a interface aço-concreto. A seguir tais ensaios são apresentados de acordo com o respectivo autor, assim como algumas pesquisas que os empregaram. Maior ênfase é dada ao ensaio slipblock, proposto por Patrick e Poh (1990), quer foi o ensaio de pequenas dimensões empregado no programa experimental deste trabalho.

\subsection{Schuster (1970)}

Um dos primeiros ensaios de deslizamento desenvolvido para lajes mistas foi o pushout, realizado por Schuster em 1970 e reportado por Porter e Ekberg (1978). O protótipo é composto por dois blocos de concreto moldados entre duas fôrmas de aço, conforme ilustra a Figura 4.1. O ensaio consiste em posicionar um macaco hidráulico entre os blocos de concreto e aplicar força de modo a empurrar os blocos para fora das fôrmas. Esses ensaios foram realizados em conjunto com ensaios de flexão objetivando investigar a característica da ligação de cisalhamento de vários tipos de fôrmas de aço disponíveis na época.

Esse ensaio foi utilizado na tentativa de estabelecer a relação entre a força máxima para empurrar os blocos de concreto e o momento fletor resistente de lajes com o mesmo vão de cisalhamento. Os resultados obtidos por Porter e Ekberg (1978) mostraram que a tensão de cisalhamento da interface variou em função do comprimento do bloco de concreto. 
Figura 4.1 - Esquema do ensaio push-out proposto por Schuster (1970)

Fonte: Adaptado de ABDULLAH, 2004

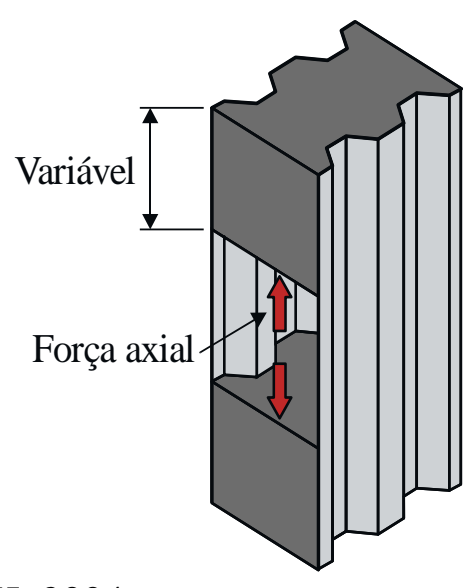

Os resultados obtidos por meio desse ensaio não ofereceram uma solução prática para a determinação da resistência da interface para todos os tipos de fôrmas analisadas, uma vez que não se obteve boa correlação com a resistência da interface das respectivas lajes mistas sob flexão. Dessa forma, a abordagem desse ensaio push-out foi abandonada e o ensaio de flexão em escala real foi adotado como o método preferido para avaliar as lajes mistas e se tornou a base para o desenvolvimento do Método $m-k$.

\subsection{Plooksawasdi (1977)}

O ensaio do tipo pull-out proposto por Plooksawasdi (1977) consiste em dois pedaços de uma fôrma de aço dispostas uma de costas para a outra e imersas em um bloco de concreto, conforme ilustra a Figura 4.2. As dimensões das amostras foram variadas de acordo com a largura de uma nervura da fôrma de aço.

Figura 4.2 - Esquema do ensaio pull-out proposto por Plooksawasdi (1977)

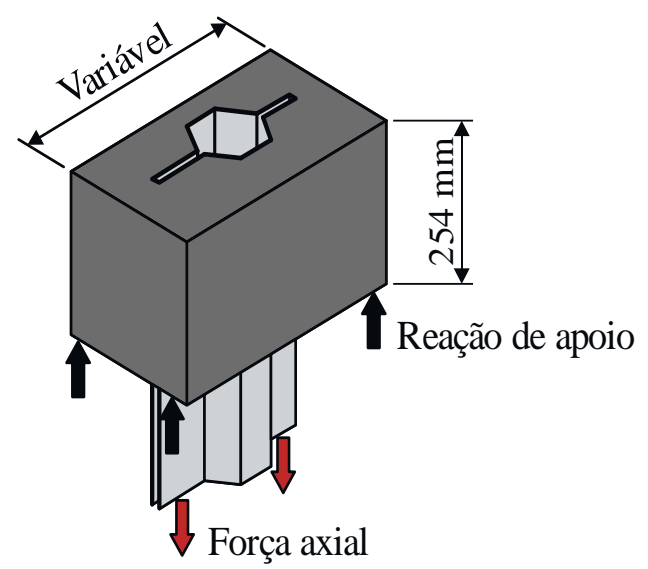

Fonte: Adaptado de ABDULLAH, 2004 
Os dados obtidos desse ensaio foram utilizados em um modelo matemático desenvolvido pelo autor para prever o momento resistente de lajes mistas cujo modo de ruptura foi o cisalhamento longitudinal. Segundo Abdullah (2004), o modelo matemático não atraiu atenção suficiente para posterior aplicação.

\subsection{Stark (1978)}

A configuração do ensaio do tipo push-out proposto por Stark (1978) consiste num modelo em que o concreto é moldado entre duas fôrmas de aço e o carregamento é aplicado de modo a empurrar o bloco de concreto, submetendo a fôrma de aço à compressão, conforme ilustra a Figura 4.3. Também são aplicados carregamentos transversais sobre o modelo.

Figura 4.3 - Esquema de ensaio push-out proposto por Skart (1978)

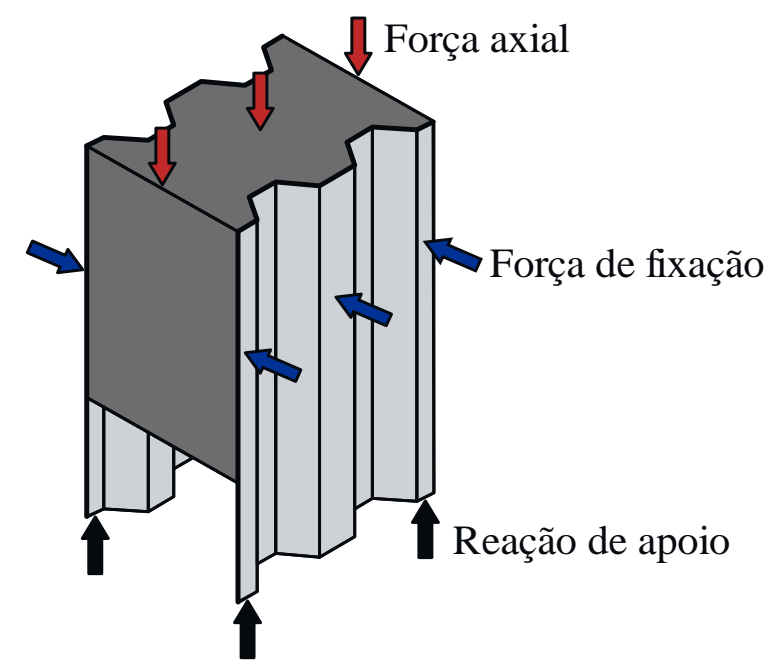

Fonte: Adaptado de ABDULLAH, 2004

Esse ensaio foi realizado para confirmar os resultados dos ensaios de flexão em escala real, em que se empregou o Método da Interação Parcial. A divergência entre os resultados obtidos pelo ensaio push-out e pelo ensaio de flexão foi atribuída ao fato de que as arestas das almas do perfil no ensaio de flexão estavam livres para fletir, enquanto que no ensaio push-out estavam restringidas.

\subsection{Jolly e Zubair (1978)}

A configuração de ensaio denominado push-off proposta por Jolly e Zubair (1978) consiste em dois blocos de concreto, moldados sobre uma nervura da fôrma de aço, que são empurrados para fora da nervura por meio de um macaco hidráulico, conforme ilustra a Figura 4.4. 
Figura 4.4 - Esquema de ensaio push-out proposto por Jolly e Zubair (1978)

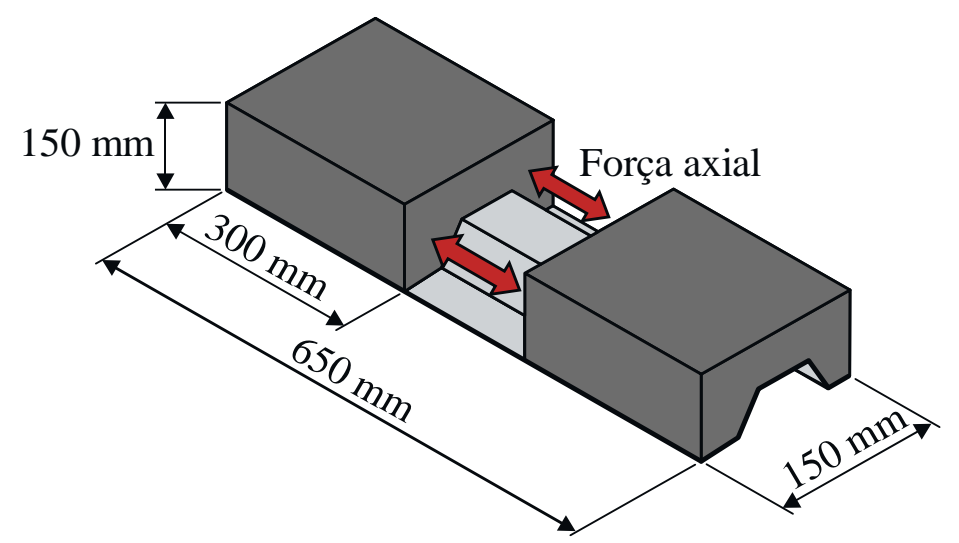

Fonte: Adaptado de ABDULLAH, 2004

O objetivo principal da realização dos ensaios foi avaliar o efeito de diferentes mossas sobre a resistência ao cisalhamento da interface, uma vez que a melhoria da fôrma poderia ser obtida por meio da modificação da forma, tamanho, profundidade e espaçamento das mossas. Verificou-se que as mossas descontínuas permitiram que a chapa de aço se distorcesse e passasse sobre o concreto com mais facilidade. Faces de mossas ortogonais à direção do deslizamento foram consideradas mais efetivas que as inclinadas. Além disso, nenhuma vantagem sobre maior número de mossas e menores tamanhos foi observada.

\subsection{Daniels (1988)}

O ensaio do tipo pull-out planejado por Daniels (1988) possui o objetivo de investigar o comportamento da conexão de cisalhamento entre o aço e o concreto ao longo da interface, assim como determinar sua resistência. A conexão entre os materiais é garantida pela própria geometria do modelo e pelas mossas. O modelo desse ensaio consiste em duas partes de uma fôrma unidas verticalmente uma de costas para a outra e com parte das faces externas cobertas com a capa de concreto. As fôrmas são parafusadas entre si por meio de uma chapa de apoio que fica entre os dois perfis, o que elimina o movimento lateral e simula a presença de nervuras adjacentes, segundo o autor. A Figura 4.5 ilustra o esquema de ensaio.

Devido aos grandes deslizamentos relativos observados para a maioria das fôrmas, uma distribuição linear de transferência de cisalhamento sobre o comprimento de uma amostra curta pode ser assumida, segundo Daniels e Crisinel (1993). Entretanto, a distribuição da transferência de cisalhamento devido à ligação química não é linear ao longo do comprimento da amostra. Os autores destacam que a resistência da ligação química é superestimada por tal ensaio devido à falta de curvatura imposta. 
Figura 4.5 - Esquema do ensaio pull-out proposto por Daniels (1988)

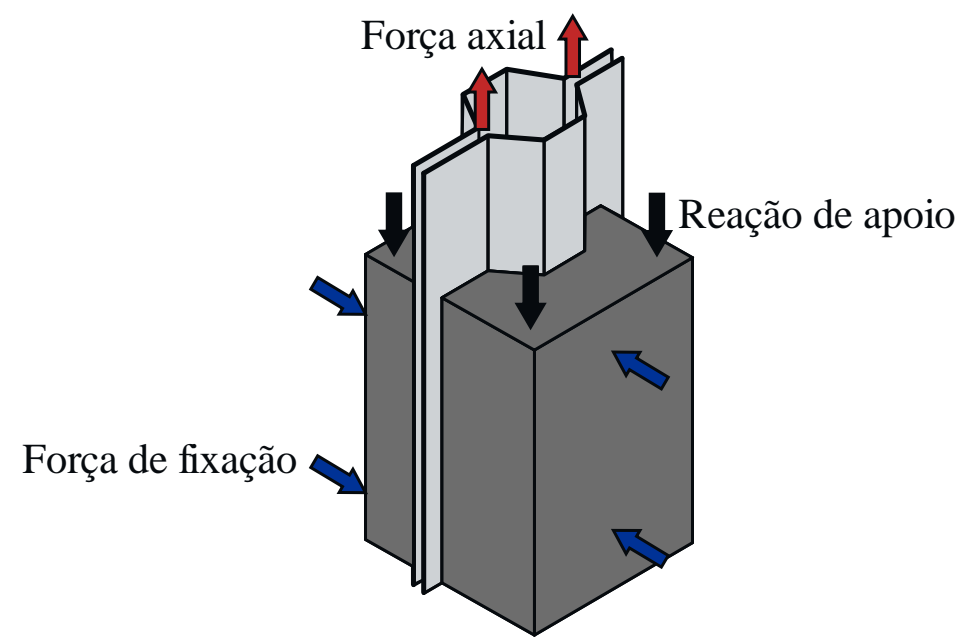

Fonte: Adaptado de DANIELS; CRISINEL, 1993

O comprimento concretado da amostra deve ser grande o suficiente para conter um número representativo de mossas, mas não dever ser muito longo ao ponto de induzir a plastificação da fôrma ou distribuições de tensão de cisalhamento não lineares. Além disso, a fôrma deve ser mantida sob tração para evitar a ocorrência de instabilidades locais, assim como simular o comportamento mais usual da fôrma nas lajes mistas, ou seja, tracionada na região de momento fletor positivo.

As forças transversais nas regiões superior e inferior da superfície do concreto em ambos os lados do modelo, que representam um valor mínimo correspondente ao peso próprio do concreto sobre a fôrma e parte do carregamento aplicado sobre a laje, devem ser aplicadas e controladas durante o ensaio para garantir que se mantenham constantes.

As amostras possuem normalmente $400 \mathrm{~mm}$ de comprimento, incluindo $100 \mathrm{~mm}$ da fôrma que não é concretada. A fôrma é cortada para que a largura do modelo seja a de uma nervura mais $50 \mathrm{~mm}$ de material de cada lado da borda. Daniels e Crisinel (1993) destacam que os perfis da amostra devem ser do mesmo painel da fôrma. A concretagem do protótipo é realizada após a montagem das fôrmas com a chapa de aço.

Após a aplicação do carregamento transversal, a carga axial é aplicada na extremidade superior da fôrma e resistida por apoios localizados na face transversal superior de cada bloco de concreto, conforme indicado na Figura 4.5. Sendo assim, essa carga é aumentada gradativamente sob controle de deslocamento e o respectivo deslizamento entre a extremidade não carregada da fôrma e o bloco de concreto é medido continuamente por meio de transdutores de deslocamento. A realização do ensaio normalmente continua após a carga máxima resistida pela interface ter sido atingida. 
Com a realização deste ensaio pull-out, é possível determinar a tensão resistente de cisalhamento $\left(\tau_{\mathrm{u}}\right)$ por meio da divisão do valor do máximo carregamento aplicado pelo valor da área superficial da fôrma em contato com o concreto. Dessa forma, gráficos da tensão de cisalhamento $(\tau)$ versus deslizamento podem ser plotados, caracterizando o comportamento da conexão como frágil ou dúctil.

A resistência máxima das conexões com comportamento frágil é devida à ligação química entre a fôrma de aço e o concreto (situação típica de fôrmas sem mossas ou com mossas pequenas), enquanto que as conexões dúcteis apresentam resistência máxima após a ocorrência de deslizamento entre os materiais. A Figura 4.6 ilustra um exemplo do gráfico da tensão de cisalhamento $(\tau)$ versus deslizamento obtido por meio do ensaio pull-out.

Figura 4.6 - Gráfico da tensão de cisalhamento versus o deslizamento para o ensaio pull-out

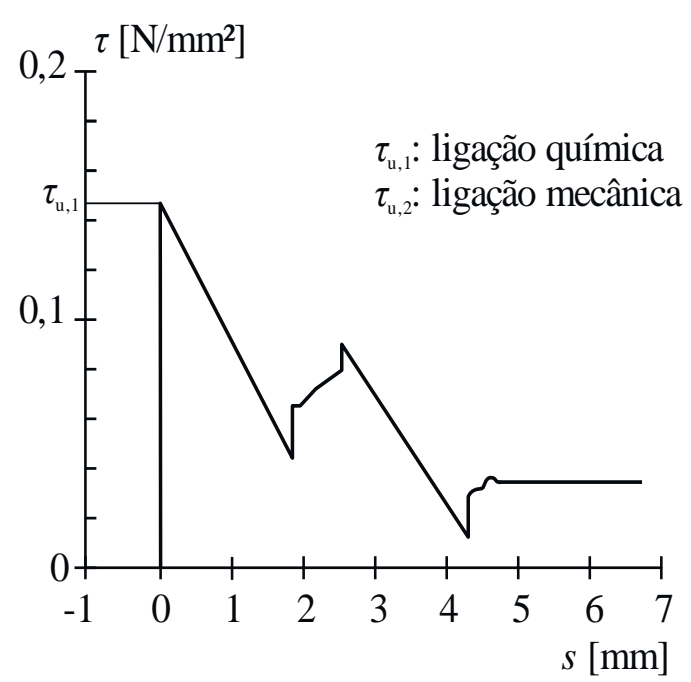

(a) Conexão de cisalhamento frágil

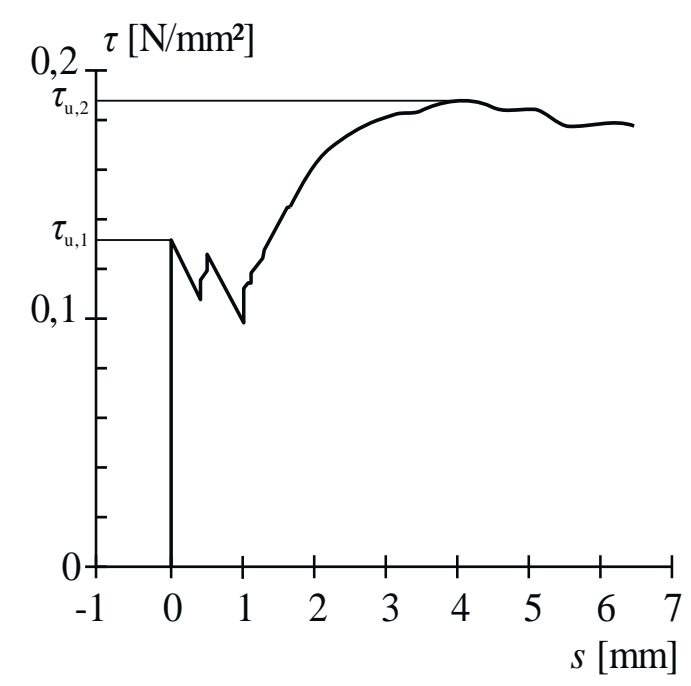

(b) Conexão de cisalhamento dúctil

Fonte: Adaptado de CRISINEL; MARIMON, 2004

A realização desse ensaio permite a identificação da participação da ligação química sobre a resistência da amostra, conforme se observa na Figura 4.6. Após a ligação ser rompida, verifica-se a participação das ligações mecânica e de atrito sobre o comportamento e a resistência da amostra.

Para o comportamento frágil, presume-se que as interações mecânicas e de atrito sejam a resistência ao cisalhamento última e estável obtida após o início do deslizamento em cada lado da amostra. Para o comportamento dúctil, a ligação química inicial representa apenas uma pequena parte de toda a curva da tensão de cisalhamento versus deslizamento, sendo o comportamento inicial estimado usando o restante da curva. 
Vários trabalhos recentes da literatura empregaram este modelo de ensaio pull-out com o objetivo de avaliar o desempenho da interface e, assim, obter parâmetros para serem utilizados em métodos teóricos desenvolvidos e/ou em modelos numéricos utilizando elementos finitos: Crisinel e Marimon (2004), Vianna (2005), Ferrer (2005), Ferrer, Marimon e Crisinel (2006), Lopes e Simões (2008) e Chen e Shi (2011). No trabalho de Ferrer (2005) são apresentadas algumas críticas e propostas de mudanças para o ensaio.

\subsection{Daniels, O’Leary e Crisinel (1990)}

O ensaio do tipo push-off apresentado por Daniels, O'Leary e Crisinel (1990), tem por objetivo investigar o comportamento e resistência da ancoragem de extremidade entre a seção de aço, a fôrma e a laje de concreto nos apoios. O modelo desse ensaio consiste de duas lajes mistas de comprimento curto dispostas verticalmente uma de costas para outra com duas vigas de aço entre elas para a simular os apoios, conforme o esquema ilustrado na Figura 4.7.

Figura 4.7 - Esquema do ensaio push-off proposto por Daniels, O’Leary e Crisinel (1990)

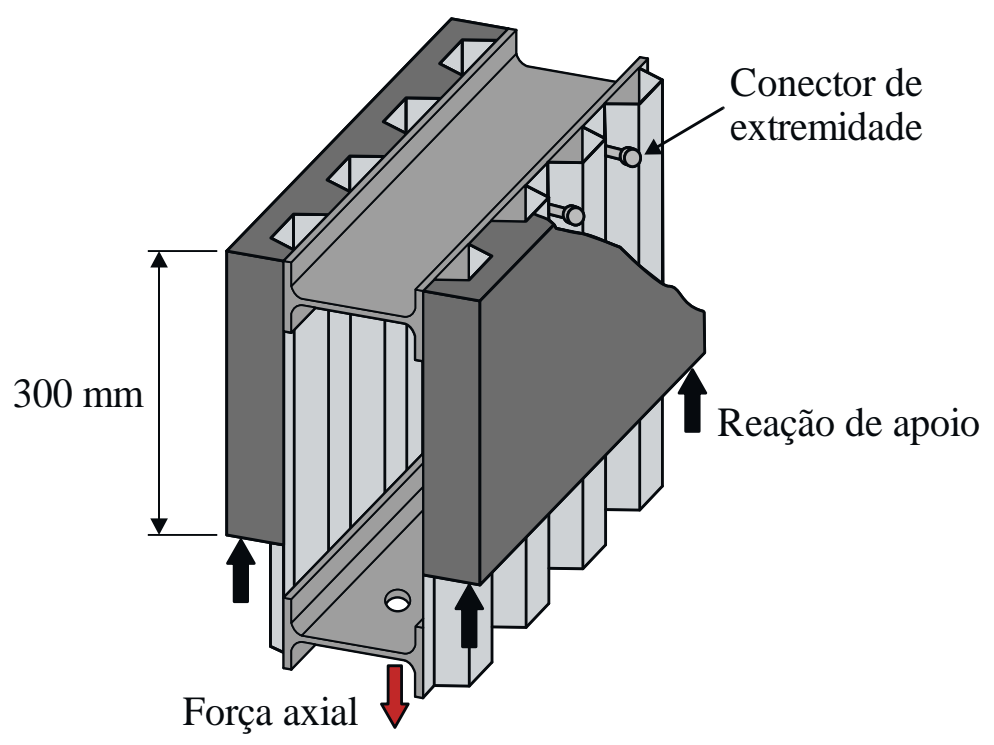

Fonte: Adaptado de DANIELS; CRISINEL, 1993

As fôrmas de aço possuem $450 \mathrm{~mm}$ de comprimento, dos quais $300 \mathrm{~mm}$ são concretados e $150 \mathrm{~mm}$ são deixados expostos. Daniels e Crisinel (1993) destacam que a fôrma de aço preferencialmente deve ser do mesmo material base usado nos modelos do ensaio pull-out proposto por Daniels (1988), se possível, quando se utiliza os dois tipos de ensaio. Além disso, eles afirmam que o material com mossas não deve ser usado, porém se a fôrma não puder ser fornecida sem mossas, deve-se levar em consideração a sua presença ao analisar os resultados do ensaio. 
Os conectores devem ser fixados apenas à viga superior e da mesma maneira realizada no local da construção. O carregamento, sob controle de deslocamento, é aplicado à viga inferior e a força axial é resistida pelos suportes de reação localizados na face inferior da capa de concreto, conforme ilustra a Figura 4.7. Neste ensaio nenhuma força transversal externa é aplicada sobre o modelo. Tanto o carregamento quanto o correspondente deslizamento entre a extremidade não carregada da fôrma e o bloco de concreto são medidos continuamente. A realização do ensaio geralmente continua após a carga máxima resistida pela interface ter sido atingida.

\subsection{Patrick e Poh (1990)}

O ensaio de deslizamento conhecido como slip-block foi desenvolvido por Patrick e Poh (1990) com o objetivo de estudar o fenômeno físico que governa a ruptura por cisalhamento longitudinal de lajes mistas de aço e concreto e determinar se parâmetros apropriados poderiam ser usados em modelos físicos para prever a capacidade resistente dessas lajes.

O protótipo do ensaio consiste numa nervura da fôrma de aço, cortada da região central do perfil e com $300 \mathrm{~mm}$ de comprimento. Essa peça da fôrma é posicionada sobre uma placa de aço de $10 \mathrm{~mm}$ de espessura (placa de base) com a nervura alinhada centralmente e fixada por meio de soldas ponteadas. Ao final, o protótipo é concretado horizontalmente.

Após a idade de cura adequada do concreto, esse é desformado e o protótipo é posicionado com a placa de base fixada à uma base rígida de uma máquina de ensaio servocontrolada composta por um atuador vertical e um atuador horizontal que funcionam de forma independente um do outro. Em seguida um sistema de rolamento, composto por duas placas com roletes maciços de aço entre elas, é posicionado na face superior da capa e uma carga vertical $\left(F_{\mathrm{V}}\right)$ é aplicada sobre ela por meio do atuador vertical da máquina de ensaio operando com controle de força.

Utilizando o atuador horizontal operando com controle de deslocamento, uma força horizontal $\left(F_{\mathrm{H}}\right)$ é aplicada gradualmente em uma das extremidades da capa de concreto e na direção da nervura da fôrma de aço. O deslocamento relativo entre o concreto e a fôrma de aço é medido por meio de transdutores de deslocamento posicionados na extremidade oposta da qual o carregamento horizontal é aplicado. O sistema de rolamento é orientado para permitir o deslizamento da capa na direção da nervura sem a interferência da máquina de ensaio. A configuração do ensaio e o protótipo estão ilustrados na Figura 4.8. 
Figura 4.8 - Esquema de ensaio slip-block proposto por Patrick e Poh (1990)

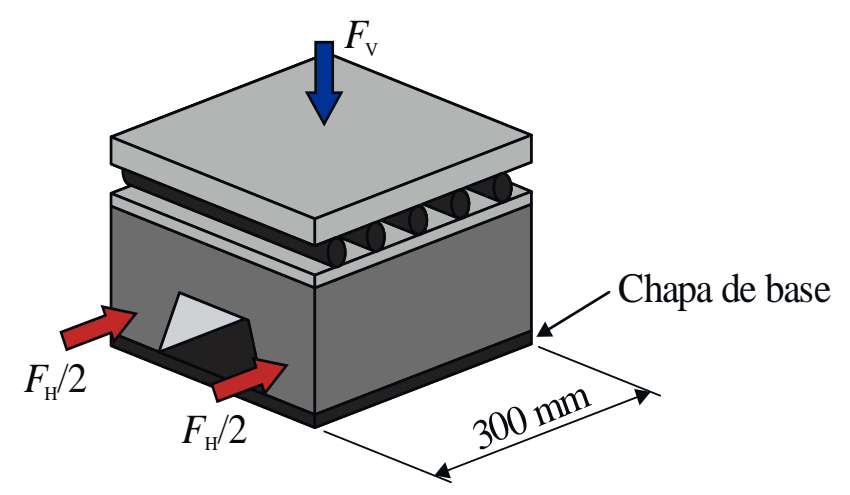

Fonte: Adaptado de PATRICK; POH, 1990

A configuração da aplicação dos carregamentos vertical e horizontal é explicada a seguir com o auxílio da Figura 4.9. Evidentemente, os resultados experimentais coletados na prática não apresentam distribuição tão linear como esboçado nessa figura, mas de tal modo regular que se podem ajustar tais retas aos pontos.

Figura 4.9 - Resultados típicos do ensaio slip-block

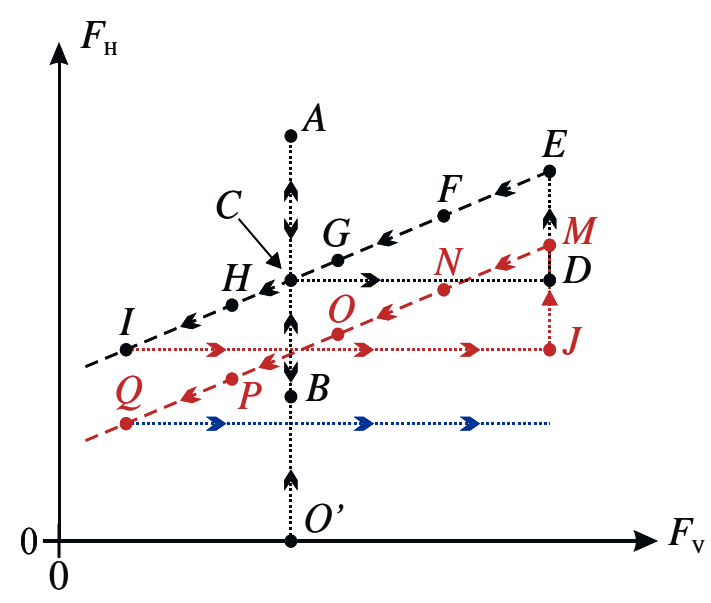

(a) Gráfico de $F_{\mathrm{H}}$ versus $F_{\mathrm{V}}$

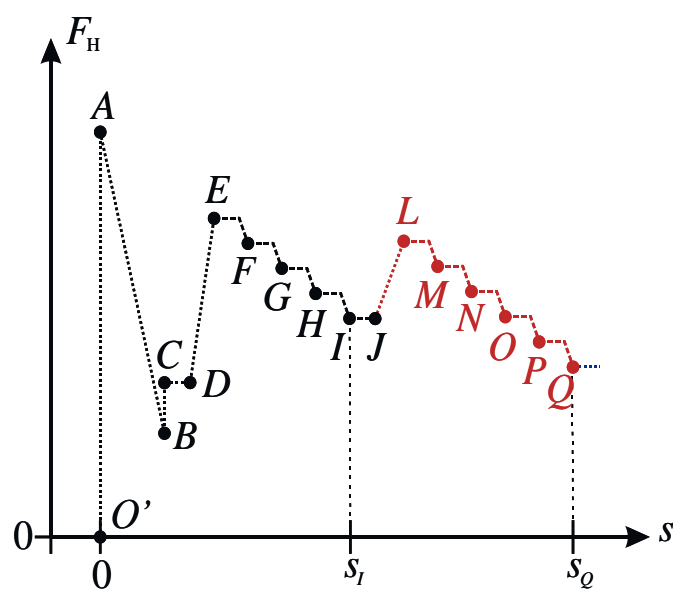

(b) Gráfico de $F_{\mathrm{H}}$ versus $s$

Fonte: Autoria própria

$\mathrm{O}$ primeiro estágio da sequência de carregamento é realizado sob força vertical $\left(F_{\mathrm{V}}\right)$ constante e é identificado pelos pontos $O^{\prime}, A, B$ e $C$. Portanto, inicialmente é aplicada uma carga vertical $\left(F_{\mathrm{V}}\right)$ constante, representado pelo ponto $O$ ' nos gráficos, confinando o modelo. Em seguida, aplica-se uma força horizontal $\left(F_{\mathrm{H}}\right)$ que aumenta gradativamente até a ligação química romper repentinamente (ponto $A$ ) seguida do deslizamento do bloco de concreto e redução da força $F_{\mathrm{H}}$ (ponto $B$ ). Com o deslizamento induzido, a força $F_{\mathrm{H}}$ aumenta gradativamente até atingir um valor relativamente constante (ponto $C$ ). Quando isso ocorre, se diz que a resistência da interface aço-concreto é atingida para este valor de $F_{\mathrm{V}}$. 
Patrick e Poh (1990) citam que o valor inicial escolhido para a força $F_{\mathrm{V}}$ deve ser suficiente para prevenir a rotação da capa de concreto antes de se atingir o ponto $A$, ou seja, antes de romper a ligação química.

No estágio seguinte, a força $F_{\mathrm{V}}$ é aumentada sem ajustar o valor da força $F_{\mathrm{H}}$ (ponto $D$ ). Mediante o deslizamento induzido continuamente, a força $F_{\mathrm{H}}$ aumenta novamente para um novo valor (ponto $E$ ), em que a resistência da interface é novamente atingida. A partir do ponto $E$, diminui-se gradualmente a força $F_{\mathrm{V}}$ sem ajuste do sistema de aplicação da força $F_{\mathrm{H}}$. Essa redução promove acréscimo de deslizamento relativo e decréscimo da resultante horizontal, até novamente a resistência da interface ser atingida (ponto $F$ ). $\mathrm{O}$ processo de redução de $F_{\mathrm{V}}$ e, consequentemente, de $F_{\mathrm{H}}$, que leva a alcançar configurações de resistência da interface (pontos $F, G$ e $H$ ), ocorre até se atingir o ponto $I$. A partir deste momento, mantém-se a força $F_{\mathrm{H}}$ constante e eleva-se a força $F_{\mathrm{V}}$ até o mesmo valor referente ao do ponto $D$, então o ciclo é repetido. Para uma mesma amostra pode-se realizar vários ciclos de carregamento, obtendo-se várias distribuições de pontos aproximadamente lineares semelhantes às do gráfico da Figura 4.9 (a).

Sempre que a resistência da interface é atingida, o equilíbrio das forças horizontais atuantes na capa de concreto é dado pela Equação 4.1, em que $b$ é a largura do bloco de concreto, $F_{\underline{H} \text {,nerv }}$ é a resistência da nervura da fôrma de aço por unidade de comprimento devido ao intertravamento mecânico e $\mu$ é o coeficiente de atrito entre o concreto e a fôrma de aço.

$$
F_{\mathrm{H}}=b \cdot F_{\mathrm{H}, \text { nerv }}+\mu \cdot F_{V}
$$

A partir dos pontos em que a resistência da interface é atingida referentes a cada ciclo (pontos $E$ até $I$ e pontos $L$ até $Q$ ), pode-se ajustar uma reta para cada caso no gráfico da Figura 4.9 (a), cujas equações são dadas pela Equação 4.1. Dessa forma, a inclinação da reta que une cada conjunto de pontos alinhados é igual ao coeficiente de atrito $(\mu)$ entre a fôrma de aço e o concreto. Extrapolando a reta até atingir o eixo vertical do gráfico da Figura 4.9 (a), determinase a contribuição da ligação mecânica $\left(F_{\mathrm{H}, \text { nerv }}\right)$, que independe da magnitude de carregamento vertical aplicado.

Verifica-se, portanto, que a realização desse ensaio permite avaliar a contribuição das ligações por atrito e mecânica separadamente, conforme expressa a Equação 4.1. Além disso, é possível determinar o coeficiente de atrito entre a fôrma de aço e o concreto. Contudo, é necessário utilizar um sistema de atuadores horizontal e vertical independentes e servocontrolados para possibilitar a realização do ensaio adequadamente. A seguir são descritas algumas pesquisas que empregaram esse método de ensaio. 
Patrick e Bridge (1994) desenvolveram um novo modelo de cálculo que define a resistência da conexão de cisalhamento parcial, considerando um segmento da laje mista simplesmente apoiada e sob qualquer condição de carregamento. Para sua aplicação, a laje deve atingir a ruptura por flexão ou por cisalhamento longitudinal, pois a teoria não considera a ruptura devido ao cisalhamento vertical. O modelo incorpora o desempenho da conexão de cisalhamento derivado do ensaio slip-block. Ensaios de flexão em lajes mistas provaram que o modelo físico é confiável e, segundo os autores, pode explicar prontamente os efeitos das mudanças no desempenho da conexão de cisalhamento, padrão de carga, condições de apoio da extremidade da fôrma, dispositivos de ancoragem de extremidade, armadura convencional e etc. O modelo foi desenvolvido para possível uso em uma norma australiana sobre projetos de lajes mistas.

Bode e Minas (1997) propuseram um aperfeiçoamento para o Método da Interação Parcial empregando os resultados obtidos de ensaios do tipo slip-block para considerar a influência do atrito na região dos apoios. Segundo os autores, a influência do comprimento de cisalhamento é claramente reduzida, se a ação do atrito sobre os apoios for levada em consideração.

Makelainen e Sun (1999) realizaram um estudo experimental empregando um ensaio muito semelhante ao slip-block, exceto pelo fato de não existir carga vertical aplicada. Um tipo particular de fôrma foi avaliado de modo que diferentes configurações foram consideradas. Informações importantes sobre o efeito da altura, comprimento e forma das mossas, assim como sobre a ductilidade das lajes foram obtidas. Os autores concluíram que, para fôrma de aço analisada, a profundidade das mossas tem mais efeito sobre o comportamento e resistência ao cisalhamento do que o comprimento e o formato das mossas.

Ganesh, Upadhyay e Kaushlk (2005) propuseram uma abordagem simplificada para o projeto de lajes mistas utilizando os resultados do ensaio slip-block em um modelo de cálculo simples para obter o momento fletor resistente baseado no Método da Interação Parcial. Os resultados obtidos usando esta abordagem foram verificados por comparação com os resultados baseados no Método $m-k$ e mostraram boa correlação. Os autores concluíram que o ensaio é simples e econômico, podendo ser usado como uma abordagem alternativa para avaliar a resistência ao cisalhamento longitudinal das lajes mistas.

Venkat e Upadhyay (2008) realizaram um estudo experimental envolvendo ensaios do tipo slip-block e de flexão em escala real. Os resultados do ensaio slip-block foram utilizados no Método da Interação Parcial para determinar o momento fletor resistente da laje mista em estudo, que foi comparado com o resultado experimental dos modelos ensaiados à flexão. Os 
momentos fletores resistentes determinados por meio dos dados do ensaio slip-block ficaram entre $14 \%$ e $20 \%$ abaixo dos resultados experimentais das lajes em escala real.

Os trabalhos realizados inicialmente por Holomek e Bajer (2012), Holomek et al. (2012), Holomek et al. (2014) empregaram um novo arranjo para o ensaio slip-block. A amostra possui a largura de duas nervuras e a fôrma é parafusada à placa de base, conforme ilustra a Figura 4.10. Nesses trabalhos, o ensaio de deslizamento foi realizado para avaliar seu desempenho e seus resultados em comparação com os ensaios em escala real. Além disso, simulações numéricas simples de caráter exploratório foram desenvolvidas empregando os resultados provenientes do ensaio de pequenas dimensões.

Figura 4.10 - Ensaio de deslizamento proposto por Holomek, Bajer e Vilda (2016)
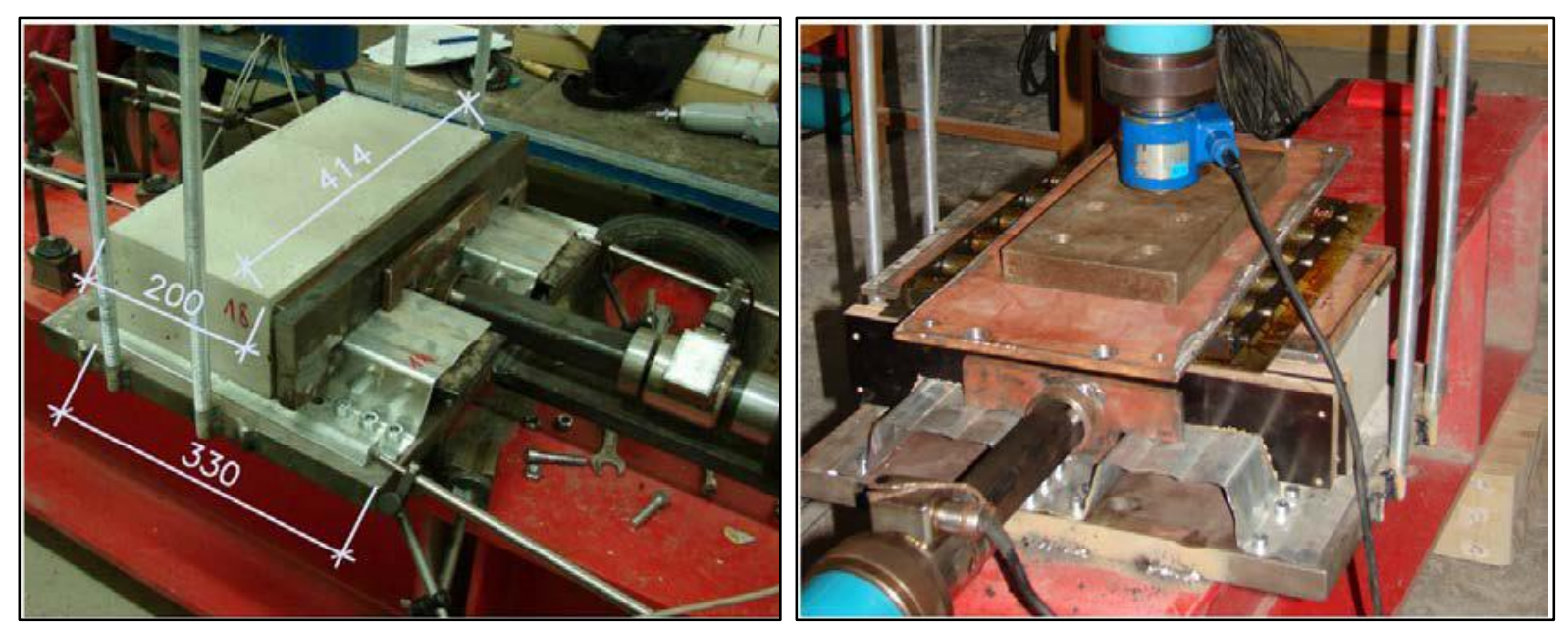

Fonte: HOLOMEK; BAJER; VILDA, 2016

Holomek et al. (2015) realizaram ensaios experimentais de flexão a quatro pontos e com carregamento a vácuo, para produzir um carregamento uniformemente distribuído sobre a laje. Também foram realizados ensaios de deslizamento, semelhantes ao slip-block. Os autores compararam os resultados obtidos pelos ensaios experimentais realizados com os obtidos pelos métodos de cálculo $m-k$, da interação parcial e o método simplificado proposto por Crisinel e Marimon (2004). No caso desse último método, os autores empregaram os parâmetros obtidos do ensaio slip-block. Foi analisado o efeito da separação vertical e da adição de parafusos fixados ao longo da fôrma para aumentar o intertravamento entre o aço e o concreto. Diante dos resultados obtidos para os momentos últimos, observou-se que o método simplificado proposto por Crisinel e Marimon (2004) se apresentou menos conservador. Contudo, o desempenho do ensaio de deslizamento apresentou incertezas significantes e os resultados apresentaram grande variação. 
Diante dos ensaios realizados, Holomek, Bajer e Vilda (2016) propuseram, então, as seguintes recomendações no intuito de reduzir a dispersão dos resultados do novo arranjo para o ensaio slip-block: cada amostra deve ter a placa de suporte fixada na parte inferior da amostra, desde a concretagem até o ensaio; o sistema de carregamento com controle de deslocamento é recomendado; a velocidade de carregamento mínima recomendada é de $0,2 \mathrm{~mm} / \mathrm{min}$ até 2,5 $\mathrm{mm}$ de deslocamento, $0,8 \mathrm{~mm} / \mathrm{min}$ até $10 \mathrm{~mm}$ de deslocamento e $5 \mathrm{~mm} / \mathrm{min}$ até o final do ensaio; o deslocamento do bloco de concreto, bem como o deslocamento da fôrma fixa devem ser medidos em ambos os lados da amostra.

Yi et al. (2018) realizaram um estudo experimental empregando o ensaio slip-block para investigar as características da ligação entre a fôrma reentrante e o concreto com borracha triturada (crumb rubber concrete). A configuração do ensaio foi semelhante a desenvolvida por Holomek et al. (2015), conforme ilustra a Figura 4.11.

Figura 4.11 - Ensaio de deslizamento realizado por Yi et al. (2018)

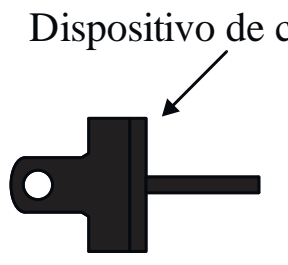

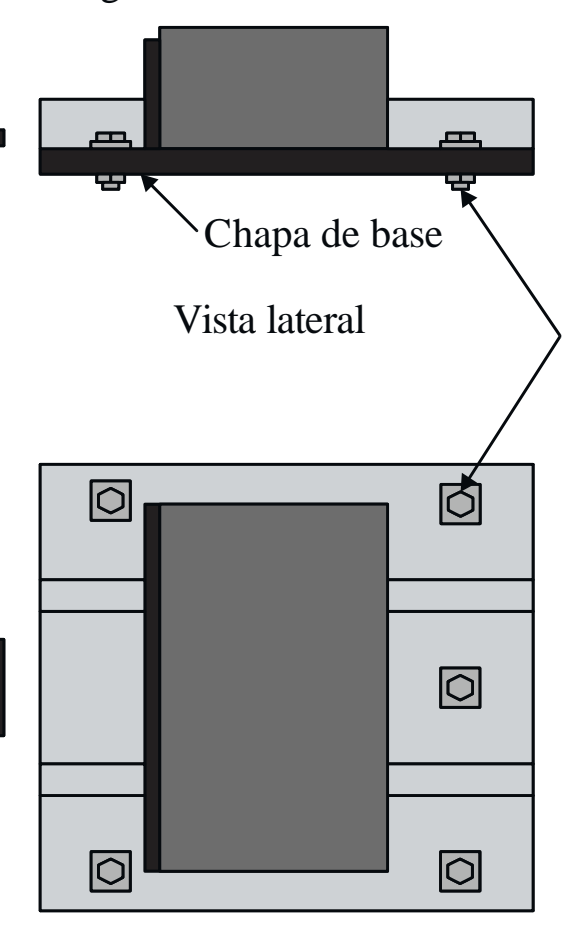

Vista superior

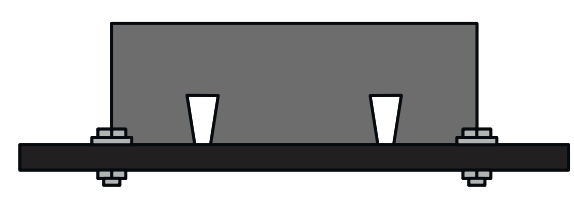

Vista frontal

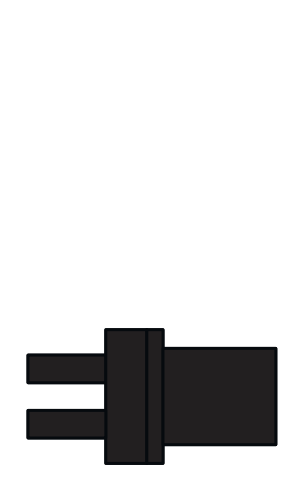

Fonte: Adaptado de YI et al., 2018

Os autores realizaram o ensaio de duas formas: sem nenhuma carga vertical aplicada e com um carregamento constante de $2,0 \mathrm{kN}$ aplicado verticalmente. Em ambos os casos a curva da força resistente ao cisalhamento horizontal versus deslizamento possuiu a configuração apresentada na Figura 4.12. 
Figura 4.12 - Gráfico típico da força resistente ao cisalhamento versus deslizamento do ensaio slip-block sob força vertical nula ou constante realizado por Yi et al. (2018)

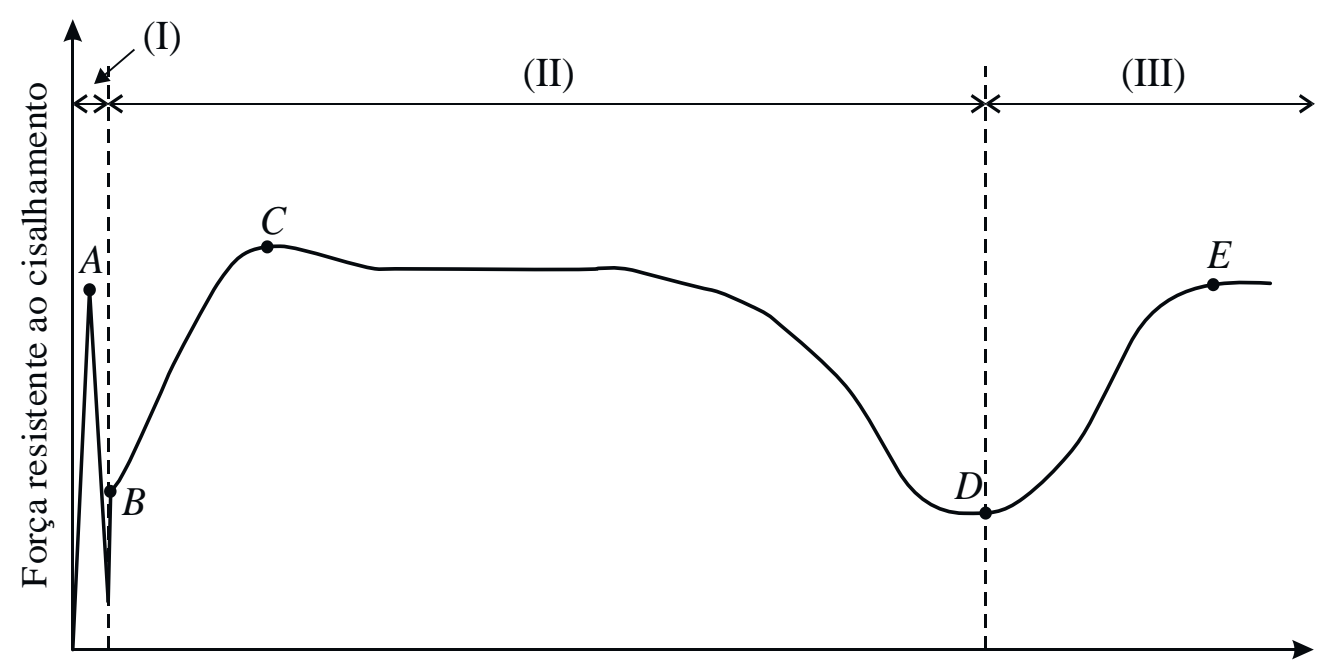

Deslizamento

Fonte: Adaptado de YI et al., 2018

De acordo com Yi et al. (2018), a região I do gráfico, definida como zona de ligação inicial, é referente à ligação química entre o aço e o concreto. A região II reflete a atuação das ligações mecânica (intertravamento mecânico) e por atrito. Segundo os autores, o comprimento dessa seção é geralmente o espaçamento de centro a centro entre duas mossas da nervura, que é definido como $1^{\mathrm{o}}$ ciclo de deslizamento de mossa. A resistência ao cisalhamento no ponto $C$ é geralmente adotada no cálculo como a resistência da ligação aço-concreto para o projeto. A terceira seção, repetindo o comportamento mostrado da região II, é o $2^{\circ}$ ciclo do deslizamento da mossa (III). O ponto extremo no vale (ponto $D$ ) diferenciando as regiões II e III, é definido como a resistência mínima, a partir da qual o $2^{\circ}$ ciclo de deslizamento se inicia e atinge a segunda resistência extrema (ponto $E$ ).

Diante do que foi exposto nesta seção, verifica-se que o ensaio slip-block fornece mais uma alternativa de avaliar o comportamento da interface aço-concreto em lajes mistas, possibilitando determinar isoladamente as contribuições das ligações por atrito e mecânica, que são informações pertinentes ao se avaliar o desempenho e eficiência de uma fôrma de aço. Apesar de não permitir avaliar os efeitos da curvatura devido à flexão e da separação vertical, é possível extrair parâmetros que podem fornecer informações importantes quando adequadamente utilizados e levando em conta tais limitações. Esses parâmetros podem ser, então, aplicados em métodos analíticos pertinentes, assim como para a modelagem numérica da interface aço-concreto. 


\subsection{Airumyan et al. (1990)}

O ensaio do tipo push-out proposto por Airumyan et al. (1990) consiste num bloco de concreto moldado entre duas chapas de aço. As chapas são ancoradas em uma das extremidades e, em seguida, uma carga é aplicada ao bloco de concreto para fazê-lo deslizar em relação ao aço, conforme ilustra a Figura 4.13. O ensaio foi utilizado para investigar qualitativamente o efeito de várias geometrias de mossas sobre o comportamento da ligação aço-concreto.

Figura 4.13 - Esquema de ensaio push-out proposto por Airumyan et al. (1990)

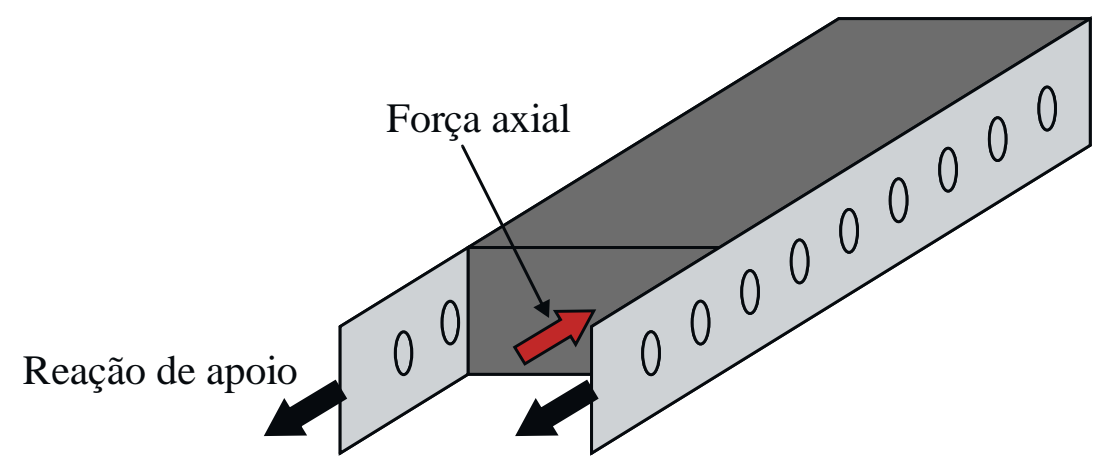

Fonte: Adaptado de ABDULLAH, 2004

Conforme se observa na Figura 4.13, nenhum mecanismo externo é empregado para manter a chapa de aço em contato com o concreto. Dessa forma, assim que a ligação química fosse quebrada, haveria uma tendência para a chapa se afastar do concreto e, assim, reduzir a carga aplicada à zero. Devido à sua configuração, que não utiliza a própria fôrma e negligencia a contribuição do formato das nervuras do perfil, este ensaio se torna inadequado para avaliar o comportamento da interface aço-concreto de lajes mistas.

\subsection{An (1993)}

O ensaio desenvolvido por An (1993) procura incluir o efeito da curvatura devido à flexão da laje mista para determinar a tensão de cisalhamento na interface aço-concreto. Duas configurações de ensaio foram empregadas. A primeira teve a fôrma de aço em contato direto com os apoios para que o efeito da resistência devido ao atrito sobre a resistência ao deslizamento pudesse ser estudado, conforme ilustra a Figura 4.14 (a). A segunda configuração não possui a fôrma de aço em contato direto com os apoios, sendo utilizada para obter a resistência ao cisalhamento sem a presença do atrito proporcionado pelo apoio, conforme ilustra a Figura 4.14 (b). A tensão de cisalhamento foi determinada pelo cálculo da força de tração na fôrma usando métodos analíticos. As dimensões expressas na Figura 4.14 estão em milímetros. 
Figura 4.14 - Esquema de ensaio proposto por An (1993)
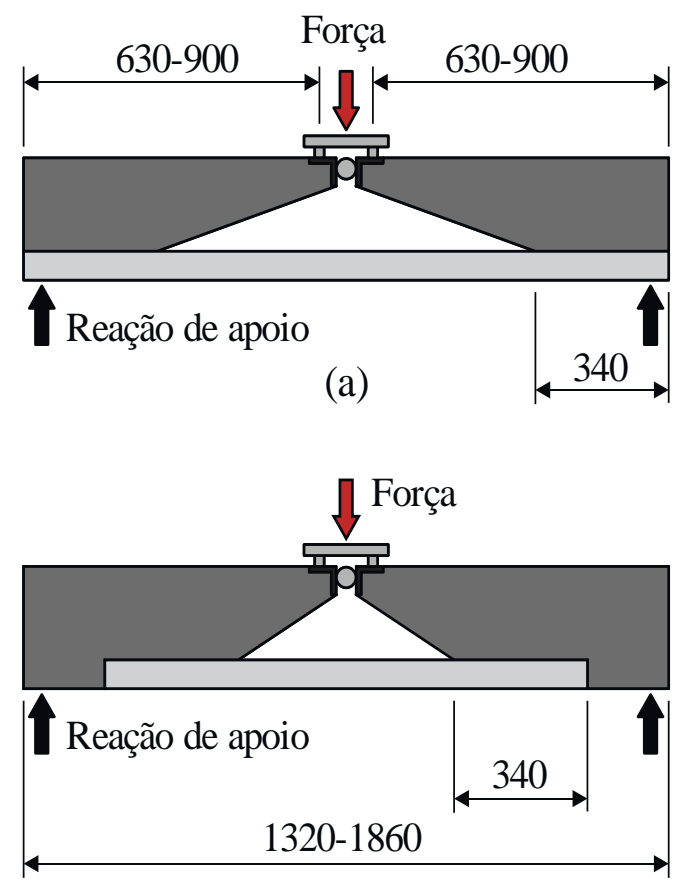

(b)

Fonte: Adaptado de ABDULLAH, 2004

Os parâmetros estudados por An (1993) foram o tipo de concreto (concreto normal e leve) e a relação entre o vão de cisalhamento e a altura da laje mista. Os resultados do ensaio foram utilizados como dados de entrada na análise de elementos finitos realizada.

\subsection{Veljkovic (1996)}

O trabalho desenvolvido por Veljkovic (1996) fez parte do projeto denominado "Partial Interaction in Composite Slabs" (Interação Parcial em Lajes Mistas), realizado pela Divison of Steel Structures (Divisão de Estruturas de Aço) da Luleå University of Technology, na Suécia. O projeto foi desenvolvido em duas fases de 1991 a 1996. Três séries de ensaios foram realizadas para analisar a interação parcial de lajes mistas. Cada série consistiu de ensaios em escala real e de modelos de pequenas dimensões. No total foram realizados 12 ensaios de flexão em escala real e aproximadamente 200 ensaios de modelos de pequenas dimensões realizados em vários tipos de fôrmas de aço. Além disso, foram realizadas mais de 200 simulações numéricas utilizando o Método dos Elementos Finitos. De acordo com Veljkovic (1994), um dos objetivos do projeto foi conectar a resistência ao cisalhamento determinada por meio dos ensaios de modelos de pequenas dimensões com a resistência das lajes mistas ensaiadas em escala real. 
Dois tipos de ensaio de deslizamento foram desenvolvidos por Veljkovic (1996) para obter dados e, assim, estudar o comportamento de lajes mistas usando o Método dos Elementos Finitos. O primeiro tipo de ensaio, denominado push-test, consiste em aplicar uma força para deslizar o bloco de concreto (moldado sobre a fôrma) em relação à fôrma de aço, conforme ilustra a Figura 4.15 (a). Esse ensaio foi utilizado para determinar a resistência mecânica devido ao intertravamento, desprezando a influência do atrito. O segundo tipo de ensaio, denominado tension push-test, consiste em aplicar uma força tracionando a fôrma de aço e outra força para deslizar o bloco de concreto em relação à fôrma de aço, conforme ilustra a Figura 4.15 (b). Esse segundo tipo de ensaio foi utilizado para determinar uma função de redução da resistência ao cisalhamento devido à deformação da fôrma de aço tracionada. Além desses dois tipos de ensaio, foi realizado o ensaio slip-block (descrito na seção 4.7), porém com um procedimento de ensaio diferente, que foi utilizado para determinar o coeficiente de atrito na região de apoio.

Figura 4.15 - Esquema de ensaio proposto por Veljkovic (1996)

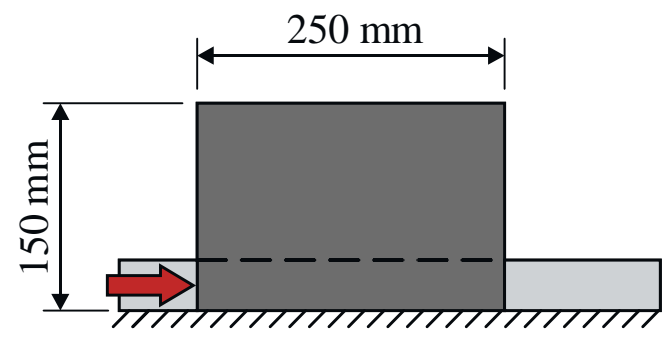

(a) Push-test

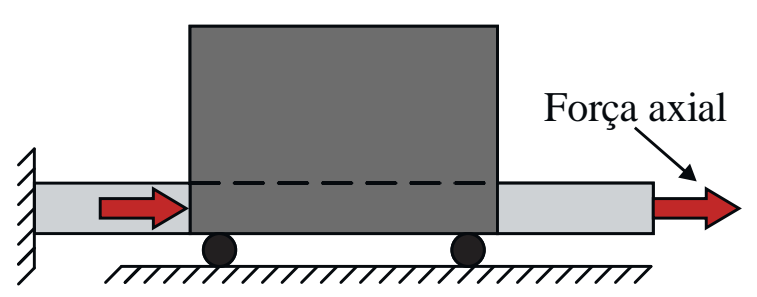

(b) Tension push-test

Fonte: Adaptado de ABDULLAH, 2004

Uma vez extraídos os parâmetros dos três tipos de ensaio, utilizou-se no modelo de elementos finitos a resistência mecânica de intertravamento (ligação de cisalhamento deslizamento), um coeficiente de atrito e uma função de redução. A partir do ensaio com a fôrma tracionada, o autor constatou que a tensão de tração poderia esticar e achatar as mossas, o que, por sua vez, reduziria a resistência ao cisalhamento e aumentaria o deslizamento correspondente. Dessa forma, uma função de redução foi estabelecida para corrigir a resistência mecânica de intertravamento obtida no push-test.

Veljkovic (2000) apresentou um método de projeto para lajes mistas com chapas rasas baseado em ensaios de modelos de pequenas dimensões e numa análise de elementos finitos, ou seja, três parâmetros do método da resistência de conexão parcial. A envoltória da resistência do momento fletor pode ser determinada de acordo com o modelo mecânico, em que são consideradas as influências do atrito entre o apoio e a borda da laje. 


\subsection{Burnet (1998)}

Uma nova forma do push-out foi desenvolvida por Burnet (1998) para medir diretamente a resistência mecânica ao cisalhamento do intertravamento ocorrente na interface das nervuras, ignorando o benefício do atrito ativo que ocorre na região dos apoios da laje mista. Os autores utilizaram a configuração do ensaio proposto por Stark (1978), mas sem a presença das forças laterais de fixação. $\mathrm{O}$ autor constatou que o arranjo de modo a tracionar a fôrma poderia ser mais fácil de se realizar. O modelo do ensaio é ilustrado na Figura 4.16.

Figura 4.16 - Esquema de ensaio push-out proposto por Burnet (1998)

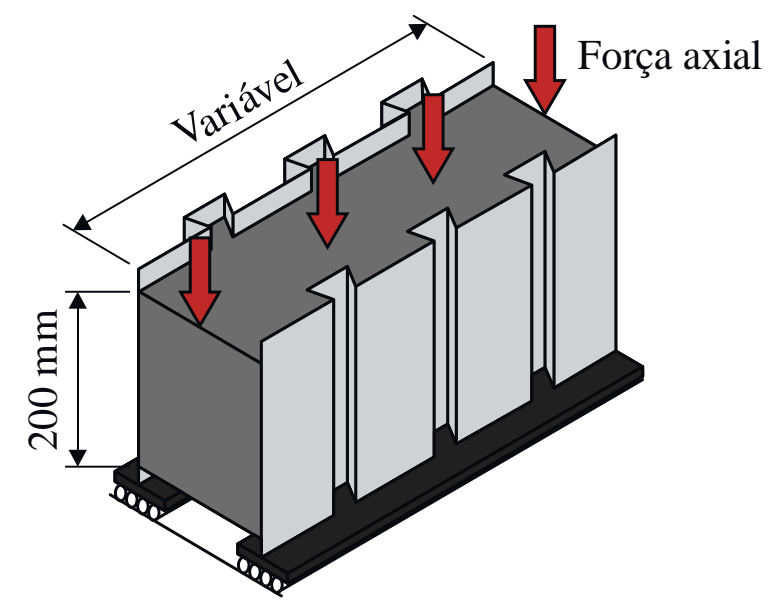

Fonte: Adaptado de ABDULLAH, 2004

O modelo é ensaiado em dois estágios para determinar a resistência química antes do deslizamento e, em seguida, a ligação mecânica após o início do deslizamento. A ruptura da ligação química foi considerada não uniforme e repentina. Por meio desse ensaio o autor avaliou vários tipos de perfis trapezoidais e reentrantes.

Burnet (1998) observou que para perfis com mossas, o deslizamento longitudinal era acompanhado por separação lateral da chapa da superfície do concreto. Para perfis reentrantes, a separação foi menor do que para perfis trapezoidais. Perfis com maior abertura de nervura (perfil trapezoidal) apresentaram menor resistência ao cisalhamento do que com menor abertura de nervura.

O autor cita que para a transferência de cisalhamento das mossas das nervuras entre apoios em uma laje mista, o ensaio de tração sem forças laterais externas seria apropriado, porém na região de apoio onde a fôrma pode ficar presa entre o componente de concreto e o apoio, o atrito ativo pode predominar. Contudo, a dificuldade na região de apoio é determinar quanto do cisalhamento vertical atravessa a interface aço-concreto quando a fôrma não cobre todo o apoio. 


\subsection{Tremblay et al. (2002)}

A amostra do ensaio do tipo push-out desenvolvido por Tremblay et al. (2002) consiste em um bloco de concreto moldado entre duas fôrmas de aço que é ensaiado horizontalmente para simular os efeitos ocorrentes na laje mista sob flexão, conforme ilustra a Figura 4.17. A fôrma é submetida a uma tensão uniforme aplicada ao seu centroide, enquanto o concreto é carregado sob compressão para reproduzir a situação típica das lajes fletidas. Nesta configuração, uma carga de $6 \mathrm{kN}$ é aplicada na extremidade da amostra para fornecer contenção e, de acordo com os autores, para simular uma condição de extremidade típica da laje simplesmente apoiada.

Figura 4.17 - Esquema de ensaio push-out proposto por Tremblay et al. (2002)

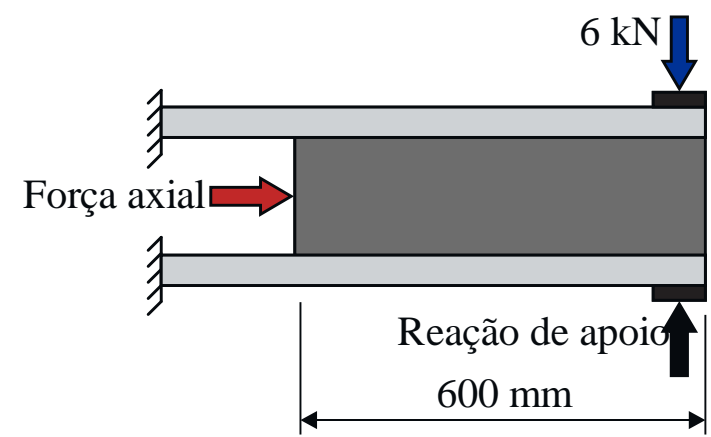

Vista lateral

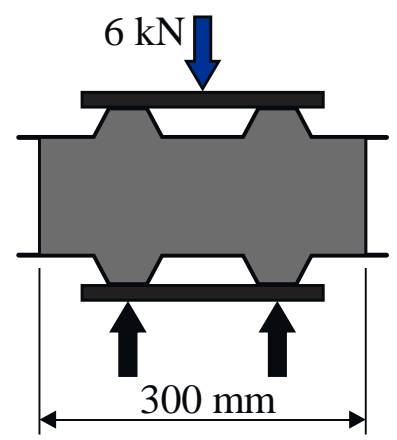

Vista frontal

Fonte: Adaptado de ABDULLAH, 2004

Esta abordagem foi seguida sob o pressuposto de que os resultados dos ensaios de arrancamento poderiam ser aplicados na previsão do comportamento à flexão de lajes mistas. Os autores utilizaram o ensaio para estudar o efeito da espessura do aço, categoria do aço, revestimento de superfície, posição da fôrma (normal ou invertida), idade de cura do concreto e presença de eletroduto na laje.

\subsection{Abdullah (2004)}

Abdullah (2004) desenvolveu um novo procedimento de ensaio denominado ensaio de flexão elementar (elemental bending test, em inglês) com o objetivo de desenvolver um método e procedimento de ensaio eficiente, simples e econômico de pequenas dimensões para lajes mistas com a capacidade de fornecer parâmetros necessários para todos os métodos de projeto e análise, ou seja, empírico, analítico ou numérico. Além disso, o autor estabeleceu uma configuração de ensaio de modo a incorporar os fenômenos presentes na interface da laje mista submetida à flexão, como a separação vertical e o efeito causado pela curvatura da laje. 
O protótipo consiste numa nervura da laje mista que é submetida a flexão, de maneira análoga ao ensaio de flexão a quatro pontos. Presilhas foram, então, fixadas sob as mesas inferiores da fôrma, num intervalo predeterminado ao longo do comprimento das lajes, para simular o efeito de restrição das nervuras adjacentes da fôrma. A Figura 4.18 ilustra o protótipo e o esquema de ensaio.

Figura 4.18 - Esquema do ensaio de flexão elementar proposto por Abdullah (2004)

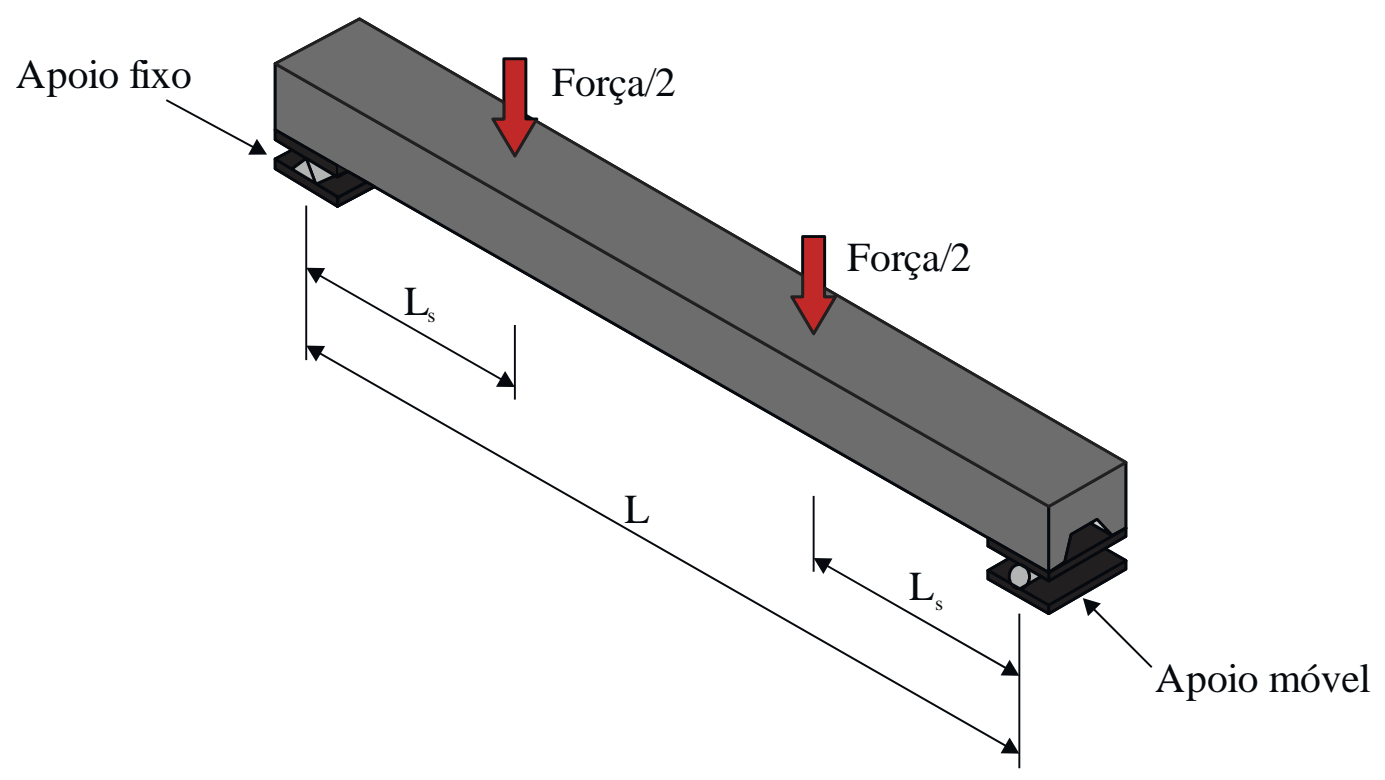

Fonte: Adaptado de ABDULLAH, 2004

O autor também desenvolveu um procedimento de cálculo chamado de Equilíbrio de Forças, que considera o efeito da esbeltez da laje, para gerar propriedades da ligação de cisalhamento a partir do ensaio de flexão elementar. A esbeltez da laje mista é definida como o comprimento de cisalhamento dividido pela altura da laje $\left(L_{\mathrm{s}} / h\right)$.

No estudo realizado Abdullah (2004) verificou que a ligação de cisalhamento das lajes mistas sob flexão varia com o parâmetro de esbeltez e, portanto, influencia a resistência e o comportamento das lajes, além de afetar a precisão das análises de elementos finitos. Usando este procedimento, a precisão da análise de elementos finitos de lajes mistas de várias esbeltezes foi melhorada. A Figura 4.19 ilustra curvas da tensão de cisalhamento longitudinal versus deslizamento para várias lajes, indicando a influência da esbeltez entre lajes esbeltas e compactas.

Para lajes mistas esbeltas, a ligação de cisalhamento e as magnitudes de deslizamento de extremidade são relativamente pequenas em comparação com as lajes mais compactas. A mudança do comportamento da ligação de cisalhamento também é menos sensível para as lajes esbeltas em comparação com as mais compactas. 
Figura 4.19 - Gráfico da tensão de cisalhamento longitudinal versus deslizamento para os resultados de Abdullah (2004)

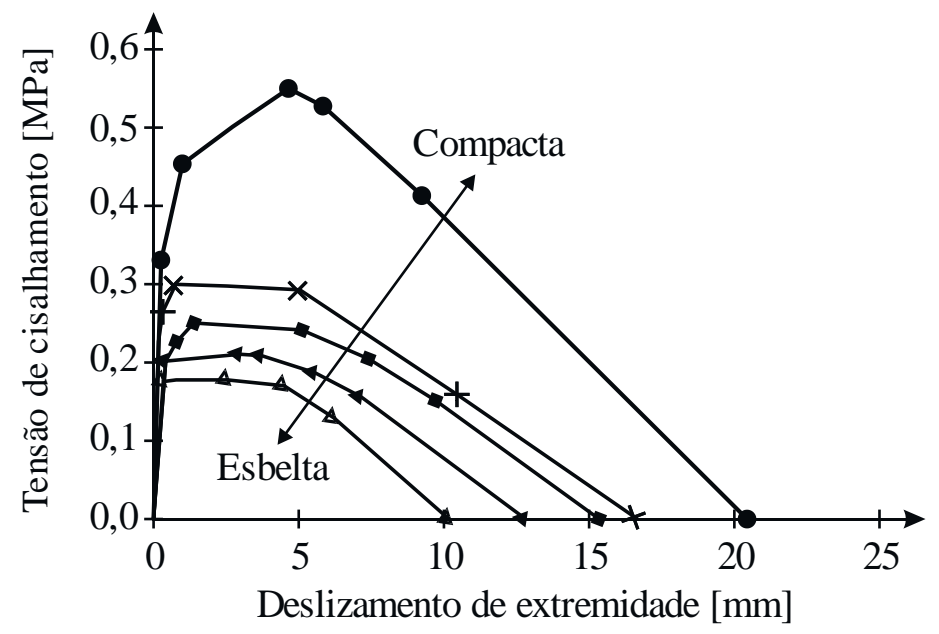

Fonte: Adaptado de ABDULLAH, 2004

Como a propriedade de ligação de cisalhamento de uma laje mista é dependente da geometria, o autor apresentou um método de interpolação linear que foi usado para estimar a curva da ligação de cisalhamento versus deslizamento da extremidade para lajes de esbeltez diferente. A interpolação é conduzida utilizando a curva da tensão de cisalhamento versus deslizamento de extremidade de dois resultados do ensaio elementar de flexão: uma amostra compacta e uma esbelta. A relação linear foi assumida com base no fato de que as capacidades de carga de lajes de qualquer esbeltez construídas no mesmo perfil de fôrma variam linearmente com a esbeltez da laje $\left(L_{\mathrm{s}} / h\right)$.

\subsection{Fontes (2016)}

Com objetivo determinar a resistência da interface aço-concreto de lajes mistas, Fontes (2016) desenvolveu um ensaio do tipo push-out que consiste na aplicação de um carregamento para empurrar a amostra da fôrma de aço em relação ao concreto. O protótipo consiste de duas amostras da fôrma de aço, com largura de uma nervura, dispostas uma de costas para a outra e soldadas entre si, assim como são soldadas em perfis de aço do tipo U, conforme ilustra a Figura 4.20. O protótipo é concretado e após decorrido a cura o ensaio é realizado. Forças laterais são aplicadas à capa de concreto por meio de tirantes de aço pré-tracionados objetivando simular a carga que atua transversalmente à laje mista. Em seguida uma força vertical é aplicada sobre os perfis do tipo U por meio de um atuador hidráulico, promovendo o deslizamento da fôrma. Ao longo do ensaio a força aplicada, a deformação da estrutura de reação e o deslocamento relativo entre o aço e o concreto são medidos continuamente. 
Figura 4.20 - Esquema do ensaio push-out proposto por Fontes (2016)

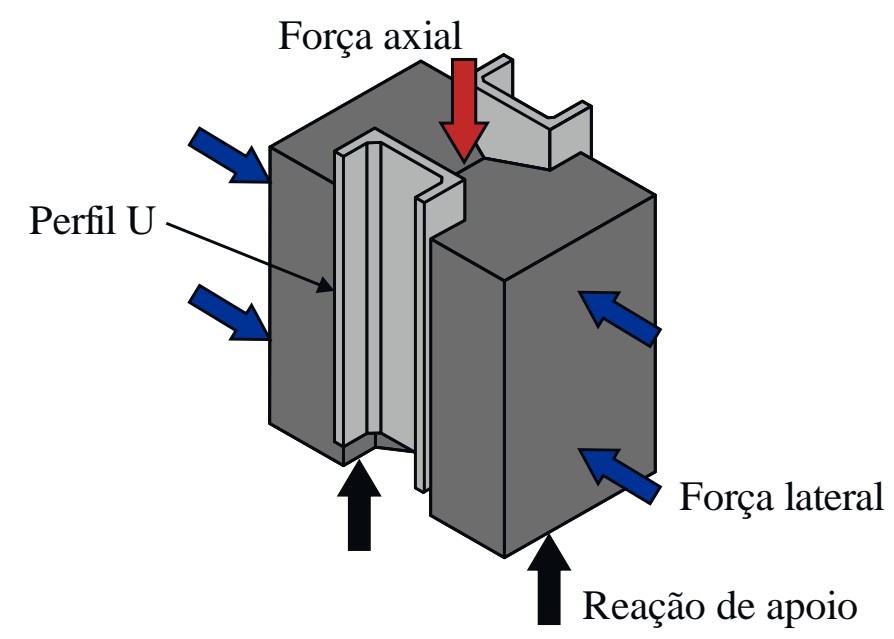

Fonte: Adaptado de FONTES, 2016

Por meio deste ensaio o autor avaliou a resistência da ligação aço-concreto e os fenômenos envolvidos referentes à transferência de esforços na interface. Com base numa análise numérica e numa análise analítica que empregava o modelo de bielas e tirantes, o autor desenvolveu uma nova configuração para as mossas com o objetivo de aumentar a resistência ao cisalhamento longitudinal. Tal configuração foi avaliada por meio do ensaio aqui descrito, que verificou um aumento de aproximadamente 6 vezes na capacidade resistente da interface aço-concreto da fôrma analisada. No entanto, vale ressaltar que as mossas da configuração proposta foram executadas manualmente.

\subsection{Trabalhos Realizados no Brasil}

Os trabalhos nacionais até então desenvolvidos se concentraram na análise do comportamento e da capacidade resistente de lajes mistas por meio do ensaio normativo de flexão a quatro pontos. Neste quesito, algumas pesquisas caracterizaram fôrmas de aço produzidas pela indústria brasileira, a exemplo dos trabalhos de Ferraz (1999), Melo (1999), Vieira (2003), Brendolan (2007) e Sieg (2015).

Martins (2001) avaliou respostas estruturais de algumas fôrmas metálicas incorporadas às lajes, disponíveis nos mercados nacional e internacional. Gomes (2001) estudou o comportamento e a resistência de um sistema de lajes mistas com fôrma de aço incorporada empregando concreto estrutural leve. Campos (2001) verificou o efeito da continuidade sobre o comportamento e a resistência de um sistema de lajes mistas. Souza Neto (2001), por sua vez, analisou o comportamento e a resistência das lajes mistas com ancoragem de extremidade 
simplesmente apoiadas com consideração da fôrma de aço isolada e atrito nos apoios. Já Sommer (2002) analisou as vibrações em pisos mistos de aço e concreto.

Trabalhos sobre novos sistemas de lajes mistas foram desenvolvidos por Takey (2001), Beltrão (2003), Vianna (2005) e Friedrich (2012). Estudos sobre o comportamento das fôrmas de aço antes da fase de cura do concreto foram desenvolvidos por Baião Filho (2003) e Carvalho (2005). Spíndola (2002), Andrade (2012), Cordeiro (2014) e Santos (2014) realizaram estudos sobre lajes mistas em situação de incêndio. A presença de armadura adicional em lajes mistas foi estudada por Calixto (2006) e por Grossi (2016).

Silva (2018) fez uma análise numérica não-linear empregando o Método Elementos Finitos e uma discretização bidimensional de lajes mistas, simulando ensaios experimentais. Com relação ao comportamento em serviço das lajes mistas, Oliveira (2019) realizou um estudo teórico-experimental sobre o tema, com ênfase nos deslocamentos verticais (flechas) diferidos ao longo do tempo.

Dentre os trabalhos citados, apenas Vianna (2005) empregou ensaios de modelos de pequenas dimensões, que foi o do tipo pull-out desenvolvido por Daniels (1988), apresentado na seção 4.5. Esse tipo de ensaio foi realizado para estabelecer a resistência ao deslizamento da interface aço-concreto da laje mista estudada.

O trabalho realizado por Britto Junior (2017) avaliou o comportamento das lajes mistas antes e após a cura do concreto e empregou um ensaio alternativo, semelhante ao desenvolvido por Abdullah (2004) (seção 4.13), porém o protótipo possuía comprimento consideravelmente inferior ao da laje mista. Dessa forma, o autor comparou os parâmetros do Método $m-k$ extraídos do ensaio alternativo com os extraídos do ensaio normativo de flexão em escala real, constatando que os modelos alternativos não representaram o comportamento físico dos modelos normativos, pois seus comprimentos eram diferentes.

Observa-se, portanto, que no Brasil os trabalhos já desenvolvidos, em geral, não se concentraram especificamente no comportamento da interface aço-concreto e nem empregaram ensaios de modelos de pequenas dimensões para este propósito, ou seja, estudar a fenomenologia que se desenvolve na interface. Além disso, também não foram realizadas simulações numéricas das lajes mistas estudadas empregando os parâmetros extraídos de ensaios de modelos de pequenas dimensões para modelar a interface aço-concreto.

Diante disso, o presente trabalho busca contribuir com o conhecimento científico já estabelecido sobre o comportamento da interface aço-concreto de lajes mistas por meio da análise numérica e experimental empregando uma nova abordagem para o ensaio slip-block. 


\subsection{Considerações Finais do Capítulo}

Apesar de possuírem configurações diferentes, alguns tipos de ensaios apresentam certas peculiaridades que são comuns entre eles. Os ensaios do tipo pull-out, push-off, push-out e slip-block não englobam os efeitos da curvatura e do travamento induzido pela flexão da laje, assim como não incorporam a resistência do atrito na região de apoio e a deformação ocasionada pela tração da fôrma de aço, segundo Abdullah (2004).

Nas lajes mistas as mossas e reentrâncias na nervura, que promovem o intertravamento mecânico, ou simplesmente sua curvatura fazem com que a nervura se comprima dentro do vazio de concreto moldado por ela, como descrito na seção 2.3 , induzindo tensões passivas normais e de cisalhamento através da interface aço-concreto. No vão entre os apoios das lajes mistas o cisalhamento longitudinal só pode ser transferido por meio das tensões normais passivas atuantes na interface aço-concreto.

$\mathrm{O}$ ato de prender a fôrma numa base de fixação ou numa outra fôrma oposta confere restrições adicionais que não estão presentes na realidade e que dificultam a tendência natural da fôrma se separar do concreto, conforme ilustra a Figura 4.21. Essa restrição artificial aumenta a compressão da nervura da fôrma, que passa a forçar mais o concreto (como uma mola), e a correspondente componente de intertravamento da ligação mecânica. Além disso, os ensaios em que cargas transversais são aplicadas à interface aço-concreto, como nos ensaios propostos por Stark (1978), Daniels (1988), Patrick e Poh (1990), Tremblay et al. (2002) e Fontes (2016), podem promover aumento da resistência da ligação por atrito e eventualmente resultar numa superestimativa da resistência da ligação-aço concreto.

Figura 4.21 - Efeito da fixação da fôrma de aço em lajes mistas com fôrma trapezoidal

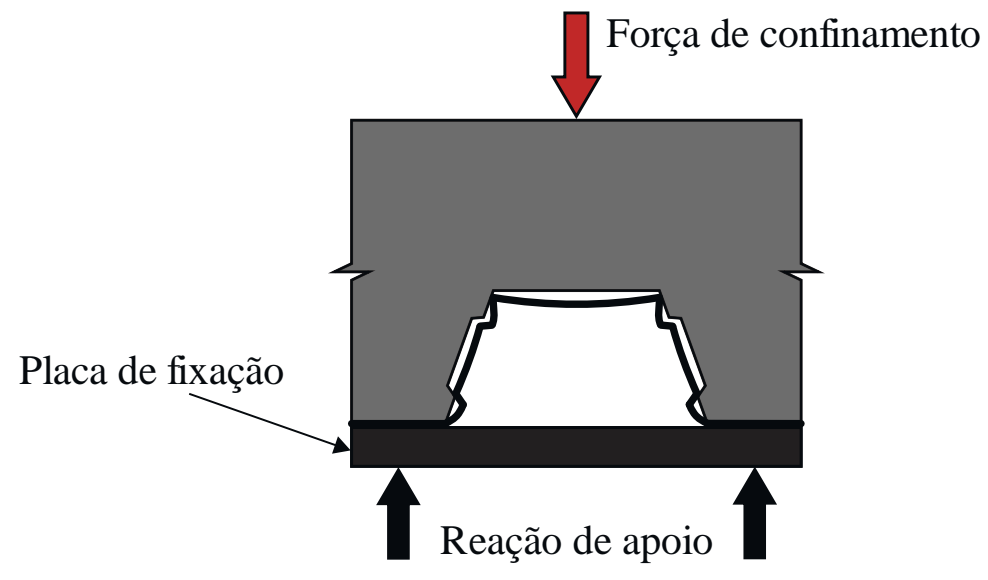

Fonte: Adaptado de BURNET; OEHLERS, 2001 
Burnet (1998) afirma que a força normal resultante que atua ao longo do comprimento da interface aço-concreto de lajes mistas de vãos longos é muito pequena e destaca que quando o concreto está totalmente fissurado possui uma resistência significativa ao cisalhamento transversal. Dessa forma, o peso próprio da laje é suportado pela capa de concreto e pela fôrma de aço. Tais considerações foram feitas para confrontar a justificativa da aplicação das forças transversais à interface no ensaio proposto por Daniels (1988), que seriam para simular a ação do peso próprio da laje. Além disso, o autor afirma que a aplicação de forças transversais aumenta a não uniformidade da pressão atuante na interface aço-concreto devido ao equilíbrio de momentos que deve existir no caso dos ensaios propostos por Daniels (1988) e Patrick e Poh (1990).

Apesar das críticas existentes sobre alguns ensaios de modelos de pequenas dimensões, deve-se considerar que o principal objetivo deles é avaliar o comportamento da interface açoconcreto, possibilitando fazer uma análise comparativa entre vários tipos de fôrmas ensaiadas, assim como extrair parâmetros que possam ser devidamente empregados em métodos analíticos e/ou em modelagens numéricas. Dessa forma, para o emprego dos dados obtidos por meio desses ensaios, é necessário a devida compreensão e consideração das suas limitações para a utilização adequada de tais dados.

Além disso, todos os ensaios de modelos de pequenas dimensões presentes na literatura técnica apresentam limitações, sendo incapazes de simular completamente todos os fenômenos que ocorrem na interface aço-concreto de uma laje mista sob flexão, o que remete mais uma vez ao objetivo, já descrito, de se realizar ensaios de modelos de pequenas dimensões.

Como já apresentado, existem trabalhos presentes na literatura em que metodologias analíticas e numéricas foram desenvolvidas empregando os dados obtidos de certos ensaios de modelos de pequenas dimensões do tipo pull-out, push-out e slip-block que revelaram boas concordâncias com os resultados dos ensaios de flexão em escala real.

Dentre os ensaios apresentados neste capítulo escolheu-se o slip-block devido a sua configuração e a possibilidade de analisar precisamente as contribuições das ligações química, mecânica e por atrito. A configuração do ensaio permite realizá-lo sem a necessidade de construir um protótipo devidamente simétrico composto por duas frações de laje mista. Além disso, devido ao controle do carregamento de confinamento aplicado, pode-se analisar isoladamente a contribuição da ligação por atrito.

Portanto, o programa experimental deste trabalho contempla a realização do ensaio do tipo slip-block proposto por Patrick e Poh (1990), porém com algumas adaptações relativas ao protótipo e ao procedimento de ensaio. 



\section{CAPÍTULO 5 - MÉTODOS ANALÍTICOS - RESISTÊNCIA AO CISALHAMENTO LONGITUDINAL}

Certos autores realizaram estudos e elaboraram modelos de cálculo para a determinação da resistência de lajes mistas de aço e concreto mediante os modos de ruptura existentes, apresentados na seção 3.2. Alguns desses modelos foram incorporados às normas técnicas referentes às estruturas mistas.

A determinação dos estados limites últimos de flexão, de cisalhamento vertical e de punção empregam métodos empíricos preconizados por várias normas vigentes. A determinação do estado limite último de cisalhamento longitudinal, por sua vez, é realizada por meio de métodos semi-empíricos que empregam resultados obtidos de ensaios experimentais de flexão em escala real.

Neste capítulo são apresentados os métodos analíticos utilizados para a determinação da resistência ao cisalhamento longitudinal abordados por algumas normas vigentes, ou seja, o Método $m-k$ e o Método da Interação Parcial. As normas aqui abordadas são a brasileira ABNT NBR 8800:2008, a europeia Eurocode 4:2004, a americana ANSI/ASCE 3-91:1992, a canadense CSSBI S3:2017 e a australiana AS/NZS 2327:2017. As considerações referentes a cada norma são apresentadas.

\subsection{Método $m-k$}

Proposto originalmente por Schuster (1970), o Método $m-k$ é semi-empírico e fundamentado por meio da consideração de uma laje mista submetida ao ensaio de flexão a quatro pontos, ou seja, simplesmente apoiada e submetida a duas forças concentradas de mesma intensidade a uma distância $L_{\mathrm{s}}$ dos apoios, conforme ilustra a Figura 5.1. O objetivo do método é determinar a força cortante última $\left(V_{\mathrm{u}}\right)$ associada à capacidade resistente última ao cisalhamento longitudinal.

A metodologia proposta por Schuster (1970) era restrita às lajes de comportamento frágil, que eram as únicas existentes na época. Schuster e Ling (1980) observaram que as novas lajes mistas estavam apresentando comportamento dúctil, então propuseram um novo equacionamento para a força cortante última associada ao cisalhamento longitudinal $\left(V_{\mathrm{u}}\right)$ que se aplica tanto para lajes as mistas de comportamento frágil quanto para as de comportamento dúctil. Este novo equacionamento define atualmente o Método $m-k$. 
Figura 5.1 - Esquema de forças na laje mista
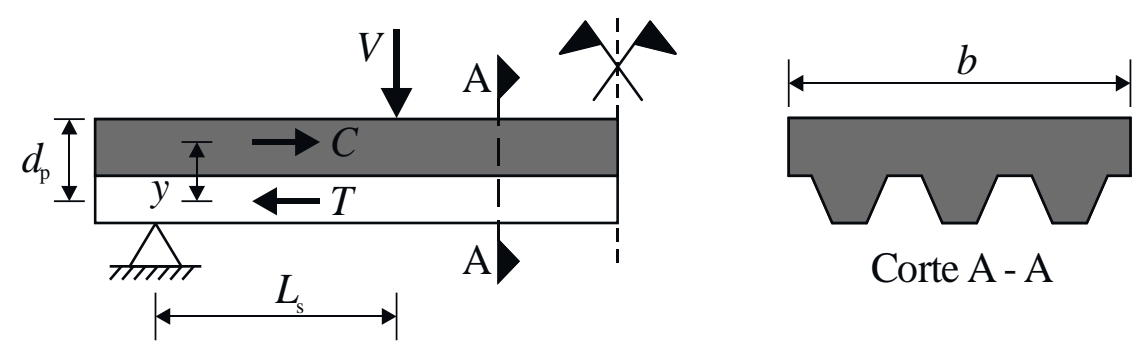

Corte A - A

Fonte: Adaptado de QUEIROZ; PIMENTA; DA MATA, 2001

A configuração apresentada na Figura 5.1 acarreta no momento fletor máximo $M=V \cdot L_{\mathrm{s}}$ e, como é possível observar, o momento resistente dado por $M=T \cdot y$. Como o ensaio é configurado para que a laje falhe por cisalhamento longitudinal, a força de tração $T$ é limitada pela resistência ao cisalhamento longitudinal que se desenvolve nas faces da fôrma de aço em contato com o concreto ao longo do vão de cisalhamento $L_{s}$ e pelo atrito na região dos apoios. O braço de alavanca pode ser assumido como $d_{\mathrm{p}}$, que é a distância entre a face superior da laje e o centro de gravidade da fôrma, e a superfície aproximada por $b \cdot L_{s}$, onde atua a tensão média de cisalhamento longitudinal.

Tais considerações são atribuídas sem introduzir erro significativo. Dessa forma, é possível definir que o momento resistente é proporcional à $d_{\mathrm{p}} \mathrm{e}$ à área $b \cdot L_{\mathrm{s}}$, assim como à parcela de atrito atuante na região dos apoios, conforme expressa a Equação 5.1, em que $\tau$ é a tensão de cisalhamento atuante na interface aço-concreto.

$$
M=V L_{\mathrm{s}} \propto\left(F_{\text {atrito }}+\tau b L_{\mathrm{s}}\right) d_{\mathrm{p}}
$$

A força cortante última $\left(V_{\mathrm{u}}\right)$ já é determinada considerando os pesos próprios da laje e dos dispositivos utilizados no ensaio e é calculada por meio da Equação 5.2, em que $m$ e $k$ são constantes empíricas determinadas por meio dos ensaios experimentais em escala real. Essa expressão só é válida para uma da espessura de um dado tipo de fôrma de aço, de modo que mudando esses parâmetros ocorre mudança dos valores dos coeficientes $m$ e $k$.

$$
\frac{V_{\mathrm{u}}}{b d_{\mathrm{p}}}=\frac{m}{L_{\mathrm{s}}}+k
$$

As equações normativas são equivalentes à Equação 5.2, porém com alguns ajustes de organização e características inerentes de cada norma, conforme exposto posteriormente. Para a determinação dos parâmetros $m$ e $k$ cada norma apresenta procedimentos específicos para o ensaio descrito na seção 3.1, bem como considerações para determinação dos parâmetros. De 
modo geral, faz-se $y=\frac{V_{\mathrm{u}}}{b d_{\mathrm{p}}}$ e $x=\frac{1}{L_{\mathrm{s}}}$, reescrevendo a Equação 5.2 na forma $y=m x+k$. Obtidos os dados experimentais, plotam-se os resultados num gráfico de $y$ versus $x$. Em seguida, ajustando-se uma reta entre eles, determinam-se os valores dos parâmetros $m$ (coeficiente angular da reta) e $k$ (coeficiente linear, ou seja, interseção com o eixo $y$ ), conforme ilustra a Figura 5.2.

Figura 5.2 - Determinação gráfica das constantes $m$ e $k$

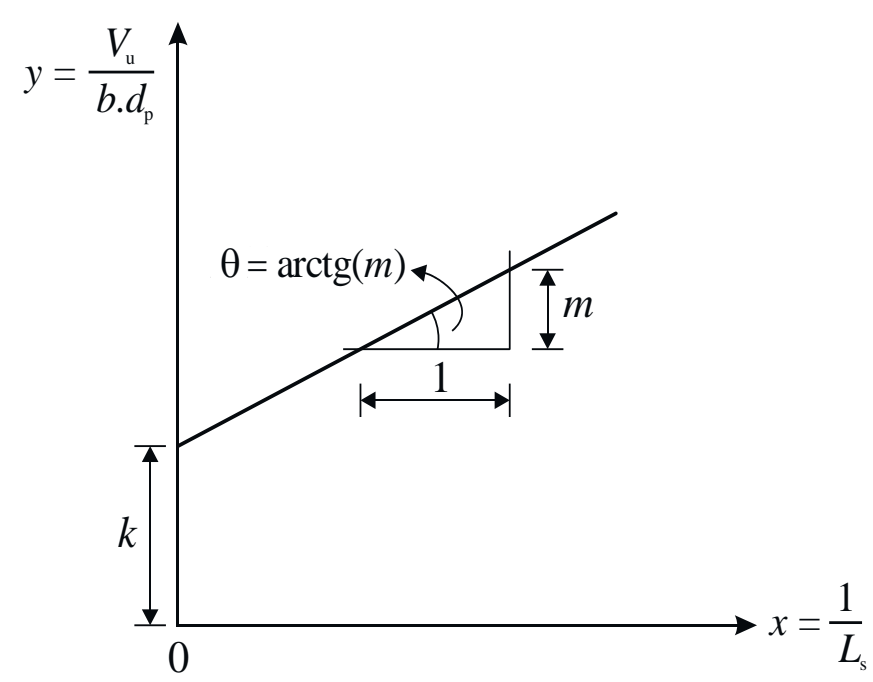

Fonte: Adaptado do EUROCODE 4: 2004

Como se pode observar, o Método $m-k$ não descreve o comportamento físico das lajes mistas e é baseado nos resultados extraídos dos ensaios realizados. Dessa forma, no caso da determinação da resistência ao cisalhamento longitudinal de lajes mistas com a presença de ancoragens de extremidade e/ou com a presença de armadura positiva adicional, deve-se fazer novas séries de ensaios para cada situação a ser avaliada. Além disso, tanto para as lajes mistas frágeis quanto para as dúcteis o método de avaliação dos parâmetros extraídos dos ensaios é o mesmo, apesar de algumas normas atribuírem um coeficiente de penalização para reduzir a resistência de projeto das lajes mistas de comportamento frágil.

As normas que tratam dos critérios de projeto de lajes mistas apresentam recomendações relacionadas à aplicação do Método $m-k$. Algumas dessas normas também apresentam diretrizes para a realização do ensaio de flexão em escala real. As normas que não apresentam tais diretrizes citam a norma que é adotada como referência para a especificação da configuração do ensaio. A seguir são expostas algumas recomendações normativas sobre o Método $m-k$. Ressalta-se que a ABNT NBR 8800:2008 faz referência às normas do ANSI/ASCE 3, EUROCODE 4 e CSSBI S2 para a definição da configuração do ensaio de flexão. 
a) Dispersão dos dados experimentais e redução da linha de regressão

Ao se realizar o ensaio, criam-se dois grupos de amostras ( $A$ e $B$, sendo um para cada comprimento $L_{\mathrm{s}}$ ) e faz-se uma regressão linear de modo a ajustar uma reta entre estes grupos, conforme ilustra a Figura 5.3. Para as amostras das regiões $A$ e $B$, o vão de cisalhamento $\left(L_{\mathrm{s}}\right)$ deve ser o maior e o menor possível, respectivamente, enquanto ainda fornecem ruptura por cisalhamento longitudinal.

As normas apresentam recomendações restritivas com relação a dispersão dos dados experimentais apresentados por cada amostra do respectivo grupo. De modo geral, elas preconizam que os valores dos parâmetros $m$ e $k$ devem ser reduzidos para ajustar a configuração da linha de regressão a ser utilizada em projeto, conforme ilustra a Figura 5.3.

Figura 5.3 - Linha de regressão linear e linha reduzida de regressão linear

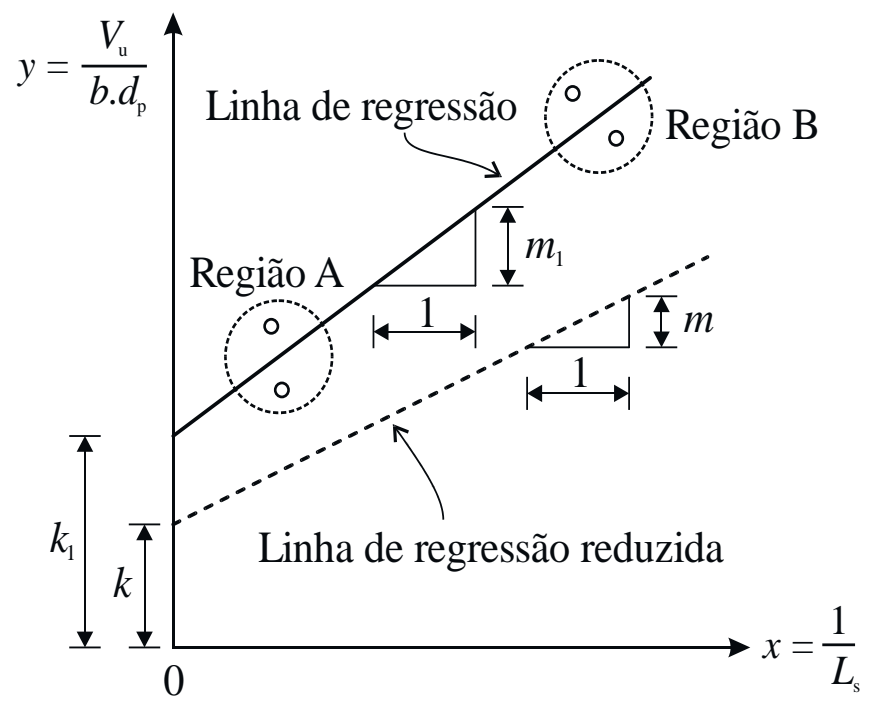

Fonte: Adaptado de ANSI/ASCE 3-91:1992

A norma ANSI/ASCE 3-91:1992 recomenda que pelo menos duas amostras devem ser ensaiadas em cada uma das duas regiões para a obtenção dos dados. Se apenas dois ensaios forem realizados para cada região e o valor da ordenada de qualquer amostra diverge da média das duas em mais de $\pm 15 \%$, pelo menos dois ensaios adicionais do mesmo tipo devem ser realizados e os dois resultados de valores menores devem ser usados na determinação da linha de regressão linear, a menos que uma fabricação da amostra ou o procedimento de ensaio inadequados determine o contrário. Uma vez determinados os valores $m$ e $k$ da linha de regressão linear, esta norma cita que os valores devem ser reduzidos em 15\%. Contudo, se oito ou mais ensaios são usados na análise, os valores de $m$ e $k$ devem ser reduzidos em apenas $10 \%$ para a obtenção de seus novos valores. 
O Eurocode 4: 2004 preconiza que para cada variável a ser investigada dois grupos de três ensaios ou três grupos de dois ensaios devem ser realizados. A resistência ao cisalhamento característica deve ser calculada como 5\% de quantil usando um modelo estatístico apropriado. Contudo, se dois grupos de três ensaios forem utilizados e o desvio de qualquer resultado individual em um grupo em relação à média do grupo não exceder $10 \%$, o valor característico de cada grupo é considerado o obtido pelo valor mínimo do grupo reduzido em $10 \%$. A norma DR/NZS 2327: 2017 apresenta essas mesmas recomendações.

A norma CSSBI S3: 2017 faz referência à norma CSSBI S2:2017 para a configuração dos ensaios, a qual recomenda que quando três ou mais espessuras diferentes de fôrmas são usadas no programa experimental, um mínimo de dois ensaios para cada espessura de fôrma deve ser realizado, de modo que para cada espessura deve ser efetuado um ensaio para cada região $(A$ e $B)$. Essa recomendação está relacionada à equação do Método $m-k$, cuja configuração considera a influência da espessura da fôrma de aço, conforme será apresentado no subitem (c). Quando um número de diferentes espessuras de fôrma é produzido para o projeto e apenas a espessura mais fina de fôrma é usada no programa experimental, a norma recomenda a realização de no mínimo quatro ensaios, sendo dois para cada região $(A$ e $B)$. Ao se fazer a regressão linear com os dados experimentais e obter os coeficientes de cisalhamento, faz-se uma comparação entre os valores experimentais e os calculados da resistência ao cisalhamento longitudinal para todos os dados. Se as variações forem inferiores a $15 \%$, os coeficientes de cisalhamento são reduzidos em $5 \%$.

b) Força máxima aplicada durante o ensaio

O Eurocode 4: 2004 e a DR/ NZS 2327:2017 preconizam que se a carga máxima for atingida com uma flecha excedendo $L / 50$, a carga de ruptura deve ser tomada como a carga na flecha de $L / 50$, sendo $L$ o comprimento da laje. As demais normas aqui discutidas não apresentam restrições quanto ao valor da força máxima aplicada.

c) Configuração da equação

Apesar do método ser o mesmo para todas as normas, cada uma delas apresenta uma configuração diferente para representar a mesma situação da Equação 5.2, ou seja, consideram a presença de demais características da laje mista. Além disso, a nomenclatura utilizada em cada norma é diferente, porém neste trabalho é utilizada uma mesma nomenclatura para as variáveis envolvidas. 
A equação apresentada pela norma ANSI/ASCE 3-91:1992 é praticamente a mesma proposta por Porter e Ekberg (1975) e é expressa pela Equação 5.3, em que $\rho$ é a taxa de aço e $f_{\text {ck }}$ é a resistência característica do concreto à compressão.

$$
\frac{V_{\mathrm{u}}}{b d_{\mathrm{p}}}=m \frac{\rho d_{\mathrm{p}}}{L_{\mathrm{s}}}+k \sqrt{f_{\mathrm{ck}}}
$$

O Eurocode 4: 2004 apresenta uma equação ajustada para que as constantes $m$ e $k$ possuam a mesma unidade $\left(\mathrm{N} / \mathrm{mm}^{2}\right)$, conforme apresentado pela Equação 5.4, em que $A_{\mathrm{p}}$ é a área da seção transversal nominal da fôrma de aço. Esta equação é a mesma adotada pelas normas ABNT NBR 8800:2008 e DR/ NZS 2327:2017.

$$
\frac{V_{\mathrm{u}}}{b d_{\mathrm{p}}}=m \frac{A_{\mathrm{p}}}{b L_{\mathrm{s}}}+k
$$

Conforme descrito no subitem (a), a CSSBI S3:2017 descreve duas configurações possíveis de arranjo experimental para a determinação das constantes obtidas da regressão linear. Quando apenas uma espessura (a mais fina) é empregada para as lajes ensaiadas, a forma da equação é a mesma da Equação 5.2. Quando três ou mais espessuras diferentes de fôrmas são usadas no programa experimental, a norma recomenda o uso da Equação 5.5, cujas constantes $k_{1}, k_{2}, k_{3}$, e $k_{4}$ são as constantes obtidas da regressão multilinear dos pontos do gráfico da Figura 5.3.

$$
\frac{V_{\mathrm{u}}}{b d_{\mathrm{p}}}=\frac{k_{1} t}{L_{\mathrm{s}}}+\frac{k_{2}}{L_{\mathrm{s}}}+k_{3} t+k_{4}
$$

O Método $m$ - $k$ pode ser aplicado para as lajes mistas tanto de comportamento dúctil quanto as de comportamento frágil, como já mencionado. Contudo, as normas Eurocode 4:2004 e DR/ NZS 2327:2017 preconizam a redução em 20\% da carga de ruptura obtida experimentalmente $\left(V_{\mathrm{u}}\right)$ para o caso em que as lajes ensaiadas sejam consideradas frágeis. Nenhuma especificação desse tipo consta nas demais normas aqui abordadas.

\section{d) Coeficiente de Ponderação}

Para a obtenção do valor da força resistente de projeto associada ao cisalhamento longitudinal de projeto $\left(V_{\mathrm{Rd}}\right)$, o valor da força última determinada por meio das retas normativas $\left(V_{\mathrm{R}}\right)$, que já consideram as reduções dos valores de $m$ e $k$, deve ser minorada empregando o coeficiente de ponderação da respectiva norma. A norma ABNT NBR 8800:2008 determina 
que o coeficiente de ponderação da resistência deve ser igual ao determinado pela norma ou especificação utilizada nos ensaios. A Tabela 5.1 apresenta um resumo das equações descritas no subitem (c), assim como seus respectivos valores dos coeficientes de ponderação.

Tabela 5.1 - Forças resistentes associadas ao cisalhamento longitudinal e seus coeficientes de ponderação para a obtenção dos valores de projeto

\begin{tabular}{cccc}
\hline \multicolumn{1}{c}{ Norma } & $\begin{array}{c}\text { Força Resistente } \\
\left(\boldsymbol{V}_{\mathbf{R}}\right)\end{array}$ & $\begin{array}{c}\text { Coeficiente de } \\
\text { Ponderação }\end{array}$ & $\begin{array}{c}\text { Força Resistente de } \\
\text { Projeto }\left(\boldsymbol{V}_{\mathbf{R d}}\right)\end{array}$ \\
\hline ANSI/ASCE 3-91: 1992 & $\frac{V_{\mathrm{R}}}{b d_{\mathrm{p}}}=m \frac{\rho d_{\mathrm{p}}}{L_{\mathrm{s}}}+k \sqrt{f_{\mathrm{ck}}}$ & $\phi=0,75$ & $V_{\mathrm{Rd}}=\phi V_{\mathrm{R}}$ \\
\hline EUROCODE 4: 2004 & $\frac{V_{\mathrm{R}}}{b d_{\mathrm{p}}}=m \frac{A_{\mathrm{p}}}{b L_{\mathrm{s}}}+k$ & $\gamma_{\mathrm{VS}}=1,25$ & $V_{\mathrm{Rd}}=\frac{V_{\mathrm{R}}}{\gamma_{\mathrm{VS}}}$ \\
\hline CSSBI S3: 2017 & $\frac{V_{\mathrm{R}}}{b d_{\mathrm{p}}}=\frac{m}{L_{\mathrm{s}}}+k$ & $\phi_{\mathrm{V}}=0,70$ & $V_{\mathrm{Rd}}=\phi_{\mathrm{V}} V_{\mathrm{R}}$ \\
\hline DR/NZS 2327: 2017 & $\frac{V_{\mathrm{R}}}{b d_{\mathrm{p}}}=m \frac{A_{\mathrm{p}}}{b L_{\mathrm{s}}}+k$ & $\phi_{\mathrm{VS}}=0,63$ & $V_{\mathrm{Rd}}=\phi_{\mathrm{VS}} V_{\mathrm{R}}$ \\
\hline
\end{tabular}

Fonte: Autoria própria

\subsection{Método da Interação Parcial}

Inicialmente proposto por Stark (1978) e posteriormente melhor desenvolvido por Stark e Brekelmans (1990), o Método da Interação Parcial (Partial Shear Connection Method, em inglês) também é um método semi-empírico que emprega resultados de ensaios de flexão de lajes mistas em escala real. Todavia, esse método só pode ser aplicado para a determinação da resistência ao cisalhamento longitudinal de lajes mistas de comportamento dúctil.

As normas Eurocode 4: 2004, ABNT NBR 8800: 2008 e DR/ NZS 2327: 2017 permitem o emprego do Método da Interação Parcial. A ABNT NBR 8800: 2008 faz referência ao procedimento apresentado pelo Eurocode 4.

O intuito do método é a determinação do momento fletor resistente de cálculo seção a seção, $M_{R d}(x)$. Inicialmente admite-se uma distribuição de tensões de plastificação no aço e no concreto, com interação parcial (duas linhas neutras) e para todas as seções da laje, conforme ilustrado na parte $I$ da Figura 5.4, que ilustra a distribuição de tensões numa seção transversal de largura $b$ e fôrma de aço com espessura $t$ e área efetiva da seção transversal $A_{\mathrm{F}, \text { ef. Todo o }}$ concreto localizado dentro da nervura é desconsiderado, mesmo se estiver comprimido. 
Aqui não são abordadas de forma minuciosa a formulação de cada variável da Figura 5.4, uma vez que estas estão descritas na norma que se deseje utilizar.

Figura 5.4 - Distribuição de tensões de momento fletor positivo em uma seção qualquer da laje mista empregando o Método da Interação Parcial

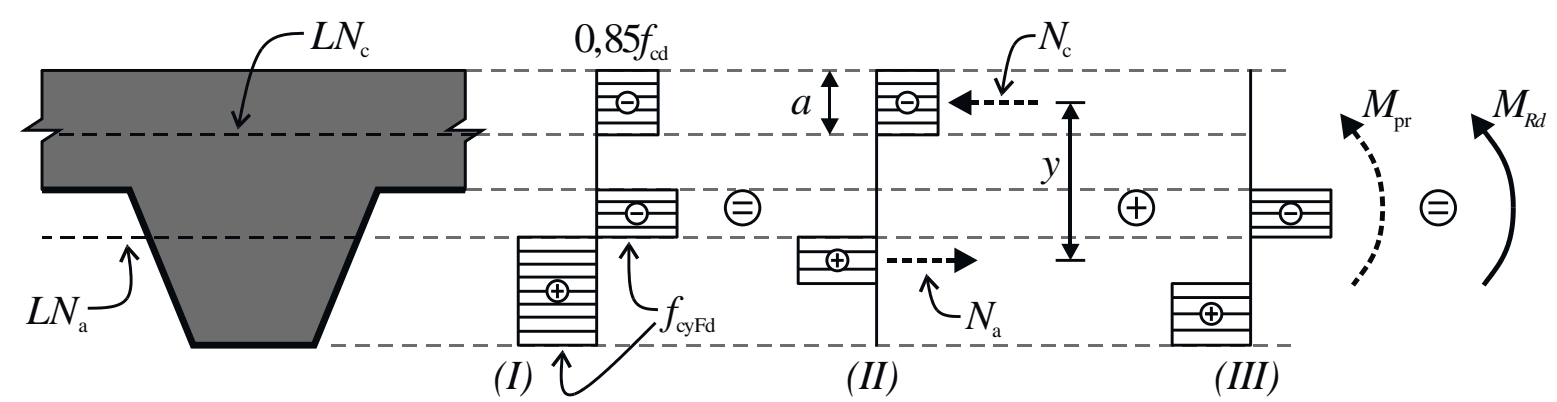

Fonte: Adaptado de GROSSI, 2016

Na Figura 5.4, tem-se:

- $L N_{\mathrm{c}}$ e $L N_{\mathrm{a}}$ são as linhas neutras da capa de concreto e da fôrma de aço, respectivamente;

- $f_{\text {cd }}$ é a resistência de projeto referente à compressão do concreto;

- $f_{\mathrm{yFd}}$ é a resistência de projeto referente ao escoamento do aço da fôrma;

- $\quad N_{c}$ é a força resultante atuante na seção transversal do concreto;

- $N_{\mathrm{a}}$ é a força resultante atuante na seção transversal da fôrma de aço na distribuição (II);

- $a$ é a profundidade da linha neutra do concreto $\left(L N_{\mathrm{c}}\right)$;

- $y$ é a distância entre os vetores das forças $N_{\mathrm{c}}$ e $N_{\mathrm{a}}$;

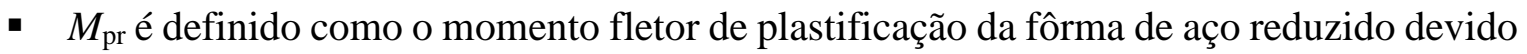
à presença da força axial $N_{\mathrm{a}}$;

- $M_{\mathrm{Rd}}$ é o momento fletor resistente de projeto referente à situação de interação parcial.

De acordo com o Eurocode 4: 2004 e DR/NZS 2327: 2017, $M_{\mathrm{pr}}$ e $y$ são expressos segundo a Equações 5.6 e 5.7, respectivamente.

$$
\begin{gathered}
M_{\mathrm{pr}}=1,25 M_{\mathrm{pa}}\left(1-\frac{N_{\mathrm{cf}}}{N_{\mathrm{pa}}}\right) \leq M_{\mathrm{pa}} \\
y=h_{\mathrm{t}}-0,5 a-e_{\mathrm{p}}+\left(e_{\mathrm{p}}-e\right) \frac{N_{\mathrm{c}}}{N_{\mathrm{pa}}}
\end{gathered}
$$

Na Equação 5.6, $N_{\text {pa }}$ e $M_{\text {pa }}$ são, respectivamente, a força e o momento fletor que causam a plastificação do aço da fôrma. Na Equação 5.7, e é a distância do centro geométrico da área efetiva da fôrma à sua face inferior, $e_{p}$ é a distância da linha neutra de plastificação da seção efetiva da fôrma à sua face inferior e $h_{\mathrm{t}}$ é a altura total da laje mista, conforme ilustra a Figura 5.5 . 
Figura 5.5 - Características da seção transversal da laje mista genérica utilizada no Método da Interação Parcial

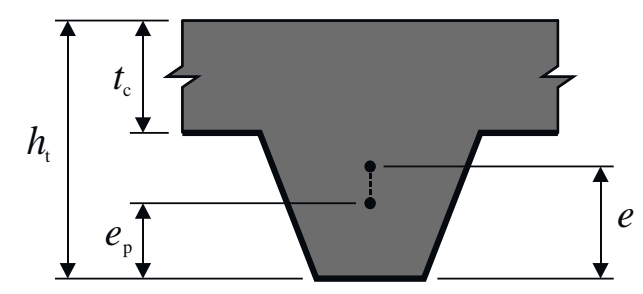

Fonte: Autoria própria

Do equilíbrio de momentos da seção transversal, resulta a Equação 5.8. Além disso, tem-se que $N_{\mathrm{a}}=N_{\mathrm{c}} \cdot M_{\mathrm{pr}}$ é determinado de acordo com a expressão da norma adotada.

$$
M_{\mathrm{Rd}}=N_{\mathrm{c}} y+M_{\mathrm{pr}}
$$

A expressão da força de compressão $N_{c}$ é determinada pelo equilíbrio de forças horizontais no concreto de uma seção transversal distante $L_{\mathrm{x}}$ do apoio mais próximo de uma laje mista apoiada, conforme ilustrado na Figura 5.6.

Figura 5.6 - Forças atuantes num segmento de laje mista

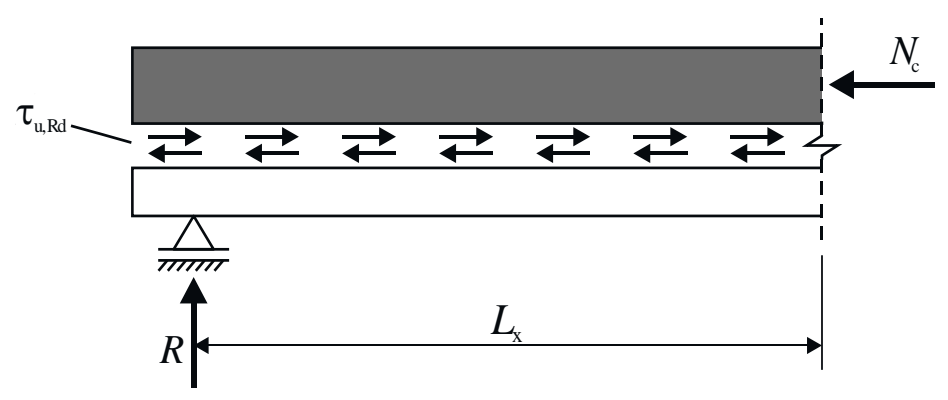

Fonte: Adaptado de GROSSI, 2016

Na Figura 5.6, $\tau_{\mathrm{u}, \mathrm{Rd}}$ é a tensão média resistente (de projeto) ao cisalhamento longitudinal, tomada como constante (em módulo) em toda interface e considerada atuando numa área retangular que consiste na projeção horizontal da área real da interface, ou seja, $b \cdot L_{\mathrm{x}} . R$ é a reação do apoio. Dessa forma, do equilíbrio das forças atuantes no concreto resulta a Equação 5.9, em que $\mu$ é o coeficiente de atrito entre o aço e o concreto (considerado igual a 0,5 pelas normas aqui citadas) e $N_{\text {cf }}$ é a força resultante atuante na seção transversal do concreto na situação de interação completa, calculada de acordo com a norma utilizada.

$$
N_{\mathrm{c}}=\tau_{\mathrm{u}, \mathrm{Rd}} b L_{\mathrm{x}}+\mu R \leq N_{\mathrm{cf}}
$$


A tensão $\tau_{\mathrm{u}, \mathrm{Rd}}$ é determinada por meio de ensaios experimentais de flexão em escala real. Com base nos resultados experimentais, encontra-se, para cada protótipo, o momento fletor, na seção com força aplicada, que leva à sua falha por cisalhamento longitudinal $\left(M_{\text {test }}\right)$. Dessa forma, substituindo as expressões descritas anteriormente na Equação 5.9 e fazendo $N_{\mathrm{c}}=\eta N_{\mathrm{cf}}$, em que $\eta$ é o grau de interação da laje mista, tem-se a Equação 5.10 como resultado, $\operatorname{com} 0 \leq \eta \leq 1$.

$$
M_{\text {test }}=\eta N_{\mathrm{cf}}\left[h_{\mathrm{t}}-0,5 \frac{\eta N_{\mathrm{cf}}}{0,85 f_{\mathrm{c}} b}-e_{\mathrm{p}}\left(e_{\mathrm{p}}-e\right) \frac{\eta N_{\mathrm{cf}}}{N_{\mathrm{pa}}}\right]+1,25 M_{\mathrm{pa}}\left(1-\frac{\eta N_{\mathrm{cf}}}{N_{\mathrm{pa}}}\right)
$$

Sendo assim, os valores de $\eta$, determinados para cada protótipo, podem ser calculados analiticamente por equações de segundo grau, considerando $a_{1} \eta^{2}+a_{2} \eta+a_{3}=0$, ou graficamente, plotando-se um gráfico $M / M_{p R m}$ versus $\eta$, sendo $M$ valores genéricos, conforme ilustra a Figura 5.7. Nesse gráfico, fazendo-se o caminho $A \rightarrow B \rightarrow C$, determinam-se os valores de $\eta$.

Figura 5.7 - Determinação gráfica do grau de interação parcial ao cisalhamento ( $)$ dos protótipos ensaiados

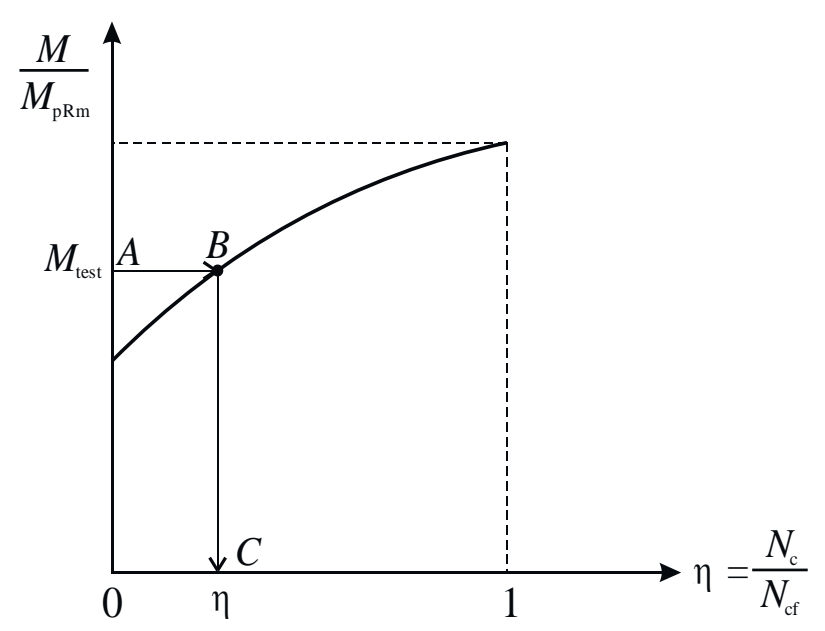

Fonte: adaptado do EUROCODE 4: 2004

Após a determinação de $\eta$ e, consequentemente, de $N_{\mathrm{c}}$, deve-se verificar se para este valor de $N_{\mathrm{c}}$ determinado, é satisfeita a desigualdade $M_{\mathrm{pr}} \leq M_{\mathrm{pa}}$. Caso não seja, deve-se impor $M_{\mathrm{pa}}$ no lugar de $M_{\mathrm{pr}}$ na Equação 5.8, resultando na Equação 5.11, com $0 \leq \eta \leq 1$

$$
M_{\text {test }}=\eta N_{\mathrm{cf}}\left[h_{\mathrm{t}}-0,5 \frac{\eta N_{\mathrm{cf}}}{0,85 f_{\mathrm{c}} b}-e_{\mathrm{p}}\left(e_{\mathrm{p}}-e\right) \frac{\eta N_{\mathrm{cf}}}{N_{\mathrm{pa}}}\right]+M_{\mathrm{pa}}
$$


Com os valores de $\eta$, pode-se, então, calcular os valores de $N_{c}$ para cada protótipo, pois $N_{c}=\eta N_{c f}$. Assim, determina-se os valores de $\tau_{u}$, conforme Equação 5.12, recomendada tanto pelo Eurocode 4: 2004 quanto pela DR/ NZS 2327: 2017. Como a seção analisada é a de aplicação dos carregamentos, é usado $L_{x}=L_{s}+L_{0}$, sendo $L_{0}$ o balanço após o apoio. As duas

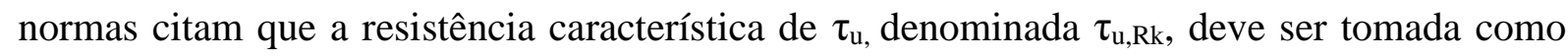
sendo o valor referente a um percentil de $5 \%$ dos $\tau_{\mathrm{u}}$, conforme o método estatístico recomendado pela respectiva norma.

$$
\tau_{\mathrm{u}}=\frac{\eta N_{\mathrm{cf}}-\mu R}{b\left(L_{\mathrm{s}}+L_{0}\right)}
$$

O valor de projeto da tensão resistente ao cisalhamento longitudinal ( $\left.\tau_{\mathrm{u}, \mathrm{Rd}}\right)$ é calculado com $\gamma_{v s}=1,25$ na Equação 5.13, conforme recomenda o Eurocode 4: 2004. Já a norma DR/ NZS 2327: 2017 preconiza o uso da Equação 5.14, $\operatorname{com} \phi_{\mathrm{VS}}=0,63$.

$$
\begin{gathered}
\tau_{\mathrm{u}, \mathrm{Rd}}=\frac{\tau_{\mathrm{u}, \mathrm{Rk}}}{\gamma_{\mathrm{vs}}} \\
\tau_{\mathrm{u}, \mathrm{Rd}}=\phi_{\mathrm{vs}} \tau_{\mathrm{u}, \mathrm{Rk}}
\end{gathered}
$$

Uma vez determinado o valor de $\tau_{\mathrm{u}, \mathrm{Rd}}$, pode-se determinar o momento fletor resistente $\left(M_{\mathrm{Rd}}\right)$ seção a seção empregando a Equação 5.15 ou a Equação 5.16, conforme o caso, sendo $N_{\mathrm{c}}$ calculado segundo a Equação 5.9 e empregando $\tau_{\mathrm{u}, \mathrm{Rd}}$ calculado na Equação 5.13 ou 5.14.

$$
\begin{gathered}
M_{\mathrm{Rd}}=N_{\mathrm{c}}\left[h_{\mathrm{t}}-0,5 \frac{N_{\mathrm{c}}}{0,85 f_{\mathrm{c}} b}-e_{\mathrm{p}}\left(e_{\mathrm{p}}-e\right) \frac{N_{\mathrm{c}}}{N_{\mathrm{pa}}}\right]+1,25 M_{\mathrm{pa}}\left(1-\frac{N_{\mathrm{c}}}{N_{\mathrm{pa}}}\right) \\
M_{\mathrm{Rd}}=N_{\mathrm{c}}\left[h_{\mathrm{t}}-0,5 \frac{N_{\mathrm{c}}}{0,85 f_{\mathrm{c}} b}-e_{\mathrm{p}}\left(e_{\mathrm{p}}-e\right) \frac{N_{\mathrm{c}}}{N_{\mathrm{pa}}}\right]+M_{\mathrm{pa}}
\end{gathered}
$$

Dessa forma, o procedimento a ser seguido é de arbitrar um valor de $L_{x}$ na Equação 5.9, calculando-se um $N_{\mathrm{c}}$, em seguida inserindo-o na Equação 5.15 ou 5.16, conforme o caso. Varrendo-se $L_{x}$ por todo o comprimento $L$ da laje, constrói-se uma curva $M_{\mathrm{Rd}}$ versus $L_{x}$, conforme ilustra a Figura 5.8.

O procedimento de verificação do estado limite de cisalhamento longitudinal pelo Método da Interação Parcial consiste na comparação entre a curva de momento fletor resistente de cálculo da laje mista, como a da Figura 5.8, e a curva de momento fletor solicitante de cálculo $\left(M_{S d}\right)$ 
Figura 5.8 - Curva típica $M_{\mathrm{Rd}}$ versus $L_{\mathrm{x}}$ para Método da Interação Parcial

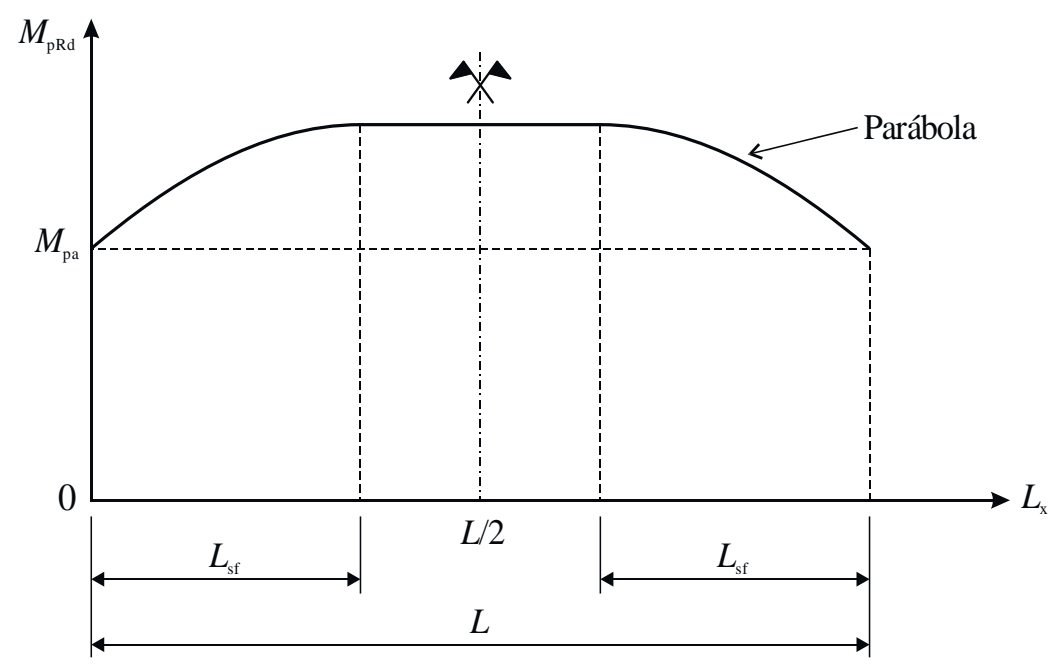

Fonte: Adaptado de GROSSI, 2016

Sendo assim, a condição $M_{\mathrm{Rd}} \geq M_{\mathrm{Sd}}$ deve ser satisfeita em todos os pontos do gráfico, de modo que a curva do momento fletor resistente esteja acima da curva do momento fletor solicitante.

\subsection{Considerações Finais do Capítulo}

Conforme apresentado, o Método $m-k$ consiste em estabelecer uma relação linear entre duas variáveis, definidas pelas propriedades da laje mista e pela força máxima resistente do ensaio de flexão. Já o Método da Interação Parcial considera uma distribuição de tensões de plastificação no aço e no concreto para determinar as variáveis envolvidas empregando o máximo momento fletor que causa a falha por cisalhamento longitudinal, obtido experimentalmente.

Embora só possa ser aplicado em lajes mistas de comportamento dúctil, o Método da Interação Parcial possui uma abordagem física do problema, ao contrário do Método $m-k$. Entretanto, ambos os métodos ainda necessitam de dados provenientes de ensaios em escala real, que demandam consideráveis custos, mão de obra e tempo para sua realização.

Considerando que cada variável das lajes mistas (espessura da capa de concreto, espessura da fôrma de aço, comprimento da laje, resistência do concreto e resistência do aço) deve ser analisada por meio de um conjunto de ensaios experimentais para se aplicar esses métodos de cálculo, os recursos requeridos num estudo preliminar de desenvolvimento de fôrmas de aço são ainda mais significantes. Com base nesses aspectos o presente trabalho foi desenvolvido. 


\section{CAPÍTULO 6 - ANÁLISE EXPERIMENTAL}

A análise experimental contemplou a realização de quatro ensaios de modelos de pequenas dimensões do tipo slip-block e dois ensaios de flexão em escala real. Os ensaios slipblock foram realizados sob diferentes forças de confinamento, possibilitando verificar o comportamento da interface aço-concreto e promovendo sua caracterização e a obtenção de parâmetros para sua simulação numérica. Os ensaios de flexão, por sua vez, foram realizados com o objetivo de analisar o comportamento global da laje mista, assim como os efeitos da flexão sobre o comportamento da interface, e fornecer modelos de referência para avaliar os resultados e a representatividade do modelo proveniente da simulação numérica.

Este capítulo apresenta a laje mista objeto deste trabalho, as propriedades dos materiais utilizados e a metodologia empregada para a realização de cada ensaio. Em seguida os resultados experimentais são apresentados e discutidos. Os ensaios slip-block foram realizados no Laboratório de Mecânica das Rochas do Departamento de Geotecnia da Escola de Engenharia de São Carlos - Universidade de São Paulo (EESC-USP). Os ensaios de flexão foram realizados no Laboratório de Estruturas do Departamento de Engenharia de Estruturas da mesma instituição.

\subsection{Considerações Gerais}

A fôrma de aço que compõe a laje mista estudada neste trabalho é a MODULAR DECK - MD 55 de espessura nominal $\left(t_{\mathrm{n}}\right)$ de $0,80 \mathrm{~mm}$ e espessura de cálculo $\left(t_{\mathrm{s}}\right)$ de 0,76 $\mathrm{mm}$.

Obtida por meio da perfilação à frio de chapa de aço zincada de alta resistência ASTM A653 grau 40, a fôrma de aço possui resistência teórica ao escoamento de $280 \mathrm{MPa}$, resistência teórica à ruptura de $380 \mathrm{MPa}$ e revestimento de $275 \mathrm{~g} / \mathrm{m}^{2}$ de zinco. A Figura 6.1 ilustra o perfil dessa fôrma de aço e a Figura 6.2 apresenta a configuração das mossas.

Figura 6.1 - Perfil MODULAR DECK - MD 55

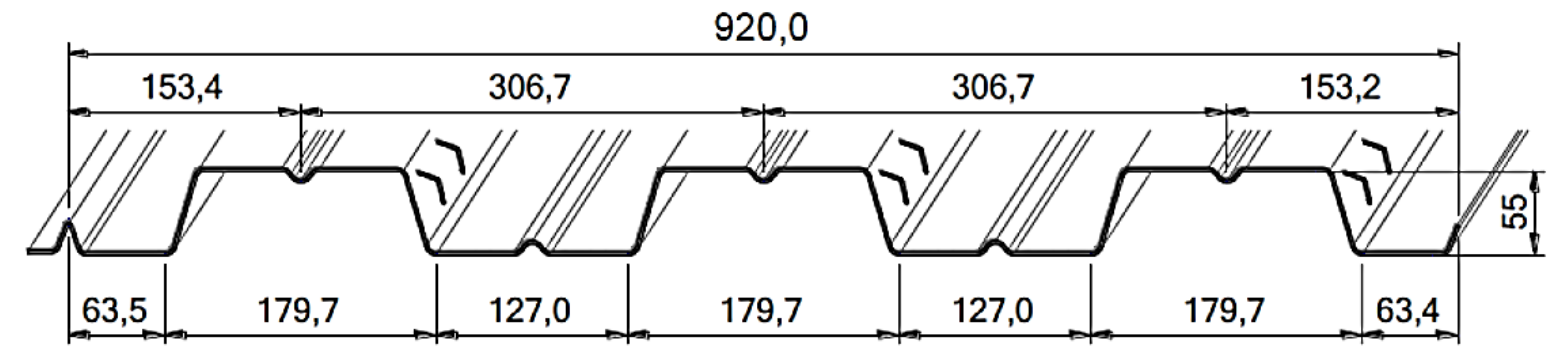

Fonte: MODULAR, 2014

(Dimensões em mm) 
Figura 6.2 - Configuração das mossas da fôrma MODULAR DECK - MD 55

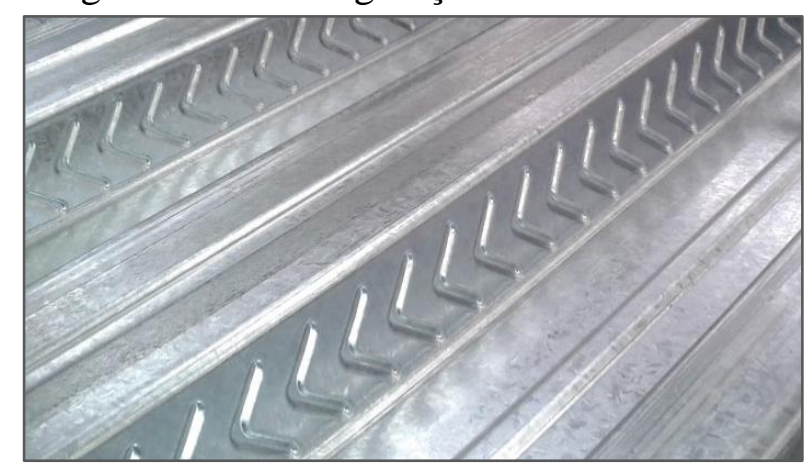

Fonte: Autoria própria

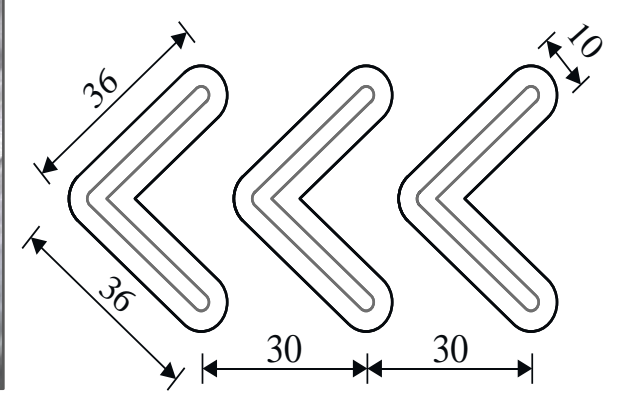

(Dimensões em milímetros)

Essa fôrma foi estudada por Sieg (2015), que fez a análise teórica do perfil de aço e uma análise teórica e experimental de lajes mistas compostas por essa fôrma. Oliveira (2019) também empregou essa mesma fôrma de aço nas lajes mistas do seu trabalho, porém avaliando seu comportamento em serviço.

Todo o programa experimental foi desenvolvido estabelecendo-se a seção transversal ilustrada na Figura 6.3 para a laje mista objeto deste trabalho. Adotou-se uma altura total de $150 \mathrm{~mm}$ e a largura dependente do tipo de ensaio. No caso dos protótipos em escala real foi utilizada uma armadura para combater os efeitos da retração, do tipo tela soldada de malha $\phi 4,2 \times \phi 4,2$ - 150x150 (Q - 92), conforme ilustrado na Figura 6.3.

Figura 6.3 - Laje mista objeto do estudo

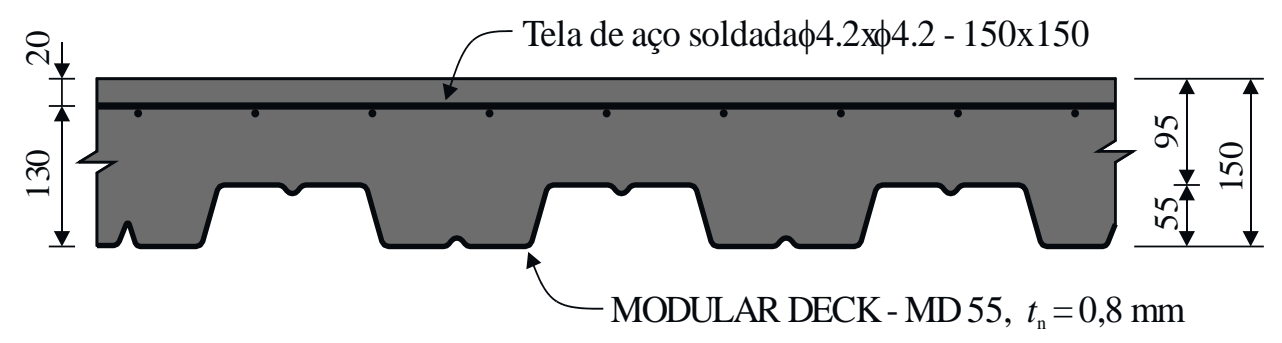

Fonte: Autoria própria

(Dimensões em milímetros)

Visto que a composição e a resistência do concreto podem influenciar o comportamento da interface aço-concreto, conforme alguns estudos da literatura técnica constataram, objetivouse utilizar o mesmo traço para o concreto que constitui os protótipos dos dois tipos de ensaios, isto é, o slip-block e o de flexão. Esse fato torna relevante a realização do ensaio de flexão, embora na literatura existam resultados experimentais de outros trabalhos que empregaram a mesma fôrma de aço nas lajes mistas.

Dessa forma, fez-se o estudo de dosagem do concreto e definiu-se um traço com resistência característica à compressão $\left(f_{\text {ck }}\right)$ prevista da ordem de $40 \mathrm{MPa}$. 


\subsection{Propriedades dos Materiais}

Os materiais foram caracterizados segundo as especificações técnicas normativas referenciadas a seguir. As propriedades do aço da tela soldada, que serve como armadura de retração dos protótipos em escala real, não foram determinadas, porque não são relevantes para os objetivos deste trabalho.

\subsubsection{Concreto}

Utilizou-se um concreto de densidade normal e produzido no próprio Laboratório de Estruturas do Departamento de Engenharia de Estruturas da EESC-USP. Para sua composição utilizou-se agregados naturais: areias grossa e fina oriundas de rio e brita basáltica com diâmetro máximo característico de $19 \mathrm{~mm}$ (brita $\mathrm{n}^{\circ}$ 01). O cimento Portland CPII-E-32 foi empregado e o traço em massa adotado foi o 1: 1,65: 2,35: 0,43 (cimento: areia: brita: a/c), com consumo de cimento de $456 \mathrm{~kg} / \mathrm{m}^{3}$ de concreto. A massa total de areia do traço foi composta por $60 \%$ de areia grossa e $40 \%$ de areia fina.

Para cada betonada realizada moldou-se corpos de provas cilíndricos com dimensões $100 \mathrm{~mm}$ x $200 \mathrm{~mm}$ e prismáticos com dimensões $150 \mathrm{~mm}$ x $150 \mathrm{~mm}$ x $500 \mathrm{~mm}$ devidamente adensados e curados sob as mesmas condições dos respectivos protótipos. Para confecção dos protótipos do ensaio slip-block realizou-se uma única betonada, enquanto que para a execução de cada protótipo do ensaio de flexão (Lajes 1 e 2) realizou-se duas betonadas. Os concretos produzidos apresentaram abatimentos slump de 15,5 cm, 10,0 cm, e 12,0 cm, respectivamente, para os protótipos do ensaio slip-block, Laje 1 e Laje 2.

A resistência à compressão $\left(f_{\mathrm{c}}\right)$ do concreto foi determinada aos 28 dias de idade e nos dias dos respectivos experimentos dos protótipos por meio de ensaios de compressão dos corpos de prova cilíndricos, realizados segundo a ABNT NBR 5739: 2018. A resistência à tração na flexão $\left(f_{\mathrm{ct}, \mathrm{f}}\right)$, por sua vez, foi determinada apenas no dia dos experimentos dos protótipos por meio de ensaios de flexão dos corpos de prova prismáticos, executados conforme a ABNT NBR 12142: 2010. Dessa forma, a resistência à tração direta $\left(f_{\mathrm{ct}}\right)$ foi calculada de acordo com a ABNT NBR 6118: 2014, que determina que $f_{\text {ct }}$ pode ser igual à $0,7 \cdot f_{\text {ct,f. }}$ Para a determinação de cada uma dessas propriedades, empregou-se três corpos de prova para cada betonada executada.

Ambos os ensaios foram realizados na máquina hidráulica ELE ${ }^{\circledR}$ Autotest 2000. A Tabela 6.1 e a Tabela 6.2 sintetizam os resultados da caracterização mecânica do concreto à compressão e à tração, respectivamente, de acordo com a sua idade e os protótipos dos ensaios. 
Tabela 6.1 - Resistência à compressão do concreto segundo os respectivos protótipos

\begin{tabular}{|c|c|c|c|c|c|c|}
\hline \multirow[t]{2}{*}{ Protótipo } & \multirow{2}{*}{$\begin{array}{l}\text { Idade } \\
\text { [Dias] }\end{array}$} & \multirow{2}{*}{$\begin{array}{c}\text { Corpo de } \\
\text { Prova } \\
\text { (CP) } \\
\end{array}$} & \multicolumn{2}{|c|}{$\begin{array}{c}\text { Resistência à Compressão } \\
\left(f_{c}\right)[\mathrm{MPa}]\end{array}$} & \multirow{2}{*}{$\begin{array}{c}\text { Desvio } \\
\text { Padrão } \\
\text { [MPa] }\end{array}$} & \multirow{2}{*}{$\begin{array}{c}\text { Coeficiente } \\
\text { de Variação } \\
(\%)\end{array}$} \\
\hline & & & $\mathbf{C P}$ & Média $\left(f_{c, m}\right)$ & & \\
\hline \multirow{6}{*}{$\begin{array}{l}\text { Ensaio } \\
\frac{\text { slip-block }}{\text { (todos) }}\end{array}$} & \multirow{3}{*}{28} & $\mathrm{CP} 1-\mathrm{SB}$ & 46,12 & \multirow{3}{*}{45,26} & \multirow{3}{*}{1,07} & \multirow{3}{*}{2,37} \\
\hline & & CP2-SB & 45,91 & & & \\
\hline & & CP3-SB & 43,75 & & & \\
\hline & \multirow{3}{*}{33} & CP4-SB & 44,35 & \multirow{3}{*}{45,92} & \multirow{3}{*}{1,19} & \multirow{3}{*}{2,60} \\
\hline & & CP5-SB & 46,18 & & & \\
\hline & & CP6-SB & 45,94 & & & \\
\hline \multirow{6}{*}{$\begin{array}{l}\text { Ensaio de } \\
\text { flexão } \\
\text { (Laje 1) }\end{array}$} & \multirow{3}{*}{28} & CP1-L1 & 48,71 & \multirow{3}{*}{53,66} & \multirow{3}{*}{3,63} & \multirow{3}{*}{6,76} \\
\hline & & CP2-L1 & 54,95 & & & \\
\hline & & CP3-L1 & 57,31 & & & \\
\hline & \multirow{3}{*}{80} & CP4-L1 & 63,58 & \multirow{3}{*}{61,16} & \multirow{3}{*}{2,54} & \multirow{3}{*}{4,15} \\
\hline & & CP5-L1 & 57,66 & & & \\
\hline & & CP6-L1 & 62,24 & & & \\
\hline \multirow{6}{*}{$\begin{array}{l}\text { Ensaio de } \\
\text { flexão } \\
\text { (Laje 2) }\end{array}$} & \multirow{3}{*}{28} & CP1-L2 & 38,61 & \multirow{3}{*}{42,40} & \multirow{3}{*}{3,91} & \multirow{3}{*}{9,22} \\
\hline & & CP2-L2 & 47,78 & & & \\
\hline & & CP3-L2 & 40,82 & & & \\
\hline & \multirow{3}{*}{80} & CP4-L2 & 57,70 & \multirow{3}{*}{57,62} & \multirow{3}{*}{0,29} & \multirow{3}{*}{0,50} \\
\hline & & CP5-L2 & 57,94 & & & \\
\hline & & CP6-L2 & 57,24 & & & \\
\hline
\end{tabular}

Fonte: Autoria própria

Tabela 6.2 - Resistência à tração do concreto segundo os respectivos protótipos

\begin{tabular}{|c|c|c|c|c|c|c|c|}
\hline \multirow[t]{2}{*}{ Protótipo } & \multirow{2}{*}{$\begin{array}{l}\text { Idade } \\
\text { [Dias] }\end{array}$} & \multirow{2}{*}{$\begin{array}{c}\text { Corpo } \\
\text { de } \\
\text { Prova } \\
\text { (CP) }\end{array}$} & \multicolumn{2}{|c|}{$\begin{array}{c}\text { Resistência à } \\
\text { Tração na Flexão } \\
\left(f_{\text {ct,ff }}[\mathrm{MPa}]\right.\end{array}$} & \multirow{2}{*}{$\begin{array}{c}\text { Resistência } \\
\text { Média à } \\
\text { Tração } \\
\text { Direta }\left(f_{\text {ct,m }}\right) \\
{[\mathrm{MPa}]} \\
\end{array}$} & \multirow{2}{*}{$\begin{array}{l}\text { Desvio } \\
\text { Padrão } \\
\text { [MPa] }\end{array}$} & \multirow{2}{*}{$\begin{array}{c}\text { Coeficiente } \\
\text { de } \\
\text { Variação } \\
(\%)\end{array}$} \\
\hline & & & $\mathbf{C P}$ & Média & & & \\
\hline \multirow{3}{*}{$\begin{array}{l}\text { Ensaio } \\
\text { slip-block } \\
\text { (todos) }\end{array}$} & \multirow{3}{*}{33} & PR1-SB & 5,15 & & & & \\
\hline & & PR2-SB & 5,15 & 5,01 & 3,51 & 0,20 & 4,03 \\
\hline & & PR3-SB & 4,72 & & & & \\
\hline \multirow{3}{*}{$\begin{array}{l}\text { Ensaio de } \\
\text { flexão } \\
\text { (Laje 1) }\end{array}$} & \multirow{3}{*}{80} & PR1-L1 & 5,07 & & & & \\
\hline & & PR2-L1 & 4,83 & 5,02 & 3,51 & 0,14 & 2,82 \\
\hline & & PR3-L1 & 5,16 & & & & \\
\hline \multirow{3}{*}{$\begin{array}{l}\text { Ensaio de } \\
\text { flexão } \\
\text { (Laje 2) }\end{array}$} & \multirow{3}{*}{80} & PR1-L2 & 5,91 & & & & \\
\hline & & PR2-L2 & 5,35 & 5,43 & 3,80 & 0,37 & 6,75 \\
\hline & & PR3-L2 & 5,02 & & & & \\
\hline
\end{tabular}

Fonte: Autoria própria

De modo geral, os resultados se apresentaram coerentes e com variabilidade aceitável, de acordo com os parâmetros estatísticos utilizados. 
Os corpos de prova dos concretos das lajes referentes ao dia dos ensaios de flexão foram instrumentados com extensômetros removíveis para medição das deformações durante o ensaio de compressão, obtendo-se, assim, o módulo de elasticidade $\left(E_{\mathrm{c}}\right)$ de acordo com a norma ABNT NBR 8522: 2017. Esses corpos de prova foram ensaiados na máquina de ensaio servohidráulica Instron Satec ${ }^{\circledR} 300$ HVL 8506. A Tabela 6.3 apresenta os resultados obtidos de acordo com o protótipo do ensaio de flexão.

Tabela 6.3 - Módulo de elasticidade do concreto segundo os respectivos protótipos

\begin{tabular}{|c|c|c|c|c|c|c|}
\hline \multirow[t]{2}{*}{ Protótipo } & \multirow{2}{*}{$\begin{array}{l}\text { Idade } \\
\text { [Dias] }\end{array}$} & \multirow{2}{*}{$\begin{array}{l}\text { Corpo de } \\
\text { Prova } \\
\text { (CP) }\end{array}$} & \multicolumn{2}{|c|}{$\begin{array}{l}\text { Módulo de Elasticidade } \\
\qquad\left(E_{c}\right)[\mathrm{GPa}]\end{array}$} & \multirow{2}{*}{$\begin{array}{c}\text { Desvio } \\
\text { Padrão } \\
\text { [GPa] }\end{array}$} & \multirow{2}{*}{$\begin{array}{c}\text { Coeficiente } \\
\text { de Variação } \\
(\%)\end{array}$} \\
\hline & & & $\mathbf{C P}$ & Média $\left(E_{c, m}\right)$ & & \\
\hline \multirow{3}{*}{$\begin{array}{c}\text { Ensaio de } \\
\text { flexão } \\
\text { (Laje 1) }\end{array}$} & \multirow{3}{*}{80} & CP4-L1 & 34,14 & & & \\
\hline & & CP5-L1 & 35,41 & 37,57 & 4,00 & 10,64 \\
\hline & & CP6-L1 & 43,19 & & & \\
\hline \multirow{3}{*}{$\begin{array}{c}\text { Ensaio de } \\
\text { flexão } \\
\text { (Laje 2) }\end{array}$} & \multirow{3}{*}{80} & CP4-L2 & 39,60 & & & \\
\hline & & CP5-L2 & 33,72 & 35,92 & 2,62 & 7,29 \\
\hline & & CP6-L2 & 34,54 & & & \\
\hline
\end{tabular}

Fonte: Autoria própria

Apesar do concreto possuir o mesmo traço em todos os casos, os corpos de prova dos protótipos do ensaio de flexão apresentaram resistência consideravelmente superior aos dos protótipos do ensaio slip-block. Essa discrepância pode ser atribuída ao fato de que as areais utilizadas no concreto dos protótipos do ensaio slip-block foram devidamente secas antes da concretagem, enquanto que as areias utilizadas no concreto das lajes estavam úmidas e corrigiuse a quantidade de água com base na umidade determinada por meio de amostras secas em estufa. Dessa forma, é provável que essas amostras não foram representativas, culminando no desconto de uma quantidade de água superior, o que acarretou também na redução do abatimento do concreto.

\subsubsection{Aço}

A caracterização mecânica do aço foi realizada por meio do ensaio de tração de corpos de prova extraídos diretamente da fôrma de aço. O método de ensaio seguiu as recomendações da ASTM A370-19: 2019 e determinou-se, assim, a resistência à tração $\left(f_{\mathrm{y}}\right)$, a resistência à ruptura $\left(f_{\mathrm{u}}\right)$ do aço e o alongamento total. Foram ensaiados seis corpos de prova que foram extraídos de diferentes posições do perfil da fôrma de aço (mesa superior e mesa inferior). A Tabela 6.4 apresenta os resultados obtidos da caracterização mecânica do aço. 
Tabela 6.4 - Propriedades mecânicas do aço constituinte da fôrma MODULAR MD 55

\begin{tabular}{cccc}
\hline Corpo de Prova & $\begin{array}{c}\text { Resistência ao } \\
\text { Escoamento }\left(\boldsymbol{f}_{\mathbf{y}}\right)[\mathbf{M P a}]\end{array}$ & $\begin{array}{c}\text { Resistência à } \\
\text { Ruptura }\left(\boldsymbol{f}_{\mathbf{u}}\right)[\mathbf{M P a}]\end{array}$ & $\begin{array}{c}\text { Alongamento } \\
\text { Total }(\boldsymbol{\%})\end{array}$ \\
\hline CP1 & 296,45 & 380,93 & 36,02 \\
CP2 & 282,55 & 369,12 & 32,20 \\
CP3 & 290,10 & 376,52 & 33,60 \\
CP4 & 283,40 & 351,27 & 35,96 \\
CP5 & 279,10 & 369,30 & 34,74 \\
CP6 & 284,20 & 375,87 & 34,24 \\
\hline \hline Média & $285,97 \mathrm{MPa}$ & $370,50 \mathrm{MPa}$ & $34,46 \%$ \\
\hline Desvio Padrão & $5,71 \mathrm{MPa}$ & $9,55 \mathrm{MPa}$ & $1,33 \%$ \\
\hline Coef. de Variação & $2,00 \%$ & $2,58 \%$ & $3,87 \%$ \\
\hline
\end{tabular}

Fonte: Autoria própria

De acordo com a ABNT NBR 7008-3: 2012, que trata de chapas e bobinas revestidas com zinco pelo processo contínuo de imersão à quente, observa-se que a resistência média à tração está acima do limite inferior exigido de $280 \mathrm{MPa}$, enquanto que a resistência média à ruptura está abaixo do valor limite inferior exigido, que é $380 \mathrm{MPa}$. Além disso, segundo a referida norma, o alongamento médio total dos corpos de prova ensaiados apresentou valor superior ao mínimo especificado pela referida norma, ou seja, $16 \%$.

\subsection{Ensaio Slip-Block}

O modelo adotado para o ensaio slip-block possuiu configuração semelhante à adotada por Holomek, Bajer e Vilda (2016) e por Yi et al. (2018). Essa configuração foi empregada com base na praticidade de execução do ensaio e objetivando maior amostragem da região que contém mossas, pois cada protótipo possui a interface aço-concreto com o dobro da área do protótipo originalmente proposto por Patrick e Poh (1990).

Diante da configuração do carregamento, analisou-se dois métodos de ensaio:

a) Carregamento vertical constante ao longo do ensaio;

b) Carregamento vertical variável ao longo do ensaio.

Por meio do primeiro método foi possível analisar com mais clareza os fenômenos causados pelo cisalhamento longitudinal da interface aço-concreto, sem a influência da variação do carregamento de confinamento ao longo do ensaio. Dessa forma, construiu-se o gráfico da Força Vertical $\left(F_{\mathrm{v}}\right)$ versus Deslizamento $(s)$ e analisou-se a influência de cada fenômeno identificado sobre a configuração do gráfico de maneira qualitativa e quantitativa. 
Além disso, realizar ensaios sob carregamento vertical constante diferente em cada caso possibilitou avaliar a influência da força de confinamento sobre o comportamento do protótipo. Logo, foi proposta uma metodologia de modo a aplicar os resultados experimentais obtidos para cada nível de carregamento vertical constante e obter o coeficiente de atrito global $(\mu)$ e a capacidade resistente devido ao intertravamento mecânico $\left(F_{\mathrm{m}}\right)$ da interface aço-concreto da laje mista estudada, conforme explicado na próxima seção.

Ao se realizar o ensaio com carregamento vertical variável, seguindo a metodologia proposta por Patrick e Poh (1990), objetivou-se avaliar esse método de ensaio e comparar os resultados experimentais obtidos com os da metodologia proposta neste trabalho.

No caso dos ensaios sob carregamento vertical constante, empregou-se três níveis de força vertical, objetivando maior representatividade dos resultados obtidos diante do uso de regressões lineares para a obtenção dos parâmetros. Foram realizados três ensaios slip-block sob carregamento vertical constante e um sob carregamento vertical variável. A Tabela 6.5 apresenta as características de cada protótipo ensaiado.

Tabela 6.5 - Configuração do carregamento aplicado em cada ensaio slip-block

\begin{tabular}{ccc}
\hline Protótipo & Tipo de Carregamento Vertical & Força Vertical $\left(\boldsymbol{F}_{\mathbf{V}}\right)^{(\mathbf{a})}[\mathbf{k N}]$ \\
\hline SB-C-01 & Constante & 27,14 \\
SB-C-02 & Constante & 18,14 \\
SB-C-03 & Constante & $1,94^{(\mathrm{b})}$ \\
SB-V-01 & Variável & $50 \rightarrow 40 \rightarrow 30 \rightarrow 20 \rightarrow 10$ \\
\hline
\end{tabular}

(a) Força Vertical = Carregamento aplicado pelo atuador vertical + Peso do aparato.

(b) No protótipo SB-C-03 a Força Vertical atuante foi apenas o peso de parte do aparato.

Fonte: Autoria própria

As magnitudes da força vertical foram definidas com base nas utilizadas por Patrick e Poh (1990) e para se obter uma variação significativa entre os resultados obtidos de acordo com o nível de força vertical aplicada. Assim, foi possível comparar melhor as duas metodologias desconsiderando a influência da diferença da magnitude do carregamento aplicado.

No caso do protótipo SB-V-01 aplicou-se a mesma sequência e magnitude de carregamento proposta por Patrick e Poh (1990), explicado detalhadamente na seção 6.3.2.2. 


\subsubsection{Configuração do Ensaio e Instrumentação}

O protótipo do ensaio slip-block consistiu numa região recortada da fôrma de aço contendo duas nervuras. A largura do protótipo corresponde à largura de duas nervuras e o seu comprimento é de $600 \mathrm{~mm}$, dos quais $300 \mathrm{~mm}$ possuíram uma capa de concreto com $150 \mathrm{~mm}$ de altura (mesma altura do protótipo do ensaio de flexão).

O equipamento utilizado foi desenvolvido originalmente para a execução de ensaios de cisalhamento direto em rochas. Dessa forma, foi projetado e fabricado um aparato de adaptação para possibilitar a realização do ensaio slip-block nesse equipamento. Os protótipos foram executados para que a força horizontal fosse aplicada no sentido de menor resistência do chaveamento promovido pelas mossas, pois é a condição de cisalhamento que limita a resistência da interface analisada. A Figura 6.4 apresenta as vistas em perspectiva do protótipo e do esquema de ensaio, ilustrando o aparato utilizado.

Figura 6.4 - Vistas em perspectiva do ensaio slip-block

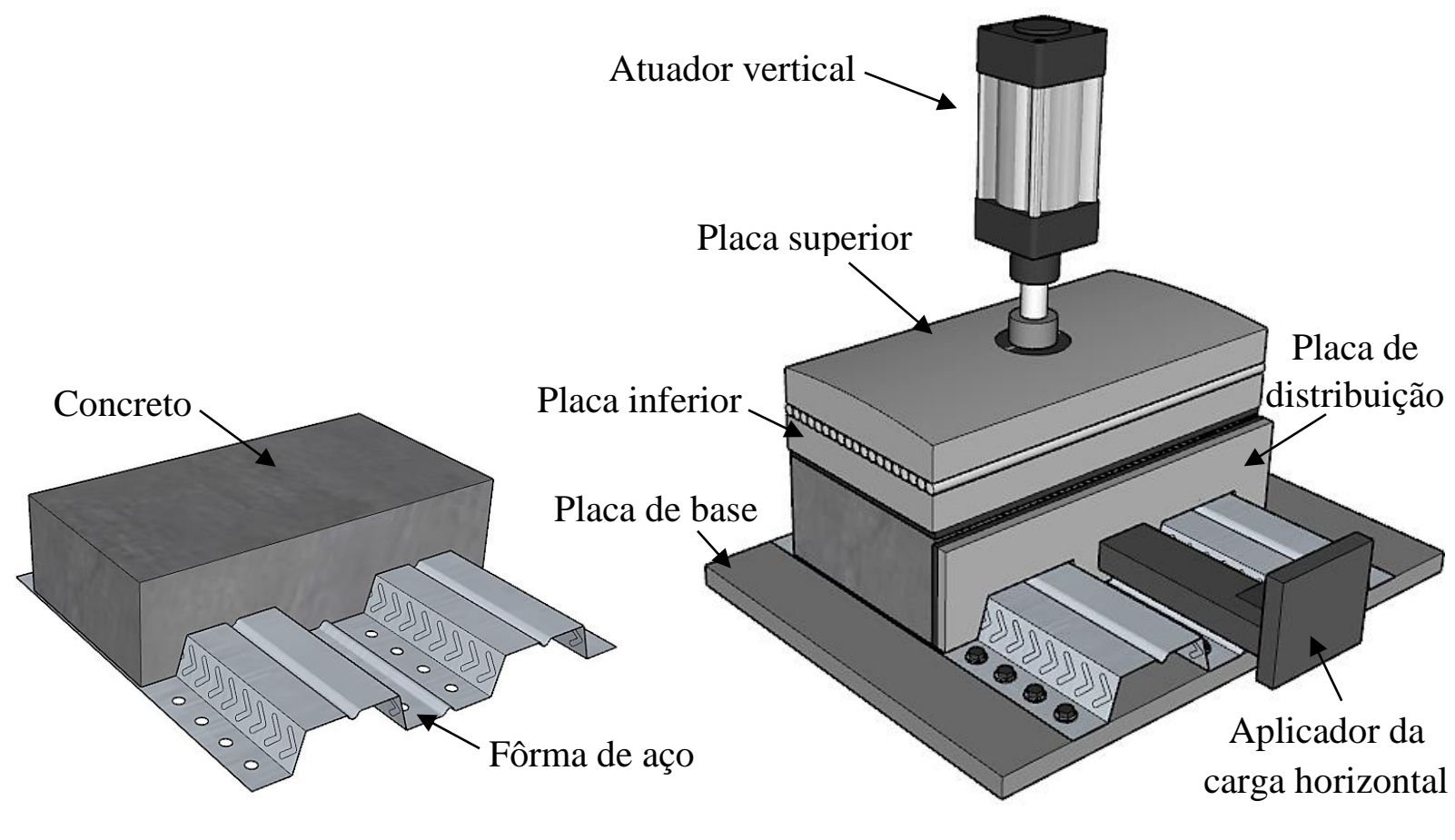

(a) Protótipo

(b) Aparato de ensaio

Fonte: Autoria própria

A Figura 6.5, por sua vez, descreve detalhadamente o protótipo e o aparato empregado para a realização do ensaio, cujas dimensões estão em milímetros. 
Figura 6.5 - Aparato do ensaio slip-block

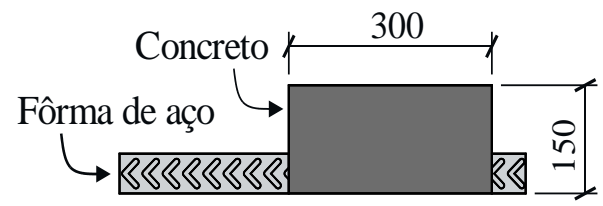

a) Vista Lateral do Protótipo

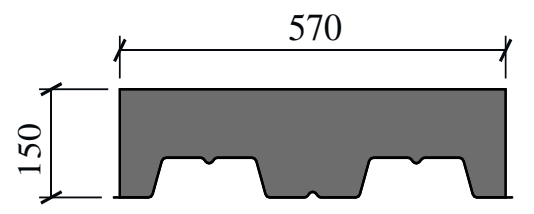

b) Vista Frontal do Protótipo

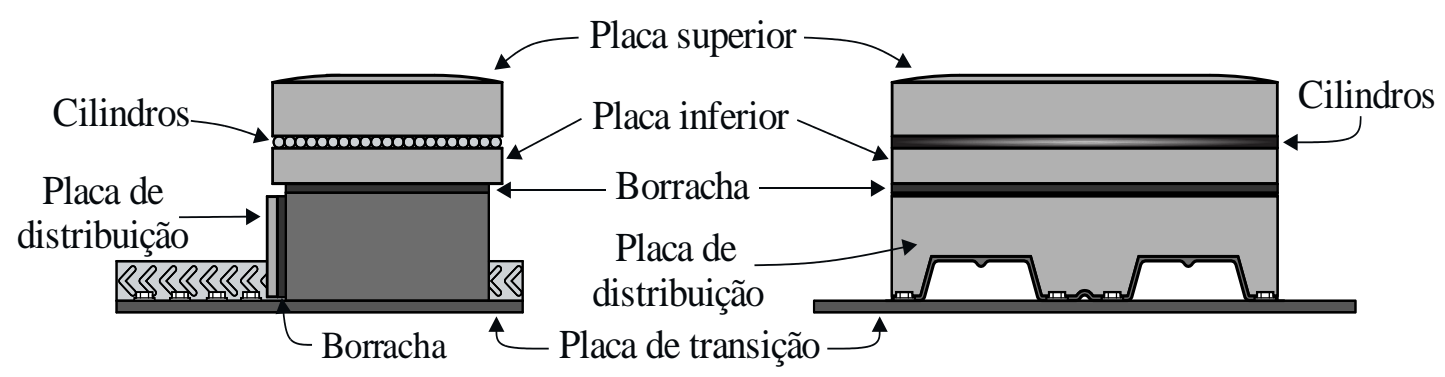

c) Vista Lateral do Ensaio

d) Vista Frontal do Ensaio

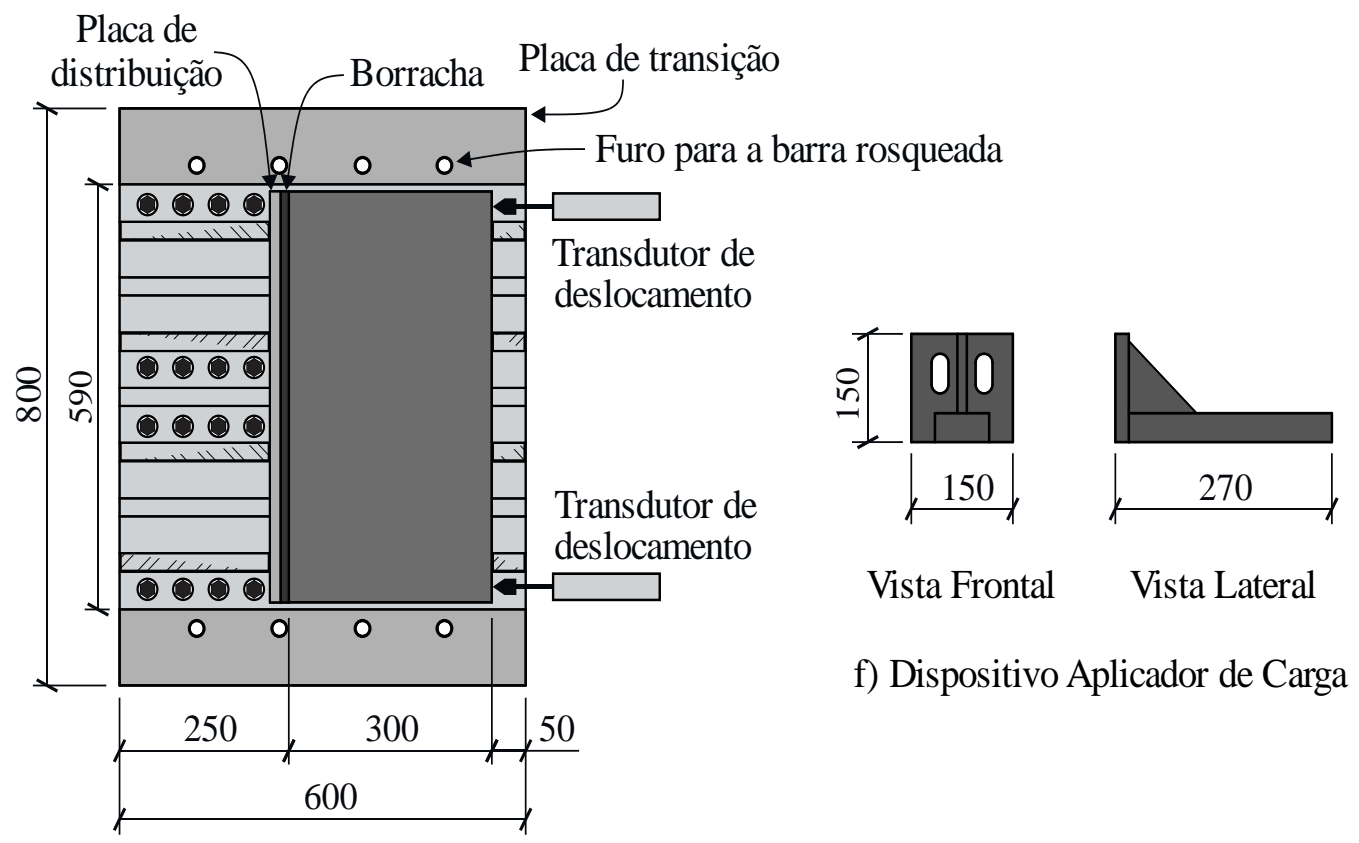

e) Vista Superior do Ensaio

Fonte: Autoria própria

(Dimensões em milímetros)

A fixação do protótipo à placa de transição foi realizada por meio de parafusos devido a sua praticidade. Na parte frontal da fôrma de aço de cada protótipo foram executados, antes da concretagem, 16 furos para permitir a fixação do protótipo à placa de transição por meio de parafusos M16, conforme ilustrado nas Figuras 6.4 e 6.5.

A localização dos furos (apenas à frente do concreto) foi adotada para que a porção da fôrma de aço localizada sob o concreto fosse mantida tracionada ao longo do ensaio, simulando a situação usual da laje mista submetida à um momento fletor positivo. Os furos e parafusos 
foram dimensionados com base nos esforços aplicados em trabalhos da literatura técnica que empregaram ensaios do tipo slip-block.

Conforme se observa na Figura 6.5 (e), após a capa de concreto do protótipo existe um trecho da fôrma de aço com $50 \mathrm{~mm}$ de comprimento. Optou-se por projetar o protótipo com esse trecho para que a área da interface fosse mantida constante durante o ensaio, o que não ocorre nos ensaios realizados por Patrick e Poh (1990) e Holomek, Bajer e Vilda (2016).

A placa de transição consiste numa placa de aço de $15 \mathrm{~mm}$ de espessura, fabricada para permitir a fixação do protótipo à base do equipamento de ensaio e para transmitir os esforços aplicados sobre o mesmo. Ela possui 16 furos rosqueados para fixação dos parafusos e é presa à base do equipamento de ensaio por meio de 8 barras rosqueadas.

Objetivando a aplicação da força horizontal distribuída sobre a superfície do concreto, foi utilizada uma placa de aço (Placa de distribuição na Figura 6.5) com 15 mm de espessura, recortada no formato da seção transversal da capa de concreto. Com o mesmo objetivo utilizouse outra placa de aço acima da capa de concreto (Placa inferior na Figura 6.5) para distribuir a força vertical aplicada. Sobre essa placa foram posicionados cilindros maciços de aço para permitir o movimento horizontal do protótipo e acima deles posicionou-se outra placa de aço (Placa superior na Figura 6.5) para distribuir a força proveniente do atuador sevo-hidráulico vertical. Entre as placas de aço e o concreto, posicionou-se borrachas de $10 \mathrm{~mm}$ de espessura para melhor uniformizar os carregamentos aplicados diante da superfície irregular do concreto.

Para a aplicação da força horizontal fabricou-se um dispositivo aplicador de carga (Figura 6.5 (f)) que foi fixado ao atuador servo-hidráulico horizontal. Este dispositivo foi devidamente posicionado para que a força horizontal fosse aplicada no centro geométrico da placa de distribuição, que coincide com o centro geométrico da fôrma de aço.

$\mathrm{O}$ deslizamento relativo entre o concreto e a fôrma de aço foi medido por meio de dois transdutores de deslocamento (marca VISHAY, modelo HS25 e curso $=50 \mathrm{~mm}$ ) fixados à fôrma de aço e posicionados na face oposta à qual o carregamento foi aplicado, conforme ilustrado na Figura 6.5 (e). No ensaio do primeiro protótipo instalou-se transdutores posicionados verticalmente para medir alguma separação vertical entre o concreto e a fôrma de aço, no entanto nenhuma separação foi constatada, dispensando seu uso nos demais ensaios.

$\mathrm{O}$ equipamento de ensaio consiste num sistema servo-hidráulico para ensaios de cisalhamento direto, com atuadores da marca MTS $^{\circledR}$ para forças normal e cisalhante individualmente controlados. Os atuadores vertical e horizontal possuem capacidade de $500 \mathrm{kN}$ e $1.000 \mathrm{kN}$, respectivamente. A Figura 6.6 apresenta o equipamento de ensaio e a Figura 6.7 apresenta a realização do ensaio, com o aparato fabricado. 
Figura 6.6 - Equipamento do ensaio slip-block

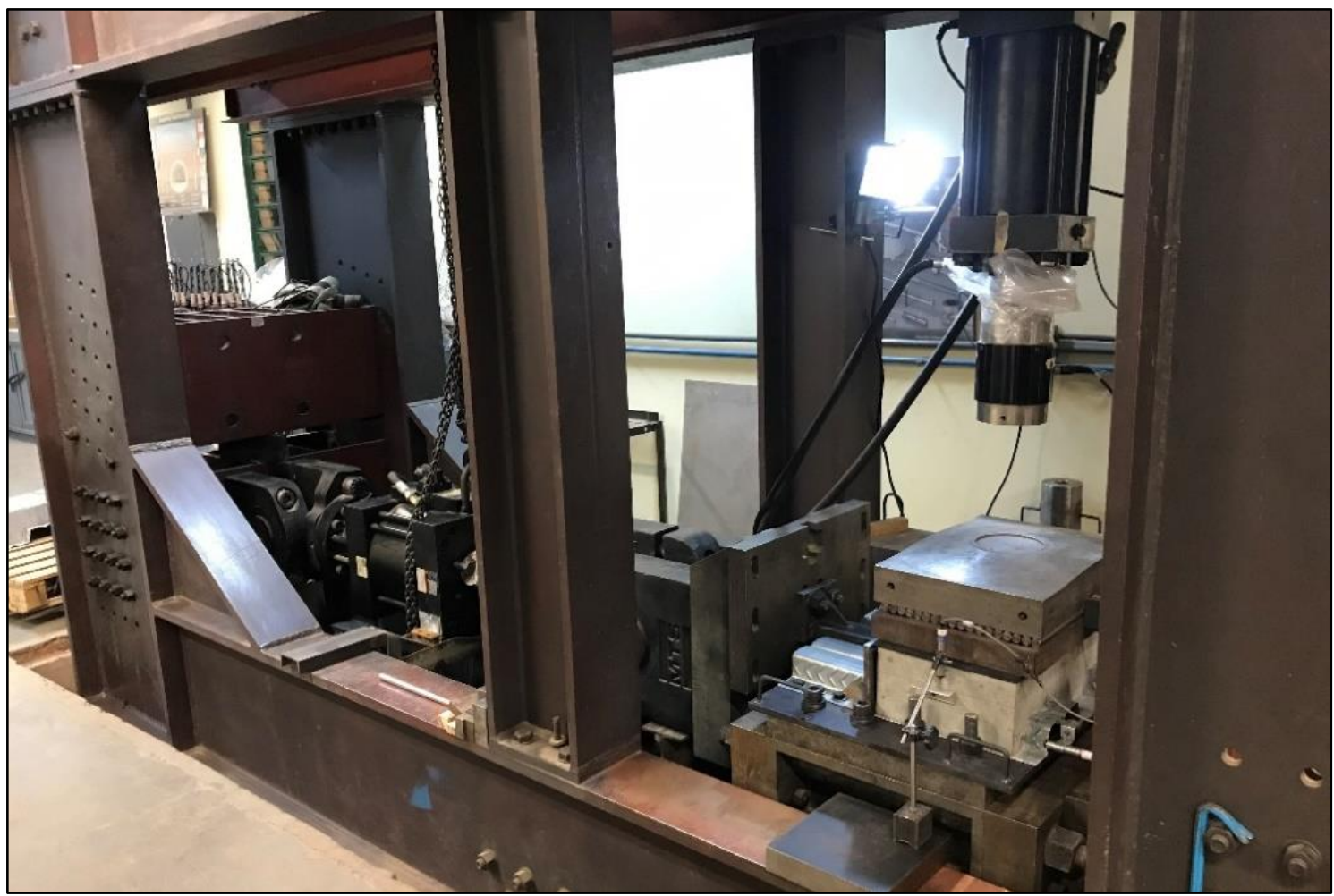

Fonte: Autoria própria

Figura 6.7 - Ensaio slip-block

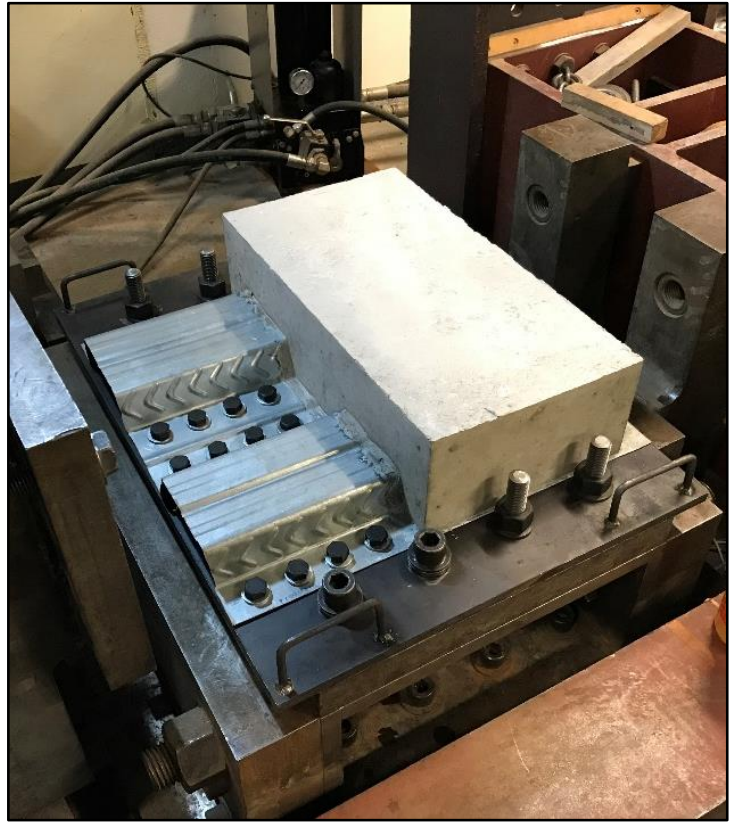

(a) Protótipo posicionado

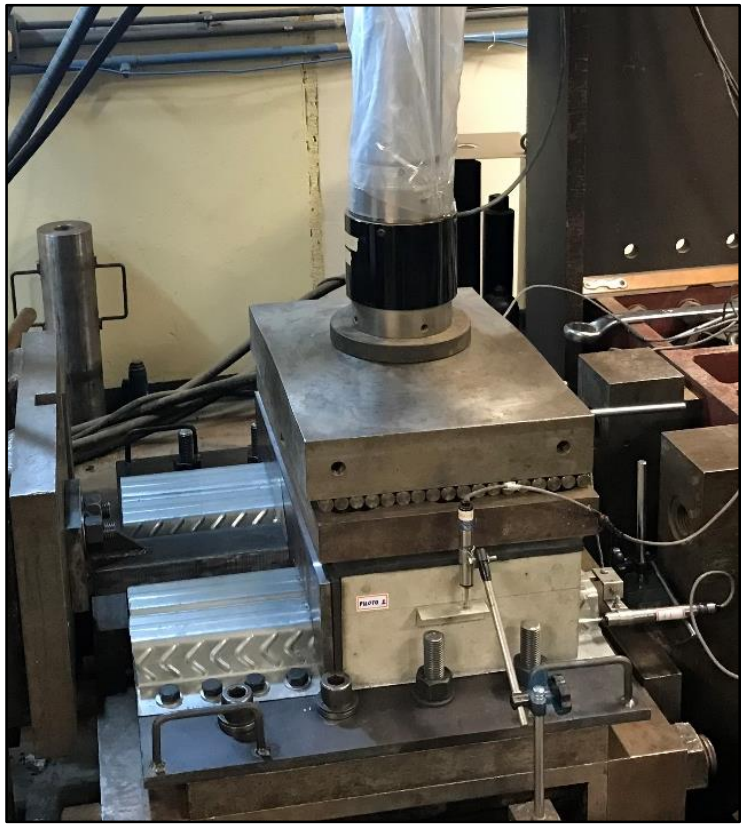

(b) Aparato de ensaio

Fonte: Autoria própria

As placas superior e inferior, assim como os cilindros maciços foram pesados para contabilizar seu peso sobre os protótipos. A Tabela 6.6 apresenta o peso de cada um destes aparatos. 
Tabela 6.6 - Peso de alguns componentes do aparato do ensaio slip-block

\begin{tabular}{cccc}
\hline Aparato & Quantidade & Peso Unitário [kN] & Peso Total [kN] \\
\hline Placa Inferior & 1 & 0,71 & 0,71 \\
Placa Superior & 1 & 1,23 & 1,23 \\
Cilindros & 18 & 0,01 & 0,20 \\
\hline \multicolumn{3}{c}{ Somatório dos Pesos Totais } & $2,14 \mathrm{kN}$ \\
\hline
\end{tabular}

Observação: No protótipo SB-C-03 utilizou-se apenas as placas inferior e superior como Força Vertical $(F \mathrm{v})$, totalizando $1,94 \mathrm{kN}$.

Fonte: Autoria própria

\subsubsection{Procedimento de Ensaio}

Conforme já mencionado, analisou-se dois métodos de ensaio diferentes: carregamento vertical constante ao longo do ensaio e carregamento vertical variável ao longo do ensaio (proposto por Patrick e Poh (1990)).

\subsubsection{Carregamento Vertical Constante ao Longo do Ensaio}

Após fixar o protótipo na placa de base, posicionar devidamente o aparato de ensaio e fixar corretamente os transdutores de deslocamento, o atuador vertical é posicionado no centro da placa superior. Dessa forma, aplicou-se a força vertical prescrita, confinando o protótipo. Em seguida, o dispositivo aplicador de força horizontal é posicionado para aplicar corretamente o carregamento no centro geométrico da placa de distribuição. Sendo assim, é induzido o deslocamento horizontal a uma taxa prescrita de $0,01 \mathrm{~mm} / \mathrm{s}$.

A cada segundo foram registradas a força vertical e a força horizontal aplicadas, os deslocamentos dos pistões dos dois atuadores e os deslizamentos relativos medidos pelos dois transdutores. O ensaio foi encerrado depois que a capa de concreto deslizou por todo o trecho de $50 \mathrm{~mm}$ da fôrma de aço.

\subsubsection{Carregamento Vertical Variável ao Longo do Ensaio}

Uma vez preparados e posicionados o aparato de ensaio, instrumentação e atuadores vertical e horizontal, aplicou-se uma Força Vertical, $F_{\mathrm{V}}$, (carga aplicada pelo atuador vertical + peso do aparato de ensaio) de $27,14 \mathrm{kN}$ sobre o protótipo. O valor desse carregamento inicial foi o mesmo utilizado por Patrick e Poh (1990), que estabelecem que o valor inicial de $F_{\mathrm{V}}$ deve 
ser escolhido de modo a prevenir a rotação da capa de concreto antes que a ligação química da interface aço-concreto seja rompida. Em seguida, o carregamento horizontal foi aplicado por meio de deslocamento induzido pelo atuador horizontal a uma velocidade de $0,01 \mathrm{~mm} / \mathrm{s}$.

Após a ligação química ser rompida (fato verificado pelo início do deslizamento relativo entre o concreto e a fôrma de aço, medido pelos transdutores de deslocamento) e ser identificado um nível de força horizontal relativamente constante enquanto o deslizamento ocorria, aumentou-se o carregamento vertical aplicado pelo atuador para $50 \mathrm{kN}$. Esse carregamento foi mantido até que fosse identificado que a força horizontal se mantinha relativamente constante por cerca de $1 \mathrm{~mm}$ de deslizamento ocorrido. Em seguida, o carregamento aplicado pelo atuador vertical foi reduzido para $40 \mathrm{kN}$ e mantido enquanto a força horizontal se mantinha constante por cerca de $1 \mathrm{~mm}$ de deslizamento ocorrido. Este procedimento foi repetido: sempre reduzindo $10 \mathrm{kN}$ de carregamento vertical aplicado pelo atuador, após constatado que a força horizontal se mantinha constante por cerca de $1 \mathrm{~mm}$ de deslizamento.

O carregamento vertical mínimo aplicado pelo atuador ao longo do ensaio foi de $10 \mathrm{kN}$, ou seja, a sequência de carregamento vertical aplicado pelo atuador foi: $50 \mathrm{kN} \rightarrow 40 \mathrm{kN} \rightarrow$ $30 \mathrm{kN} \rightarrow 20 \mathrm{kN} \rightarrow 10 \mathrm{kN}$. Logo, cada estágio de carregamento correspondia à um carregamento vertical $10 \mathrm{kN}$ inferior ao aplicado anteriormente e à um deslizamento de $1 \mathrm{~mm}$ ocorrido sob força vertical constante.

Uma vez concluído o último estágio de carregamento (carregamento vertical de $10 \mathrm{kN}$ aplicado pelo atuador durante $1 \mathrm{~mm}$ de deslizamento ocorrido), iniciou-se um novo ciclo de carregamento, ou seja, aumentou-se o carregamento aplicado pelo atuador vertical para $50 \mathrm{kN}$ e repetiu-se todo o procedimento já descrito. A Tabela 6.7 apresenta o procedimento de carregamento empregado e a Figura 6.8 ilustra um gráfico generalizado da Força Horizontal $\left(F_{\mathrm{H}}\right)$ versus Deslizamento relativo $(s)$ para o procedimento de carregamento aplicado.

Utilizando um mesmo protótipo, foi possível realizar vários ciclos de carregamento até que o deslizamento total da capa de concreto atinja o limite máximo de $50 \mathrm{~mm}$, a partir do qual a capa de concreto ultrapassa o limite da fôrma de aço e a área da interface passa a ser reduzida em função do deslizamento.

O fato de se manter a força vertical constante por cerca de $1 \mathrm{~mm}$ de deslizamento está relacionado com a resistência da interface aço-concreto, pois uma vez que se aplica uma força vertical constante, a força horizontal se mantém constante enquanto o deslizamento ocorre, indicando que a resistência da interface foi atingida. Dessa forma, escolheu-se um deslizamento de $1 \mathrm{~mm}$ para indicar a ocorrência desse fenômeno com base no trabalho de Patrick e Poh (1990). 
Contudo, conforme apresenta o próximo item, a resistência da interface depende do nível de deslizamento entre o aço e o concreto devido à presença das mossas, que não promovem uma interface com superfície constante.

Tabela 6.7 - Sequência de carregamento do slip-block sob força vertical variável

\begin{tabular}{cccc}
\hline Ciclo & Estágio & $\begin{array}{c}\text { Força Vertical aplicada } \\
\text { pelo atuador }[\mathbf{k N}]\end{array}$ & $\begin{array}{c}\text { Força Vertical Total }\left(\boldsymbol{F}_{\mathbf{V}}\right) \\
{[\mathbf{k N}]}\end{array}$ \\
\hline $\begin{array}{c}\text { Ruptura da } \\
\text { Ligação Química }\end{array}$ & Único & 25 & 27,14 \\
\hline & 1 & 50 & 52,14 \\
1 & 2 & 40 & 42,14 \\
& 3 & 30 & 32,14 \\
& 4 & 20 & 22,14 \\
& 5 & 10 & 12,14 \\
\hline & 1 & 50 & 52,14 \\
& 2 & 40 & 42,14 \\
& 3 & 30 & 32,14 \\
& 4 & 20 & 22,14 \\
& 5 & 10 & 12,14 \\
\hline & $\vdots$ & $\vdots$ & $\vdots$ \\
& 1 & 50 & 42,14 \\
& 2 & 40 & 32,14 \\
& 3 & 30 & 22,14 \\
& 4 & 20 & 12,14 \\
\hline
\end{tabular}

Fonte: Autoria própria

Figura 6.8 - Gráfico generalizado da Força horizontal $\left(F_{\mathrm{H}}\right)$ versus Deslizamento $(s)$

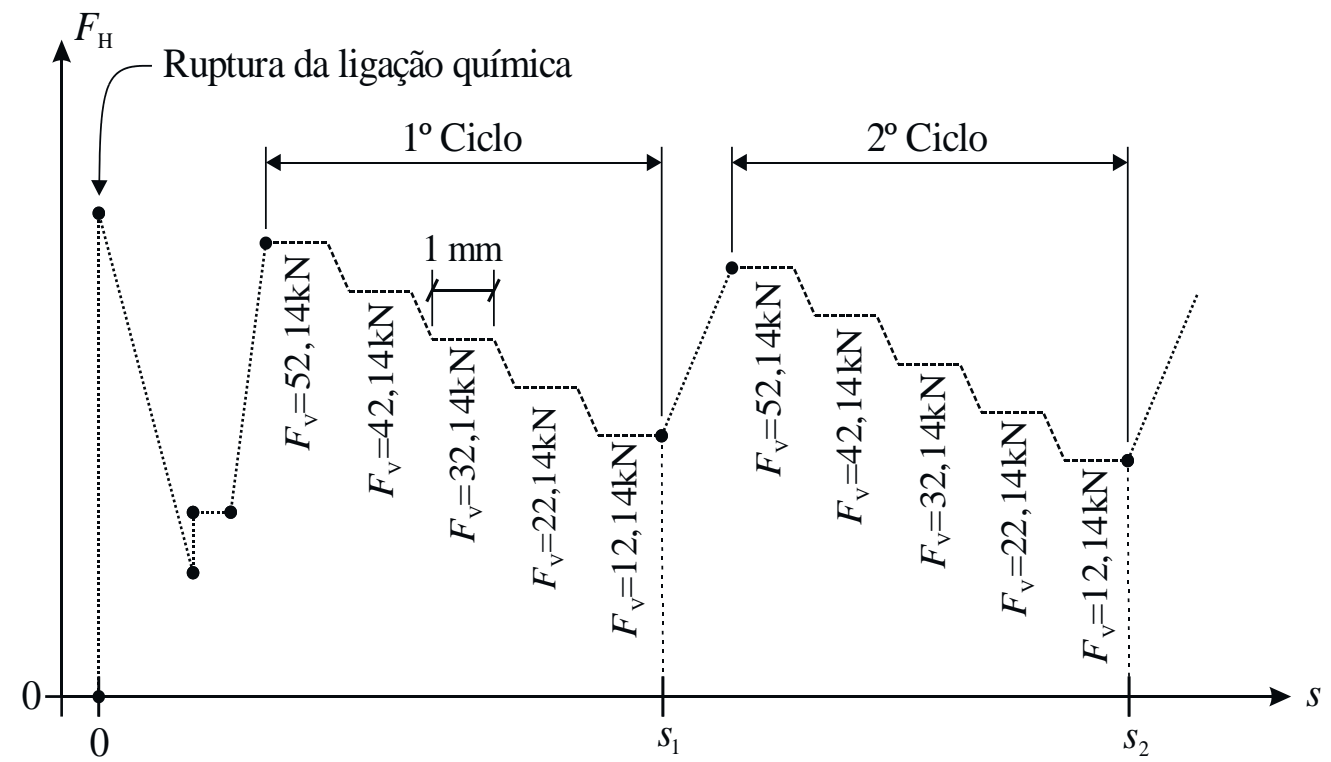

Fonte: Autoria própria 


\subsubsection{Resultados e Discussão}

\subsubsection{Carregamento Vertical Constante ao Longo do Ensaio}

O gráfico da Força horizontal $\left(F_{\mathrm{H}}\right)$ versus Deslizamento $(s)$ de cada protótipo ensaiado sob carregamento vertical constante está ilustrado na Figura 6.9. O deslizamento considerado é a média dos valores medidos pelos dois transdutores de deslocamento. Devido à limitação do curso dos transdutores, os resultados são exibidos até o deslizamento máximo de $40 \mathrm{~mm}$.

Figura 6.9 - Gráfico da Força horizontal $\left(F_{\mathrm{H}}\right)$ versus Deslizamento $(s)$ sob Força vertical $\left(F_{\mathrm{V}}\right)$ constante

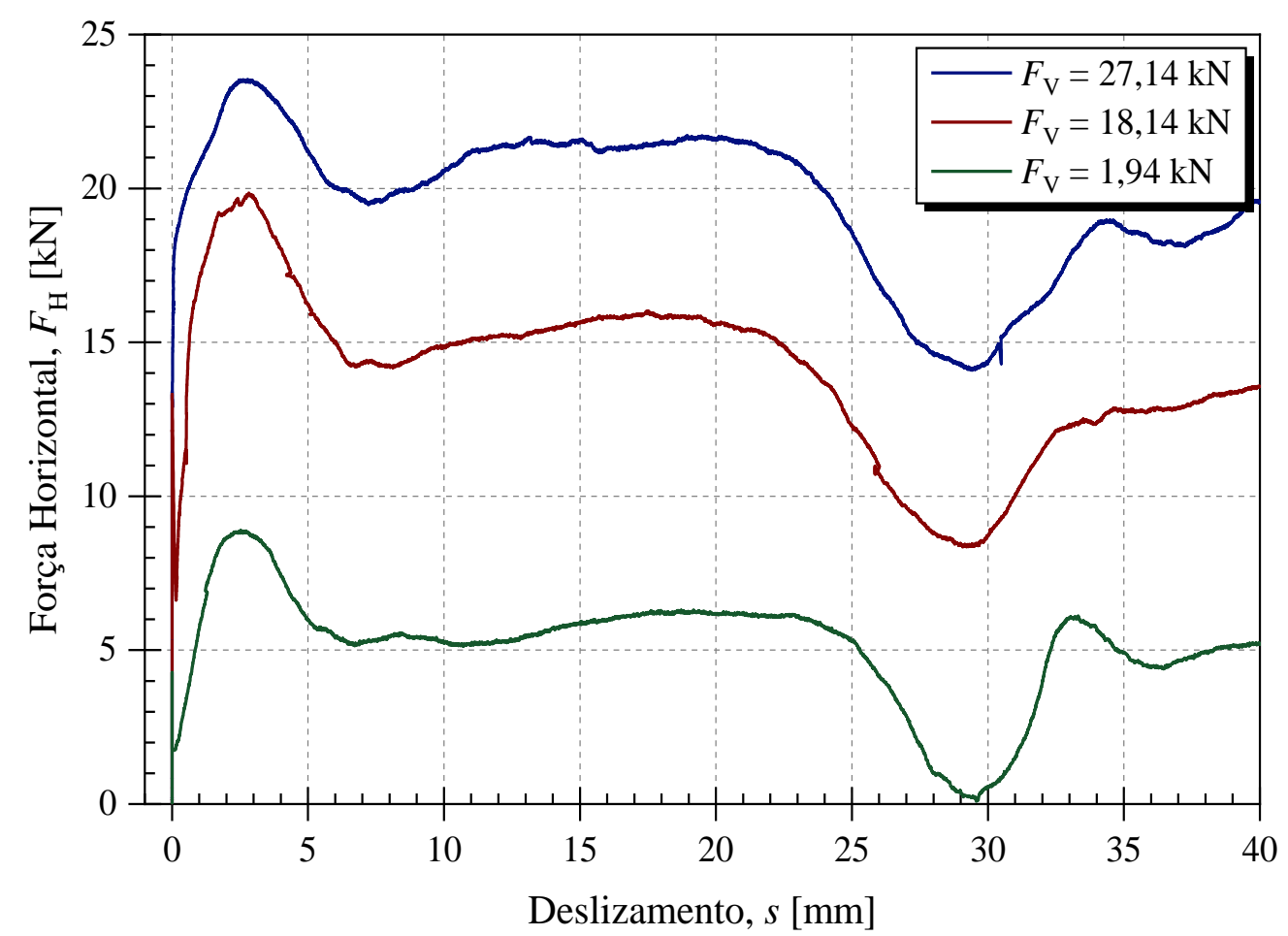

Fonte: Autoria própria

Verifica-se por meio do gráfico acima que a magnitude da Força vertical $\left(F_{\mathrm{V}}\right)$ afeta a resistência da interface aço-concreto, pois quanto maior o valor de $F \mathrm{~V}$ maior o valor da Força horizontal $\left(F_{\mathrm{H}}\right)$ para um mesmo deslizamento $s$. Esse fato está relacionado com os fenômenos que se desenvolveram na interface mediante a ocorrência do cisalhamento (principalmente devido a participação do atrito entre o aço e o concreto) e, no caso de lajes mistas sob flexão, se torna mais significante na região de apoio e na região sob o carregamento aplicado.

Constata-se, entretanto, que o formato das curvas do gráfico permanece praticamente o mesmo em todos os casos, o que está relacionado com a configuração da interface, ou seja, com a superfície da fôrma de aço em contato com o concreto. 
Dessa forma, o tipo de seção transversal da fôrma de aço (reentrante ou trapezoidal), assim como o formato (altura, ângulo de retenção e inclinação) e disposição das mossas determinam a configuração da curva no gráfico de $F_{\mathrm{H}}$ versus $s$, obtido do ensaio slip-block realizado sob carregamento vertical constante. Esse fato pode ser evidenciado ao se comparar o formato das curvas do gráfico da Figura 6.9 com o da Figura 4.12 (Seção 4.7), que apresenta o formato típico dos gráficos obtidos por Yi et. al (2018) ao realizarem o ensaio slip-block utilizando uma fôrma de aço de perfil reentrante com mossas presentes apenas na mesa superior.

Os fenômenos que se desenvolvem durante a realização dos ensaios estão diretamente relacionados com a configuração das curvas do gráfico da Figura 6.9. Sendo assim, para melhor explicar a fenomenologia ocorrida durante a realização dos ensaios, considera-se a curva apresentada na Figura 6.10 como sendo a curva típica do gráfico de $F_{\mathrm{H}}$ versus $s$, cujos valores de $F_{\mathrm{H}}$ para os pontos indicados, respectivos a cada protótipo, são apresentados na Tabela 6.9. A Figura 6.11, por sua vez, descreve o comportamento de um trecho do protótipo durante o ensaio slip-block.

Figura 6.10 - Gráfico típico da Força horizontal $\left(F_{\mathrm{H}}\right)$ versus Deslizamento $(s)$ dos protótipos

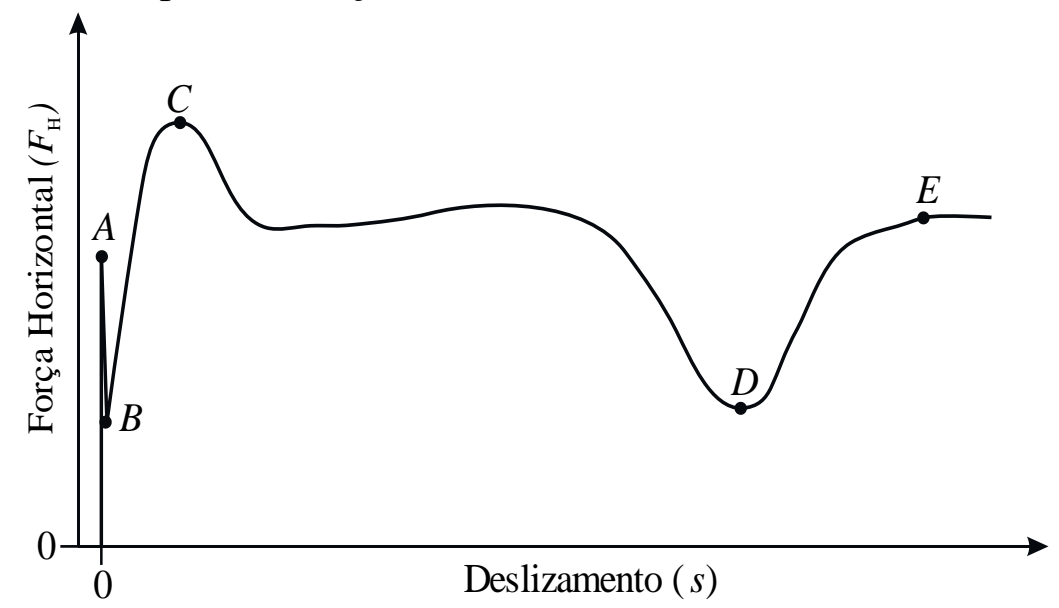

Fonte: Autoria própria

Tabela 6.8 - Valores de $F_{\mathrm{H}}$ de acordo com a curva típica da Figura 6.10

\begin{tabular}{ccccc}
\hline \multirow{2}{*}{ Protótipo } & \multicolumn{4}{c}{ Força horizontal $\left(\boldsymbol{F}_{\mathbf{H}}\right)$} \\
\cline { 2 - 5 } & Ponto $\boldsymbol{A}$ & Ponto $\boldsymbol{B}$ & Ponto $\boldsymbol{C}$ & Ponto $\boldsymbol{D}$ \\
\hline $\begin{array}{c}\text { SB-C-01 } \\
\left(\boldsymbol{F}_{\mathbf{V}}=\mathbf{2 7 , 1 4} \mathbf{k N}\right)\end{array}$ & $17,76 \mathrm{kN}$ & - & $23,56 \mathrm{kN}$ & $14,07 \mathrm{kN}$ \\
\hline $\begin{array}{c}\text { SB-C-02 } \\
\left(\boldsymbol{F}_{\mathbf{V}}=\mathbf{1 8 , 1 4} \mathbf{~ k N}\right)\end{array}$ & $13,46 \mathrm{kN}$ & $6,53 \mathrm{kN}$ & $19,86 \mathrm{kN}$ & $8,36 \mathrm{kN}$ \\
\hline $\begin{array}{c}\text { SB-C-03 } \\
\left(\boldsymbol{F}_{\mathbf{V}}=\mathbf{1 , 9 4} \mathbf{~ k N}\right)\end{array}$ & $4,39 \mathrm{kN}$ & $1,74 \mathrm{kN}$ & $8,91 \mathrm{kN}$ & $0,09 \mathrm{kN}$ \\
\hline
\end{tabular}

Fonte: Autoria própria 
Figura 6.11 - Comportamento da interface aço-concreto de um trecho do protótipo do ensaio slip-block

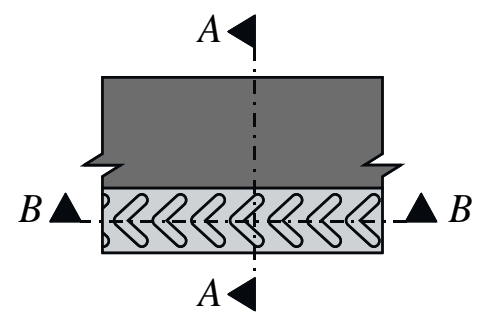

(a) Trecho do protótipo do ensaio slip-block

Corte $A-A$

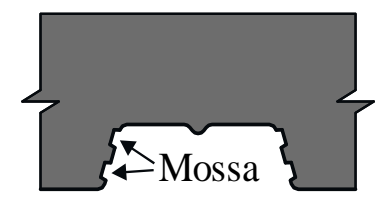

Corte $B-B$

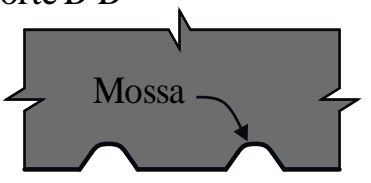

(b) Posição inicial

Corte $A-A$

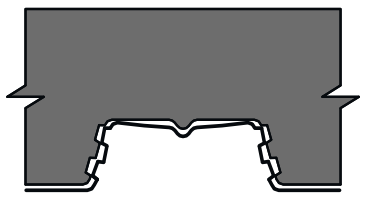

Corte $B-B$

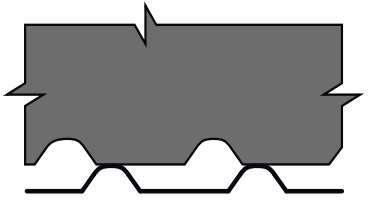

(e) Mossa próxima da indentação seguinte
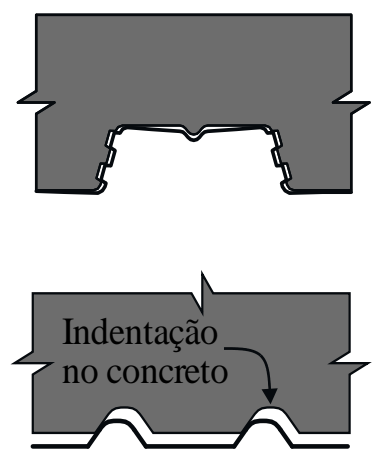

(c) Nervura comprimida e indentação saindo da mossa
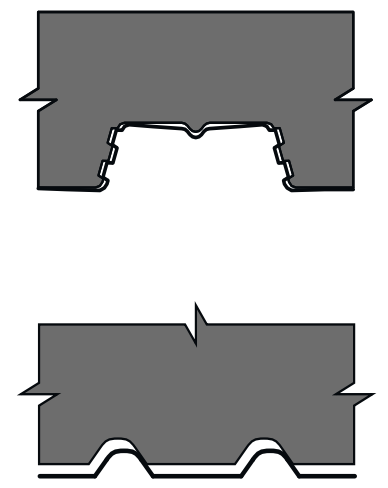

(f) Mossa entrando na indentação seguinte
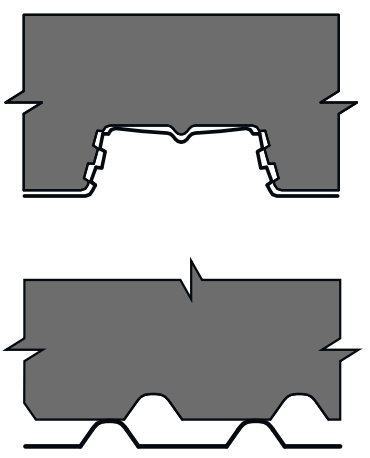

(d) Nervura comprimida e mossa fora da identação
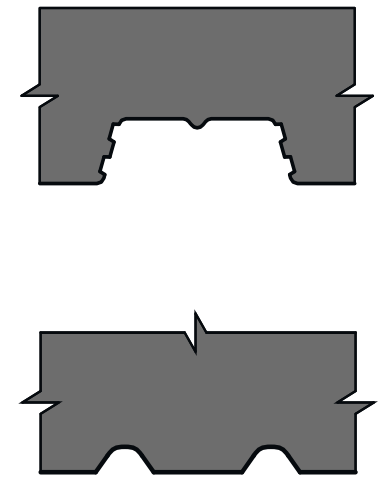

(g) Encaixe completo da mossa na identação seguinte

Fonte: Autoria própria

Até o ponto $A$ ser atingido, praticamente não ocorreu deslizamento relativo entre o concreto e o aço, ou seja, há interação total entre estes dois materiais (Figura 6.11 (b)). Nesse caso, atuam as ligações química, por atrito e mecânica. Uma vez que o deslizamento se iniciou, ocorreu a quebra da ligação química de maneira frágil e a capacidade resistente da interface aço-concreto foi reduzida repentinamente para o ponto $B$ (ver Figura 6.10). O protótipo SB-C$01\left(F_{\mathrm{V}}=27,14 \mathrm{kN}\right)$, entretanto, não apresentou redução brusca de sua capacidade resistente após o início do deslizamento, conforme se observa na Figura 6.9. 
A parcela de resistência devido à ligação química é afetada principalmente pelo tratamento superficial e pelas condições de sua superfície da fôrma de aço antes da concretagem, assim como pela possível atuação de carregamento cíclico aplicado ao elemento estrutural. Portanto, é provável que a ligação química do protótipo SB-C-01 $\left(F_{\mathrm{V}}=27,14 \mathrm{kN}\right)$ tenha sido parcialmente danificada durante sua manipulação, apesar de todas as precauções tomadas para manter a integridade da interface aço-concreto.

Comparando os valores de $F_{\mathrm{H}}$ referentes aos pontos $A$ e $B$, verifica-se que os protótipos SB-C-02 $\left(F_{\mathrm{V}}=18,14 \mathrm{kN}\right)$ e SB-C-03 $\left(F_{\mathrm{V}}=1,94 \mathrm{kN}\right)$ apresentaram uma redução de 51,5\% e $60,4 \%$, respectivamente. Diante disso, no ensaio slip-block, a ruptura da ligação química entre o aço e o concreto acarretou numa redução imediata de mais da metade da capacidade máxima resistente do protótipo no regime de interação total.

Além disso, um aumento de quase 10 vezes no valor de $F_{\mathrm{V}}$, ou seja, de $F_{\mathrm{V}}=1,94 \mathrm{kN}$ para $F_{\mathrm{V}}=18,14 \mathrm{kN}$, promoveu um aumento de 3 vezes no valor de $F_{\mathrm{H}}$ referente ao ponto $A$ e de quase 4 vezes no valor de $F_{\mathrm{H}}$ referente ao ponto $B$. Isso está associado à ligação por atrito, cuja magnitude depende do carregamento confinante aplicado à interface aço-concreto.

Iniciado o deslizamento, atuam apenas as ligações por atrito e mecânica. Ocorreu, então, progressivo aumento da capacidade resistente da interface aço-concreto até se atingir a resistência máxima no ponto $C$ do gráfico da Figura 6.10, cujos valores estão apresentados na Tabela 6.9. Essa resistência máxima ocorreu no momento em que as mossas da fôrma de aço estavam saindo de suas indentações no concreto, conforme ilustrado na Figura 6.11 (c).

A magnitude da resistência máxima da interface depende principalmente da magnitude da força de confinamento $\left(F_{\mathrm{V}}\right)$, do coeficiente de atrito entre o aço e o concreto, da configuração das mossas e da rigidez à flexão local da fôrma de aço, uma vez que para o deslizamento ocorrer as nervuras devem se contrair para que as mossas transpassem suas indentações no concreto.

Comparando-se as resistências ao cisalhamento máximas dos três protótipos ensaiados, verifica-se que o aumento de 9,35 vezes e de 14,0 vezes no valor de $F_{\mathrm{V}}$ promoveu o aumento de $122,9 \%$ e $164,4 \%$, respectivamente, no valor de $F_{\mathrm{H}}$. Esses aumentos estão relacionados ao aumento na resistência por atrito, que é dependente de $F_{\mathrm{V}}$, conforme discutido posteriormente.

No momento em que o deslizamento se iniciou, devido à deformação das nervuras da fôrma de aço, que provocou a separação entre o aço e o concreto, apenas parte das mossas da fôrma de aço se mantiveram em contato com o concreto. Ocorreu, portanto, concentração de tensões, tanto no concreto quanto no aço, na região das mossas em contato com o concreto, conforme explicado na seção 2.2. 
À medida que o deslizamento aumentou, a área das mossas em contato com o concreto se reduziu, concentrando mais tensões na região de contato até que as mossas saíram completamente de suas indentações no concreto (Figura 6.11 (d)).

Dessa forma, após a resistência máxima ser atingida, ocorreu redução gradual na capacidade resistente da interface, pois as mossas estavam concluindo a saída de suas indentações. Em seguida, notou-se a formação de praticamente um patamar no gráfico de $F_{\mathrm{H}}$ versus $s$, caracterizado pela baixa variação de $F_{\mathrm{H}}$ com $s$, conforme se observa na Figura 6.9. Isso ocorreu, porque as nervuras se deformaram bastante e as mossas da fôrma de aço se desengataram, permanecendo apenas seus topos em contato com o concreto, conforme ilustrado a Figura 6.11 (d). Além disso, houve separação vertical entre a capa de concreto e a fôrma de aço.

Neste momento do ensaio, tornou-se mais significativa a participação da ligação por atrito, pois o intertravamento mecânico promovido pelas mossas da fôrma de aço deixou de existir. Em contrapartida, devido à deformação elástica das nervuras, essas tenderam a retornar à sua posição inicial e exerceram pressão na região do concreto que permaneceu em contato com as mossas, aumentando o efeito do atrito, conforme ilustra a Figura 6.12.

Figura 6.12 - Pressão exercida pela fôrma de aço sobre o concreto

Fonte: Autoria própria

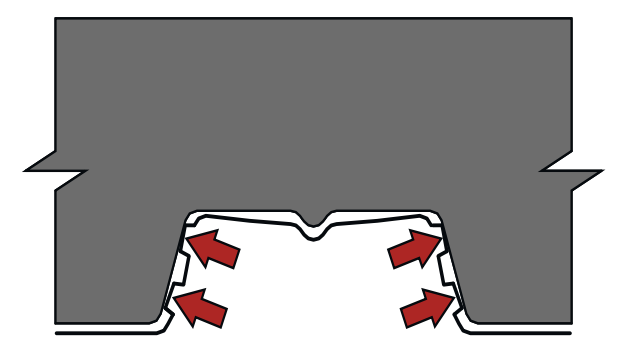

Esse estágio do ensaio se manteve por grande parte do deslizamento ocorrido, pois as mossas permaneceram fora de suas indentações por uma magnitude de deslizamento correspondente à quase o espaçamento entre mossas da fôrma de aço (Figura 6.11 (e)). Em seguida, houve uma diminuição de $F_{\mathrm{H}}$ por causa da entrada das mossas nas indendações seguintes, conforme ilustrado a Figura 6.11 (f), até se atingir o ponto $D$ (Figura 6.10), quando as mossas se encaixaram completamente nas indentações seguintes (Figura $6.11(\mathrm{~g})$ ).

A redução na capacidade resistente até se atingir o ponto $D$ ocorreu devido à facilidade que as mossas encontraram de engrenarem nas indentações seguintes diante da contribuição das próprias nervuras da fôrma de aço que tendem a retornarem à sua posição inicial, forçando as mossas a entrarem nas indentações. 
Ao se verificar no gráfico da Figura 6.9 o deslizamento ocorrido entre os pontos $A$ e $D$ ilustrados no gráfico da Figura 6.10, constatou-se que sua dimensão é de aproximadamente $30 \mathrm{~mm}$, que é igual ao espaçamento entre as mossas da fôrma de aço. Portanto, o fenômeno da transposição das mossas para as indentações seguintes foi evidenciado. Esse fato também foi constatado no trabalho realizado por Yi et al. (2018).

A partir do ponto $D$ (Figura 6.10), iniciou-se um novo processo que leva as mossas a se desengrenarem das indentações novamente, ocorrendo a repetição de todos os fenômenos descritos. Entretanto, é importante notar no gráfico da Figura 6.9 que a carga máxima que se atinge quando as mossas estão saindo das indentações novamente (ponto $E$ da Figura 6.10) foi inferior à atingida no ponto $C$, pois houve certa degradação da interface, ou seja, ocorreu uma degradação do concreto e do aço ao longo do ensaio que alterou a condição da interface e comprometeu as ligações por atrito e mecânica.

Os fenômenos descritos e ilustrados na Figura 6.11 são apresentados na Figura 6.13 por meio de fotografias realizadas durante o ensaio. A Figura 6.14 apresenta o estado de degradação do concreto e da fôrma de aço após a realização do ensaio.

Figura 6.13 - Comportamento da interface aço-concreto durante o ensaio slip-block

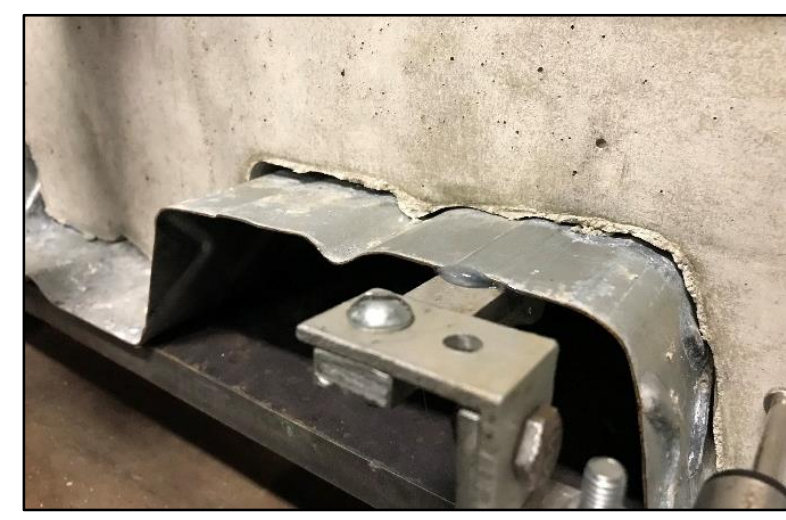

(a) Início do deslizamento

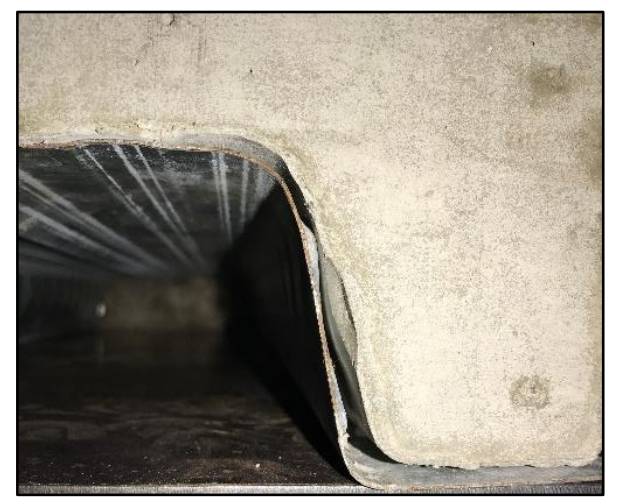

(c) Detalhe da mossa fora da indentação

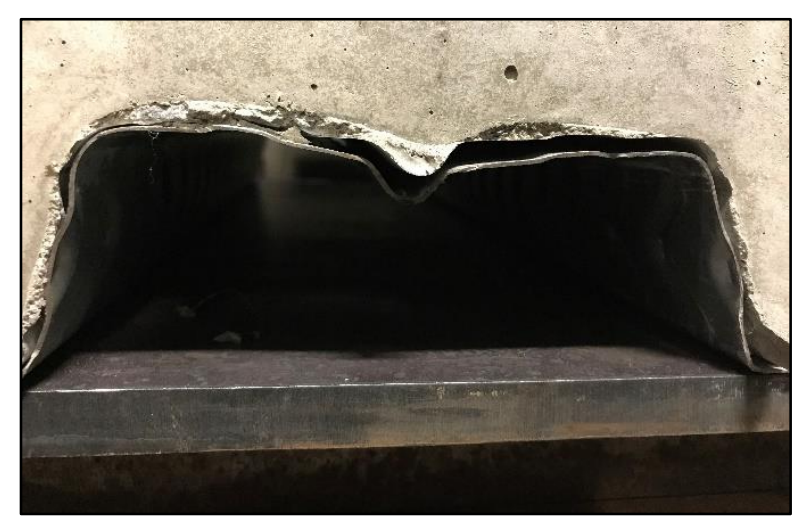

(b) Deformação da fôrma de aço e separação

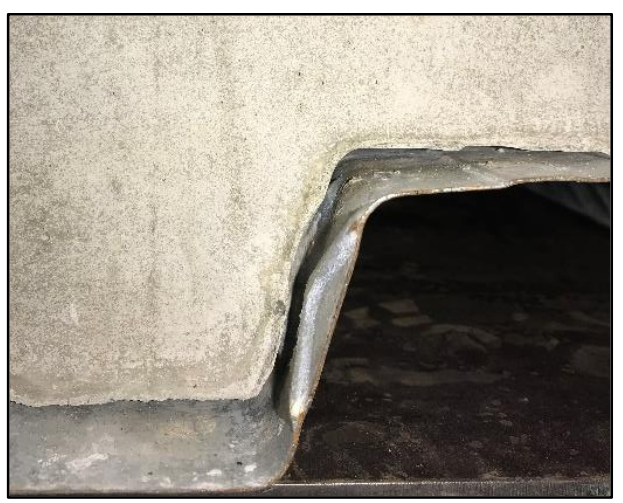

(d) Separação vertical

Fonte: Autoria própria 
Figura 6.14 - Situação do concreto e da fôrma de aço após a realização do ensaio

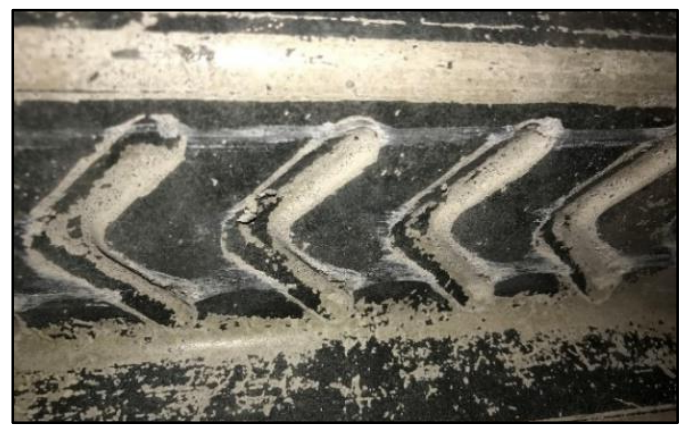

(a) Concreto

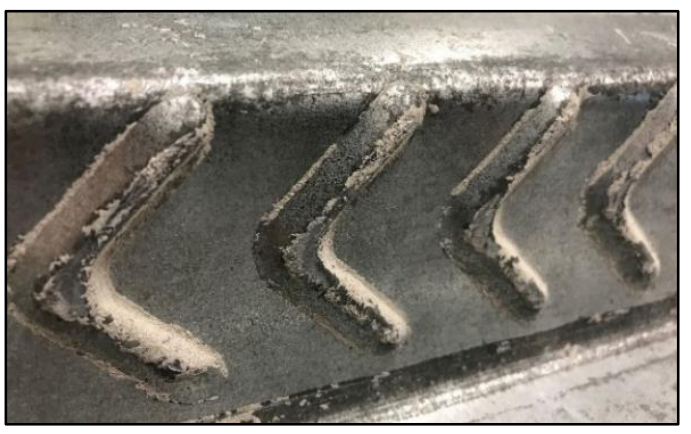

(b) Fôrma de aço

Fonte: Autoria própria

Por meio dos resultados do ensaio slip-block realizado sob carregamento vertical constante foi possível identificar a participação das ligações química, por atrito e mecânica, conforme discutido. Além disso, pode-se determinar separadamente as resistências ao cisalhamento devido ao atrito e ao intertravamento mecânico promovido pelas mossas.

De posse das curvas de $F_{\mathrm{H}}$ versus $s$ apresentadas na Figura 6.9, é possível obter, para um dado deslizamento $s$, o seu respectivo valor de $F_{\mathrm{H}}$ para cada um dos três protótipos. Uma vez que já se conhece o valor de $F_{\mathrm{V}}$ aplicado ao protótipo, pode-se traçar o gráfico da Força Horizontal $\left(F_{\mathrm{H}}\right)$ versus Força Vertical $\left(F_{\mathrm{V}}\right)$ referente ao deslizamento $s$. Nesse gráfico, identificou-se uma relação linear entre $F_{\mathrm{H}}$ e $F_{\mathrm{V}}$, conforme esperado. A equação da regressão linear obtida dos três pontos plotados no gráfico é apresentada na Equação 6.1.

$$
F_{\mathrm{H}}(s)=\mu(s) \cdot F_{\mathrm{V}}+F_{\mathrm{m}}(s)
$$

Na Equação 6.1, $\mu$ é o Coeficiente de Atrito Global e $F_{\mathrm{m}}$ é a Força Mecânica Resistente referente ao intertravamento promovido pelas mossas da fôrma de aço. A Força Resistente devido ao Atrito entre o aço e o concreto é dada por $F_{\mathrm{a}}(s)=\mu(s) \cdot F_{\mathrm{V}}$. A Tensão Mecânica Resistente ao Cisalhamento $\left(\tau_{\mathrm{m}}\right)$, por sua vez, é obtida dividindo o valor de $F_{\mathrm{m}}$ pela área da interface aço-concreto do protótipo do ensaio slip-block.

A metodologia proposta neste trabalho consiste, portanto, na determinação de $\mu$ e $F_{\mathrm{m}}$ para cada deslizamento $s$ com base nas curvas de $F_{\mathrm{H}}$ versus $s$ dos três protótipos ensaiados sob diferentes valores de $F_{\mathrm{V}}$, diferentemente do método proposto por Patrick e Poh (1990), que determina os valores de $\mu$ e $F_{\mathrm{m}}$ para cada ciclo de carregamento com $F_{\mathrm{V}}$ variável aplicado num mesmo protótipo.

A Figura 6.15 ilustra o exemplo de um dos gráficos de $F_{\mathrm{H}}$ versus $F_{\mathrm{V}}$ para o deslizamento de 2,5 mm, que é aproximadamente quando se atinge o valor máximo de $F_{\mathrm{H}}$ nas curvas do gráfico da Figura 6.9. 
Figura 6.15 - Gráfico da Força horizontal $\left(F_{\mathrm{H}}\right)$ versus Força vertical $\left(F_{\mathrm{V}}\right)$ para $s=2,5 \mathrm{~mm}$

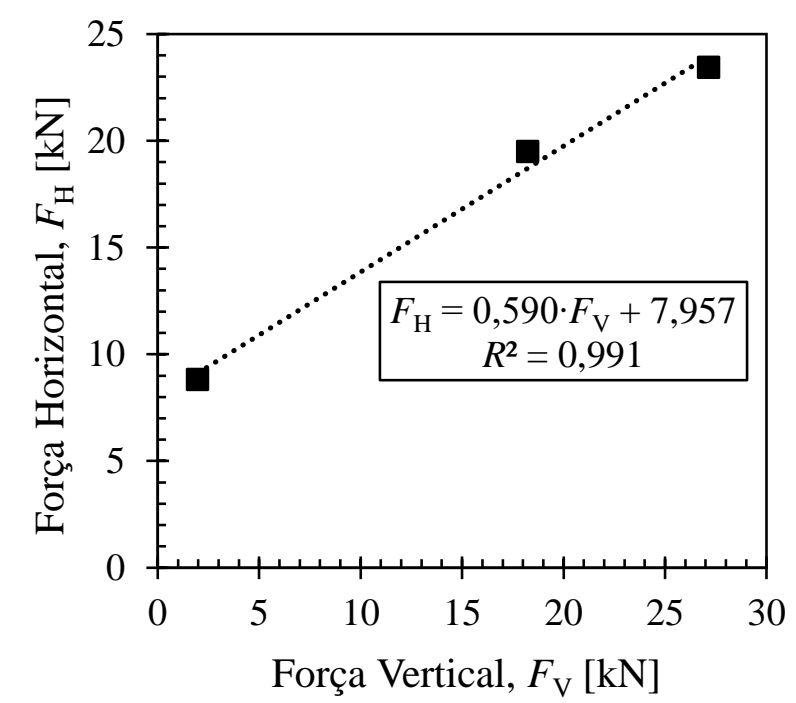

Fonte: Autoria própria

É importante salientar que $\mu$ é um coeficiente de atrito global, ou seja, que leva em consideração a configuração da superfície da interface, pois diante do carregamento aplicado sobre o protótipo ocorre uma distribuição de tensões normais de contato entre o aço e o concreto cujos valores dependem de sua posição na fôrma de aço. Além disso, conforme já explicado, a área de contato entre o aço e o concreto varia de acordo com o deslizamento devido ao fenômeno de transposição das mossas.

Todavia, por meio dos gráficos de $F_{\mathrm{H}}$ versus $F_{\mathrm{V}}$ obtidos para cada deslizamento, verificou-se que de fato existe uma relação linear entre $F_{\mathrm{H}}$ e $F_{\mathrm{V}}$, obtendo-se em todos os casos valores satisfatórios para os coeficientes de regressão linear $\left(R^{2}\right)$, que ficaram entre 0,977 e 1 . $\mathrm{O}$ fato de ter realizado ensaios sob três níveis de $F_{\mathrm{V}}$, possibilitou a identificação dessa relação linear de acordo com o deslizamento. Os dados experimentais utilizados nas regressões lineares estão apresentados no Apêndice A.

A Tabela 6.9 apresenta os valores de $\mu$ e $\tau_{\mathrm{m}}$ respectivos a cada deslizamento $(s)$. Para tal, foi considerado um espaçamento de 1,0 mm para os primeiros $10,0 \mathrm{~mm}$ de deslizamento, 2,0 mm para a região do patamar e de 1,0 mm novamente para a região final, objetivando melhor representar a variação desses parâmetros. Também são apresentados os valores de $\mu$ e de $\tau_{\mathrm{m}}$ para $s=2,5 \mathrm{~mm}$, em que ocorre o máximo valor de $F_{\mathrm{H}}$ nos gráficos da Figura 6.9.

A fenomenologia explicada de acordo com o formato das curvas de $F_{\mathrm{H}}$ versus $s$ pode ser verificada, portanto, em termos quantitativos, pois é possível mensurar cada parcela de contribuição das ligações por atrito e mecânica associando os valores de $\mu$ e de $\tau_{\mathrm{m}}$ com $s$ de acordo com o gráfico da Figura 6.9 e com a geometria da fôrma de aço. 
Tabela 6.9 - Resultados de $\mu$ e $\tau_{\mathrm{m}}$ obtidos por meio dos ensaios com $F_{\mathrm{V}}$ constante

\begin{tabular}{ccc|ccc}
\hline $\boldsymbol{s}[\mathbf{m m}]$ & $\boldsymbol{\mu}$ & $\boldsymbol{\tau}_{\mathbf{m}}[\mathbf{M P a}]$ & $\boldsymbol{s}[\mathbf{m m}]$ & $\boldsymbol{\mu}$ & $\boldsymbol{\tau}_{\mathbf{m}}[\mathbf{M P a}]$ \\
\hline 0,01 & 0,557 & 0,015 & 18 & 0,602 & 0,022 \\
0,1 & 0,295 & 0,005 & 20 & 0,607 & 0,022 \\
1 & 0,610 & 0,022 & 22 & 0,593 & 0,022 \\
2 & 0,578 & 0,035 & 24 & 0,556 & 0,019 \\
2,5 & 0,590 & 0,036 & 25 & 0,514 & 0,018 \\
3 & 0,595 & 0,035 & 26 & 0,490 & 0,013 \\
4 & 0,608 & 0,029 & 27 & 0,491 & 0,007 \\
5 & 0,608 & 0,022 & 28 & 0,533 & 0,000 \\
6 & 0,581 & 0,019 & 29 & 0,544 & 0,000 \\
7 & 0,572 & 0,018 & 30 & 0,543 & 0,000 \\
8 & 0,568 & 0,019 & 32 & 0,492 & 0,013 \\
9 & 0,579 & 0,019 & 33 & 0,456 & 0,022 \\
10 & 0,606 & 0,018 & 34 & 0,509 & 0,019 \\
12 & 0,633 & 0,018 & 36 & 0,547 & 0,014 \\
14 & 0,621 & 0,020 & 38 & 0,535 & 0,017 \\
16 & 0,606 & 0,022 & 40 & 0,564 & 0,018 \\
\hline
\end{tabular}

Fonte: Autoria própria

A Figura 6.16 apresenta graficamente a relação de $\mu$ e $\tau_{\mathrm{m}}$ com $s$, possibilitando a visualização clara da variação de $\mu$ e $\tau_{\mathrm{m}}$ em função do deslizamento.

Figura 6.16 - Gráfico do Coeficiente de atrito $(\mu)$ e da Tensão mecânica resistente $\left(\tau_{\mathrm{m}}\right)$ versus Deslizamento $(s)$

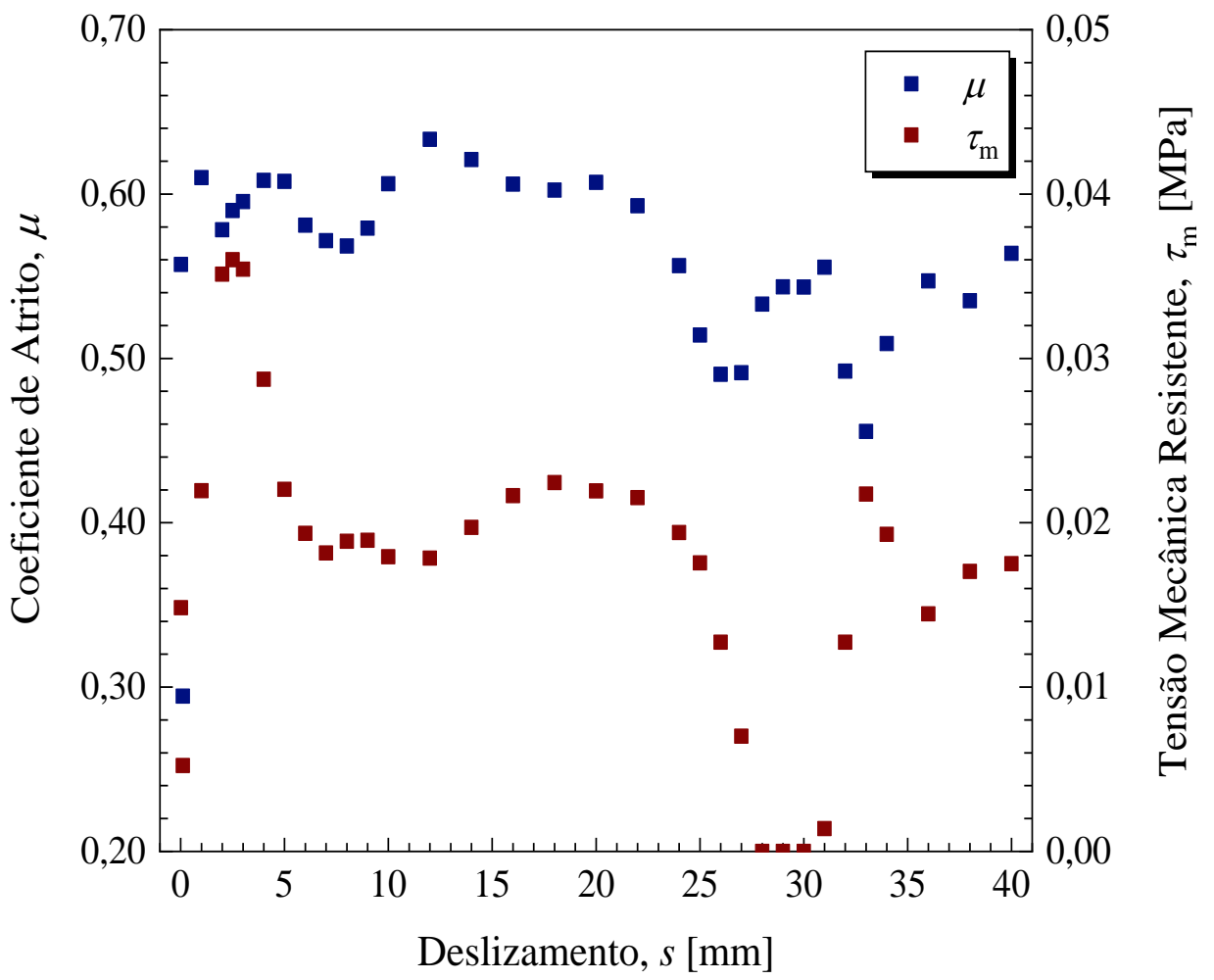

Fonte: Autoria própria 
Os deslizamentos cujos valores são $0,01 \mathrm{~mm}$ e $0,1 \mathrm{~mm}$ correspondem aos pontos de ruptura da ligação química e o da queda de $F_{\mathrm{H}}$ após o início do deslizamento (pontos $A$ e $B$ do gráfico da Figura 6.10, respectivamente). Sendo assim, de acordo com a Tabela 6.9, verificouse uma redução $47,0 \%$ no valor de $\mu$ e de $66,7 \%$ no valor de $\tau_{\mathrm{m}}$. Em seguida, nota-se aumento considerável nos valores de $\mu$ e de $\tau_{\mathrm{m}}$.

Os maiores valores de $\tau_{\mathrm{m}}$ ocorreram no intervalo de $s$ entre 2,0 $\mathrm{mm}$ e 3,0 $\mathrm{mm}$, sendo o maior valor de $\tau_{\mathrm{m}}$ referente ao deslizamento de aproximadamente $2,5 \mathrm{~mm}$, de acordo com a Tabela 6.9 e a Figura 6.16. Em contrapartida, os valores de $\mu$ respectivos aos deslizamentos entre $2,0 \mathrm{~mm}$ e $3,0 \mathrm{~mm}$ não foram os maiores valores identificados. Esses valores de $s$ representam o quanto que a mossa se moveu horizontalmente em relação à sua indentação no concreto.

A Figura 6.17 apresenta o processo de deslizamento do concreto em relação à mossa da fôrma de aço, evidenciando melhor a associação dos fenômenos desenvolvidos com a Tabela 6.9 e as Figuras 6.9 e 6.16.

Figura 6.17 - Processo de deslizamento do concreto em relação à mossa da fôrma de aço

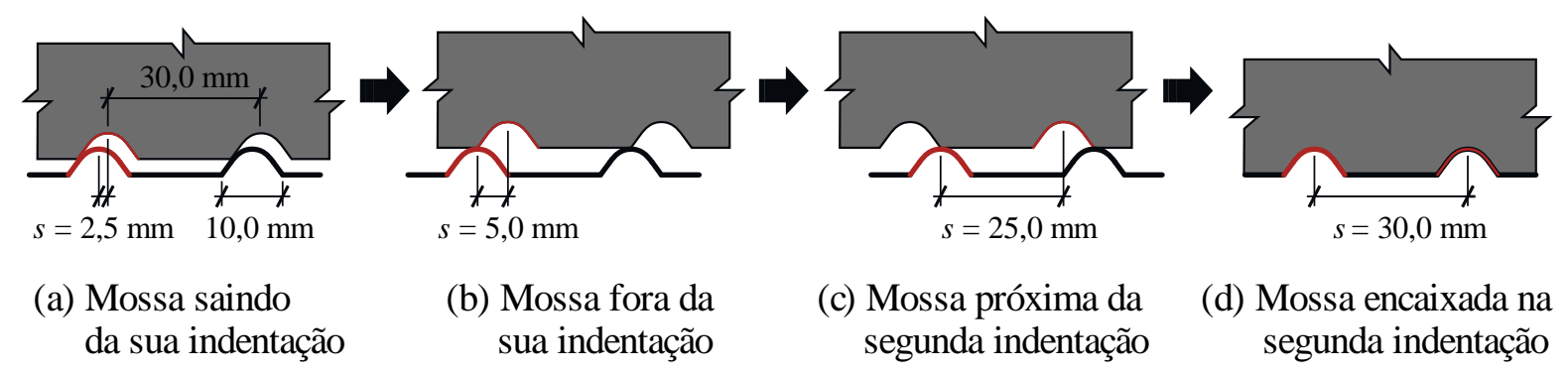

Fonte: Autoria própria

Sabendo que a largura da seção transversal da mossa é de aproximadamente 10,0 mm (ver Figura 6.2), verifica-se que a resistência máxima foi atingida quando a mossa se deslocou aproximadamente 1/4 de sua largura, que corresponde à aproximadamente metade do deslocamento horizontal que cada mossa deve realizar para sair completamente de sua indentação, ou seja, 5,0 mm. A Figura 6.17 (a) ilustra este fenômeno.

Verifica-se, portanto, que a maior colaboração da ligação mecânica, isto é, a maior tensão mecânica resistente ao cisalhamento $\left(\tau_{\mathrm{m}}\right)$, correspondeu justamente ao instante em que $F_{\mathrm{H}}$ atingiu seu maior valor durante o ensaio slip-block sob carregamento vertical constante, conforme se observa no gráfico da Figura 6.9. Isso ocorreu, porque após a ligação química ser quebrada, a ligação mecânica foi mais solicitada e passou a contribuir mais efetivamente. Nesse momento, as mossas da fôrma de aço atuaram para impedir o deslizamento entre o aço e o 
concreto. Entretanto, com a deformação das nervuras, as mossas foram forçadas a saírem de suas indentações no concreto, ocorrendo o deslizamento.

Quando $s$ atingiu o valor de 3,0 mm, a capacidade resistente da ligação mecânica $\left(\tau_{\mathrm{m}}\right)$ reduziu gradualmente. A partir do momento em que as mossas se deslocaram 5,0 mm horizontalmente em relação às suas indentações no concreto $(s=5,0 \mathrm{~mm})$, os valores de $\tau_{\mathrm{m}}$ se mantiveram entre 0,018 $\mathrm{MPa}$ e 0,022 $\mathrm{MPa}$ até o deslizamento atingir o valor de 25,0 mm, conforme apresenta a Tabela 6.9. Isso ocorreu, porque o instante em que $s$ atinge o valor de $5,0 \mathrm{~mm}$ correspondeu ao momento em que as mossas saíram completamente de suas indentações no concreto (Figura 6.17 (b)). Dessa forma, quando o deslizamento relativo atingiu o valor de 25,0 mm, cada mossa começou a engrenar na indentação seguinte, conforme ilustra a Figura 6.17 (c).

De acordo com a Tabela 6.9, entre os deslizamentos de 5,0 $\mathrm{mm}$ e 25,0 $\mathrm{mm}$ os valores de $\mu$ variaram entre 0,514 e 0,633, conforme ilustra o gráfico da Figura 6.16. Essa variação está associada com a variação da área de contato entre o aço e o concreto, com à degradação que estes dois materiais sofrem e com a deformação das nervuras.

Depois que $s$ atingiu o valor de $25,0 \mathrm{~mm}$, o valor de $\tau_{\mathrm{m}}$ reduziu gradualmente, se tornando nulo até quando $s$ atingiu o valor de $30,0 \mathrm{~mm}$. Nesse mesmo intervalo, os valores de $\mu$ reduziram e variaram entre 0,490 e 0,544, conforme apresentado na Tabela 6.9 e na Figura 6.16. Essa redução nos valores de $\tau_{\mathrm{m}} \mathrm{e} \mu$ corresponde ao fenômeno de engrenamento das mossas nas indentação seguintes, de modo que as mossas se encaixaram completamente nessas indentações quando $s=30,0 \mathrm{~mm}$, conforme ilustrado a Figura 6.17 (d).

Nota-se que no intervalo $28,0 \mathrm{~mm} \leq s \leq 30,0 \mathrm{~mm}$, o valor de $\tau_{\mathrm{m}}$ é nulo, o que de fato ocorreu, pois nesse intervalo as mossas estavam sendo forçadas pelas nervuras a engrenarem nas indentações seguintes. Logo, as mossas não ofereceram resistência mecânica ao cisalhamento da interface. A partir dos 30,0 mm de deslizamento, o processo de transposição das mossas foi iniciado novamente e se observa, assim, aumento nos valores de $\mu$ e $\tau_{\mathrm{m}}$.

É importante notar que o instante em que $s=33,0 \mathrm{~mm}\left(\tau_{\mathrm{m}}=0,22 \mathrm{MPa}\right)$ corresponde a um deslocamento horizontal de aproximadamente 1/4 da largura da seção transversal da mossa, considerando que a mossa estava encaixada completamente quando $s=30,0 \mathrm{~mm}$ (ver Figura $6.17(d))$.

Ao se comparar os valores de $\mu$ e $\tau_{\mathrm{m}}$ do momento correspondente ao de maior resistência mecânica quando as mossas estavam saindo das indentações novamente $(32,0 \mathrm{~mm} \leq s \leq$ $33,0 \mathrm{~mm}$ ) com o momento correspondente ao de maior resistência mecânica quando elas estavam saindo da suas indentações originais $(2,0 \mathrm{~mm} \leq s \leq 3,0 \mathrm{~mm})$, percebe-se redução dos 
valores de $\mu$ e $\tau_{\mathrm{m}}$. Comparando, por exemplo, os valores de $s=3,0 \mathrm{~mm}$ e $s=33,0 \mathrm{~mm}$, verificase uma redução de $23,4 \%$ no valor de $\mu$ e de $37,1 \%$ no valor de $\tau_{\mathrm{m}}$.

Diante disso, o fato de as mossas engrenarem nas próximas indentações novamente não forneceu resistência ao cisalhamento próxima da máxima obtida incialmente (ponto $C$ na Figura 6.10) devido à degradação da interface e à deformação das nervuras, o que comprometeu as ligações mecânica e por atrito. Portanto, quando cada mossa estava atuando na segunda indentação os valores de $F_{\mathrm{H}}$ se apresentam inferiores (ponto $D$ na Figura 6.10), conforme apresentado o gráfico da Figura 6.9.

Diante de toda discussão dos fenômenos e dos resultados quantitativos obtidos do ensaio slip-block sob força vertical constante sob diferentes valores de $F_{\mathrm{V}}$, verifica-se que esta metodologia permite analisar detalhadamente o comportamento da interface quando ocorre o cisalhamento longitudinal. Além disso, foi possível identificar separadamente as contribuições das ligações química, por atrito e mecânica, assim como extrair os parâmetros $\mu$ e $\tau_{\mathrm{m}}$ referentes a cada deslizamento e, portanto, analisar de forma quantitativa a influência de cada fenômeno do comportamento sobre a resistência ao cisalhamento da interface aço-concreto.

Uma vez que os fenômenos que ocorrem durante o ensaio estão diretamente relacionados com a configuração da fôrma de aço (formato e espaçamento das mossas e rigidez à flexão local do perfil da fôrma), sua influência pode ser analisada por meio da metodologia apresentada nesta seção. Logo, diante de um estudo visando a eficiência da resistência ao cisalhamento longitudinal de uma fôrma de aço, a realização do ensaio slip-block sob carregamento de confinamento constante, associado à metodologia desenvolvida neste trabalho, possibilita analisar a contribuição da geometria da nervura, do tratamento superficial e da configuração e disposição das mossas.

\subsubsection{Carregamento Vertical Variável ao Longo do Ensaio}

O gráfico da Força Horizontal $\left(F_{\mathrm{H}}\right)$ versus Deslizamento $(s)$ do protótipo ensaiado sob carregamento vertical variável está ilustrado na Figura 6.18. O deslizamento considerado é a média dos valores medidos pelos dois transdutores de deslocamento.

Conforme explicado na seção 6.3.2.2, a Força Vertical $\left(F_{\mathrm{V}}\right)$ foi de $27,14 \mathrm{kN}$ desde o início do ensaio até se identificar que $F_{\mathrm{H}}$ se mantinha constante, quando seu valor se manteve aproximadamente $25,0 \mathrm{kN}$, conforme ilustra a Figura 6.18. Posteriormente $F_{\mathrm{V}}$ foi aumentada para $52,14 \mathrm{kN}$, motivo pelo qual o valor de $F_{\mathrm{H}}$ aumentou repentinamente para aproximadamente $42,5 \mathrm{kN}$. 
Figura 6.18 - Gráfico da Força horizontal $\left(F_{\mathrm{H}}\right)$ versus Deslizamento $(s)$ sob Força vertical $\left(F_{\mathrm{V}}\right)$ variável

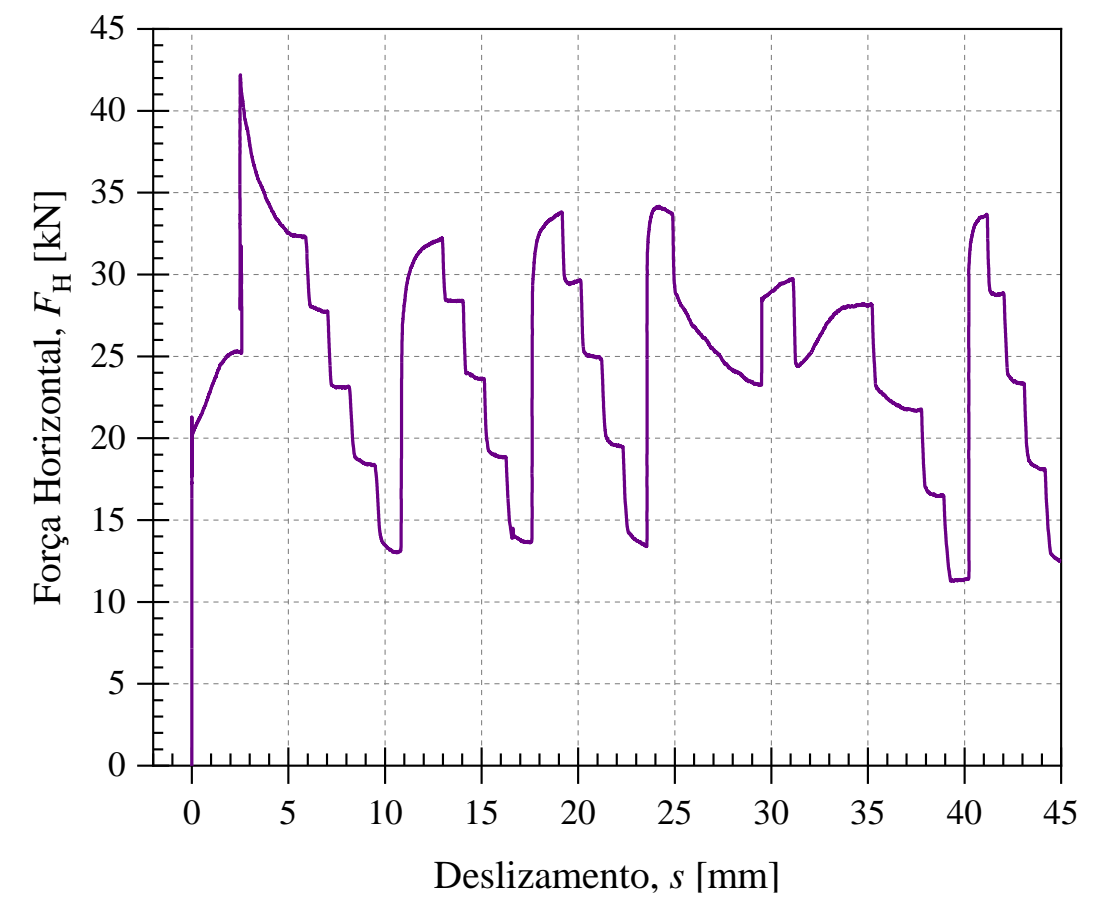

Fonte: Autoria própria

A partir desse momento, o valor de $F_{\mathrm{H}}$ reduziu continuamente até se manter constante por aproximadamente $1,0 \mathrm{~mm}$. A partir deste momento, foi executado o procedimento de ensaio explicado na seção 6.3.2.2, que consiste nos estágios de redução de $F_{\mathrm{V}}$ em $10,0 \mathrm{kN}$ depois de $F_{\mathrm{H}}$ se manter constante por aproximadamente $1,0 \mathrm{~mm}$ de deslizamento. Quando se atinge o último estágio do ciclo, correspondente à $F_{\mathrm{V}}=12,14 \mathrm{kN}$, aumentou-se $F_{\mathrm{V}}$ para $52,14 \mathrm{kN}$ e um novo ciclo foi iniciado.

Conforme se observa na Figura 6.18, foi possível realizar completamente quatro ciclos de carregamento no protótipo ensaiado. Para os deslizamentos entre 25,0 mm e 40,0 mm tentouse realizar um novo ciclo de carregamento, porém até os $35,0 \mathrm{~mm}$ de deslizamento não se conseguiu identificar constância no valor de $F_{\mathrm{H}}$ durante $1,0 \mathrm{~mm}$ de deslizamento, como podese verificar na Figura 6.18.

A impossibilidade de se estabelecer patamares de deslizamento sob força vertical constante no intervalo $25,0 \mathrm{~mm} \leq s \leq 30,0 \mathrm{~mm}$ se deve aos fenômenos identificados quando se realizou os ensaios com $F_{\mathrm{V}}$ constante, explicados na seção anterior, pois esse intervalo corresponde o momento em que as mossas estão adentrando nas indentações seguintes (ver Figura 6.17). Dessa forma, as ligações por atrito e mecânica variaram continuamente até que as mossas saíram das indentações novamente, quando $s \approx 35,0 \mathrm{~mm}$. 
Esse fato pode ser verificado com mais clareza ao se plotar, no mesmo gráfico de $F_{\mathrm{H}}$ versus $s$, as curvas dos ensaios sob $F_{\mathrm{V}}$ constante e sob $F_{\mathrm{V}}$ variável, conforme apresenta a Figura 6.19 .

Figura 6.19 - Gráfico de $F_{\mathrm{H}}$ versus s sob $F_{\mathrm{V}}$ constante e sob $F_{\mathrm{V}}$ variável

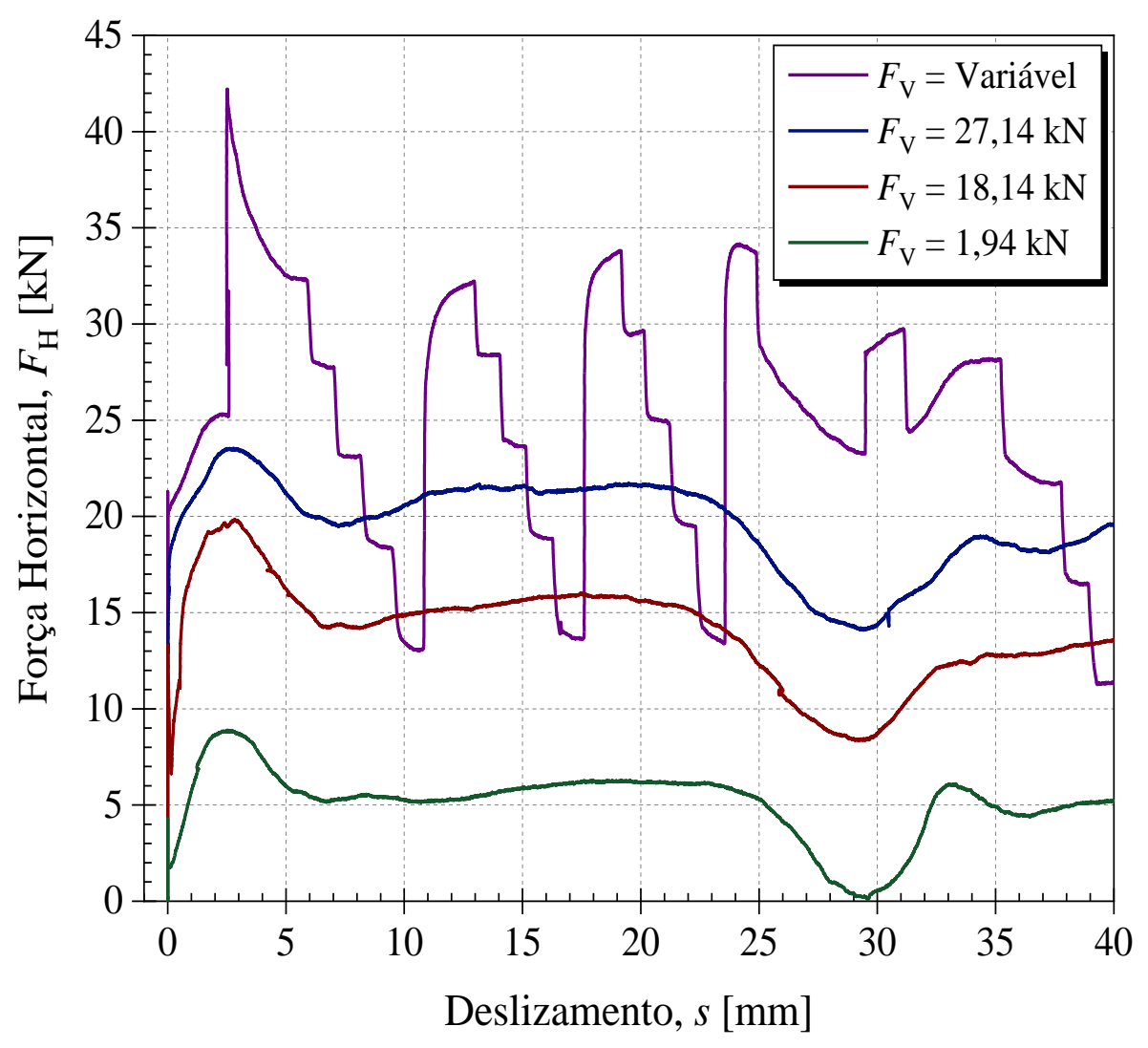

Fonte: Autoria própria

O aparente patamar que se formou quando $s \approx 2,0 \mathrm{~mm}$ foi justamente quando a interface estava atingindo sua resistência máxima, conforme ilustra a figura acima. Já a redução contínua no valor de $F_{\mathrm{H}}$ após $s \approx 3,0 \mathrm{~mm}$ corresponde ao momento de redução nos gráficos com $F_{\mathrm{V}}$ constante após a resistência máxima ser atingida, que está relacionado ao fenômeno de saída das mossas de suas indentações no concreto. Da mesma forma, a redução gradual de $F_{\mathrm{H}}$ após $s \approx 25,0 \mathrm{~mm}$ e posterior aumento após $s \approx 30,0 \mathrm{~mm}$ corresponde aos mesmos momentos de redução e aumento dos gráficos com $F_{\mathrm{V}}$ constante, que estão relacionados aos fenômenos de entrada e saída das mossas nas indentações seguintes, conforme constatado na seção anterior e ilustrado na Figura 6.17.

Verifica-se, portanto, que este método de ensaio só é exequível na situação em que as mossas da fôrma de aço estão desengrenadas de suas indentações no concreto. Dessa forma, os parâmetros obtidos por meio da realização deste tipo de ensaio correspondem a esta situação: quando apenas os topos das mossas estão em contato com o concreto. 
Se a fôrma de aço fosse desprovida de mossas, os parâmetros obtidos do ensaio seriam referentes à resistência da interface aço-concreto em si. Todavia, a presença das mossas faz com que haja o intertravamento mecânico entre a fôrma de aço e o concreto, causando uma resistência mecânica adicional ao cisalhamento da interface, que depende da magnitude de deslizamento relativo, conforme se constatou ao se realizar o ensaio com $F_{\mathrm{V}}$ mantida constante.

Outra forma de execução do ensaio slip-block sob carregamento vertical variável é realizá-lo reduzindo $F_{\mathrm{V}}$ gradualmente (a uma taxa constante) em cada ciclo de carregamento e não estabelecendo patamares de aproximadamente $1,0 \mathrm{~mm}$ de deslizamento sob $F_{\mathrm{V}}$ constante. Esse procedimento de ensaio também foi realizado por Patrick e Poh (1990) e por Patrick (1990). Todavia, ao se reduzir gradualmente $F_{\mathrm{V}}$ durante o intervalo de deslizamento correspondente ao aumento de resistência devido à ligação mecânica, pode-se mascarar a participação do intertravamento mecânico devido à redução gradual da ligação por atrito causada pela redução gradual de $F_{\mathrm{V}}$.

Os fenômenos que se desenvolvem na interface aço-concreto do ensaio sob $F_{\mathrm{V}}$ variável são os mesmos que ocorrem quando $F_{V}$ é constante, apresentados na seção anterior. Entretanto, não é possível correlacionar diretamente tais fenômenos com a configuração do gráfico apresentado na Figura 6.18, porque há variação $F_{\mathrm{H}}$ em função da variação de $F_{\mathrm{V}}$.

Ao se analisar o gráfico da Figura 6.18 verifica-se o quanto o atrito entre o aço e o concreto influencia na resistência ao cisalhamento, pois a diferença no valor de $F_{\mathrm{V}}$ em cada patamar formado num mesmo ciclo é de $10,0 \mathrm{kN}$. Sendo assim, a diferença correspondente ao valor de $F_{\mathrm{H}}$ refere-se à contribuição da ligação por atrito.

Analogamente ao procedimento realizado na metodologia apresentada na seção anterior, fez-se os gráficos de $F_{\mathrm{H}}$ versus $F_{\mathrm{V}}$ para cada ciclo de carregamento, verificando-se a relação linear entre estas duas forças e obtendo-se o Coeficiente de Atrito Global $(\mu)$ e a Força Mecânica Resistente $\left(F_{\mathrm{m}}\right)$ referentes a cada ciclo por meio da regressão linear dos pontos plotados. Nesse gráfico, cada ponto corresponde à um estágio do ciclo, ou seja, a um valor de $F_{\mathrm{V}}$ aplicado, totalizando cinco pontos. Entretanto, diferentemente da metodologia apresentada na seção anterior, $\mu$ e $F_{\mathrm{m}}$ não variam em função do deslizamento. Dessa forma, a equação da regressão linear obtida para cada ciclo de carregamento é apresentada na Equação 6.2.

$$
F_{\mathrm{H}}=\mu \cdot F_{\mathrm{V}}+F_{\mathrm{m}}
$$

A Força Resistente devido ao Atrito entre o aço e o concreto é dada por $F_{\mathrm{a}}=\mu \cdot F_{\mathrm{V}}$ e a Tensão Mecânica Resistente ao Cisalhamento $\left(\tau_{\mathrm{m}}\right)$ é calculada dividindo o valor de $F_{\mathrm{m}}$ pela área da interface aço-concreto do protótipo do ensaio slip-block. 
A Figura 6.20 ilustra, por exemplo, o gráfico de $F_{\mathrm{H}}$ versus $F_{\mathrm{V}}$ correspondente ao primeiro ciclo de carregamento. A Tabela 7.10 apresenta os resultados obtidos de acordo com o ciclo de carregamento. Os dados experimentais referentes aos demais ciclos de carregamento, utilizados gráficos de $F_{\mathrm{H}}$ versus $F_{\mathrm{V}}$, estão apresentados no Apêndice A.

Figura 6.20 - Gráfico da Força horizontal $\left(F_{\mathrm{H}}\right)$ versus Força vertical $\left(F_{\mathrm{V}}\right)$ correspondente ao $1^{\circ}$ Ciclo de carregamento

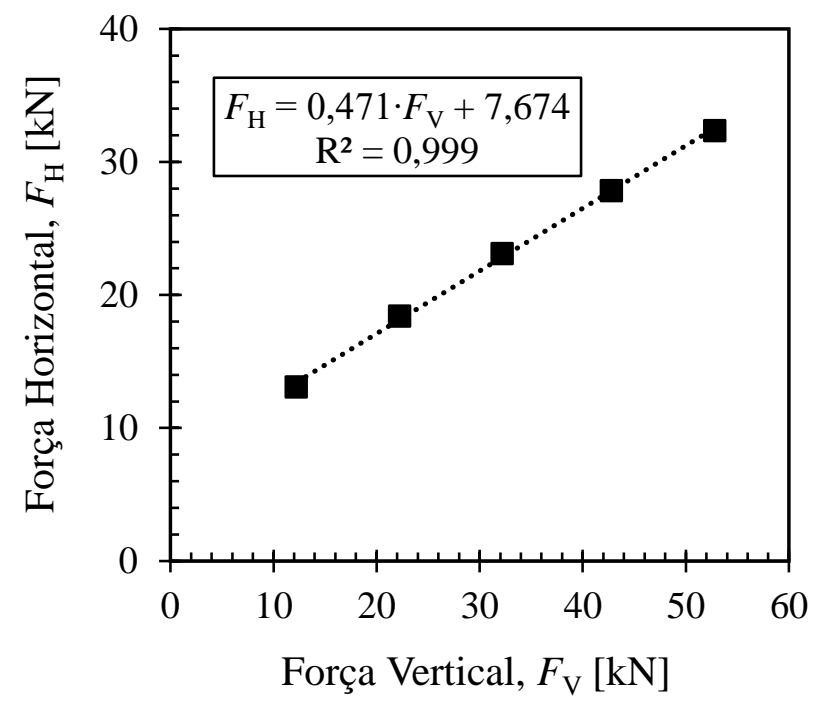

Fonte: Autoria própria

Tabela 6.10 - Resultados de $\mu$ e $\tau_{\mathrm{m}}$ obtidos por meio do ensaio com $F_{\mathrm{V}}$ variável

\begin{tabular}{ccc}
\hline Ciclo & $\boldsymbol{\mu}$ & $\boldsymbol{\tau}_{\mathbf{m}}[\mathbf{M P a}]$ \\
\hline 1 & 0,471 & 0,034 \\
2 & 0,462 & 0,038 \\
3 & 0,504 & 0,036 \\
4 & 0,527 & 0,028 \\
\hline
\end{tabular}

Fonte: Autoria própria

Os ciclos 1, 2 e 3 correspondem ao momento em que as mossas estavam fora de suas indetações e se deslizando para engrenarem nas mossas seguintes. O ciclo 4 foi executado depois que as mossas saíram das indentações novamente. Os gráficos das Figuras 6.18 e 6.19 permitem identificar isso.

Verifica-se, de acordo com a Tabela 7.10, que entre os ciclos 1 e 3 não há variação significativa nos valores de $\mu$ e de $\tau_{m}$. Em relação aos valores do primeiro ciclo, $\mu$ e $\tau_{m}$ variaram em $-2,1 \%$ e $+11,8 \%$, respectivamente, para o ciclo 2 , e em $+7,0 \%$ e $+5,9 \%$, respectivamente, para o ciclo 3. Já para o ciclo $4, \mu$ aumentou em $11,9 \%$ e $\tau_{m}$ reduziu em $17,6 \%$ em relação aos valores obtidos no primeiro ciclo de carregamento. 
A variação no valor de $\mu$ está relacionada com a modificação da condição das superfícies da fôrma de aço e do concreto que constituem a interface, pois as superfícies desses dois materiais se desgastam conforme o cisalhamento ocorre, o que compromete o coeficiente de atrito entre o aço e o concreto. Todavia, observa-se um aumento no valor de $\mu$, o que é contrário ao esperado, que seria uma redução no seu valor de um ciclo para o próximo.

Com relação ao ciclo 4 , verificou-se uma redução considerável no valor de $\tau_{m}$ obtido, que é $22,2 \%$ inferior ao obtido no ciclo imediatamente anterior (ciclo 2). Isso ocorreu, também, devido à degradação sofrida pela interface após as mossas se desengrenarem das indentações pela segunda vez, o que comprometeu a contribuição da ligação mecânica.

A realização de um único ensaio slip-block com $F_{\mathrm{V}}$ variável permitiu a obtenção dos parâmetros $\mu$ e $\tau_{m}$ por meio de quatro ciclos de carregamento. Diante dos resultados obtidos, verifica-se que não foi possível correlacionar claramente a fenomenologia que ocorreu durante o ensaio com a configuração da curva do gráfico de $F_{\mathrm{H}}$ versus $s$. Além disso, os parâmetros obtidos são referentes à situação em que as mossas estão desengrenadas de suas indentações no concreto, após a ocorrência de mais de 5,0 mm de deslizamento. Dessa forma, não foi possível obter os valores de $\mu$ e $\tau_{m}$ correspondentes ao momento em que a mossa estava saindo de sua indentação, que implica na resistência máxima da interface, conforme constatado na seção anterior.

\subsubsection{Comparação das Metodologias e Considerações sobre o Ensaio Slip-Block}

Uma vez apresentadas e discutidas as duas metodologias de ensaio e obtenção de resultados, pode-se compará-las e analisar a diferença entre elas. A Tabela 6.11 apresenta os resultados obtidos por meio das duas metodologias. Para isso, relacionou-se a média dos valores de $\mu$ e $\tau_{m}$ da Tabela 6.9 correspondentes à mesma faixa de deslizamento dos ciclos da Tabela 6.10, observando-se o gráfico da Figura 6.18. Como o deslizamento dos ensaios realizados sob $F_{\mathrm{V}}$ constante foram medidos até os $40,0 \mathrm{~mm}$, não é possível comparar seus resultados com os do ciclo 4 do ensaio sob $F_{\mathrm{V}}$ variável.

Tabela 6.11 - Resultados obtidos por meio dos ensaios com $F_{\mathrm{V}}$ constante e com $F_{\mathrm{V}}$ variável

\begin{tabular}{ccccc}
\hline $\begin{array}{c}\text { Deslizamento } \\
\text { [mm] }\end{array}$ & \multicolumn{2}{c}{ Ensaio com $\boldsymbol{F}_{\mathbf{V}}$ constante } & \multicolumn{2}{c}{ Ensaio com $\boldsymbol{F}_{\mathbf{V}}$ variável } \\
\cline { 2 - 5 } & $\boldsymbol{\mu}$ & $\boldsymbol{\tau}_{\boldsymbol{m}}[\mathbf{M P a}]$ & $\boldsymbol{\mu}$ & $\boldsymbol{\tau}_{\boldsymbol{m}}[\mathbf{M P a}]$ \\
\hline 5 a 10 (ciclo 1) & 0,586 & 0,019 & 0,471 & 0,034 \\
12 a 18 (ciclo 2) & 0,615 & 0,020 & 0,462 & 0,038 \\
20 a 24 (ciclo 3) & 0,585 & 0,021 & 0,504 & 0,036 \\
\hline
\end{tabular}

Fonte: Autoria própria 
De acordo com a Tabela 6.11, os valores de $\mu$ obtidos por meio do ensaio com $F_{\mathrm{V}}$ variável correspondentes aos ciclos 1, 2 e 3 foram 19,6\%,24,9\% e 14,0\%, respectivamente, inferiores aos obtidos por meio dos ensaios com $F_{\mathrm{V}}$ constante. Em contrapartida, os valores de $\tau_{m}$ obtidos para o ensaio com $F_{\mathrm{V}}$ variável correspondentes aos ciclos 1,2 e 3 foram 78,9\%, $90,0 \%$ e $71,4 \%$, respectivamente, superiores aos obtidos por meio dos ensaios com $F_{\mathrm{V}}$ constante.

Portanto, verifica-se que há consideráveis diferenças entre os resultados fornecidos pelas duas metodologias, uma vez que ao se realizar o ensaio com $F_{\mathrm{V}}$ variável, obteve-se resistências mecânicas muito superiores.

Considerando que no ensaio realizado com carregamento vertical variável foram aplicados valores de $F_{\mathrm{V}}$ superiores aos aplicados nos três ensaios realizados sob carregamento vertical constante, é possível que as superfícies da fôrma de aço e do concreto da interface tenham sofrido mais degradação mediante o cisalhamento e acarretado na redução do coeficiente de atrito. Do mesmo modo, há indícios de que a magnitude da força de confinamento da interface influencia na contribuição da resistência mecânica ao cisalhamento.

É importante salientar que a contribuição da interface é mais significativa nas lajes durante o deslizamento inicial (até aproximadamente 3,0 $\mathrm{mm}$ no caso da laje mista ensaiada neste trabalho), quando a laje atinge sua resistência máxima ao cisalhamento longitudinal ou quando se atinge a flecha máxima admissível. Diante disso, a metodologia aplicada com $F_{\mathrm{V}}$ variável não possibilitou identificar os parâmetros para essa magnitude de deslizamento.

Mesmo se fosse aplicada a metodologia de redução gradual de $F_{\mathrm{V}}$ em cada ciclo de carregamento, poderia haver contradição nos resultados, pois após a ligação química ser quebrada há aumento de $F_{\mathrm{H}}$ com o deslizamento quando se realiza o ensaio sob $F_{\mathrm{V}}$ constante (ver Figura 6.9). Dessa forma, ao se realizar um ciclo de carregamento imediatamente após a ligação química ser quebrada, reduzindo gradualmente $F_{\mathrm{V}}$, haveria a redução gradual da ligação por atrito em função da redução de $F_{\mathrm{V}}$, mas aumento da ligação mecânica em função da geometria da mossa.

Comparando a execução dos ensaios, o método proposto por Patrick e Poh (1990) é um pouco mais complexo, porque é necessário estar sempre ajustando o carregamento vertical durante todo o ensaio. Apesar disso, pode-se realizar vários ciclos de carregamento e extrair os resultados realizando-se um único ensaio. Entretanto, os ciclos de carregamento aplicados durante o ensaio podem comprometer o valor do coeficiente de atrito devido à degradação da interface aço-concreto. Além disso, não é possível correlacionar a configuração das curvas de $F_{\mathrm{H}}$ versus $s$ com os fenômenos desenvolvidos na interface durante o ensaio. 
A execução do ensaio sob carregamento vertical constante é mais simples e permite gerar um gráfico de $F_{\mathrm{H}}$ versus $s$ que possibilita identificar a influência de cada fenômeno do comportamento da interface durante o ensaio. Para aplicar a metodologia proposta neste trabalho e obter os parâmetros $\mu$ e $\tau_{m}$, porém, é necessária a realização de três ensaios, no mínimo. Além disso, como o carregamento de confinamento é constante durante o ensaio, a degradação da interface não sofre influência devido à variação de $F_{\mathrm{V}}$.

Por meio da metodologia proposta neste trabalho foi possível determinar quantitativamente a contribuição das ligações por atrito e mecânica em função do deslizamento, e, principalmente, identificar a contribuição do intertravamento mecânico promovido pelas mossas, correlacionando-a com o comportamento da interface aço-concreto. Isso é importante, especialmente, para analisar a influência da geometria da fôrma de aço e de suas mossas, assim como do tratamento superficial, sobre o comportamento e resistência da interface. Dessa forma, é possível analisar previamente a configuração da fôrma de aço, assim como determinar uma configuração mais eficiente antes de se realizar os ensaios de flexão das lajes mistas para aplicar os métodos de cálculo normativos.

\subsection{Ensaio de Flexão}

O modelo dos protótipos do ensaio de flexão foi definido com base nos vãos usuais de lajes mistas de aço e concreto, que se situam entre 2 e 4 metros de comprimento, e para que a ruptura da laje ocorresse devido ao cisalhamento longitudinal da interface aço-concreto.

Foram fabricados dois protótipos com as mesmas dimensões: largura igual à da fôrma de aço $(953 \mathrm{~mm})$ e comprimento total de $3.200 \mathrm{~mm}$, sendo o vão teórico $(L)$ igual a $3.000 \mathrm{~mm}$. A Figura 6.21 ilustra a seção transversal considerada para os protótipos das lajes mistas.

Figura 6.21 - Seção transversal dos protótipos do ensaio de flexão

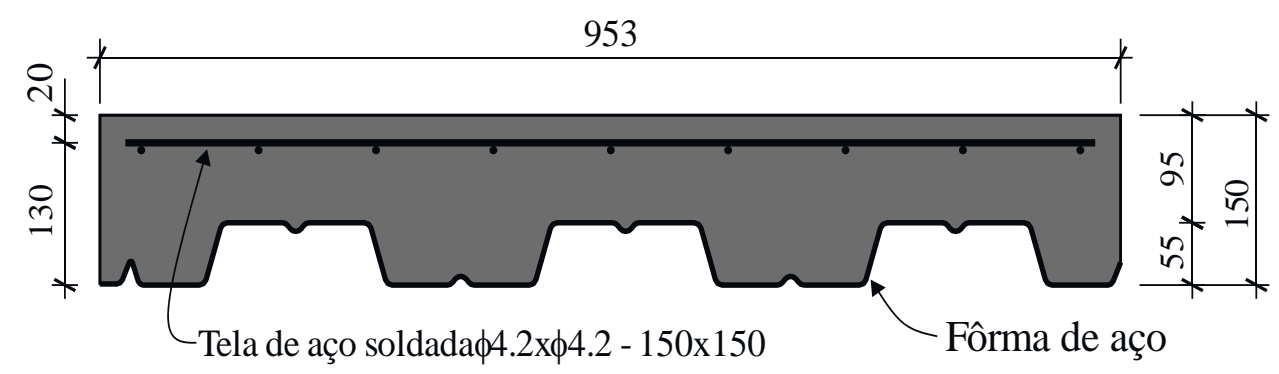

Fonte: Autoria própria

(Dimensões em milímetros) 
A concretagem dos protótipos foi realizada com a fôrma de aço totalmente apoiada. A configuração e o procedimento do ensaio de flexão seguiram as recomendações normativas do Eurocode 4: 2004, da AS/NZS 2327: 2017 e da CSSBI-S2: 2017.

\subsubsection{Configuração e Procedimento de Ensaio}

O ensaio consiste em submeter o protótipo na condição estática simplesmente apoiado à flexão à quatro pontos. Dessa forma, são formados dois vãos de cisalhamento, cada um de comprimento $\left(L_{\mathrm{s}}\right)$ igual a 1/4 do vão teórico, e o vão central com comprimento igual a 2/4 do vão teórico. As seções transversais localizadas nos vãos de cisalhamento estão submetidas à flexão simples, enquanto as seções localizadas no vão central estão submetidas à flexão pura.

A Figura 6.22 ilustra a configuração do ensaio de flexão, detalhando suas dimensões e a instrumentação utilizada. A aplicação do carregamento foi realizada empregando um atuador servo-hidráulico (fixado à um pórtico de reação) e uma viga metálica utilizada para distribuir igualmente o carregamento para as regiões de aplicação, conforme ilustra a Figura 6.22 (a). O ensaio foi realizado sob controle do deslocamento do pistão do atuador, empregando uma taxa de deslocamento de $0,01 \mathrm{~mm} / \mathrm{s}$.

Utilizou-se os seguintes equipamentos e instrumentos de medição:

- Aplicação de força: atuador servo-hidráulico MTS ${ }^{\circledR}$ com capacidade nominal de $500 \mathrm{kN}$ e curso de pistão de $150 \mathrm{~mm}$;

- Medição da força aplicada: célula de carga com capacidade nominal de $500 \mathrm{kN}$ e rótula acoplada;

- Medição de deslizamento relativo nas extremidades: dois transdutores de deslocamento à base de extensômetros - marca VISHAY, modelo HS25, curso = 25 mm (TD-1 e TD5 na Figura 6.22);

- Medição dos deslocamentos verticais: três transdutores de deslocamento à base de extensômetros - marca KYOWA, modelo DT-100-A, curso = 100 mm (TD-2, TD-3 e TD-4 na Figura 6.22);

- Medição de deformação específica no aço: seis extensômetros elétricos de resistência marca KYOWA, modelo KFG-5-120-C1-11;

- Medição de deformação específica no concreto: dois extensômetros elétricos de resistência - marca KYOWA, modelo KFG-10-120-C1-11;

- Aquisição automática de leituras de forças, deslocamentos e deformações específicas: sistema de aquisição de dados System 5000 - marca VISHAY. 
Figura 6.22 - Esquema do ensaio de flexão

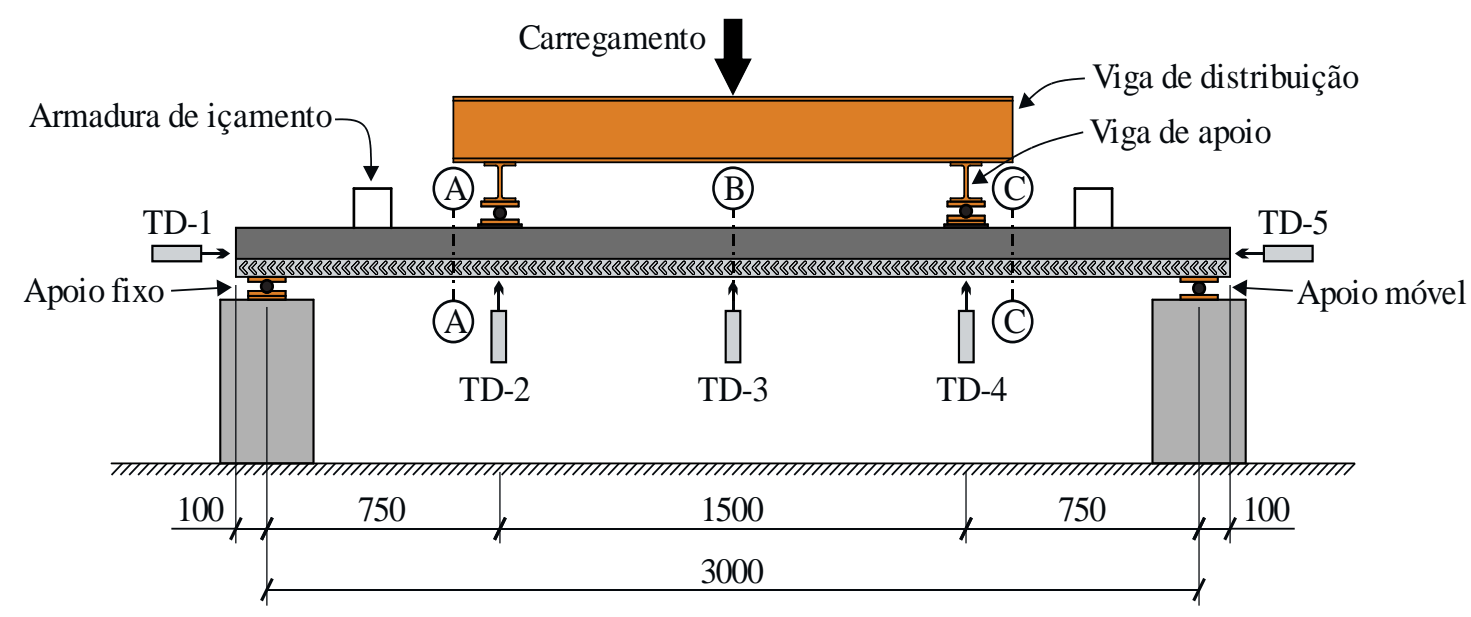

a) Vista Lateral do Ensaio

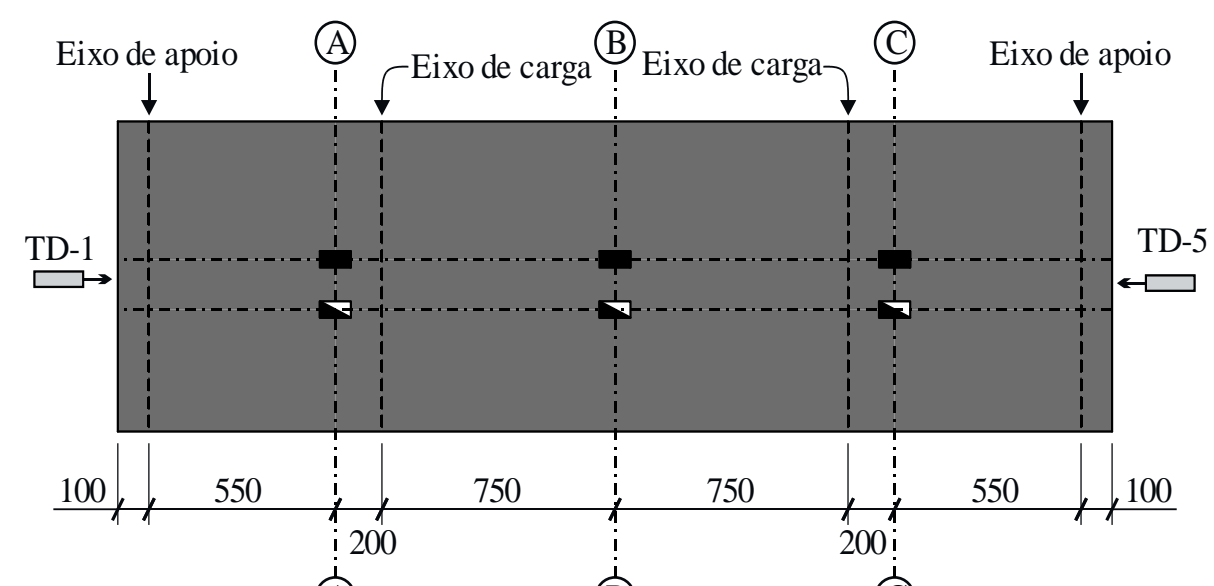

(A) (B)

(C)

b) Vista Superior do Protótipo e Instrumentação

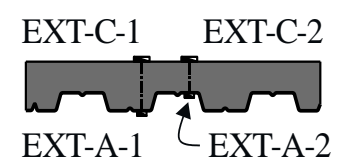

Seção A-A

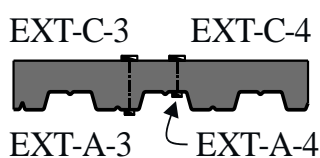

Seção B-B

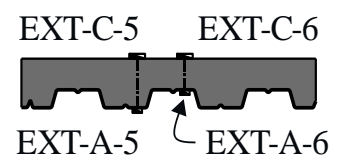

Seção C-C

c) Localização dos Extensômetros nas Seções Transversais

Legenda: TD - Transdutor de deslocamento

EXT-C - Extensômetro de resistência elétrica fixado no concreto

EXT-A - Extensômetro de resistência elétrica fixado na fôrma de aço

Fonte: Autoria própria

(Dimensões em milímetros)

A Figura 6.23 apresenta uma fotografia do ensaio realizado. Outras fotografias detalhando a instrumentação do ensaio estão apresentadas no Apêndice B. 
Figura 6.23 - Ensaio de flexão da laje mista

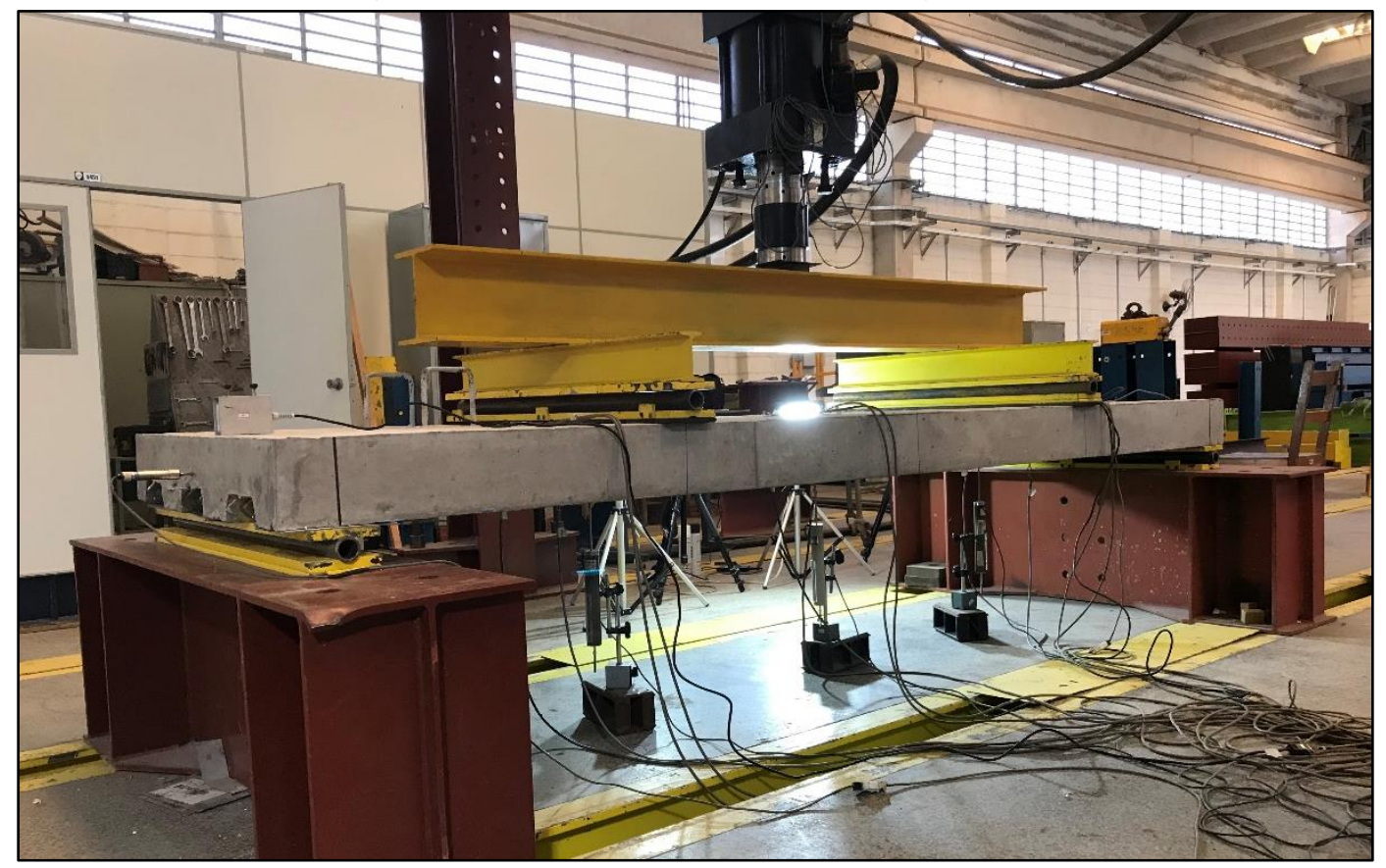

Fonte: Autoria própria

Conforme já mencionado, as mossas da fôrma de aço possuem formato em V, o que faz a interface se comportar de maneira distinta ao cisalhamento longitudinal mediante a direção do esforço cisalhante desenvolvido sobre ela. Diante disso, instrumentou-se os vãos de cisalhamento com extensômetros (seções A-A e C-C) para avaliar a implicância dessa configuração da mossa sobre o comportamento local do protótipo. As seções A-A e C-C foram definidas de modo a evitar a perturbação provocada pelo carregamento aplicado, respeitando o Princípio de Saint-Venant.

Empregou-se transdutores de deslocamento para medir os deslocamentos verticais das seções onde o carregamento é aplicado (TD-2 e TD-4), além do utilizado para medir o deslocamento vertical no meio do vão (TD-3). Com isso também é possível verificar a influência da configuração das mossas da fôrma de aço sobre o comportamento global do elemento estrutural.

Antes do ensaio foi realizada a escorva por meio da aplicação de um carregamento correspondente à $10 \%$ da resistência máxima prevista para o protótipo. Posteriormente, o carregamento foi aplicado com controle de deslocamento a uma taxa de $0,01 \mathrm{~mm} / \mathrm{s}$ durante todo o ensaio.

A cada segundo foram registrados o carregamento aplicado, o deslocamento imposto pelo atuador, os deslocamentos verticais medidos pelos transdutores, os deslizamentos relativos das extremidades dos protótipos e as deformações medidas pelos extensômetros. 


\subsubsection{Resultados e Discussão}

A Figura 6.24 apresenta os gráficos da Força $(F)$ versus Deslocamento vertical no meio do vão $(\delta)$ para os dois protótipos ensaiados (Laje 1 e Laje 2). A Tabela 6.12 apresenta os resultados obtidos dos ensaios realizados, cujos valores foram determinados segundo as preconizações normativas do Eurocode 4: 2004, da AS/NZS 2327: 2017 e da CSSBI-S2: 2017.

Figura 6.24 - Gráfico da Força $(F)$ versus Deslocamento vertical no meio do vão $(\delta)$ das Lajes 1 e 2

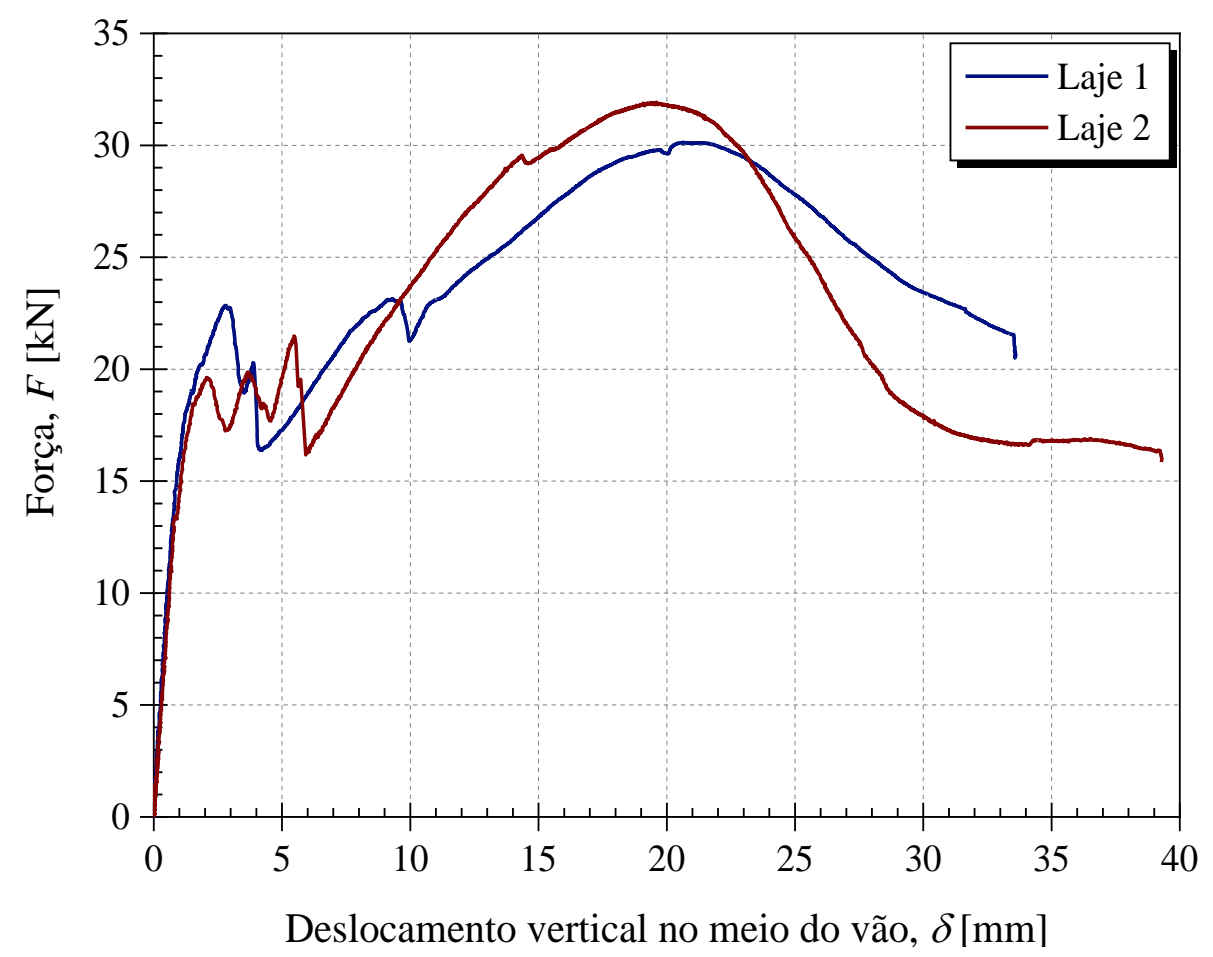

Fonte: Autoria própria

Tabela 6.12 - Resultados obtidos por meio dos ensaios de flexão

\begin{tabular}{cccccc}
\hline Protótipo & $\boldsymbol{F}_{\text {desl }^{\mathbf{a}}}[\mathbf{k N}]$ & $\boldsymbol{F}_{\text {máx }}{ }^{\mathbf{b}}[\mathbf{k N}]$ & $\boldsymbol{F}_{\text {total }^{\mathbf{c}}}[\mathbf{k N}]$ & $\boldsymbol{F}_{\text {máx }} / \boldsymbol{F}_{\text {des }}$ & Comportamento \\
\hline Laje 1 & 19,00 & 30,12 & 41,48 & 1,58 & Dúctil \\
Laje 2 & 16,31 & 31,92 & 43,28 & 1,96 & Dúctil \\
\hline
\end{tabular}

(a) Força convencional associada ao início do deslizamento relativo entre o concreto e a fôrma de aço, correspondente ao deslizamento de extremidade igual a 0,10 mm.

(b) Menor valor entre a força máxima aplicada durante o ensaio e a força correspondente ao deslocamento vertical de $L / 50$.

(c) Força máxima aplicada $\left(F_{\text {máx }}\right)$ adicionada ao seu peso próprio e ao peso do aparato de ensaio sobre o protótipo.

Fonte: Autoria própria 
Apesar de o concreto empregado na Laje 1 possuir resistência um pouco superior ao da Laje 2, o comportamento dos protótipos ao longo do ensaio foi semelhante. Dessa forma, como os valores de $F_{\text {máx }} / F_{\text {des }}$ foram maiores que 1,10 , ambos os protótipos apresentaram comportamento dúctil, conforme indicado na Tabela 6.12.

O desenvolvimento do comportamento dos protótipos durante o ensaio seguiu a mesma descrição apresentada na seção 3.3. Inicialmente o carregamento foi suportado pelo concreto e a fôrma de aço, cuja transferência de cisalhamento entre estes dois materiais aconteceu sob interação total. Nesta situação os dois protótipos apresentaram comportamento semelhantes, com rigidezes coincidentes, conforme se verifica no gráfico da Figura 6.24.

Com o aumento do carregamento aplicado, os mecanismos de deslizamentos, apresentados no Capítulo 2, se desenvolveram devido ao surgimento de fissuras no vão central e à diferença de rigidez entre a fôrma de aço e o concreto. Diante disso, ocorreu perda da interação total em regiões localizadas da interface, causada pela separação e deslizamento relativos locais entre os dois materiais. Logo, a rigidez dos protótipos diminuiu gradativamente até se atingir uma resistência máxima antes do início do deslizamento de extremidade ocorrer.

$\mathrm{Na}$ Laje 2 detectou-se um certo empenamento sofrido pela fôrma de aço durante a concretagem, comprometendo seu condicionamento perfeito sobre os apoios e fazendo com que houvesse uma certa acomodação do protótipo ao longo do ensaio. Dessa forma, essa imperfeição pode ser o motivo pelo qual sua curva do gráfico de $F$ versus $\delta$ apresentou três picos antes do deslizamento de extremidade ocorrer, assim como maior rigidez após seu início, conforme ilustrado no gráfico da Figura 6.24.

Juntamente com algumas fissuras no vão central dos protótipos, ocorreu, também, o desenvolvimento da fissura principal, localizada próximo à uma das regiões onde o carregamento foi aplicado. Com o aumento do carregamento, ocorreu maior separação entre a fôrma de aço e o concreto localizados no vão de cisalhamento adjacente à fissura principal. Em seguida, o deslizamento relativo se iniciou na extremidade desse vão e ocorreu uma redução brusca da capacidade resistente dos protótipos.

A partir desse momento, pode-se considerar que os protótipos estavam globalmente sob o regime de interação parcial, pois essa situação passou a governar o comportamento do elemento estrutural, embora existiram regiões dos protótipos sob o regime de interação total (parte do vão central e o vão de cisalhamento que não apresentou deslizamento de extremidade).

A Figura 6.25 apresenta o deslizamento e a separação vertical na região da fissura principal ao longo do ensaio da Laje 2. A Figura 6.26 apresenta a deformação da nervura da fôrma de aço deste protótipo e o deslizamento de extremidade. 
Figura 6.25 - Deslizamento e separação vertical na região da fissura principal (Laje 2)

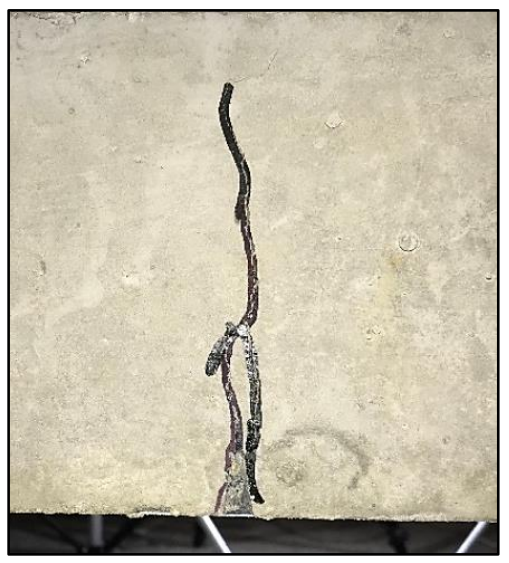

(a) Início do deslizamento

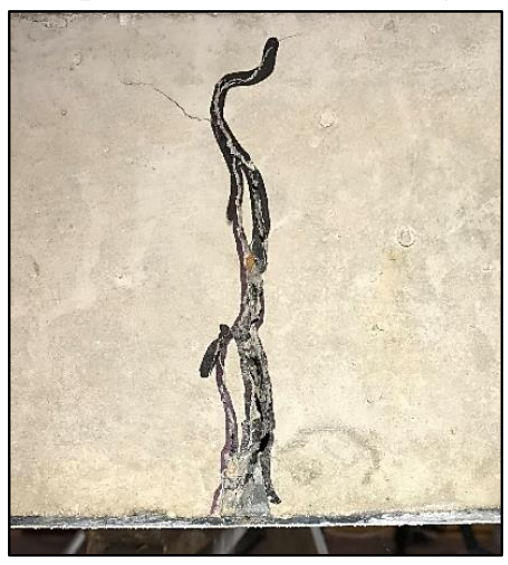

(b) Separação vertical

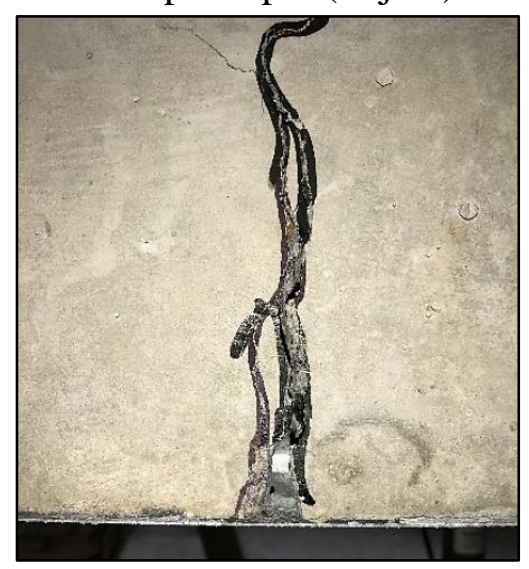

(c) Final do ensaio

Fonte: Autoria própria

Figura 6.26 - Deformação da nervura na extremidade que deslizou (Laje 2)

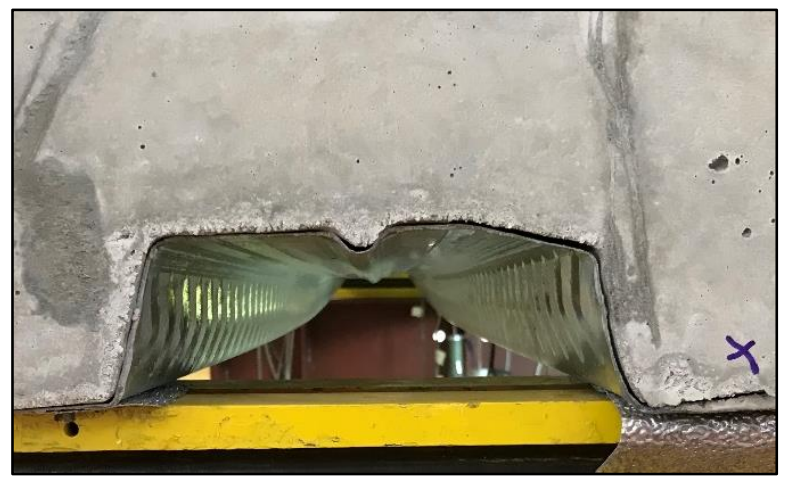

(a) Início do deslizamento

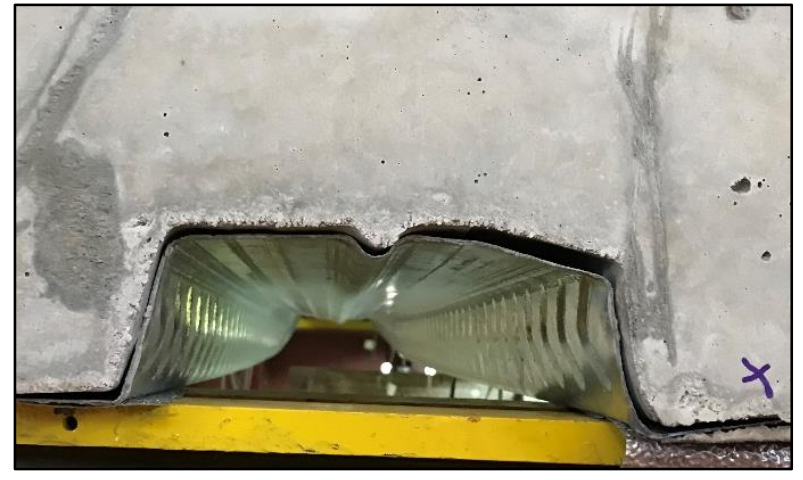

(b) Final do ensaio

Fonte: Autoria própria

O deslizamento da extremidade do protótipo ocorreu porque, para um dado nível de carregamento, os esforços e deslizamentos atuantes na interface aço-concreto promoveram a deformação das nervuras da fôrma de aço e a sua separação do concreto na região do vão de cisalhamento adjacente à fissura principal. Dessa forma, as mossas da fôrma se desengrenaram gradativamente durante o ensaio, acarretando no deslizamento da capa de concreto localizada entre a fissura principal e a extremidade do seu vão de cisalhamento adjacente.

Na região do apoio o comportamento da interface foi semelhante ao que ocorre no ensaio slip-block devido ao confinamento existente, por isso a situação da nervura apresentada na Figura 6.26 (b) se asemelha com a verificada no ensaio slip-block. Na vizinhança da fissura principal e no seu vão de cisalhamento adjacente, entretanto, ocorreu maior separação vertical entre a fôrma de aço e o concreto devido à ausência de confinamento. Dessa forma, nota-se que a configuração da fôrma de aço é fundamental para a resistência ao deslizamento, que interfere na resistência ao cisalhamento longitudinal da laje mista. 
A Figura 6.27 apresenta o panorama de deslizamento desenvolvido na Laje 1, em que foram desenhadas linhas verticais na face do protótipo protótipo antes do ensaio, permitindo verificar visualmente o deslizamento e a separação vertical ocorrida.

Figura 6.27 - Deslizamento e separação vertical ao longo do vão de cisalhamento (Laje 1)

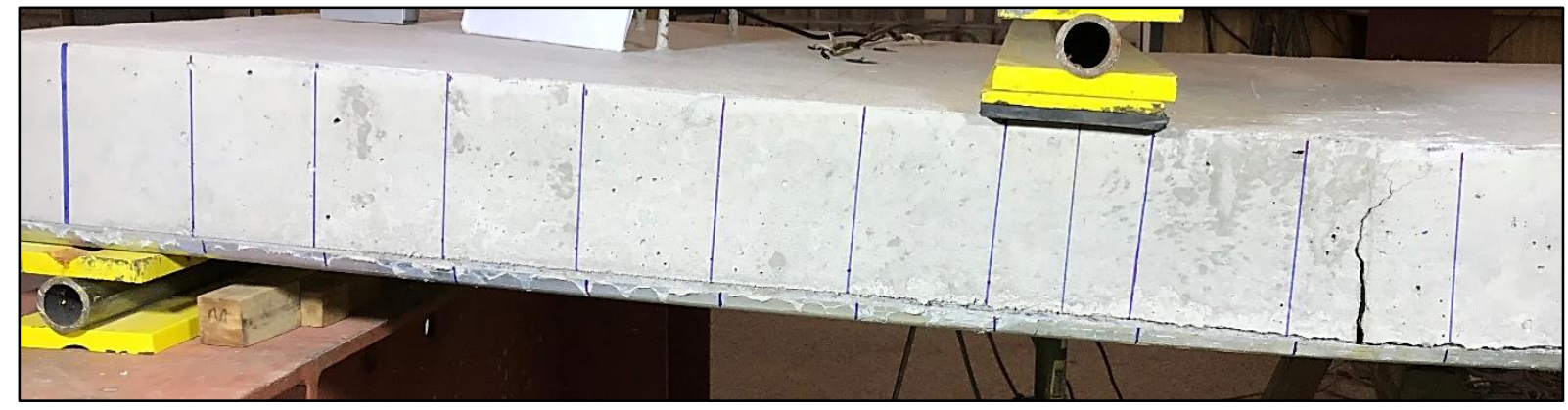

Fonte: Autor

Constatou-se nos dois protótipos ensaiados que o vão de cisalhamento que deslizou possuía a orientação de menor resistência do intertravamento mecânico promovido pelas mossas. Isso ocorreu porque, diante do seu formato em V, uma orientação confina mais o concreto que a outra, conforme ilustra a Figura 6.28, causando contribuições distintas da ligação mecânica. Sendo assim, a configuração das mossas determinou qual o vão de cisalhamento que deslizou.

Figura 6.28 - Influência da orientação das mossas sobre a resistência da ligação mecânica

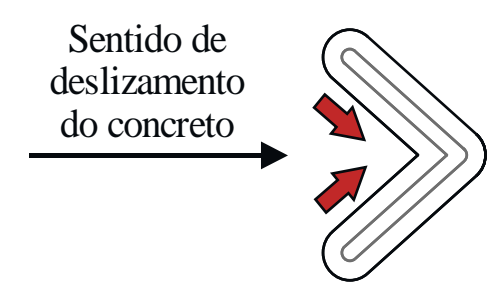

a) Orientação de maior resistência

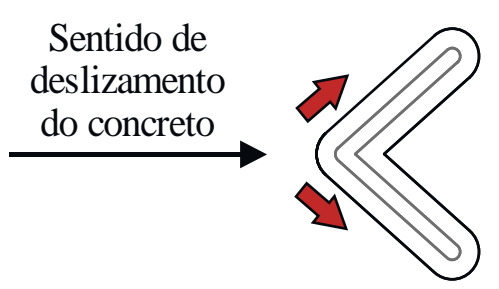

b) Orientação de menor resistência

Fonte: Autoria própria

Diante da configuração das mossas, pode-se considerar que os protótipos ensaiados não eram simétricos, pois a configuração das mossas provoca a falta de simetria. Logo, o vão de cisalhamento cujas mossas estavam orientadas segundo o sentido de menor resistência possuía, consequentemente, menor resistência ao cisalhamento longitudinal. Na Figura 6.26 é possível constatar a orientação das mossas no vão de cisalhamento que deslizou.

A implicância, sobre a configuração deformada do protótipo, do deslizamento ocorrido apenas em um dos vãos de cisalhamento pode ser verificada nos gráficos da Figura 6.29, pois o transdutor TD-2, localizado abaixo da região que não deslizou (ver Figura 6.22), registrou menos deslocamento vertical que os demais após o início do deslizamento de extremidade. 
Figura 6.29 - Gráficos da Força versus Deslocamento vertical nos três pontos de medição

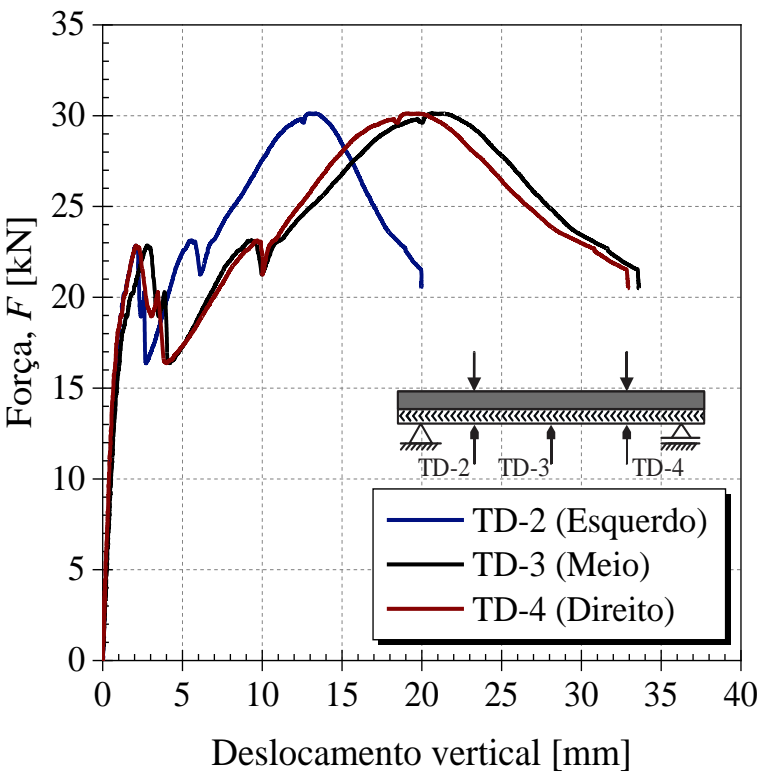

(a) Laje 1

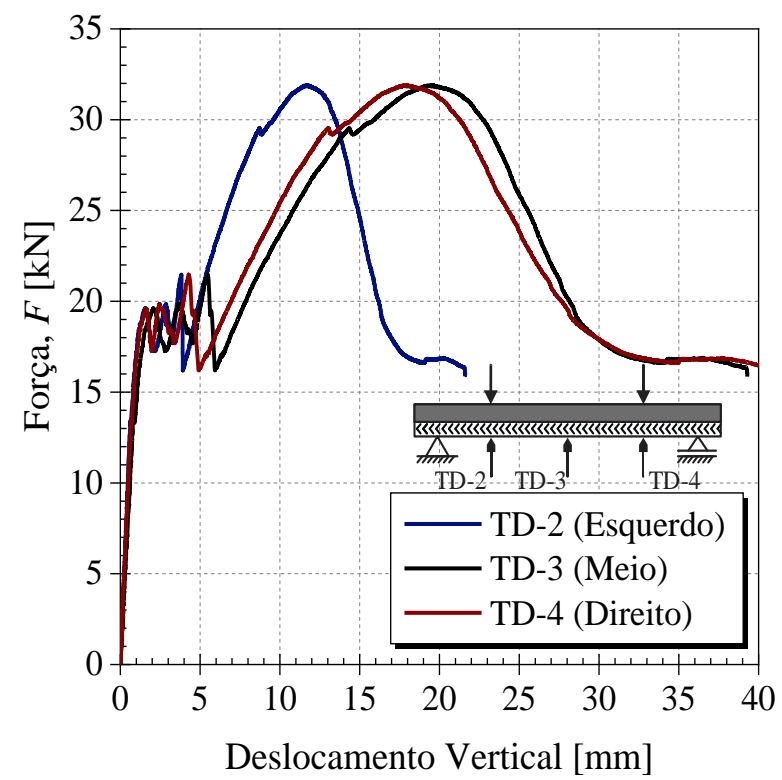

(b) Laje 2

Fonte: Autoria própria

Após o início do deslizamento de extremidade, ocorreu aumento gradativo da força aplicada até a capacidade máxima $\left(F_{\text {máx }}\right)$ dos protótipos ser atingida. Esse aumento ocorreu em função da resistência da interface aço-concreto promovida pelas ligações mecânica e por atrito nas regiões sob interação parcial, uma vez que a ligação química havia sido eliminada por causa a separação ocorrida inicialmente entre o aço e o concreto.

Como a laje foi governada pelo regime de interação parcial, sua rigidez após o início do deslizamento foi determinada pela resistência da interface, que foi condicionada pela configuração da fôrma de aço.

Após $F_{\text {máx }}$ ser atingida, iniciou-se o colapso do sistema, em que os protótipos não suportaram mais acréscimos de carregamento e houve diminuição gradativa da rigidez dos modelos. A Figura 6.30 apresenta a configuração da Laje 1 após a realização do ensaio.

Figura 6.30 - Laje 1 após a realização do ensaio de flexão

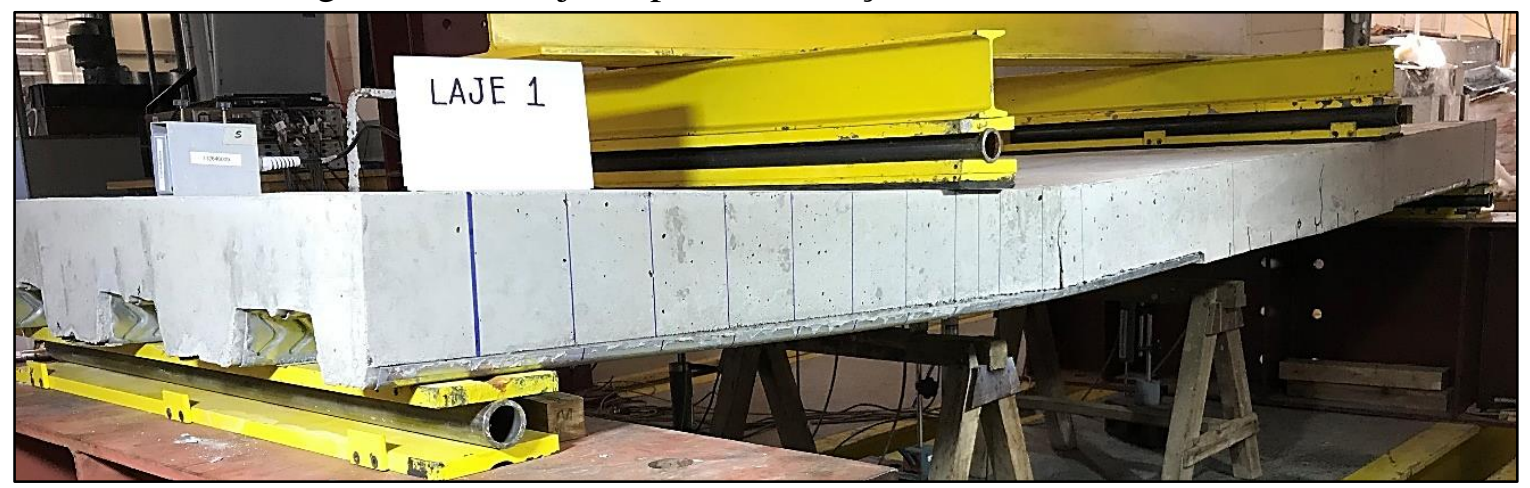

Fonte: Autoria própria 
A configuração do colapso identificada em ambos os protótipos foi a formação de ondulações na parte comprimida da fôrma de aço, conforme ilustra a Figura 6.31.

Figura 6.31 - Ondulações na parte comprimida da fôrma de aço no final do ensaio (Laje 1)

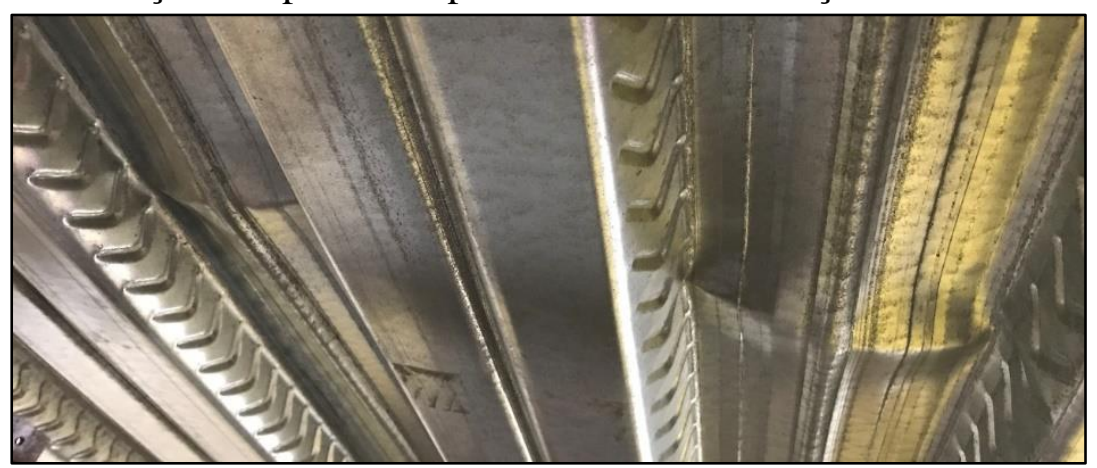

Fonte: Autoria própria

A Figura 6.32 e Figura 6.33 apresentam os gráficos da Força $(F)$ versus Deslizamento de extremidade e os gráficos da Força $(F)$ versus Deformação específica $(\varepsilon)$ dos materiais nas seções instrumentadas da Laje 1 e da Laje 2, respectivamente.

De acordo com os gráficos da Figura 6.32 (a) e Figura 6.33 (b), constatou-se que o deslizamento de extremidade se iniciou juntamente com a redução brusca da capacidade de carga dos protótipos. A implicância do deslizamento de extremidade sobre os deslocamentos verticais dos protótipos pode ser verificada na Figura 6.29, que está em concordância com os gráficos das Figuras 6.32 (a) e 6.33 (a).

Após o início do deslizamento, a resistência dos protótipos aumentou continuamente em função da atuação das ligações mecânicas e por atrito até a capacidade máxima resistente ser atingida. No caso da Laje 1, o transdutor TD-5, que registrava os deslizamentos da extremidade que deslizou, descolou da fôrma de aço, impossibilitando a medição ao longo do ensaio, infelizmente. No gráfico da Figura 6.33 (a) é possível verificar a redução da rigidez do protótipo após atingir sua capacidade resistente máxima. Além disso, nota-se que em nenhum dos protótipos ocorreu deslizamento na outra extremidade, cujas mossas do vão de cisalhamento possuíam a orientação de maior resistência.

Em todas as seções instrumentadas dos dois protótipos, os dois pontos instrumentados no concreto apresentaram comportamento linear, de acordo com as Figuras 6.32 e 6.33. Considerando os módulos de elasticidade determinados experimentalmente e apresentados na seção 6.2.1, a tensão de compressão máxima na Laje 1 foi de 4,32 MPa, registrada na sua seção do meio do vão. Já a Laje 2 apresentou tensão de compressão máxima de 3,63 MPa, registrada na seção localizada no vão de cisalhamento que não deslizou. Dessa forma, o concreto foi pouco solicitado à compressão ao longo dos ensaios. 
Figura 6.32 - Resultados referentes ao deslizamento e às deformações do aço e do concreto da Laje 1

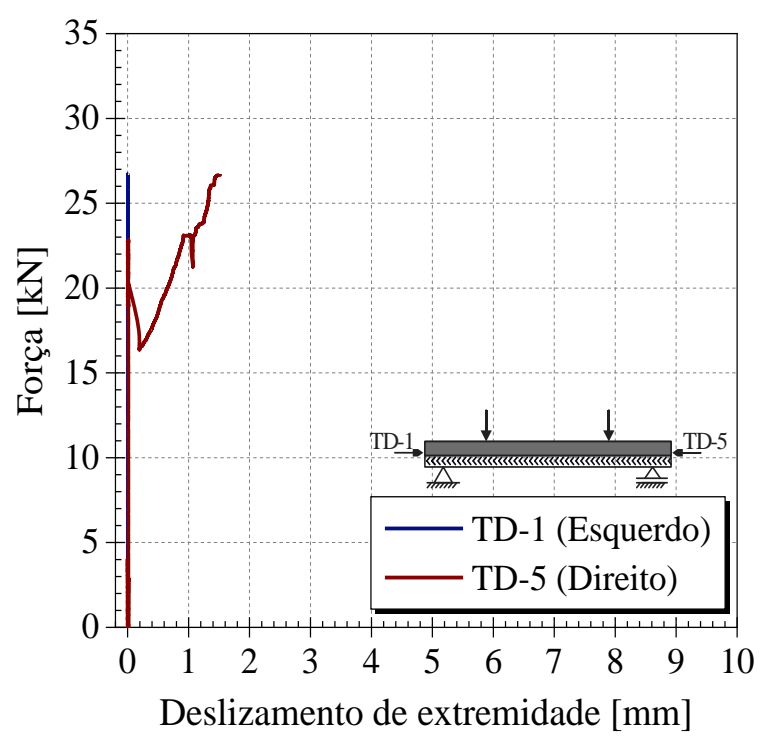

(a) Gráfico da Força versus Deslizamento de extremidade

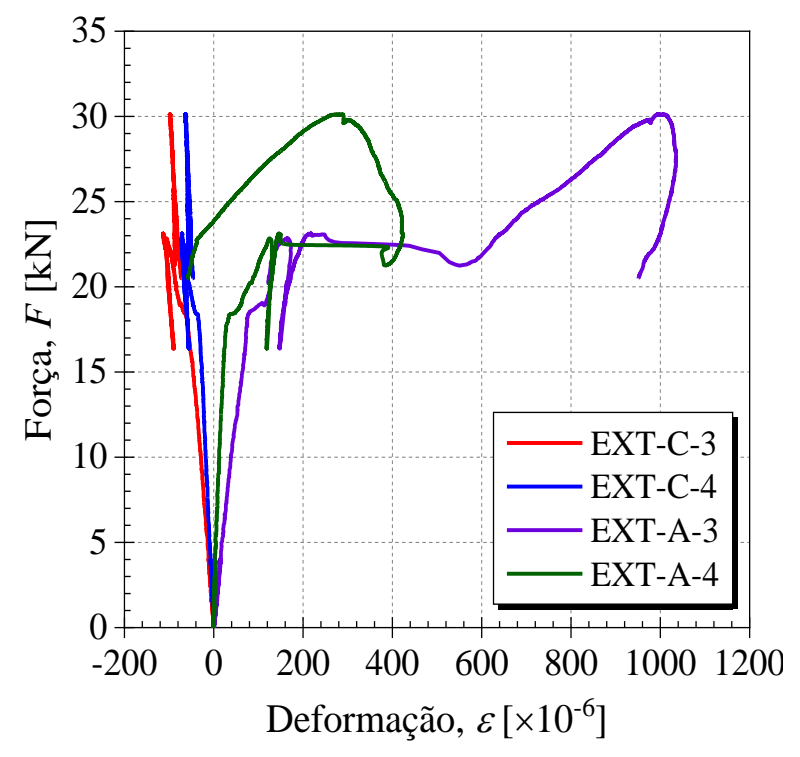

(c) Gráfico da Força versus Deformação específica dos materiais - Seção B-B

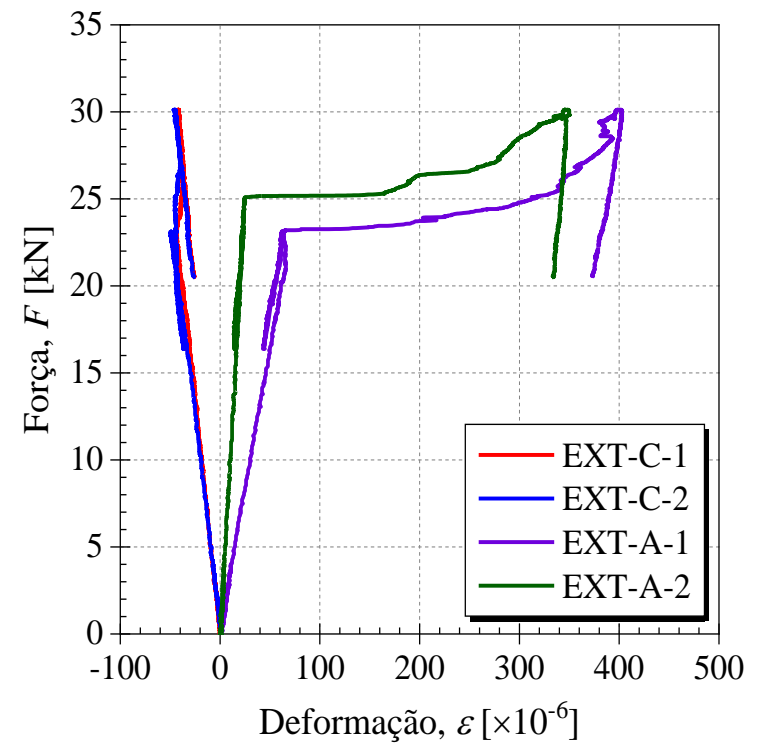

(b) Gráfico da Força versus Deformação específica dos materiais - Seção A-A

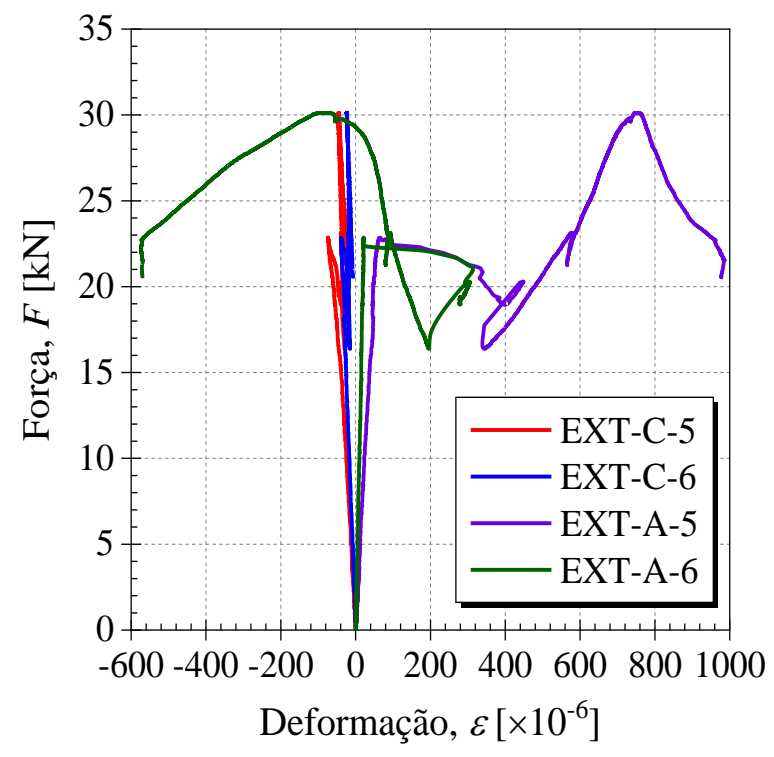

(d) Gráfico da Força versus Deformação específica dos materiais - Seção C-C

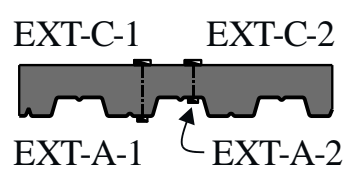

Seção A-A

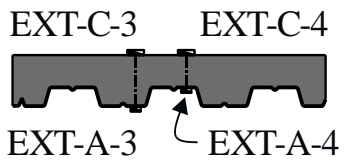

Seção B-B

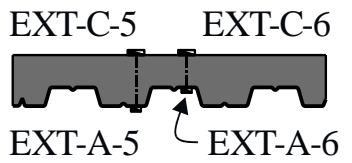

Seção C-C

(e) Disposição dos extensômetros nas seções transversais de acordo com a Figura 6.22

Fonte: Autoria própria 
Figura 6.33 - Resultados referentes ao deslizamento e à deformação do aço e do concreto da Laje 2

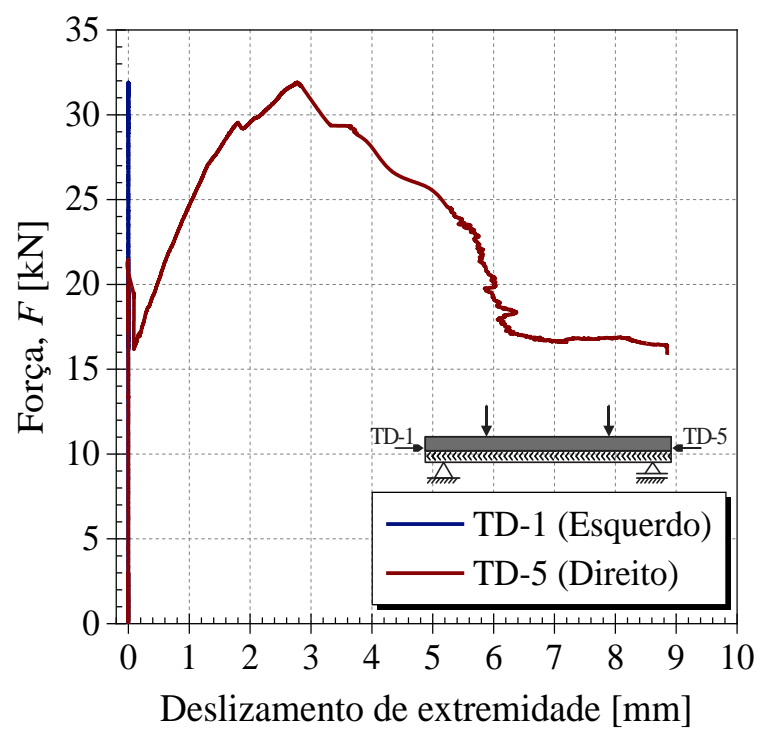

(a) Gráfico da Força versus Deslizamento de extremidade

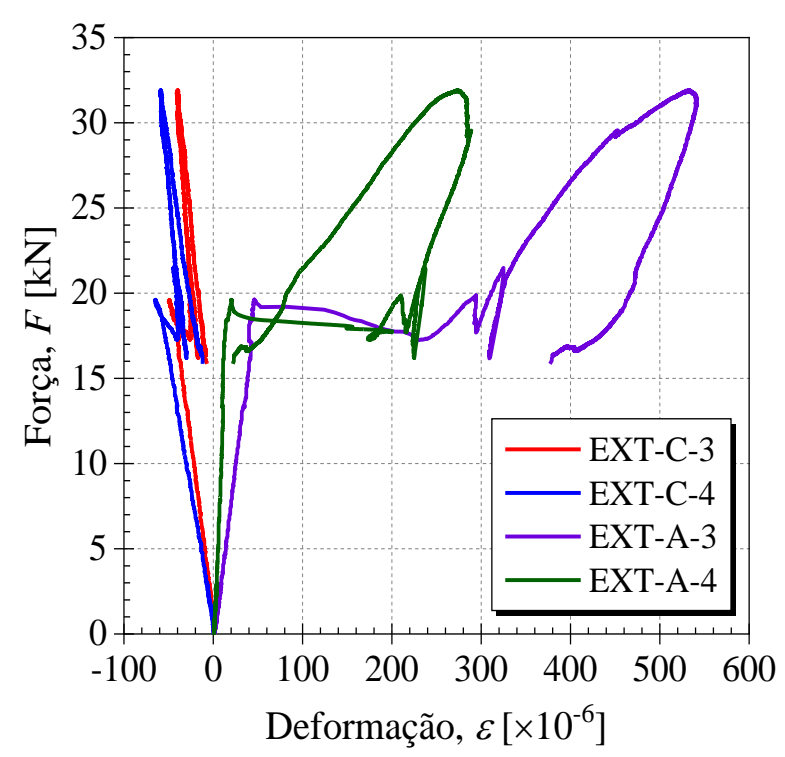

(c) Gráfico da Força versus Deformação específica dos materiais - Seção B-B

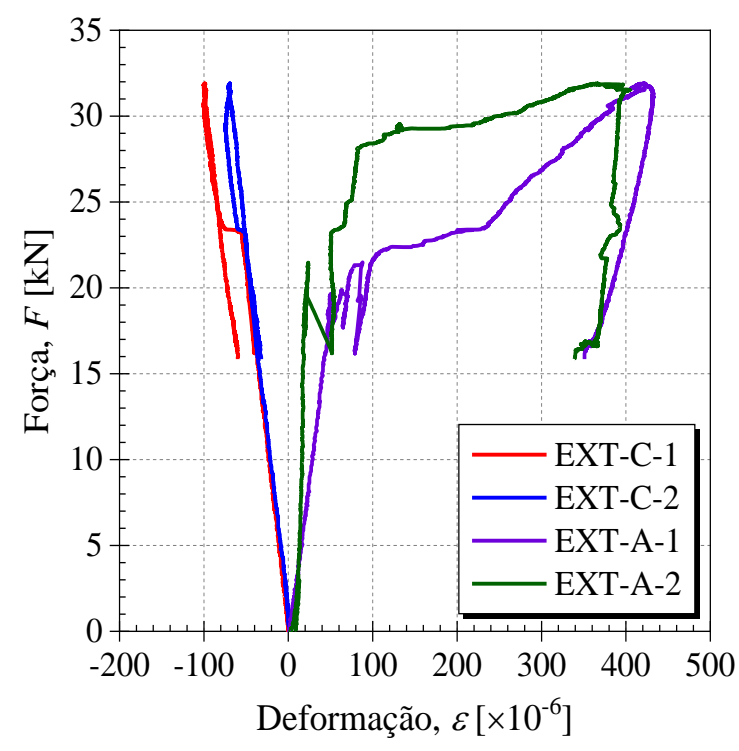

(b) Gráfico da Força versus Deformação específica dos materiais - Seção A-A

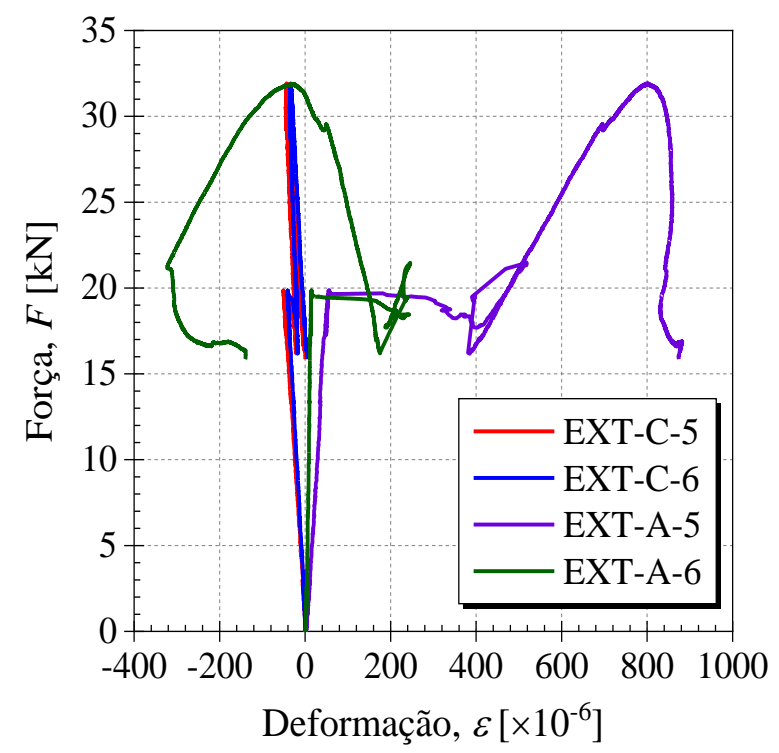

(d) Gráfico da Força versus Deformação específica dos materiais - Seção C-C

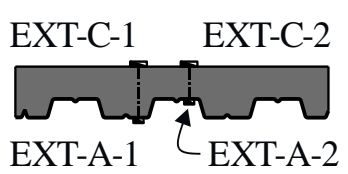

Seção A-A

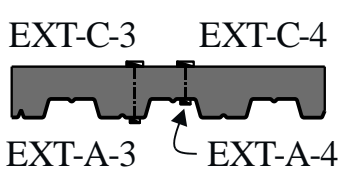

Seção B-B

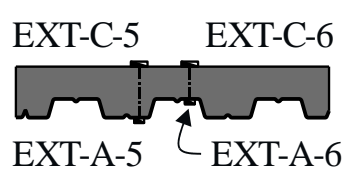

Seção C-C

(e) Disposição dos extensômetros nas seções transversais de acordo com a Figura 6.22

Fonte: Autoria própria 
É importante notar nos gráficos acima que após o início do deslizamento de extremidade, o concreto apresentou redução das deformações e, como estava sob comportamento linear, também, das tensões. Posteriormente, o concreto tornou a se deformar à medida que o carregamento era aplicado.

De acordo com as Figuras 6.32 (b) e 6.33 (b), referentes à seção localizada no vão de cisalhamento que não deslizou, verifica-se que tanto a mesa alta quanto a mesa baixa da fôrma de aço se mantiveram tracionadas ao longo do ensaio. As curvas referentes à fôrma de aço dos gráficos apresentados nessas figuras apresentaram comportamento linear até o início do deslizamento de extremidade. Em seguida, há uma redução repentina e, posteriormente, aumento progressivo das deformações da fôrma de aço. Com o deslizamento de extremidade iniciado, as mesas alta e baixa da Laje 1 apresentaram comportamentos semelhantes, enquanto que as da Laje 2 apresentaram comportamentos diferentes.

Os gráficos das Figuras 6.32 (c) e 6.33 (c) são referentes à seção localizada no meio do vão das Lajes 1 e 2, respectivamente. Nessas figuras é possível verificar que as curvas do aço e do concreto sofrem uma redução da inclinação antes do início do deslizamento de extremidade ser verificado, que está relacionada com a redução da rigidez das lajes antes da força referente ao início do deslizamento $\left(F_{\text {des }}\right)$ ser atingida, como pode ser constatado ao correlacionar esses gráficos com os apresentados na Figura 6.29.

Além disso, na seção do meio do vão, após o início do deslizamento de extremidade, as deformações da mesa baixa aumentam com o aumento do carregamento aplicado. Já as deformações da mesa alta reduzem continuamente após um certo nível de carregamento aplicado, conforme se observa nas Figuras 6.32 (c) e 6.33 (c). Isso ocorreu, porque essas seções passaram a atuar no regime de interação parcial e, com o aumento do carregamento aplicado, a mesa alta passou a ser menos solicitada à tração.

De maneira semelhante à ocorrida nas seções do meio do vão das lajes, as seções localizadas no vão de cisalhamento que deslizou apresentaram comportamento linear até o nível de carregamento correspondente à perda de rigidez das lajes, conforme se observa nas Figuras 6.32 (d) e 6.33 (d). Após o deslizamento de extremidade ser iniciado, inicia o regime de interação parcial e as deformações das mesas alta e baixa aumentam. Entretanto, após um determinado nível de carregamento aplicado, as mesas altas das Lajes 1 e 2 apresentaram redução gradual das deformações, à medida que o carregamento era aplicado, até passarem a serem comprimidas, conforme apresentam seus respectivos gráficos. Dessa forma, pode-se constatar a formação de duas linhas neutras nessas seções. Este fenômeno pode provocar a formação de ondulações na mesa superior, conforme apresentado na Figura 6.31. 
A capacidade resistente sob o regime de interação parcial dos protótipos ensaiados pode ser avaliada em relação à sua capacidade resistente prevista no regime de interação total, obtida por meio do equilíbrio plástico da seção transversal segundo a ABNT NBR 8800: 2008. Dessa forma, pode-se comparar o momento fletor máximo resistente experimental $\left(M_{\mathrm{exp}}\right)$, com o momento fletor máximo resistente previsto sob interação total $\left(M_{\mathrm{R}}\right)$. A Tabela 6.13 apresenta o resultado dessa avaliação.

Tabela 6.13 - Avaliação da capacidade resistente dos protótipos do ensaio de flexão

\begin{tabular}{cccccc}
\hline Protótipo & $\boldsymbol{F}_{\text {máx }}{ }^{(\mathbf{a})}[\mathbf{k N}]$ & $\boldsymbol{F}_{\text {total }}[\mathbf{k N}]$ & $\boldsymbol{M}_{\mathbf{e x p}}{ }^{(\mathbf{b})}[\mathbf{k N} \cdot \mathbf{m}]$ & $\boldsymbol{M}_{\mathbf{R}}{ }^{(\mathbf{c})}[\mathbf{k N} \cdot \mathbf{m}]$ & $\boldsymbol{M}_{\mathbf{e x p}} / \boldsymbol{M}_{\mathbf{R}}$ \\
\hline Laje 1 & 30,12 & 41,48 & 15,56 & 31,26 & 0,50 \\
Laje 2 & 31,92 & 43,28 & 16,23 & 31,22 & 0,52 \\
\hline
\end{tabular}

(a) Menor valor entre a força máxima aplicada durante o ensaio e a força correspondente ao deslocamento vertical de $L / 50$.

(b) Momento fletor máximo resistente experimental, dado por $M_{\exp }=0,5 \cdot F_{\text {total }} \cdot L_{\mathrm{s}}$, com $L_{\mathrm{s}}=750 \mathrm{~mm}$.

(c) Momento fletor máximo resistente previsto sob interação total, calculado de acordo com a ABNT NBR 8800: 2008.

Fonte: Autoria própria

Conforme apresenta na tabela acima, os protótipos atingiram aproximadamente metade da capacidade resistente sob interação total. Diante disso, é possível verificar a implicância do nível de interação entre o concreto e a fôrma de aço sobre a resistência das lajes mistas. Vale lembrar que o nível de interação entre os dois materiais é principalmente condicionado pela configuração da fôrma de aço, ou seja, o formato do perfil da fôrma, o formato e disposição das mossas e o revestimento superficial da fôrma de aço.

De modo geral os dois protótipos ensaiados apresentaram comportamentos semelhantes e conforme o previsto. Por meio dos ensaios foi possível verificar os fenômenos desenvolvidos na interface mediante a ocorrência do cisalhamento longitudinal e identificar o comportamento dúctil das lajes, realizando sua classificação. A instrumentação utilizada possibilitou obter resultados que auxiliaram no entendimento dos fenômenos desenvolvidos e identificar a implicância do regime de interação parcial entre o aço e o concreto sobre o comportamento local e global das lajes mistas. Além disso, foi possível analisar a influência da orientação das mossas sobre a resistência da interface aço-concreto. 


\subsection{Considerações Finais do Capítulo}

A análise experimental realizada por meio dos ensaios slip-block permitiu analisar o comportamento da interface e obter os parâmetros $\mu$ e $\tau_{\mathrm{m}}$. Por meio da comparação entre a metodologia proposta neste trabalho e a proposta por Patrick e Poh (1990), constatou-se que a primeira permitiu maior compreensão da fenomenologia desenvolvida ao longo do ensaio, assim como a determinação das resistências por atrito e mecânica da interface de acordo com o deslizamento. Dessa forma, ao empregar a metodologia proposta neste trabalho, foi possível identificar a relação existente entre o deslizamento, o coeficiente de atrito global, a resistência mecânica e a configuração da fôrma de aço, especialmente o formato das mossas.

Por meio das comparações realizadas entre os parâmetros obtidos por meio das duas metodologias, constatou-se diferenças consideráveis, principalmente com relação à resistência mecânica promovida pelas mossas. Isso pode estar relacionado ao método de ensaio e à degradação sofrida pela interface ao longo do ensaio, pois o método proposto por Patrick e Poh (1990) aplica vários ciclos de carregamentos verticais com cinco estágios cada um, o que compromete a integridade dos materiais ao longo do ensaio.

Os ensaios dos protótipos em escala real permitiram analisar o comportamento da interface aço-concreto sob flexão e realizar sua classificação da laje mista estudada como dúctil, assim como fornecer modelos reais para avaliar os resultados oriundos da análise numérica. Identificou-se nesses ensaios a influência dos fenômenos desenvolvidos na interface sobre o comportamento local e global das lajes mistas. Além disso, a instrumentação das três seções em cada protótipo permitiu analisar a diferença do comportamento entre as seções com e sem a ocorrência de interação parcial entre a fôrma de aço e o concreto.

Verificou-se que a resistência máxima da Laje 2 foi atingida quando o deslizamento de extremidade atingiu aproximadamente $3 \mathrm{~mm}$, conforme apresentado na Figura 6.32 (b). Diante da correspondência entre o deslizamento $(s)$ e a resistência mecânica da interface aço-concreto $\left(\tau_{\mathrm{m}}\right)$, identificada por meio da metodologia proposta, constatou-se que a laje mista atingiu sua resistência máxima quando a ligação mecânica da interface atingiu sua resistência máxima no vão de cisalhamento que deslizou. Esse fato é coerente com o verificado ao longo do ensaio, uma vez que quando o vão de cisalhamento está inteiramente no regime de interação parcial, esta situação passa a governar o comportamento da laje mista como um todo.

Dessa forma, uma vez caracterizado o comportamento da interface aço concreto por meio da metodologia proposta neste trabalho, foi possível correlacionar o comportamento da interface no ensaio slip-block com a do ensaio de flexão. 
O ensaio slip-block representa mais o comportamento das regiões dos apoios das lajes mistas, pois nessas regiões há o efeito do confinamento promovido pelas reações de apoio. Nas regiões dos vãos, entretanto, não há confinamento promovido diretamente por carregamentos externos, havendo, assim, maior separação vertical entre o aço e o concreto. Esse fato reduz a resistência promovida pelas ligações mecânica e por atrito. Apesar disso, ainda foi possível estabelecer relações coerentes entre o comportamento da interface nos dois tipos de ensaio.

O ensaio slip-block pode ser aplicado, portanto, no estudo da configuração da fôrma de aço, auxiliando a determinação de um formato mais eficiente que promova maior contribuição das ligações química, mecânica e por atrito. Os resultados fornecidos pelo ensaio slip-block podem ser relacionados com o comportamento da interface aço-concreto de protótipos ensaiados à flexão, conforme apresentado nesta seção. Além disso, tais resultados podem ser aplicados para a modelagem numérica da interface aço-concreto utilizando elementos finitos, conforme apresenta o capítulo seguinte. 


\section{CAPÍTULO 7 - ANÁLISE NUMÉRICA}

A análise numérica de lajes mistas empregando o Método dos Elementos Finitos (MEF) têm sido objeto de muitas pesquisas. Por meio desse tipo de análise é possível simular o ensaio do elemento estrutural, auxiliando a compreensão do seu comportamento. Isso é muito importante especialmente na análise do comportamento da interface aço-concreto por causa da sua complexidade, conforme discutido no Capítulo 2 e verificado na análise experimental realizada neste trabalho.

Uma vez que a análise experimental muitas vezes é composta por uma quantidade reduzida de ensaios, por causa do trabalho e custos envolvidos, a análise numérica auxilia o entendimento e o tratamento da análise experimental, assim como possibilita a extrapolação de resultados por meio de uma análise paramétrica do modelo validado.

A modelagem da interface aço-concreto de lajes mistas, além de complexa, é inerente à sua fôrma de aço constituinte, haja vista que a sua configuração determina o comportamento da interface e, consequentemente, da própria laje. Sendo assim, a modelagem da interface usualmente é realizada empregando parâmetros provenientes de ensaios experimentais, seja o ensaio de flexão em escala real ou ensaios de modelos de pequenas dimensões.

O objetivo da análise numérica realizada neste trabalho foi avaliar o emprego dos parâmetros obtidos por meio da metodologia desenvolvida, que utilizou o ensaio slip-block, para modelar a interface aço concreto e simular o comportamento da laje mista. Para isso utilizou-se o pacote computacional DIANA ${ }^{\circledR}$, versão 9.6 , que possui um modelo constitutivo de interface coerente com o propósito da análise, conforme explicado posteriormente.

A análise consistiu, portanto, na simulação dos ensaios slip-block e de flexão, realizando-se em cada caso a análise do comportamento da interface empregando os parâmetros obtidos por meio da metodologia desenvolvida neste trabalho, apresentada na seção 6.3.3.1. Para cada modelo analisou-se e discutiu-se previamente a influência de cada parâmetro do modelo constitutivo da interface e realizou-se a validação do modelo numérico.

No caso do modelo da laje mista, fez-se uma análise mais aprofundada do modelo da interface a fim de discutir a influência de cada parâmetro envolvido e, assim, compreender o desempenho do modelo numérico. Após sua validação, fez-se uma análise paramétrica avaliando a influência das seguintes propriedades da laje mista: espessura da capa de concreto, espessura da fôrma de aço, comprimento efetivo da laje mista e tensão de escoamento do aço da fôrma. 
Neste capítulo é apresentado, inicialmente, uma revisão de trabalhos recentes que utilizaram o MEF na análise numérica de lajes mistas, descrevendo os aspectos relevantes referentes à simulação numérica, além de situar o presente trabalho no cenário científico atual. Em seguida é realizada uma breve apresentação do pacote computacional DIANA ${ }^{\circledR}$ e os aspectos das simulações numéricas realizadas. A estrutura, validação e análise paramétrica de cada modelo são apresentadas na sequência, juntamente com a discussão das respectivas análises realizadas.

\subsection{Emprego do MEF em Lajes Mistas}

Vários trabalhos presentes na literatura empregaram a modelagem numérica por meio de elementos finitos para simular o comportamento de lajes mistas. Alguns desses trabalhos utilizaram os resultados de ensaios de modelos de pequenas dimensões para obter os parâmetros e simular a interface aço-concreto, enquanto outros utilizaram os resultados dos ensaios de flexão em escala real. Dentre esses trabalhos, alguns considerados relevantes são brevemente descritos a seguir, ressaltando os aspectos referentes às modelagens numéricas desenvolvidas.

Abdullah (2004) realizou uma análise numérica não-linear empregando elementos finitos por meio do software ABAQUS ${ }^{\circledR} /$ Explicit. Simulou-se $1 / 4$ da nervura da laje mista, considerando as condições de simetria longitudinal e transversais. $\mathrm{O}$ modelo constitutivo do aço foi o elástico-plástico perfeito, de modo que nas almas do perfil da fôrma, onde contém as mossas, a tensão de escoamento e o módulo de elasticidade do aço foram reduzidos em $50 \%$. O comportamento do concreto à compressão foi assumido sempre elástico-linear por meio do modelo brittle cracking do software. O concreto foi modelado com elementos sólidos do tipo C3D8R, enquanto a fôrma de aço foi modelada com elementos de casca do tipo S4R. A interação entre o concreto e o aço foi modelada com elementos de conexão do tipo radial-thrust (CONN3D2), que relaciona a tesão de cisalhamento com o deslizamento, utilizando os parâmetros obtidos do ensaio de flexão elementar, apresentado na seção 4.13.

Por meio do estudo desenvolvido, Abdullah (2004) propôs um novo método de cálculo chamado de Método de Equilíbrio de Forças para determinar a resistência ao cisalhamento entre o aço e o concreto considerando o efeito da esbeltez da laje mista. Além disso, o autor propôs um método de interpolação linear para prever o comportamento da ligação aço-concreto de uma laje mista de esbeltez diferente com base nos resultados de outras duas lajes mistas com a mesma fôrma de aço. Com a calibração de uma das lajes, o autor utilizou este método para 
determinar as curvas da tensão de cisalhamento versus deslizamento para as demais lajes, que foram empregadas nas suas respectivas modelagens numéricas.

No estudo já citado, realizado por Ferrer, Marimon e Crisinel (2006), foram simulados os mecanismos de deslizamento longitudinal da interface aço-concreto de protótipos submetidos ao ensaio pull-out proposto por Daniels (1988). Para tal empregou-se o software ANSYS $^{\circledR}$. A fôrma de aço foi modelada com as mossas, utilizando elementos de casca com 4 nós, enquanto o concreto foi tratado com uma superfície de contato perfeitamente rígida com atrito. Logo, o comportamento do concreto não foi efetivamente analisado. As condições de contorno consideraram a simetria longitudinal dupla e simetria cíclica do padrão das mossas. A força aplicada para promover o deslizamento consistiu na aplicação de deslocamentos prescritos. Para modelar a interface aço-concreto, foram empregados elementos de contato, cujo valor do coeficiente de atrito foi analisado variando-o de 0 a 0,6. Não se considerou a ligação química e nem a existência de tensões residuais na fôrma de aço. As conclusões deste trabalho foram apresentadas na seção 4.5 .

Ávila, Quevedo e Morfa (2009) desenvolveram um estudo numérico no software ABAQUS ${ }^{\circledR} /$ Implicit, no qual simularam o ensaio pull-out proposto por Daniels (1988). As mossas da fôrma de aço foram modeladas. Foram realizados estudos sobre a consideração da simetria e da malha. Utilizou-se elementos sólidos de 4 nós e de 8 nós para modelar o concreto e de casca de 4 nós para modelar a fôrma de aço. A interface foi modelada empregando o algoritmo small sliding, porém não se especificou seu modelo constitutivo. Para o concreto utilizou-se o modelo Concrete Damaged Plasticity, enquanto o aço foi modelado com comportamento elástico-plástico perfeito. A simulação numérica foi validada comparando-se seus resultados com os experimentais.

Tsalkatidis e Avdelas (2010) realizaram um estudo numérico e experimental abordando o problema do contato unilateral das lajes mistas. Foi simulada metade da laje mista considerando sua simetria longitudinal. A formulação matemática do problema da interface aço-concreto foi apresentada e envolveu a associação das tensões normais e tangenciais com os deslocamentos relativos e empregou o Princípio dos Trabalhos Virtuais. Entretanto, a simulação numérica realizada no trabalho não empregou esta formulação, mas sim um modelo de contato com atritos estático e dinâmico constantes, disponível no software ANSYS ${ }^{\circledR}$. Dessa forma, modelou-se o concreto com elementos sólidos de 8 nós e a fôrma de aço com elementos de casca. Utilizou-se um modelo não linear que considera a fissuração e o esmagamento com o critério de William-Warnke para o concreto e o elástico-plástico com encruamento para o aço. Os resultados numéricos apresentaram-se congruentes com os experimentais. 
Chen e Shi (2011) realizaram uma abordagem empregando elementos finitos, por meio do software ANSYS $^{\circledR}$, em que a interação entre o aço e o concreto foi tratada como um problema de contato considerando a adesão e o atrito por meio do modelo de atrito de Coulomb. Simulou-se metade da laje mista, considerando sua simetria longitudinal. O concreto foi definido com uma lei constitutiva de comportamento isotrópico multilinear, enquanto uma lei cinemática multilinear foi considerada para o perfil de aço. Empregou-se elementos sólidos com 8 nós para o concreto e elementos de casca com 4 nós para a fôrma de aço. A fôrma foi modelada sem a presença das mossas e a interface aço-concreto foi modelada com elementos de contato, que simularam a presença das mossas pela introdução de parâmetros de contato extraídos do ensaio pull-out proposto por Daniels (1988).

Dessa forma, Chen e Shi (2011) realizaram uma análise preliminar do modelo, que foi verificada na simulação dos ensaios pull-out, em que a coesão e a ligação por atrito da interface de contato foram consideradas. A verificação do modelo refinado foi realizada no estudo das lajes mistas submetidas ao ensaio de flexão. Os modelos foram calibrados com base nos resultados experimentais e realizou-se uma análise paramétrica avaliando a influência do comprimento de cisalhamento. O modelo de contato utilizado para a interface resultou numa boa aproximação dos resultados experimentais e analíticos.

Abdinasir, Abdullah e Mustaffa (2012) realizaram um estudo numérico explorando a modelagem da interface aço-concreto de lajes mistas utilizando elementos coesivos, assim como estudaram a esbeltez das lajes, utilizando o software ABAQUS ${ }^{\circledR} /$ Explicit. Foi modelada $1 / 4$ da nervura da laje, considerando suas simetrias transversais e longitudinal. Tanto o concreto quanto a fôrma de aço foram modelados com elementos sólidos de 8 nós (C3D8R). A interface foi modelada com elementos coesivos de 8 nós (COH3D8) de espessura nula. O modelo Concrete Damaged Plasticity foi utilizado para o concreto enquanto o comportamento do aço foi definido como elástico-plástico perfeito. Os parâmetros da interface foram extraídos do trabalho de Abdullah e Easterling (2009), que realizaram o ensaio apresentado na seção 4.5. Os autores empregaram os resultados numéricos para avaliar o efeito da esbeltez sobre o comportamento das lajes mistas.

Abas (2014) desenvolveu um trabalho numérico e experimental sobre lajes mistas de aço e concreto reforçado com fibras de aço. A simulação numérica foi realizada no software ABAQUS ${ }^{\circledR} /$ Explicit. Simulou-se metade da nervura da laje, considerando as simetrias longitudinal e transversais. O concreto e os apoios foram modelados com elementos sólidos do tipo C3D8R e o aço foi modelado com elementos de casa do tipo S4R. O modelo constitutivo do concreto foi o Concrete Damaged Plasticity e o do aço da fôrma e da armadura foi o elástico- 
plástico perfeito. A interface aço-concreto foi simulada empregando o algoritmo General Contact, que combinou dois tipos de interação entre os dois materiais: superfície coesiva, por meio de um modelo que relaciona a tensão com o deslizamento, e o atrito, utilizando o modelo de Coulomb. Os parâmetros utilizados na modelagem da interface foram baseados nos resultados obtidos por Burnet e Oehlers (2001), que realizaram ensaios do tipo push-out, apresentado na seção 4.11. Os resultados numéricos foram utilizados para analisar o comportamento das lajes, assim como realizar a análise paramétrica.

Cheng, Shi e Zhou (2014) propuseram um modelo numérico para simular lajes mistas com ancoragens de extremidade do tipo stud, utilizando o software ANSYS ${ }^{\circledR}$ e simulando apenas metade de uma das nervuras da laje mista, considerando as simetrias transversais e longitudinal. O concreto e os studs foram modelados com elementos sólidos de 8 nós e a fôrma de aço com elementos de casca de 4 nós. A interface foi simulada com elementos de contato considerando os efeitos do atrito e da coesão por meio de um modelo constitutivo do software. O concreto e foi modelado com um modelo do ANSYS ${ }^{\circledR}$, que considera a fissuração e o esmagamento, enquanto o material do aço foi definido com um comportamento elásticoplástico com encruamento. Os resultados numéricos foram validados e comparados com os experimentais obtidos por Chen, Shi e Qiu (2011), apresentando boa concordância. Por fim, realizou-se uma análise paramétrica avaliando os efeitos da espessura da fôrma de aço, do diâmetro e da resistência do stud, da resistência do concreto e do comprimento do vão de cisalhamento.

No trabalho realizado por Gholamhoseini et al. (2014), a análise numérica foi realizada para investigar a resistência última das lajes mistas ensaiadas. O software empregado foi o ATENA 3D. Simulou-se uma nervura da laje mista, considerando as simetrias transversais. Tanto o concreto quanto a fôrma de aço e as chapas de apoio foram modeladas com elementos tetraédricos sólidos com 4 nós. $\mathrm{O}$ aço constituinte da fôrma foi modelado como um material elástico-plástico perfeito e o concreto foi modelado com um modelo do software capaz de considerar a fissuração, esmagamento e seu comportamento plástico. A interface foi simulada utilizando um modelo do software baseado no critério de Mohr-Coulomb, cujos parâmetros de entrada são a coesão e o coeficiente de atrito. Os resultados numéricos apresentaram boa concordância com os experimentais.

Santos (2014) realizou uma modelagem numérica de lajes mistas de aço e concreto em situação de incêndio empregando o software DIANA ${ }^{\circledR}$. Modelou-se $1 / 4$ da nervura da laje mista, considerando as simetrias longitudinal e transversais. No que diz respeito ao modelo estrutural da análise, empregou-se elementos sólidos do tipo HX8HT para o concreto, elementos de casca do tipo CHX60 para a fôrma de aço e elementos de interface do tipo CQ48I para a interação 
aço-concreto. Com relação aos modelos constitutivos, utilizou-se o Total Strain Crack Model para o concreto, um diagrama tensão-deformação multilinear para o aço e o modelo Bond-Slip para interface. Tal modelo de interface inclui uma relação linear inicial, regida por rigidezes normal e tangencial, e uma relação tensão-deslizamento para o comportamento não linear do elemento. Uma vez realizada a análise termoestrutural, o autor validou os modelos e realizou a análise paramétrica.

No estudo numérico e experimental realizado por Hedaoo, Raut e Gupta (2015) realizou-se ensaios de flexão de lajes mistas e os modelou utilizando o software ANSYS ${ }^{\circledR}$. Simulou-se $1 / 4$ da laje empregando as condições de simetrias longitudinal e transversais. O concreto foi modelado com elementos sólidos de 8 nós, enquanto a fôrma de aço foi modelada com elementos de casca de 4 nós. A interface, por sua vez, foi modelada com elementos de contato (CONTAC 52) - definido por duas rigidezes, um coeficiente de amortecimento, um comprimento associado e uma força de deslizamento limitante - e elementos de combinação (COMBIN 40) - definido por duas rigidezes, um intervalo inicial e um status inicial do elemento. Empregou-se um material não-linear dos $\mathrm{ANSYS}^{\circledR}$, que considera a fissuração e o esmagamento, para o concreto e um material elástico-plástico com encruamento para o aço da fôrma. Os resultados da simulação foram satisfatórios e realizou-se uma análise paramétrica avaliando a influência do comprimento do vão de cisalhamento.

Rabanal et al. (2016) realizaram um estudo numérico e experimental objetivando analisar o comportamento de lajes mistas constituídas por concreto leve e concreto normal. Utilizou-se o software ANSYS ${ }^{\circledR}$ e modelou-se apenas $1 / 4$ da nervura das lajes, considerando as condições de simetria longitudinal e transversais. As mossas da fôrma também foram modeladas. O concreto e a fôrma de aço foram modelados com elementos sólidos de 8 nós e de casca de 4 nós, respectivamente, ambos com modelos constitutivos que foram definidos por leis multilineares que consideram a plasticidade. A interface foi modelada com elementos de contato que consideram o atrito por meio do modelo de Coulomb, assim como a coesão, que foi incluída para simular a ligação química entre o aço e o concreto. Os autores utilizaram resultados de ensaios do tipo pull-out para modelar a interface. Os resultados numéricos apresentaram boa correlação com os experimentais

Rana (2016) realizou um estudo numérico e experimental sobre lajes mistas de aço e concreto protendidas, empregando o software ABAQUS ${ }^{\circledR} /$ Explicit. Foi simulado o ensaio pushout (semelhante ao desenvolvido por Burnet (1998)) dos protótipos protendidos e o ensaio de flexão das lajes mistas protendidas. No caso do modelo do ensaio de flexão, simulou-se uma nervura da laje, considerando as condições de simetria transversais. Além disso, o autor também 
simulou as ancoragens de extremidade para avaliar seu efeito sobre o comportamento das lajes. O concreto foi modelado com elementos sólidos do tipo C3D8R e a fôrma de aço com elementos de casca do tipo S4R. A interface foi modelada com elementos do tipo radial-thrust (CONN3D2) empregando os resultados obtidos do ensaio do tipo push-out. O material constitutivo do concreto foi o Concrete Damaged Plasticity e o do aço da fôrma foi considerado como um material elástico-plástico com encruamento. Após a validação dos modelos, foi realizada uma análise paramétrica dos ensaios de flexão. O emprego dos ensaios push-out para simular a interface apresentou resultados satisfatórios.

Ríos et al. (2017) desenvolveram um modelo de elementos finitos que reproduz o comportamento do cisalhamento longitudinal das lajes mistas estudadas. Simulou-se $1 / 4$ da nervura, empregando condições de simetria longitudinal e transversais. O software utilizado

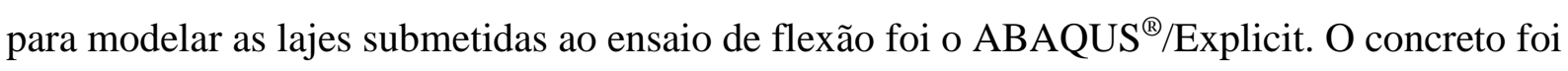
modelado com o modelo Concrete Damaged Plasticity e o aço da fôrma foi considerado como um material elástico-plástico perfeito. A interface aço-concreto foi simulada empregando conectores do tipo radial-thrust (CONN3D2) com uma lei de comportamento não-linear para o cisalhamento longitudinal desenvolvida pelos autores. Essa lei está relacionada à geometria e foi calculada com base na curva da carga versus flecha das lajes mistas ensaiadas sob flexão, em que se empregou o Método da Interação Parcial para calcular a tensão de cisalhamento e um processo iterativo para calcular os respectivos deslizamentos. Para o concreto empregou-se elementos sólidos do tipo C3D8R e para a fôrma de aço utilizou-se elementos de casca do tipo S4R. Os modelos numéricos foram validados com base nos resultados dos ensaios de flexão a quatro pontos realizados por Cifuentes e Medina (2013) e nos resultados dos ensaios de flexão a seis pontos realizados pelos próprios autores com o objetivo de simular um carregamento distribuído. Na análise paramétrica os autores empregaram o método de interpolação linear desenvolvido por Abdullah (2004) para obter os dados do comportamento da interface. De um modo geral, observou-se boa correlação entre os resultados numéricos e experimentais.

Hossain, Attarde e Anwar (2019) realizaram uma modelagem numérica de lajes mistas formadas com Compósito Cimentício Projetado (Engineered Cementitious Composite - ECC) e concreto auto adensável (Self-Consolidating Concrete - SCC). As lajes foram simuladas completamente, empregando o software ABAQUS ${ }^{\circledR}$. O concreto foi modelado com o modelo Concrete Damaged Plasticity e o comportamento do aço foi modelado como elástico-plástico considerando o encruamento. Empregou-se elementos sólidos hexaédricos do tipo C3D8R para o concreto e elementos de casca quadriláteros do tipo S4R para a fôrma de aço. As barras de aço utilizadas para combater os efeitos da temperatura e da retração foram modeladas usando 
elementos de treliça linear 3D (T3D2). Para a definição da interface aço-concreto foram avaliados três tipos de contato: deslizamento cinemático finito (kinematic-finite sliding), deslizamento cinemático pequeno (kinematic-small sliding) e contato de penalidade (penalty contact). Esse último tipo de contato proporcionou uma melhor simulação e resultados satisfatórios, sendo o modelo adotado para a análise paramétrica. Nessa análise, realizou-se um estudo extensivo para investigar a influência dos parâmetros numéricos, de material e geométricos sobre a reposta carga-deslocamento, resistência, desenvolvimento da tensãodeformação no concreto e características da relação carga-deslizamento. Os resultados desse estudo sugeriram que os modelos não-lineares deveriam empregar análise com controle de deslocamentos com restrição de carga acoplada, modelo Concrete Damage Plasticity modificado e interação de contato penalizada explícita do tipo surface-to-surface entre o aço e o concreto.

Pereira e Simões (2019) realizaram um estudo numérico e experimental sobre a resistência ao cisalhamento vertical de lajes mistas. O modelo numérico foi desenvolvido no software ABAQUS ${ }^{\circledR} /$ Explicit e considerou-se as simetrias longitudinal e transversais, de modo que foi modelada apenas $1 / 4$ de uma nervura da laje. Utilizou-se elementos sólidos do tipo C3D8R e de casca do tipo S4R, respectivamente, para modelar o concreto e a fôrma de aço. O modelo Concrete Damaged Plasticity foi utilizado para modelar o comportamento do concreto, enquanto o aço foi considerado com comportamento elástico-plástico com encruamento. Utilizou-se um modelo de contato para simular a interface aço-concreto, com a propriedade normal hard contact e a tangencial regida pela lei de atrito de Coulomb. O modelo numérico foi calibrado e fez-se uma análise paramétrica avaliando propriedades geométricas da laje.

No trabalho realizado por Soltanalipour et al. (2020) simulou-se lajes mistas submetidas à flexão a quatro pontos e ao carregamento uniformemente distribuído, utilizando o software ANSYS $^{\circledR}$. O estudo foi focado nos mecanismos de transferência de deslizamento da interface aço-concreto, portanto modelou-se as mossas da fôrma de aço. Foi simulada metade da nervura da laje, considerando as simetrias longitudinal e transversais. O concreto foi modelado com elementos sólidos do tipo SOLID65 e a fôrma de aço com elementos de casca do tipo SHELL281. Os modelos constitutivos do concreto e do aço foram um modelo do ANSYS ${ }^{\circledR}$ com critério de ruptura de Willam-Warnke e o elástico-plástico perfeito, respectivamente. A interface, por sua vez, foi modelada com elementos de contato do tipo CONTA174, que simulam a participação apenas do atrito. Os resultados do modelo numérico permitiram analisar a distribuição das tensões e deslizamento na interface e verificar a diferença destas mediante o tipo de carregamento aplicado (concentrado ou distribuído). 
A Tabela 7.1 sintetiza os trabalhos acima descritos de acordo com os autores.

Tabela 7.1 - Síntese das considerações realizadas nos trabalhos numéricos referenciados

\begin{tabular}{|c|c|c|c|c|c|}
\hline Trabalho & Software & Geometria & Componente & Estrutura & $\begin{array}{c}\text { Comportamento } \\
\text { do Material }\end{array}$ \\
\hline \multirow{3}{*}{$\begin{array}{l}\text { Abdullah } \\
\text { (2004) }\end{array}$} & \multirow{3}{*}{$\begin{array}{l}\text { ABAQUS }^{\circledR} / \\
\text { Explicit }\end{array}$} & \multirow{3}{*}{$\begin{array}{c}1 / 4 \text { da nervura } \\
\text { da laje mista } \\
\text { considerando } \\
\text { as simetrias } \\
\text { transversais } \\
\text { e } \\
\text { longitudinal }\end{array}$} & Concreto & $\begin{array}{c}\text { Elementos } \\
\text { sólidos de } 8 \\
\text { nós }\end{array}$ & $\begin{array}{l}\text { Compressão } \\
\text { elástico linear e } \\
\text { fissuração }\end{array}$ \\
\hline & & & Fôrma de aço & $\begin{array}{c}\text { Elementos } \\
\text { de casca de } \\
4 \text { nós }\end{array}$ & $\begin{array}{l}\text { Elástico-plástico } \\
\text { perfeito }\end{array}$ \\
\hline & & & Interface & $\begin{array}{l}\text { Elementos } \\
\text { conectores } \\
\text { radial-thrust }\end{array}$ & $\begin{array}{l}\text { Relação tensão } \\
\text { de cisalhamento } \\
\text { vs. deslizamento } \\
\text { obtida do ensaio } \\
\text { elementar de } \\
\text { flexão }\end{array}$ \\
\hline \multirow{3}{*}{$\begin{array}{l}\text { Ferrer, } \\
\text { Marimon } \\
\text { e Crisinel } \\
(2006)\end{array}$} & \multirow{3}{*}{ ANSYS $^{\circledR}$} & \multirow{3}{*}{$\begin{array}{c}\text { Simetria } \\
\text { longitudinal } \\
\text { dupla e } \\
\text { simetria } \\
\text { cíclica do } \\
\text { padrão das } \\
\text { mossas do } \\
\text { ensaio pull- } \\
\text { out } \\
\end{array}$} & Concreto & $\begin{array}{l}\text { Superfície } \\
\text { de contato }\end{array}$ & $\begin{array}{l}\text { Perfeitamente } \\
\text { rígido }\end{array}$ \\
\hline & & & Fôrma de aço & $\begin{array}{c}\text { Elementos } \\
\text { de casa de } 4 \\
\text { nós }\end{array}$ & $\begin{array}{l}\text { Elástico-plástico } \\
\text { perfeito }\end{array}$ \\
\hline & & & Interface & $\begin{array}{l}\text { Elementos } \\
\text { de contato }\end{array}$ & $\begin{array}{c}\text { Modelo de } \\
\text { Coulomb para o } \\
\text { atrito }\end{array}$ \\
\hline \multirow{3}{*}{$\begin{array}{c}\text { Ávila, } \\
\text { Quevedo e } \\
\text { Morfa } \\
(2009)\end{array}$} & \multirow{3}{*}{$\begin{array}{l}\text { ABAQUS }^{\circledR} / \\
\text { Implicit }\end{array}$} & \multirow{3}{*}{$\begin{array}{c}\text { Simetria } \\
\text { longitudinal } \\
\text { dupla e } \\
\text { simetria } \\
\text { cíclica do } \\
\text { padrão das } \\
\text { mossas do } \\
\text { ensaio pull- } \\
\text { out }\end{array}$} & Concreto & $\begin{array}{c}\text { Elementos } \\
\text { sólidos de } 8 \\
\text { nós e de } 4 \\
\text { nós }\end{array}$ & $\begin{array}{c}\text { Consideração do } \\
\text { esmagamento e } \\
\text { da fissuração }\end{array}$ \\
\hline & & & Fôrma de aço & $\begin{array}{c}\text { Elementos } \\
\text { de casca de } \\
4 \text { nós }\end{array}$ & $\begin{array}{l}\text { Elástico-plástico } \\
\text { perfeito }\end{array}$ \\
\hline & & & Interface & $\begin{array}{l}\text { Elementos } \\
\text { de contato } \\
\text { com } \\
\text { algoritmo } \\
\text { small sliding }\end{array}$ & $\begin{array}{c}\text { Não especificado } \\
\text { no trabalho }\end{array}$ \\
\hline \multirow{3}{*}{$\begin{array}{l}\text { Tsalkatidis } \\
\text { e Avdelas } \\
\text { (2010) }\end{array}$} & \multirow{3}{*}{ ANSYS $^{\circledR}$} & \multirow{3}{*}{$\begin{array}{l}1 / 2 \text { da laje } \\
\text { mista } \\
\text { considerando } \\
\text { a simetria } \\
\text { longitudinal }\end{array}$} & Concreto & $\begin{array}{c}\text { Elementos } \\
\text { sólidos de } 8 \\
\text { nós }\end{array}$ & $\begin{array}{c}\text { Consideração do } \\
\text { esmagamento e } \\
\text { da fissuração }\end{array}$ \\
\hline & & & Fôrma de aço & $\begin{array}{c}\text { Elementos } \\
\text { de casca de } \\
4 \text { nós }\end{array}$ & $\begin{array}{c}\text { Elástico-plástico } \\
\text { com } \\
\text { encruamento }\end{array}$ \\
\hline & & & Interface & $\begin{array}{l}\text { Elementos } \\
\text { de contato }\end{array}$ & $\begin{array}{c}\text { Modelo de } \\
\text { Coulomb com } \\
\text { atritos estático e } \\
\text { dinâmico }\end{array}$ \\
\hline
\end{tabular}




\begin{tabular}{|c|c|c|c|c|c|}
\hline Trabalho & Software & Geometria & Componente & Estrutura & $\begin{array}{c}\text { Comportamento } \\
\text { do Material }\end{array}$ \\
\hline \multirow{3}{*}{$\begin{array}{l}\text { Chen e Shi } \\
\text { (2011) }\end{array}$} & \multirow{3}{*}{$\mathrm{ANSYS}^{\circledR}$} & \multirow{3}{*}{$\begin{array}{l}\text { - } 1 / 2 \text { do ensaio } \\
\text { pull-out } \\
\text { - } 1 / 2 \text { da mista } \\
\text { considerando } \\
\text { a simetria } \\
\text { longitudinal }\end{array}$} & Concreto & $\begin{array}{c}\text { Elementos } \\
\text { sólidos de } 8 \\
\text { nós }\end{array}$ & $\begin{array}{c}\text { Consideração do } \\
\text { esmagamento e } \\
\text { da fissuração }\end{array}$ \\
\hline & & & Fôrma de aço & $\begin{array}{c}\text { Elementos } \\
\text { de casca de } \\
4 \text { nós }\end{array}$ & $\begin{array}{c}\text { Elástico-plástico } \\
\text { perfeito }\end{array}$ \\
\hline & & & Interface & $\begin{array}{l}\text { Elementos } \\
\text { de contato }\end{array}$ & $\begin{array}{l}\text { Consideração da } \\
\text { adesão e do atrito } \\
\text { do Modelo de } \\
\text { Coulomb }\end{array}$ \\
\hline \multirow{3}{*}{$\begin{array}{l}\text { Abdinasir, } \\
\text { Abdullah } \\
\text { e Mustaffa } \\
\text { (2012) }\end{array}$} & \multirow{3}{*}{$\begin{array}{l}\text { ABAQUS }^{\circledR} / \\
\text { Explicit }\end{array}$} & \multirow{3}{*}{$\begin{array}{c}1 / 4 \text { da nervura } \\
\text { da laje mista } \\
\text { considerando } \\
\text { as simetrias } \\
\text { transversais } \\
\text { e } \\
\text { longitudinal }\end{array}$} & Concreto & $\begin{array}{c}\text { Elementos } \\
\text { sólidos de } 8 \\
\text { nós }\end{array}$ & $\begin{array}{c}\text { Consideração do } \\
\text { esmagamento e } \\
\text { da fissuração }\end{array}$ \\
\hline & & & Fôrma de aço & $\begin{array}{c}\text { Elementos } \\
\text { de casca de } \\
4 \text { nós }\end{array}$ & $\begin{array}{c}\text { Elástico-plástico } \\
\text { perfeito }\end{array}$ \\
\hline & & & Interface & $\begin{array}{l}\text { Elementos } \\
\text { coesivos de } \\
8 \text { nós }\end{array}$ & $\begin{array}{l}\text { Relação tensão } \\
\text { de cisalhamento } \\
\text { vs. deslizamento- } \\
\text { ensaio elementar } \\
\text { de flexão }\end{array}$ \\
\hline \multirow{3}{*}{$\begin{array}{l}\text { Abas } \\
(2014)\end{array}$} & \multirow{3}{*}{$\begin{array}{l}\text { ABAQUS }^{\circledR} / \\
\text { Explicit }\end{array}$} & \multirow{3}{*}{$\begin{array}{c}1 / 2 \text { da nervura } \\
\text { da laje mista } \\
\text { considerando } \\
\text { as simetrias } \\
\text { transversais } \\
e \\
\text { longitudinal }\end{array}$} & Concreto & $\begin{array}{c}\text { Elementos } \\
\text { sólidos de } 8 \\
\text { nós }\end{array}$ & $\begin{array}{c}\text { Consideração do } \\
\text { esmagamento e } \\
\text { da fissuração }\end{array}$ \\
\hline & & & Fôrma de aço & $\begin{array}{c}\text { Elementos } \\
\text { de casca de } \\
4 \text { nós }\end{array}$ & $\begin{array}{c}\text { Elástico-plástico } \\
\text { perfeito }\end{array}$ \\
\hline & & & Interface & $\begin{array}{l}\text { Elementos } \\
\text { de contato }\end{array}$ & $\begin{array}{l}\text { Combinação de } \\
\text { coesão e atrito do } \\
\text { Modelo de } \\
\text { Coulomb }\end{array}$ \\
\hline \multirow{3}{*}{$\begin{array}{l}\text { Cheng, } \\
\text { Shi e Zhou } \\
\text { (2014) }\end{array}$} & \multirow{3}{*}{ ANSYS $^{\circledR}$} & \multirow{3}{*}{$\begin{array}{c}1 / 2 \text { da nervura } \\
\text { da laje mista } \\
\text { considerando } \\
\text { as simetrias } \\
\text { transversais } \\
e \\
\text { longitudinal }\end{array}$} & Concreto & $\begin{array}{c}\text { Elementos } \\
\text { sólidos de } 8 \\
\text { nós }\end{array}$ & $\begin{array}{l}\text { Consideração do } \\
\text { esmagamento e } \\
\text { da fissuração }\end{array}$ \\
\hline & & & Fôrma de aço & $\begin{array}{c}\text { Elementos } \\
\text { de casca de } \\
4 \text { nós }\end{array}$ & $\begin{array}{c}\text { Elástico-plástico } \\
\text { perfeito }\end{array}$ \\
\hline & & & Interface & $\begin{array}{l}\text { Elementos } \\
\text { de contato }\end{array}$ & $\begin{array}{l}\text { Consideração da } \\
\text { adesão e do atrito } \\
\text { do Modelo de } \\
\text { Coulomb }\end{array}$ \\
\hline
\end{tabular}




\begin{tabular}{|c|c|c|c|c|c|}
\hline Trabalho & Software & Geometria & Componente & Estrutura & $\begin{array}{c}\text { Comportamento } \\
\text { do Material }\end{array}$ \\
\hline \multirow{3}{*}{$\begin{array}{l}\text { Gholam- } \\
\text { hoseini et } \\
\text { al. (2014) }\end{array}$} & \multirow{3}{*}{ ATENA 3D } & \multirow{3}{*}{$\begin{array}{l}\text { Uma nervura } \\
\text { da laje mista } \\
\text { considerando } \\
\text { a simetria } \\
\text { longitudinal }\end{array}$} & Concreto & $\begin{array}{c}\text { Elementos } \\
\text { sólidos de } 4 \\
\text { nós }\end{array}$ & $\begin{array}{l}\text { Consideração do } \\
\text { esmagamento e } \\
\text { da fissuração }\end{array}$ \\
\hline & & & Fôrma de aço & $\begin{array}{c}\text { Elementos } \\
\text { sólidos de } 4 \\
\text { nós }\end{array}$ & $\begin{array}{l}\text { Elástico-plástico } \\
\text { perfeito }\end{array}$ \\
\hline & & & Interface & $\begin{array}{l}\text { Elementos } \\
\text { de contato }\end{array}$ & $\begin{array}{l}\text { Adesão e atrito } \\
\text { por meio do } \\
\text { modelo de Morh- } \\
\text { Coulomb }\end{array}$ \\
\hline \multirow{3}{*}{$\begin{array}{l}\text { Santos } \\
(2014)\end{array}$} & \multirow{3}{*}{$\begin{array}{l}\text { DIANA } \\
\text { FEA }^{\circledR}\end{array}$} & \multirow{3}{*}{$\begin{array}{l}1 / 4 \text { da nervura } \\
\text { da laje mista } \\
\text { considerando } \\
\text { as simetrias } \\
\text { transversais } \\
\text { e } \\
\text { longitudinal }\end{array}$} & Concreto & $\begin{array}{c}\text { Elementos } \\
\text { sólidos de } 8 \\
\text { nós }\end{array}$ & $\begin{array}{c}\text { Consideração do } \\
\text { esmagamento e } \\
\text { da fissuração }\end{array}$ \\
\hline & & & Fôrma de aço & $\begin{array}{c}\text { Elementos } \\
\text { de casca de } \\
4 \text { nós }\end{array}$ & Multilinear \\
\hline & & & Interface & $\begin{array}{l}\text { Elementos } \\
\text { de interface }\end{array}$ & $\begin{array}{l}\text { Relação tensão } \\
\text { de cisalhamento } \\
\text { vs. deslizamento }\end{array}$ \\
\hline \multirow{3}{*}{$\begin{array}{l}\text { Hedaoo, } \\
\text { Raut e } \\
\text { Gupta } \\
(2015)\end{array}$} & \multirow{3}{*}{ ANSYS $^{\circledR}$} & \multirow{3}{*}{$\begin{array}{l}1 / 4 \text { da nervura } \\
\text { da laje mista } \\
\text { considerando } \\
\text { as simetrias } \\
\text { transversais } \\
\text { e } \\
\text { longitudinal }\end{array}$} & Concreto & $\begin{array}{c}\text { Elementos } \\
\text { sólidos de } 8 \\
\text { nós }\end{array}$ & $\begin{array}{c}\text { Consideração do } \\
\text { esmagamento e } \\
\text { da fissuração }\end{array}$ \\
\hline & & & Fôrma de aço & $\begin{array}{c}\text { Elementos } \\
\text { de casca de } \\
4 \text { nós }\end{array}$ & $\begin{array}{c}\text { Elástico-plástico } \\
\text { com } \\
\text { encruamento }\end{array}$ \\
\hline & & & Interface & $\begin{array}{c}\text { Elementos } \\
\text { de contato e } \\
\text { de } \\
\text { combinação }\end{array}$ & $\begin{array}{c}\text { Rigidezes e } \\
\text { critério de } \\
\text { ruptura associado } \\
\text { à força deslizante }\end{array}$ \\
\hline \multirow{3}{*}{$\begin{array}{l}\text { Rabanal et } \\
\text { al. (2016) }\end{array}$} & \multirow{3}{*}{$\mathrm{ANSYS}^{\circledR}$} & \multirow{3}{*}{$\begin{array}{l}1 / 4 \text { da nervura } \\
\text { da laje mista } \\
\text { considerando } \\
\text { as simetrias } \\
\text { transversais } \\
\text { e } \\
\text { longitudinal }\end{array}$} & Concreto & $\begin{array}{c}\text { Elementos } \\
\text { sólidos de } 8 \\
\text { nós }\end{array}$ & $\begin{array}{l}\text { Consideração do } \\
\text { esmagamento e } \\
\text { da fissuração }\end{array}$ \\
\hline & & & Fôrma de aço & $\begin{array}{l}\text { Elementos } \\
\text { de casca de } \\
4 \text { nós }\end{array}$ & $\begin{array}{l}\text { Elástico-plástico } \\
\text { (multilinear) }\end{array}$ \\
\hline & & & Interface & $\begin{array}{l}\text { Elementos } \\
\text { de contato }\end{array}$ & $\begin{array}{l}\text { Adesão e atrito } \\
\text { do modelo de } \\
\text { Coulomb }\end{array}$ \\
\hline
\end{tabular}




\begin{tabular}{|c|c|c|c|c|c|}
\hline Trabalho & Software & Geometria & Componente & Estrutura & $\begin{array}{c}\text { Comportamento } \\
\text { do Material }\end{array}$ \\
\hline \multirow{3}{*}{$\begin{array}{l}\text { Rana } \\
\text { (2016) }\end{array}$} & \multirow{3}{*}{$\begin{array}{l}\text { ABAQUS }{ }^{\circledR} / \\
\text { Explicit }\end{array}$} & \multirow{3}{*}{$\begin{array}{l}\text { - push-out } \\
\text { - } 1 \text { nervura } \\
\text { considerando } \\
\text { as simetrias } \\
\text { transversais }\end{array}$} & Concreto & $\begin{array}{c}\text { Elementos } \\
\text { sólidos de } 8 \\
\text { nós }\end{array}$ & $\begin{array}{c}\text { Compressão } \\
\text { elástico linear e } \\
\text { fissuração }\end{array}$ \\
\hline & & & Fôrma de aço & $\begin{array}{c}\text { Elementos } \\
\text { de casca de } \\
4 \text { nós }\end{array}$ & $\begin{array}{c}\text { Elástico-plástico } \\
\text { perfeito }\end{array}$ \\
\hline & & & Interface & $\begin{array}{l}\text { Elementos } \\
\text { conectores } \\
\text { radial-thrust }\end{array}$ & $\begin{array}{c}\text { Relação tensão } \\
\text { de cisalhamento } \\
\text { vs. deslizamento } \\
\text { obtida do ensaio } \\
\text { push-out }\end{array}$ \\
\hline \multirow{3}{*}{$\begin{array}{l}\text { Ríos et al. } \\
\text { (2017) }\end{array}$} & \multirow{3}{*}{$\begin{array}{l}\text { ABAQUS }^{\circledR} / \\
\text { Explicit }\end{array}$} & \multirow{3}{*}{$\begin{array}{c}1 / 4 \text { da nervura } \\
\text { da laje mista } \\
\text { considerando } \\
\text { as simetrias } \\
\text { transversais } \\
\text { e } \\
\text { longitudinal }\end{array}$} & Concreto & $\begin{array}{c}\text { Elementos } \\
\text { sólidos de } 8 \\
\text { nós }\end{array}$ & $\begin{array}{l}\text { Compressão } \\
\text { elástico linear e } \\
\text { físsuração }\end{array}$ \\
\hline & & & Fôrma de aço & $\begin{array}{c}\text { Elementos } \\
\text { de casca de } \\
4 \text { nós }\end{array}$ & $\begin{array}{l}\text { Elástico-plástico } \\
\text { perfeito }\end{array}$ \\
\hline & & & Interface & $\begin{array}{l}\text { Elementos } \\
\text { conectores } \\
\text { radial-thrust }\end{array}$ & $\begin{array}{l}\text { Relação tensão } \\
\text { de cisalhamento } \\
\text { vs. deslizamento } \\
\text { obtida do método } \\
\text { desenvolvido } \\
\text { pelos autores }\end{array}$ \\
\hline \multirow{3}{*}{$\begin{array}{l}\text { Hossain, } \\
\text { Attarde e } \\
\text { Anwar } \\
(2019)\end{array}$} & \multirow{3}{*}{$\begin{array}{l}\text { ABAQUS }{ }^{\circledR} / \\
\text { Explicit }\end{array}$} & \multirow{3}{*}{$\begin{array}{l}\text { Laje mista } \\
\text { completa }\end{array}$} & Concreto & $\begin{array}{c}\text { Elementos } \\
\text { sólidos de } 8 \\
\text { nós }\end{array}$ & $\begin{array}{c}\text { Compressão } \\
\text { elástico linear e } \\
\text { fissuração }\end{array}$ \\
\hline & & & Fôrma de aço & $\begin{array}{c}\text { Elementos } \\
\text { de casca de } \\
4 \text { nós }\end{array}$ & $\begin{array}{c}\text { Elástico-plástico } \\
\text { com } \\
\text { encruamento }\end{array}$ \\
\hline & & & Interface & $\begin{array}{l}\text { Elementos } \\
\text { de contato }\end{array}$ & $\begin{array}{c}\text { Modelo de } \\
\text { Coulomb para o } \\
\text { atrito }\end{array}$ \\
\hline \multirow{3}{*}{$\begin{array}{l}\text { Pereira e } \\
\text { Simões } \\
(2019)\end{array}$} & \multirow{3}{*}{$\begin{array}{l}\text { ABAQUS }^{\circledR} / \\
\text { Explicit }\end{array}$} & \multirow{3}{*}{$\begin{array}{c}1 / 4 \text { da nervura } \\
\text { da laje mista } \\
\text { considerando } \\
\text { as simetrias } \\
\text { transversais } \\
\text { e } \\
\text { longitudinal }\end{array}$} & Concreto & $\begin{array}{c}\text { Elementos } \\
\text { sólidos de } 8 \\
\text { nós }\end{array}$ & $\begin{array}{l}\text { Compressão } \\
\text { elástico linear e } \\
\text { fissuração }\end{array}$ \\
\hline & & & Fôrma de aço & $\begin{array}{l}\text { Elementos } \\
\text { de casca de } \\
4 \text { nós }\end{array}$ & $\begin{array}{c}\text { Elástico-plástico } \\
\text { com } \\
\text { encruamento }\end{array}$ \\
\hline & & & Interface & $\begin{array}{l}\text { Elementos } \\
\text { de contato }\end{array}$ & $\begin{array}{c}\text { Modelo de } \\
\text { Coulomb para o } \\
\text { atrito } \\
\end{array}$ \\
\hline
\end{tabular}




\begin{tabular}{|c|c|c|c|c|c|}
\hline Trabalho & Software & Geometria & Componente & Estrutura & $\begin{array}{c}\text { Comportamento } \\
\text { do Material }\end{array}$ \\
\hline \multirow{3}{*}{$\begin{array}{l}\text { Soltanalipour } \\
\text { et al. (2020) }\end{array}$} & \multirow{3}{*}{ ANSYS $^{\circledR}$} & \multirow{3}{*}{$\begin{array}{c}1 / 4 \text { da nervura } \\
\text { da laje mista } \\
\text { considerando } \\
\text { as simetrias } \\
\text { transversais } \\
\mathrm{e} \\
\text { longitudinal }\end{array}$} & Concreto & $\begin{array}{l}\text { Elementos } \\
\text { sólidos de } \\
8 \text { nós }\end{array}$ & $\begin{array}{c}\text { Consideração do } \\
\text { esmagamento e } \\
\text { da fissuração }\end{array}$ \\
\hline & & & Fôrma de aço & $\begin{array}{c}\text { Elementos } \\
\text { de casca de } \\
4 \text { nós }\end{array}$ & $\begin{array}{c}\text { Elástico-plástico } \\
\text { perfeito }\end{array}$ \\
\hline & & & Interface & $\begin{array}{l}\text { Elementos } \\
\text { de contato }\end{array}$ & $\begin{array}{l}\text { Adesão e atrito } \\
\text { do modelo de } \\
\text { Coulomb }\end{array}$ \\
\hline
\end{tabular}

Fonte: Autoria própria

Os trabalhos acima descritos empregaram diferentes estruturas para o modelo numérico diante da simetria considerada, assim como diferentes modelos para simular o comportamento da interface aço-concreto das lajes mistas. Além disso, alguns realizaram uma modelagem mais detalhada, modelando as mossas, enquanto outros consideraram a presença das mossas por meio dos modelos de interface utilizados. A maioria dos trabalhos empregou, com êxito, modelos tridimensionais com elementos sólidos para modelar o concreto e elementos de casca para modelar a fôrma de aço. Os trabalhos que utilizaram o modelo de Coulomb para simular a ação do atrito na interface empregaram coeficientes de atrito entre 0,3 e 0,6.

Quando se considerou uma relação entre a tensão de cisalhamento e o deslizamento para simular a interface das lajes mistas, os trabalhos de Abdullah (2004) e Abdinasir, Abdullah e Mustaffa (2012) utilizam um formato semelhante ao ilustrado na Figura 7.1, em que, a partir de determinado deslizamento, a tensão de cisalhamento resistente se anula. Além disso, essa relação se altera de acordo com a esbeltez da laje, como foi explicado na seção 4.13. Comportamento semelhante a esse também foi utilizado por Ríos et al. (2017).

Figura 7.1 - Gráfico da tensão de cisalhamento versus deslizamento - Abdullah (2004)

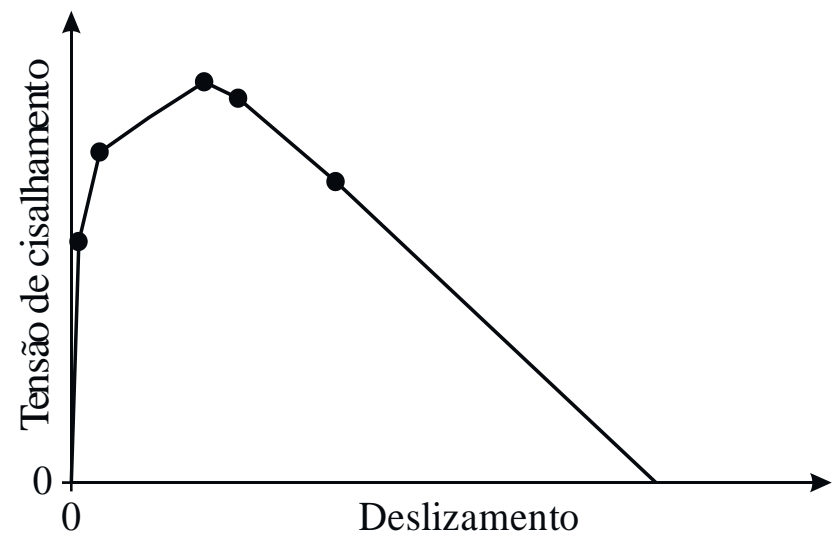

Fonte: Adaptado de ABDULLAH, 2004 
De modo geral, as técnicas empregadas para simular lajes mistas apresentaram bons resultados, que permitiram melhor compreensão do comportamento desses elementos estruturais, assim como realizar previsões, por meio de uma análise paramétrica, do comportamento de outras lajes não ensaiadas experimentalmente.

Em todos os casos foram necessários a realização de ensaios para poder simular o comportamento da interface aço-concreto. Dentre os trabalhos que empregaram parâmetros obtidos de ensaios de modelos de pequenas dimensões, entretanto, nenhum utilizou parâmetros obtidos por meio do ensaio slip-block.

Dessa forma, objetivando analisar melhor o comportamento da interface aço-concreto de lajes mistas e constatado que nenhum dos trabalhos presentes na literatura técnica empregou parâmetros obtidos do ensaio slip-block, desenvolveu-se a análise numérica apresentada a seguir, que emprega a metodologia desenvolvida neste trabalho para a obtenção dos parâmetros da interface.

\subsection{O Pacote Computacional DIANA ${ }^{\circledR}$}

O DIANA ${ }^{\circledR}$ consiste num extenso pacote de software de elementos finitos de uso múltiplo, dedicado a uma ampla gama de problemas oriundos da Engenharia Civil, como estruturas, geotecnia, engenharia de óleo e gás, entre outros. Foi desenvolvido desde 1972 por engenheiros civis da TNO Building and Construction Research Company, na Holanda.

O FX + DIANA é um pré e pós processador adicional ao pacote, incluso desde a versão 9.2, que possui uma interface gráfica que permite construir modelos complexos com mais rapidez e eficácia. Diante disso, essa ferramenta foi utilizada neste trabalho.

O pacote DIANA ${ }^{\circledR}$ oferece uma extensa biblioteca de elementos que permite a modelagem de estruturas complexas. A biblioteca possui elementos de viga retos e curvos, sólidos, membranas, placas, cascas, elementos de contato e elementos de interface. O software também disponibiliza vários modelos constitutivos complexos e interessantes em muitas simulações numéricas de estruturas, além de permitir a realização de análises estáticas e dinâmicas com ou sem linearidade física, análise termoestrutural, análise de fase, entre outras.

Os softwares que realizam simulações numéricas utilizando elementos finitos, em geral, possuem a mesma sequência de desenvolvimento da análise numérica. A sequência utilizada neste trabalho foi:

a) Pré-Processamento:

- Criação da geometria do modelo; 
- Definição das propriedades físicas dos materiais e da interface;

- Definição dos elementos finitos utilizados;

- Criação da malha de elementos finitos;

- Definição das condições de contorno;

- Definição do carregamento.

b) Processamento:

- Definição dos passos de carga;

- Definição do método de convergência;

- Definição da tolerância do erro da resposta obtida.

c) Pós-Processamento:

- Obtenção dos resultados do modelo numérico.

Apresentada acima a sequência da modelagem numérica, os aspectos da simulação numérica relacionados à construção dos modelos são apresentados a seguir, uma vez que os mesmos elementos finitos, materiais e interface foram empregados na modelagem dos ensaios slip-block e de flexão.

\subsection{Aspectos da Simulação Numérica}

Foram desenvolvidos modelos tridimensionais para simular os ensaios slip-block e de flexão da laje mista. Em ambos os casos se empregou os mesmos elementos finitos, modelos constitutivos e modelo de interface.

\subsubsection{Geometria da Seção Transversal}

Adotou-se algumas simplificações relacionadas à geometria da seção transversal da fôrma de aço, o que modifica a seção transversal dos modelos simulados, consequentemente. Dessa forma, considerou-se o perfil da fôrma linearizado, ou seja, desconsiderando a presença dos enrijecedores de mesa e os encaixes macho-fêmea, formando, assim, uma seção transversal simétrica em relação à um plano vertical que passe no seu centroide, conforme ilustra a Figura 7.2 .

Essa simplificação é usualmente empregada quando se trata da modelagem numérica de lajes mistas, conforme se verifica nos trabalhos presentes na literatura técnica, e pode ser adotada sem grandes prejuízos relacionados aos resultados provenientes da simulação numérica, conforme previamente analisado. 
Figura 7.2 - Seção transversal da fôrma de aço linearizada

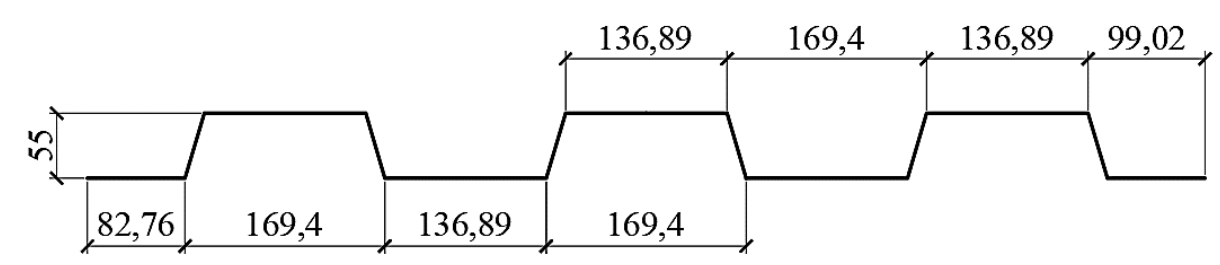

Fonte: Autoria própria

(Dimensões em milímetros)

As mossas presentes na fôrma de aço também não foram modeladas, uma vez que a sua presença será considerada por meio do modelo de interface utilizado, que simula a presença das ligações química, por atrito e mecânica entre a fôrma de aço e o concreto.

\subsubsection{Elementos Finitos Utilizados}

O concreto e os acessórios, no caso do modelo de laje mista, foram modelados com elementos sólidos do tipo HX24L (Figura 7.3 (a)), que consiste num elemento finito isoparamétrico com 8 nós, aproximação linear para os deslocamentos e integração de Gauss. Os polinômios para as translações $u_{\mathrm{xyz}}$ podem ser expressos pela Equação 7.1, em que $\xi, \eta$ e $\zeta$ são as direções locais do elemento.

$$
u_{\mathrm{i}}(\xi, \eta, \zeta)=a_{0}+a_{1} \xi+a_{2} \eta+a_{3} \zeta+a_{4} \xi \eta+a_{5} \eta \zeta+a_{6} \zeta \xi+a_{7} \xi \eta \zeta
$$

A fôrma de aço foi modelada com elementos de casca do tipo Q20SH (Figura 7.3 (b)), que é um elemento de casca curvo isoparamétrico quadrilateral de 4 nós, interpolação linear e integração de Gauss sobre a área do elemento. Os polinômios para as translações $u$ e as rotações $\phi$ podem ser expressos pelas Equações 7.2 e 7.3, respectivamente.

$$
\begin{gathered}
u_{\mathrm{i}}(\xi, \eta)=a_{0}+a_{1} \xi+a_{2} \eta+a_{3} \xi \eta \\
\phi_{\mathrm{i}}(\xi, \eta)=b_{0}+b_{1} \xi+b_{2} \eta+b_{3} \xi \eta
\end{gathered}
$$

A viga de distribuição, utilizada no modelo numérico definitivo da laje mista, foi modelada com o elemento do tipo L12BE (Figura 7.3 (c)), que é um elemento finito de viga tridimensional com dois nós e integração de Gauss. Os polinômios de interpolação para os deslocamentos podem ser expressos pelas Equações 7.4, 7.5 e 7.6.

$$
\begin{gathered}
u_{x}(\xi)=a_{0}+a_{1} \xi \\
u_{y}(\xi)=b_{0}+b_{1} \xi+b_{2} \xi^{2}+b_{3} \xi^{3} \\
u_{z}(\xi)=c_{0}+c_{1} \xi+c_{2} \xi^{2}+c_{3} \xi^{3}
\end{gathered}
$$


A interface aço-concreto foi modelada utilizando o elemento finito Q24IF (Figura 7.3 (d)), que consiste num elemento de interface entre dois planos numa configuração tridimensional e baseado numa interpolação linear. Os eixos locais xyz para os deslocamentos são avaliados no primeiro nó com $x$ do nó 1 para o nó 2 e $z$ perpendicular ao plano.

Figura 7.3 - Elementos finitos utilizados na simulação numérica

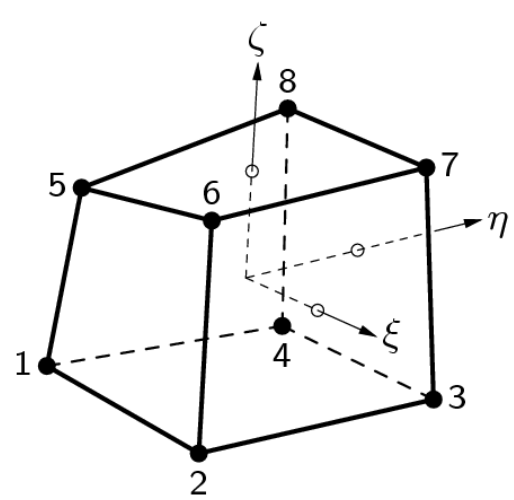

(a) Elemento sólido HX24L

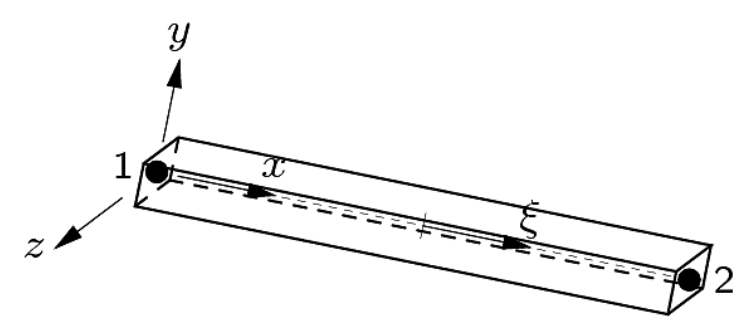

(c) Elemnto de viga L12BE

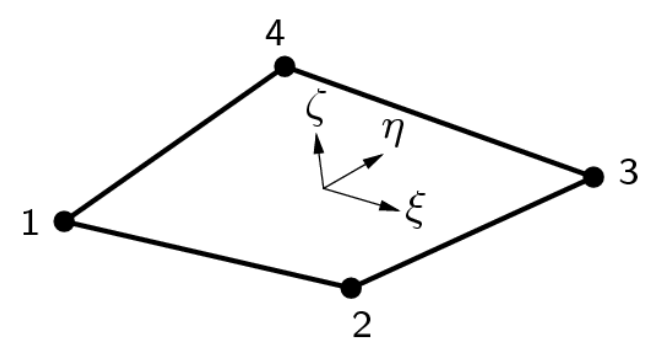

(b) Elemento de casca curvo Q20SH

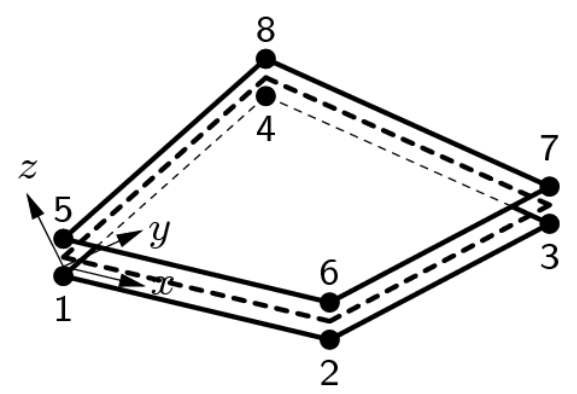

(d) Elemento de interface Q24IF

Fonte: Adaptado de DIANA, 2020

No caso do modelo da laje mista, não foi modelada a tela de aço que serve como armadura de retração, pois a participação dela sobre o comportamento da laje não é relevante, principalmente quando se objetiva analisar o comportamento da interface aço-concreto. Essa consideração foi baseada em simulações realizadas com e sem a presença da malha de aço, que não apresentaram diferenças significativas sobre o comportamento estrutural do modelo.

\subsubsection{Modelos Constitutivos}

\subsubsection{Concreto}

O comportamento do concreto é complexo e de difícil simulação devido ao seu desempenho no regime não-linear, uma vez que ao sofrer certa intensidade de solicitação, ocorre redução da sua capacidade resistente com acréscimo significativo de deformação. Isso é 
resultado do efeito do amolecimento do material (strain softening), que corresponde ao início da fissuração, e ocorre no comportamento tanto à tração quanto à compressão.

Para simular o efeito da fissuração existem basicamente dois tipos de modelos: modelos de fissuração distribuída (smeared crack models) e modelos de fissuração discreta (discrete crack models). No primeiro tipo de modelo, o material danificado pela abertura de fissuras é considerado como meio contínuo e as notações de tensão e deformação ainda podem ser aplicadas sem a necessidade de se construir uma nova malha enquanto as fissuras se propagam, segundo Ramos (2010). No modelo de fissuração discreta a fissura é tratada de forma muito realista, uma vez que para cada incremento de carga uma nova malha de elementos finitos é gerada na região de propagação da fissura.

Neste trabalho utilizou-se o modelo de fissuração distribuída baseado na deformação total (Total Strain Crack Model), que foi desenvolvido ao longo das linhas da Teoria dos Campos de Compressão Modificada, proposta originalmente por Vecchio e Collins (1986). Sendo um modelo de fissura multidirecional, os modelos de fissuração baseados na deformação total seguem uma abordagem difusa para a energia de fratura. A extensão tridimensional dessa teoria foi proposta por Selby e Vecchio (1993), cuja descrição teórica foi seguida durante a implementação do DIANA ${ }^{\circledR}$.

O modelo baseado na deformação total descreve, portanto, o comportamento à tração e à compressão do concreto com base numa relação tensão-deformação. Existem duas abordagens diferentes para o uso desse modelo: Total Strain Rotating Crack Model e Total Strain Fixed Crack Model. O primeiro modelo permite que a abertura da fissura mude de direção enquanto ela se propaga, ou seja, as fissuras corrotacionam com os eixos da deformação principal, de modo que a direção da fissura coincida com a direção principal da deformação. Já o modelo Total Strain Fixed Crack mantém o mesmo ângulo da abertura da primeira fissura, permitindo que esta mude de direção apenas nos casos em que a variação do ângulo da fissura seja igual a $90^{\circ}$ em relação ao ângulo inicial. Neste trabalho empregou-se a abordagem Total Strain Fixed Crack Model.

As informações necessárias para a utilização desse modelo compreendem a definição dos comportamentos linear e não-linear do concreto. Dessa forma, para definição do comportamento linear são necessários valores do módulo de elasticidade $\left(E_{\mathrm{c}}\right)$ e do coeficiente de Poisson $\left(v_{\mathrm{c}}\right)$. Em seguida, são definidos os comportamentos do concreto à tração, à compressão e ao cisalhamento.

Para definição do comportamento do concreto à tração e à compressão, o software DIANA $^{\circledR}$ dispõe de uma biblioteca com diversas leis constitutivas baseadas na mecânica da 
fratura, assim como multilineares que podem ser inseridas pelo usuário. Além disso, algumas leis são modelos constitutivos preconizados por normas internacionais, como o CEB-FIP Model Code (2010) e o Eurocode 2 (1992), por exemplo. Dessa forma, os parâmetros necessários para a definição do comportamento do concreto são: largura de banda de fissura $(h)$, resistência à tração $\left(f_{\mathrm{t}}\right)$, energia de fratura à tração $\left(G_{\mathrm{f}}\right)$, resistência à compressão $\left(f_{\mathrm{c}}\right)$, energia de fratura à compressão $\left(G_{\mathrm{c}}\right)$ e o coeficiente de retenção ao cisalhamento $(\beta)$.

A largura de banda de fissura $(h)$ é um parâmetro utilizado para suprir a dependência da malha, fazendo com que a caracterização do surgimento da fissura e do efeito de dano irreversível possa ser feita em determinado elemento finito, segundo Ramos (2010). Seu valor deve corresponder a uma dimensão representativa dos elementos da malha, sendo dependente do tipo de elemento e de sua forma. Tal parâmetro pode ser fornecido pelo usuário ou calculado automaticamente pelo software. Neste último caso, $h$ é igual a raiz cúbica do volume do elemento, quando se utiliza elementos sólidos.

Os parâmetros de energia de fratura $\left(G_{\mathrm{f}}\right.$ e $\left.G_{\mathrm{c}}\right)$ são necessários para produzir o efeito irreversível do dano no material. Na ausência de resultados experimentais, estes os parâmetros podem ser estimados com base nas recomendações normativas ou da literatura técnica.

O coeficiente de retenção de cisalhamento $(\beta)$ é um parâmetro que reduz o módulo de elasticidade transversal do material após o início da fissuração, de modo que essa redução pode ser por completa, constante ou variável. Na situação de retenção completa, o módulo de elasticidade transversal não é reduzido. Já na situação de retenção constante, o usuário define um valor para o parâmetro dentro do intervalo entre 0 e 1 . Em se tratando de problemas em que o cisalhamento é importante no modo de ruptura, o valor de $\beta$ deve ser próximo de zero; quando o cisalhamento não for relevante no modo de ruptura, o valor de $\beta$ dever ser próximo de 1 , segundo Diogenes (2013).

No caso de retenção variável, o DIANA $^{\circledR}$ possibilita a utilização de modelos multilineares baseados na curva da tensão de cisalhamento versus deformação por cisalhamento ou na curva do parâmetro de retenção versus deformação por cisalhamento.

Tanto no modelo do ensaio slip-block quanto no modelo da laje mista, utilizou-se os mesmos modelos de comportamento para o concreto. O modelo do comportamento à tração utilizado foi o proposto por Hordijk (1991), que possui uma expressão para o amolecimento do concreto, cuja relação da tensão versus deformação está ilustrada na Figura 7.4 (a). Já o modelo de comportamento à compressão utilizado foi o preconizado pelo CEB-FIP Model Code (2010), cuja relação da tensão versus deformação está ilustrada na Figura 7.4 (b). 
Figura 7.4 - Comportamento do concreto adotado no modelo numérico

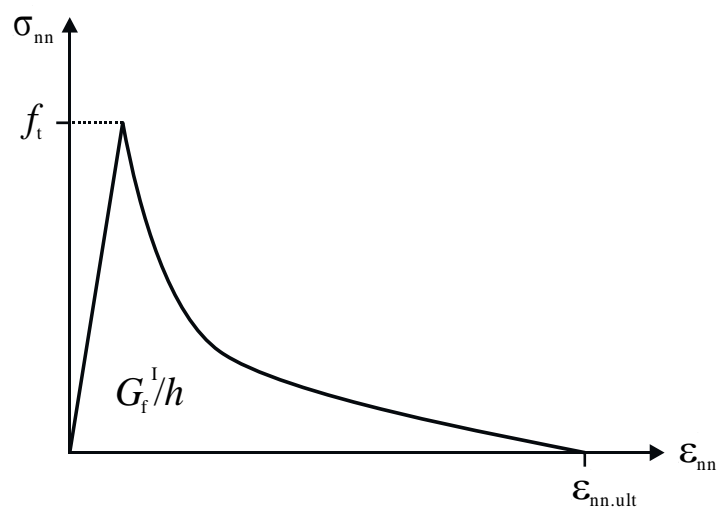

(a) Comportamento à tração Hordijk (1991)

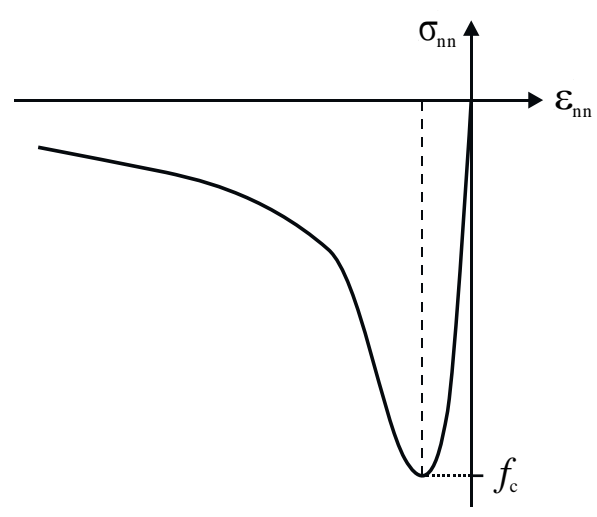

(b) Comportamento à compressão CEB-FIP Model Code (2010)

Fonte: Adaptado de DIANA, 2020

Neste trabalho o Total Strain Crack Model foi utilizado por meio do software MeshEdit, do pacote DIANA ${ }^{\circledR}$, após conceber a estrutura completa do modelo no software FX+DIANA.

\subsubsection{Aço}

O modelo constitutivo adotado para o aço da fôrma foi o elástico-plástico perfeito, ilustrado na Figura 7.5, cuja relação tensão-deformação à tração e a compressão são iguais.

Figura 7.5 - Comportamento do aço adotado no modelo numérico

Fonte: Autoria própria

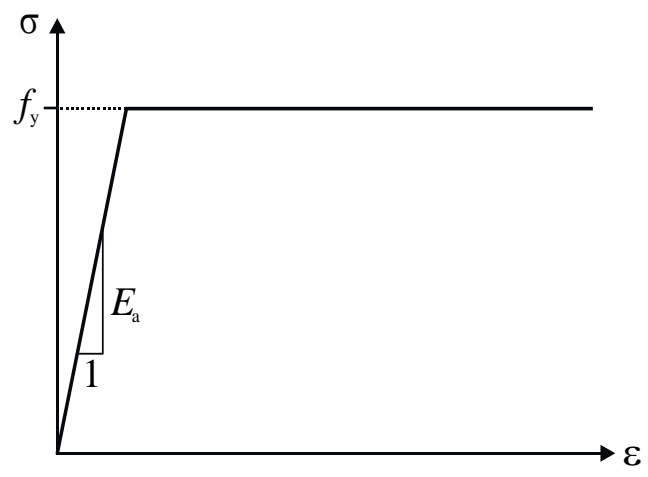

O trecho elástico é definido pelo módulo de elasticidade $\left(E_{\mathrm{a}}\right)$ e o coeficiente de Poisson do aço $\left(v_{\mathrm{a}}\right)$. O critério de ruptura utilizado foi o de Von Mises, usualmente empregado para materiais dúcteis, como o aço. A Equação 7.7 define esse critério de ruptura, em que $f_{\mathrm{y}}$ é a tensão de escoamento e $\sigma_{\mathrm{p} 1}, \sigma_{\mathrm{p} 2}$ e $\sigma_{\mathrm{p} 3}$ são as tensões principais.

$$
\sqrt{\frac{\left(\sigma_{\mathrm{p} 1}-\sigma_{\mathrm{p} 2}\right)^{2}+\left(\sigma_{\mathrm{p} 1}-\sigma_{\mathrm{p} 3}\right)^{2}+\left(\sigma_{\mathrm{p} 2}-\sigma_{\mathrm{p} 3}\right)^{2}}{2}}<f_{\mathrm{y}}
$$




\subsubsection{Interface Aço-Concreto}

Para a definição do comportamento de interfaces, a biblioteca de materiais do pacote DIANA ${ }^{\circledR}$ fornece alguns modelos para vários tipos de elementos finitos de interface. Esses elementos relacionam as tensões que atuam na interface ao deslocamento relativo das suas duas direções, como ilustra a Figura 7.6, para interfaces tridimensionais, sendo $n$ a direção normal à interface e $t$ e $s$ as direções tangenciais.

Figura 7.6 - Características do elemento finito de interface<smiles>C=CC=CC=C</smiles>

(a) Deslocamentos

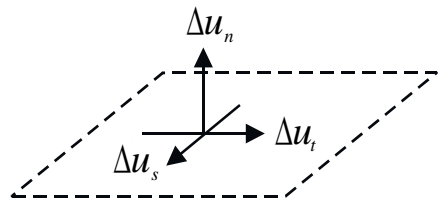

(b) Deslocamentos relativos

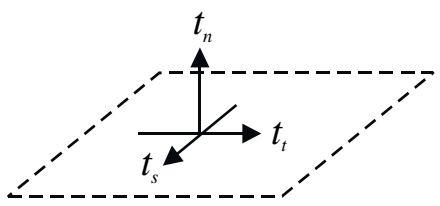

(c) Tensões

Fonte: DIANA, 2020

Os vetores deslocamento, deslocamento relativo e tensão são expressos pelas equações 7.8, 7.9 e 7.10, respectivamente.

$$
\mathbf{u}_{\mathbf{e}}=\left\{\begin{array}{l}
u_{n} \\
u_{t} \\
u_{s}
\end{array}\right\} \quad(7.8) \quad \boldsymbol{\Delta}_{\mathbf{u}}=\left\{\begin{array}{l}
\Delta u_{n} \\
\Delta u_{t} \\
\Delta u_{s}
\end{array}\right\} \quad \mathbf{t}=\left\{\begin{array}{l}
t_{n} \\
t_{t} \\
t_{s}
\end{array}\right\}
$$

A relação constitutiva elástica linear entre o vetor tensão e o vetor de deslocamento relativo é dada pela Equação 7.11, em que $k_{n}$ é a rigidez normal e $k_{t}$ e $k_{s}$ são as rigidezes tangenciais da interface. Se $k_{s}$ não é atribuído, o modelo o assume igual à $k_{t}$.

$$
\left\{\begin{array}{l}
t_{n} \\
t_{t} \\
t_{s}
\end{array}\right\}=\left[\begin{array}{ccc}
k_{n} & 0 & 0 \\
0 & k_{t} & 0 \\
0 & 0 & k_{s}
\end{array}\right]\left\{\begin{array}{l}
\Delta u_{n} \\
\Delta u_{t} \\
\Delta u_{s}
\end{array}\right\}
$$

Uma vez que o deslocamento relativo geralmente ocorre em apenas uma direção, a abordagem do modelo pode ser simplificada, aplicando-o apenas às direções $n$ e $t$. A relação constitutiva geral, portanto, é assumida como sendo incrementalmente linear, como apresenta a Equação 7.12, em que $\dot{\mathfrak{t}}$ é o vetor tensão de cisalhamento, $\Delta \dot{\mathbf{u}}$ o vetor de deslizamento relativo e D a matriz de rigidez, dada pela Equação 7.13.

$$
\dot{\mathbf{t}}=\mathbf{D} \Delta \dot{\mathbf{u}}
$$




$$
\mathbf{D}=\left[\begin{array}{ll}
D_{11} & D_{12} \\
D_{21} & D_{22}
\end{array}\right]
$$

Os coeficientes de rigidez da matriz $\mathbf{D}$ são geralmente dependentes de $\Delta u_{n}, \Delta u_{t}, t_{n}, t_{t} \mathrm{e}$ outros parâmetros possíveis, de acordo com o modelo constitutivo adotado para a interface.

Dentre os modelos constitutivos de interface disponíveis no pacote DIANA ${ }^{\circledR}$, existe o modelo denominado Coulomb Friction, que possui uma semelhança muito próxima com o modelo de plasticidade de Mohr-Coulomb para elementos contínuos. Nesse modelo de interface, a suposição da decomposição dos deslocamentos tangenciais relativos totais ( $\Delta \dot{\mathbf{u}}$ ) na parcela reversível ( $\left.\Delta \dot{\mathbf{u}}^{\mathbf{e}}\right)$ e na parcela irreversível ( $\left.\Delta \dot{\mathbf{u}}^{\mathbf{p}}\right)$ é expressa pela Equação 7.14.

$$
\Delta \dot{\mathbf{u}}=\Delta \dot{\mathbf{u}}^{\mathrm{e}}+\Delta \dot{\mathbf{u}}^{p}
$$

No regime elástico linear a parcela irreversível não existe e $D_{11}=k_{t}, D_{22}=k_{s}$ e $D_{12}=$ $D_{21}=0$. No regime plástico, $\Delta \dot{\mathbf{u}}^{\mathbf{p}}$ é determinado seguindo o fluxo da teoria da plasticidade, que no modelo Coulomb Friction é basicamente dada pelo critério de ruptura (Equação 7.15) e pela superfície potencial plástica (Equação 7.16).

$$
\begin{gathered}
f=\sqrt{t_{t}^{2}}+t_{n} \tan \phi(\kappa)-c(\kappa)=0 \\
g=\sqrt{t_{t}^{2}}+t_{n} \tan \psi
\end{gathered}
$$

Nas equações acima, $\tan \phi(\kappa)$ é o coeficiente de atrito $(\mu)$ e $c(\kappa)$ é a coesão, ambos em função do parâmetro interno $K$. A direção dos deslocamentos irreversíveis é dada pela função potencial plástica $g$, em que a "elevação" é determinada pelo ângulo de dilatância $\psi$. O parâmetro interno $\kappa$, por sua vez, é assumido como sendo definido pelo componente de deslocamento irreversível na direção $t\left(\Delta u_{\mathrm{p}}\right)$.

O critério de ruptura pode ser constante, assumindo $\mu$ e $c$ constantes, ou pode ser variável em função do deslocamento irreversível (plástico), chamado de Hardening pelo DIANA ${ }^{\circledR}$. Neste último caso, é necessário fornecer ao software os pontos das curvas de $\mu$ versus $\kappa$ e de $c$ versus $\kappa$.É importante salientar que cada curva deve possuir, no máximo, 25 pontos.

O modelo Coulomb Friction também dispõe de um critério de separação em que o DIANA $^{\circledR}$ assume que uma separação surge se $t_{n}$ excede um certo valor especificado pelo usuário, denominado tension cut-off $\left(f_{\mathrm{t}}\right)$. Após a formação da separação, $t_{n}$ é reduzida a zero imediatamente. $\mathrm{O}$ valor padrão utilizado pelo software corresponde ao máximo do modelo Coulomb Friction: $f_{\mathrm{t}}=c / \tan \phi$. 
Outra maneira de expressar o critério de ruptura do modelo, dado pela Equação 7.15, é apresentado pela Equação 7.17.

$$
t_{t}=c(\kappa)-t_{n} \tan \phi(\kappa)
$$

A equação acima estabelece uma relação linear entre $t_{\mathrm{t}}$ e $t_{n}$, semelhante à Equação 6.1 da metodologia desenvolvida neste trabalho empregando o ensaio slip-block, reescrita na Equação 7.18 , a qual relaciona a força horizontal $\left(F_{\mathrm{H}}\right)$ com a força vertical $\left(F_{\mathrm{V}}\right)$, sendo que $\mu \mathrm{e}$ $F_{\mathrm{m}}$ variam em função do deslizamento $(s)$.

$$
F_{\mathrm{H}}(s)=F_{\mathrm{m}}(s)+\mu(s) \cdot F_{\mathrm{V}}
$$

A diferença entre a Equação 7.17 e a Equação 7.18 é que a primeira relaciona as tensões normal $\left(t_{n}\right)$ e tangencial $\left(t_{t}\right)$ sobre a interface, enquanto a segunda relaciona as forças vertical $\left(F_{\mathrm{V}}\right)$ e horizontal $\left(F_{\mathrm{H}}\right)$ sobre o protótipo do ensaio slip-block. Além disso, o sinal negativo na equação acima se dá porque quando a tensão normal é de compressão, $t_{n}$ possui valor negativo.

As tensões $t_{n}$ e $t_{t}$ estão associadas à $F_{\mathrm{V}}$ e $F_{\mathrm{H}}$, respectivamente, mediante a distribuição de tensões no modelo do ensaio slip-block. Entretanto, para a determinação do critério de ruptura, são necessários apenas os valores dos parâmetros $c(\kappa)$ e $\tan \phi(\kappa)$. Logo, devido à correlação existente entre a metodologia desenvolvida neste trabalho e a do modelo de interface Coulomb Friction, optou-se por utilizá-lo para simular o comportamento da interface nos modelos numéricos deste trabalho. Este também foi o motivo pelo qual se escolheu o pacote DIANA $^{\circledR}$ para realizar a análise numérica.

Sendo assim, na simulação numérica da interface aço-concreto a coesão $c(\kappa)$ e $\tan \phi(\kappa)$ são tratados como sendo, respectivamente, a tensão mecânica resistente $\left(\tau_{\mathrm{m}}\right)$ e o coeficiente de atrito global $(\mu)$, definidos na seção 6.3.2.1. Uma vez que $\kappa$ é definido pela componente de deslocamento plástico $\left(\Delta u_{\mathrm{p}}\right)$, este parâmetro é assumido igual ao próprio deslizamento $s$, que ocorre após a ruptura da ligação química no ensaio slip-block.

Tem-se, portanto, um critério de plastificação tridimensional, definido pelos parâmetros $c(\kappa), \tan \phi(\kappa)$ e $\kappa$, em que $c(\kappa)=\tau_{\mathrm{m}}, \tan \phi(\kappa)=\mu$ e $\kappa=\Delta u_{\mathrm{p}}=s$, quando se utiliza os valores dos parâmetros determinados pela metodologia apresentada na seção 6.3.2.1.

Dessa forma, o modelo de interface simula a presença das ligações química (comportamento linear inicial), por atrito (modelo de atrito de Coulomb, definido pelo parâmetro $\mu$ ) e mecânica (considerada como coesão, definida pelo parâmetro $c$ ). 


\subsection{Análise Numérica do Ensaio Slip-Block}

A análise numérica do ensaio slip-block consistiu na elaboração do modelo numérico, na análise da influência da malha sobre o resultado numérico e na validação do modelo. Antes da validação foi realizada uma análise da influência de cada parâmetro do modelo de interface sobre o comportamento do modelo numérico.

\subsubsection{Modelo Numérico do Ensaio Slip-Block}

O protótipo do ensaio slip-block foi modelado por completo, não utilizando nenhuma consideração de simetria, uma vez que o modelo é relativamente pequeno e não exigia significativo custo computacional para seu processamento. Dessa forma, o modelo numérico possui as mesmas dimensões do protótipo do ensaio, descritas na Figura 6.5 da seção 6.3.1.

\subsubsection{Estrutura do Modelo e Propriedades dos Materiais}

A estrutura do modelo do ensaio slip-block é composta por três partes: capa de concreto, fôrma de aço e interface aço-concreto, conforme ilustra a Figura 7.7, em que se utilizou elementos finitos com dimensão máxima de $30 \mathrm{~mm}$ para representar a malha do modelo.

Figura 7.7 - Estrutura do modelo numérico do ensaio slip-block

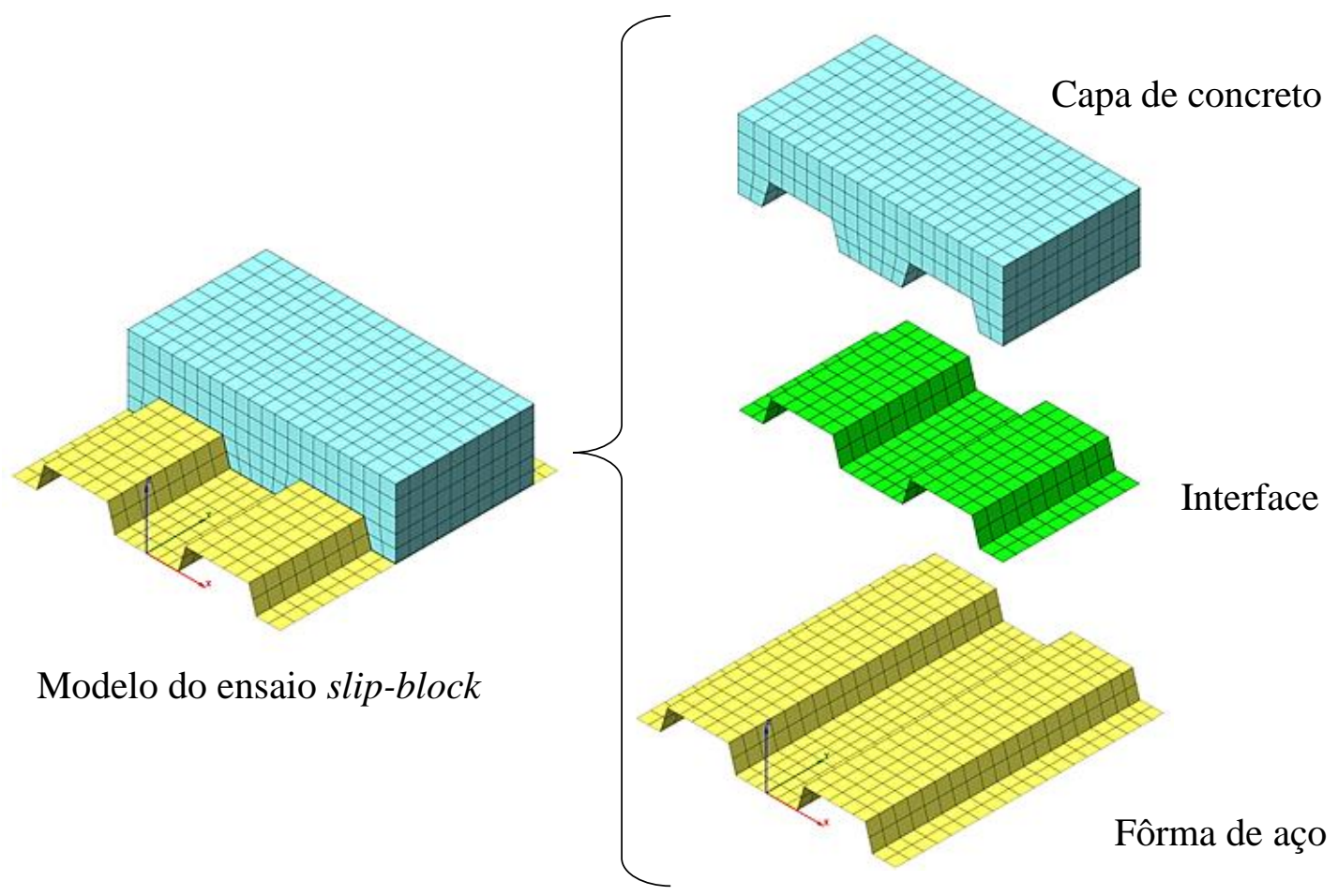

Fonte: Autoria própria 
As propriedades utilizadas para o concreto foram as obtidas experimentalmente (seção 6.2.1), com exceção do módulo de elasticidade (calculado segundo a ABNT NBR 6118: 2014), do coeficiente de Poisson (adotado igual a 0,2) e da energia de fratura, que foi estimada com base na norma CEB-FIP Model Code (2010). A Tabela 7.2 apresenta as propriedades utilizadas para modelar comportamento do concreto empregando o modelo Total Strain Crack Model.

Tabela 7.2 - Parâmetros do concreto do modelo numérico do ensaio slip-block

\begin{tabular}{cc}
\hline Modelo Total Strain Crack & Fixed \\
Largura de banda da fissura $(\boldsymbol{h})$ & $30 \mathrm{~mm}$ \\
Módulo de Elasticidade $\left(\boldsymbol{E}_{\mathbf{c}}\right)$ & $31.950 \mathrm{~N} / \mathrm{mm}^{2}$ \\
Coeficiente de Poisson $\left(\boldsymbol{v}_{\mathbf{c}}\right)$ & 0,2 \\
Resistência à tração $\left(\boldsymbol{f}_{\mathbf{t}}\right)$ & $3,51 \mathrm{~N} / \mathrm{mm}^{2}$ \\
Energia de fratura $\left(\boldsymbol{G}_{\mathbf{f}}\right)$ & $0,087 \mathrm{~N} / \mathrm{mm}^{2}$ \\
Resistência à compressão $\left(\boldsymbol{f}_{\mathbf{c}}\right)$ & $45,92 \mathrm{~N} / \mathrm{mm}^{2}$ \\
Função de retenção ao cisalhamento & Constante \\
Coeficiente de retenção ao cisalhamento $(\boldsymbol{\beta})$ & 0,01 \\
\hline
\end{tabular}

Fonte: Autoria própria

A Tabela 7.3 apresenta as propriedades utilizadas para modelar o aço, em que o módulo de elasticidade e o coeficiente de Poisson foram estimados com base nos valores comumente empregados na literatura técnica. Para a tensão de escoamento do critério de ruptura de Von Mises, utilizou-se o valor determinado experimentalmente (seção 6.2.2).

Tabela 7.3 - Parâmetros do aço do modelo numérico do ensaio slip-block

\begin{tabular}{cc}
\hline Módulo de Elasticidade $\left(\boldsymbol{E}_{\mathbf{a}}\right)$ & $200.000 \mathrm{~N} / \mathrm{mm}^{2}$ \\
Coeficiente de Poisson $\left(\boldsymbol{v}_{\mathbf{a}}\right)$ & 0,3 \\
Resistência ao escoamento $\left(\boldsymbol{f}_{\mathbf{y}}\right)$ & $285,97 \mathrm{~N} / \mathrm{mm}^{2}$ \\
\hline
\end{tabular}

Fonte: Autoria própria

Os parâmetros utilizados para simular o comportamento da interface no modelo Coulomb Friction foram definidos com base nos resultados provenientes da metodologia proposta neste trabalho, obtidos experimentalmente utilizando o ensaio slip-block.

Além dos parâmetros de definição do critério de plastificação, são necessários os parâmetros elásticos $k_{\mathrm{n}}$ e $k_{\mathrm{t}} \mathrm{e}$ o parâmetro $\psi$, que define a superfície potencial plástica. $\mathrm{O}$ parâmetro $k_{t}$ também pode ser obtido do ensaio slip-block, pois corresponde a inclinação inicial (antes da ruptura da ligação química) da curva da Força horizontal $\left(F_{\mathrm{H}}\right)$ versus Deslizamento $(s)$ dividida pela área da interface aço-concreto. O parâmetro $k_{n}$, por sua vez, foi estimado por meio 
de análises prévias do modelo numérico, pois não foi obtido experimentalmente. Já a dilatância $(\psi)$ foi considerada nula.

Inicialmente foram realizadas simulações a fim de identificar a influência de cada parâmetro sobre o comportamento da interface e do modelo como um todo. Posteriormente, empregou-se os parâmetros experimentais obtidos por meio da metodologia apresentada na seção 6.3.3.1 para a definição completa da interface empregando o modelo Coulomb Friction com Hardening. Neste caso, definiu-se o coeficiente de atrito e a coesão iniciais e os pontos das curvas de $\mu$ versus $\Delta u_{\mathrm{p}}$ e de $c$ versus $\Delta u_{\mathrm{p}}$, em que $\Delta u_{\mathrm{p}}$ e $c$ correspondem, respectivamente, ao deslizamento $(s)$ e à tensão mecânica resistente $\left(\tau_{\mathrm{m}}\right)$, descritos na Tabela 6.9 (seção 6.3.3.2).

A Tabela 7.4 apresenta os parâmetros utilizados no modelo Coulomb Friction com Hardening, que resultou na validação do modelo numérico do ensaio slip-block. Tais parâmetros foram obtidos experimentalmente por meio da metodologia proposta neste trabalho.

Tabela 7.4 - Parâmetros da interface aço-concreto do modelo numérico do ensaio slip-block

\begin{tabular}{|c|c|c|c|c|c|}
\hline \multicolumn{6}{|c|}{ Parâmetros do comportamento linear } \\
\hline \multicolumn{3}{|c|}{ Rigidez normal $\left(k_{n}\right)$} & \multicolumn{3}{|c|}{ Rigidez tangencial $\left(k_{t}\right)$} \\
\hline \multicolumn{3}{|c|}{$30 \mathrm{~N} / \mathrm{mm}^{3}$} & \multicolumn{3}{|c|}{$15 \mathrm{~N} / \mathrm{mm}^{3}$} \\
\hline \multicolumn{6}{|c|}{ Parâmetros do critério de ruptura do modelo Coulomb Friction } \\
\hline \multicolumn{2}{|c|}{ Coef. de atrito inicial $\left(\mu_{0}\right)$} & \multicolumn{2}{|c|}{ Coesão inicial $\left(c_{0}\right)$} & \multicolumn{2}{|c|}{ Dilatância $(\psi)$} \\
\hline \multicolumn{2}{|c|}{0,557} & \multicolumn{2}{|c|}{$0,015 \mathrm{~N} / \mathrm{mm}^{2}$} & \multicolumn{2}{|c|}{0} \\
\hline \multicolumn{6}{|c|}{ Hardening } \\
\hline$\Delta u_{\mathrm{p}}[\mathrm{mm}]$ & $\mu$ & $c\left[\mathbf{N} / \mathbf{m m}^{2}\right]$ & $\Delta u_{\mathrm{p}}[\mathrm{mm}]$ & $\mu$ & $c\left[\mathbf{N} / \mathbf{m m}^{2}\right]$ \\
\hline 0,1 & 0,295 & 0,005 & 7,0 & 0,572 & 0,018 \\
\hline 0,5 & 0,635 & 0,007 & 8,0 & 0,542 & 0,020 \\
\hline 1,0 & 0,610 & 0,022 & 9,0 & 0,555 & 0,019 \\
\hline 1,5 & 0,569 & 0,032 & 10,0 & 0,589 & 0,018 \\
\hline 2,0 & 0,578 & 0,035 & 12,0 & 0,612 & 0,018 \\
\hline 2,5 & 0,590 & 0,036 & 15,0 & 0,604 & 0,021 \\
\hline 3,0 & 0,595 & 0,035 & 20,0 & 0,580 & 0,023 \\
\hline 3,5 & 0,596 & 0,033 & 23,0 & 0,510 & 0,023 \\
\hline 4,0 & 0,608 & 0,029 & 25,0 & 0,514 & 0,020 \\
\hline 4,5 & 0,616 & 0,025 & 27,0 & 0,417 & 0,009 \\
\hline 5,0 & 0,608 & 0,022 & 29,0 & 0,495 & 0,000 \\
\hline 6,0 & 0,581 & 0,019 & 30,0 & 0,503 & 0,000 \\
\hline
\end{tabular}

Fonte: Autoria própria

A fim de elaborar um modelo de interface mais representativo do comportamento do ensaio slip-block, realizou-se uma maior discretização da variação de $\mu$ e $c$ com o deslizamento, conforme apresentado na parcela do Hardening da Tabela 7.4. 
Além disso, considerou-se o comportamento até os $30 \mathrm{~mm}$ de deslizamento apenas, pois a quantidade de pares $\left(\mu, \Delta u_{\mathrm{p}}\right)$ e $\left(c, \Delta u_{\mathrm{p}}\right)$ permitida pelo modelo é limitada a 25 em cada caso. Essa consideração adotada é representativa, uma vez que dificilmente ocorrem deslizamentos superiores a $25 \mathrm{~mm}$ em lajes mistas que atingem o colapso devido ao cisalhamento longitudinal da interface aço-concreto.

\subsubsection{Condições de Contorno e Carregamento}

Objetivando submeter o modelo às mesmas condições de apoio do ensaio, restringiu-se todos os deslocamentos da região das mesas inferiores da fôrma de aço que contém os parafusos, simulando as presenças da placa de base e dos parafusos. Os nós da outra parte das mesas inferiores da fôrma de aço não foram restringidos apenas na direção do deslizamento a fim de simular a presença da placa de base.

No momento de criação da malha do modelo foram definidas duas propriedades de ligação de nós com o objetivo de aplicar cada carregamento em apenas um nó. Dessa forma, definiu-se um nó mestre (master node) no centro da face superior da capa de concreto ao qual todos os demais nós (slave nodes) dessa face são ligados a ele, de modo a possuírem o mesmo deslocamento vertical (direção $z$ ), simulando a presença da placa que distribui o carregamento vertical aplicado $\left(F_{\mathrm{V}}\right)$.

De maneira análoga, definiu-se um nó mestre (master node) no centro da face frontal da capa de concreto ao qual todos os demais nós (slave nodes) dessa face são ligados a ele, de modo a possuírem o mesmo deslocamento horizontal na direção do deslizamento (direção $y$ ), simulando a presença da placa de distribuição do carregamento horizontal aplicado $\left(F_{\mathrm{H}}\right)$.

Os carregamentos foram aplicados considerando dois casos de carga (load cases): carregamento vertical $\left(F_{\mathrm{V}}\right)$ e carregamento horizontal $\left(F_{\mathrm{H}}\right)$. O primeiro consistiu na aplicação de uma força vertical prescrita no nó mestre da face superior da capa de concreto. O segundo consistiu na aplicação de um deslocamento horizontal prescrito no nó mestre da face frontal da capa de concreto.

Da mesma forma que se realizou no ensaio slip-block, primeiramente foi aplicado completamente o carregamento vertical. Em seguida foi aplicado gradualmente o deslocamento horizontal, promovendo o deslizamento da capa de concreto em relação à fôrma de aço.

A Figura 7.8 apresenta o modelo numérico do ensaio slip-block com as condições de contorno adotadas e o carregamento aplicado nos nós mestres. 
Figura 7.8 - Condições de contorno do modelo numérico do ensaio slip-block

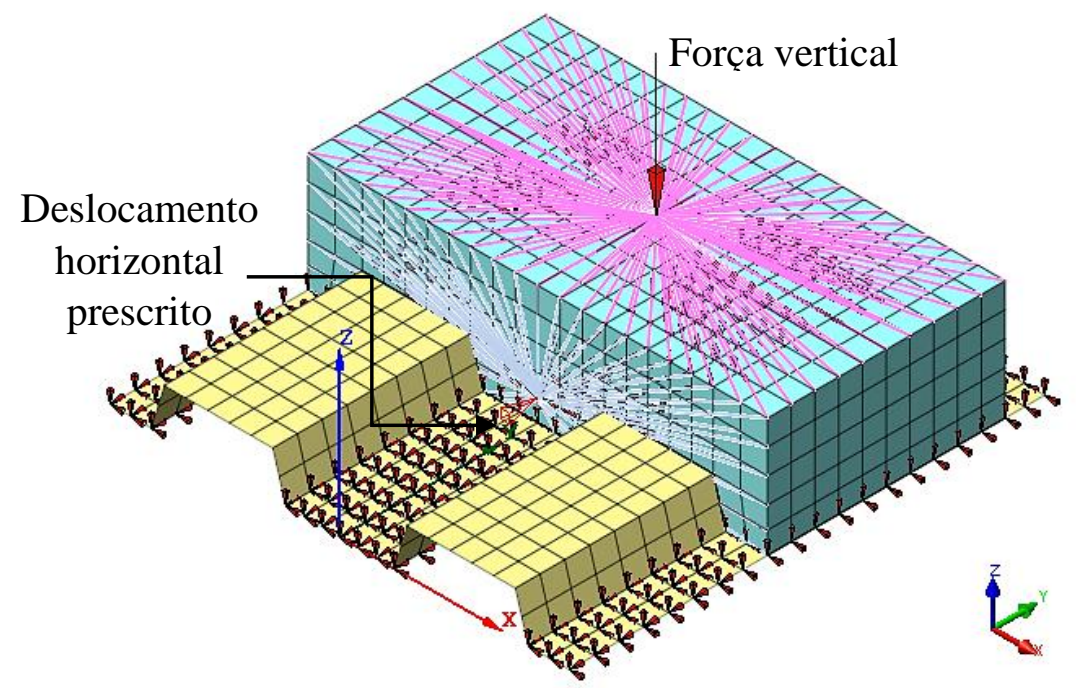

Fonte: Autoria própria

\subsubsection{Estratégia de Solução e Critério de Convergência}

Adotou-se como estratégia de solução o método iterativo Newton-Raphson. Utilizou-se o algoritmo Line Search, que tem a função de corrigir a solução encontrada nos métodos tradicionais de modo a acelerar a taxa de convergência. Empregou-se o critério de convergência em energia, com tolerância de convergência igual a 0,001.

A força vertical foi aplicada incialmente por meio de dois passos de carga, cada um com metade do carregamento. Posteriormente, aplicou-se um deslocamento horizontal de 27,0 mm com a seguinte sequência: 30 passos de $0,005 \mathrm{~mm}+77$ passos de 0,05 $\mathrm{mm}+46$ passos de $0,5 \mathrm{~mm}$. Esta sequência foi definida para o modelo validado com o intuito de simular precisamente o comportamento obtido experimentalmente.

\subsubsection{Análise da Malha}

A análise da malha de elementos finitos é uma etapa importante da análise numérica, pois através dela é possível verificar a influência da configuração da malha sobre a resposta numérica e definir uma malha mais eficiente, ou seja, que proporcione uma resposte numérica adequada aliada à um custo computacional aceitável.

Os modelos utilizados para a análise da malha já consideram as não linearidades físicas do concreto, do aço e da interface, inclusive o Hardening, a fim de verificar melhor a sensitividade da malha de elementos finitos. A força vertical aplicada foi de $18,14 \mathrm{kN}$, que foi a carga intermediária utilizada nos ensaios slip-block. 
Foram analisados modelos com malhas cujas dimensões máximas dos elementos eram: $15 \mathrm{~mm}, 20 \mathrm{~mm}, 25 \mathrm{~mm}$ e $30 \mathrm{~mm}$. A Tabela 7.5 apresenta as características de cada modelo e o tempo de processamento requerido.

Tabela 7.5 - Características de cada modelo da análise da malha do ensaio slip-block

\begin{tabular}{|c|c|c|c|c|c|c|}
\hline \multirow[b]{2}{*}{ Modelo } & \multicolumn{4}{|c|}{ Quantidade de elementos } & \multirow{2}{*}{$\begin{array}{l}\text { Quantidade } \\
\text { total de nós }\end{array}$} & \multirow{2}{*}{$\begin{array}{c}\text { Tempo de } \\
\text { processamento }^{*}\end{array}$} \\
\hline & $\begin{array}{l}\text { Capa de } \\
\text { concreto }\end{array}$ & $\begin{array}{l}\text { Fôrma de } \\
\text { aço }\end{array}$ & Interface & Total & & \\
\hline $15 \mathrm{~mm}$ & 5.760 & 2.080 & 1.040 & 8.880 & 9.376 & $36 \min 15 \mathrm{~s}$ \\
\hline $20 \mathrm{~mm}$ & 2.730 & 1.240 & 600 & 4.570 & 4.912 & $16 \mathrm{~min} 43 \mathrm{~s}$ \\
\hline $25 \mathrm{~mm}$ & 1.200 & 672 & 336 & 2.208 & 2.428 & $7 \min 57 \mathrm{~s}$ \\
\hline $30 \mathrm{~mm}$ & 800 & 560 & 280 & 1.640 & 1.819 & $4 \min 31 \mathrm{~s}$ \\
\hline
\end{tabular}

* Considerando a mesma configuração computacional (para efeito de comparação).

Fonte: Autoria própria

A Figura 7.9 ilustra o gráfico da Força Horizontal $\left(F_{\mathrm{H}}\right)$ versus Deslizamento $(s)$ obtido para cada um dos modelos avaliados na análise de malha.

Figura 7.9 - Gráfico de $F_{\mathrm{H}}$ versus $s$ - teste de malha do modelo numérico do ensaio slip-block

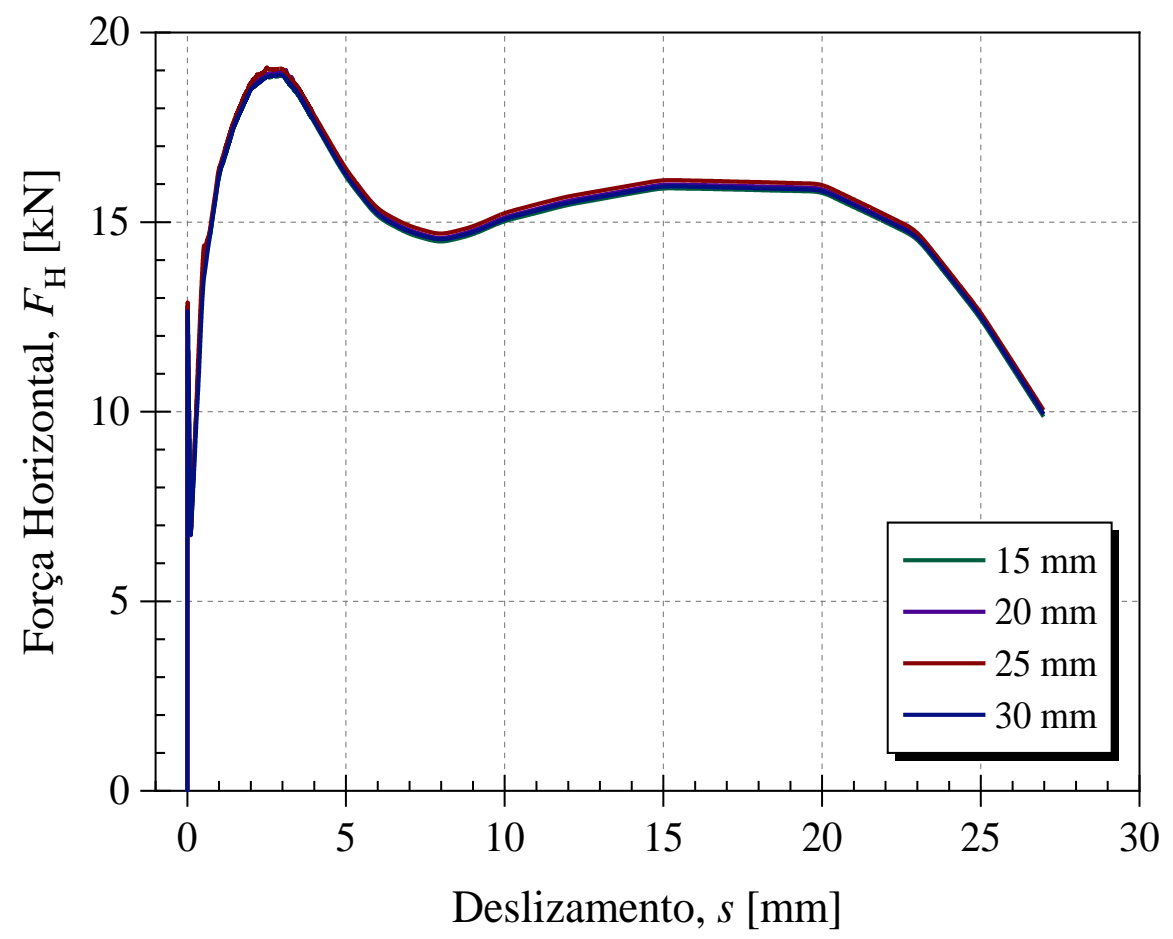

Fonte: Autoria própria

Conforme se observa no gráfico da figura acima, as curvas praticamente coincidiram, indicando que o resultado não foi sensível às malhas analisadas. Diante disso, escolheu-se o modelo com dimensão máxima do elemento de $30 \mathrm{~mm}$ para realizar as demais análises, uma vez que este modelo requisitou menor tempo de processamento em relação aos demais. 


\subsubsection{Análise de Sensibilidade do Modelo de Interface}

Com o objetivo de verificar a influência de cada parâmetro que define o modelo de interface Coulomb Friction sobre o comportamento do modelo do ensaio slip-block, fez-se uma análise dos parâmetros $k_{n}, k_{t}, \mu$ e $c$. Dessa forma, o desempenho do modelo pode ser melhor compreendido, auxiliando sua validação. Nessa análise não se utilizou o Hardening, porque considerou-se mais coerente identificar a influência desses parâmetros mantendo-se o critério de ruptura constante. $\mathrm{O}$ carregamento vertical aplicado foi de $18,14 \mathrm{kN}$.

\section{a) Rigidez normal $\left(k_{n}\right)$ e rigidez tangencial $\left(k_{t}\right)$}

A fim de realizar a análise com um espectro relevante de resultados, avaliou-se tanto para $k_{n}$ quanto para $k_{t}$ os seguintes valores: $1 \mathrm{~N} / \mathrm{mm}^{3}, 5 \mathrm{~N} / \mathrm{mm}^{3}, 10 \mathrm{~N} / \mathrm{mm}^{3}, 25 \mathrm{~N} / \mathrm{mm}^{3}$, $50 \mathrm{~N} / \mathrm{mm}^{3}$ e $100 \mathrm{~N} / \mathrm{mm}^{3}$. Os demais parâmetros permaneceram os mesmos: $\mu=0,557$, $c=0,015 \mathrm{~N} / \mathrm{mm}^{2}$ e $\psi=0$.

Para verificar a influência do parâmetro $k_{t}$, seu valor foi variado mantendo-se o valor de $k_{n}$ fixo. A Figura 7.10 apresenta, por exemplo, o gráfico da Força Horizontal $\left(F_{\mathrm{H}}\right)$ versus Deslizamento $(s)$ para $k_{n}=10 \mathrm{~N} / \mathrm{mm}^{3}$. Os gráficos para os demais valores de $k_{n}$ apresentaram comportamentos semelhantes ao da Figura 7.10 e estão apresentados no Apêndice C.

Figura 7.10 - Gráfico de $F_{\mathrm{H}}$ versus $s$ do modelo numérico do ensaio slip-block - análise de $k_{t}$ para $k_{n}=10 \mathrm{~N} / \mathrm{mm}^{3}$

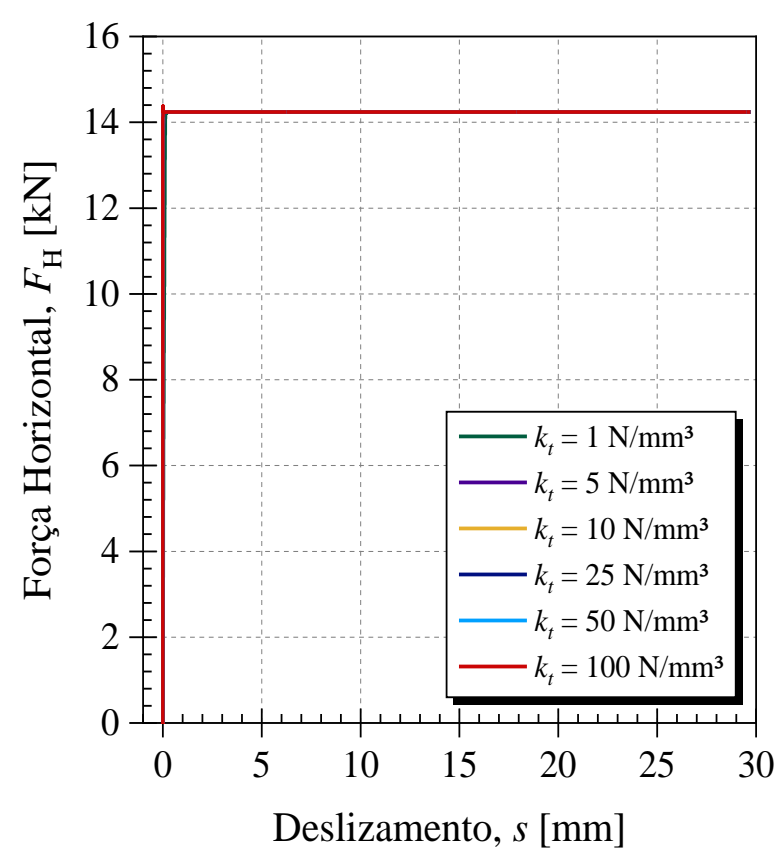

(a) Gráfico completo

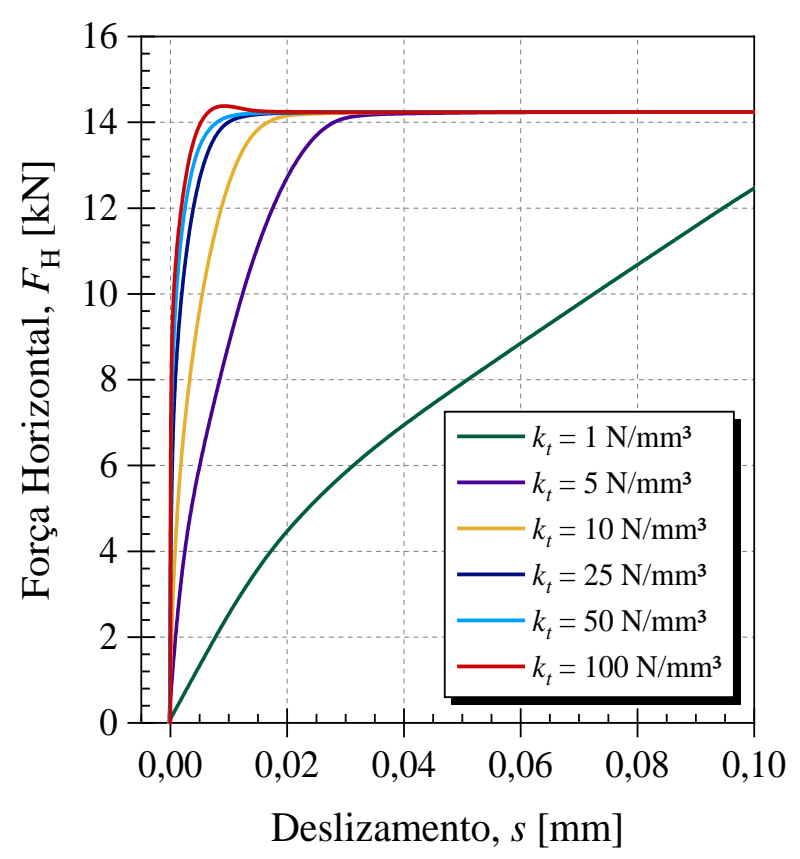

(b) Trecho inicial ampliado

Fonte: Autoria própria 
Ao se observar o gráfico de $F_{\mathrm{H}}$ versus $s$ numa perspectiva do deslizamento total imposto, as curvas para os vários valores de $k_{t}$ praticamente se sobrepõem (Figura 7.10 (a)). Contudo, quando se verifica mais precisamente o trecho inicial dessas curvas (Figura 7.10 (b)), as diferenças entre elas são notadas: quanto o maior o valor de $k_{t}$, maior a rigidez inicial da curva de $F_{\mathrm{H}}$ versus $s$. Esse fato era esperado, pois esse parâmetro configura a rigidez tangencial da interface no regime elástico.

Quando ocorre a plastificação da interface, ou seja, quando o critério de ruptura do modelo foi atingido, $F_{\mathrm{H}}$ se manteve constante. Isso ocorreu porque a tensão de cisalhamento resistente da interface foi constante, haja vista que $F_{\mathrm{V}}$ foi mantido constante e o critério de ruptura foi mantido constante com o deslizamento.

Nota-se, portanto, que o valor de $k_{t}$ determinou a rigidez tangencial da interface no seu regime elástico e, consequentemente, determinou o quanto de deslizamento ocorreu antes de se atingir o critério de ruptura estabelecido para a interface.

A influência do parâmetro $k_{n}$ sobre o comportamento da interface, por sua vez, foi verificada variando-se seu valor e fixando-se o valor de $k_{t}$. A Figura 7.11 apresenta, por exemplo, o gráfico da Força Horizontal $\left(F_{\mathrm{H}}\right)$ versus Deslizamento $(s)$ para $k_{t}=10 \mathrm{~N} / \mathrm{mm}^{3}$. Os gráficos para os demais valores de $k_{t}$ apresentaram comportamentos semelhantes ao da Figura 7.11 e estão apresentados no Apêndice C.

Figura 7.11 - Gráfico de $F_{\mathrm{H}}$ versus $s$ do modelo numérico do ensaio slip-block - análise de $k_{n}$ $\operatorname{com} k_{t}=10 \mathrm{~N} / \mathrm{mm}^{3}$

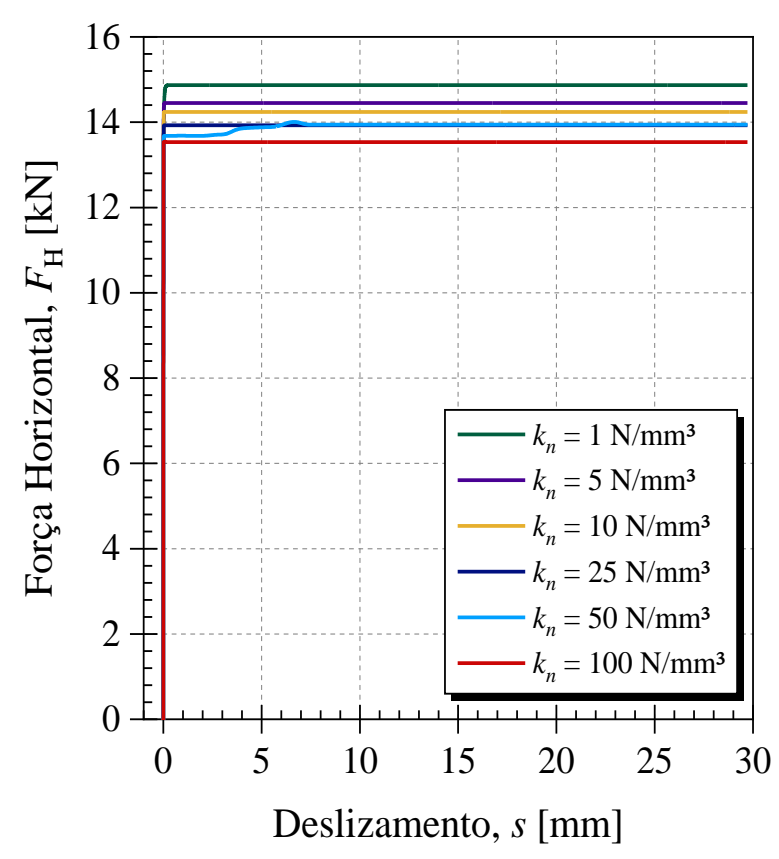

(a) Gráfico completo

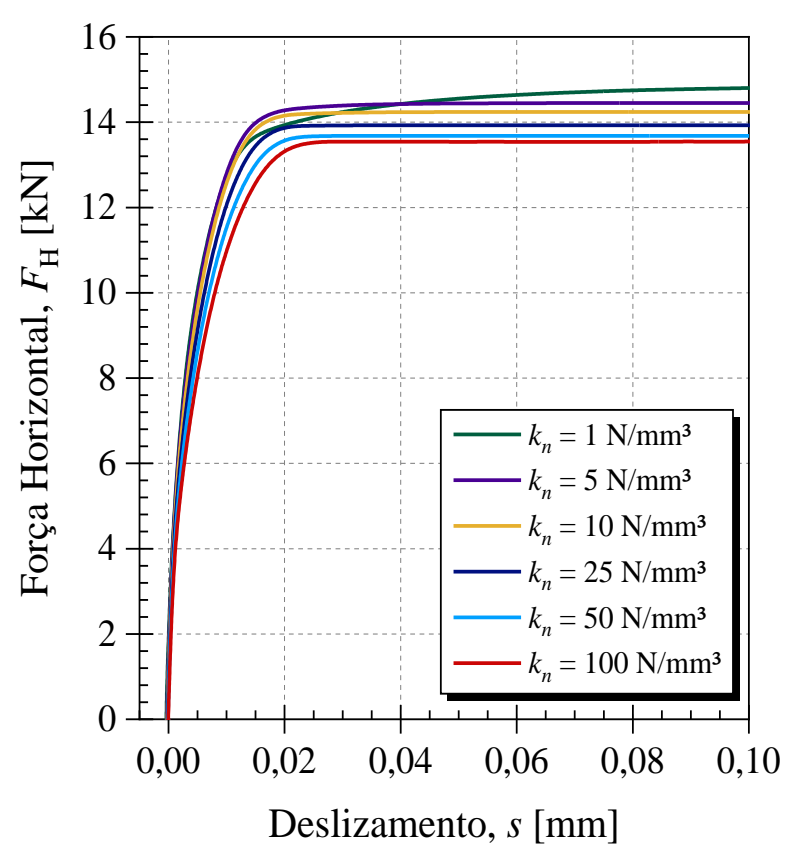

(b) Trecho inicial ampliado

Fonte: Autoria própria 
O aumento no valor de $k_{n}$ proporcionou uma redução na tensão resistente ao cisalhamento da interface, conforme se observa na Figura 7.11. Isso está relacionado com a geometria da fôrma de aço modelada, pois as regiões da mesa superior e das almas do perfil estão sujeitas a separação entre o aço e o concreto mediante o esforço aplicado. Dessa forma, como $k_{n}$ é responsável pela rigidez à separação na direção normal do elemento finito de interface, a modificação desse parâmetro influenciou a tensão normal à interface e, consequentemente, a tensão tangencial devido à relação estabelecida pelo critério de ruptura por meio do coeficiente de atrito.

A rigidez inicial, por sua vez, não sofreu influência significativa do parâmetro $k_{n}$.

\section{b) Coeficiente de atrito $(\mu)$}

A análise da influência do coeficiente de atrito foi realizada utilizando valores dentro da faixa de variação obtida no ensaio slip-block. Analisou-se os seguintes valores: $\mu=0,001$, $\mu=0,3, \mu=0,4, \mu=0,5$ e $\mu=0,6$. O primeiro valor foi escolhido objetivando analisar o comportamento da interface com um coeficiente de atrito próximo de zero. Nessa análise manteve-se os valores de $k_{n}=100 \mathrm{~N} / \mathrm{mm}^{3}, k_{t}=100 \mathrm{~N} / \mathrm{mm}^{3}, c=0,015 \mathrm{~N} / \mathrm{mm}^{2}$ e $\psi=0$.

O gráfico de $F_{\mathrm{H}}$ versus $s$ da análise da influência de $\mu$ está ilustrado na Figura 7.12. Conforme esperado, quanto maior o coeficiente de atrito $(\mu)$, maior a resistência ao cisalhamento da interface.

Figura 7.12 - Gráfico de $F_{\mathrm{H}}$ versus $s$ do modelo numérico do ensaio slip-block - análise de $\mu$

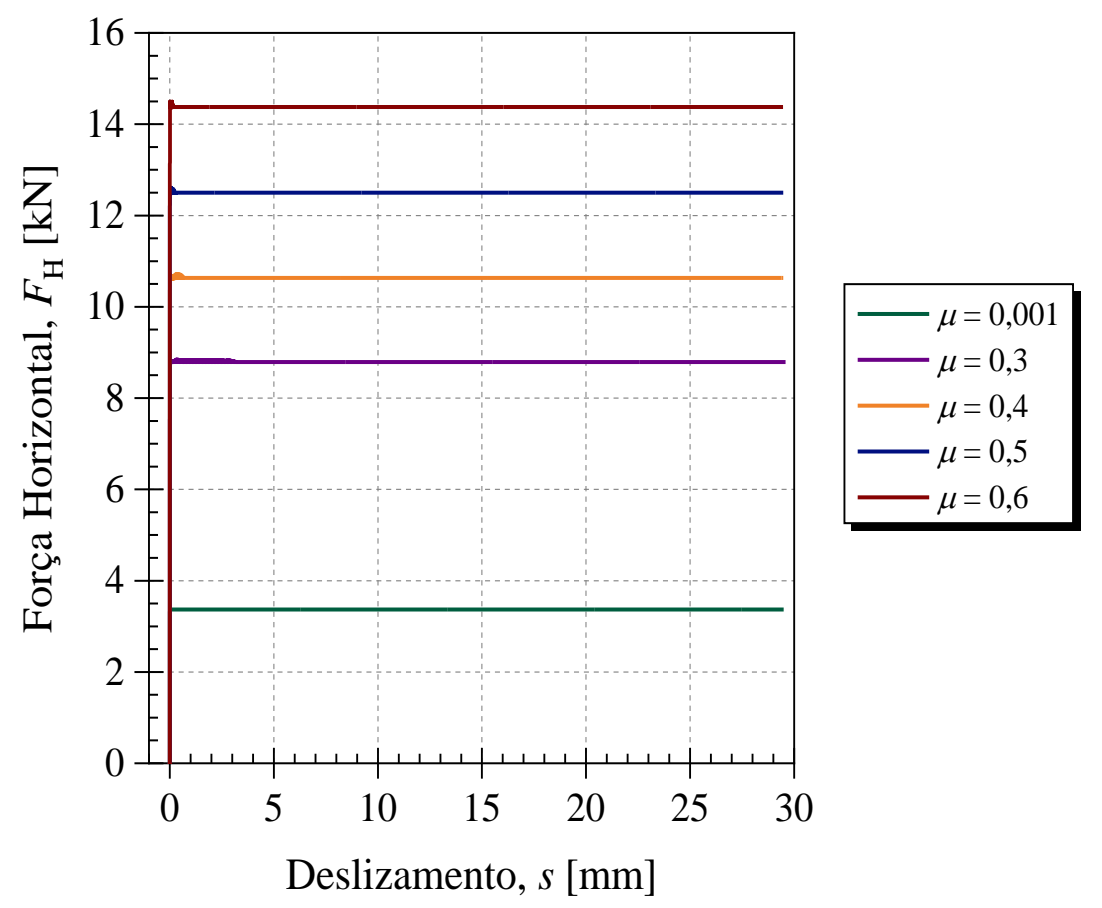

Fonte: Autoria própria 
Devido a relação linear entre $F_{\mathrm{H}}$ e $F_{\mathrm{V}}$, estabelecida pelo coeficiente de atrito $(\mu)$, a resistência ao cisalhamento aumenta proporcionalmente com o valor de $\mu$. Nota-se, portanto, a significativa participação da ligação por atrito, uma vez que quando se utilizou um valor de $\mu$ muito baixo, a resistência ao cisalhamento da interface reduziu consideravelmente.

\section{c) Coesão (c)}

Conforme já mencionado, a coesão (c) do modelo Coulomb Friction assumiu o papel da a tensão mecânica resistente $\left(\tau_{\mathrm{m}}\right)$ devido ao intertravamento mecânico promovido pelas mossas da fôrma de aço. Dessa forma, a análise deste parâmetro foi realizada com valores dentro da faixa de variação obtida por meio do ensaio slip-block. Analisou-se os seguintes valores de $c: 0,001 \mathrm{~N} / \mathrm{mm}^{2}, 0,010 \mathrm{~N} / \mathrm{mm}^{3}, 0,020 \mathrm{~N} / \mathrm{mm}^{2}, 0,030 \mathrm{~N} / \mathrm{mm}^{2}$ e $0,035 \mathrm{~N} / \mathrm{mm}^{2}$. Manteve-se os valores de $k_{n}=100 \mathrm{~N} / \mathrm{mm}^{3}, k_{t}=100 \mathrm{~N} / \mathrm{mm}^{3}, \mu=0,557 \mathrm{~N} / \mathrm{mm}^{2}$ e $\psi=0$.

O gráfico de $F_{\mathrm{H}}$ versus $s$ da análise da influência de $c$ está apresentado na Figura 7.13. Conforme esperado, o aumento no valor da coesão (c) causa um aumento proporcional na resistência ao cisalhamento da interface. A parcela de $F_{\mathrm{H}}$ referente à atuação da coesão pode ser determinada multiplicando-se seu valor pela área da interface, independentemente da força vertical aplicada.

Figura 7.13 - Gráfico de $F_{\mathrm{H}}$ versus $s$ do modelo numérico do ensaio slip-block - análise de $c$

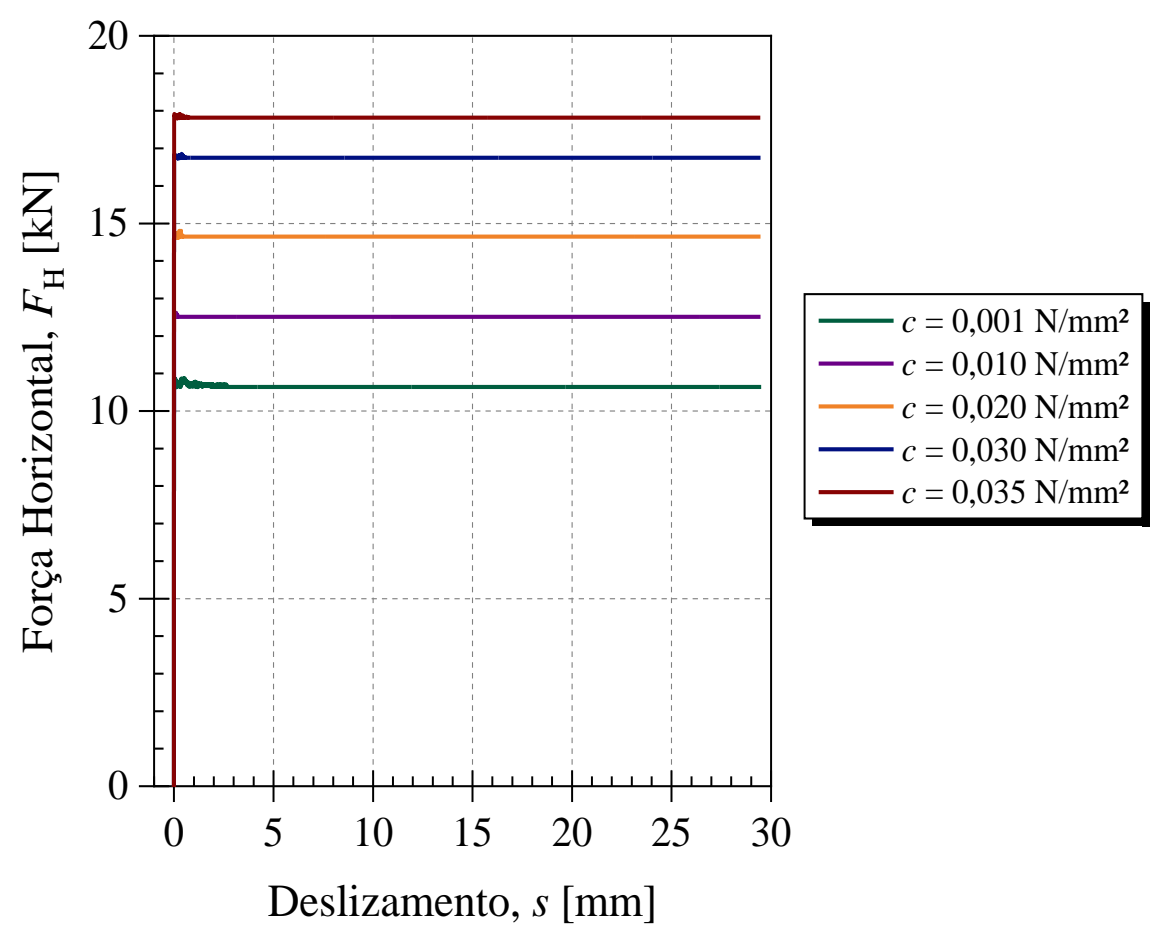

Fonte: Autoria própria 
Para o carregamento vertical aplicado nessas análises, a influência do coeficiente de atrito $(\mu)$ foi maior do que a da coesão $(c)$, uma vez que a mudança no valor deste primeiro parâmetro impactou mais o valor de $F_{\mathrm{H}}$. No entanto, como a contribuição da ligação por atrito está atrelada à magnitude de $F_{\mathrm{V}}$, o impacto de $\mu$ torna-se menor quando o valor de $F_{\mathrm{V}}$ é menor.

\subsubsection{Validação do Modelo Numérico do Ensaio Slip-Block}

Uma vez constatado a participação de cada parâmetro da interface sobre o comportamento do modelo numérico do ensaio slip-block, realizou-se sua validação com relação aos resultados experimentais obtidos, apresentados na seção 6.3.3.1.

Os parâmetros adotados para o modelo de interface Coulomb Friction com Hardening foram os apresentados na Tabela 7.4. Nessa tabela, $k_{n}$ é o único parâmetro que não foi obtido experimentalmente. Logo, seu valor foi calibrado com base na análise de sua influência, realizada na seção anterior, e nos resultados experimentais.

O Hardening é responsável pelo comportamento da interface no regime plástico e descreve a envoltória do critério de ruptura definido pelos parâmetros $\mu \mathrm{e} c$, que variam em função do deslizamento plástico. A Figura 7.14 apresenta as curvas do Coeficiente de atrito $(\mu)$ versus Deslizamento $(s)$ e da Coesão $(c)$ versus Deslizamento $(s)$, correspondentes à Tabela 7.4, que servem como dados de entrada para o Hardening do modelo de interface.

Figura 7.14 - Curvas de entrada para o Hardening do modelo Coulomb Friction

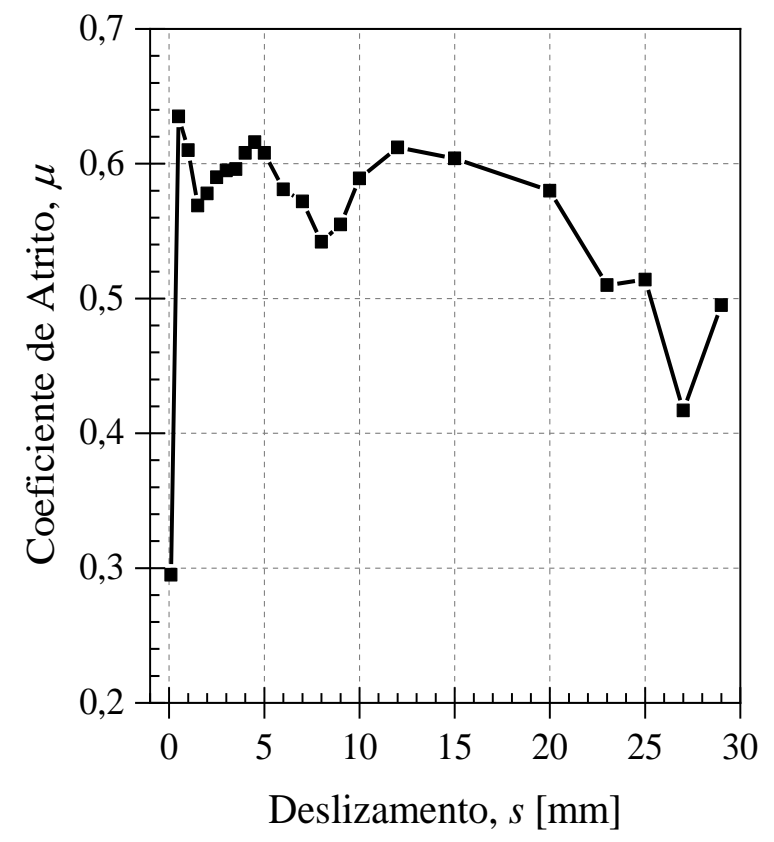

(a) Gráfico de $\mu$ versus $s$

Fonte: Autoria própria

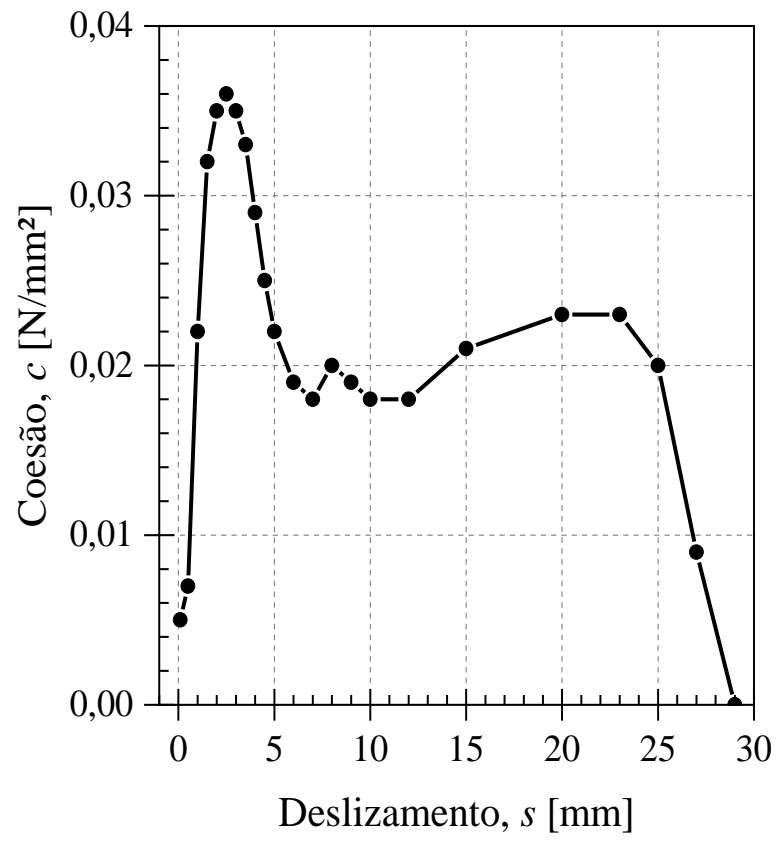

(b) Gráfico de $c$ versus $s$ 
A análise do modelo numérico foi realizada aplicando um deslocamento horizontal de $28 \mathrm{~mm}$ apenas, pois as lajes mistas, em geral, dificilmente atingem essa magnitude de deslizamento. Logo, aplicou-se um valor de deslocamento de modo a simular o comportamento até o momento em que a mossa estaria adentrando na indentação seguinte.

A Figura 7.15 apresenta o gráfico da Força Horizontal $\left(F_{\mathrm{H}}\right)$ versus Deslizamento $(s)$ com as curvas obtidas experimentalmente e as oriundas do modelo numérico validado.

Figura 7.15 - Gráfico de $F_{\mathrm{H}}$ versus s do modelo numérico validado do ensaio slip-blockcomparação com os resultados experimentais

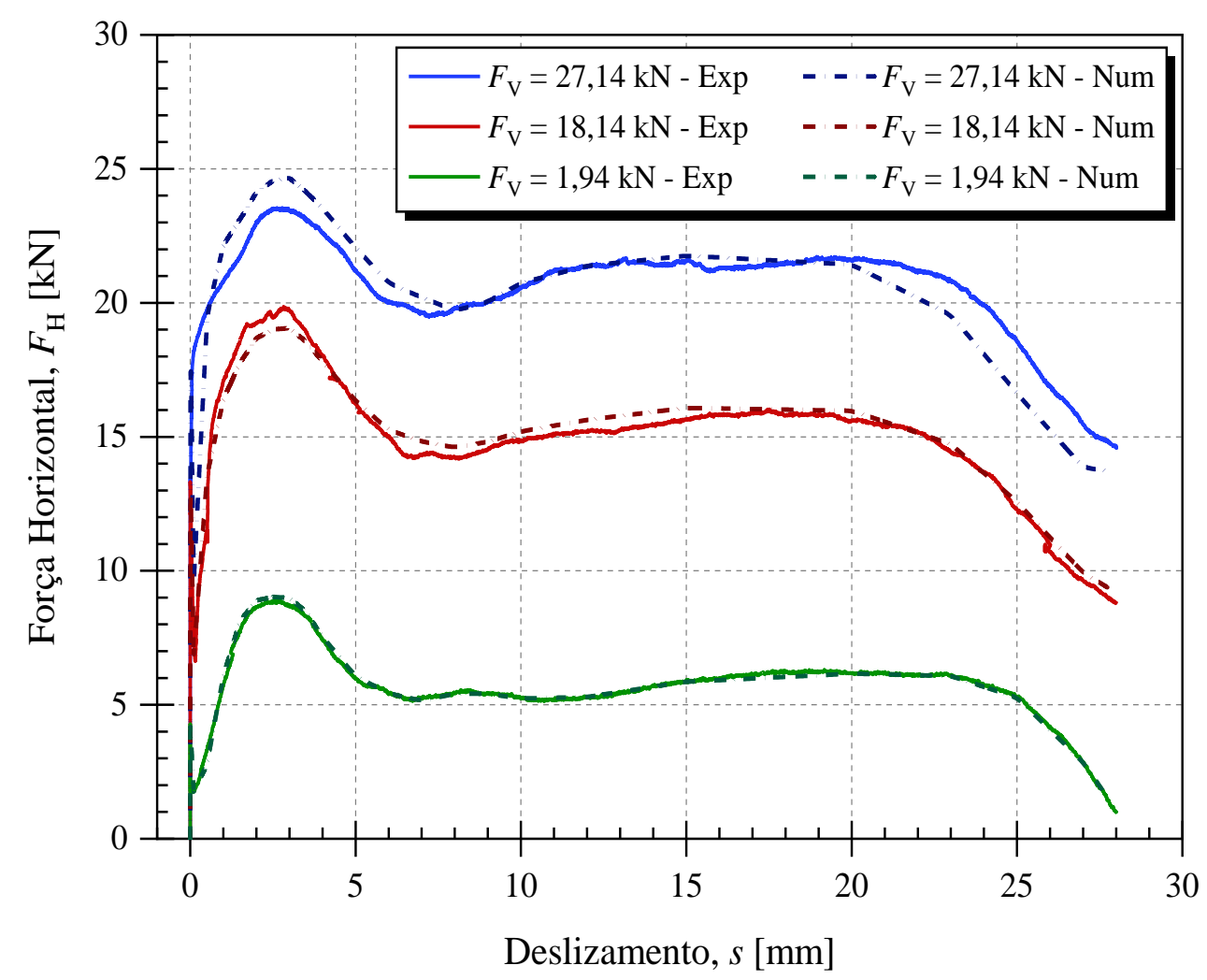

Fonte: Autoria própria

O comportamento dos protótipos ensaiados foi muito bem simulado pelo modelo numérico, conforme se verifica no gráfico da Figura 7.15. A representação de todos os fenômenos experimentais ocorridos na interface (ruptura da ligação química, ganho de resistência até se atingir a capacidade máxima, formação do patamar devido à saída da mossa da sua indentação e a redução de $F_{\mathrm{H}}$ devido ao engrenamento da mossa na indentação seguinte) foram simulados com êxito pelo modelo numérico de interface utilizado.

Nota-se que o comportamento do modelo numérico praticamente coincidiu com o experimental ao longo de todo o ensaio. A curva do modelo numérico com $F_{\mathrm{V}}=1,94 \mathrm{kN}$ praticamente sobrepôs a curva obtida experimentalmente, conforme se observa no gráfico da Figura 7.15. 
A configuração do modelo numérico da interface considerou, por meio do Hardening, a redução da capacidade resistente imediatamente após se atingir o critério de ruptura, simulando a redução existente após a ruptura da ligação química durante o ensaio experimental, observada na maioria dos protótipos ensaiados.

Sendo assim, os modelos numéricos apresentaram redução da capacidade resistente após o critério de ruptura ser atingido, porém o protótipo ensaiado com $F_{\mathrm{V}}=27,14 \mathrm{kN}$ não apresentou tal redução como os demais, conforme discutido na seção 6.3.3.1, por isso suas curvas numérica e experimental não coincidiram inicialmente.

A Tabela 7.6 apresenta a comparação entre os valores numéricos e experimentais de $F_{\mathrm{H}}$, demonstrando a precisão obtida pelo modelo numérico desenvolvido.

Tabela 7.6 - Relação entre os valores numéricos e experimentais do ensaio slip-block

\begin{tabular}{ccccc}
\hline Modelo & Referência & Experimental [kN] & Numérico [kN] & Variação* \\
\hline \multirow{2}{*}{$F_{\mathrm{V}}=27,14 \mathrm{kN}$} & $F_{\mathrm{H}, \text { rup }}$ & 17,76 & 17,52 & $-1,35 \%$ \\
& $F_{\mathrm{H} \text {,ret }}$ & - & 9,73 & - \\
& $F_{\mathrm{H} \text {,máx }}$ & 23,56 & 24,65 & $4,63 \%$ \\
\hline \multirow{3}{*}{$F_{\mathrm{V}}=18,14 \mathrm{kN}$} & $F_{\mathrm{H} \text {,rup }}$ & 13,46 & 12,88 & $-4,31 \%$ \\
& $F_{\mathrm{H} \text {,ret }}$ & 6,53 & 6,86 & $5,05 \%$ \\
& $F_{\mathrm{H} \text {,máx }}$ & 19,86 & 19,06 & $-4,03 \%$ \\
\hline \multirow{2}{*}{$F_{\mathrm{V}}=18,14 \mathrm{kN}$} & $F_{\mathrm{H} \text {,rup }}$ & 4,39 & 4,21 & $-4,10 \%$ \\
& $F_{\mathrm{H} \text {,ret }}$ & 1,74 & 1,76 & $1,15 \%$ \\
& $F_{\mathrm{H} \text {,máx }}$ & 8,91 & 9,02 & $1,23 \%$ \\
\hline
\end{tabular}

$F_{\mathrm{H}, \text { rup: }}$ Força horizontal referente à ruptura da ligação química;

$F_{\mathrm{H} \text {,ret: }}$ Força horizontal referente à retomada de resistência após a ruptura da ligação química;

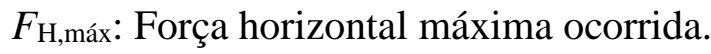

*Em relação ao valor experimental

Fonte: Autoria própria

Os resultados provenientes do modelo numérico mostraram-se muito próximos dos resultados experimentais em todos os casos, de acordo com a tabela acima. Dessa forma, visto que o comportamento da interface foi bem simulado e com valores precisos, constata-se que o modelo numérico desenvolvido foi representativo para a interface aço-concreto analisada por meio do ensaio slip-block.

É importante ressaltar que, em todos os casos, o modelo numérico é o mesmo e, portanto, a interface é a mesma, possuindo os mesmos parâmetros da Tabela 7.4. Dessa forma, a única variável foi o carregamento vertical aplicado $\left(F_{\mathrm{V}}\right)$, cuja influência foi considerada pelo modelo. 
Entretanto, em alguns outros modelos numéricos de interface, os parâmetros de entrada para o comportamento plástico são a curva da tensão de cisalhamento versus deslizamento ou a tensão de ruptura da interface. Nesses casos, a mudança do comportamento causada pela alteração da força vertical não seria considerada, pois o comportamento da interface seria sempre o mesmo, uma vez que o critério de ruptura não considera o efeito de $F_{\mathrm{V}}$. Apesar disso, alguns trabalhos presentes na literatura aplicaram esses modelos de interface.

Como o critério de ruptura do modelo numérico de interface utilizado neste trabalho estabelece uma envoltória que relaciona a tensão normal $\left(t_{n}\right)$ com a tensão tangencial $\left(t_{t}\right)$, o efeito da força de confinamento atuante é automaticamente computado juntamente com a parcela da ligação mecânica. Sendo assim, o modelo de interface é único, independentemente da força vertical aplicada. Esse foi o motivo pelo qual se optou por utilizar o pacote DIANA ${ }^{\circledR}$ para realizar a análise numérica da interface aço-concreto da laje mista estudada neste trabalho.

A Figura 7.16 e a Figura 7.17 apresentam, respectivamente, a distribuição das tensões principais e a distribuição das deformações principais na capa de concreto no instante em que a força horizontal máxima foi atingida do modelo com $F_{\mathrm{V}}=27,14 \mathrm{kN}$.

Figura 7.16 - Tensões principais na capa de concreto - modelo numérico do ensaio slip-block

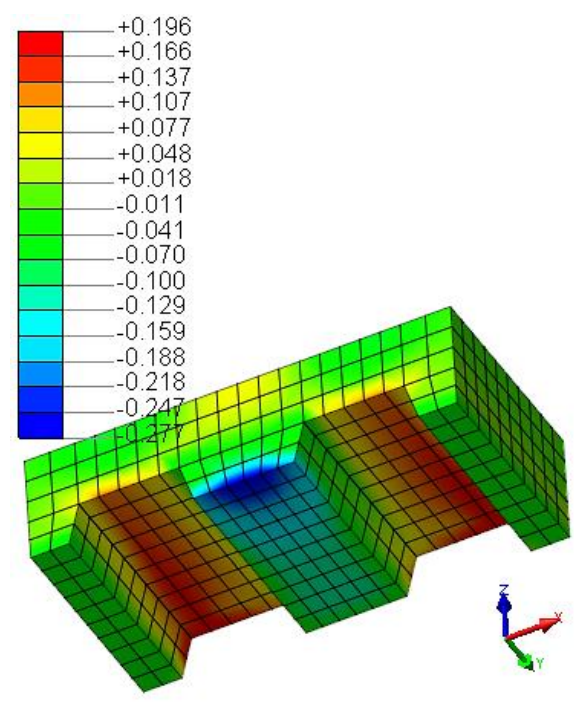

(a) Tensões principais máximas

Fonte: Autoria própria

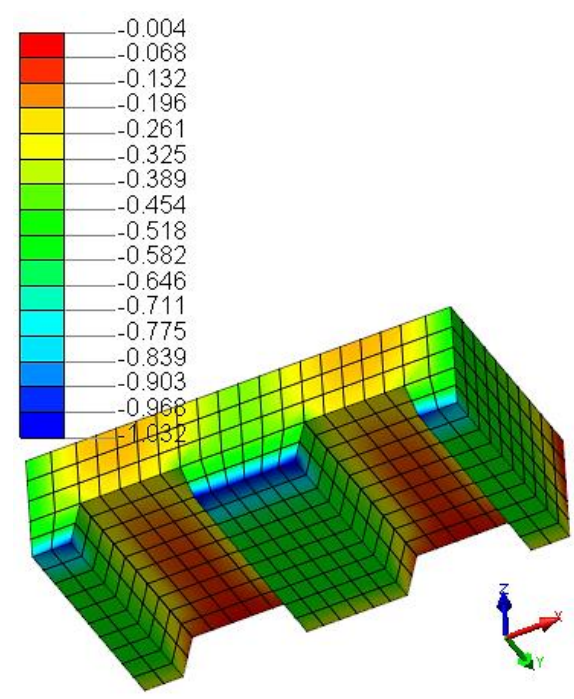

(b) Tensões principais mínimas

Tensões em MPa

Verifica-se que as tensões de compressão se concentraram na região inferior do bloco em contato com as mesas inferiores do perfil da fôrma de aço. Já as tensões de tração foram mais significativas na região em contato com as mesas superiores do perfil da fôrma de aço, devido a flexão causada pela força vertical aplicada. Contudo, as tensões principais foram muito inferiores às tensões máximas resistentes pelo concreto, portanto não ocorreu nem fissuração e nem esmagamento, assim como no ensaio experimental. 
Figura 7.17 - Deformações principais na capa de concreto - modelo numérico do ensaio slip-block

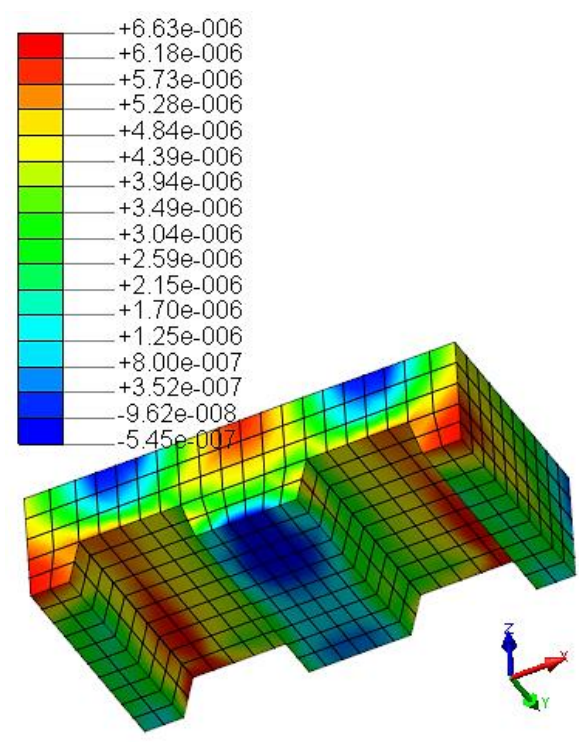

(a) Tensões principais máximas

Fonte: Autoria própria

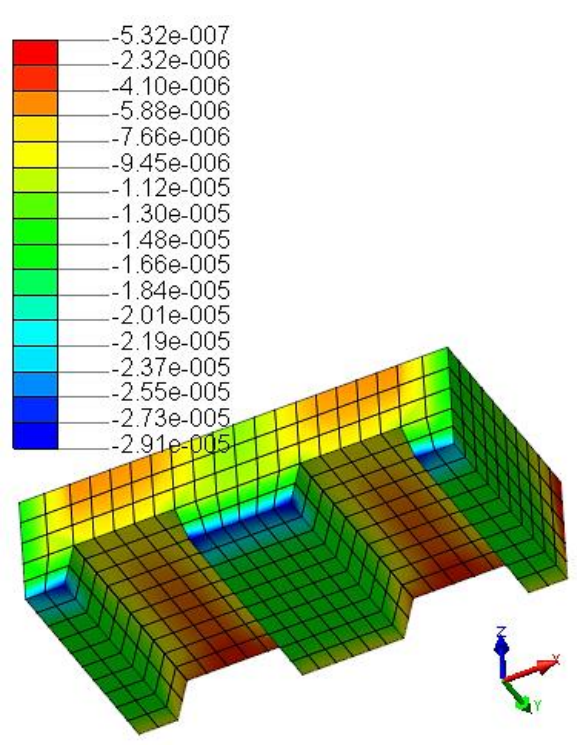

(b) Tensões principais mínimas

Tensões em MPa

Devido ao esforço de flexão localizado, causado pelo carregamento vertical aplicado, a região da face superior da capa de concreto acima das mesas altas do perfil da fôrma de aço se manteve comprimida, enquanto a região onde a mesa superior está localizada se manteve tracionada, conforme se observa na Figura 7.17.

A Figura 7.18 apresenta a distribuição de tensões de Von Mises e das deformações principais na fôrma de aço para o modelo com $F_{\mathrm{V}}=27,14 \mathrm{kN}$.

Figura 7.18 - Tensões e deformações da fôrma de aço - modelo numérico do ensaio slip-block

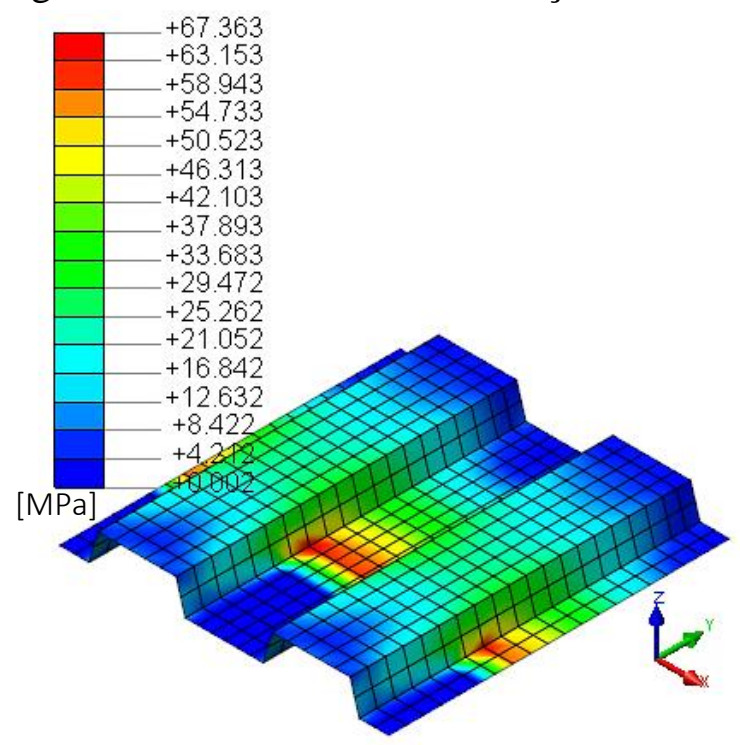

(a) Tensão de Von Mises

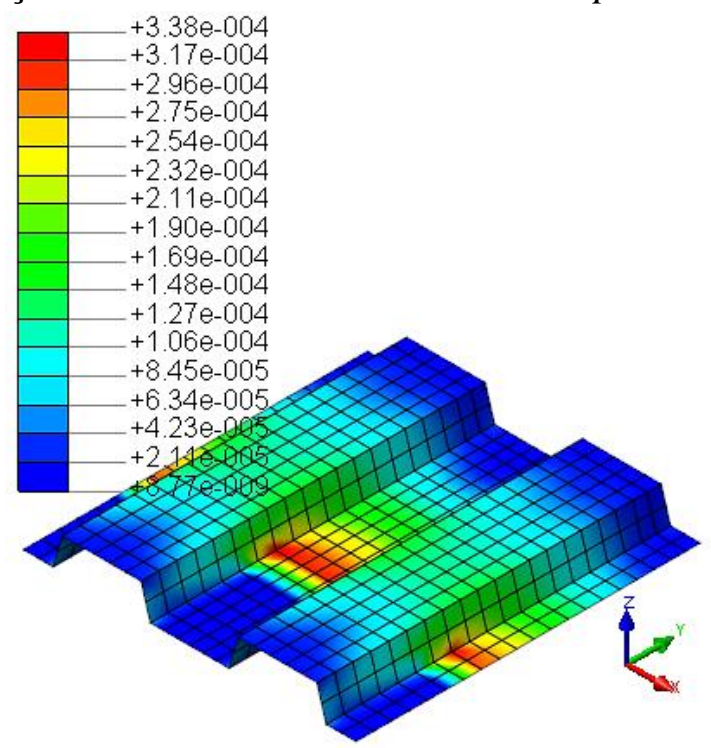

(b) Deformação principal

Fonte: Autoria própria 
A fôrma de aço se apresentou completamente tracionada. As tensões e, consequentemente, as deformações se concentram na região localizada entre os parafusos e a capa de concreto, conforme esperado, pois nessa região não há nenhuma restrição ao alongamento da fôrma de aço. Contudo, as tensões se apresentaram muito inferiores à tensão de escoamento estabelecida para o critério de Von Mises, razão pela qual não ocorreu plastificação de nenhuma região da fôrma de aço.

A distribuição das tensões normal e de cisalhamento na interface é apresentada pela Figura 7.19 .

Figura 7.19 - Tensão de cisalhamento na interface - modelo numérico do ensaio slip-block

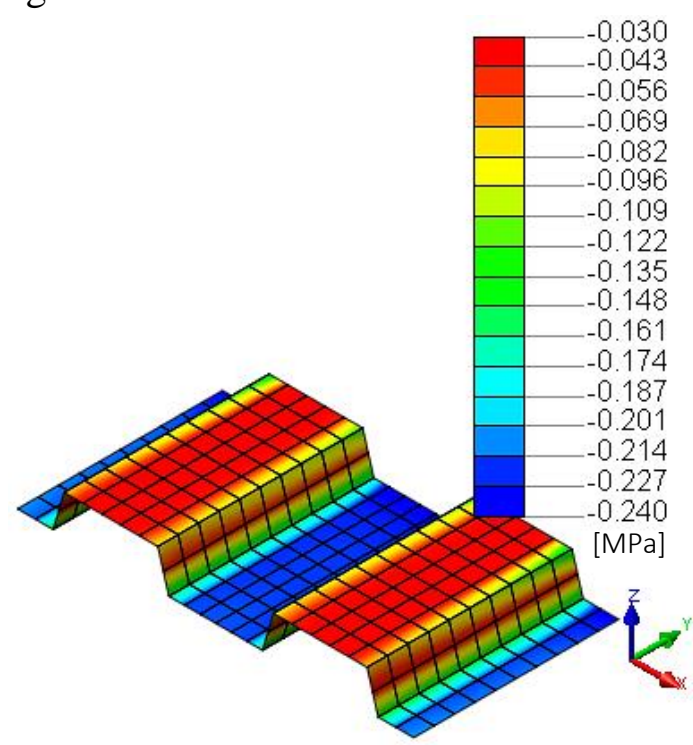

(a) Tensão normal à interface

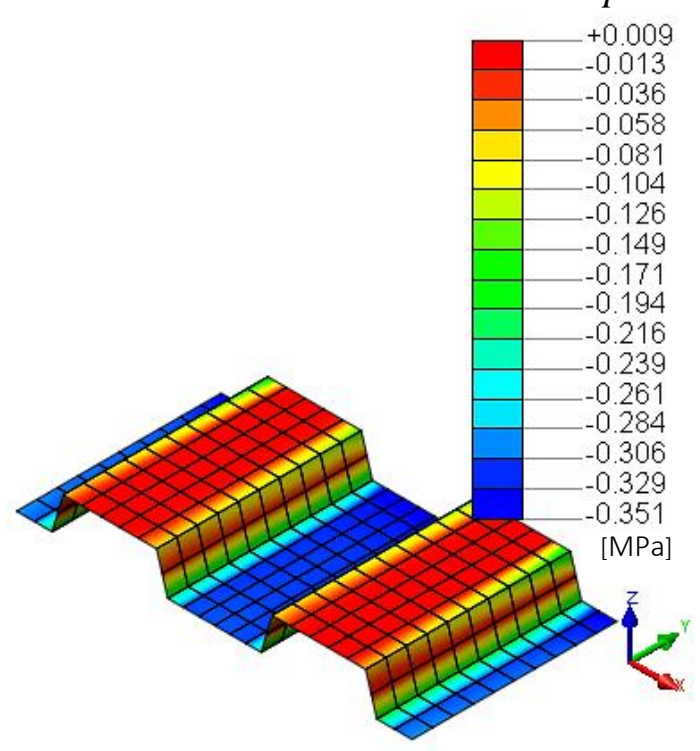

(b) Tensão de cisalhamento na direção $y$

Fonte: Autoria própria

Conforme ilustra a figura acima, a distribuição das tensões normal e de cisalhamento se apresentou uniforme ao longo da direção de deslizamento. Entretanto, suas magnitudes variaram com sua localização na fôrma de aço, de modo que a distribuição das tensões normal e de cisalhamento coincidem.

A magnitude das tensões é menor nas regiões de contato com as mesas superiores do perfil da fôrma de aço e é maior nas regiões de contato com as mesas inferiores do perfil. Esse fenômeno ocorreu devido à distribuição das tensões normais à interface causada pelo carregamento vertical aplicado e pela própria geometria do protótipo, pois as mesas inferiores do perfil estão confinadas, causando maiores tensões normais de compressão nessa região. Como a tensão de cisalhamento está relacionada com a tensão normal por meio do efeito do atrito, as maiores tensões de cisalhamento se concentraram na região em contato com as mesas inferiores, consequentemente. 
As regiões da interface em contato com as almas e as mesas superiores do perfil não estavam confinadas e, portanto, as tensões normais de compressão foram de baixa magnitude. $\mathrm{Na}$ região em contato com a mesa superior, as tensões normais foram praticamente nulas e, portanto, a tensão de cisalhamento apresentou baixa magnitude.

Verifica-se que os fenômenos observados no modelo numérico estão condizentes com os esperados e com os observados experimentalmente quando se realizou os ensaios do tipo slip-block. Dessa forma, constata-se que o modelo de interface empregado foi capaz de reproduzir adequadamente os fenômenos mediante as simplificações adotadas, uma vez que não se modelou as mossas e transferiu-se toda a responsabilidade do comportamento para o modelo de interface. Além disso, é importante ressaltar que os parâmetros de entrada do modelo de interface, com exceção de $k_{n}$, foram obtidos experimentalmente e resultaram na validação do modelo numérico.

Realizou-se uma análise paramétrica com o modelo validado a fim de identificar a influência dos seguintes parâmetros: espessura da fôrma de aço, espessura da capa de concreto e tensão de escoamento do aço. Todavia, não foram identificadas influências significativas ao se variar tais parâmetros, conforme esperado, pois o ensaio consiste num cisalhamento direto da interface e a variação desses parâmetros causam pouca influência sobre o comportamento da interface aço-concreto. Diante disso, os resultados dessa análise paramétrica não foram incluídos neste trabalho.

\subsection{Análise Numérica da Laje Mista}

A análise numérica da laje mista foi realizada em duas etapas. Primeiramente fez-se um intenso estudo sobre a influência de cada parâmetro do modelo de interface sobre o comportamento do modelo inicial da laje mista. Com base nesse estudo e nos resultados experimentais definiu-se as considerações adotadas para o modelo numérico definitivo, realizando-se sua validação seguida de uma análise paramétrica sobre algumas propriedades geométricas do modelo.

O protótipo Laje 1 foi escolhido para a realização da análise numérica, portanto as propriedades do seu concreto foram utilizadas na análise inicial, na validação e na análise paramétrica. Após a validação do modelo, as propriedades do concreto da Laje 2 foram aplicadas e o seu resultado numérico foi comparado com o experimental. 


\subsubsection{Análise do Modelo de Interface sobre o Comportamento da Laje Mista}

O objetivo desta análise é verificar a influência de cada parâmetro do modelo numérico de interface sobre o comportamento do modelo da laje mista mediante a ocorrência da flexão, pois nesse caso o comportamento da interface aço-concreto é relativamente diferente do observado no modelo numérico do ensaio slip-block devido tanto ao efeito da flexão quanto à falta de confinamento na região localizada entre os apoios.

Esta seção descreve a análise realizada sobre cada parâmetro da interface e o estudo que resultou na definição do modelo numérico definitivo. Esse modelo incorpora a estratégia aqui desenvolvida para a simulação da interface aço-concreto utilizando os resultados provenientes do ensaio slip-block.

\subsubsection{Modelo Numérico Inicial}

O modelo numérico inicial foi desenvolvido para realizar a análise do modelo de interface utilizado. Modelou-se $1 / 4$ da laje mista considerando as condições de simetria longitudinal e transversal, objetivando reduzir o custo computacional após verificado que essa simplificação não promoveu resultados diferentes quando comparados aos resultados obtidos na simulação da laje por completo. Além disso, essa consideração sobre as simetrias do modelo foi comumente utilizada em trabalhos que realizaram simulações numéricas de lajes mistas.

Os apoios utilizados no ensaio também foram modelados a fim de representar melhor o protótipo ensaiado e evitar concentração de tensões nessas regiões. A Figura 7.20 ilustra a geometria considerada para o modelo numérico, com suas dimensões.

Figura 7.20 - Geometria e simetria considerada para o modelo numérico inicial da laje mista

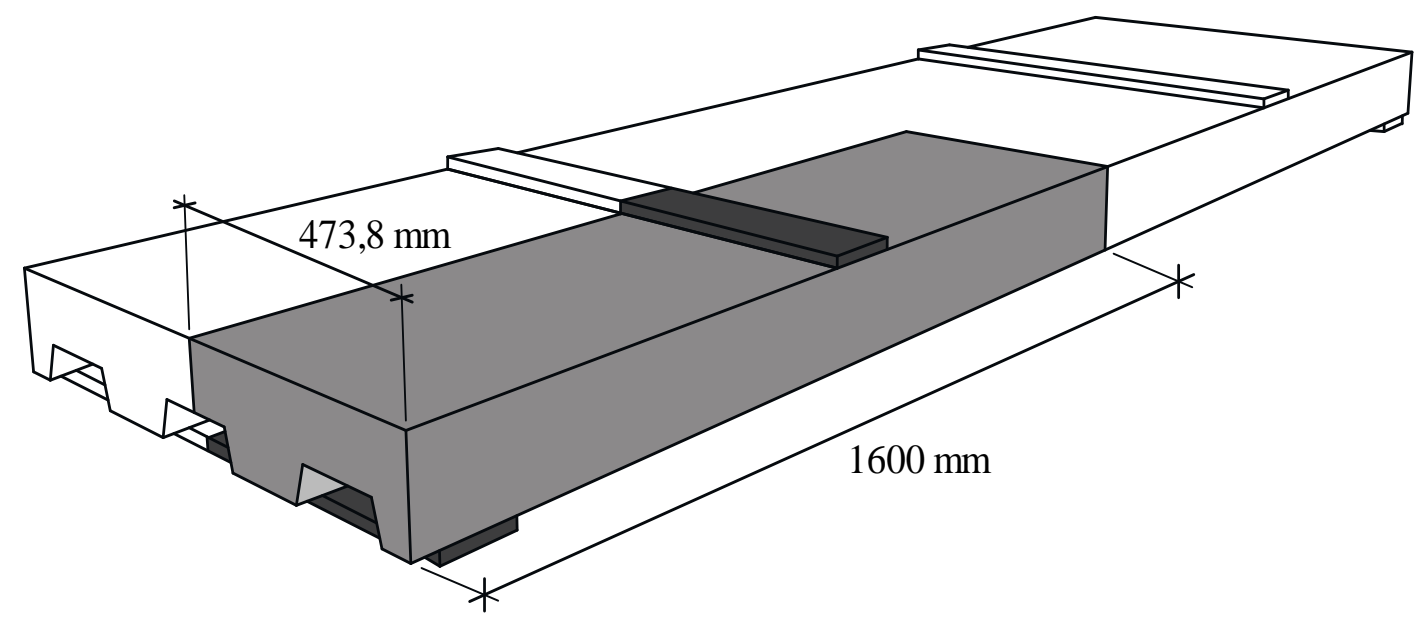

Fonte: Autoria própria 


\subsection{Estrutura do Modelo e Propriedades dos Materiais}

A estrutura do modelo numérico inicial do ensaio de flexão da laje mista foi composta por cinco partes: apoio de carregamento, capa de concreto, interface aço-concreto, fôrma de aço e apoio móvel. A Figura 7.21 ilustra o modelo e seus componentes, em que se utilizou elementos finitos com dimensão máxima de $30 \mathrm{~mm}$ para representar sua malha.

Figura 7.21 - Estrutura do modelo numérico inicial do ensaio de flexão da laje mista
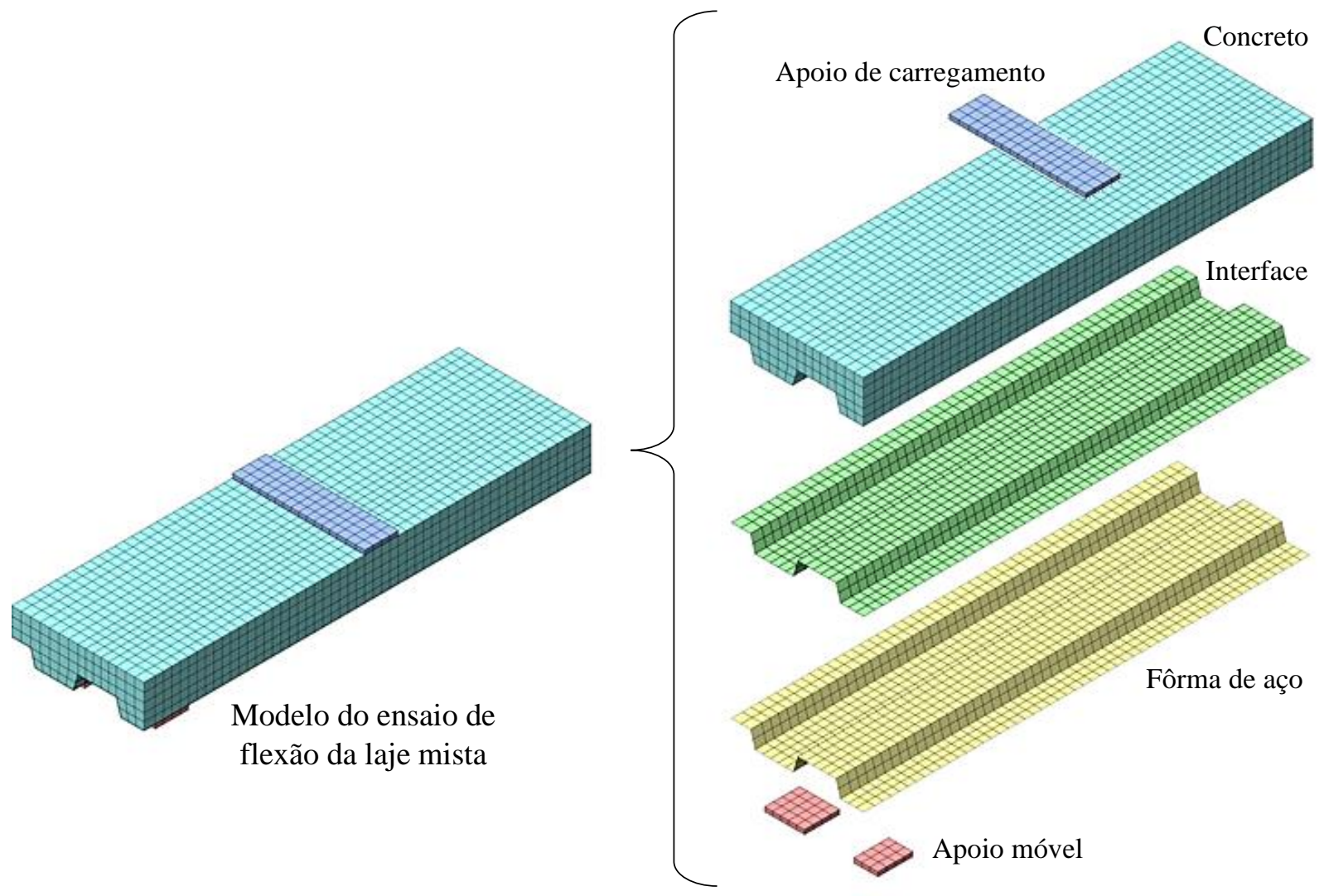

Fonte: Autoria própria

As propriedades utilizadas para o concreto foram as obtidas experimentalmente (seção 6.2.1), com exceção do coeficiente de Poisson (adotado igual a 0,2) e da energia de fratura, que foi calibrada com base em análises prévias. A Tabela 7.7 apresenta as propriedades utilizadas para modelar o comportamento do concreto empregando o modelo Total Strain Crack Model.

Considerou-se um material de comportamento elástico linear e rigidez elevada como constituinte do apoio de carregamento e do apoio móvel a fim de distribuir melhor o carregamento aplicado e a reação de apoio. Logo, adotou-se o módulo de elasticidade igual ao do aço $\left(200.000 \mathrm{~N} / \mathrm{mm}^{2}\right)$ e o coeficiente de Poisson igual a 0,3. 
Tabela 7.7 - Parâmetros do concreto do modelo numérico do ensaio de flexão da laje mista

\begin{tabular}{cc}
\hline Modelo Total Strain Crack & Fixed \\
Largura de banda da fissura $(\boldsymbol{h})$ & $30 \mathrm{~mm}$ \\
Módulo de Elasticidade $\left(\boldsymbol{E}_{\mathbf{c}}\right)$ & $36.753 \mathrm{~N} / \mathrm{mm}^{2}$ \\
Coeficiente de Poisson $\left(\boldsymbol{v}_{\mathbf{c}}\right)$ & 0,2 \\
Resistência à tração $\left(\boldsymbol{f}_{\mathbf{t}}\right)$ & $3,33 \mathrm{~N} / \mathrm{mm}^{2}$ \\
Energia de fratura $\left(\boldsymbol{G}_{\mathbf{f}}\right)$ & $0,012 \mathrm{~N} / \mathrm{mm}^{2}$ \\
Resistência à compressão $\left(\boldsymbol{f}_{\mathbf{c}}\right)$ & $61,16 \mathrm{~N} / \mathrm{mm}^{2}$ \\
Função de retenção ao cisalhamento & Constante \\
Coeficiente de retenção ao cisalhamento $(\boldsymbol{\beta})$ & 0,01 \\
\hline
\end{tabular}

Fonte: Autoria própria

A Tabela 7.8 apresenta as propriedades utilizadas para modelar o aço, em que o módulo de elasticidade e o coeficiente de Poisson foram estimados com base nos valores usualmente empregados na literatura técnica. Para a tensão de escoamento do critério de ruptura de Von Mises, utilizou-se o valor determinado experimentalmente (seção 6.2.2).

Tabela 7.8 - Parâmetros do aço do modelo numérico do ensaio de flexão da laje mista
Módulo de Elasticidade $\left(E_{\mathrm{a}}\right)$ $200.000 \mathrm{~N} / \mathrm{mm}^{2}$
Coeficiente de Poisson $(v a)$
0,3
Resistência ao escoamento $\left(f_{\mathbf{y}}\right)$
$285,97 \mathrm{~N} / \mathrm{mm}^{2}$

Fonte: Autoria própria

$\mathrm{Na}$ análise dos parâmetros de interface do modelo numérico inicial da laje mista, as propriedades do modelo de interface Coulomb Friction com Hardening foram as mesmas utilizadas no modelo numérico do ensaio slip-block, determinados com base na metodologia desenvolvida neste trabalho (seção 6.3.3.1) e apresentadas na Tabela 7.4. Logo, as curvas do Coeficiente de atrito $(\mu)$ versus Deslizamento $(s)$ e da Coesão $(c)$ versus Deslizamento $(s)$, que servem como dados de entrada para o Hardening do modelo de interface, foram as apresentadas na Figura 7.14.

Entretanto, a rigidez à separação normal à interface $\left(k_{n}\right)$ calibrada para modelo do ensaio slip-block não é necessariamente a mesma do modelo do ensaio de flexão, pois a condição a qual a interface está submetida é diferente, já que a possível separação vertical entre o concreto e a fôrma de aço é restringida no modelo do ensaio slip-block devido ao confinamento existente. Dessa forma, por meio da análise da influência do parâmetro $k_{n}$, definiu-se um valor mais adequado para a situação do ensaio de flexão da laje mista, conforme discutido posteriormente. 


\subsection{Condições de Contorno e Carregamento}

As condições de contorno foram definidas de modo a garantir as condições de simetria e de apoio estabelecidas. A Figura 7.22 ilustra as condições de contorno e de carregamento do modelo inicial do ensaio de flexão da laje mista.

Figura 7.22 - Condições de contorno e carregamento modelo numérico inicial do ensaio de flexão da laje mista

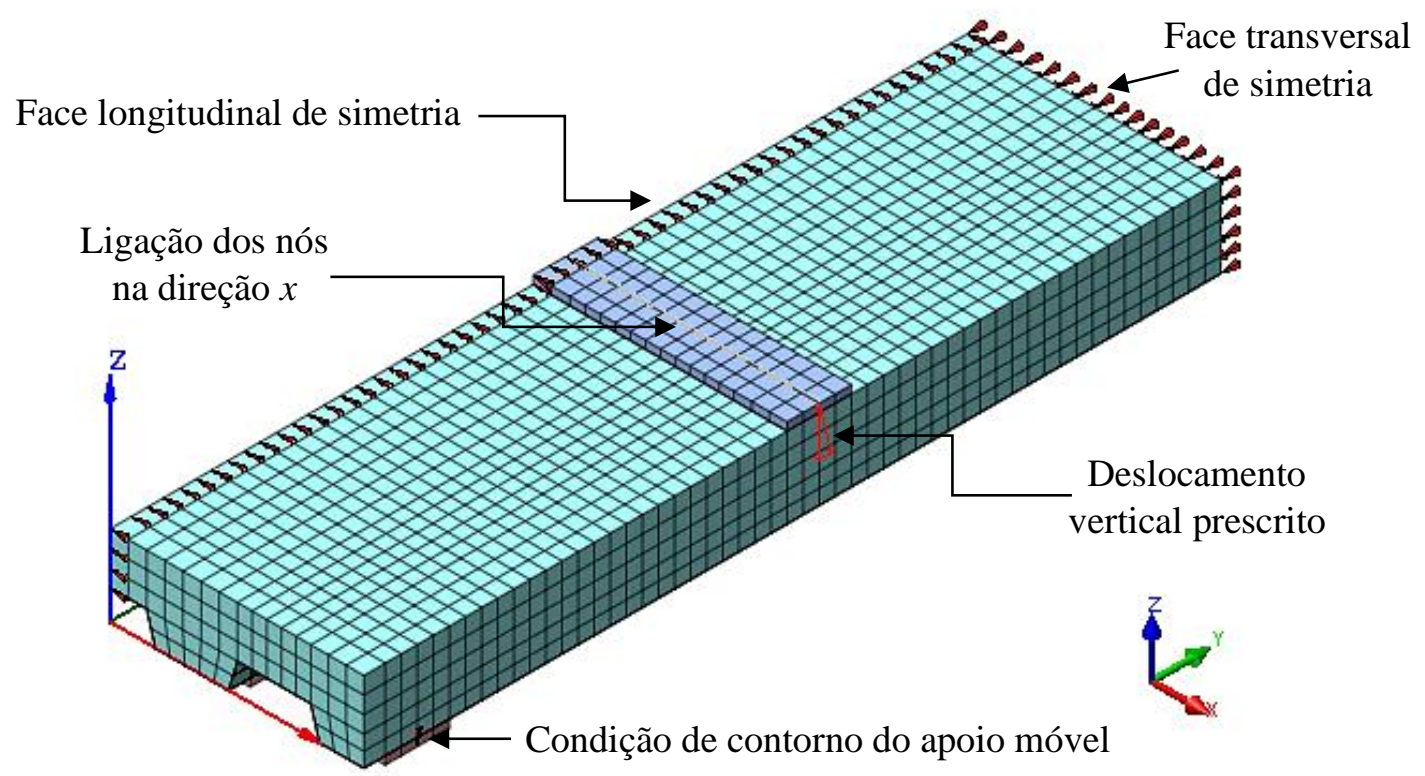

Fonte: Autoria própria

A condição de simetria transversal foi estabelecida restringindo-se os deslocamentos na direção $x$ dos nós localizados na face longitudinal de simetria (ver Figura 7.22). Já a condição de simetria longitudinal foi estabelecida restringindo-se os deslocamentos na direção y dos nós localizados na face transversal de simetria (ver Figura 7.22). A condição de apoio móvel, por sua vez, foi garantida pela restrição do deslocamento na direção $z$ dos nós localizados na linha central (direção $x$ ) da face inferior do apoio móvel. Assim, esse apoio permite o giro em torno do eixo $x$ e o deslocamento na direção $y$.

O carregamento foi aplicado como deslocamento prescrito. Com o objetivo de aplicá-lo apenas em um nó, criou-se uma propriedade de ligação dos nós localizados na linha central (direção $x$ ) do apoio de carregamento, conforme ilustra a Figura 7.22. Assim, definiu-se o nó mestre (master node), onde se aplicou o deslocamento, ao qual todos os demais nós (slave nodes) dessa linha são ligados a ele, possuindo o mesmo deslocamento vertical (direção z). 


\subsection{Estratégia de Solução e Critério de Convergência}

O método iterativo Quasi-Newton (ou Secante) foi adotado como estratégia de solução. Utilizou-se o algoritmo Line Search, que tem a função de corrigir a solução encontrada nos métodos tradicionais de modo a acelerar a taxa de convergência. $\mathrm{O}$ critério de convergência em energia foi empregado com tolerância de convergência igual a 0,001.

Analisou-se várias configurações para a aplicação do carregamento e definiu-se a que apresentou o melhor resultado aliado a um custo computacional reduzido. Logo, aplicou-se um deslocamento vertical de aproximadamente $50 \mathrm{~mm}$ com incrementos iguais a $0,1 \mathrm{~mm}$ durante todo o processamento.

\subsubsection{Análise da Malha}

Os modelos utilizados para a análise da malha já consideraram as não linearidades físicas do concreto, do aço e da interface (inclusive o Hardening ilustrado na Figura 7.14), objetivando verificar melhor a sensitividade da malha de elementos finitos. Nesta análise, utilizou-se $k_{n}=k_{t}=10 \mathrm{~N} / \mathrm{mm}^{3}$. Esse valor foi escolhido por conveniência após algumas análises previamente realizadas.

Foram analisadas malhas com dimensão máxima do elemento finito iguais a $20 \mathrm{~mm}, 25$ mm e $30 \mathrm{~mm}$. Adicionalmente, analisou-se malhas de dimensão máxima do elemento finito de $20 \mathrm{~mm}$ e $25 \mathrm{~mm}$, porém com maior quantidade de elementos sólidos ao longo da altura da fôrma de aço, objetivando verificar se essa configuração influenciaria a resposta numérica devido à maior discretização da região mais propensa à fissuração. A Tabela 7.9 apresenta as características de cada modelo e o tempo de processamento requerido.

Tabela 7.9 - Características de cada modelo da análise da malha do ensaio da laje mista

\begin{tabular}{cccc}
\hline Modelo & $\begin{array}{c}\text { Quantidade de } \\
\text { elementos }\end{array}$ & $\begin{array}{c}\text { Quantidade } \\
\text { de nós }\end{array}$ & $\begin{array}{c}\text { Tempo de } \\
\text { processamento }\end{array}$ \\
\hline 20 $\mathbf{~ m m}$ apenas & 17.874 & 18.477 & $7 \mathrm{~h} 12 \mathrm{~min} 23 \mathrm{~s}$ \\
$\mathbf{2 5} \mathbf{~ m m}$ apenas & 9.444 & 9.893 & $3 \mathrm{~h} 13 \mathrm{~min} 38 \mathrm{~s}$ \\
$\mathbf{3 0} \mathbf{~ m m}$ apenas & 5.555 & 5.884 & $1 \mathrm{~h} 43 \mathrm{~min} 27 \mathrm{~s}$ \\
$\mathbf{2 5} \mathbf{~ m m ~ c / ~ 3 ~ e l e m . ~ n a ~ a l t u r a ~ d a ~ f o ̂ r m a ~}$ & 10.515 & 10.917 & $3 \mathrm{~h} 24 \mathrm{~min} 52 \mathrm{~s}$ \\
$\mathbf{2 5} \mathbf{~ m m ~ c / ~ 4 ~ e l e m . ~ n a ~ a l t u r a ~ d a ~ f o ̂ r m a ~}$ & 12.374 & 12.743 & $3 \mathrm{~h} 57 \mathrm{~min} 45 \mathrm{~s}$ \\
$\mathbf{2 0} \mathbf{~ m m ~ c / ~ 4 ~ e l e m . ~ n a ~ a l t u r a ~ d a ~ f o ̂ r m a ~}$ & 19.413 & 19.953 & $7 \mathrm{~h} 06 \mathrm{~min} 00 \mathrm{~s}$ \\
\hline
\end{tabular}

* Considerando a mesma configuração computacional (para efeito de comparação). 
A Figura 7.23 ilustra o gráfico da Força $(F)$ versus Deslocamento vertical no meio do vão $(\delta)$ obtido para cada um dos modelos analisados no deste de malha.

Figura 7.23 - Gráfico de $F$ versus $\delta$ do teste de malha do modelo numérico inicial do ensaio de flexão

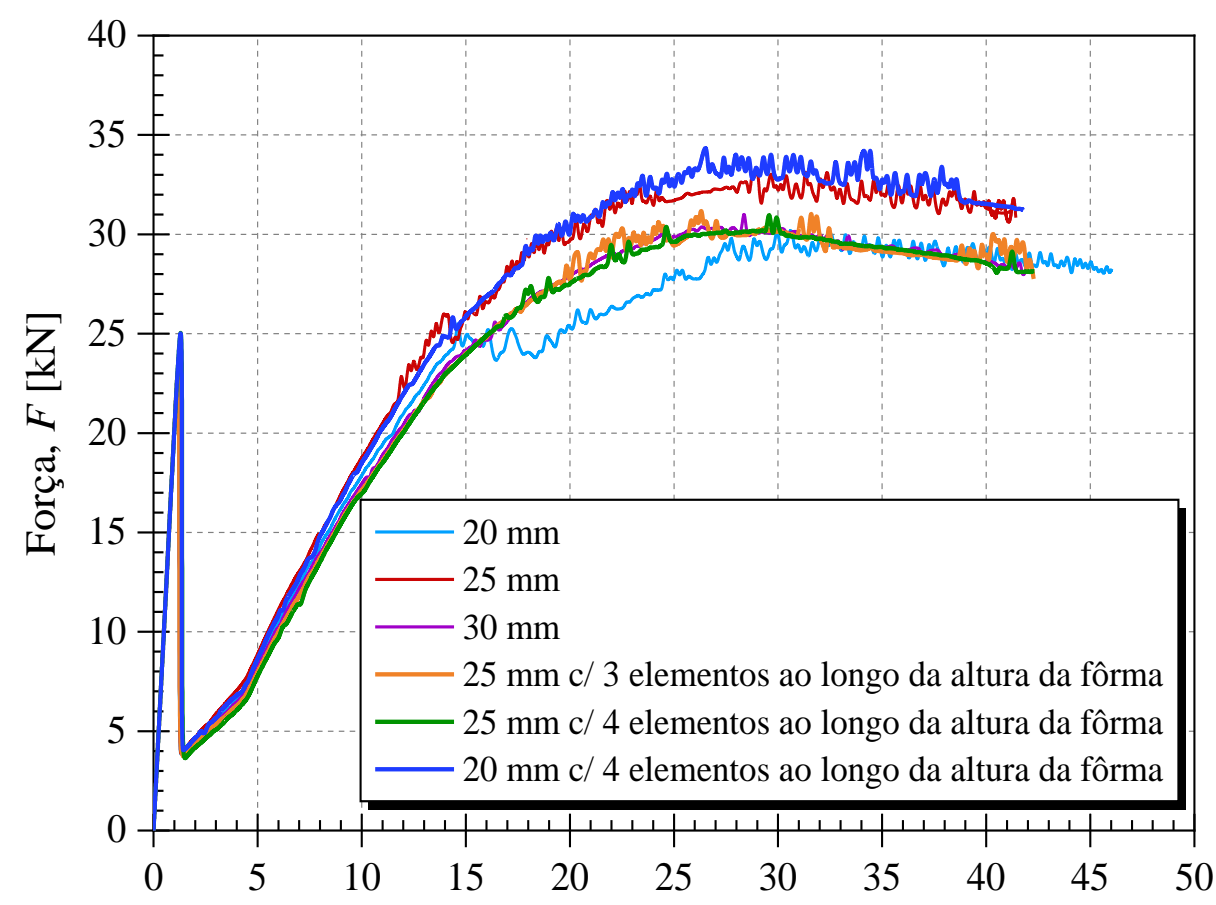

Deslocamento vertical no meio do vão, $\delta[\mathrm{mm}]$

Fonte: Autoria própria

O comportamento das curvas foi semelhante em geral, principalmente no trecho inicial, conforme se observa no gráfico acima. Entretanto, os modelos com dimensão máxima de elemento de $25 \mathrm{~mm}$ e $20 \mathrm{~mm}$ com 4 elementos finitos ao longo da altura da fôrma apresentaram maiores capacidades resistentes últimas quando comparados aos demais. O modelo com dimensão máxima do elemento igual a $20 \mathrm{~mm}$ apresentou uma perca de rigidez após atingir aproximadamente $25 \mathrm{kN}$ de capacidade resistente.

Diante dos resultados obtidos e expostos na Figura 7.23, optou-se por utilizar o modelo numérico com $30 \mathrm{~mm}$ de dimensão máxima do elemento finito, pois este apresentou comportamento compatível com os demais analisados, assim como o menor custo computacional. Além disso, essa dimensão do elemento finito está de acordo com as utilizadas e recomendadas pela literatura técnica.

A configuração do gráfico de $F$ versus $\delta$ não é discutida neste item, pois será abordada mais adiante após a análise dos parâmetros do modelo de interface utilizado. 


\subsubsection{Análise de Sensibilidade do Modelo de Interface}

Esta análise foi realizada objetivando identificar a influência de cada parâmetro que define o modelo de interface sobre o comportamento do modelo do ensaio de flexão da laje mista. Inicialmente fez-se uma análise utilizando o modelo de interface com comportamento elástico, definido apenas pelos parâmetros $k_{n}$ e $k_{t}$.

Posteriormente realizou-se a análise dos parâmetros que definem o modelo de interface Coulomb Friction: $k_{n}, k_{t}, \mu$ e $c$. Nesta análise não se utilizou o Hardening, uma vez que foi melhor compreender a influência desses parâmetros mantendo-se o critério de ruptura constante. Os valores adotados para os parâmetros foram os mesmos utilizados na análise realizada para o modelo do ensaio slip-block. Assim, pode-se correlacionar o comportamento da interface nos dois tipos de ensaios mediante a alteração do respectivo parâmetro.

\section{a) Rigidez normal $\left(k_{n}\right)$ e rigidez tangencial $\left(k_{t}\right)$ - Modelo de interface elástico linear}

Ao se realizar a análise do comportamento do modelo de laje mista com a interface atuando no regime elástico linear foi possível identificar a influência dos parâmetros $k_{n}$ e $k_{t}$ de forma isolada, ou seja, sem a consideração do critério de ruptura do modelo de interface.

A fim de realizar a análise com um espectro relevante de resultados, avaliou-se tanto para $k_{n}$ quanto para $k_{t}$ os seguintes valores: $1 \mathrm{~N} / \mathrm{mm}^{3}, 5 \mathrm{~N} / \mathrm{mm}^{3}, 10 \mathrm{~N} / \mathrm{mm}^{3}, 25 \mathrm{~N} / \mathrm{mm}^{3}, 50$ $\mathrm{N} / \mathrm{mm}^{3}$ e $100 \mathrm{~N} / \mathrm{mm}^{3}$.

Para verificar a influência do parâmetro $k_{t}$, seu valor foi variado mantendo-se o valor de $k_{n}$ fixo. A Figura 7.24 apresenta o gráfico da Força $(F)$ versus Deslocamento vertical no meio do vão $(\delta)$ para $k_{n}=10 \mathrm{~N} / \mathrm{mm}^{3}$. Os gráficos para os demais valores de $k_{n}$ apresentaram comportamentos semelhantes ao da Figura 7.24 e estão apresentados no Apêndice D.

O comportamento geral do modelo numérico foi inicialmente linear, uma vez que a maior parte do concreto ainda se comportou linearmente. Quando a força aplicada atingiu aproximadamente $24 \mathrm{kN}$, todos os modelos apresentaram uma redução brusca da capacidade resistente, que está relacionada à formação de uma fissura principal na capa de concreto próximo à região onde o carregamento foi aplicado, conforme ilustra a Figura 7.25, que apresenta o panorama de fissuração com a largura das fissuras.

Em seguida a capacidade resistente dos modelos aumentou consideravelmente até se manter constante, quando a região da fôrma de aço localizada no vão de flexão pura estava totalmente plastificada. A força máxima suportada pelos modelos, correspondente à flecha $\delta=L / 50=60 \mathrm{~mm}$, foi de aproximadamente $90 \mathrm{kN}$. 
Figura 7.24 - Gráfico de $F$ versus $\delta$ do modelo numérico inicial da laje mista utilizando interface com comportamento elástico linear - análise de $k_{t} \operatorname{com} k_{n}=10 \mathrm{~N} / \mathrm{mm}^{3}$

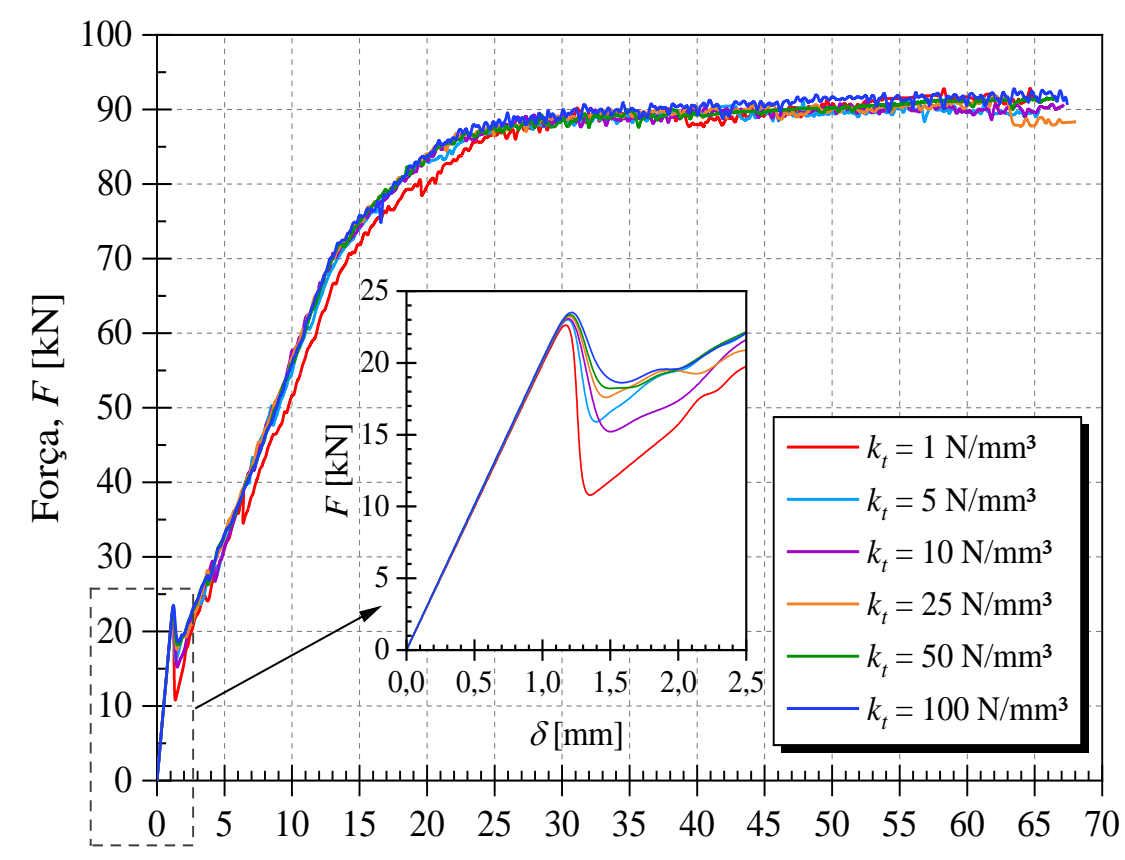

Deslocamento vertical no meio do vão, $\delta[\mathrm{mm}]$

Fonte: Autoria própria

Figura 7.25 - Largura de fissura no concreto do modelo numérico inicial da laje mista com $k_{t}=k_{n}=10 \mathrm{~N} / \mathrm{mm}^{3}$ imediatamente após a abertura da fissura principal (interface com comportamento elástico linear)

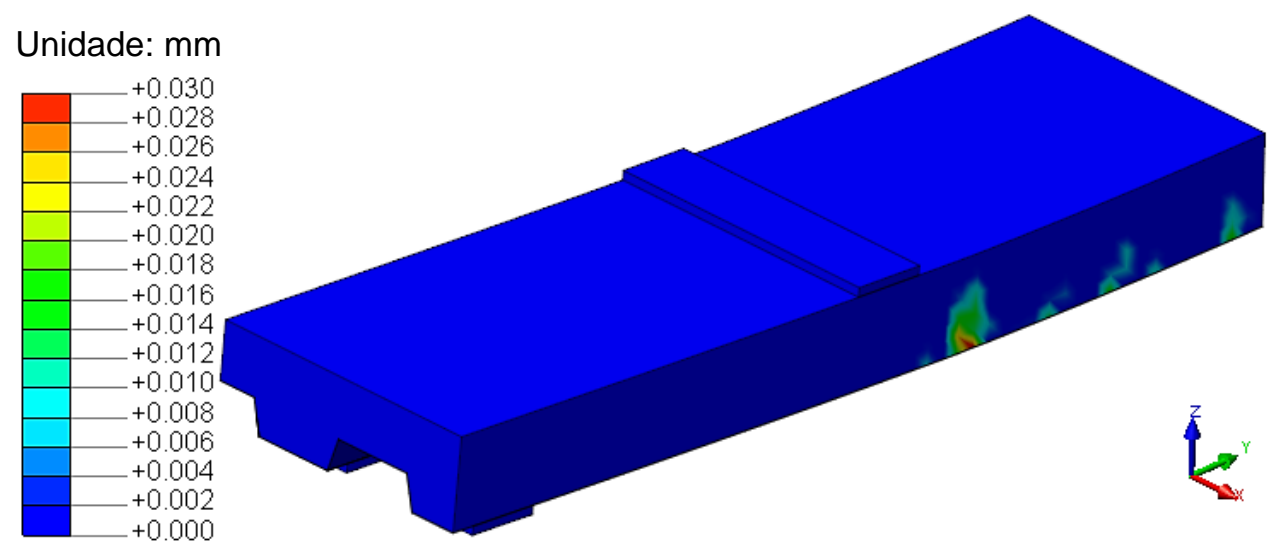

Fonte: Autoria própria

A alteração no valor do parâmetro $k_{t}$ não modificou a rigidez inicial da laje mista, que é linear, conforme se observa no gráfico da Figura 7.24. Entretanto, a magnitude da redução que ocorre quando a fissura principal surgiu foi maior quando o valor de $k_{t}$ foi menor. Isso ocorreu porque a abertura da fissura implicou no deslocamento dos nós da interface. Logo, quanto maior a rigidez tangencial, maior foi a tensão tangencial necessária para promover o mesmo deslocamento entre os nós da interface, levando à um maior valor de $F$ após a fissura se abrir. 
O comportamento dos modelos não apresentou alteração significativa após a redução brusca ter ocorrido. Dessa forma, os protótipos apresentaram rigidezes semelhantes e capacidade resistente máxima próximas. O modelo com $k_{t}=1 \mathrm{~N} / \mathrm{mm}^{3}$, porém, apresentou maior flecha que os demais conforme o carregamento foi aplicado. Esse fato ocorreu devido à baixa rigidez tangencial da interface desse modelo, que acarretou em maiores deslizamentos relativos entre os seus nós.

A Figura 7.26 e a Figura 7.27 apresentam a distribuições das tensões principais na capa de concreto e na fôrma de aço, respectivamente, quando $\delta=60 \mathrm{~mm}$ para o modelo com $k_{t}=k_{n}=10 \mathrm{~N} / \mathrm{mm}^{3}$.

Figura 7.26 - Distribuição das tensões principais no concreto do modelo numérico inicial com $k_{t}=k_{n}=10 \mathrm{~N} / \mathrm{mm}^{3}$ quando $\delta=60 \mathrm{~mm}$ (interface com comportamento elástico linear)

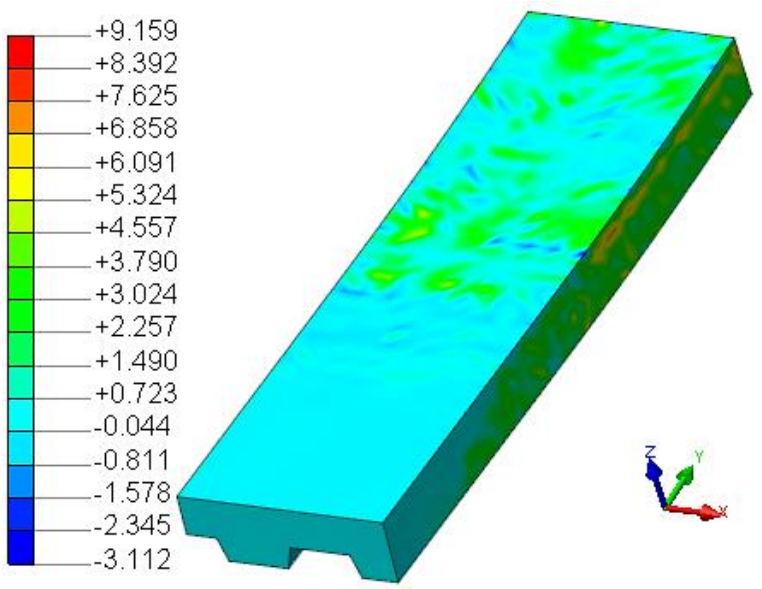

(a) Tensões principais máximas

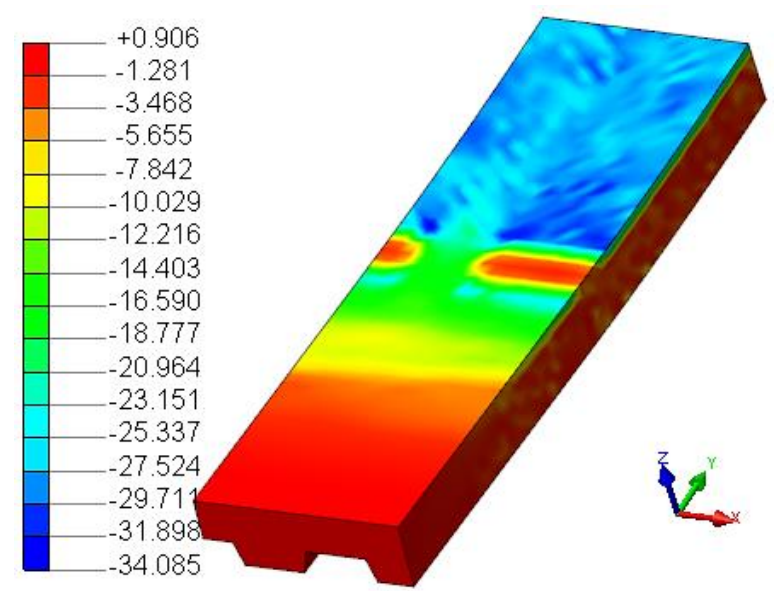

(b) Tensões principais mínimas

(Tensões em MPa)

Fonte: Autoria própria

Figura 7.27 - Distribuição das tensões principais na fôrma de aço do modelo numérico inicial com $k_{t}=k_{n}=10 \mathrm{~N} / \mathrm{mm}^{3}$ quando $\delta=60 \mathrm{~mm}$ (interface com comportamento elástico linear)

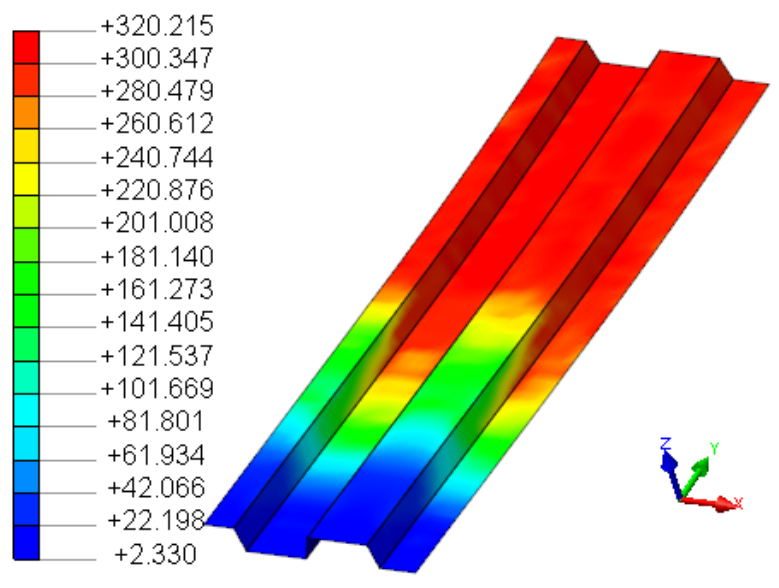

(a) Tensões principais máximas

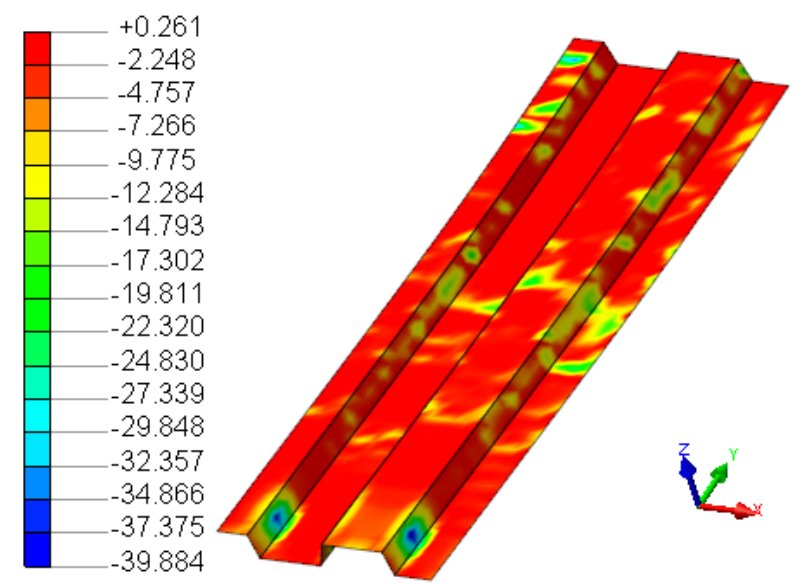

(b) Tensões principais mínimas

Fonte: Autoria própria

(Tensões em MPa) 
Verificou-se que as tensões principais máximas se distribuíram em todo o concreto e que as tensões principais mínimas se concentraram na região superior da capa localizada no vão central. Já a fôrma de aço se apresentou tracionada e levemente comprimida em algumas regiões localizadas. Além disso, notou-se que o aço da região localizada no vão central escoou.

Analogamente, a influência do parâmetro $k_{n}$ sobre o comportamento da interface foi verificada variando-se seu valor e fixando-se o valor de $k_{t}$. A Figura 7.28 apresenta, por exemplo, os gráficos da Força $(F)$ versus Deslocamento vertical no meio do vão $(\delta)$ para $k_{t}=1$ $\mathrm{N} / \mathrm{mm}^{3}$ e para $k_{t}=100 \mathrm{~N} / \mathrm{mm}^{3}$. Os gráficos para os demais valores de $k_{t}$ estão apresentados no Apêndice D.

Figura 7.28 - Gráfico de $F$ versus $\delta$ do modelo numérico inicial da laje mista utilizando interface com comportamento elástico linear - análise de $k_{n} \operatorname{com} k_{t}=1 \mathrm{~N} / \mathrm{mm}^{3}$ e com $k_{t}=100 \mathrm{~N} / \mathrm{mm}^{3}$
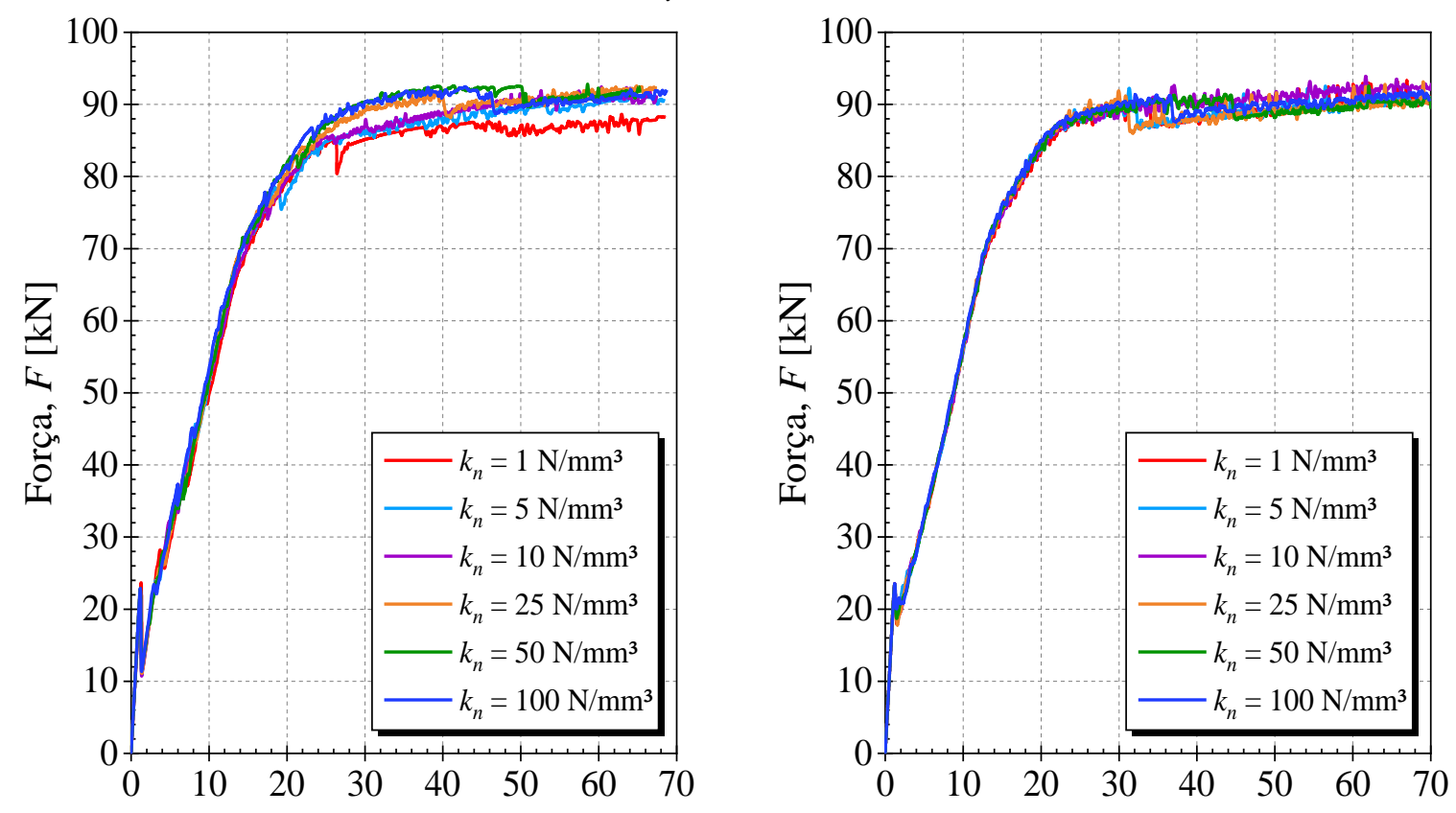

Deslocamento vertical no meio do vão, $\delta$ [mm] Deslocamento vertical no meio do vão, $\delta[\mathrm{mm}]$ (a) $k_{t}=1 \mathrm{~N} / \mathrm{mm}^{3}$

(b) $k_{t}=100 \mathrm{~N} / \mathrm{mm}^{3}$

Fonte: Autoria própria

Diante da análise realizada, verificou-se que a influência da variação de $k_{n}$ foi menor conforme o valor de $k_{t}$ foi maior, conforme ilustrado na figura acima e nos gráficos do Apêndice C. Dessa forma, para a interface com comportamento elástico linear, o parâmetro $k_{n}$ tem pouca influência sobre o comportamento da laje ao se utilizar valores de $k_{t}$ superiores à $50 \mathrm{~N} / \mathrm{mm}^{3}$. Ao se utilizar $k_{t}=1 \mathrm{~N} / \mathrm{mm}^{3}$, porém, ocorreu maior variabilidade dos resultados para $20 \mathrm{~mm} \leq \delta \leq$ $50 \mathrm{~mm}$ e o modelo com $k_{n}=1 \mathrm{~N} / \mathrm{mm}^{3}$ apresentou menor capacidade resistente. Além disso, a redução brusca observada nos gráficos de $F$ versus $\delta$ foi menor conforme o valor de $k_{t}$ foi maior. 
É importante salientar que ao se utilizar a interface com comportamento elástico e valores de $k_{t}$ elevados, como o caso da Figura 7.28 (b), a laje mista se comportou como se estivesse com interação total entre o aço e o concreto, pois praticamente não houve deslizamentos relativos entre os nós da interface.

\section{b) Rigidez normal $\left(k_{n}\right)$ e rigidez tangencial $\left(k_{t}\right)$ - Modelo Coulomb Friction}

Uma vez analisado a influência dos parâmetros $k_{n}$ e $k_{t}$ sobre o comportamento do modelo da laje mista com a interface atuando apenas no regime elástico linear, realizou-se a mesma análise com a interface atuando com o critério de ruptura definido pelo modelo Coulomb Friction. Dessa forma, verificou-se a influência desses parâmetros mediante o emprego da plasticidade do modelo de interface. Conforme já mencionado, não se utilizou o Hardening, mantendo-se o critério de ruptura da interface constante.

Utilizou-se os mesmos valores de $k_{n}$ e $k_{t}$ da análise com a interface elástica linear, ou seja: $1 \mathrm{~N} / \mathrm{mm}^{3}, 5 \mathrm{~N} / \mathrm{mm}^{3}, 10 \mathrm{~N} / \mathrm{mm}^{3}, 25 \mathrm{~N} / \mathrm{mm}^{3}, 50 \mathrm{~N} / \mathrm{mm}^{3}$ e $100 \mathrm{~N} / \mathrm{mm}^{3}$. Os demais parâmetros do modelo Coulomb Friction permaneceram os mesmos: $\mu=0,557, c=0,015 \mathrm{~N} / \mathrm{mm}^{2}$ e $\psi=0$.

Assim como no tópico anterior, para verificar a influência do parâmetro $k_{t}$, seu valor foi variado mantendo-se o valor de $k_{n}$ fixo. A Figura 7.29 apresenta, por exemplo, os gráficos da Força $(F)$ versus Deslocamento vertical no meio do vão $(\delta)$ para $k_{n}=1 \mathrm{~N} / \mathrm{mm}^{3}$ e $k_{n}=100$ $\mathrm{N} / \mathrm{mm}^{3}$. Os gráficos para os demais valores de $k_{n}$ estão apresentados no Apêndice D.

A redução brusca de $F$ corresponde à abertura da fissura principal no concreto próximo à região onde o carregamento foi aplicado, assim como ocorreu quando se utilizou a interface com comportamento elástico. Entretanto, a alteração no valor de $k_{t}$ não promoveu mudança significativa na magnitude da redução brusca de $F$ após a abertura da fissura principal, diferentemente do que se observou no quando se utilizou a interface apenas com comportamento elástico.

Observou-se uma variabilidade nos resultados obtidos, não havendo uma relação explícita referente à influência de $k_{t}$ sobre o comportamento do modelo numérico, conforme se observa na Figura 7.29. Apesar das curvas de $F$ versus $\delta$ se apresentarem semelhantes, em alguns casos a mudança no valor de $k_{t}$ promoveu alteração da rigidez após a redução brusca de $F$, conforme ilustra a Figura 7.29 (a).

Em outros casos, entretanto, a alteração de $k_{t}$ acarretou na ocorrência de uma segunda redução brusca de $F$, como ilustra a Figura 7.29 (b), correspondente à abertura de uma segunda fissura maior próxima ao meio do vão, conforme ilustra a Figura 7.30, que apresenta o panorama de fissuração com a largura das fissuras. 
Figura 7.29 - Gráfico de $F$ versus $\delta$ do modelo numérico inicial da laje mista utilizando o modelo de interface Coulomb Friction - análise de $k_{t} \operatorname{com} k_{n}=1 \mathrm{~N} / \mathrm{mm}^{3}$ e $k_{n}=100 \mathrm{~N} / \mathrm{mm}^{3}$
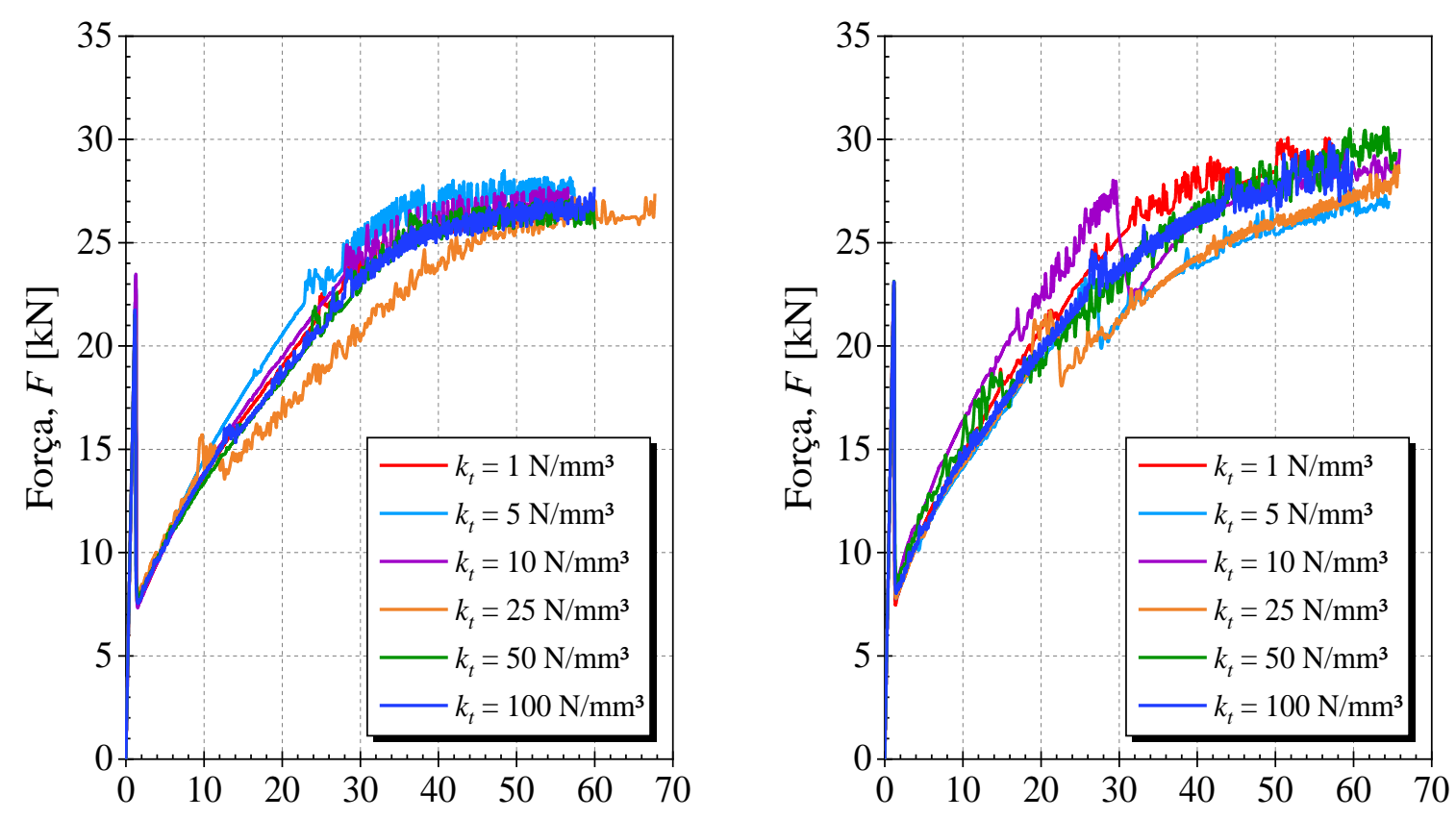

Deslocamento vertical no meio do vão, $\delta$ [mm] Deslocamento vertical no meio do vão, $\delta$ [mm] (a) $k_{n}=1 \mathrm{~N} / \mathrm{mm}^{3}$

(b) $k_{n}=100 \mathrm{~N} / \mathrm{mm}^{3}$

Fonte: Autoria própria

Figura 7.30 - Largura de fissura no concreto do modelo numérico inicial da laje mista com $k_{n}=1 \mathrm{~N} / \mathrm{mm}^{3}$ e $k_{t}=25 \mathrm{~N} / \mathrm{mm}^{3}$ imediatamente após a abertura da segunda fissura (modelo de interface Coulomb Friction)

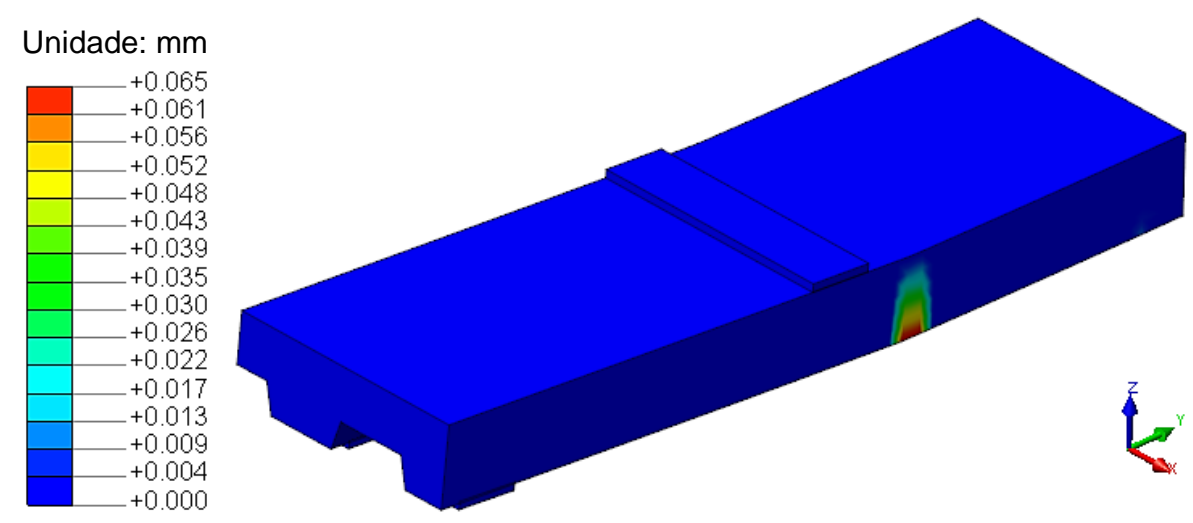

Fonte: Autoria própria

A Figura 7.31 e a Figura 7.32 apresentam as distribuições das tensões principais na capa de concreto e na fôrma de aço, respectivamente, quando $\delta=60 \mathrm{~mm}$ para o modelo com $k_{t}=k_{n}$ $=10 \mathrm{~N} / \mathrm{mm}^{3}$. Verifica-se que as tensões principais de tração na capa de concreto se concentram próximo à região onde o carregamento foi aplicado, que corresponde a região onde a fissura principal se desenvolveu. Além disso, o concreto se apresenta pouco solicitado à compressão. 
Figura 7.31 - Distribuição das tensões principais no concreto do modelo numérico com $k_{t}=k_{n}=10 \mathrm{~N} / \mathrm{mm}^{3}$ (modelo de interface Coulomb Friction)

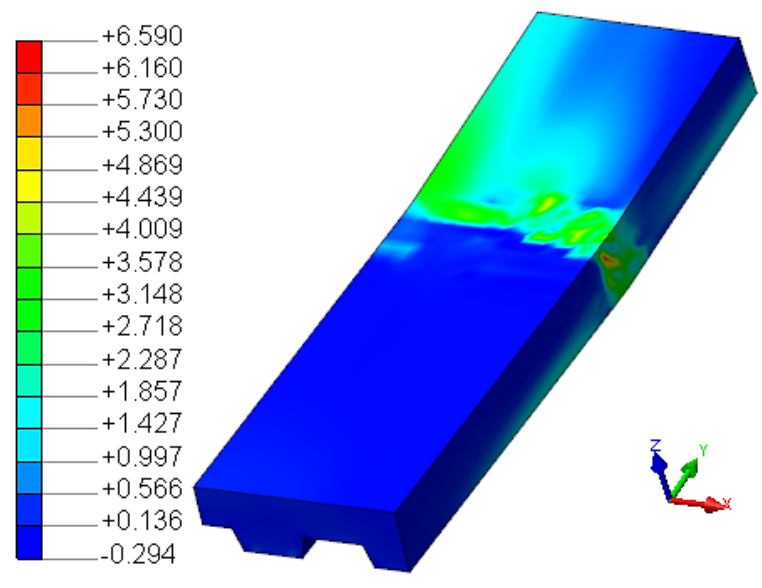

(a) Tensões principais máximas

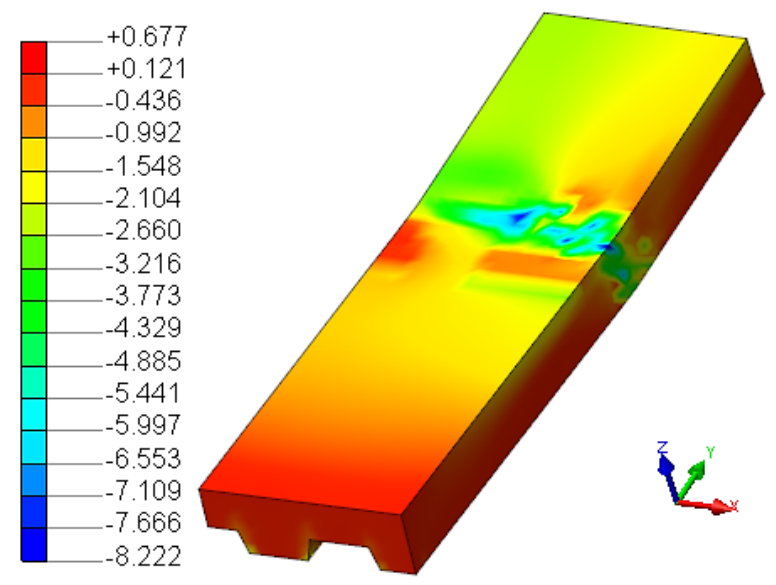

(b) Tensões principais mínimas

Fonte: Autoria própria

(Tensões em MPa)

Figura 7.32 - Distribuição das tensões principais na fôrma de aço do modelo numérico com $k_{t}=k_{n}=10 \mathrm{~N} / \mathrm{mm}^{3}$ (modelo de interface Coulomb Friction)

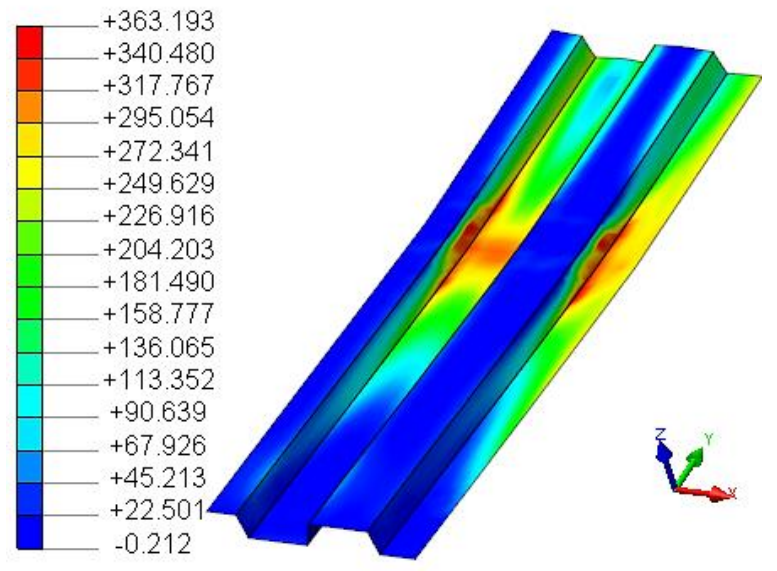

(a) Tensões principais máximas

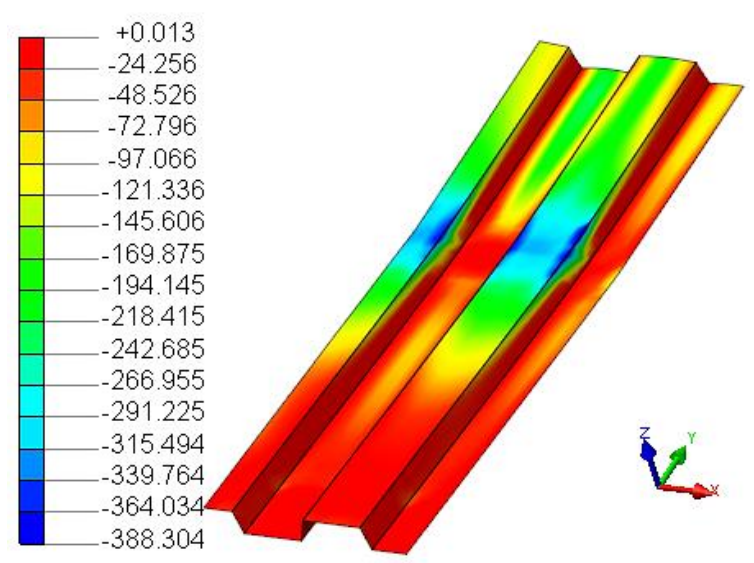

(b) Tensões principais mínimas

Fonte: Autoria própria

(Tensões em MPa)

As tensões principais de tração na fôrma de aço também se concentraram na região da fissura principal, pois há o deslizamento relativo dos nós da interface devido à abertura da fissura, o que causa aumento das tensões nesta região. As mesas altas, porém, se apresentaram comprimidas na região da fissura principal, onde o aço está escoando.

A influência do parâmetro $k_{n}$ sobre o comportamento da interface, por sua vez, foi verificada variando-se seu valor e fixando-se o valor de $k_{t}$. A Figura 7.33 apresenta, por exemplo, os gráficos da Força $(F)$ versus Deslocamento vertical no meio do vão $(\delta)$ para $k_{t}=1$ $\mathrm{N} / \mathrm{mm}^{3}$ e para $k_{t}=100 \mathrm{~N} / \mathrm{mm}^{3}$. Os gráficos para os demais valores de $k_{n}$ estão apresentados no Apêndice D. 
Figura 7.33 - Gráfico de $F$ versus $\delta$ do modelo numérico inicial da laje mista utilizando o modelo de interface Coulomb Friction - análise de $k_{n} \operatorname{com} k_{t}=1 \mathrm{~N} / \mathrm{mm}^{3}$ e $k_{t}=100 \mathrm{~N} / \mathrm{mm}^{3}$
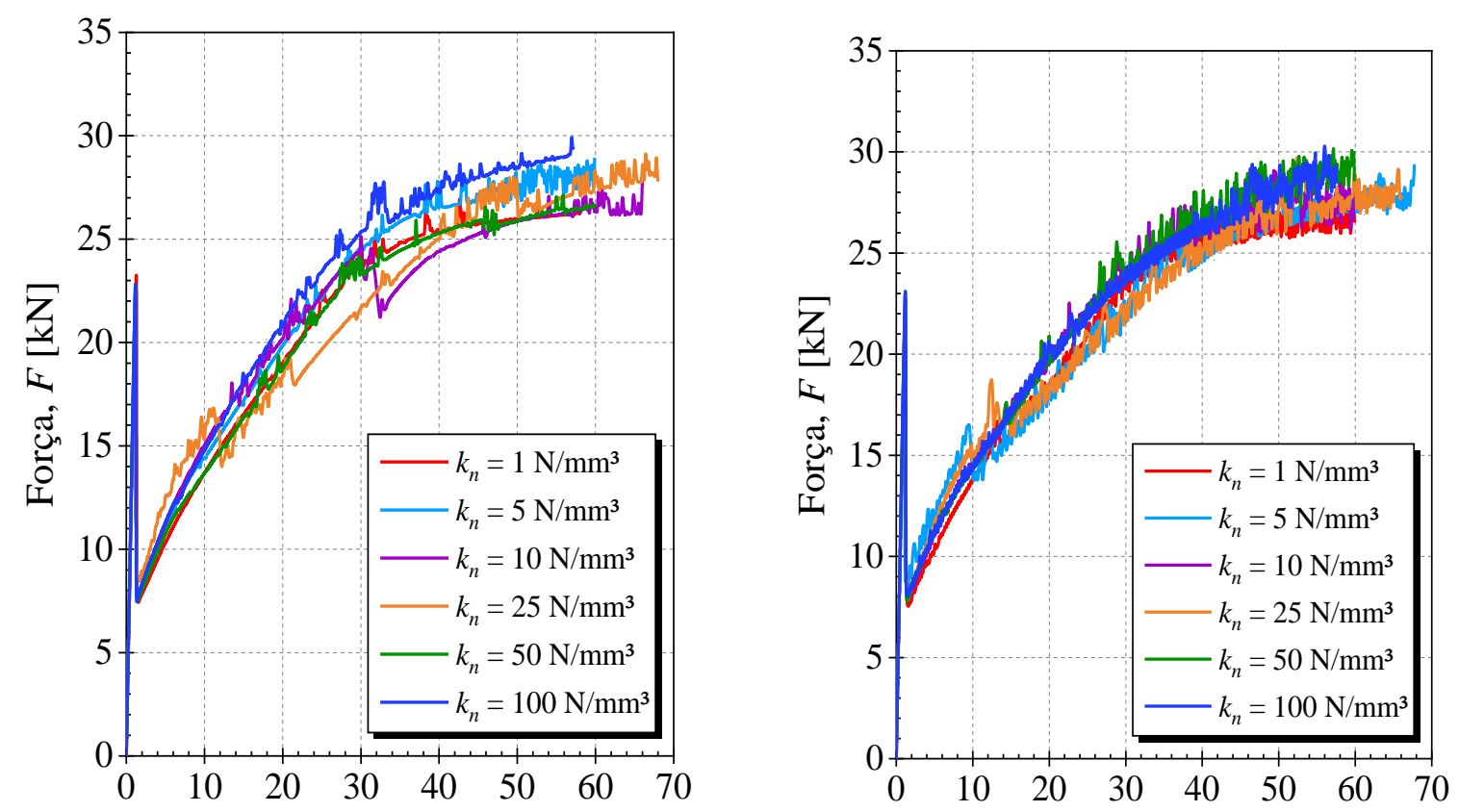

Deslocamento vertical no meio do vão, $\delta[\mathrm{mm}]$ Deslocamento vertical no meio do vão, $\delta$ [mm] (a) $k_{t}=1 \mathrm{~N} / \mathrm{mm}^{3}$

(b) $k_{t}=100 \mathrm{~N} / \mathrm{mm}^{3}$

Fonte: Autoria própria

Também não se verificou uma relação explícita sobre a implicância de $k_{n}$ sobre o comportamento do modelo numérico. Contudo, a influência da variação de $k_{n}$ pareceu ser menor conforme se utilizou maiores valores de $k_{t}$. Além disso, quando se utilizou $k_{\mathrm{n}}=1 \mathrm{~N} / \mathrm{mm}^{3}$ observou-se a abertura de uma segunda fissura maior próximo ao meio do vão para os modelos $\operatorname{com} k_{t}=10 \mathrm{~N} / \mathrm{mm}^{3}$ e $k_{t}=25 \mathrm{~N} / \mathrm{mm}^{3}$.

De modo geral, a implementação do critério de plasticidade da interface tornou mais complexo o comportamento do modelo numérico. Após a abertura da fissura principal, observou-se o início do deslizamento da capa de concreto do vão de cisalhamento. Entretanto, a região do vão central permaneceu no regime elástico até atingir o critério de ruptura. Dessa forma, o comportamento do modelo da laje mista passou a ser fortemente influenciado pelo comportamento do modelo de interface.

$\mathrm{O}$ parâmetro $k_{n}$ se refere à rigidez à separação na direção normal à superfície da interface. Logo, quando o critério de ruptura referente à direção normal à interface foi atingido, a tensão normal se anulou, conforme explicado na seção 7.3.3.3. Sendo assim, em função da distribuição de tensões sobre a interface, causada pelo carregamento aplicado, existem regiões atuando no regime elástico linear e regiões atuando no regime plástico. Além disso, existem regiões com alguma tensão normal e regiões com tensão normal nula. 
Como a tensão tangencial é influenciada pela tensão normal segundo o critério de Coulomb, a distribuição da tensão de cisalhamento na interface torna-se bastante complexa. A Figura 7.34 ilustra, por exemplo, a distribuição de tensões normal e de cisalhamento na direção $y$, do modelo com $k_{n}=k_{t}=10 \mathrm{~N} / \mathrm{mm}^{3}$.

Figura 7.34 - Distribuição das tensões da interface do modelo numérico inicial com $k_{t}=k_{n}=10 \mathrm{~N} / \mathrm{mm}^{3}$ (modelo de interface Coulomb Friction)
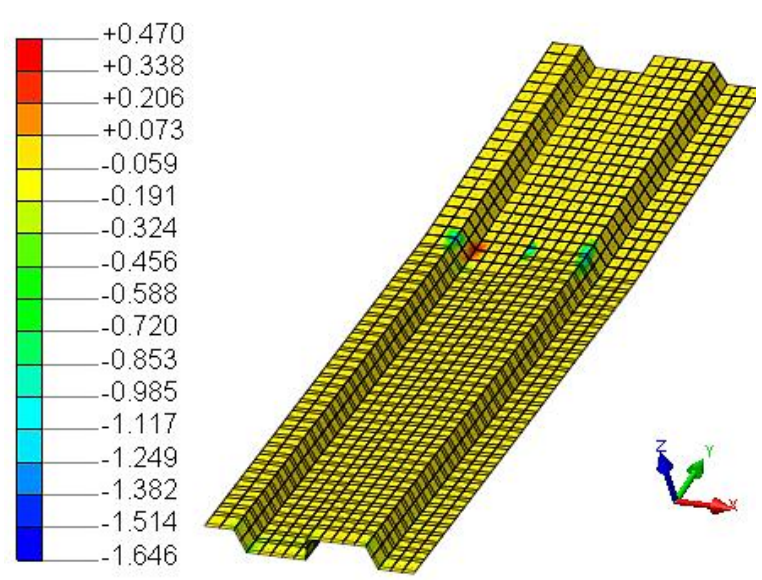

(a) Tensão normal

Fonte: Autoria própria
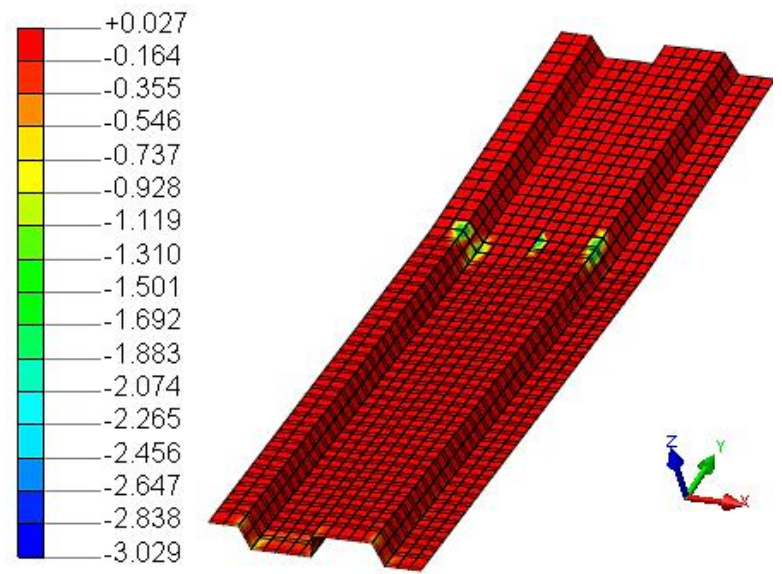

(b) Tensão de cisalhamento na direção $y$

(Tensões em MPa)

Na figura acima é possível observar que as tensões de cisalhamento e normal na interface se concentram na região onde surgiu a fissura principal, indicando que essa região foi a mais solicitada. Além disso, observa-se que o deslocamento relativo dos nós da interface foi consideravelmente maior na região do vão de cisalhamento.

É importante salientar que as lajes com o modelo de interface Coulomb Friction atingiram capacidade resistente máxima entre $25 \mathrm{kN}$ e $30 \mathrm{kN}$, aproximadamente, conforme se verifica nos gráficos deste tópico. Em comparação com as lajes com interface de comportamento elástico linear, que atingiram aproximadamente $90 \mathrm{kN}$ de resistência máxima, a consideração do critério de ruptura utilizado promoveu uma redução de aproximadamente $2 / 3$ da capacidade resistente do modelo inicial da laje mista.

\section{c) Coeficiente de atrito $(\mu)$}

A análise da influência do coeficiente de atrito $(\mu)$ também foi realizada utilizando valores dentro da faixa de variação obtida no ensaio slip-block. Logo, analisou-se os seguintes valores: $\mu=0,001, \mu=0,3, \mu=0,4, \mu=0,5$ e $\mu=0,6$. O primeiro valor foi escolhido objetivando analisar o comportamento da interface com um coeficiente de atrito próximo de zero. Nesta análise manteve-se os valores de $k_{n}=10 \mathrm{~N} / \mathrm{mm}^{3}, k_{t}=10 \mathrm{~N} / \mathrm{mm}^{3}, c=0,015 \mathrm{~N} / \mathrm{mm}^{2}$ $\mathrm{e} \psi=0$. 
O gráfico de $F$ versus $\delta$ da análise da influência de $\mu$ está ilustrado na Figura 7.35. Conforme se verifica, o comportamento inicial, antes da redução brusca de $F$, independeu do valor de $\mu$. Entretanto, o comportamento posterior a esse trecho sofreu uma certa alteração em função do valor de $\mu$.

Figura 7.35 - Gráfico de $F$ versus $\delta$ do modelo numérico inicial da laje mista com interface linear - análise de $\mu$

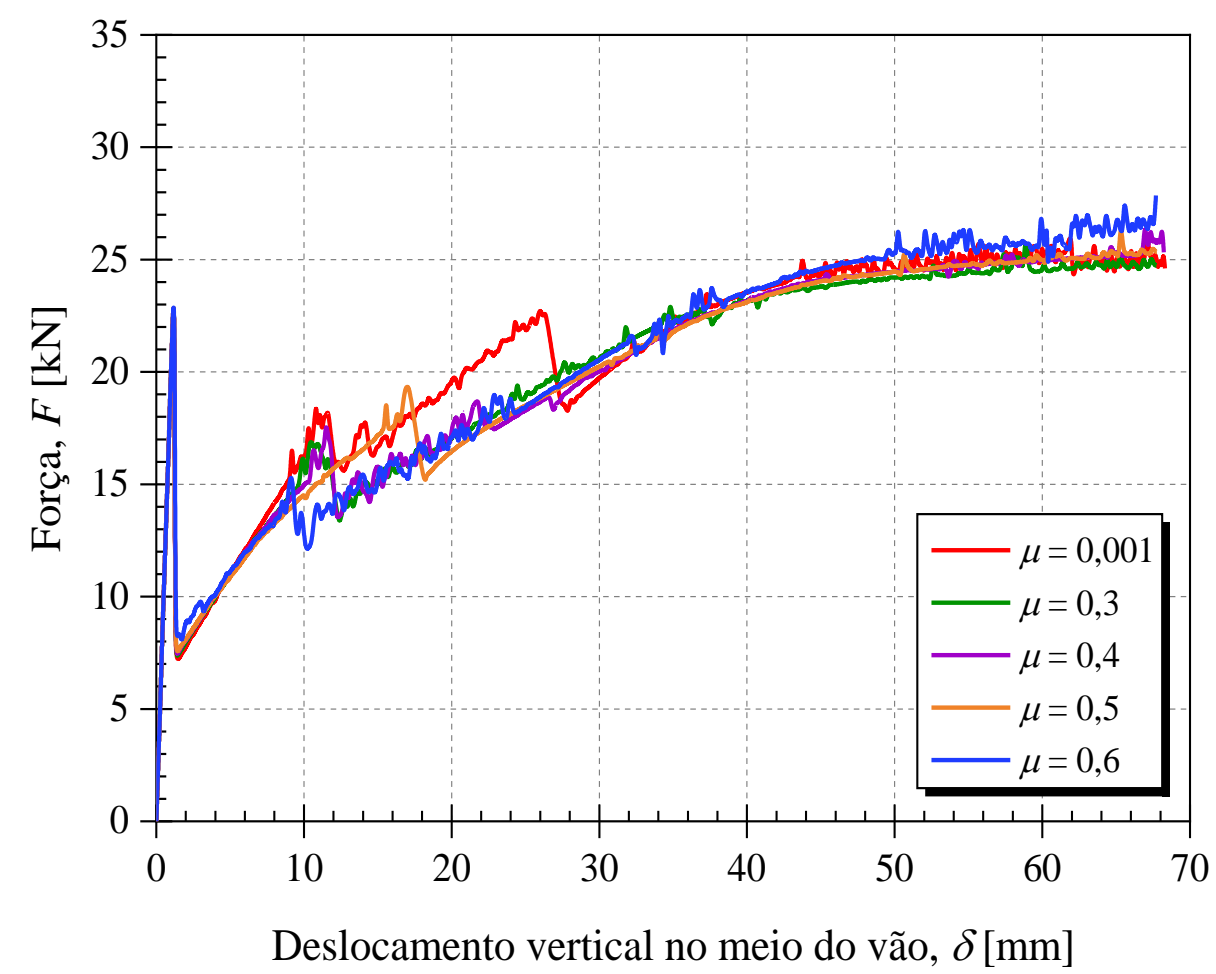

Fonte: Autoria própria

Todos os modelos apresentaram uma segunda redução brusca de $F$, correspondente à abertura de uma fissura maior próxima ao meio do vão. Essa redução está relacionada, também, aos valores de $k_{n}$ e $k_{t}$ utilizados nesta análise. Apesar disso, o comportamento dos modelos foi semelhante após o deslocamento vertical no meio do vão atingir aproximadamente $32 \mathrm{~mm}$.

O coeficiente de atrito é responsável por relacionar a tensão normal com a tensão tangencial da interface, porém não houve mudanças significativas para $0,3 \leq \mu \leq 0,6$.

A força máxima resistente, correspondente à $\delta=L / 50=60 \mathrm{~mm}$, não sofreu alterações significativas mediante a mudança no valor de $\mu$, mesmo quando se utilizou um valor muito baixo $(\mu=0,001)$ a fim de reduzir o efeito da tensão normal sobre a resistência da interface. Isso pode estar relacionado com o fato que as tensões normais sobre a interface são mais significativas numa estreita região sobre os apoios devido ao confinamento existente, porém não possuem grande influência na região entre apoios, conforme discutido no Capítulo 2. 


\section{d) Coesão (c)}

Analisou-se a coesão $(c)$ com valores dentro da faixa de variação obtida por meio do ensaio slip-block: $0,001 \mathrm{~N} / \mathrm{mm}^{2}, 0,010 \mathrm{~N} / \mathrm{mm}^{2}, 0,015 \mathrm{~N} / \mathrm{mm}^{3}, 0,020 \mathrm{~N} / \mathrm{mm}^{2}, 0,030 \mathrm{~N} / \mathrm{mm}^{2}$ e $0,035 \mathrm{~N} / \mathrm{mm}^{2}$. Manteve-se os valores de $k_{n}=10 \mathrm{~N} / \mathrm{mm}^{3}, k_{t}=10 \mathrm{~N} / \mathrm{mm}^{3}, \mu=0,557 \mathrm{~N} / \mathrm{mm}^{2}$ e $\psi=0$.

O gráfico de $F$ versus $\delta$ da análise da influência de $c$ está apresentado na Figura 7.36. Verifica-se que o aumento no valor da coesão $(c)$ resultou na mudança de comportamento a partir da redução brusca de $F$ apenas.

Figura 7.36 - Gráfico de $F$ versus $\delta$ do modelo numérico inicial da laje mista com interface linear - análise de $c$

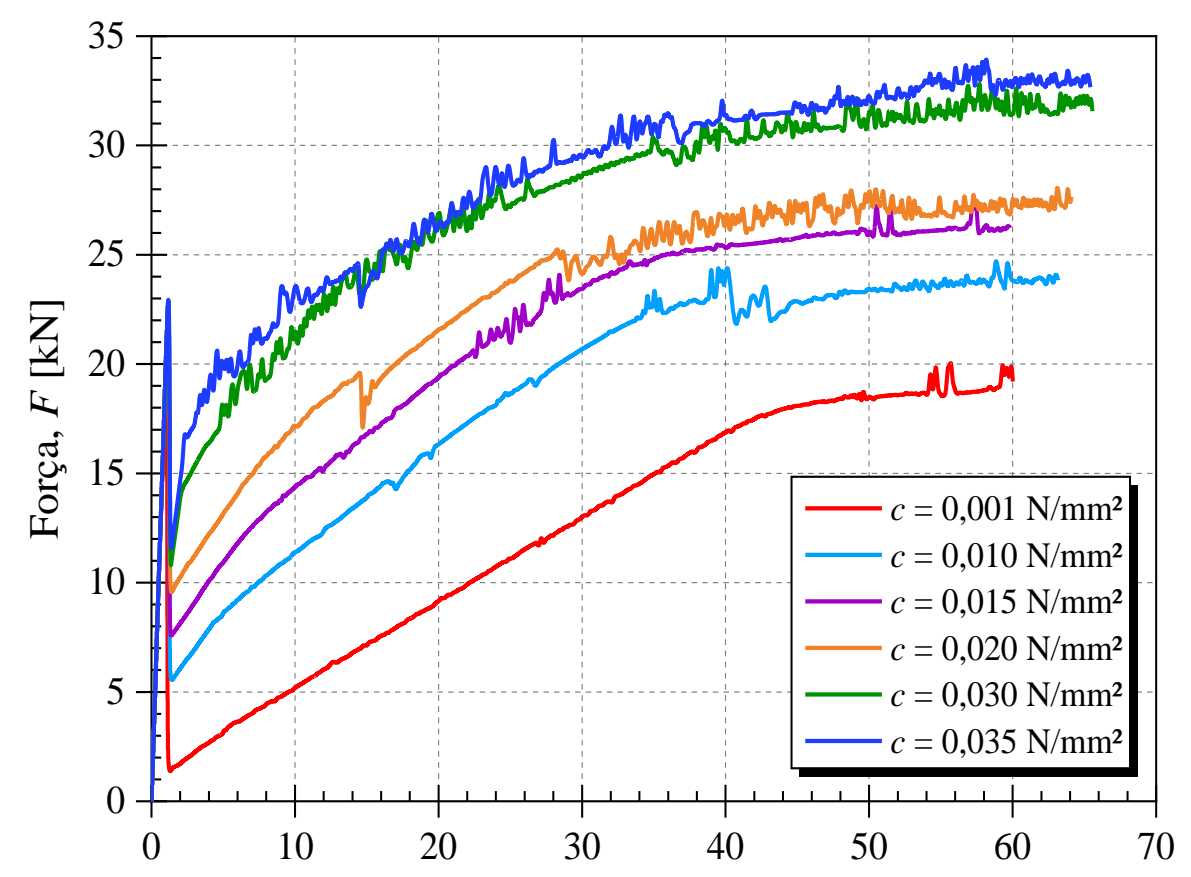

Deslocamento vertical no meio do vão, $\delta$ [mm]

Fonte: Autoria própria

A coesão interfere diretamente na resistência ao cisalhamento da interface, independentemente da tensão normal atuante. Logo, a alteração desse parâmetro influencia o comportamento da laje mista, consequentemente. Sendo assim, quanto maior o valor de $c$, maior foi o valor de $F$ para um mesmo $\delta$. Além disso, o aumento no valor de $c$ resultou em menor redução de $F$ com o surgimento da fissura principal, pois foi necessária uma maior tensão de cisalhamento para promover o mesmo deslocamento relativo dos nós dos elementos finitos de interface.

Para $c=0,010 \mathrm{~N} / \mathrm{mm}^{2}$ a redução após o primeiro pico foi de $77,27 \%$, enquanto que para $c=0,030 \mathrm{~N} / \mathrm{mm}^{2}$ a redução foi de $58,27 \%$. Além disso, a capacidade resistente do modelo 
(correspondente à $\delta=L / 50=60 \mathrm{~mm}$ ) foi igual a $23,80 \mathrm{kN}$ e $31,45 \mathrm{kN}$ para $c=0,010 \mathrm{~N} / \mathrm{mm}^{2} \mathrm{e}$ $c=0,030 \mathrm{~N} / \mathrm{mm}^{2}$, respectivamente. Logo, triplicar o valor de $c$ causou um aumento de $32,14 \%$ na capacidade resistente da laje mista.

Constata-se, portanto, que a coesão possui uma influência significativa sobre o comportamento e a capacidade resistente do modelo numérico da laje mista, enquanto que o coeficiente de atrito não influenciou significativamente nem o comportamento e nem a capacidade resistente do modelo.

\subsubsection{Aplicação Direta dos Parâmetros de Interface Obtidos no Ensaio Slip-Block}

Uma vez identificada a influência de cada parâmetro do modelo Coulomb Friction sobre o comportamento do modelo numérico inicial da laje mista, aplicou-se nesse modelo os parâmetros de interface apresentados na Tabela 7.4 e na Figura 7.14, correspondentes ao modelo validado do ensaio slip-block utilizando o Hardening. O objetivo desta análise é avaliar a utilização direta desses dados no modelo de interface da laje mista comparando os resultados numérico e experimental.

A Figura 7.37 apresenta os gráficos da Força $(F)$ versus Deslocamento vertical no meio do vão $(\delta)$ do modelo numérico e do protótipo experimental (Laje 1). A Figura 7.38, por sua vez, apresenta os gráficos da Força $(F)$ versus Deslizamento de extremidade do modelo numérico e do protótipo experimental. Aplicou-se um deslocamento prescrito de $50 \mathrm{~mm}$ no modelo numérico para avaliar seu comportamento após atingir a capacidade resistente máxima.

Ao se observar os dois gráficos, nota-se que a força máxima alcançada pelo modelo numérico antes da redução brusca corresponde ao início do deslizamento de extremidade, sendo chamada de $F_{\text {des. }}$. Dessa forma, a fissura principal inicia sua formação concomitantemente ao início do deslizamento da capa de concreto localizada sobre o vão de cisalhamento.

A rigidez inicial do modelo numérico coincidiu com a do protótipo experimental até $F$ atingir aproximadamente $12 \mathrm{kN}$, conforme se observa no gráfico da Figura 7.37. A partir de então, a rigidez do modelo numérico se apresentou maior que a experimental, mantendo o comportamento linear até atingir $F_{\text {des. }}$.

A diferença entre as rigidezes antes de se atingir $F_{\text {des }}$ pode estar relacionada ao comportamento à tração do concreto do modelo numérico, que é linear até se atingir a resistência máxima, conforme ilustrado na Figura 7.4. Apesar disso, a força $F_{\text {des }}$ do modelo numérico se apresentou muito próxima da experimental, embora a flecha correspondente foi menor. 
Figura 7.37 - Gráfico de $F$ versus $\delta$ do modelo numérico inicial da laje mista com os parâmetros de interface do modelo numérico do ensaio slip-block

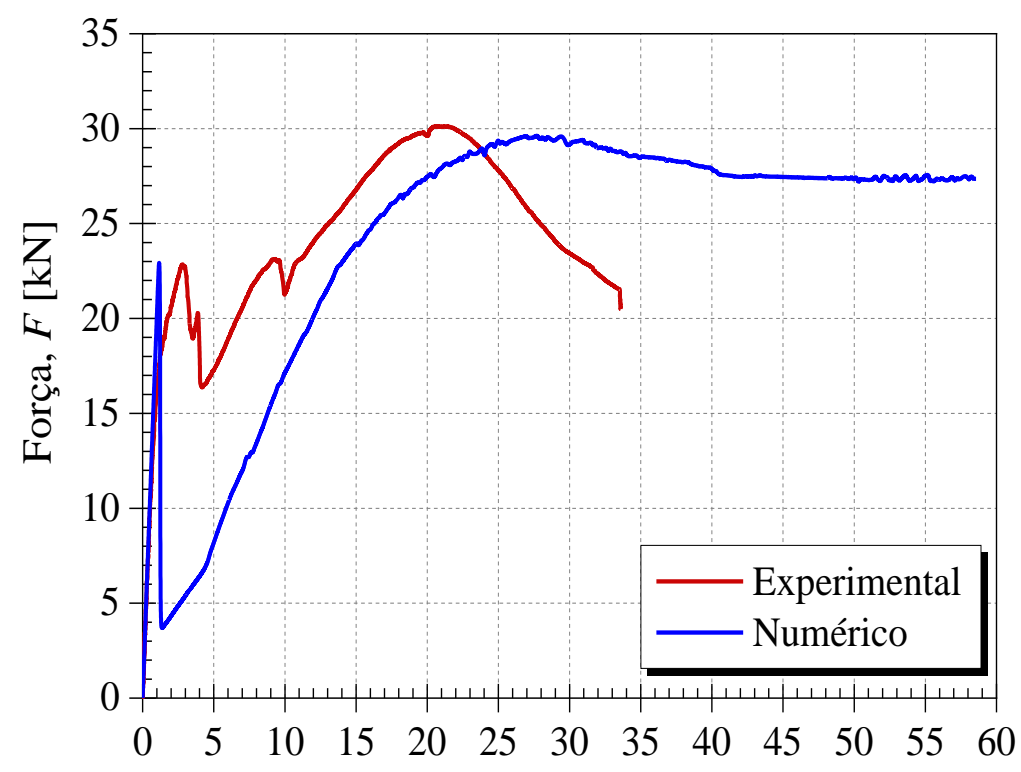

Fonte: Autoria própria

Deslocamento vertical no meio do vão. $\delta\lceil\mathrm{mm}\rceil$

Figura 7.38 - Gráfico de $F$ versus $s$ do modelo numérico inicial da laje mista com os parâmetros de interface do modelo numérico do ensaio slip-block

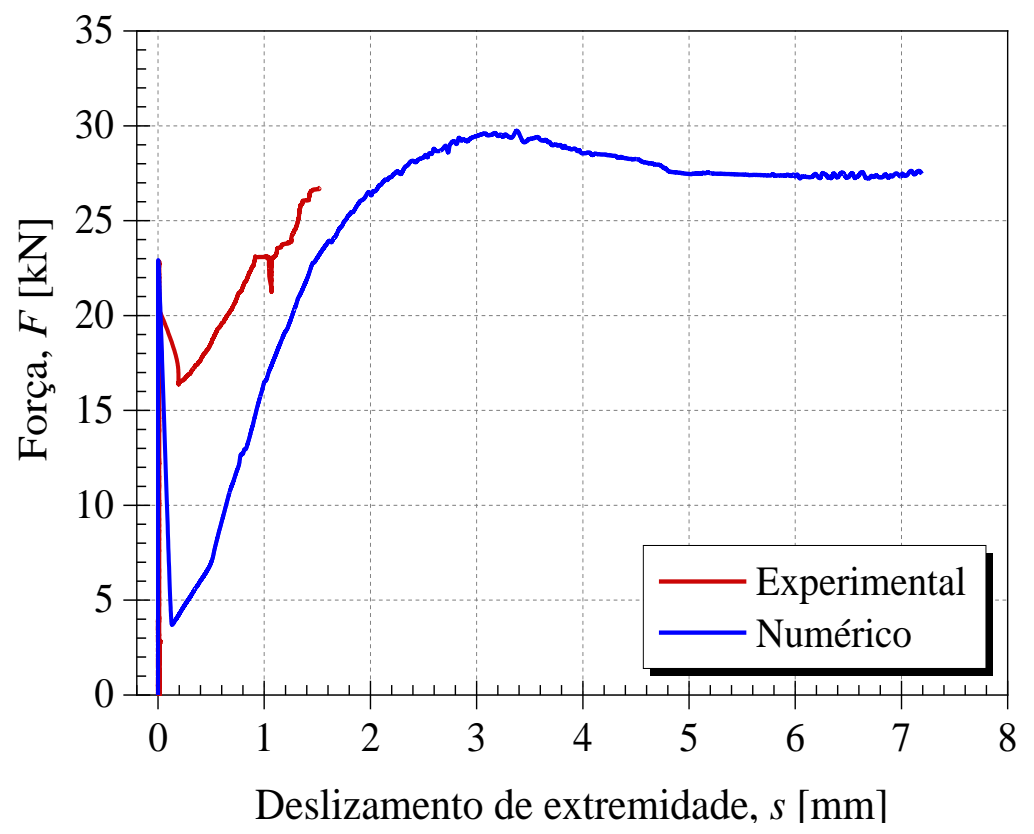

Fonte: Autoria própria

O modelo numérico apresentou a máxima capacidade resistente antes de se atingir $\delta=L / 50=60 \mathrm{~mm}$, assim como o protótipo experimental. Além disso, A força máxima resistente $\left(F_{\text {máx }}\right)$ proveniente do modelo numérico se apresentou próxima da obtida experimentalmente. A Tabela 7.10 apresenta a relação entre os valores numéricos e experimentais obtidos. 
Tabela 7.10 - Relação entre os valores numéricos e experimentais do modelo inicial da laje mista com os parâmetros de interface do modelo numérico do ensaio slip-block

\begin{tabular}{cccc}
\hline Referência & Experimental [kN] & Numérico [kN] & Variação* $^{*}$ \\
\hline$F_{\text {des }}$ & 22,84 & 24,51 & $+7,31 \%$ \\
$F_{\text {ret }}$ & 16,38 & 3,63 & $-77,84 \%$ \\
$F_{\text {máx }}$ & 30,12 & 29,67 & $-1,49 \%$ \\
\hline
\end{tabular}

$F_{\text {des: }}$ Força referente ao início do deslizamento da extremidade da laje;

$F_{\text {ret: }}$ Força referente à retomada de resistência que ocorre após o início do deslizamento;

$F_{\text {máx: }}$ Força máxima suportada.

*Em relação ao valor experimental

Fonte: Autoria própria

A redução da capacidade resistente após o deslizamento de extremidade ser iniciado foi muito maior no modelo numérico. Isso ocorreu devido tanto ao modelo constitutivo à tração do concreto quanto ao modelo de interface, pois o deslocamento dos nós na região da fissura principal é condicionado por estes dois modelos.

Com relação ao modelo de interface utilizado, a coesão é o único parâmetro que controla significativamente a magnitude desta redução brusca que ocorre imediatamente após o início do deslizamento de extremidade, conforme constatado na análise realizada na seção anterior. Como a coesão inicial é $0,015 \mathrm{~N} / \mathrm{mm}^{2}$ e, no regime plástico definido pelo Hardening, se reduz à $0,005 \mathrm{~N} / \mathrm{mm}^{2}$ para depois aumentar (ver Figura 7.14), a resistência da interface foi bastante reduzida no início do deslizamento, resultando numa $F_{\text {ret }}$ menor.

Depois do início do deslizamento de extremidade e após $F \approx 16 \mathrm{kN}$, a configuração da curva do modelo numérico se apresentou semelhante à do protótipo experimental no gráfico da Figura 7.37. Entretanto, para um mesmo valor de $F$, o modelo numérico sempre apresentou maior flecha. $\mathrm{O}$ deslocamento vertical no meio do vão, correspondente à $F_{\text {máx }}$, do protótipo experimental foi de 21,51 mm, enquanto que a do modelo numérico foi de $29,51 \mathrm{~mm}$, ou seja, $37,19 \%$ superior.

Após atingir a capacidade máxima resistente, a taxa de redução da rigidez do protótipo experimental foi superior à do modelo numérico. Além disso, $F$ manteve-se relativamente constante a partir de $\delta \approx 40 \mathrm{~mm}$. Este fenômeno foi observado no protótipo experimental Laje 2, pois, após se atingir $F_{\text {máx }}$, aplicou-se mais deslocamento que a Laje 1, conforme apresentado na Figura 6.24.

A Figura 7.39 e a Figura 7.40 apresentam a distribuição das tensões principais na capa de concreto e na fôrma de aço, respectivamente, no momento em que o modelo numérico atingiu sua capacidade máxima resistente. 
Figura 7.39 - Tensões principais no concreto do modelo numérico inicial da laje mista com os parâmetros de interface do modelo numérico do ensaio slip-block
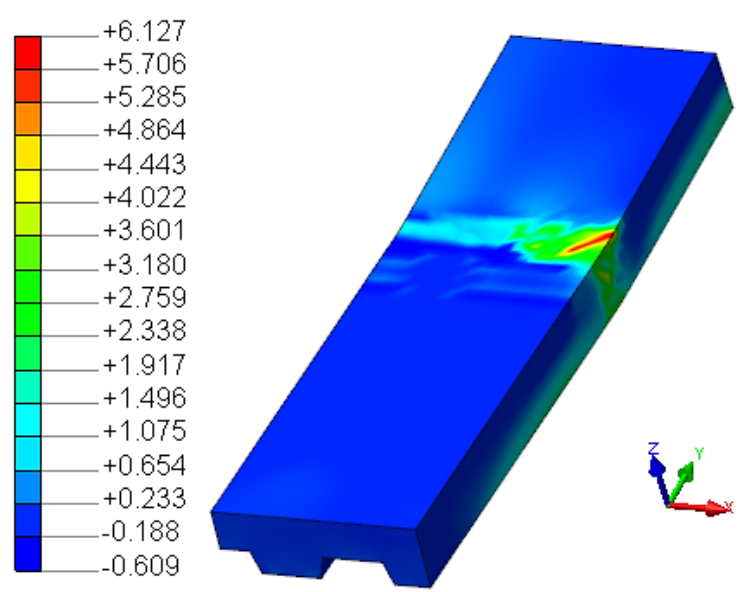

(a) Tensões principais máximas

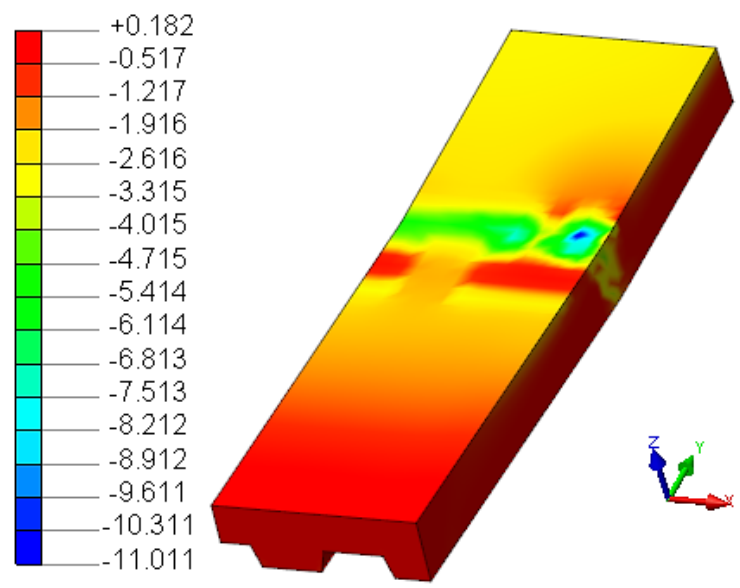

(b) Tensões principais mínimas

Fonte: Autoria própria

(Tensões em MPa)

Figura 7.40 - Tensões principais na fôrma de aço do modelo numérico inicial da laje mista com os parâmetros de interface do modelo numérico do ensaio slip-block

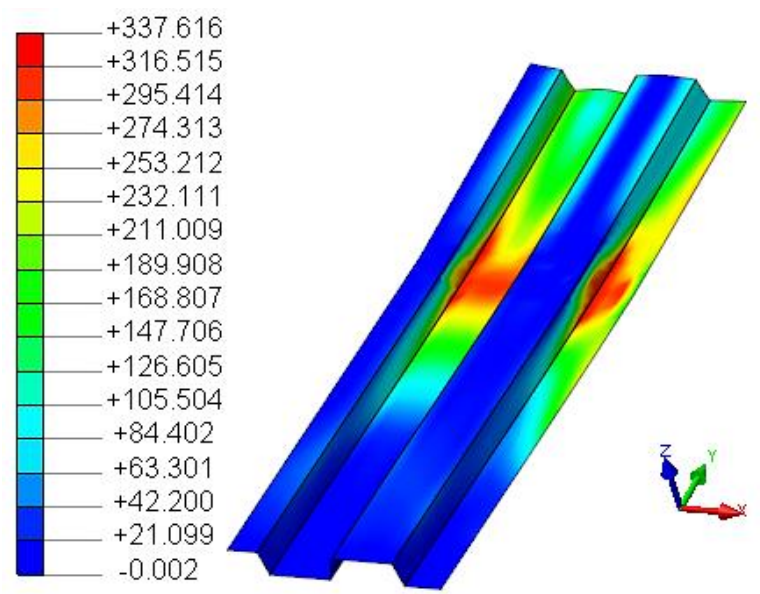

(a) Tensões principais máximas

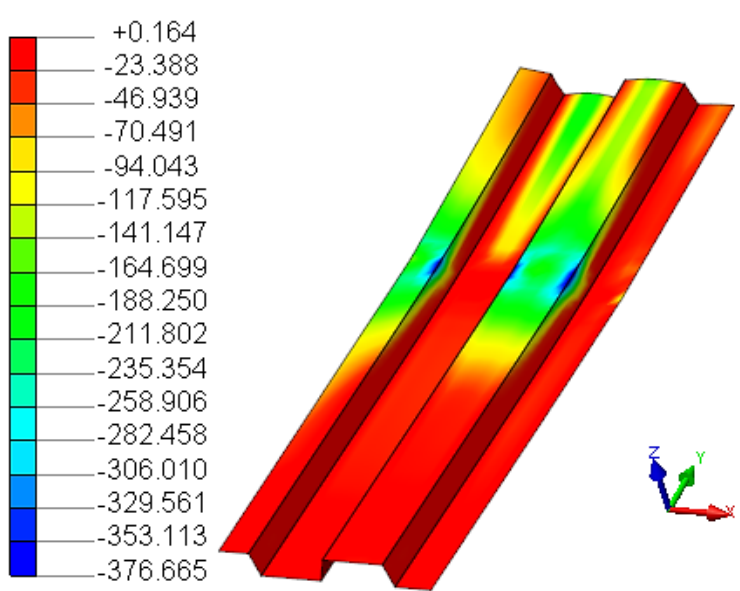

(b) Tensões principais mínimas

Fonte: Autoria própria

(Tensões em MPa)

As tensões principais no concreto e na fôrma de aço se concentraram na região da fissura principal. $\mathrm{O}$ concreto se apresentou pouco solicitado à compressão e com a região da interface tracionada. $\mathrm{O}$ aço da fôrma escoou na região da fissura principal de modo que as mesas inferiores e superiores da fôrma de aço se apresentaram, respectivamente, tracionadas e comprimidas, conforme ilustrado na Figura 7.40.

A distribuição das tensões normal e de cisalhamento (direção y) na interface está apresentada na Figura 7.41. Nessa figura também é possível verificar que o deslizamento relativo entre o aço e o concreto foi significativamente maior na região do vão de cisalhamento. 
As tensões na interface se concentraram na região da fissura principal e se apresentaram aproximadamente uniformes nas regiões do vão de cisalhamento e do vão central.

Figura 7.41 - Distribuição das tensões na interface do modelo numérico inicial da laje mista com os parâmetros de interface do modelo numérico do ensaio slip-block
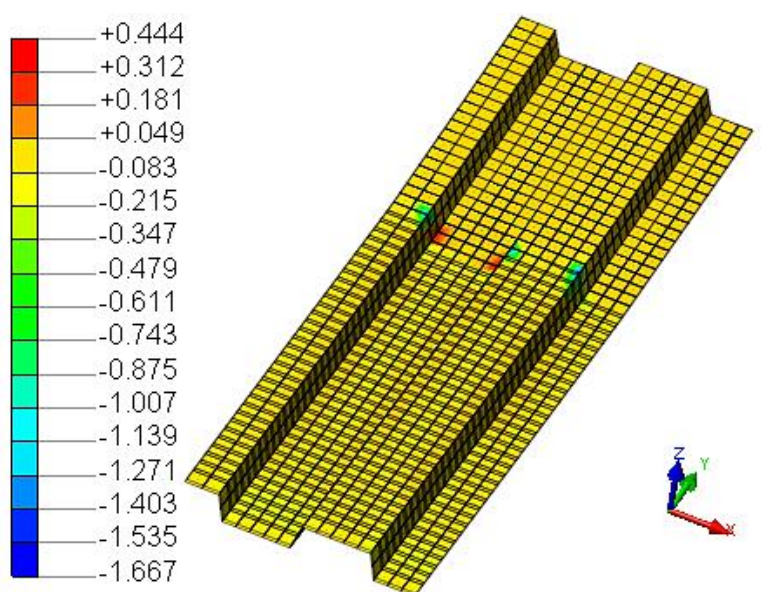

(a) Tensão normal

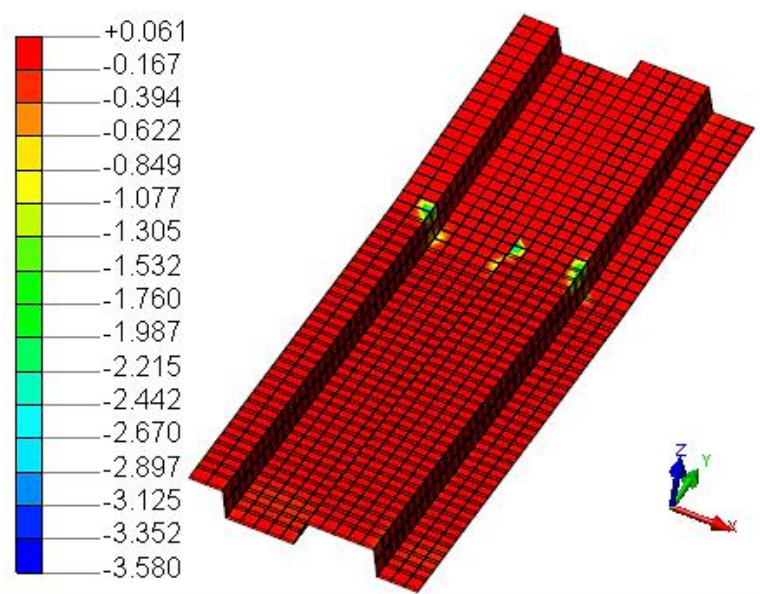

(b) Tensão de cisalhamento na direção $y$

(Tensões em MPa)

Fonte: Autoria própria

A Figura 7.42 apresenta o panorama de fissuração e as e a abertura de fissura na região fissurada imediatamente após a abertura da fissura principal. Essa figura também mostra a posição do apoio de carregamento e do apoio móvel para servirem como referência. Observase que a localização da fissura principal é parecida com a ocorrida no protótipo experimental.

Figura 7.42 - Largura de fissura no concreto do modelo numérico da laje mista com os parâmetros de interface do modelo numérico do ensaio slip-block

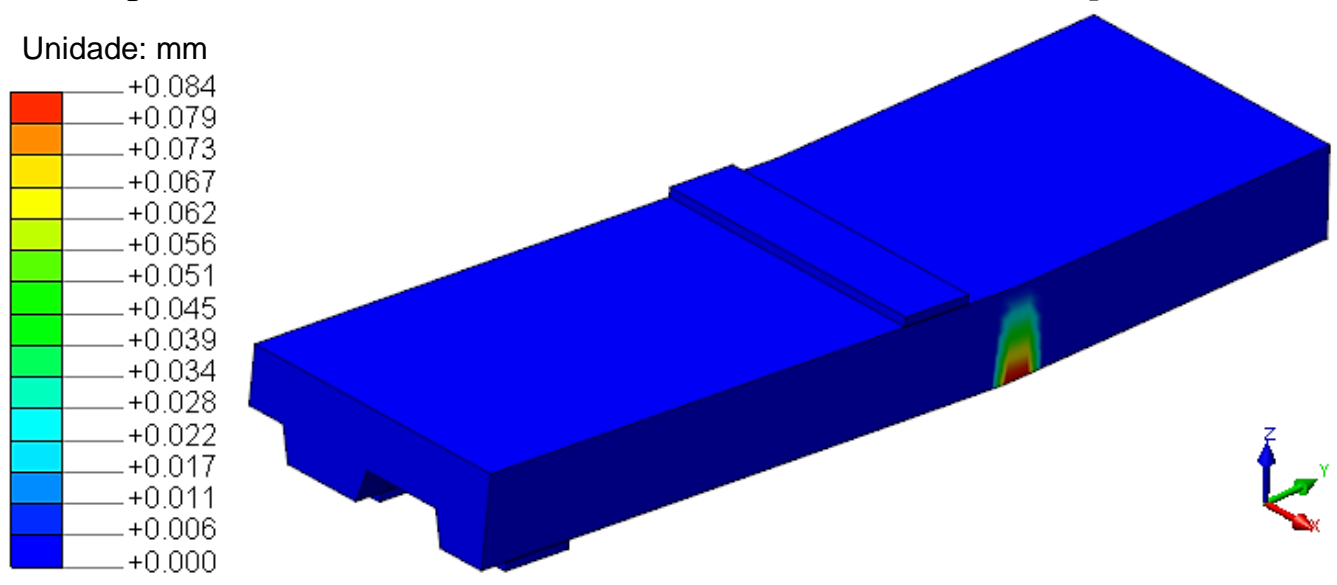

Fonte: Autoria própria

O concreto localizado adjacentemente às mesas inferiores do vão central também se apresentou fissurado, o que é coerente devido às tensões normais de tração que se desenvolveram nessa região. Entretanto, o concreto localizado no vão de cisalhamento não fissurou, assim como ocorreu no protótipo experimental. 


\subsubsection{Reavaliação dos Parâmetros de Interface Obtidos no Ensaio Slip-Block}

Uma vez que os fenômenos desenvolvidos na interface aço-concreto do ensaio de flexão diferiram dos constatados no ensaio slip-block, foi necessário reformular a aplicação dos parâmetros obtidos pela metodologia proposta neste trabalho. A diferença no comportamento da interface se dá principalmente pelo confinamento que ocorre durante a realização do ensaio slip-block, mas que não existe na região entre apoios da laje mista.

Sendo assim, o confinamento existente promove resistência à separação vertical entre o concreto e a fôrma de aço, o que acarreta no acréscimo da resistência ao cisalhamento da interface. Esse fato é considerável após a resistência máxima da interface ser atingida, situação em que as mossas desengatam das suas indentações. Ao se comparar a configuração geral das curvas do gráfico da Tensão de cisalhamento versus Deslizamento encontradas na literatura para lajes mistas com as determinadas pelo ensaio slip-block realizado neste trabalho, é possível constatar a influência do confinamento, conforme apresenta a Figura 7.43.

Figura 7.43 - Gráficos genéricos da tensão de cisalhamento versus o deslizamento dos ensaios da laje mista e do slip-block

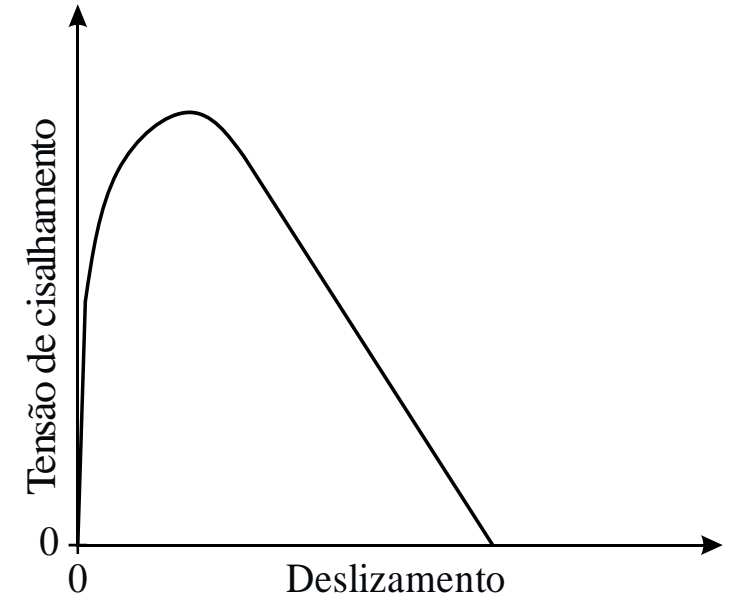

(a) Ensaio de flexão da laje mista (literatura)

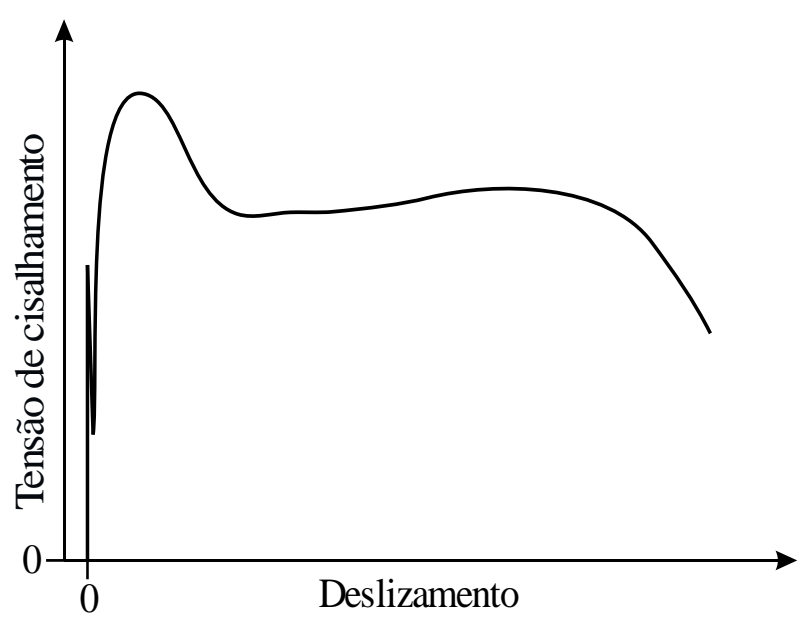

(b) Ensaio slip-block

Fonte: Autoria própria

De acordo com a Figura 7.43, a redução brusca seguida do aumento da tensão de cisalhamento observada no ensaio slip-block não ocorreria na laje mista submetida à flexão. Além disso, o patamar que se forma após a tensão de cisalhamento máxima ser atingida, no caso do ensaio slip-block, também não ocorreria. Dessa forma, após a resistência máxima da interface ser atingida, a tensão de cisalhamento é reduzida gradativamente até se anular.

A resistência residual após se atingir a resistência máxima da interface no ensaio slipblock existe justamente devido ao confinamento promovido pela força vertical aplicada, que 
promove resistência ao cisalhamento após as mossas se desengatarem de suas indentações, acarretada pelo efeito do atrito principalmente. Na ausência dessa força, a configuração póspico da curva do gráfico da Tensão de cisalhamento versus Deslizamento do ensaio slip-block seria semelhante à da Figura 7.43 (a).

Diante disso, adotou-se uma nova configuração para a curva de $c$ versus $s$ para o Hardening do modelo numérico da interface aço-concreto do modelo da laje mista, objetivando contornar o efeito do acréscimo de resistência promovido pelo confinamento. A curva de $\mu$ versus $s$ foi mantida a mesma (ilustrada na Figura 7.14 (a)), pois o efeito do coeficiente de atrito não influenciou consideravelmente o comportamento do modelo numérico, conforme já constatado e discutido.

A Figura 7.44 apresenta as curvas original e reformulada do gráfico de $c$ versus $s$ do Hardening do modelo numérico de interface da laje mista. Manteve-se uma resistência residual muito baixa, igual a $0,001 \mathrm{~N} / \mathrm{mm}^{2}$, em vez de nula, para evitar problemas de convergência numérica durante o processamento do modelo.

Figura 7.44 - Gráfico da Coesão $(c)$ versus Deslizamento $(s)$ reconsiderado para o Hardening do modelo numérico de interface da laje mista

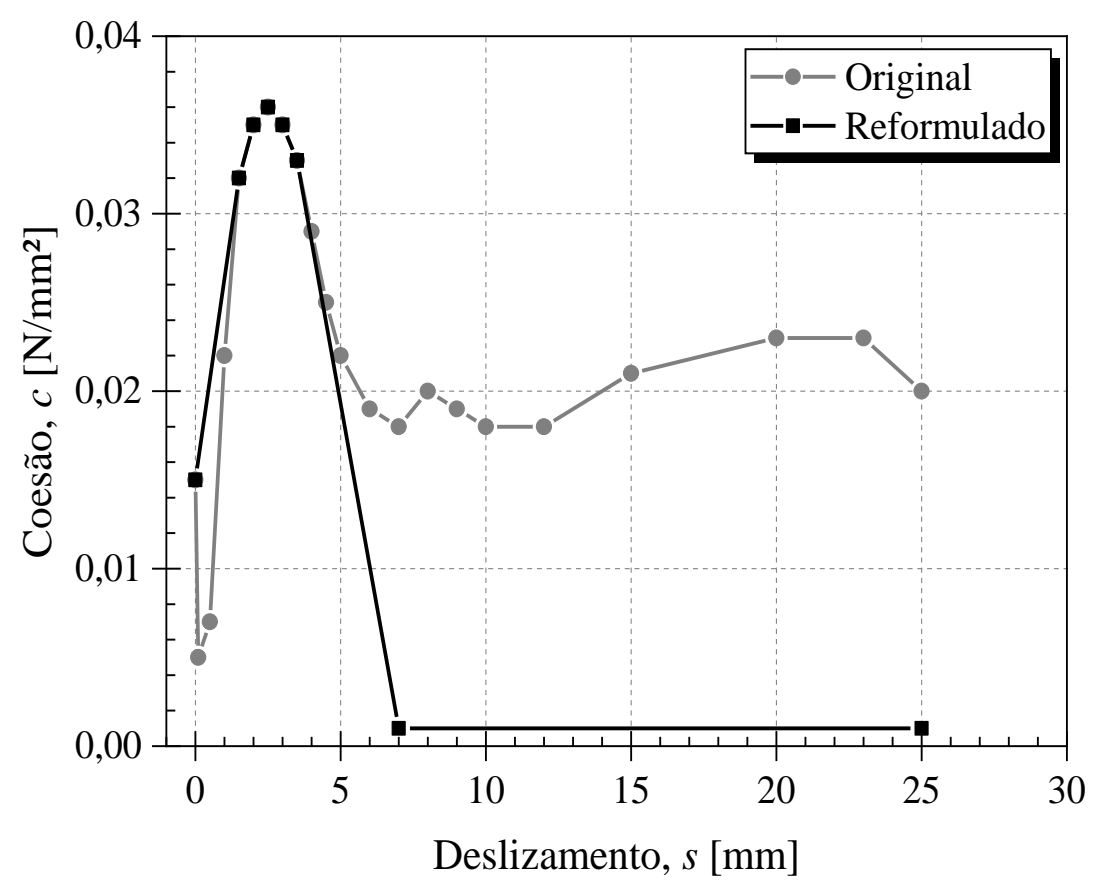

Fonte: Autoria própria

Ao se aplicar a curva reformulada de $c$ versus $s$ apresentada na figura acima, o comportamento do modelo da laje mista sofreu uma alteração significativa, principalmente após se atingir a capacidade resistente máxima do modelo, conforme se observa nos gráficos de $F$ versus $\delta$ e de $F$ versus $s$ apresentados na Figura 7.45 e na Figura 7.46, respectivamente. 
Figura 7.45 - Gráfico de $F$ versus $\delta$ do modelo numérico inicial da laje mista com os parâmetros de interface do modelo numérico do ensaio slip-block reconsiderados

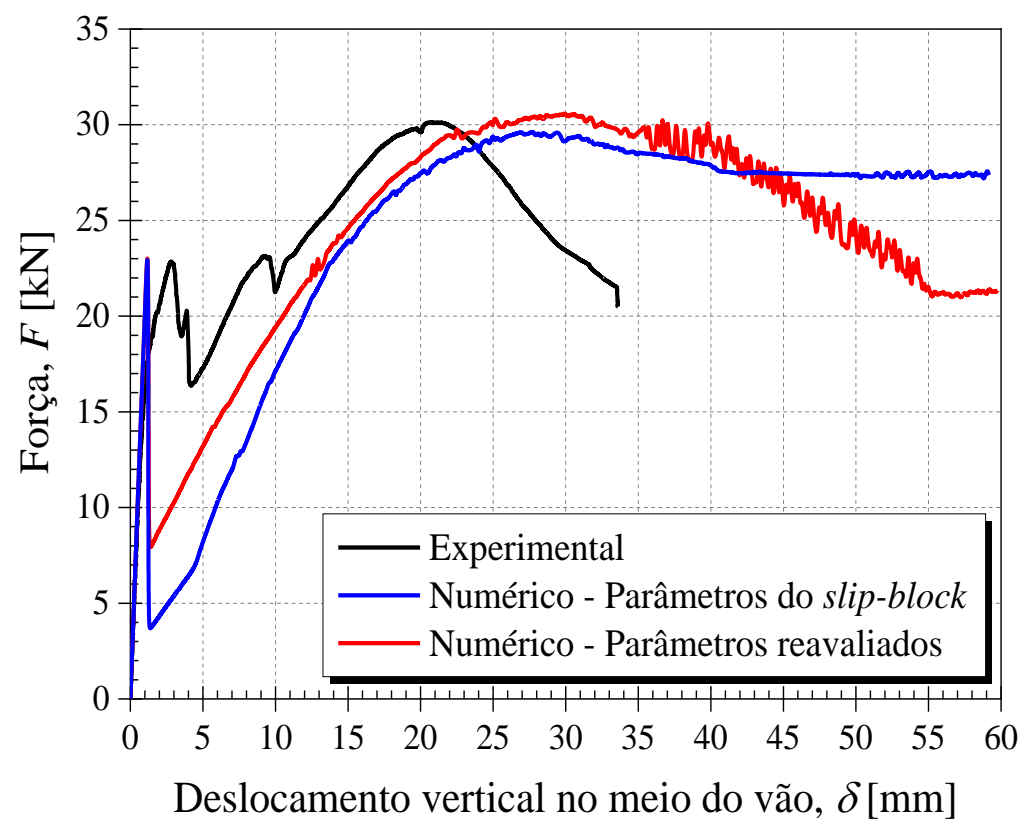

Fonte: Autoria própria

Figura 7.46 - Gráfico de $F$ versus $s$ do modelo numérico inicial da laje mista com os parâmetros de interface do modelo numérico do ensaio slip-block reconsiderados

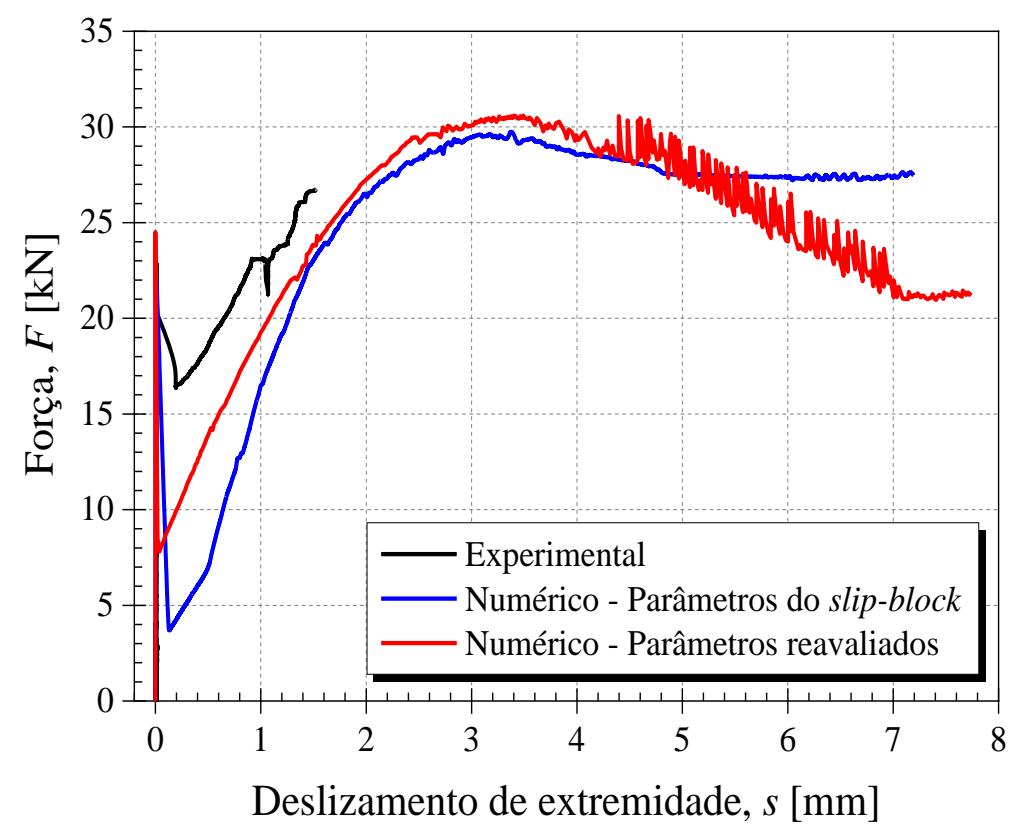

Fonte: Autoria própria

A desconsideração da queda repentina nos valores de coesão (ver Figura 7.44) culminou no aumento do valor de $F_{\text {ret }}$ em $109 \%$, porém este resultado numérico ainda ficou muito inferior ao experimental. Além disso, a curva do modelo numérico se aproximou da experimental, conforme se verifica na figura acima. Com relação ao deslizamento de extremidade, o valor de 
$s$ referente à $F_{\text {ret }}$ se apresentou consideravelmente inferior quando se utilizou os parâmetros reavaliados, conforme se observa na Figura 7.46.

A capacidade resistente máxima da laje mista aumentou 3,1\% quando se empregou os parâmetros reavaliados, se aproximando da experimental com uma variação de $+1,5 \%$. Contudo, $F_{\text {máx }}$ continuou sendo atingida com uma flecha consideravelmente superior à experimental. Com relação às distribuições de tensões e de deformações e ao panorama de fissuração, não se verificou mudanças consideráveis.

O trecho pós-pico também se modificou devido a desconsideração dos valores de coesão residuais (ver Figura 7.44), que forneciam uma resistência ao cisalhamento residual após a resistência máxima ser atingida. Dessa forma, o modelo numérico apresentou maior perda de rigidez após atingir a sua resistência máxima, se aproximando do comportamento do modelo experimental.

O emprego dos parâmetros reavaliados fez com que o modelo numérico apresentasse um comportamento mais próximo ao verificado experimentalmente do que quando se empregou diretamente os parâmetros obtidos do ensaio slip-block. Todavia, após o início do deslizamento, o modelo numérico ainda continuou apresentando, para um mesmo valor de $F$, maiores deslocamentos verticais no meio do vão que o modelo experimental, conforme se verifica no gráfico da Figura 7.45. O motivo dessa discrepância é explicado na próxima seção juntamente com a solução encontrada para simular mais adequadamente o comportamento da interface e da laje mista.

\subsubsection{Estratégia para Simulação da Interface Aço-Concreto da Laje Mista}

Diante da análise do comportamento do modelo numérico de interface sobre o comportamento do modelo da laje mista e comparando-se os resultados numéricos e experimentais, desenvolveu-se uma estratégia para a simulação da interface aço-concreto da laje mista objeto deste trabalho.

A análise realizada na seção 7.5.1.5, reconsiderando os parâmetros obtidos do ensaio slip-block, permitiu melhor considerar os efeitos da flexão sobre a transferência de cisalhamento na interface, sobretudo o fenômeno da separação entre o aço e o concreto. Logo, a reavaliação da curva de $c$ versus $s$ melhorou o comportamento da interface e aproximou o resultado numérico do experimental. Apesar disso, o deslocamento vertical no meio do vão do modelo numérico sempre se apresentou maior que o experimental para um mesmo nível de carregamento aplicado. 
Esse fato tornou mais evidente a discussão acerca da configuração da fôrma de aço constituinte da laje mista estudada, pois a mesma possui mossas em forma de V, o que resulta na falta de simetria da interface na direção longitudinal da fôrma de aço. Dessa forma, mediante o carregamento aplicado, a resistência promovida pela interface é relativa ao trecho da laje mista, uma vez que, dependendo do sentido do deslizamento, as mossas fornecem maior resistência numa orientação do que na outra, conforme discutido na seção 6.4.2. A Figura 7.47 apresenta claramente qual a orientação mais resistente do chaveamento promovido pelas mossas de acordo com o sentido de deslizamento do concreto.

Figura 7.47 - Representação dos sentidos mais e menos resistentes do chaveamento promovido pelas mossas da fôrma de aço

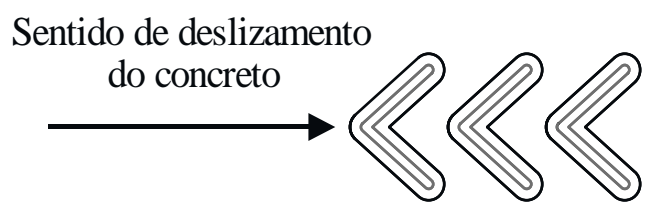

(a) Orientação de menor resistência $(\rightarrow<<)$

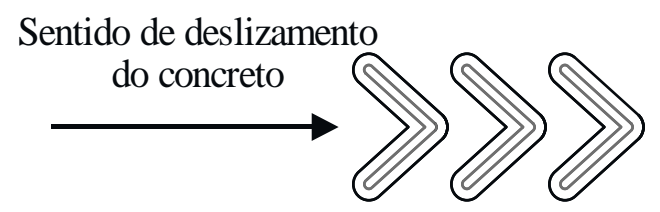

(b) Orientação de maior resistência $(\rightarrow>>)$

Fonte: Autoria própria

Essa configuração das mossas da fôrma de aço acarretou no fato de que apenas um dos vãos de cisalhamento sofreu deslizamento: aquele cuja orientação das mossas promove a menor resistência. Esse fenômeno foi constatado na análise experimental e resultou na formação da fissura adjacentemente ao vão de cisalhamento que deslizou, assim como promoveu uma configuração deformada para a laje mista diferente da qual ela apresentaria se a fôrma de aço fosse simétrica na direção longitudinal.

Diante disso, ao se simular $1 / 4$ da laje mista, considerando a simetria longitudinal, o modelo numérico inicial não representou o protótipo ensaiado, pois, na realidade, a resistência da interface é diferente de acordo com o sentido do deslizamento. Sendo assim, após o início do deslizamento de extremidade, a configuração deformada da laje mista não é simétrica longitudinalmente. Por isso a curva de $F$ versus $\delta$ do modelo numérico inicial se apresentou sempre à direita da experimental, ou seja, a flecha se apresentava maior no modelo numérico do que no modelo experimental, para um mesmo valor de $F$.

A Figura 7.48 ilustra a configuração da laje mista deformada após o ensaio de flexão para a situação idealmente simétrica (simulada pelo modelo numérico inicial) e a situação constatada experimentalmente, sendo $\Delta$ o deslocamento vertical do ponto indicado da laje. $\mathrm{Na}$ Figura 7.48 (b) é importante notar a disposição das mossas mediante o sentido do deslizamento do concreto no vão de cisalhamento menos resistente, ou seja, que sofre deslizamento. 
Figura 7.48 - Situações simulada e real da laje mista após o ensaio de flexão

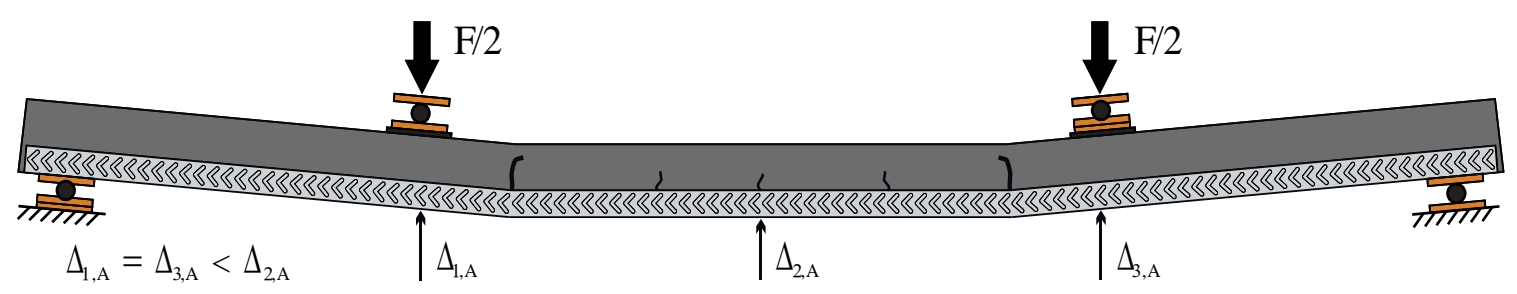

(a) Situação considerada pelo modelo numérico inicial

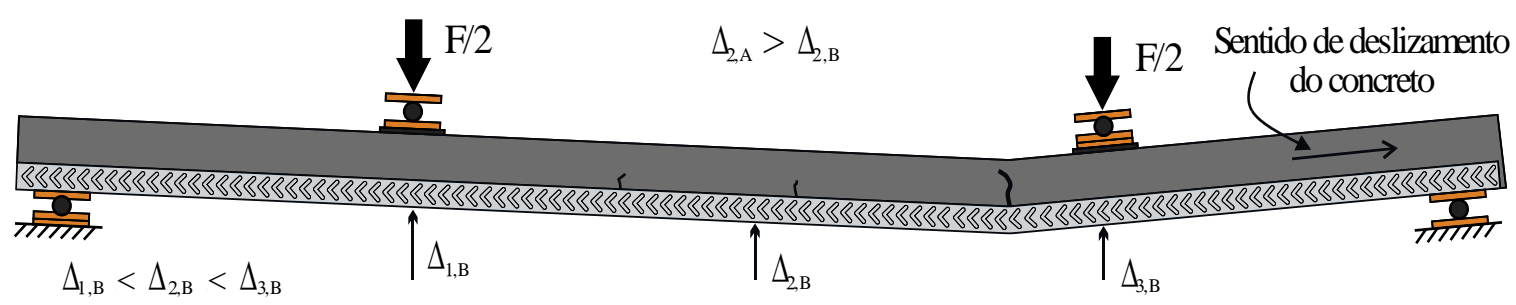

(b) Situação real verificada experimentalmente

Fonte: Autoria própria

Conforme se observa na Figura 7.48, para um mesmo carregamento aplicado e após o início do deslizamento do vão de cisalhamento, o deslocamento vertical no meio do vão do modelo simétrico é sempre superior a do modelo assimétrico.

Apesar disso, na literatura técnica se encontram trabalhos que utilizaram a condição de simetria longitudinal nos seus modelos numéricos para simular protótipos experimentais de lajes mistas cujas fôrmas de aço não são longitudinalmente simétricas. Esse foi o motivo pelo qual incialmente modelou-se a laje mista estudada considerando a simetria longitudinal. Entretanto, verificou-se que tal consideração é inconsistente, de acordo com a discussão aqui realizada.

Dessa forma, com o objetivo de desenvolver um modelo numérico representativo da laje mista estudada e que empregue uma interface aço-concreto condizente com a realidade, adotouse como solução modelar $1 / 2$ da laje mista, considerando apenas a simetria transversal. Dessa forma, o modelo numérico é constituído por duas interfaces aço-concreto, de modo a utilizar uma em cada parte do modelo e sendo uma mais resistente que a outra.

A ideia é simplificadamente simular a falta de simetria da interface da laje mista estudada adotando uma das interfaces mais resistente que a outra, uma vez que o carregamento aplicado é simétrico. Como os ensaios do tipo slip-block foram realizados com a finalidade de determinar os parâmetros para a orientação menos resistente do chaveamento das mossas da fôrma de aço, reportou-se ao trabalho de Cheng, Yang e Davison (1994) para estimar os parâmetros da orientação mais resistente e embasar a solução adotada. 
Esses autores realizaram ensaios de cisalhamento semelhante ao slip-block, exceto pela ausência de carregamento vertical confinante, para caracterizar a interface aço-concreto de lajes mistas com fôrma de aço cujas mossas possuíam formato em V. Os ensaios foram realizados para as duas orientações do chaveamento das mossas, determinando o comportamento e a resistência em ambos os sentidos de deslizamento. A Figura 7.49 apresenta as curvas dos sentidos mais e menos resistente do gráfico da Força Horizontal $\left(F_{\mathrm{H}}\right)$ versus Deslizamento $(s)$ apresentado no trabalho de Cheng, Yang e Davison (1994).

Figura 7.49 - Gráfico de $F_{\mathrm{H}}$ versus $s$ obtido por Cheng, Yang e Davison (1994)

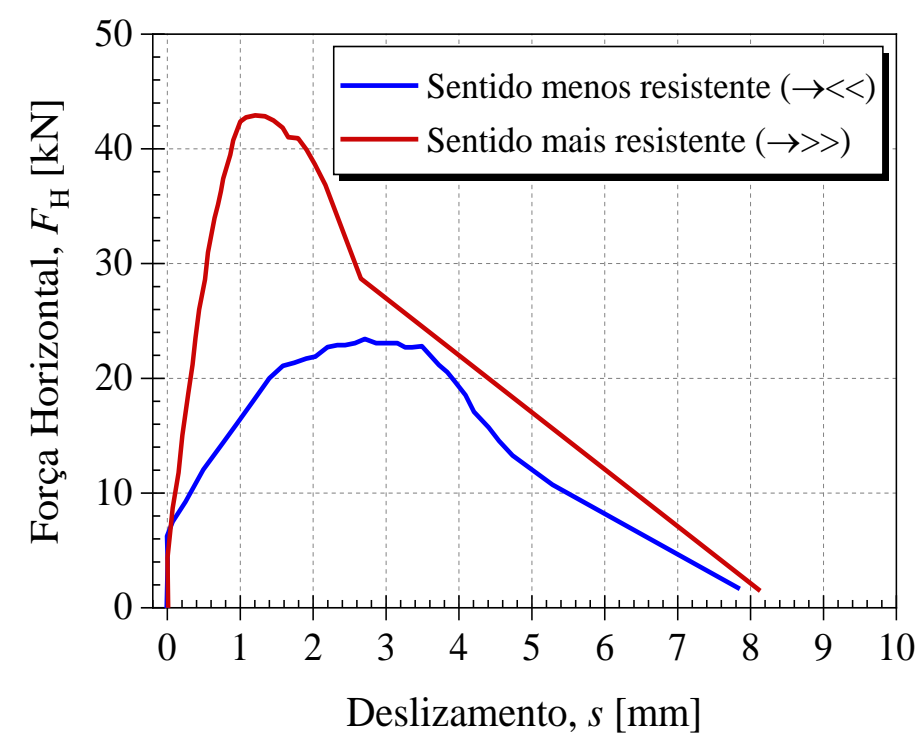

Fonte: Autoria própria

De acordo com o gráfico acima, após o início do deslizamento, a rigidez da interface aço-concreto foi aproximadamente $285 \%$ maior para a orientação mais resistente do chaveamento, em comparação com a menos resistente. Além disso, a resistência a resistência máxima para a orientação mais resistente do chaveamento foi, aproximadamente, duas vezes maior que a promovida pela menos resistente. Nota-se, também que a resistência máxima da orientação mais resistente foi atingida para um deslizamento 1,5 $\mathrm{mm}$ inferior ao deslizamento ocorrido quando atingida a máxima capacidade resistente da orientação menos resistente. Dessa forma, torna-se evidente que para a laje mista constituída por uma fôrma de aço com esse tipo de mossa, os dois vãos de cisalhamento se comportam de maneira completamente distinta.

No gráfico da Figura 7.49 é importante notar que a resistência da interface foi reduzida continuamente após o pico ser atingido, até atingir um valor próximo de zero, pois não há força vertical confinante. Nesse caso, a participação da ligação por atrito é mínima (pois apenas o peso próprio do concreto está atuando sobre a interface) e a ligação mecânica foi a responsável pela resistência ao cisalhamento. 
Dessa forma, a reavaliação dos parâmetros da ligação mecânica obtidos do ensaio slipblock, realizada na seção 7.5.1.5, torna-se fundamentada e consistente, principalmente ao se comparar o formato do gráfico reconsiderado de $c$ versus $s$ (Figura 7.44) com o gráfico de $F_{\mathrm{H}}$ versus s obtido por Cheng, Yang e Davison (1994) (Figura 7.49), sem confinamento.

Como o valor do coeficiente de atrito não possui muita influência sobre a resistência da interface do modelo da laje mista, assim como os resultados de Cheng, Yang e Davison (1994) se referem basicamente à ligação mecânica, determinou-se uma curva teórica de $c$ versus $s$ referente à orientação mais resistente do chaveamento para compor o Hardening do modelo constitutivo da interface mais resistente. Dessa forma, utilizou-se a relação entre as duas curvas da Figura 7.49 para criar uma curva teórica de $c$ versus s para a orientação mais resistente com base na curva reformulada da orientação menos resistente apresentada na Figura 7.44.

Para a definição dessa curva teórica, adotou-se a coesão máxima igual a duas vezes a máxima utilizada para a interface menos resistente. Além disso, procurou-se manter a rigidez da curva de $c$ versus $s$, após o início do deslizamento, da interface mais resistente aproximadamente $285 \%$ maior que a da interface menos resistente. O deslizamento sofrido ao se atingir a resistência máxima da orientação mais resistente foi mantido $1,5 \mathrm{~mm}$ inferior ao respectivo deslizamento da orientação menos resistente. O trecho pós-pico foi configurado para se apresentar semelhante ao da Figura 7.44. A Figura 7.50 apresenta o gráfico de $c$ versus $s$ com as curvas utilizadas no Hardening do modelo numérico definitivo das interfaces empregadas.

Figura 7.50 - Gráfico da Coesão (c) versus Deslizamento $(s)$ do Hardening do modelo numérico definitivo da interface da laje mista

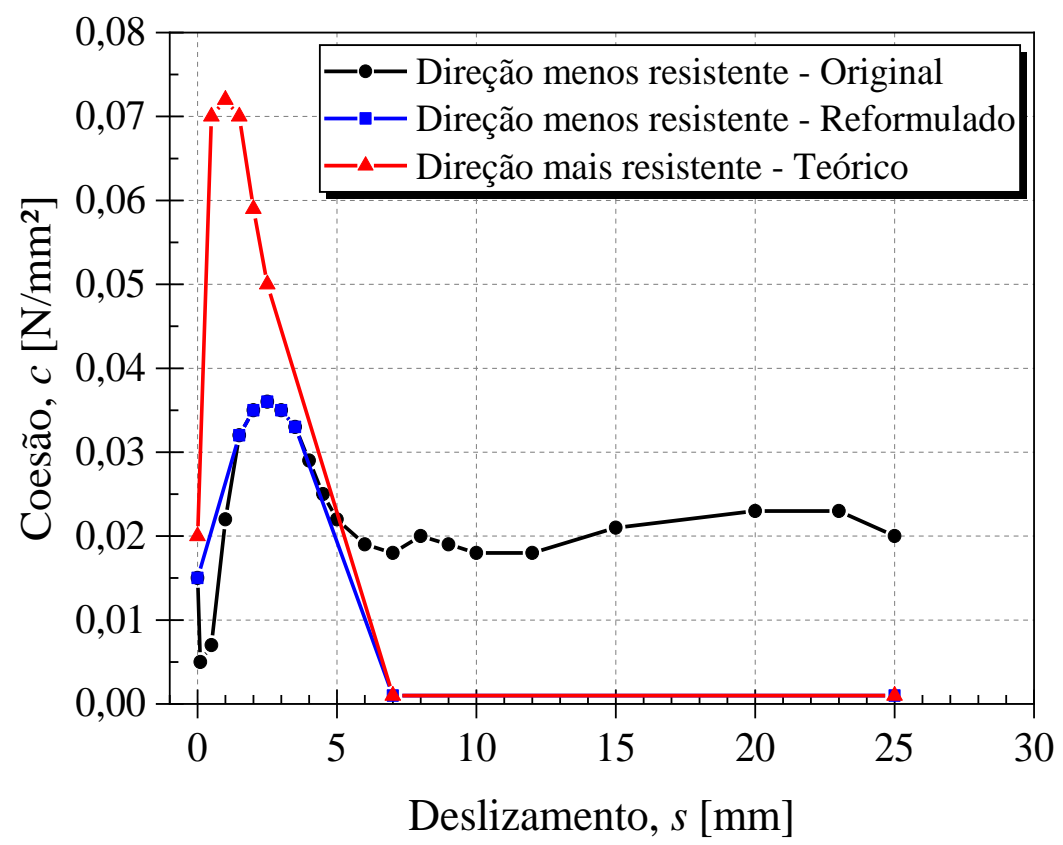

Fonte: Autoria própria 
Com relação às rigidezes referentes ao comportamento elástico da interface $\left(k_{\mathrm{n}} \mathrm{e} k_{\mathrm{t}}\right)$, verificou-se que o valor de $k_{\mathrm{n}}$ validado para o modelo numérico do slip-block $\left(k_{n}=30 \mathrm{~N} / \mathrm{mm}^{3}\right)$ não foi adequado para a simulação do comportamento da interface da laje mista, pois modificou o comportamento do modelo numérico e acarretou numa resistência à flexão superior à obtida experimentalmente.

Diante disso, utilizou-se um valor de $k_{\mathrm{n}}$ igual a $1,0 \mathrm{~N} / \mathrm{mm}^{3}$ nos dois modelos de interface da laje mista. Essa alteração no valor de $k_{\mathrm{n}}$ já era esperada, pois o valor calibrado para o ensaio slip-block representava a situação da interface naquele ensaio, ou seja, a fôrma de aço estava impedida de se separar do concreto devido ao carregamento vertical. Essa situação, portanto, é diferente da que ocorre na interface da laje mista submetida ao ensaio de flexão, em que não há confinamento da fôrma de aço, exceto na região dos apoios. Dessa forma, o valor de $k_{\mathrm{n}}$ foi validado para o comportamento da interface sob flexão.

A curva de $\mu$ versus $s$ que compõe o Hardening também foi mantida a mesma do modelo numérico inicial, apresentada na Figura 7.14 (a). A Tabela 7.11 apresenta os parâmetros do modelo numérico definitivo do ensaio de flexão da laje mista estudada neste trabalho.

Tabela 7.11 - Parâmetros da interface aço-concreto do modelo numérico definitivo da laje mista

\begin{tabular}{|c|c|c|c|c|c|}
\hline \multicolumn{6}{|c|}{ Parâmetros do comportamento linear (ambas interfaces) } \\
\hline \multicolumn{3}{|c|}{ Rigidez normal $\left(k_{n}\right)$} & \multicolumn{3}{|c|}{ Rigidez tangencial $\left(k_{t}\right)$} \\
\hline \multicolumn{3}{|c|}{$1 \mathrm{~N} / \mathrm{mm}^{3}$} & \multicolumn{3}{|c|}{$15 \mathrm{~N} / \mathrm{mm}^{3}$} \\
\hline \multicolumn{6}{|c|}{ Parâmetros do critério de ruptura do modelo Coulomb Friction } \\
\hline \multicolumn{3}{|c|}{ Interface menos resistente } & \multicolumn{3}{|c|}{ Interface mais resistente } \\
\hline $\begin{array}{c}\text { Coef. de } \\
\text { atrito inicial } \\
\qquad\left(\mu_{0}\right)\end{array}$ & $\begin{array}{c}\text { Coesão } \\
\text { inicial } \\
\left(c_{0}\right)\end{array}$ & $\begin{array}{c}\text { Dilatância } \\
(\psi)\end{array}$ & $\begin{array}{c}\text { Coef. de } \\
\text { atrito inicial } \\
\qquad\left(\mu_{0}\right)\end{array}$ & $\begin{array}{c}\text { Coesão } \\
\text { inicial } \\
\left(c_{0}\right)\end{array}$ & $\begin{array}{c}\text { Dilatância } \\
(\psi)\end{array}$ \\
\hline 0,557 & $0,015 \mathrm{~N} / \mathrm{mm}^{2}$ & 0 & 0,557 & $0,020 \mathrm{~N} / \mathrm{mm}^{2}$ & 0 \\
\hline \multicolumn{3}{|c|}{ Hardening } & \multicolumn{3}{|c|}{ Hardening } \\
\hline$\Delta u_{\mathrm{p}}[\mathrm{mm}]$ & $\mu$ & $c\left[\mathbf{N} / \mathbf{m m}^{2}\right]$ & $\Delta u_{\mathrm{p}}[\mathrm{mm}]$ & $\mu$ & $c\left[\mathbf{N} / \mathbf{m m}^{2}\right]$ \\
\hline 1,5 & 0,569 & 0,032 & 0,5 & 0,569 & 0,070 \\
\hline 2,0 & 0,578 & 0,035 & 1,0 & 0,578 & 0,072 \\
\hline 2,5 & 0,590 & 0,036 & 1,5 & 0,590 & 0,070 \\
\hline 3,0 & 0,595 & 0,035 & 2,0 & 0,595 & 0,059 \\
\hline 3,5 & 0,596 & 0,033 & 3,0 & 0,596 & 0,040 \\
\hline 4,0 & 0,608 & 0,029 & 8,0 & 0,600 & 0,001 \\
\hline 8,0 & 0,600 & 0,001 & 25,0 & 0,600 & 0,001 \\
\hline 25,0 & 0,600 & 0,001 & - & - & - \\
\hline
\end{tabular}

Fonte: Autoria própria 
Estabelecida essa estratégia para a modelagem da interface aço-concreto da laje mista, modelou-se o protótipo ensaiado e comparou-se os resultados numéricos e experimentais para avaliar a representatividade do modelo numérico definitivo.

\subsubsection{Modelo Numérico Definitivo}

Diante da discussão realizada na seção anterior sobre a incapacidade de o modelo numérico inicial simular devidamente o comportamento da laje mista objeto deste trabalho, desenvolveu-se um novo modelo numérico, denominado como definitivo. Logo, modelou-se $1 / 2$ do protótipo da laje mista considerando apenas as condições de simetria transversal, objetivando reduzir o custo computacional.

Assim como no modelo numérico inicial, os apoios utilizados no ensaio também foram modelados a fim de representar melhor o protótipo ensaiado e evitar concentração de tensões nestas regiões. A Figura 7.51 ilustra a geometria considerada para o modelo numérico, com suas dimensões.

Figura 7.51 - Geometria considerada para o modelo numérico definitivo da laje mista

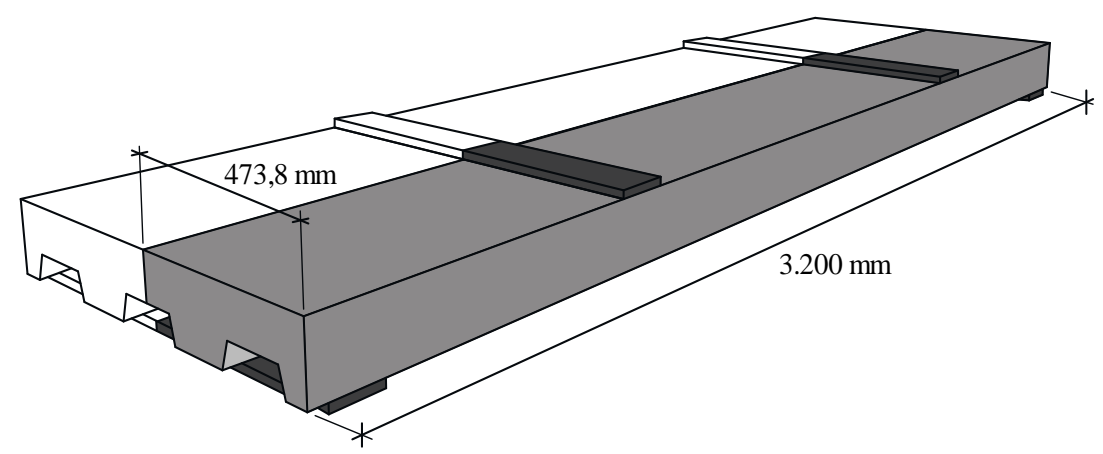

Fonte: Autoria própria

As propriedades do aço e do concreto, assim como a estratégia de solução e os critérios de convergência, foram mantidas as mesmas do modelo numérico inicial. Adotou-se uma malha com dimensão máxima do elemento finito igual a $30 \mathrm{~mm}$, com base na análise de malha já realizada para o modelo numérico inicial.

\subsubsection{Estrutura do Modelo}

A estrutura do modelo numérico definitivo do ensaio de flexão da laje mista foi composta por nove partes: dois apoios de carregamento, capa de concreto, duas interfaces açoconcreto, fôrma de aço, apoio móvel e apoio fixo. A Figura 7.52 ilustra o modelo e seus componentes e a Tabela 7.12 apresenta a quantidade de elementos utilizados. 
Figura 7.52 - Estrutura do modelo numérico do ensaio de flexão da laje mista

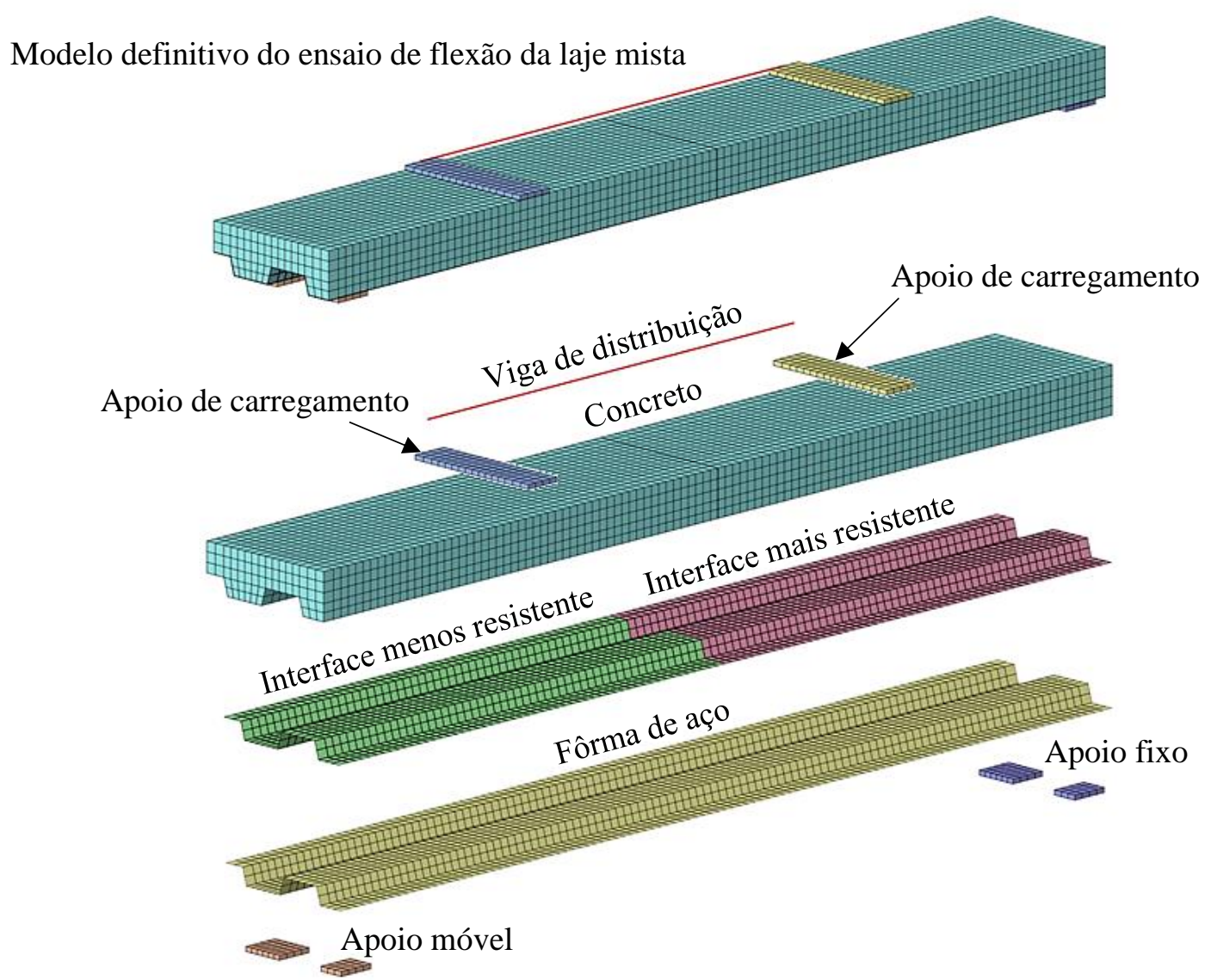

Fonte: Autoria própria

Tabela 7.12 - Quantidade de elementos utilizados no modelo numérico definitivo da laje mista

\begin{tabular}{lcccccc}
\hline $\begin{array}{c}\text { Capa de } \\
\text { concreto }\end{array}$ & $\begin{array}{c}\text { Fôrma } \\
\text { de aço }\end{array}$ & Interfaces & $\begin{array}{c}\text { Apoios de } \\
\text { carregamento }\end{array}$ & $\begin{array}{c}\text { Apoios } \\
\text { móvel e fixo }\end{array}$ & $\begin{array}{c}\text { Viga de } \\
\text { distribuição }\end{array}$ & Total \\
\hline 6.996 & 2.332 & 2.332 & 128 & 72 & 2 & 11.862 \\
\hline Quantidade total de nós: 12.439 & & & & \\
\hline
\end{tabular}

No caso deste modelo numérico, modelou-se a viga de distribuição para que o carregamento vertical fosse aplicado no meio dela e transferido para os apoios de carregamento. Dessa forma, a assimetria do modelo é respeitada, pois o deslocamento vertical de um apoio de carregamento independe do deslocamento do outro, sendo condicionado pelo comportamento global do modelo, assim como ocorre na realidade. Utilizou-se o elemento finito tridimensional de viga L12BE para modelar a viga de distribuição.

As propriedades geométricas aplicadas para a viga de distribuição do modelo numérico foram as mesmas da utilizada no ensaio, enquanto que o material foi o mesmo empregado nos apoios, ou seja, o aço com comportamento elástico linear ( $E=200 \mathrm{GPa}$ e $v=0,3)$. 


\subsubsection{Condições de Contorno e Carregamento}

As condições de contorno foram definidas de modo a garantir a condições de simetria transversal e de apoio estabelecidas. A Figura 7.53 ilustra as condições de contorno e carregamento do modelo definitivo do ensaio de flexão da laje mista.

Figura 7.53 - Condições de contorno e carregamento do modelo definitivo do ensaio de flexão da laje mista

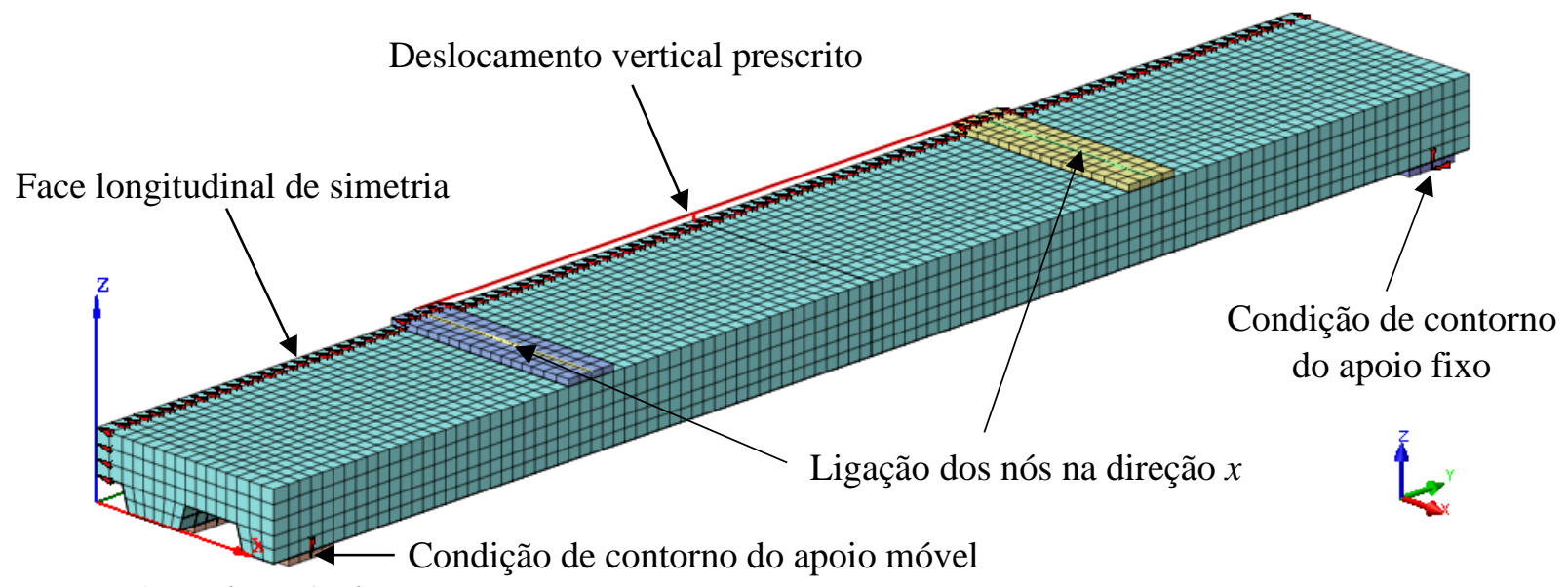

Fonte: Autoria própria

Assim como no modelo numérico inicial, a condição de simetria transversal foi estabelecida restringindo-se os deslocamentos na direção $x$ dos nós localizados na face longitudinal de simetria (ver Figura 7.53).

A condição de apoio móvel foi garantida pela restrição do deslocamento na direção $z$ dos nós localizados na linha central (na direção $x$ ) da face inferior do apoio móvel. Assim, esse apoio permite o giro em torno do eixo $x$ e o deslocamento na direção $y$.

A condição de apoio fixo, por sua vez, foi realizada restringindo-se o deslocamento nas direções $y$ e $z$ dos nós localizados na linha central (na direção $x$ ) da face inferior do apoio fixo. Logo, este apoio permite apenas o giro em torno do eixo $x$.

Em cada apoio de carregamento criou-se uma propriedade de ligação dos seus nós localizados na linha central (na direção $x$ ), conforme ilustra a Figura 7.53. Assim, definiu-se o nó mestre (master node) em cada caso, ao qual todos os demais nós (slave nodes) dessa linha são ligados a ele, possuindo o mesmo deslocamento vertical (direção $z$ ).

Os nós extremos da viga de distribuição são, então, acoplados aos nós mestres de cada apoio de carregamento e a carga vertical foi aplicada no meio da viga como deslocamento prescrito. É importante ressaltar que os nós extremos da viga de distribuição não restringem o giro. Dessa forma, o carregamento é devidamente transferido para a laje mista de maneira semelhante à realidade do ensaio. 


\subsubsection{Validação do Modelo Numérico Definitivo}

Aplicada a estratégia de modelagem da interface aço-concreto da laje mista estudada neste trabalho, simulou-se o modelo numérico definitivo e comparou-se seus resultados com os obtidos experimentalmente, comprovando sua validação.

Ao se verificar o comportamento global do modelo numérico, este se apresentou coerente e semelhante ao observado no ensaio experimental. A estratégia adotada para modelar a interface promoveu o surgimento da fissura principal na mesma região observada experimentalmente, assim como resultou numa configuração deformada assimétrica e próxima da verificada no ensaio realizado. Além disso, apenas um dos vãos de cisalhamento apresentou deslizamento de extremidade, que foi aquele onde se localizava a interface menos resistente. A Figura 7.56 ilustra o modelo completo com o panorama de fissuração do concreto após a realização do ensaio. Para efeitos de comparação, a Figura 7.56 apresenta a fotografia do modelo experimental.

Figura 7.54 - Largura de fissura no concreto do modelo numérico definitivo da laje mista após o ensaio

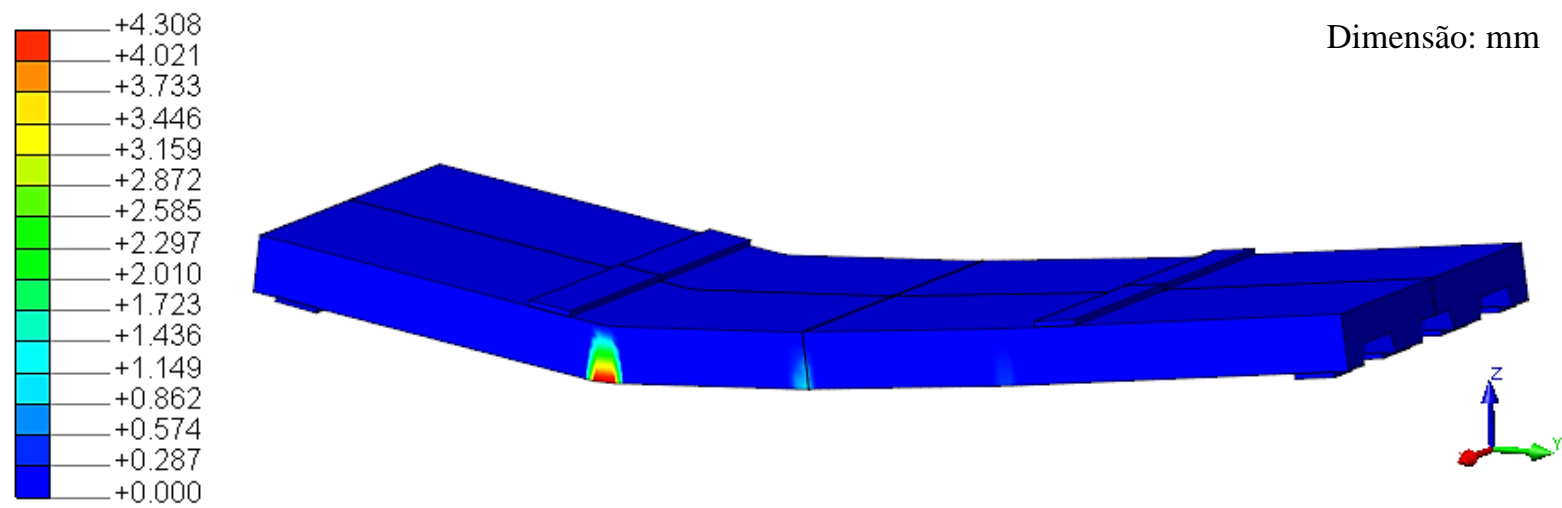

Fonte: Autoria própria

Figura 7.55 - Protótipo Laje 1 após a realização do ensaio de flexão

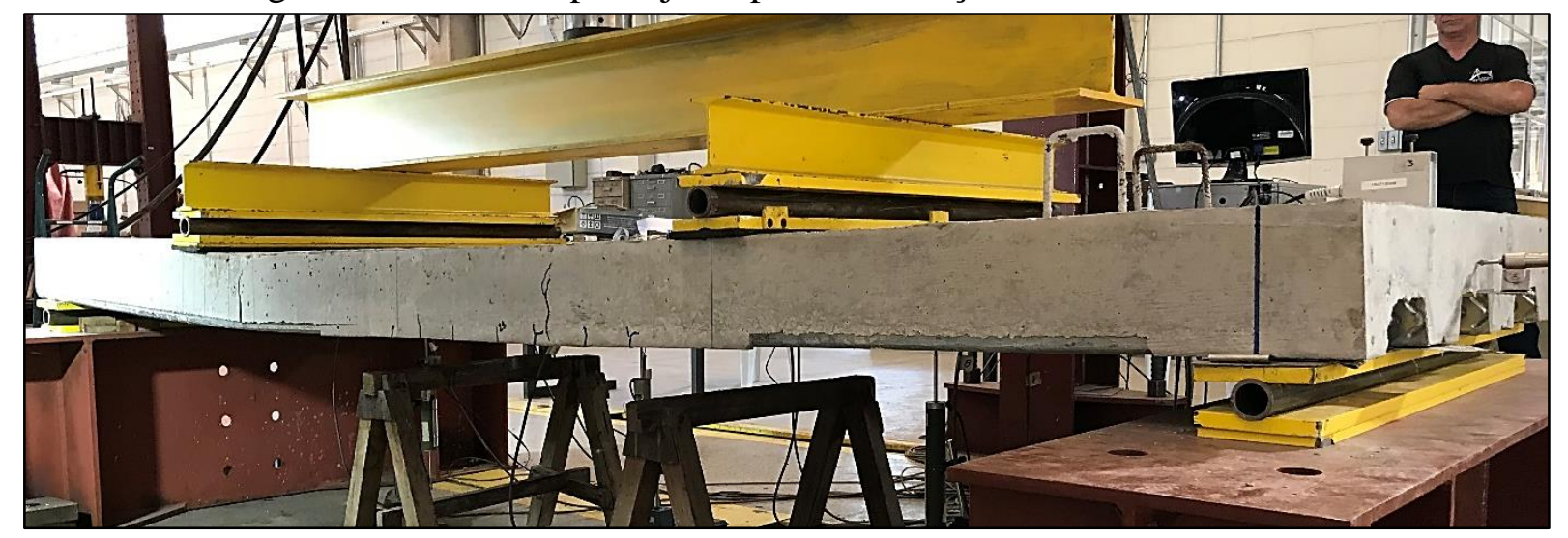

Fonte: Autoria própria 
A Figura 7.56 apresenta os gráficos da Força $(F)$ versus Deslocamento vertical no meio do vão $(\delta)$ do modelo numérico definitivo e do protótipo experimental (Laje 1). A Figura 7.57, por sua vez, apresenta os gráficos da Força $(F)$ versus Deslizamento de extremidade correspondente ao vão de cisalhamento menos resistente do modelo numérico e do protótipo experimental.

Figura 7.56 - Gráfico de $F$ versus $\delta$ do modelo numérico definitivo da laje mista - Laje 1

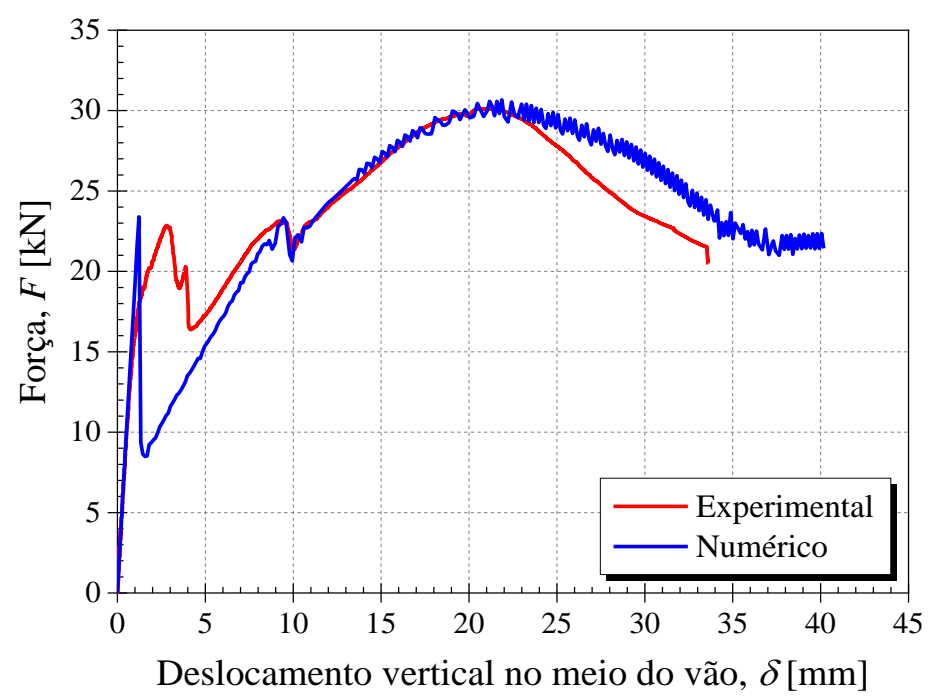

Fonte: Autoria própria

Figura 7.57 - Gráfico de $F$ versus $s$ do modelo numérico definitivo da laje mista - Laje 1

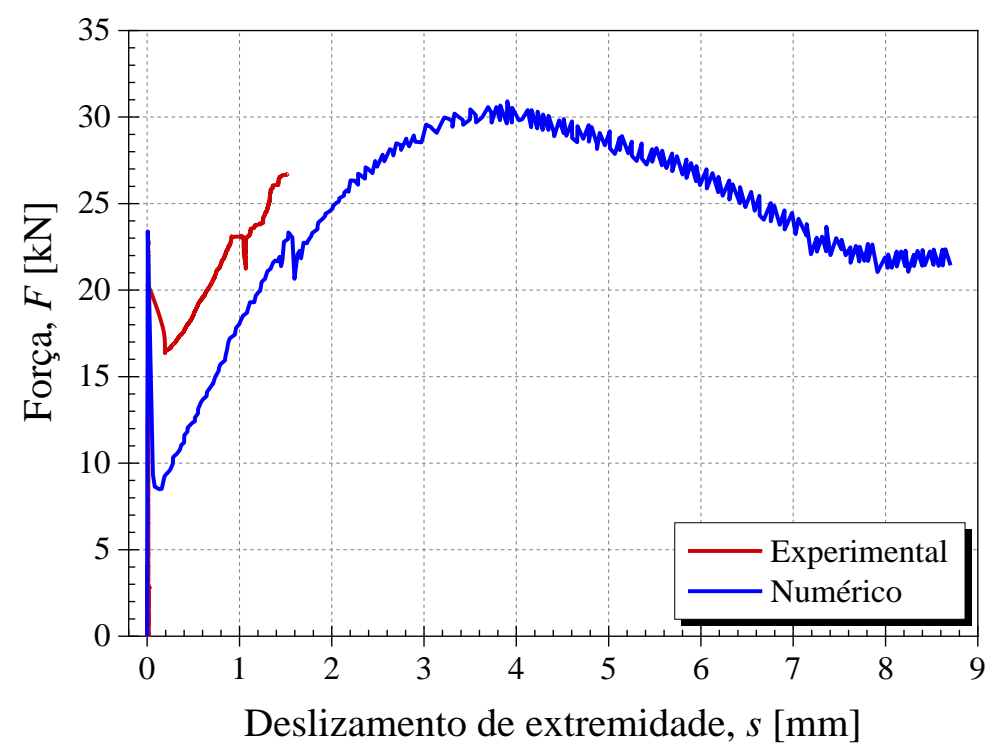

Fonte: Autoria própria

O modelo numérico definitivo apresentou comportamento mais próximo do experimental, quando comparado ao modelo numérico inicial. Sendo assim, a estratégia de simulação adotada para a interface aço-concreto no modelo numérico definitivo se mostrou coerente e adequada diante das considerações estabelecidas. 
Os resultados numéricos e experimentais indicaram que o deslizamento de extremidade do vão de cisalhamento menos resistente ocorreu imediatamente após a redução brusca de $F$. Além disso, a força máxima atingida antes do início do deslizamento $\left(F_{\text {des }}\right)$ pelo modelo numérico se apresentou muito próxima da experimental. Sendo assim, o modelo conseguiu simular esse fenômeno.

O trecho linear inicial das curvas numérica e experimental do gráfico da Figura 7.56 se sobrepuseram até quando $F \approx 15 \mathrm{kN}$, revelando que o comportamento elástico da estrutura foi bem simulado pelo modelo numérico. A partir de então, a rigidez do modelo numérico se apresentou maior que a do protótipo experimental, mantendo o comportamento linear até atingir a força $F_{\text {des. }}$ Diante disso, a flecha do modelo numérico correspondente a $F_{\text {des }}$ se apresentou $53,76 \%$ inferior à do protótipo experimental.

A força mínima resistida pelo modelo numérico após o início do deslizamento $\left(F_{\text {ret }}\right)$ continuou sendo muito inferior à resistida pelo protótipo experimental. Isso ocorreu devido tanto ao modelo constitutivo à tração do concreto quanto ao modelo de interface, uma vez que o deslocamento dos nós na região da fissura principal foi condicionado por estes dois modelos.

A Tabela 7.13 apresenta a relação entre os valores numéricos e experimentais da força aplicada e do deslocamento vertical no vão provenientes do modelo numérico definitivo da laje mista.

Tabela 7.13 - Relação entre os valores numéricos e experimentais do modelo definitivo da laje mista - Laje 1

\begin{tabular}{cccc}
\hline Referência & Experimental & Numérico & Variação* \\
\hline$F_{\text {des }}$ & $22,84 \mathrm{kN}$ & $23,39 \mathrm{kN}$ & $2,41 \%$ \\
$F_{\text {ret }}$ & $16,38 \mathrm{kN}$ & $8,49 \mathrm{kN}$ & $-48,17 \%$ \\
$F_{\text {máx }}$ & $30,12 \mathrm{kN}$ & $30,57 \mathrm{kN}$ & $1,47 \%$ \\
\hline$\delta_{\text {des }}$ & $2,79 \mathrm{~mm}$ & $1,29 \mathrm{~mm}$ & $-53,76 \%$ \\
$\delta_{\text {ret }}$ & $4,20 \mathrm{~mm}$ & $1,56 \mathrm{~mm}$ & $-62,86 \%$ \\
$\delta_{\text {máx }}$ & $21,41 \mathrm{~mm}$ & $21,58 \mathrm{~mm}$ & $0,79 \%$ \\
\hline
\end{tabular}

$F_{\text {des: }}$ Força referente ao início do deslizamento da extremidade da laje;

$F_{\text {ret: }}$ Força referente à retomada de resistência após o início do deslizamento;

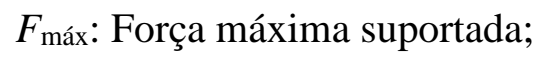

$\delta_{\text {des: }}$ Flecha correspondente à $F_{\text {des; }}$;

$\delta_{\text {ret: }}$ Flecha correspondente à $F_{\text {ret; }}$;

$\delta_{\text {máx: }}$ Flecha correspondente à $F_{\text {máx. }}$.

*Em relação ao valor experimental

Fonte: Autoria própria 
Apesar o modelo numérico apresentar maior redução brusca de $F$ após o início do deslizamento de extremidade ser iniciado, seu comportamento após este fenômeno se mostrou muito próximo do verificado experimentalmente. Além disso, os valores referentes à resistência máxima do modelo numérico foram precisos, de acordo com a Tabela 7.13.

Após a capacidade resistente máxima ser atingida, o modelo numérico apresentou maior capacidade resistente que o experimental para um mesmo valor de $\delta$. Além disso, para um mesmo nível de carregamento aplicado, o modelo numérico inicialmente apresentou maior deslizamento de extremidade, conforme se observa na Figura 7.57. A falta da medição do deslizamento de extremidade durante todo o ensaio impediu a verificação deste fenômeno e compará-lo totalmente com o desenvolvido pelo modelo numérico.

A Figura 7.58 apresenta o gráfico da Força $(F)$ versus Deslocamento vertical das seções localizadas abaixo das regiões de aplicação do carregamento, o que possibilita verificar se a configuração deformada do modelo numérico está de acordo com a observada experimentalmente.

Figura 7.58 - Gráficos da Força versus Deslocamento vertical das seções localizadas abaixo do carregamento aplicado - modelo numérico definitivo - Laje 1

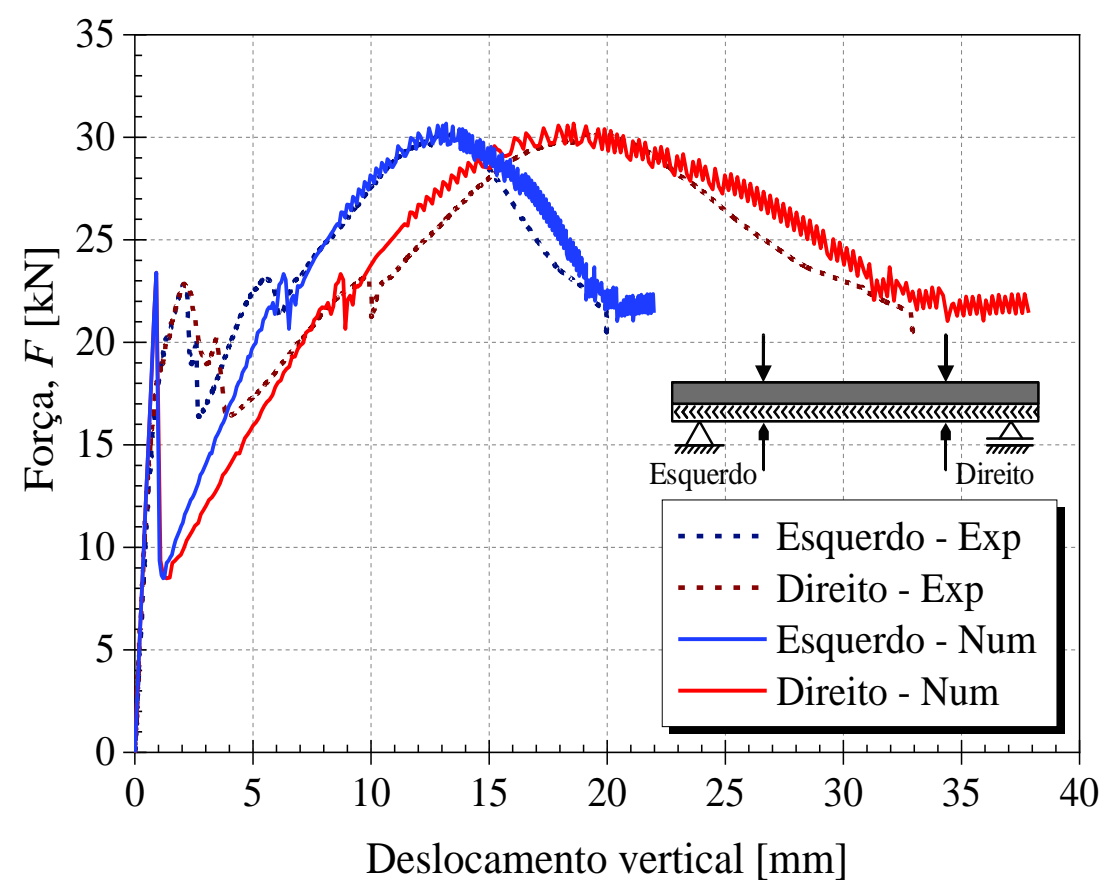

Fonte: Autoria própria

De acordo com a figura acima, verifica-se que o modelo numérico definitivo representou adequadamente os deslocamentos verticais, revelando que o comportamento global foi bem simulado e que a estratégia adotada para considerar a assimetria da fôrma de aço se mostrou pertinente. 
A Figura 7.59 apresenta a distribuição das tensões principais na capa de concreto no momento em que o modelo numérico atingiu sua capacidade máxima resistente.

Figura 7.59 - Tensões principais no concreto do modelo numérico definitivo - Laje 1
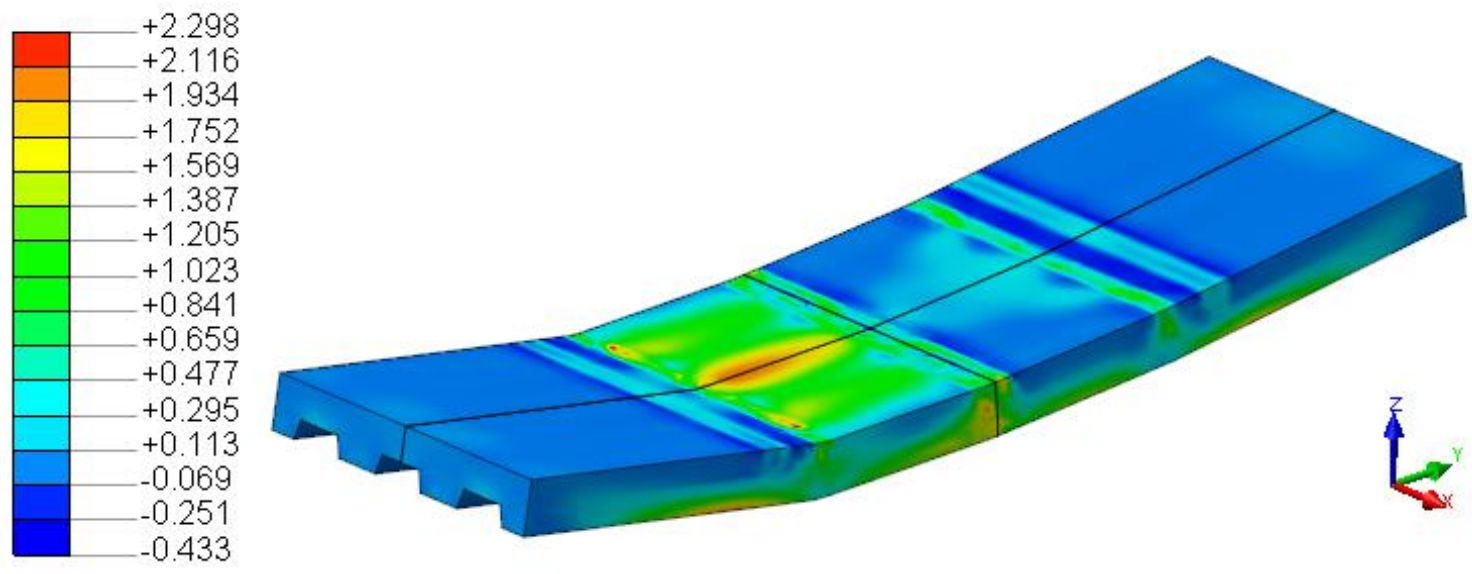

(a) Tensões principais máximas
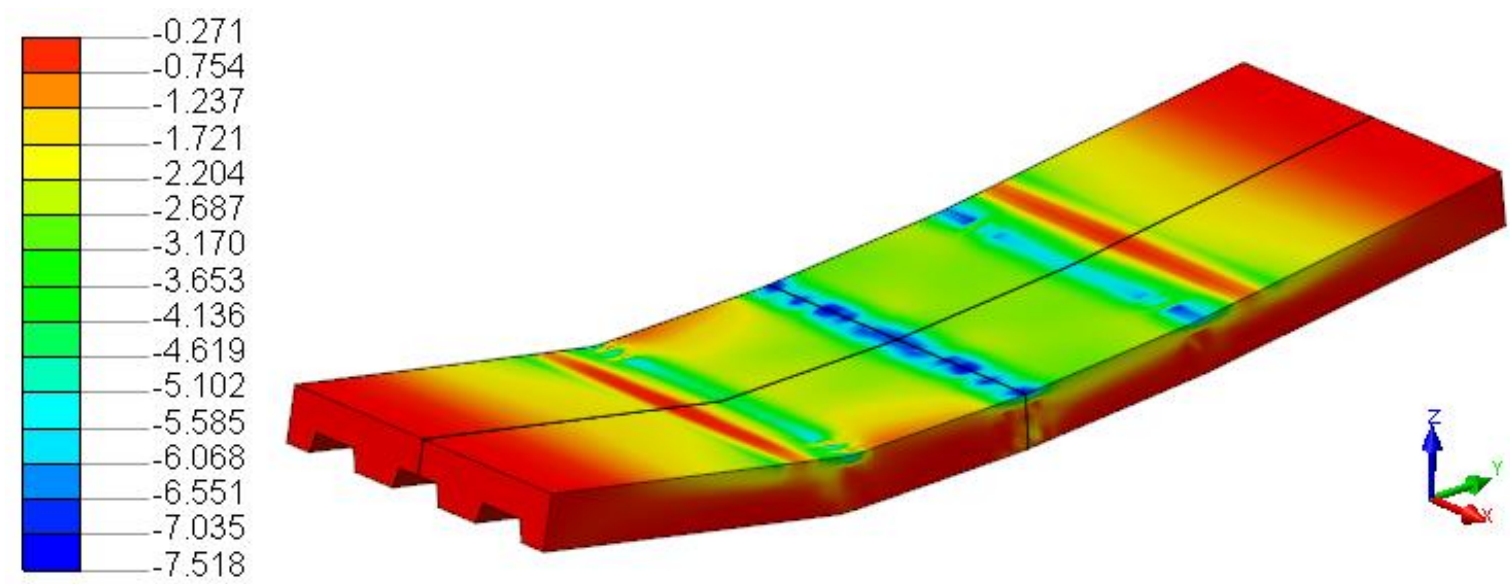

(b) Tensões principais mínimas

Fonte: Autoria própria

A distribuição das tensões principais no concreto não é simétrica, conforme ilustram as figuras acima. $\mathrm{O}$ concreto se apresentou pouco solicitado à compressão, como esperado. A região mais tracionada da capa de concreto se localizou no vão de cisalhamento que deslizou e no vão central. Além disso, houve concentração de tensões nas regiões onde o carregamento foi aplicado.

Como na região central do modelo numérico ocorre a união das duas interfaces utilizadas, ocorreu concentração de tensão no meio do vão. Contudo isto não foi um fator que comprometeu o comportamento do modelo e influenciou os demais resultados. 
A Figura 7.60 apresenta a distribuição das tensões principais na fôrma de aço no momento em que o modelo numérico atingiu sua capacidade resistente máxima.

Figura 7.60 - Tensões principais na fôrma de aço do modelo numérico definitivo - Laje 1

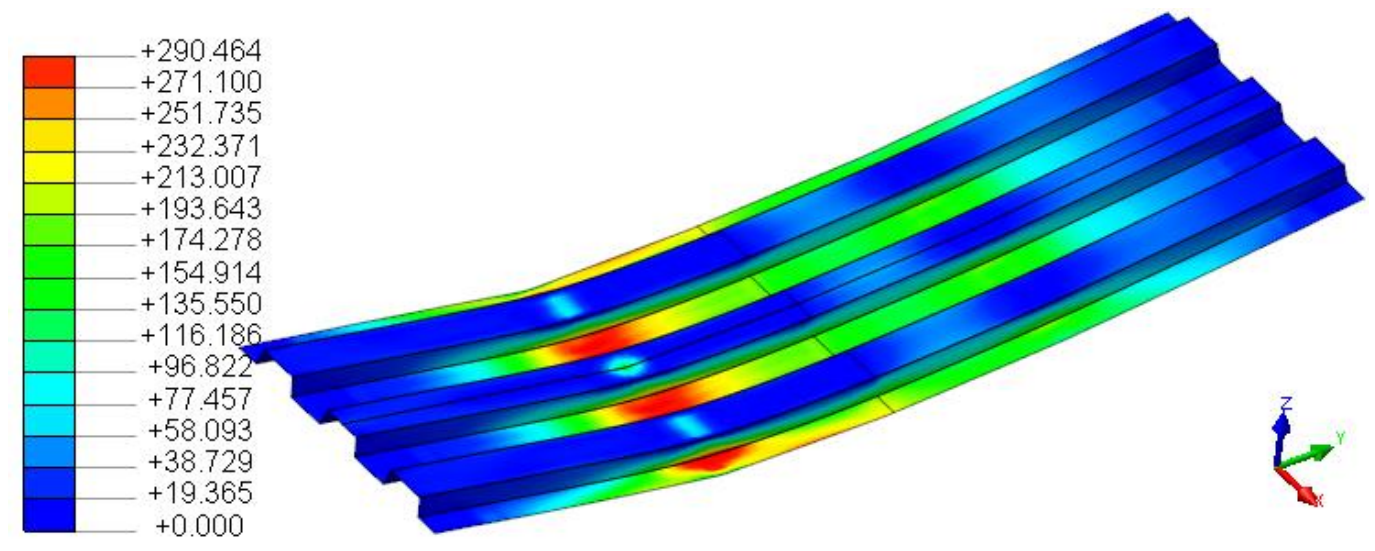

(a) Tensões principais máximas

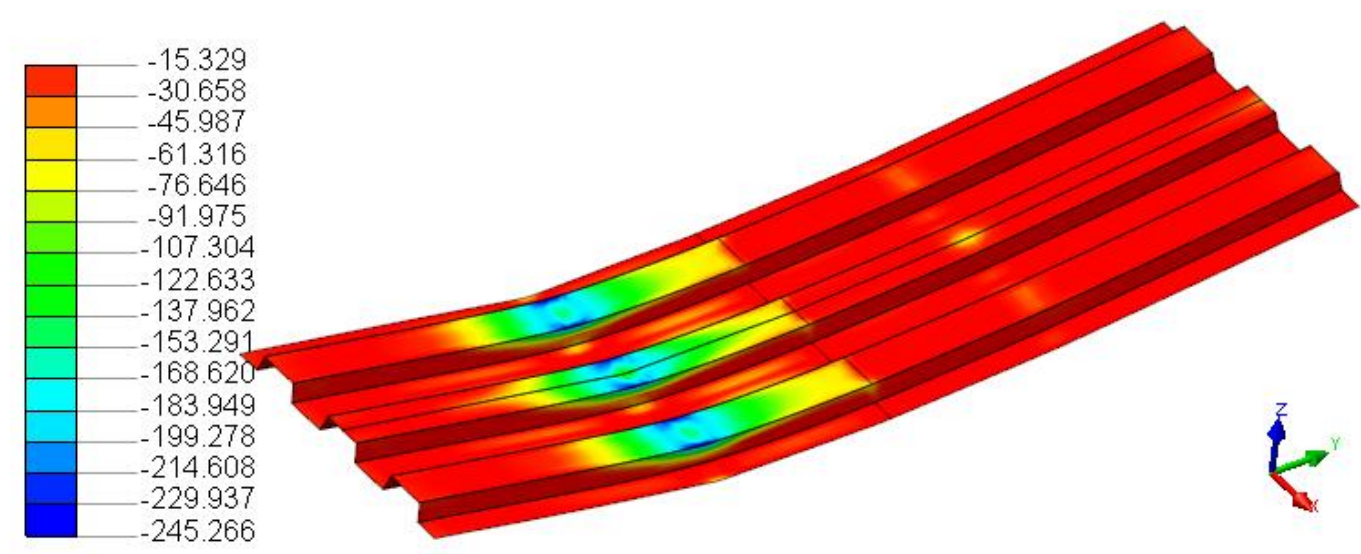

(b) Tensões principais mínimas

Fonte: Autoria própria

Observa-se que as tensões principais máximas são maiores nas mesas inferiores da fôrma e se concentraram na região da fissura principal, conforme ilustra a figura acima. As tensões principais mínimas, por sua vez, se concentraram nas mesas superiores localizadas na região da fissura principal. Estes resultados estão de acordo com o esperado e em conformidade com os resultados experimentais.

A formação de ondulações na parte comprimida da fôrma de aço localizada nas imediações da fissura principal também ocorreu no modelo numérico, conforme ilustra a Figura 7.61. Logo, a configuração de colapso dos modelos numérico e experimental coincidiram.

A Figura 7.62 apresenta a distribuição das tensões normal e de cisalhamento longitudinal (tangencial na direção $y$ ) na interface aço-concreto do modelo numérico no instante em que a sua capacidade resistente máxima foi atingida $\left(F_{\text {máx }}\right)$. 
Figura 7.61 - Ondulações na parte comprimida da fôrma de aço após o ensaio

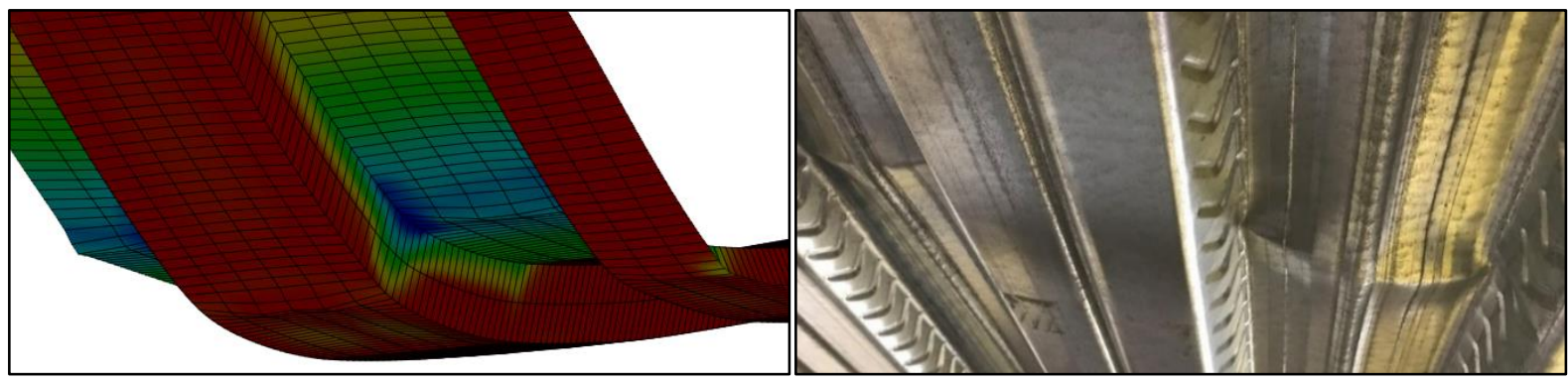

(a) Modelo numérico

(b) Protótipo experimental (Laje 1)

Fonte: Autoria própria

Figura 7.62 - Distribuição das tensões normais e de cisalhamento na interface do modelo numérico definitivo - Laje 1
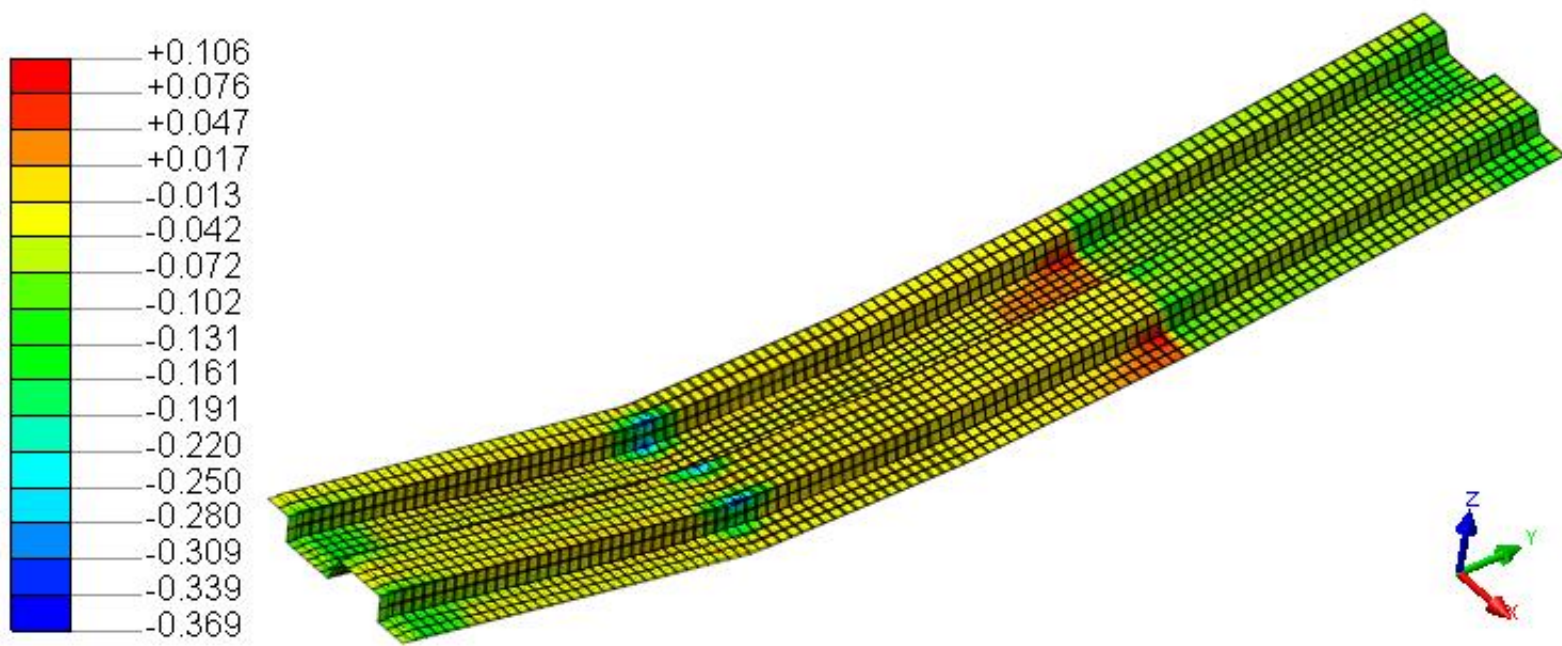

(a) Tensão normal
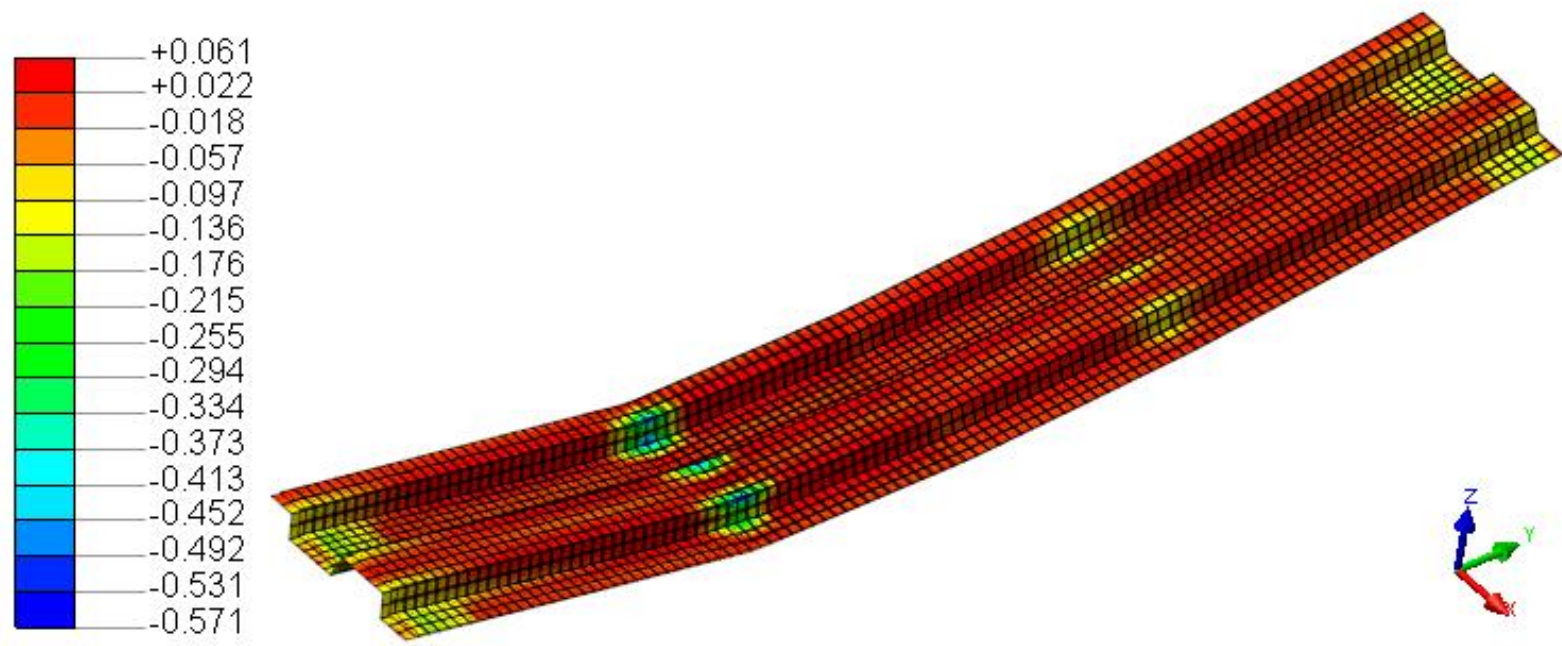

(b) Tensão de cisalhamento longitudinal (direção y)

Fonte: Autoria própria 
Quando a capacidade resistente máxima do modelo numérico foi atingida, as tensões normais e cisalhantes se concentraram nas regiões vizinhas onde o carregamento foi aplicado e na região dos apoios. Entretanto, na região da fissura principal, a interface estava comprimida, enquanto que na região do carregamento aplicado à direita, a interface se apresentou tracionada, conforme ilustra a Figura 7.62 (a). Isso ocorreu devido à distribuição de tensões no concreto e à deformação sofrida pelo aço, que interferem na distribuição das tensões normais à interface.

As interfaces localizadas no vão central e nos vãos de cisalhamento apresentaram tensões normais próximas de zero, conforme esperado, uma vez que não estão confinadas. Contudo, a interface do vão de cisalhamento que não deslizou apresentou tensões normais maiores, pois esta região da laje se manteve mais íntegra, promovendo uma distribuição de esforços diferente das demais.

Ao se analisar a distribuição de cisalhamento longitudinal (Figura 7.62 (b)), verifica-se que estas também se concentraram nas regiões vizinhas onde o carregamento foi aplicado e na região dos apoios. Esse fato está relacionado ao efeito do atrito, considerado pelo modelo numérico da interface, pois nessas regiões se concentraram as tensões normais de compressão (ver Figura $7.62(\mathrm{a})$ ).

A interface localizada na região da fissura principal se apresentou mais comprimida, e, portanto, apresentou maiores tensões de cisalhamento. A interface do vão central e dos vãos de cisalhamento apresentaram tensões cisalhantes menores, pois as tensões normais são próximas de zero e, portanto, o efeito do atrito é menor. Logo, o efeito da coesão do modelo numérico de interface é mais significativo nessas regiões.

A Figura 7.63 apresenta os gráficos da Força $(F)$ versus Deformação específica $(\varepsilon)$ dos materiais nas seções instrumentadas da Laje 1, comparando os resultados numéricos e os experimentais. Conforme pode-se verificar, o modelo numérico conseguiu representar o comportamento do aço e do concreto, apesar de suas limitações e da variabilidade do comportamento real desses materiais, como se constata no Capítulo 6 ao se comparar os resultados das deformações das duas lajes ensaiadas.

Os fenômenos observados nos ensaios experimentais e citados na literatura técnica foram adequadamente representados pelo modelo numérico definitivo da laje mista. O modelo de interface foi capaz de simular a contribuição das ligações por atrito e mecânica de forma coerente, o que resultou num comportamento semelhante ao constatado experimentalmente e ao previsto segundo a literatura. 
Figura 7.63 - Gráfico de $F$ versus $\varepsilon$ do modelo numérico definitivo da laje mista - Laje 1

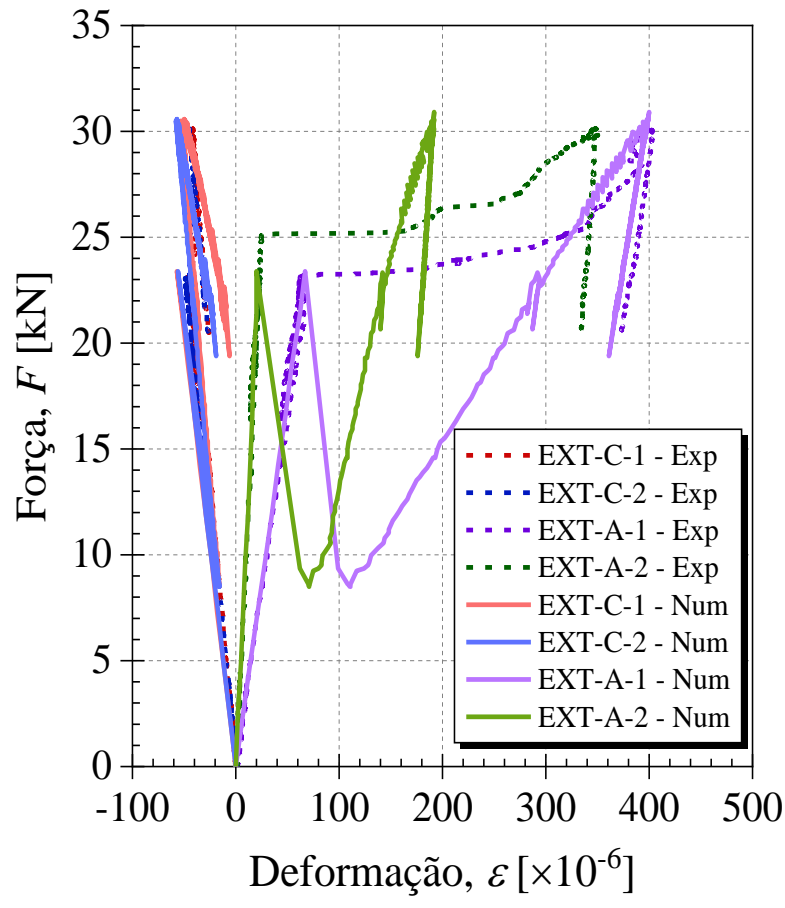

(a) Gráfico da Força versus Deformação específica dos materiais - Seção A-A

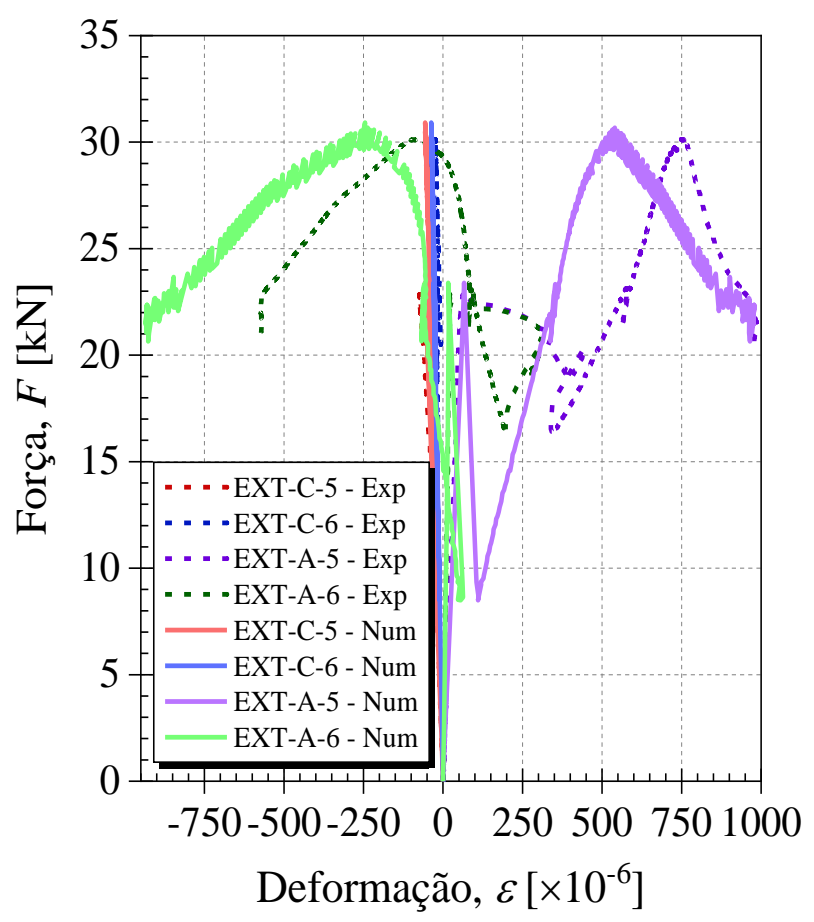

(c) Gráfico da Força versus Deformação específica dos materiais - Seção C-C

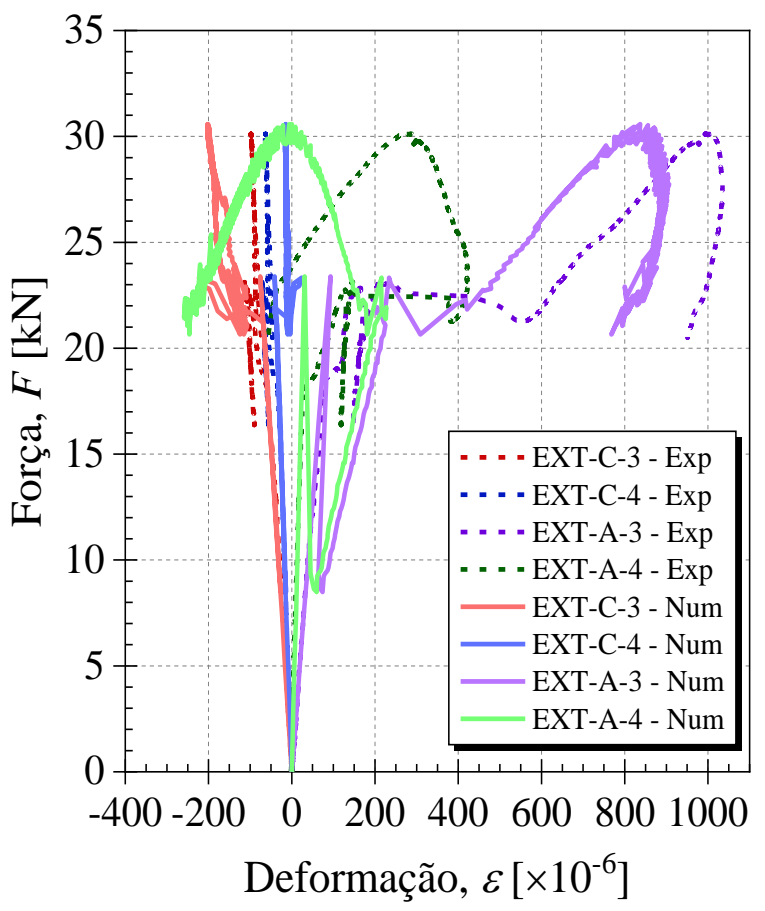

(b) Gráfico da Força versus Deformação específica dos materiais - Seção B-B
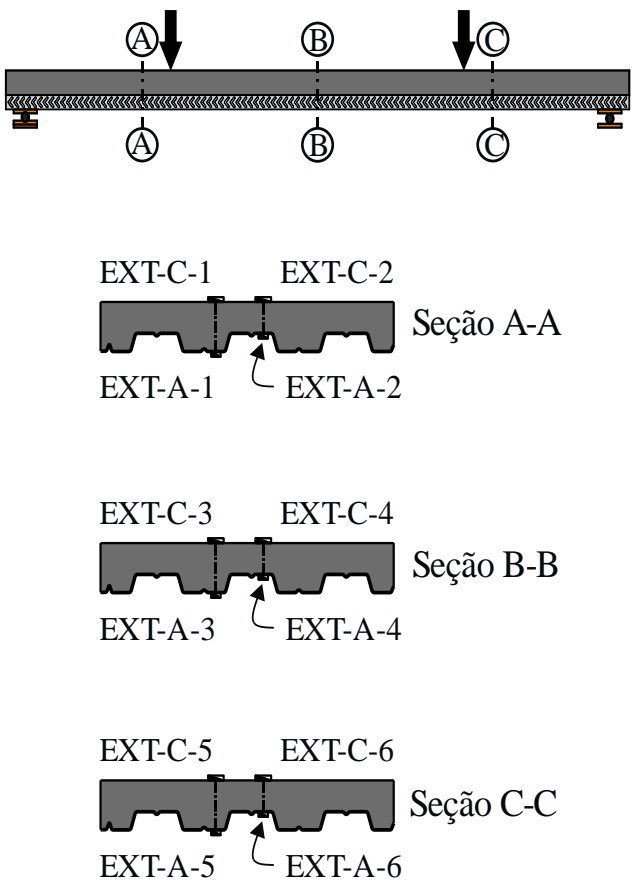

(e) Disposição dos extensômetros nas seções transversais de acordo com a Figura 6.22

Fonte: Autoria própria

A fim de verificar a precisão do modelo numérico definitivo, simulou-se o protótipo Laje 2, modificando apenas as propriedades do concreto. Nesse caso, aplicou-se, no modelo 
constitutivo do concreto, as propriedades referentes ao concreto do respectivo protótipo.

As Figuras 7.64 e 7.65 apresentam, respectivamente, os gráficos da Força $(F)$ versus Deslocamento vertical no meio do vão $(\delta)$ e da Força $(F)$ versus Deslizamento de extremidade correspondente ao vão de cisalhamento menos resistente do modelo numérico definitivo e do protótipo experimental da Laje 2. A Figura 7.66, por sua vez, apresenta o gráfico da Força versus Deslocamento vertical nas demais seções instrumentadas da Laje 2.

A Tabela 7.14 apresenta a relação entre os valores numéricos e experimentais da força aplicada e do deslocamento vertical no meio do vão do modelo numérico definitivo da Laje 2.

Figura 7.64 - Gráfico de $F$ versus $\delta$ do modelo numérico definitivo da laje mista - Laje 2

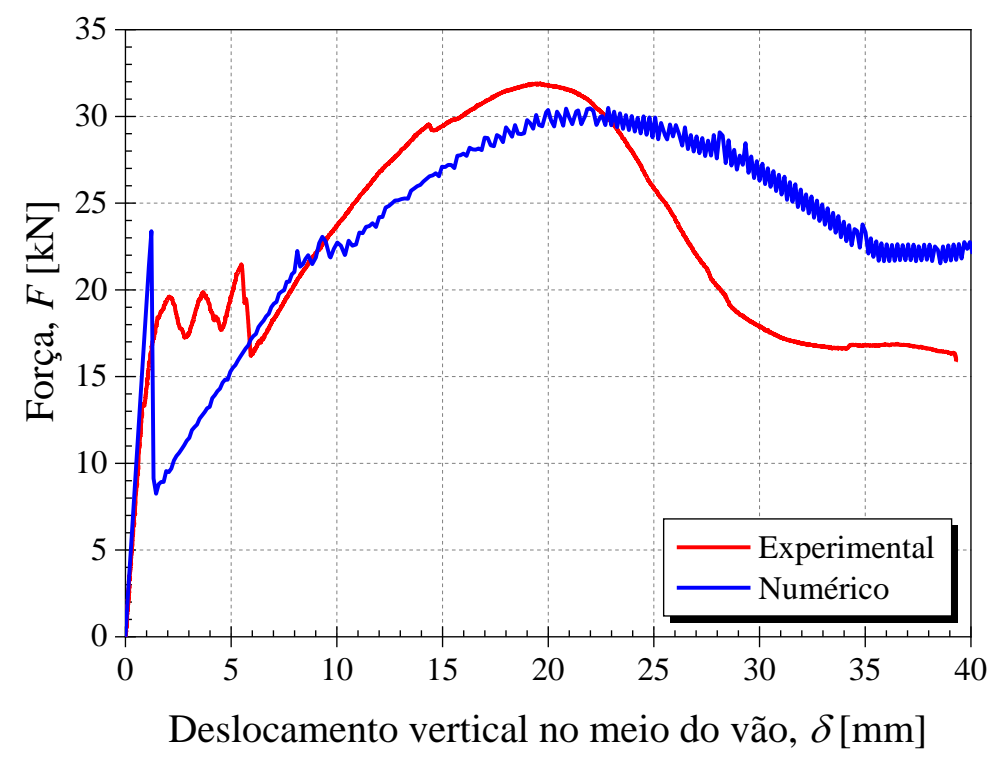

Fonte: Autoria própria

Figura 7.65 - Gráfico de $F$ versus $s$ do modelo numérico definitivo da laje mista - Laje 2

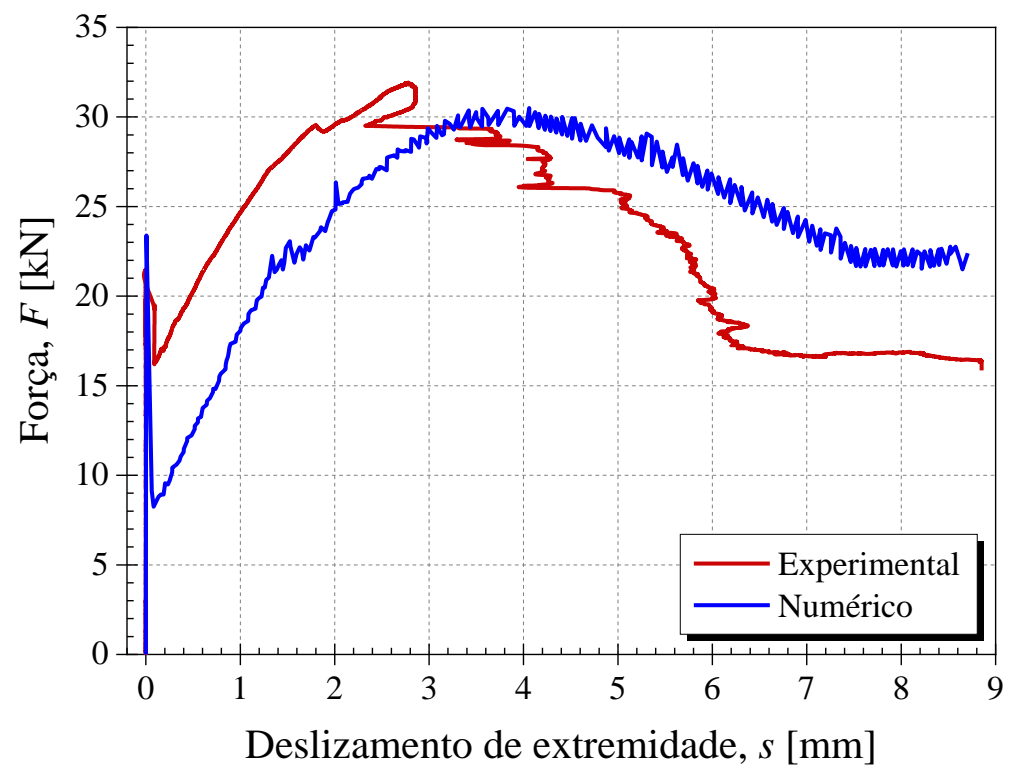

Fonte: Autoria própria 
Figura 7.66 - Gráfico da Força versus Deslocamento vertical das seções localizadas abaixo do carregamento aplicado - Laje 2

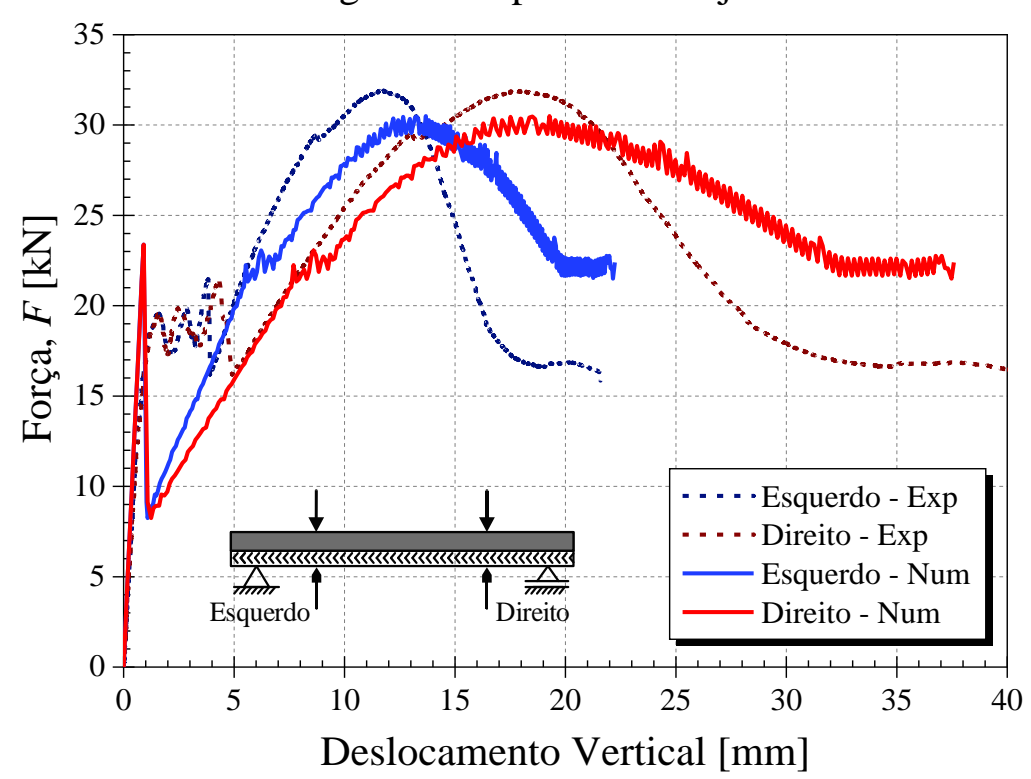

Fonte: Autoria própria

Tabela 7.14 - Relação entre os valores numéricos e experimentais do modelo definitivo da laje mista - Laje 2

\begin{tabular}{cccc}
\hline Referência & Experimental & Numérico & Variação* $^{*}$ \\
\hline$F_{\text {des }}$ & $20,30 \mathrm{kN}$ & $27,38 \mathrm{kN}$ & $34,88 \%$ \\
$F_{\text {ret }}$ & $16,31 \mathrm{kN}$ & $8,25 \mathrm{kN}$ & $-44,42 \%$ \\
$F_{\text {máx }}$ & $31,92 \mathrm{kN}$ & $30,49 \mathrm{kN}$ & $-4,48 \%$ \\
\hline$\delta_{\text {des }}$ & $4,43 \mathrm{~mm}$ & $1,23 \mathrm{~mm}$ & $-72,23 \%$ \\
$\delta_{\text {ret }}$ & $5,00 \mathrm{~mm}$ & $1,45 \mathrm{~mm}$ & $-71,00 \%$ \\
$\delta_{\text {máx }}$ & $19,60 \mathrm{~mm}$ & $22,84 \mathrm{~mm}$ & $16,53 \%$ \\
\hline
\end{tabular}

$F_{\text {des}}:$ Força referente ao início do deslizamento da extremidade da laje;

$F_{\text {ret: }}$ Força referente à retomada de resistência após o início do deslizamento;

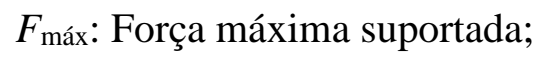

$\delta_{\text {des: }}$ Flecha correspondente à $F_{\text {des; }}$;

$\delta_{\text {ret: }}$ Flecha correspondente à $F_{\text {ret }}$;

$\delta_{\text {máx }}$ : Flecha correspondente à $F_{\text {máx }}$.

*Em relação ao valor experimental

Fonte: Autoria própria

Conforme se verifica, o modelo numérico da Laje 2 se comportou de maneira semelhante ao da Laje 1 e apresentou comportamento próximo ao do protótipo experimental. Contudo, os resultados apresentaram algumas divergências significativas. Isso deve estar relacionado ao fato do empenamento existente no protótipo Laje 2, que comprometeu seus resultados e não o tornam um modelo experimental propriamente representativo. 


\subsubsection{Análise Paramétrica}

Com o intuito de estudar a influência de algumas propriedades geométricas da laje mista sobre o seu comportamento estrutural, realizou-se uma análise paramétrica sobre a espessura da capa de concreto, a espessura da fôrma de aço e o comprimento efetivo da laje mista. Adicionalmente, analisou-se a resistência à tração do aço constituinte da fôrma.

\subsubsection{Espessura da Capa de Concreto}

Esta análise foi realizada considerando valores usuais de espessuras para a capa de concreto. Logo, manteve-se o comprimento efetivo da laje igual a 3,00 metros e avaliou-se os seguintes valores de espessura da capa de concreto $(h): 100 \mathrm{~mm}, 125 \mathrm{~mm}, 150 \mathrm{~mm}$ e $175 \mathrm{~mm}$. A Figura 7.67 apresenta o gráfico de $F$ versus $\delta$ dos modelos avaliados e a Tabela 7.15 apresenta uma comparação dos resultados numéricos de acordo com $h$.

Figura 7.67 - Análise paramétrica - Espessura da capa de concreto $(h)$

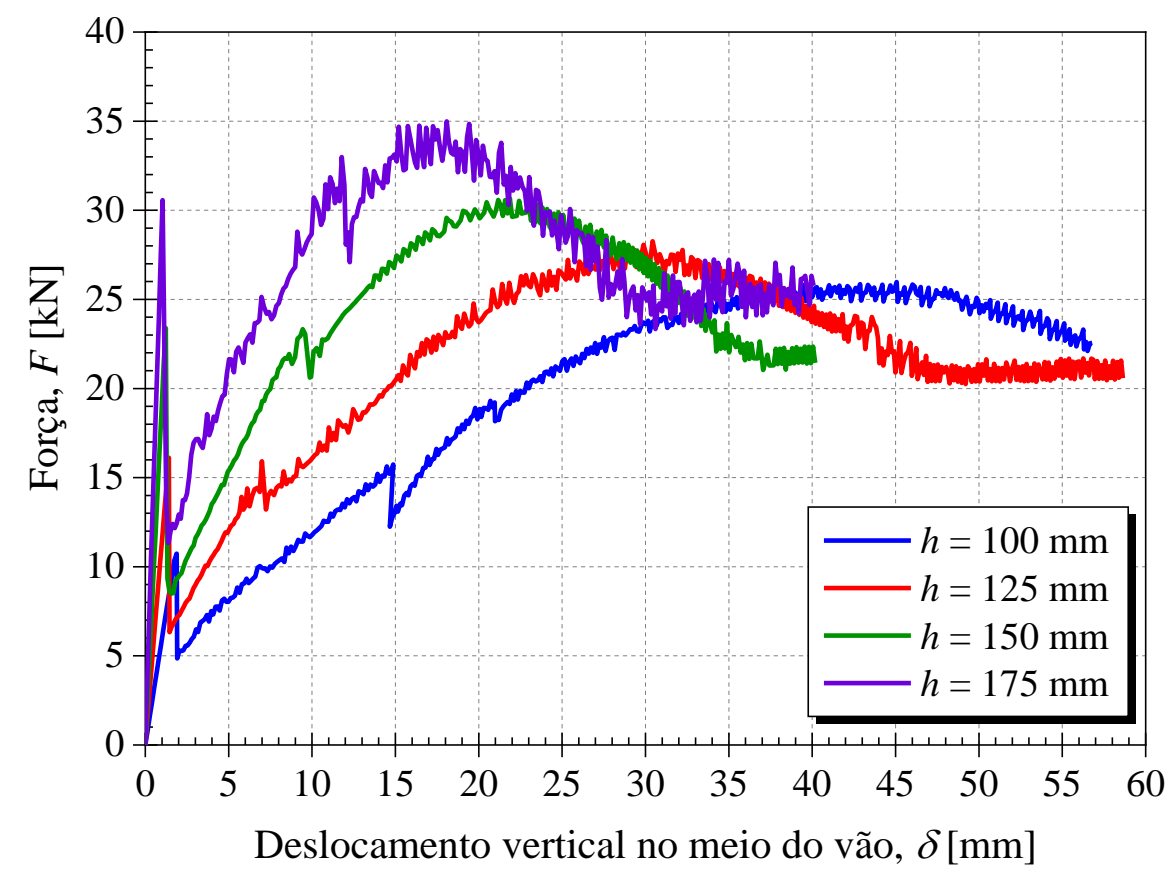

Fonte: Autoria própria

Tabela 7.15 - Análise paramétrica - Espessura da capa de concreto $(h)$

\begin{tabular}{cccccc}
\hline $\boldsymbol{h}[\mathbf{m m}]$ & $\boldsymbol{F}_{\text {des }}[\mathbf{k N}]$ & $\boldsymbol{F}_{\text {máx }}[\mathbf{k N}]$ & $\boldsymbol{\delta}_{\text {des }}[\mathbf{m m}]$ & $\boldsymbol{\delta}_{\text {máx }}[\mathbf{m m}]$ & $\boldsymbol{F}_{\text {máx }} / \boldsymbol{F}_{\text {des }}$ \\
\hline $100 \mathrm{~mm}$ & 10,74 & 25,98 & 1,88 & 45,07 & 2,42 \\
$125 \mathrm{~mm}$ & 16,11 & 28,26 & 1,41 & 30,43 & 1,75 \\
$150 \mathrm{~mm}$ & 23,39 & 30,57 & 1,29 & 21,58 & 1,31 \\
$175 \mathrm{~mm}$ & 30,57 & 34,99 & 1,04 & 18,07 & 1,14 \\
\hline
\end{tabular}

Fonte: Autor 
Conforme esperado, o aumento da altura da capa de concreto promoveu maior rigidez ao elemento estrutural. Além disso, quanto maior o valor de $h$, maiores os valores de $F_{\text {des }}$ e $F_{\text {máx }}$ e menores os valores de $\delta_{\text {des }}$ e $\delta_{\text {máx }}$. Verificou-se, também, que a redução brusca ocorrida após o início do deslizamento de extremidade aumentou conforme $h$ aumentou.

De acordo com a Tabela 7.15, quanto menor a espessura da capa de concreto, maior a relação $F_{\text {máx }} / F_{\text {des, }}$ ou seja, maior o acréscimo de carregamento suportado pelo modelo após o início do deslizamento de extremidade. Adicionalmente, constatou-se que o comportamento dos modelos avaliados foi considerado dúctil, pois $F_{\text {máx }} / F_{\text {des }}>1,10$ em todos os casos.

\subsubsection{Espessura da Fôrma de Aço}

Nesta análise, o comprimento efetivo do modelo da laje mista foi mantido $\left(L_{\mathrm{ef}}=3,00 \mathrm{~m}\right)$, assim como a espessura da capa de concreto $(h=150 \mathrm{~mm})$. Avaliou-se os seguintes valores de cálculo para a espessura da fôrma de aço $\left(t_{\mathrm{s}}\right): 0,76 \mathrm{~mm}, 0,96 \mathrm{~mm}$ e 1,21 mm. Esses valores foram baseados nas espessuras das chapas usualmente utilizadas para a confecção das fôrmas de aço e já descontam a espessura do revestimento de zinco, considerada igual a 0,04 mm.

O gráfico de $F$ versus $\delta$ dos modelos avaliados está apresentado na Figura 7.68, enquanto a Tabela 7.16 apresenta a comparação dos resultados numéricos de acordo com a espessura da fôrma de aço.

Figura 7.68 - Análise paramétrica - Espessura da fôrma de aço $\left(t_{\mathrm{s}}\right)$

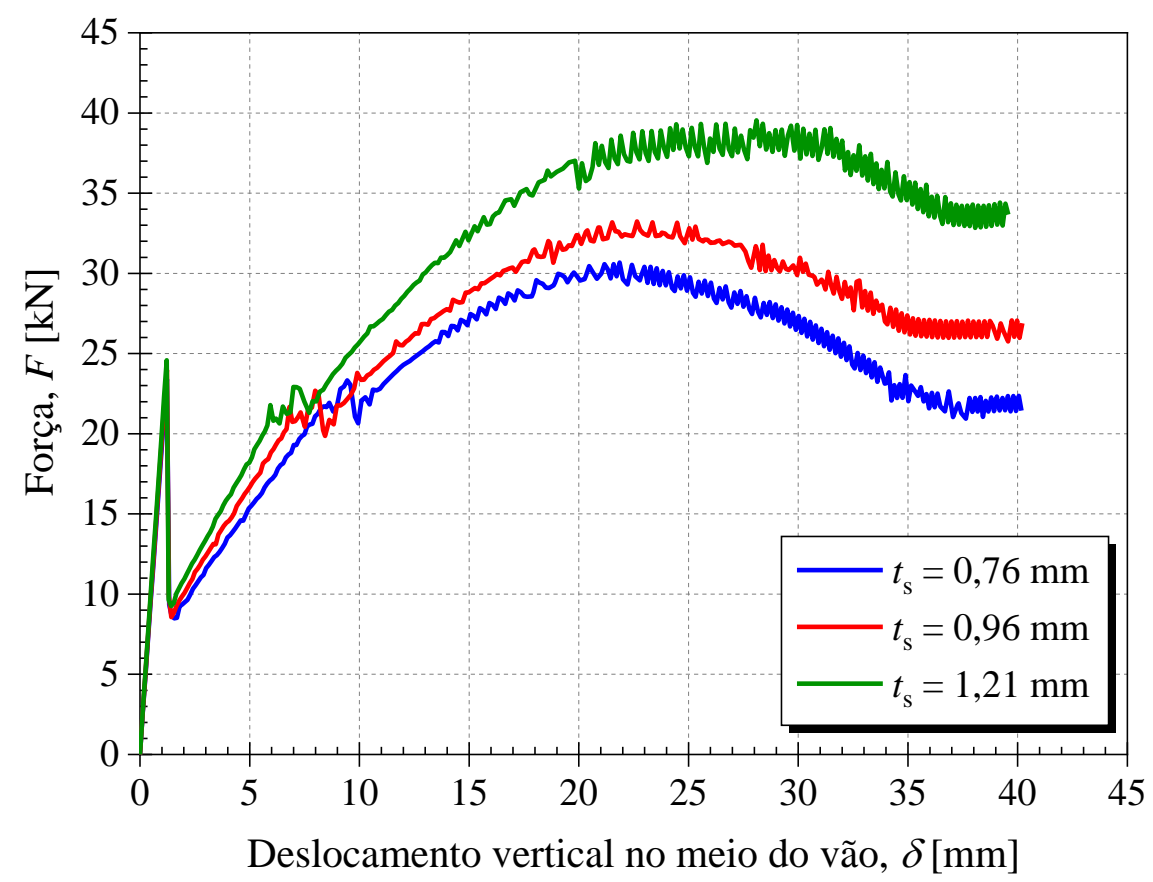

Fonte: Autoria própria 
Tabela 7.16 - Análise paramétrica - Espessura da fôrma de aço $\left(t_{\mathrm{s}}\right)$

\begin{tabular}{cccccc}
\hline $\boldsymbol{t}_{\mathbf{c}}[\mathbf{m m}]$ & $\boldsymbol{F}_{\text {des }}[\mathbf{k N}]$ & $\boldsymbol{F}_{\text {máx }}[\mathbf{k N}]$ & $\boldsymbol{\delta}_{\text {des }}[\mathbf{m m}]$ & $\boldsymbol{\delta}_{\text {máx }}[\mathbf{m m}]$ & $\boldsymbol{F}_{\text {máx }} / \boldsymbol{F}_{\text {des }}$ \\
\hline 0,76 & 23,39 & 30,57 & 1,29 & 21,58 & 1,31 \\
0,96 & 23,97 & 34,31 & 1,22 & 22,36 & 1,43 \\
1,21 & 24,58 & 39,54 & 1,22 & 28,10 & 1,61 \\
\hline
\end{tabular}

Fonte: Autor

O aumento da espessura da fôrma de aço acarretou no aumento da rigidez da laje mista, conforme esperado. A força referente ao início do deslizamento $\left(F_{\text {des }}\right)$ não foi consideravelmente influenciada. Contudo, $F_{\text {máx }}$ aumentou $12,23 \%$ e $29,34 \%$, respectivamente, ao se aumentar a espessura em $26,32 \%$ e $59,21 \%$. Diante disso, a relação $F_{\text {máx }} / F_{\text {des }}$ aumentou com o aumento de $t_{\mathrm{s}}$, indicando que este parâmetro possui maior influência após o início do deslizamento do vão de cisalhamento.

Ao se comparar os dois parâmetros avaliados da seção transversal da laje mista, isto é, $h$ e $t_{\mathrm{s}}$, verifica-se que o primeiro possui mais influência sobre a rigidez devido à sua maior contribuição ao momento de inércia da seção transversal. Entretanto, o aumento de $h$ acarretou na redução de $F_{\text {máx }} / F_{\text {des }}$, enquanto que o aumento de $t_{\mathrm{c}}$ promoveu o aumento dessa relação.

A análise desses dois parâmetros é interessante, pois, dependendo dos seus valores, a relação $F_{\text {máx }} / F_{\text {des }}$ pode ser modificada de tal forma que o comportamento estrutural da laje mista pode ser classificado como dúctil ou frágil.

\subsubsection{Comprimento Efetivo da Laje Mista}

A análise do comprimento efetivo da laje mista $\left(L_{\mathrm{ef}}\right)$ foi realizada variando-se seu valor e mantendo constante a espessura do concreto $(h=150 \mathrm{~mm})$ e a espessura da fôrma de aço $\left(t_{\mathrm{s}}=0,76 \mathrm{~mm}\right.$ ). Os valores de $L_{\mathrm{ef}}$ avaliados foram: $2,00 \mathrm{~m}, 3,00 \mathrm{~m}, 4,00 \mathrm{~m}$ e 5,00 m. Em todos os casos o comprimento de cisalhamento $\left(L_{\mathrm{s}}\right)$ foi igual à $L_{\mathrm{ef}} / 4$. Nesse caso, é prudente avaliar a capacidade resistente da laje mista verificando o momento fletor no meio do vão $(M)$, uma vez que esse esforço está atrelado ao comprimento da laje. A Figura 7.69 apresenta o gráfico de $M$ versus $\delta$ dos modelos simulados e a Tabela 7.17 descreve uma comparação entre os resultados obtidos, mostrando, também, as forças máximas suportadas pelos modelos.

Quanto menor o vão efetivo, maior foi a rigidez do modelo da laje mista, como esperado. O momento fletor resistido pelas lajes com $L_{\mathrm{ef}}=2,00$ e $L_{\mathrm{ef}}=3,00 \mathrm{~m}$ foram muito próximos, porém verificou-se que quanto maior o comprimento da laje mista, maior sua capacidade resistente ao momento fletor. Além disso, o valor do momento fletor referente ao início do deslizamento de extremidade foram semelhantes, conforme ilustra a Figura 7.69. 
Figura 7.69 - Análise paramétrica - Comprimento efetivo da laje mista $\left(L_{\mathrm{ef}}\right)$

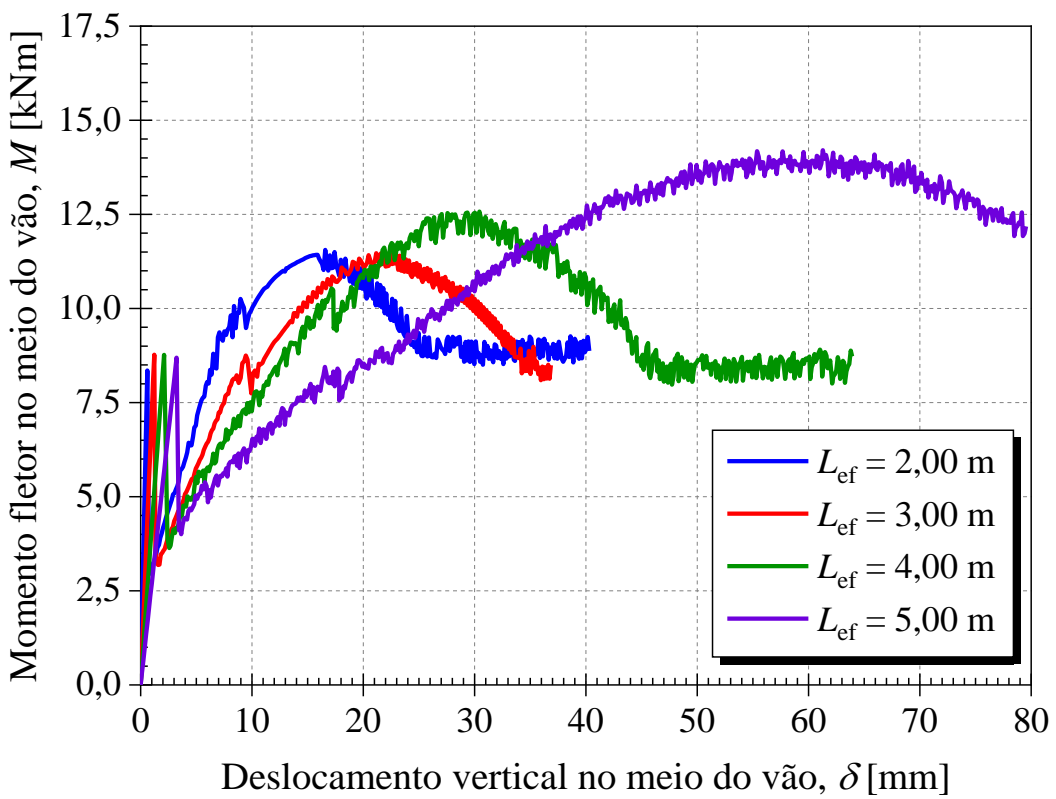

Fonte: Autoria própria

Tabela 7.17 - Análise paramétrica - Comprimento efetivo da laje mista $\left(L_{\mathrm{ef}}\right)$

\begin{tabular}{ccccccc}
\hline $\boldsymbol{L}_{\mathbf{e f}}[\mathbf{m}]$ & $\boldsymbol{M}_{\text {máx }}[\mathbf{k N m}]$ & $\boldsymbol{F}_{\text {des }}[\mathbf{k N}]$ & $\boldsymbol{F}_{\text {máx }}[\mathbf{k N}]$ & $\boldsymbol{\delta}_{\text {des }}[\mathbf{m m}]$ & $\boldsymbol{\delta}_{\text {máx }}[\mathbf{m m}]$ & $\boldsymbol{F}_{\text {máx }} / \boldsymbol{F}_{\text {des }}$ \\
\hline 2,00 & 11,56 & 33,41 & 46,23 & 0,60 & 16,58 & 1,38 \\
3,00 & 11,46 & 23,39 & 30,57 & 1,29 & 21,58 & 1,31 \\
4,00 & 12,57 & 17,54 & 25,15 & 2,10 & 30,43 & 1,43 \\
5,00 & 14,21 & 13,91 & 22,73 & 3,23 & 61,28 & 1,63 \\
\hline
\end{tabular}

Fonte: Autor

O modo de ruptura em todos os casos foi por cisalhamento longitudinal da interface açoconcreto. Logo, quanto menor o vão da laje mista mais ela suporta carregamento até que ocorra o cisalhamento da interface e até atingir sua capacidade resistente última.

As forças $F_{\text {des }}$ e $F_{\text {máx }}$ aumentaram com a redução de $L_{\mathrm{ef}}$, ocorrendo sob menores valores de $\delta_{\text {des }}$ e $\delta_{\text {máx }}$, respectivamente. Entretanto, a relação $F_{\text {máx }} / F_{\text {des }}$ para as lajes com $L_{\text {ef }}=2,00 \mathrm{~m}$ $L_{\mathrm{ef}}=3,00 \mathrm{~m}$ não apresentou diferença significativa. A partir de $L_{\mathrm{ef}}=3,00 \mathrm{~m}$, quanto maior o vão efetivo, maior o valor de $F_{\text {máx }} / F_{\text {des. }}$ Esse fato está relacionado com a tensão de cisalhamento longitudinal, uma vez que esta é menor quando o vão de cisalhamento é maior, conforme explicado na seção 3.2 .

O modelo com o vão de cisalhamento mais longo $\left(L_{\mathrm{s}}=5,00 \mathrm{~m}\right)$ apresentou uma configuração deformada muito aproximadamente simétrica e ambas as extremidades sofreram deslizamentos relativos entre a fôrma de aço e o concreto. Além disso, foi verificado que o aumento no valor de $L_{\text {ef }}$ promoveu redução das tensões de cisalhamento da interface e aumento das tensões de compressão no concreto. 


\subsubsection{Resistência ao Escoamento do Aço}

Como o aço possui um processo de fabricação com rigoroso controle de qualidade, promovendo melhor definição de suas propriedades físicas, analisou-se a influência da tensão de escoamento $\left(f_{\mathrm{y}}\right)$ do aço constituinte da fôrma. Considerou-se valores de $f_{\mathrm{y}}$ geralmente utilizados para a fabricação de fôrmas de aço para lajes mistas. A Figura 7.70 apresenta o gráfico de $F$ versus $\delta$ e a Tabela 7.18 destaca os resultados obtidos nesta análise.

Figura 7.70 - Análise paramétrica - Resistência ao escoamento do aço da fôrma $\left(f_{\mathrm{y}}\right)$

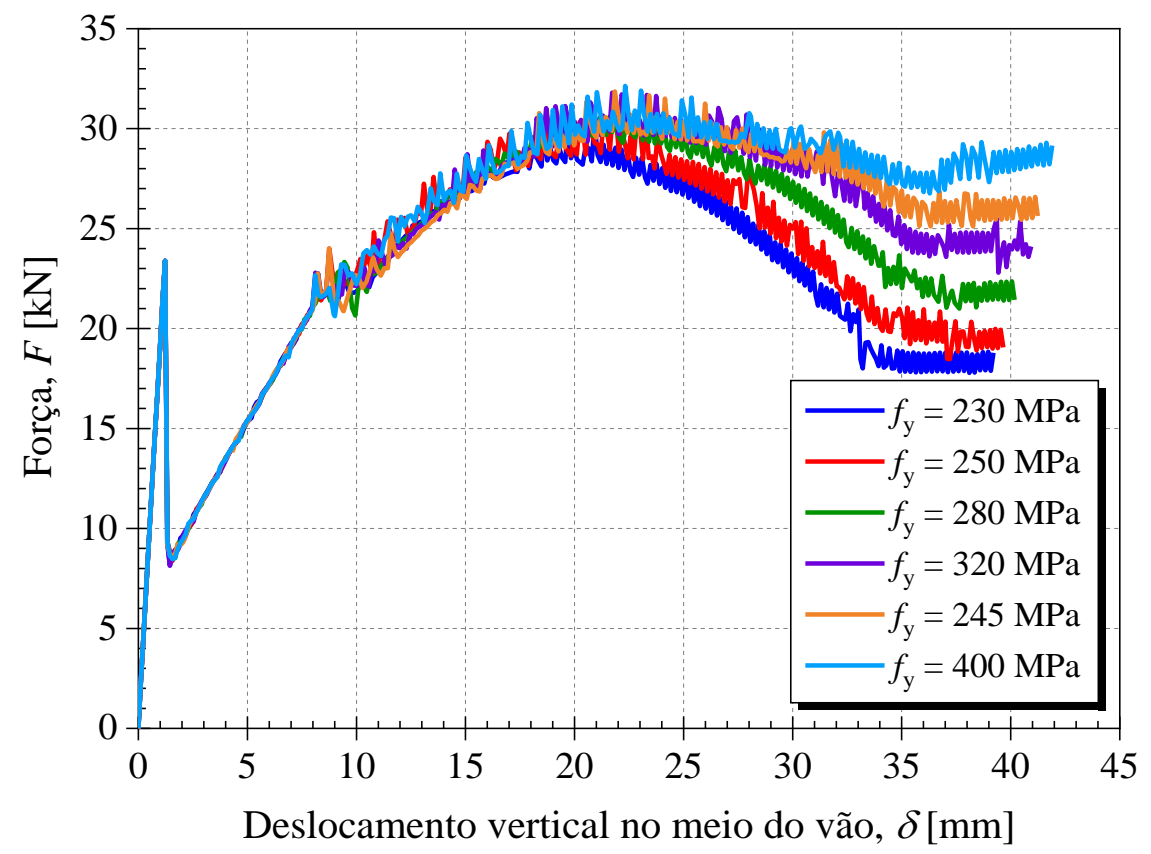

Fonte: Autoria própria

Tabela 7.18 - Análise paramétrica - Tensão de escoamento do aço da fôrma $\left(f_{\mathrm{y}}\right)$

\begin{tabular}{cccccc}
\hline $\boldsymbol{f}_{\mathbf{y}}[\mathbf{M P a}]$ & $\boldsymbol{F}_{\text {des }}[\mathbf{k N}]$ & $\boldsymbol{F}_{\text {máx }}[\mathbf{k N}]$ & $\boldsymbol{\delta}_{\text {des }}[\mathbf{m m}]$ & $\boldsymbol{\delta}_{\text {máx }}[\mathbf{m m}]$ & $\boldsymbol{F}_{\text {máx }} / \boldsymbol{F}_{\text {des }}$ \\
\hline 230 & 23,39 & 29,19 & 1,23 & 21,33 & 1,25 \\
250 & 23,39 & 30,73 & 1,23 & 21,75 & 1,31 \\
280 & 23,39 & 30,57 & 1,29 & 21,58 & 1,31 \\
320 & 23,39 & 31,80 & 1,23 & 21,72 & 1,36 \\
345 & 23,39 & 31,86 & 1,23 & 21,85 & 1,36 \\
400 & 23,39 & 32,13 & 1,23 & 22,32 & 1,37 \\
\hline
\end{tabular}

Fonte: Autor

A tensão de escoamento do aço não influenciou significativamente o comportamento dos modelos até a capacidade máxima resistente ser atingida. A força $F_{\text {des }}$ não sofreu alteração

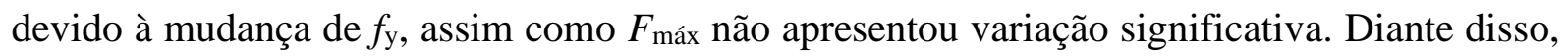
a relação $F_{\text {máx }} / F_{\text {des }}$ também não foi alterada consideravelmente. 
A maior influência de $f_{\mathrm{y}}$ foi constatada após $F_{\text {máx ser atingida, conforme apresentado na }}$ Figura 7.70, pois o aço passa a ser mais solicitado neste estágio do ensaio devido ao estado de danificação do concreto e da própria interface.

\subsubsection{Considerações Finais do Capítulo}

O comportamento da interface aço-concreto de lajes mistas é bastante complexo, conforme já discutido, e influencia fortemente o comportamento estrutural dessas lajes. Sendo assim, simular numericamente esse elemento estrutural foi uma tarefa complexa e delicada mediante o elevado grau de não linearidade do seu comportamento.

Neste trabalho, o comportamento da interface foi simulado por meio do próprio modelo de interface utilizado (Coulomb Friction), ou seja, as mossas não foram modeladas. Dessa forma, o modelo de interface foi responsável por simular a atuação das ligações química, por atrito e mecânica.

A correlação próxima entre as variáveis do modelo de interface Coulomb Friction (com Hardening) e os parâmetros obtidos por meio da metodologia desenvolvida neste trabalho possibilitou simular numericamente o ensaio slip-block com grande precisão, aplicando diretamente estes parâmetros.

Por meio das análises realizadas com o objetivo de verificar a influência de cada parâmetro do modelo numérico de interface sobre o comportamento dos modelos numéricos dos ensaios slip-block e de flexão, verificou-se como cada parâmetro atuou mediante as condições diferentes de solicitação da interface, ou seja, cisalhamento direto e flexão. Dessa forma, essas análises permitiram constatar que a ligação por atrito influenciou consideravelmente no ensaio slip-block, porém afetou pouco o desempenho da laje mista sob flexão.

A aplicação direta, no modelo da laje mista, dos parâmetros de interface empregados no modelo numérico do ensaio slip-block não se mostrou adequada. Isso ocorreu porque a interface se comporta diferente quando esta está submetida ao cisalhamento direto do que quando está submetida à flexão. Dessa forma, a reformulação dos parâmetros de interface, com base nos resultados do ensaio slip-block e na literatura técnica, se mostrou adequada para considerar os efeitos da flexão, principalmente a ausência do confinamento existente neste ensaio.

Diante da falta de simetria longitudinal da fôrma de aço da laje mista objeto deste trabalho, constatou-se que sua simulação numérica considerando a simetria longitudinal não foi adequada, pois não representou o comportamento desse elemento estrutural. Sendo assim, a 
estratégia de simulação da laje mista empregando duas interfaces (uma mais resistente que a outra) se mostrou apropriada para considerar a falta de simetria e resultou na validação do modelo numérico.

A grande maioria dos trabalhos presentes na literatura consideram a simetria longitudinal das lajes mistas em suas simulações numéricas, mesmo quando a fôrma de aço não é longitudinalmente simétrica. O objetivo disso é a redução do custo computacional requerido para o processamento do modelo numérico. Todavia, o estudo aqui realizado demonstra que tal consideração é inconsistente e não simula corretamente o comportamento do elemento estrutural.

Por fim, a análise paramétrica do modelo validado permitiu verificar como determinadas propriedades da laje mista afetam o seu comportamento, sem a necessidade de se realizar ensaios experimentais para se ter uma noção disso. Adicionalmente, foi possível analisar que a estratégia de simulação se apresentou coerente mediante a alteração de algumas características da laje mista estudada.

Analisando a influência das duas propriedades que alteram a seção transversal da laje mista, isto é, a altura da capa de concreto e a espessura da fôrma de aço, constatou-se que o primeiro impactou mais a rigidez do modelo de laje mista. Contudo, o aumento de $h$ acarretou na redução de $F_{\text {máx }} / F_{\text {des, }}$ enquanto que o aumento de $t_{\mathrm{c}}$ promoveu o aumento dessa relação.

O comprimento da laje mista interferiu no comportamento do seu modelo numérico, de modo que sua rigidez e sua capacidade resistente foram maiores conforme o seu comprimento foi menor. A resistência ao escoamento do aço, por sua vez, só promoveu uma discreta influência no comportamento estrutural após a capacidade resistente do modelo ser atingida. 


\section{CAPÍTULO 8 - CONCLUSÕES E SUGESTÕES}

O presente trabalho consistiu de uma análise da interface aço-concreto de lajes mistas por meio de um intenso estudo numérico e experimental. Diante do comportamento complexo e visando estudar e fundamentar cientificamente todo o estudo aqui desenvolvido, o Capítulo 2 abordou a fenomenologia que ocorre na interface aço-concreto de lajes mistas, enquanto o Capítulo 3 se ateve a discutir o comportamento e classificação dessas lajes. Os ensaios de modelos de pequenas dimensões desenvolvidos foram apresentados no Capítulo 4, enquanto o Capítulo 5 discutiu os métodos de cálculo normativos existentes.

Por meio do exposto nesses capítulos verificou-se a complexidade do comportamento das lajes mistas promovida pelo comportamento complexo da interface aço-concreto, constatandose (i) a necessidade de estudos mais aprofundados sobre o comportamento da interface, (ii) a dificuldade de caracterização da interface por meio de uma série de ensaios em escala real e (iii) a deficiência de obtenção de parâmetros da interface por meio das metodologias existentes aliadas aos ensaios de modelos de pequenas dimensões.

Diante disso, realizou-se a análise experimental descrita no Capítulo 6 utilizando o ensaio slip-block para analisar e caracterizar a interface aço-concreto e o ensaio de flexão em escala real para analisar o comportamento da laje mista. A análise numérica descrita no Capítulo 7 foi realizada com o objetivo de verificar a aplicação dos parâmetros de interface obtidos neste trabalho para modelar a interface aço-concreto e, assim, simular numericamente a laje mista e ampliar o estudo aqui realizado.

\subsection{Conclusões}

$\mathrm{Na}$ análise experimental foram realizados três ensaios slip-block sob carregamento confinante constante ao longo do ensaio, porém com diferentes magnitudes em cada ensaio, e um ensaio sob carregamento confinante variável, seguindo o procedimento desenvolvido por Patrick e Poh (1990). Por meio dos resultados obtidos dos ensaios sob carregamento confinante constante desenvolveu-se uma metodologia que permitiu determinar o coeficiente de atrito global $(\mu)$ e a tensão mecânica resistente ao cisalhamento $\left(\tau_{\mathrm{m}}\right)$, correlacionando-os com a geometria da fôrma de aço por meio do deslizamento relativo $(s)$. Essa parte da análise experimental possibilitou as seguintes conclusões:

a) A realização do ensaio sob carregamento confinante constante se mostrou mais simples, coerente e eficiente do que a realizada sob carregamento confinante variável 
(originalmente proposta por Patrick e Poh (1990)), permitindo identificar os fenômenos que se desenvolvem devido a ocorrência do cisalhamento longitudinal, assim como identificar a contribuição das ligações química, por atrito e mecânica;

b) As curvas do gráfico da força confinante versus deslizamento possuíram um formato típico, que está diretamente relacionado com a configuração da fôrma de aço e de suas mossas, assim como com os fenômenos ocorridos mediante o cisalhamento longitudinal. A alteração do carregamento confinante causou aumento da resistência ao cisalhamento da interface devido ao efeito do atrito, porém o comportamento geral do protótipo não foi alterado;

c) A metodologia proposta neste trabalho permitiu caracterizar qualitativa e quantitativamente a interface aço-concreto de modo que os parâmetros $\mu$ e $\tau_{\mathrm{m}}$ refletissem os fenômenos observados durante o ensaio;

d) A resistência máxima ao cisalhamento longitudinal foi atingida após o início do deslizamento e possuiu magnitude entre 1,5 e 2,0 vezes à apresentada no instante de ruptura da ligação química. A resistência máxima foi atingida no instante de maior participação da ligação mecânica, ou seja, quando $\tau_{\mathrm{m}}$ atingiu seu valor máximo, que correspondeu ao momento em que as mossas da fôrma de aço estavam saindo de suas indentações no concreto;

e) Não se observou uma relação explícita da variação do valor de $\mu$ com o deslizamento e o comportamento observado durante o ensaio. Seus valores se situaram entre 0,295 e 0,633, o que pode estar relacionado com a geometria da fôrma de aço e com a degradação da interface sofrida durante o cisalhamento;

f) A metodologia original do ensaio slip-block (proposta por Patrick e Poh (1990)) é incompleta, pois não permite identificar os fenômenos desenvolvidos na interface açoconcreto e não considera a influência da geometria da fôrma de aço para a obtenção dos parâmetros de interface. Diante disso, a metodologia proposta neste trabalho apresentase consistente e promove resultados precisos frente às análises comparativas.

Dois ensaios de flexão de protótipos em escala real foram realizados a fim de analisar o comportamento da laje mista, verificando a influência da interface e da configuração da fôrma de aço sobre os fenômenos desenvolvidos. Logo, foi possível correlacionar o comportamento observado nesses ensaios com os verificados no ensaio slip-block. Além disso, os protótipos em escala real serviram como modelos de referência para a análise numérica realizada. Sobre essa parte da análise experimental, concluiu-se o seguinte: 
a) Os protótipos apresentaram comportamento semelhantes, com modo de ruptura por cisalhamento longitudinal e comportamento considerado dúctil, com relações $F_{\text {máx }} / F_{\text {des }}$ de 1,58 e 1,96;

b) A configuração das mossas da fôrma de aço (em forma de V) fornecem um certo chaveamento, que resulta em maior resistência num sentido de deslizamento do que no outro. Esse fato determinou qual vão de cisalhamento sofreu deslizamento, de modo que o vão de cisalhamento de maior resistência não deslizou e, por isso, a configuração deformada da laje mista se apresentou longitudinalmente assimétrica;

c) Os protótipos ensaiados apresentaram cerca de 50\% da capacidade resistente ao momento fletor previsto sob interação total, revelando a limitação imposta pela resistência da interface do vão de cisalhamento menos resistente;

d) O ensaio slip-block refletiu mais o comportamento da laje mista na região de apoio devido ao confinamento existente. $\mathrm{O}$ valor do deslizamento de extremidade referente ao instante em que a laje mista atingiu sua capacidade máxima resistente correspondeu, aproximadamente, ao mesmo valor de quando os protótipos do ensaio slip-block atingiram a máxima capacidade resistente ao cisalhamento. Logo, nota-se a significativa influência da geometria da fôrma de aço, assim como a correlação existente entre os dois ensaios ao se aplicar a metodologia proposta neste trabalho.

A análise numérica consistiu na simulação dos ensaios slip-block e de flexão da laje mista. Após elencar as técnicas de modelagem presentes na literatura técnica, definiu-se a configuração e propriedades de cada modelo numérico. Os parâmetros do modelo de interface utilizado (Coulomb Friction) foram os obtidos experimentalmente utilizando o ensaio slipblock de acordo com a metodologia desenvolvida neste trabalho. Em cada caso realizou-se previamente a análise de sensibilidade aos parâmetros do modelo de interface objetivando avaliar a influência de cada um e entender seu comportamento. Com isso, desenvolveu-se uma estratégia para simulação da interface aço-concreto da laje mista considerando a configuração da fôrma de aço. Com base na análise numérica realizada concluiu-se que:

a) A aplicação direta dos parâmetros experimentais $\mu$ e $\tau_{\mathrm{m}}$ no modelo de interface Coulomb Friction (com o Hardeniong) resultou na validação do modelo do ensaio slip-block com excelente precisão. $\mathrm{O}$ modelo numérico simulou adequadamente o comportamento mediante as simplificações adotadas, uma vez que as mossas da fôrma de aço não foram modeladas; 
b) De acordo com os resultados da análise de sensibilidade do modelo numérico da laje mista, constatou-se que o parâmetro $\mu$ não influenciou significativamente seu comportamento, enquanto o parâmetro $\tau_{\mathrm{m}}$ (simulado pela coesão do modelo de interface) interferiu bastante no comportamento, de modo que a rigidez e a capacidade resistente da laje aumentam com o aumento de $\tau_{\mathrm{m}}$. Portanto, pode-se concluir que a tensão normal sobre a interface aço-concreto da laje mista não foi tão significativa, tornando discreto o efeito do atrito;

c) Devido aos efeitos da flexão, a aplicação direta dos parâmetros $\mu$ e $\tau_{\mathrm{m}}$ no modelo de interface não é adequada. Adicionalmente, a assimetria promovida pela configuração das mossas da fôrma de aço utilizada torna inconsistente a consideração da simetria longitudinal da laje mista no modelo numérico;

d) A estratégia adotada para a modelagem numérica da interface aço-concreto da laje mista, que consistiu no ajuste da curva de $\tau_{\mathrm{m}}$ versus $s$ com base em resultados experimentais da literatura, permitiu incorporar os efeitos da flexão. Além disso, a estratégia utilizada para considerar a assimetria no modelo numérico da laje mista mostrou-se consistente e promoveu a validação do seu modelo numérico, que apresentou um desempenho satisfatório, embora o comportamento inicial seja um pouco diferente do observado experimentalmente;

e) Por meio da análise paramétrica, concluiu-se que o aumento tanto a espessura da capa de concreto $(h)$ quanto da espessura da fôrma de aço $\left(t_{\mathrm{s}}\right)$ promoveram o aumento da rigidez e da capacidade resistente da laje mista. Entretanto, o aumento de $h$ acarretou numa redução da relação $F_{\text {máx }} / F_{\text {des }}$, enquanto o aumento de $t_{\mathrm{s}}$ promoveu aumento dessa relação;

f) Com relação à análise do comprimento efetivo da laje mista $\left(L_{\mathrm{ef}}\right)$, não se verificou mudança na capacidade resistente ao momento fletor no meio do vão para os comprimentos de 2,00 m e 3,00 m. Em geral, quanto maior o valor de $L_{\mathrm{ef}}$, menor a rigidez da laje e maior a capacidade resistente ao momento fletor no meio do vão. Além disso, a relação $F_{\text {máx }} / F_{\text {des }}$ aumenta com o aumento de $L_{\mathrm{ef}}$;

g) A resistência ao escoamento do aço da fôrma não possui influencia significativa sobre o comportamento estrutural do modelo numérico da laje mista até a capacidade máxima resistente ser atingida.

Diante do exposto nesta seção, conclui-se que a aplicação da metodologia para determinação de parâmetros desenvolvida neste trabalho, que utiliza ensaios slip-block sob 
carregamento confinante constante, se apresenta como uma alternativa de baixo custo para a caracterização de fôrma de aço de lajes mistas. Adicionalmente, a simulação numérica do ensaio de flexão da laje mista, aplicando esses parâmetros e considerando devidamente os efeitos da flexão, possibilita ter um indicativo prévio do seu comportamento. Dessa forma, essas duas ferramentas oferecem uma robusta técnica que serve de auxílio à etapa de estudo para o desenvolvimento de uma nova configuração de fôrma de aço.

\subsection{Sugestões para Trabalhos Futuros}

Considerando os resultados e conclusões obtidas neste trabalho e objetivando o desenvolvimento técnico-científico sobre o comportamento das lajes mistas, principalmente da interface aço-concreto, apresentam-se algumas sugestões para futuras pesquisas:

a) Realizar o ensaio slip-block para ambas as orientações do chaveamento promovido pelas mossas, no caso em que essas promovam a assimetria longitudinal da fôrma de aço;

b) Nos ensaios de flexão em escala real, realizar a medição das forças de reação nos apoios a fim de verificar a redistribuição dos esforços mediante o início do deslizamento de extremidade;

c) Desenvolver um estudo mais abrangente, empregando vários tipos de fôrmas de aço, a fim de estabelecer a correlação entre suas geometrias com os parâmetros obtidos;

d) Desenvolver propostas de ensaios experimentais para determinar as rigidezes normal e tangencial da interface aço-concreto;

e) Aperfeiçoar o modelo numérico e a estratégia de modelagem adotada para consideração da assimetria da fôrma de aço. 



\section{REFERÊNCIAS BIBLIOGRÁFICAS}

ABAS, F. Z. M. Strenght of fibre reinforced concrete composite slabs with deep trapezoidal profiled steel decking. 2014. 312 p. Ph. D. Thesis (Civil Engineering) - School of Civil and Environmental Engineering, University of New South Wales, Sydney, 2014.

ABDULLAH, R. Experimental evaluation and analytical modeling of shear bond in composite slabs. 208 p. Ph. D. Thesis (Civil Engineering) - Virginia Polytechnic Institute and State University, Blacksburg, 2004.

ABDULLAH, R.; EASTERLING, W. S. New evaluation and modeling procedure for horizontal shear bond in composite slabs. Journal of Constructional Steel Research, v. 65, n. 4, p. 891-899, abr. 2009.

ABDINASIR, Y.; ABDULLAH, R.; MUSTAFFA, M. Modelling of Shear Bond With Cohesive Element And Slenderness Study of Composite Slabs. In: ASIA PACIFIC STRUCTURAL ENGINEERING \& CONSTRUCTION CONFERENCE (APSEC 2012), 8. \& INTERNATIONAL CONFERENCE OF CIVIL ENGINEERING RESEARCH (ICCER 2012), 1., 2012, Surabaya. Proceedings... Surubaya: Faculty of Civil Engineering, Universiti Teknologi Malaysia, 2012. p. 208-216.

AIRUMYAN, E. et al. Efficient embossment for corrugated steel sheeting. IABSE Symposium on Mixed Structures Including New Materials, Brussels, Belgium, p. 137-142, 1990.

AMERICAN NATIONAL STANDARDS INSTITUTE/AMERICAN SOCIETY OF CIVIL ENGINEERS. ANSI/ASCE 3-91: Standard for the structural design of composite slabs. New York, New York k, United States of America, 1992. 104 p.

AMERICAN SOCIETY FOR TESTING AND MATERIALS. ASTM A370-19: Standard methods and definitions for mechanical testing of steel products. West Conshohocken, Pennsylvania, United States of America, 2019. 50 p.

AN, L. Load bearing capacity and behaviour of composite slabs with profiled steel sheet. Ph.D. Thesis (Civil Engineering) - Chalmers University of Technology, Gothenburg, Sweden, 1993.

ANDRADE, T. Sobre as lajes mistas de aço e concreto em situação de incêndio. 2012. 183p. Iniciação Científica - Escola Politécnica de São Paulo, Universidade de São Paulo, São Paulo, 2012.

ASSOCIAÇÃO BRASILEIRA DE NORMAS TÉCNICAS. NBR 5739: Concreto - Ensaio de compressão de corpos de prova cilíndricos. Rio de Janeiro, 2018. 13p.

ASSOCIAÇÃO BRASILEIRA DE NORMAS TÉCNICAS. NBR 6118: Projeto de estruturas de concreto - procedimento. Rio de Janeiro, 2014. 256 p. 
ASSOCIAÇÃO BRASILEIRA DE NORMAS TÉCNICAS. NBR 7008-3: Chapas e bobinas de aço revestidas com zinco ou liga zinco-ferro pelo processo contínuo de imersão a quente (Parte 3: Aços estruturais). Rio de Janeiro, 2012. 7 p.

ASSOCIAÇÃO BRASILEIRA DE NORMAS TÉCNICAS. NBR 8522: Determinação dos módulos estáticos de elasticidade e de deformação à compressão. Rio de Janeiro, 2017. 16 p. ASSOCIAÇÃO BRASILEIRA DE NORMAS TÉCNICAS. NBR 8800: Projeto de estruturas de aço e de estruturas mistas de aço e concreto de edifícios. Rio de Janeiro, 2008. 237 p.

ASSOCIAÇÃO BRASILEIRA DE NORMAS TÉCNICAS. NBR 12142: Concreto Determinação da resistência à tração na flexão de corpos de prova prismáticos. Rio de Janeiro, 2010.9 p.

ASSOCIAÇÃO BRASILEIRA DE NORMAS TÉCNICAS. NBR 14323: Projeto de estruturas de aço e de estruturas mistas de aço e concreto de edifícios em situação de incêndio. Rio de Janeiro, 2013. 66 p.

AUSTRALIAN STANDARD/NEW ZELAND STANDARD. AS/NZS 2327: Composite structures-composite steel-concrete construction in buildings. Wellington, 2017, 267 p.

ÁVILA, M. L.; QUEVEDO, R. L.; MORFA, C. A. R. Estimación de la resistencia al cortante longitudinal en losas compuestas con lámina metálica colaborante. Revista Ingeniería de Construcción, v. 24, n. 1, p. 95-113, abr. 2009.

BAIÃO FILHO, O. T. Estudo comparativo de respostas estruturais antes da cura do concreto de fôrmas metálicas incorporadas às lajes. 2003. 162 p. Dissertação (Mestrado em Engenharia de Estruturas) - Escola de Engenharia, Universidade Federal de Minas Gerais, Belo Horizonte, 2003.

BELTRÃO, A. J. N. Comportamento estrutural de lajes-mistas com corrugações na alma de perfis de chapa dobrada. 2003. 124p. Dissertação (Mestrado) - Departamento de Engenharia Civil, Pontifícia Universidade Católica do Rio de Janeiro, Rio de Janeiro, 2003.

BODE, H; MINAS, F. Composite slabs with and without end anchorage under static and dynamic loading. In: IABSE CONFERENCE: COMPOSITE CONSTRUCTION CONVENTIONAL AND INNOVATIVE, 24., 1997, Innsbruck. Reports... Zürich: ETH- eperiodica, 1997, p. 265-270.

BRENDOLAN, G. Análise do comportamento e da resistência do sistema de lajes com fôrma de aço incorporada. 2007. 160 p. Dissertação (Mestrado em Engenharia de Estruturas) - Escola de Engenharia, Universidade Federal de Minas Gerais, Belo Horizonte, 2007.

BRITISH STANDARD. BS 5950-4: Structural use of steelwork in buildings - Part 4: Code of practice for design of composite slabs with profiled steel sheeting. London, 1994.

BRITTO JUNIOR, G. F. Análise experimental do cisalhamento longitudinal de lajes mistas. Dissertação (Mestrado em Engenharia de Estruturas) - Escola Politécnica, Universidade Federal da Bahia, Salvador, 2017. 
BURNET, M. Analysis of composite steel and concrete flexural members that exhibit partial shear connection. 502 p. Ph. D. Thesis (Civil Engineering). University of Adelaide, South Australia, 1998.

BURNET, M. J.; OEHLERS, D. J. Rib shear connectors in composite profiled slabs. Journal of Constructional Steel Research, v. 57, n. 12, p. 1267-1287, dez. 2001.

CALADO, L.; SANTOS, J. Estruturas Mistas de aço e betão: 1. ed. Lisboa: IST Press, 2010.

CALIXTO, J. M. et al. Comportamento de lajes mistas com fôrma de aço incorporada com armaduras de reforço. In: CONGRESSO INTERNACIONAL DA CONSTRUÇÃO METÁliCA, 3, 2006, Ouro Preto. Resumos... Ouro Preto, 2006.

CAMPOS, P. C. Efeito da continuidade no comportamento e na resistência de lajes mistas com fôrma de aço incorporada. 2001. 157 p. Dissertação (Mestrado em Engenharia de Estruturas) - Escola de Engenharia, Universidade Federal de Minas Gerais, Belo Horizonte, 2001.

CANADIAN SHEET STEEL BUILDING INSTITUTE. CSSBI S2-2017: Criteria for the testing of composite slabs. Cambridge, 2017. $4 \mathrm{p}$.

CANADIAN SHEET STEEL BUILDING INSTITUTE. CSSBI S3-2017: Criteria for the design of composite slabs. Cambridge, 2017. 7 p.

CARVALHO, F. S. Fôrma metálica profunda, com alma corrugada, para incorporação a lajes de concreto - comportamento na fase antes da cura do concreto. 2005. 104 p. Dissertação (Mestrado em Engenharia de Estruturas) - Escola de Engenharia, Universidade Federal de Minas Gerais, Belo Horizonte, 2005.

CHEN, S. Load carrying capacity of composite slabs with various end constrains. Journal of Constructional Steel Research, v. 59, p. 385-403, mar. 2003.

CHEN S.; SHI, X. Shear bond mechanism of composite slabs - a universal FE approach. Journal of Constructional Steel Research, v. 67, n. 10, p. 1475-1484, out. 2011.

CHEN, S.; SHI, X.; QIU, Z. Shear bond failure in composite slabs - a detailed experimental study. Steel and Composite Structures, v. 11, n. 3, p. 233-250, jun. 2011.

CHEN, S.; SHI, X.; ZHOU, Y. Strength of composite slabs with end-anchorage studs. Proceedings of the Institution of Civil Engineers - Structures and Buildings, v. 168, n. SB2, p. 127-140, set. 2014.

CHENG, J. J. R.; YAM, M. C. H.; DAVISON, E. B. Behavior and failure mechanism of composite slabs. In: INTERNATIONAL SPECIALTY CONFERENCE ON COLD-FORMED STEEL STRUCTURES, 20., 1994, Saint Louis. Proceedings... Rolla: Scholars' Mine, 1994. p. 361-383.

CIFUENTES, H.; MEDINA, F. Experimental study on shear bond behavior of composite slabs according to Eurocode 4. Journal of Constructional Steel Research, v. 82, p. 99-110, mar. 2013. 
CORDEIRO, L. C. S. Sobre as lajes mistas de aço e concreto em situação de incêndio. 2014. 262 p. Dissertação (Mestrado em Engenharia de Estruturas) - Escola Politécnica de São Paulo, Universidade de São Paulo, São Paulo, 2014.

CRISINEL, M.; MARIMON, F. A new simplified method for the design of composite slabs. Journal of Constructional Steel Research, v. 60, n. 3-5, p. 481-491, mar. 2004.

DANIELS, B. J. Shear bond pull-out tests for cold-formed-steel composite slabs. 1988. Rapport d'essais - Steel Structures Laboratory (ICOM), Department de Genie Civil, École Polytechnic Fédérale de Lausanne (EPFL), Lausanne, 1988.

DANIELS, B. J.; O'LEARY, D.; CRISINEL, M. The analysis of composite slabs with profiled sheeting using a computer based semi-empirical partial interaction approach. In: INTERNATIONAL SPECIALTY CONFERENCE ON COLD-FORMED STEEL STRUCTURES, 10., 1990, Saint Louis. Proceedings... Rolla: Scholars' Mine, 1990. p. 49-63.

DANIELS, B. J.; CRISINEL, M. Composite slab behavior and strength analysis. Part I: Calculation procedure. Journal of Structural Engineering, v. 119, n. 1, p. 16-35, jan. 1993.

DIANA, T. DIANA Finite Element Analysis. User's manual release 9.6. Delft, Netherland, 2020.

DIÓGENES, H. J. F. Análise numérica e experimental de ligações por aderência açoconcreto aplicada em estruturas mistas. 2013. 198 p. Tese (Doutorado) - Escola de Engenharia de São Carlos, Universidade de São Paulo, São Carlos, 2013.

ESHWARI, S. K. et al. Experimental studies on effects of steel studs in composite slabs. In: INTERNATIONAL CONFERENCE ON SUSTAINABLE INFRASTRUCTURE 2017, 2017, New York. Proceedings... New York: ASCE, 2017. p. 213-224.

EUROPEAN COMMITTEE FOR STANDARDIZATION. EN 1992-1-1: Eurocode 2 Design of concrete structures - Part 1-1: General rules for buildings. Brussels, Belgium, 2004. $227 \mathrm{p}$.

EUROPEAN COMMITTEE FOR STANDARDIZATION. EN 1994-1-1: Eurocode 4 Design of composite steel and concrete structures - Part 1-1: General rules for buildings. Brussels, Belgium, 2004. 118 p.

FÉDÉRATION INTERNATIONALE DU BÉTON. Model Code 2010 - First Complete Draft. FIB Bulletin, n. 55, 2010. 318 p.

FERRAZ, C. B. Análise do comportamento e da resistência do sistema de lajes mistas. 1999. 168 p. Dissertação (Mestrado em Engenharia de Estruturas) - Escola de Engenharia, Universidade Federal de Minas Gerais, Belo Horizonte, 1999.

FERRER, M. B. Estudio numérico y experimental de la interacción entre la chapa de acero y el hormigón. 2005. 205 p. Tesi Doctoral. Escola Tècnica Superior D’Enginyeria Industrial de Barcelona. Barcelona, 2005. 
FERRER, M.; MARIMON, F.; CRISINEL, M. Designing cold-formed steel sheets for composite slabs: an experimentally validated FEM approach to slip failure mechanics. ThinWalled Structures, v. 44, n. 12, p. 1261-1271, dez. 2006.

FONTES, J. P. P. B. R. Lajes mistas de betão armado sobre chapa metálica colaborante. Estudo da interface aço-betão. 2016. 175 p. Dissertação (Mestrado em Engenharia Civil). Universidade da Beira Interior, Covilhã, 2016.

FREIRE, J. T. Analysis on the behavior of composite slabs under concentrated loads. Journal of Constructional Steel Research, v. 5, n. 10, p. 385-403, 2016.

FRIEDRICH, J. T. Análise teórico-experimental de pisos mistos de pequena altura. 2012. 151 p. Dissertação (Mestrado em Engenharia de Estruturas) - Departamento de Engenharia de Estruturas, Escola de Engenharia de São Carlos, Universidade de São Paulo, São Carlos, 2012.

GANESH, V.; UPADHYAY, A.; KAUSHIK, S. K. Simplified design of composite slabs using slip block test. Journal of Advanced Concrete Technology, v. 3, n. 3, p. 403412, out. 2005.

GHOLAMHOSEINI, A. et al. Longitudinal shear stress and bond-slip relationships in composite concrete slabs. Engineering Structures, v. 69, p. 37-48, jun. 2014.

GOMES, L. C. Estudo do sistema de lajes mistas com fôrma de aço incorporada empregando concreto estrutural leve. 2001. 186 p. Dissertação (Mestrado em Engenharia de Estruturas) - Escola de Engenharia, Universidade Federal de Minas Gerais, Belo Horizonte, 2001.

GROSSI, L. G. F. Sobre o comportamento estrutural e o dimensionamento de lajes mistas de aço e concreto com armadura adicional. 2016. 275 p. Dissertação (Mestrado em Engenharia Civil de Estruturas) - Departamento de Engenharia de Estruturas, Escola de Engenharia de São Carlos, Universidade de São Paulo, São Carlos, 2016.

HICKS, S. J.; PENNINGTON, A. F.; JONES, A. S. Longitudinal shear resistance of composite slabs. Proceedings of the Institution of Civil Engineers - Structures and Buildings, v. 167, n. SB10, p. 610-617, fev. 2014.

HOLOMEK, J. et al. Comparasion of methods of testing composite slabs. International Journal of Mechanical and Mechatronics Engineering, v. 6, n. 7, p. 1201-1206, jul. 2012.

HOLOMEK et al. Shear of composite slabs, experimental and numerical investigation. Advanced Materials Research, v. 923, p. 217-220, 2014.

HOLOMEK, J. et al. Design of composite slabs with prepressed embossments using smallscale tests. Structural Concrete, v. 16, n.1, p. 137-148, ago. 2015.

HOLOMEK, J.; BAJER, M. Experimental and numerical investigation of composite action os steel concrete slab. Procedia Engineering, v. 40, p. 143-147, ago. 2012. 
HOLOMEK, J.; BAJER, M.; VILDA, M. Test Arrangement of Small-scale Shear Tests of Composite Slabs. Procedia Engineering, v. 161, p. 716-721, out. 2016.

HORDIJK, D. A. Local approach to fatigue of concrete. 1991. $216 \mathrm{p}$. PhD thesis, Delft University of Technology, Delft, 1991.

HOSSAIN, K. M. A.; ATTARDE, S.; ANWAR, M. S. Finite element modelling of profiled steel deck composite slab system with engineered cementitious composite under monotonic loading. Engineering Structures, v. 186, p. 13-25, fev. 2019.

JOLLY, C. K.; ZUBAIR, A. K. The efficiency of shear-bond interlock between profiled steel sheeting and concrete. International Conference on Steel and Aluminium Structures, Cardiff, Wales, p. 127-136, 1978.

LOPES, E.; SIMÕES, R. Experimental and analytical behaviour of composite slabs. Steel and Composite Structures, v. 8, n. 5, p. 361-388, 2008.

MAKELAINEN, P.; SUN, Y. The longitudinal shear behaviour of a new steel sheeting for composite slabs. Journal of Constructional Steel Research, v. 49, n. 2, p. 117-128, fev. 1999.

MARIMUTHU, V. et al. Experimental studies on composite deck slabs to determine the shearbond characteristic $(m-k)$ values of the embossed profiled sheet. Journal of Constructional Steel Research, v. 63, n. 6, p. 791-803, jun. 2007.

MARTINS, A. G. Estudo comparativo de respostas estruturais, após a cura do concreto, de algumas fôrmas metálicas incorporadas às lajes, disponíveis nos mercados nacional e internacional. 2001. 128p. Dissertação (Mestrado em Engenharia de Estruturas) Universidade Federal de Minas Gerais, Belo Horizonte, 2001.

MELO, C. B. Análise do comportamento e da resistência do sistema de lajes mistas. 1999. 168p. Dissertação (Mestrado em Engenharia de Estruturas) - Escola de Engenharia, Universidade Federal de Minas Gerais, Belo Horizonte, 1999.

MODULAR. (Catálogo) Modular Sistemas Construtivos: Modular Deck MD 55. 2014.

OLIVEIRA, L. A. M. Comportamento em serviço de lajes mistas de aço e concreto ao longo do tempo. 2019. 250 p. Dissertação (Mestrado em Engenharia Civil de Estruturas) Departamento de Engenharia de Estruturas, Escola de Engenharia de São Carlos, Universidade de São Paulo, São Carlos, 2019.

PATRICK, M. A new partial shear connection strenght model for composite slabs. Journal of Australian Steel Institute, v. 24, n. 3, p. 1-20, 1990.

PATRICK, M.; POH, K. W. Controlled test for composite slab design parameters. In: IABSE SYMPOSIUM (BRUSSELS): MIXED STRUCTURES, INCLUDING NEW MATERIALS, 1990, Brussels. Reports... Zürich: ETH- e-periodica, 1990, p. 227-231.

PATRICK, M.; BRIDGE, Q. Partial shear connection desing of composite slabs. Engineering Structures, v. 16, n. 5, 1994. 
PEREIRA, M.; SIMÕES, R. Contribution of steel sheeting to the vertical shear capacity of composite slabs. Journal of Constructional Steel Research, v. 161, p. 275-284, out. 2019.

PLOOKSAWASDI, S. Evaluation and design formulations for composite steel deck. Ph. D. Thesis (Civil Engineering) - West Virginia University, West Virginia, 1977.

PORTER, M. L.; EKBERG, C. E. Design recommendations for steel deck floor slabs. In: INTERNATIONAL SPECIALTY CONFERENCE ON COLD-FORMED STEEL STRUCTURES, 3., 1975, Saint Louis. Proceedings... Rolla: Scholars' Mine, 1975, p. 21212136.

PORTER, M. L.; EKBERG, C.E. 1978. Compendium of ISU Research Conducted on ColdFormed Steel Deck-Reinforced Slab Systems. Engineering Research Institute, Iowa State University, Ames, 1978.

QUEIROZ, G.; PIMENTA, R. J.; DA MATA, L. A. C. Lajes mistas. Elementos das estruturas mistas aço-concreto. Belo Horizonte: O Lutador, 2001. Cap. 5, p. 149-190.

RABANAL, F. P. A. et al. Bending and shear experimental tests and numerical analysis of composite slabs made up of lightweight concrete. Journal of Engineering, p. 1-10, dez. 2016.

RANA, M. M. The effects of bond and anchorage on the behaviour and design of composite slabs. 2016. 299 p. Ph. D. Thesis (Civil Engineering) - School of Civil and Environmental Engineering, Faculty of Engineering, University of New South Wales, Sydney, 2016.

RAMOS, A.L. Análise numérica de pisos mistos aço-concreto de pequena altura. 2010. 138 p. Dissertação (Mestrado) - Escola de Engenharia de São Carlos, Universidade de São Paulo, São Carlos, 2010.

RANA, M. M.; UY, B.; MIRZA, O. Experimental and numerical study of end anchorage in composite slabs. Journal of Constructional Steel Research, v. 115, p. 372-386, 2015.

RÍOS, D. J. et al. Numerical modelling of the shear-bond behaviour of composite slabs in four and six-point bending tests. Engineering Structures, v. 133, p. 91-104, fev. 2017.

SANTOS, D. B. R. Modelagem numérica de lajes mistas de aço e concreto em situação de incêndio. 2014. 243 p. Dissertação (Mestrado em Engenharia Civil de Estruturas) Departamento de Engenharia de Estruturas, Escola de Engenharia de São Carlos, Universidade de São Paulo, São Carlos, 2014.

SCHUSTER, R. M. Strength and behavior of cold-rolled steel-deck-reinforced concrete floor slabs. 229 p. Ph. D. Thesis (Structural Engineering) - Iowa State University of Science and Technology, Ames, 1970.

SCHUSTER, R. M.; LING, W. C. Mechanical interlocking capacity of composite slabs. In: INTERNATIONAL SPECIALTY CONFERENCE ON COLD-FORMED STEEL STRUCTURES, 5., 1980, Saint Louis. Reports... Rolla: Scholars' Mine, 1980, p. 387-407. 
SELBY, R. G., AND VECCHIO, F. J. Three-dimensional Constitutive Relations for Reinforced Concrete. Tech. Rep. 93-02, Civil Engineering Department, University of Toronto, Toronto, 1993.

SHUURMAN, R. G.; STARK, J. W. B. Longitudinal shear resistance of coposite slabs - a new model. In: COMPOSITE CONSTRUCTION IN STEEL AND CONCRETE, 4., 2000, Banff. Proceedings... Banff: ASCE, 2000, p. 334-343.

SIEG, A. P. A. Estudo de um sistema de laje com fôrma de aço incorporada. 2015. 143p. Dissertação (Mestrado em Engenharia Civil de Estruturas) - Escola de Engenharia de São Carlos, Universidade de São Paulo. São Carlos, 2015.

SILVA, P. B. Análise numérica não linear de lajes de concreto com fôrma de aço incorporada. 2018. 117p. Dissertação (Mestrado em Engenharia Civil) - Escola de Minas, Universidade Federal de Ouro Preto, Ouro Preto, 2018.

SOLTANALIPOUR, M. et al. Shear transfer behavior in composite slabs under 4-point and uniform-load tests. Journal of Constructional Steel Research, v. 164, p. 1-15, jan. 2020.

SOMMER, R. M. R. Análise de vibrações em pisos mistos aço/concreto. 2002. 140 p. Dissertação (Mestrado em Engenharia de Estruturas) - Escola de Engenharia, Universidade Federal de Minas Gerais, Belo Horizonte, 2002.

SPÍNDOLA, C. C. Dimensionamento de pisos mistos em situação de incêndio com proteção apenas das vigas principais. 2002. 146 p. Dissertação (Mestrado em Engenharia de Estruturas) - Universidade Federal de Minas Gerais, Belo Horizonte, 2002.

SOUZA NETO, A. S. Análise do comportamento e da resistência do sistema de lajes mistas com ancoragem de extremidade com considerações sobre a fôrma de aço isolada e o atrito nos apoios. 2001. 236 p. Dissertação (Mestrado em Engenharia de Estruturas) - Escola de Engenharia, Universidade Federal de Minas Gerais, Belo Horizonte, 2001.

STARK, J. Design of composite floors with profiled steel sheet. In: INTERNATIONAL SPECIALTY CONFERENCE ON COLD-FORMED STEEL STRUCTURES, 4., 1978, Saint Louis. Proceedings... Rolla: Scholars' Mine, 1978, p. 893-992.

STARK, J. W. B.; BREKELMANS, J. W. P. M. Plastic design of continuous composite slabs. Journal of Constructional Steel Research, Great Britain, v. 15, p. 23-47, 1990.

TAKEY, T. H. Sistema de laje mista para edificações com uso de perfis de chapa metálica. 2001. 208 p. Dissertação (Mestrado em Ciências de Engenharia Civil) - Departamento de Engenharia Civil da Pontifícia Universidade Católica do Rio de Janeiro, Rio de Janeiro, 2001.

TREMBLAY, R. et al. Variables affecting the shear-bond resistance of composite floor deck systems. In: INTERNATIONAL SPECIALTY CONFERENCE ON COLD-FORMED STEEL STRUCTURES, 16., 2002, Orlando. Proceedings... Rolla: Scholars' Mine, 2002, p. 663-676.

TSALKATIDIS, T.; AVDELAS, A. The unilateral contact problem in composite slabs: experimental study and numerical treatment. Journal of Constructional Steel Research, v. 66, n. 3, p. 480-486, mar. 2010. 
VECCHIO, J. F.; COLLINS, M. P. Compression response of cracked reinforced concrete. Journal of Structural Engineering, v. 119, n. 12, p. 3590-3610, 1993.

VELJKOVIC, M. Behaviour and resistance of composite slabs: experiments and finite element analysis. 36 p. Ph. D. Thesis (Civil Engineering) - Department of Civil and Mining Engineering, Division of Steel Structures, Luleå University of Technology, Luleå, Norrbotten, Sweden, 1996.

VELJKOVIC, M. 3D Nonlinear analysis of composite slabs. IN: FIRST INTERNATIONAL DIANA CONFERENCE ON COMPUTATIONAL MECHANICS '94, 1., 1994, Netherlands. Proceedings... Netherlands: Kluwer Academic Publisher, 1994. p. 395-404.

VELJKOVIC, M. Behaviour and Design of Shallow Composite Slab. In: COMPOSITE CONSTRUCTION IN STEEL AND CONCRETE, 4., 2000, Banff. Proceedings... Banff: ASCE, 2000.

VENKAT, L.; UPADHYAY, A. Slip-block test: interpretation and validation. The Indian Concrete Journal, p. 9-15, dez. 2008.

VIANNA, J. C. Sistema de laje-mista para edificações residenciais com o uso de perfis embossados de chapa dobrada. 2005. 189p. Dissertação (Mestrado) - Departamento de Engenharia Civil, Pontifícia Universidade Católica do Rio de Janeiro, Rio de Janeiro, 2005.

VIEIRA, J. D. Estudo teórico-experimental do comportamento de lajes mistas com perfis incorporados de aço. Rio de Janeiro. 2003. 121p. Dissertação (Mestrado) - Departamento de Engenharia Civil, Pontifícia Universidade Católica do Rio de Janeiro, Rio de Janeiro, 2003.

WALDMANN, D.; MAY, A.; THAPA, V. B. Influence of sheet profile design on the composite action of slabs mad of lightweight woodchip concrete. Construction and Building Materials, v. 148, p. 887-899, set. 2017.

YI, O. et al. Small-scale testing on bond behaviour of profiled steel reinforced CRC composite slabs. In: INTERNATIONAL FIB CONGRESS, 5., 2018, Melbourne. Proceedings... Melbourne: FIB, 2018. 



\section{APÊNDICE A - RESULTADOS EXPERIMENTAIS DO ENSAIO SLIP-BLOCK}

Neste apêndice são apresentadas as tabelas com a Força horizontal $\left(F_{\mathrm{H}}\right)$ e a Força vertical $\left(F_{\mathrm{V}}\right)$, obtidos dos resultados do ensaio slip-block, que permitiram a obtenção do Coeficiente de atrito global $(\mu)$ e da Força mecânica resistente $\left(F_{\mathrm{m}}\right)$ por meio da regressão linear de cada gráfico $F_{\mathrm{H}}$ versus $F_{\mathrm{V}}$.

\section{A.1 Força Vertical Constante ao Longo do Ensaio}

De posse dos gráficos da Força horizontal $\left(F_{\mathrm{H}}\right)$ versus Deslizamento $(s)$ dos três protótipos ensaiados, obteve-se a tabela abaixo, que relaciona $F_{\mathrm{H}}$ e $F_{\mathrm{V}}$ de acordo com $s$. Também são apresentados os respectivos parâmetros $\mu$ e $F_{\mathrm{m}}$.

Tabela A.1 $-F_{\mathrm{H}}$ e $F_{\mathrm{V}}$ de acordo com $s$ - ensaio slip-block com $F_{\mathrm{V}}$ constante

\begin{tabular}{|c|c|c|c|c|c|}
\hline \multirow{2}{*}{$s[\mathrm{~mm}]$} & \multicolumn{3}{|c|}{ Força Vertical [kN] } & \multirow{2}{*}{$\mu$} & \multirow{2}{*}{$F_{\mathrm{m}}[\mathrm{kN}]$} \\
\hline & $F_{\mathrm{V}}=27,14 \mathrm{kN}$ & $F_{\mathrm{V}}=18,14 \mathrm{kN}$ & $F_{\mathrm{V}}=1,94 \mathrm{kN}$ & & \\
\hline 0,01 & - & 18,21 & 1,95 & 0,557 & 3,31 \\
\hline 0,1 & - & 6,53 & 1,74 & 0,295 & 1,17 \\
\hline 1 & 20,75 & 17,09 & 5,71 & 0,610 & 4,90 \\
\hline 2 & 22,98 & 19,23 & 8,67 & 0,578 & 7,84 \\
\hline 2,5 & 23,44 & 19,50 & 8,82 & 0,590 & 7,96 \\
\hline 3 & 23,44 & 19,72 & 8,73 & 0,595 & 7,91 \\
\hline 4 & 22,59 & 18,01 & 7,42 & 0,608 & 6,41 \\
\hline 5 & 21,24 & 16,24 & 6,01 & 0,608 & 4,92 \\
\hline 6 & 19,99 & 15,05 & 5,40 & 0,581 & 4,32 \\
\hline 7 & 19,66 & 14,31 & 5,22 & 0,572 & 4,05 \\
\hline 8 & 19,84 & 14,25 & 5,43 & 0,568 & 4,21 \\
\hline 9 & 20,08 & 14,56 & 5,43 & 0,579 & 4,23 \\
\hline 10 & 20,57 & 14,86 & 5,25 & 0,606 & 4,00 \\
\hline 12 & 21,33 & 15,26 & 5,31 & 0,633 & 3,99 \\
\hline 14 & 21,43 & 15,44 & 5,71 & 0,621 & 4,40 \\
\hline 16 & 21,27 & 15,87 & 6,01 & 0,606 & 4,83 \\
\hline 18 & 21,49 & 15,78 & 6,26 & 0,602 & 5,01 \\
\hline 20 & 21,58 & 15,63 & 6,20 & 0,607 & 4,90 \\
\hline 22 & 21,15 & 15,20 & 6,10 & 0,593 & 4,81 \\
\hline 24 & 19,96 & 13,64 & 5,71 & 0,556 & 4,33 \\
\hline 25 & 18,53 & 12,27 & 5,28 & 0,514 & 3,92 \\
\hline 26 & 16,85 & 10,68 & 4,18 & 0,490 & 2,84 \\
\hline 27 & 15,47 & 9,61 & 2,84 & 0,491 & 1,56 \\
\hline
\end{tabular}




\begin{tabular}{|c|c|c|c|c|c|}
\hline \multirow{2}{*}{$s[\mathrm{~mm}]$} & \multicolumn{3}{|c|}{ Força Vertical [kN] } & \multirow{2}{*}{$\mu$} & \multirow{2}{*}{$F_{\mathrm{m}}[\mathrm{kN}]$} \\
\hline & $F_{\mathrm{V}}=27,14 \mathrm{kN}$ & $F_{\mathrm{V}}=18,14 \mathrm{kN}$ & $F_{\mathrm{V}}=1,94 \mathrm{kN}$ & & \\
\hline 28 & 14,65 & 8,82 & 1,04 & 0,533 & 0,00 \\
\hline 29 & 14,25 & 8,45 & 0,40 & 0,544 & 0,00 \\
\hline 30 & 14,38 & 8,73 & 0,55 & 0,543 & 0,00 \\
\hline 32 & 16,39 & 11,51 & 3,91 & 0,492 & 2,84 \\
\hline 33 & 17,76 & 12,30 & 6,04 & 0,456 & 4,86 \\
\hline 34 & 18,86 & 12,42 & 5,71 & 0,509 & 4,31 \\
\hline 36 & 18,31 & 12,82 & 4,43 & 0,547 & 3,23 \\
\hline 38 & 18,56 & 13,19 & 4,98 & 0,535 & 3,80 \\
\hline 40 & 19,59 & 13,58 & 5,22 & 0,564 & 3,91 \\
\hline
\end{tabular}

Fonte: Autor

\section{A.2 Força Vertical Variável ao Longo do Ensaio}

De posse do gráfico da Força horizontal $\left(F_{\mathrm{H}}\right)$ versus Deslizamento $(s)$ do protótipo ensaiado, obteve-se a tabela abaixo, que relaciona $F_{\mathrm{H}}$ e $F_{\mathrm{V}}$ de acordo com o ciclo de carregamento. Também são apresentados os respectivos parâmetros $\mu$ e $F_{\mathrm{m}}$.

Tabela A. $2-F_{\mathrm{H}}$ e $F_{\mathrm{V}}$ de acordo com o ciclo - ensaio slip-block com $F_{\mathrm{V}}$ variável

\begin{tabular}{|c|c|c|c|c|c|}
\hline Ciclo & Estágio & $F_{\mathrm{V}}[\mathrm{kN}]$ & $F_{\mathrm{H}}[\mathrm{kN}]$ & $\mu$ & $F_{\mathrm{m}}[\mathrm{kN}]$ \\
\hline \multirow{5}{*}{1} & 1 & 52,81 & 32,34 & \multirow{5}{*}{0,471} & \multirow{5}{*}{7,68} \\
\hline & 2 & 42,78 & 27,83 & & \\
\hline & 3 & 32,20 & 23,12 & & \\
\hline & 4 & 22,22 & 18,40 & & \\
\hline & 5 & 12,22 & 13,09 & & \\
\hline \multirow{5}{*}{2} & 1 & 52,07 & 32,11 & \multirow{5}{*}{0,463} & \multirow{5}{*}{8,48} \\
\hline & 2 & 42,50 & 28,40 & & \\
\hline & 3 & 32,04 & 23,75 & & \\
\hline & 4 & 22,10 & 18,87 & & \\
\hline & 5 & 12,09 & 13,67 & & \\
\hline \multirow{5}{*}{3} & 1 & 52,08 & 33,76 & \multirow{5}{*}{0,504} & \multirow{5}{*}{8,09} \\
\hline & 2 & 42,12 & 29,53 & & \\
\hline & 3 & 32,05 & 25,00 & & \\
\hline & 4 & 22,12 & 19,52 & & \\
\hline & 5 & 12,06 & 13,54 & & \\
\hline \multirow{5}{*}{4} & 1 & 52,34 & 33,61 & \multirow{5}{*}{0,527} & \multirow{5}{*}{8,31} \\
\hline & 2 & 42,25 & 28,82 & & \\
\hline & 3 & 32,02 & 23,34 & & \\
\hline & 4 & 22,18 & 18,12 & & \\
\hline & 5 & 12,11 & 12,46 & & \\
\hline
\end{tabular}

Fonte: Autor 


\section{APÊNDICE B - RELATÓRIO FOTOGRÁFICO DO ENSAIO DE FLEX̃̃̃}

Algumas fotografias referentes ao ensaio de flexão das lajes mistas, que destacam a instrumentação utilizada, assim como o estado final dos protótipos, são apresentadas neste apêndice.

Figura B.1 - Posicionamento dos extensômetros no concreto

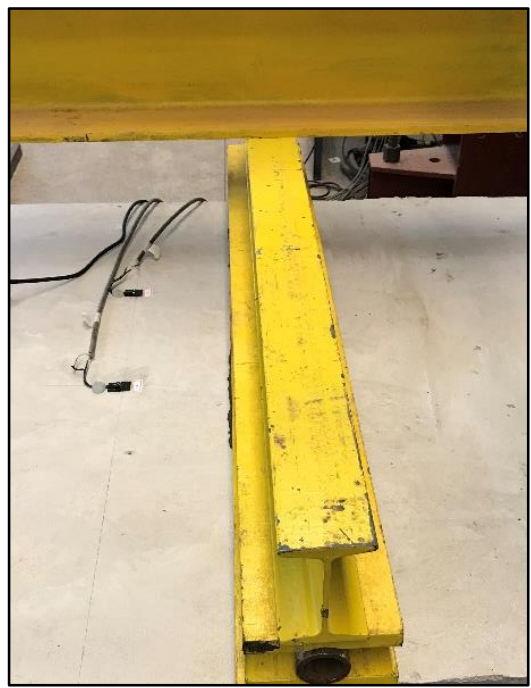

(a) Lado esquerdo

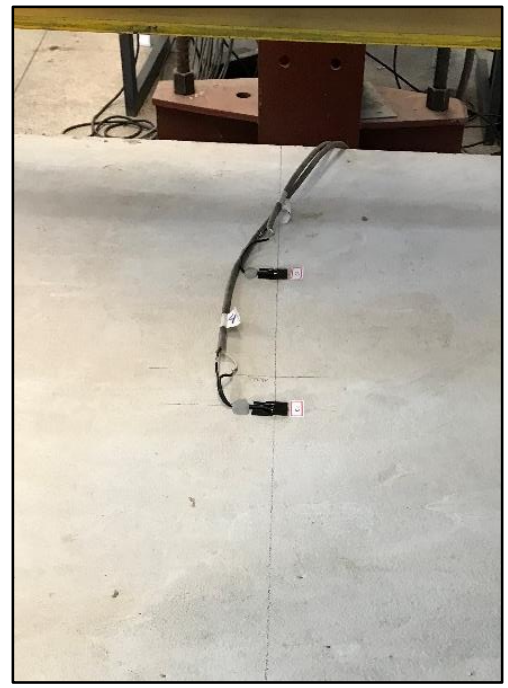

(b) Meio do vão

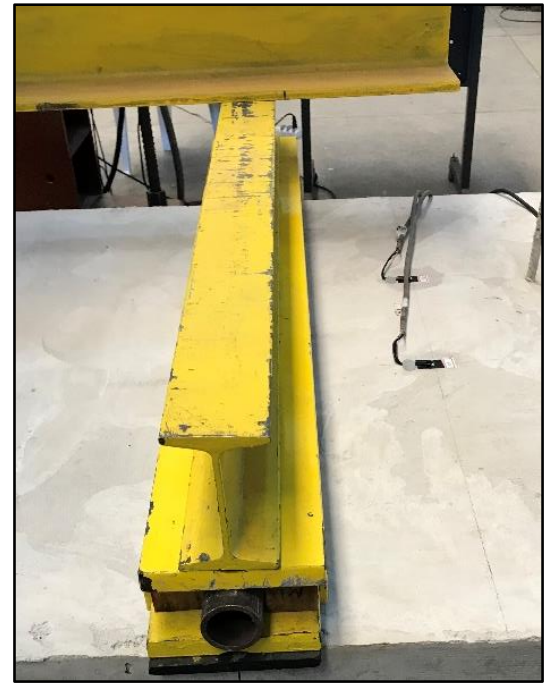

(d) Lado direito

Fonte: Autor

Figura B.2 - Posicionamento dos extensômetros na fôrma de aço
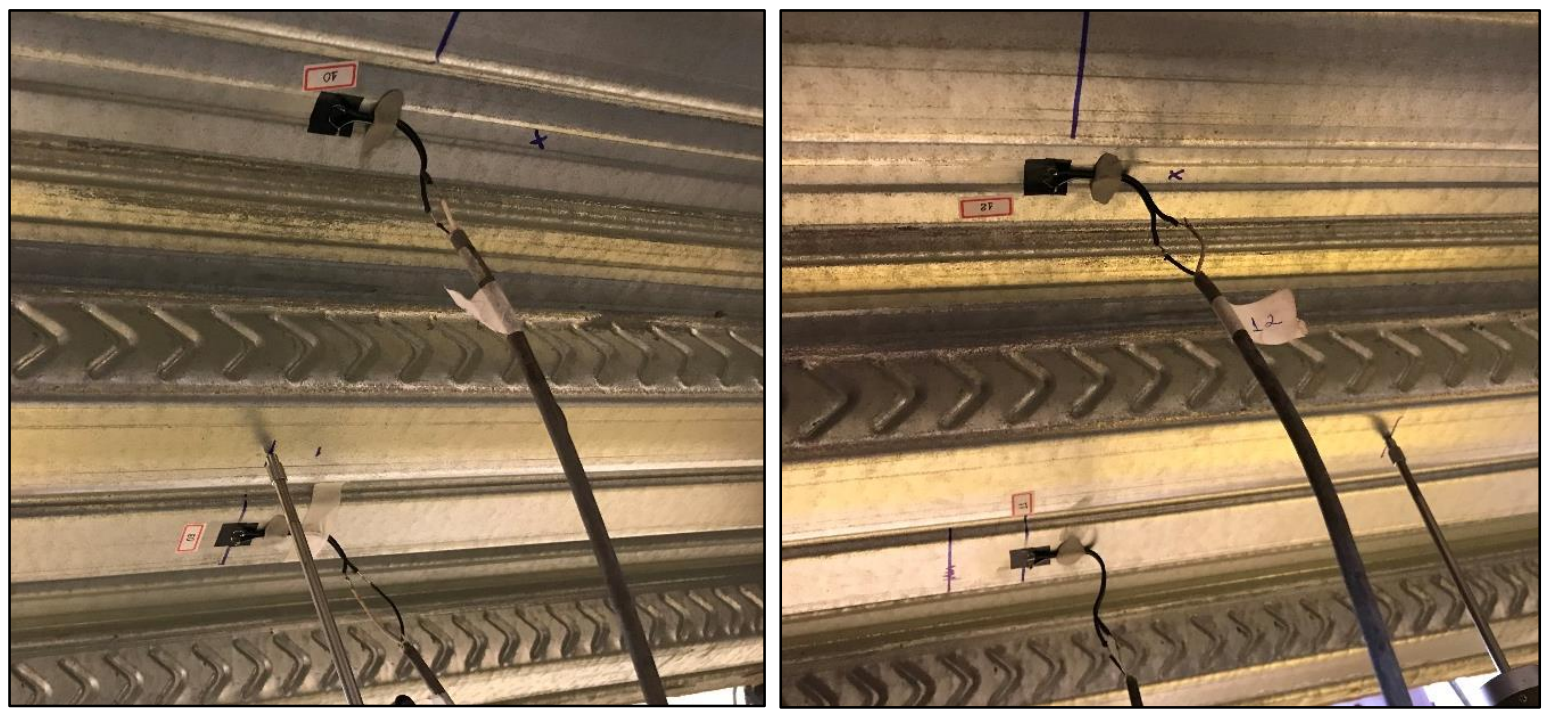

Fonte: Autor 
Figura B.3 - Laje 1 ao final do ensaio

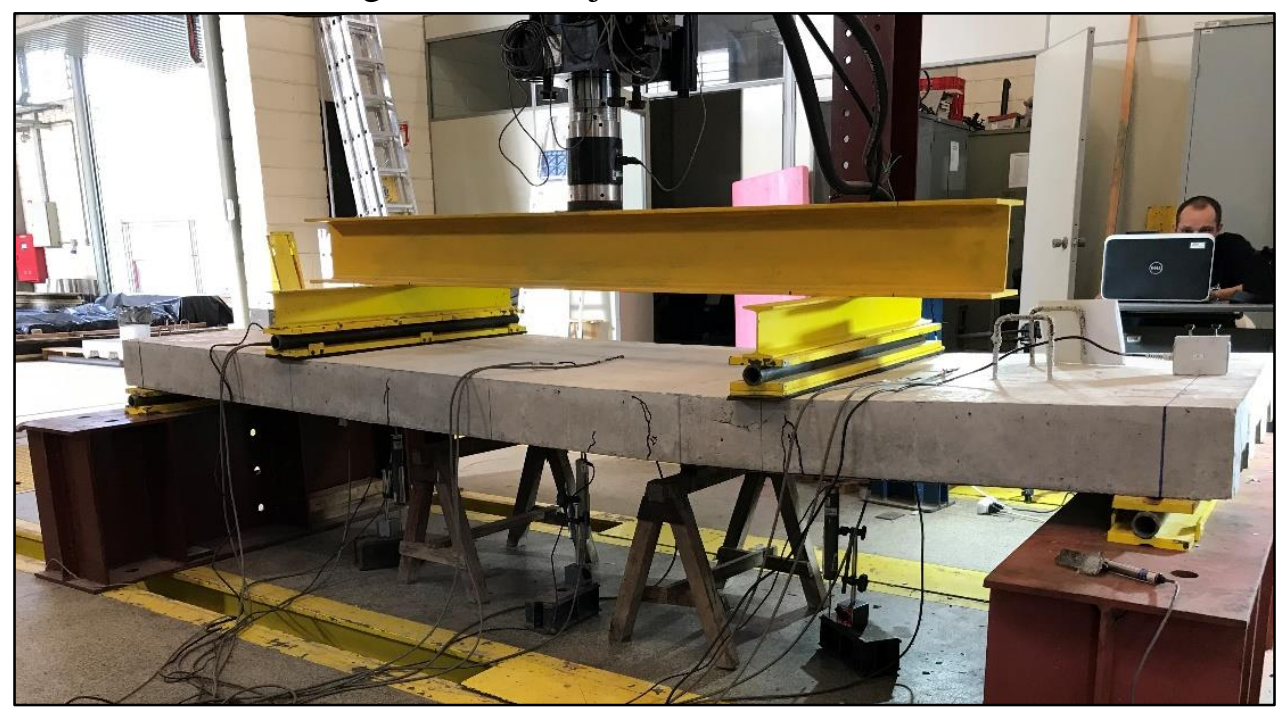

Figura B.4 - Laje 2 ao final do ensaio

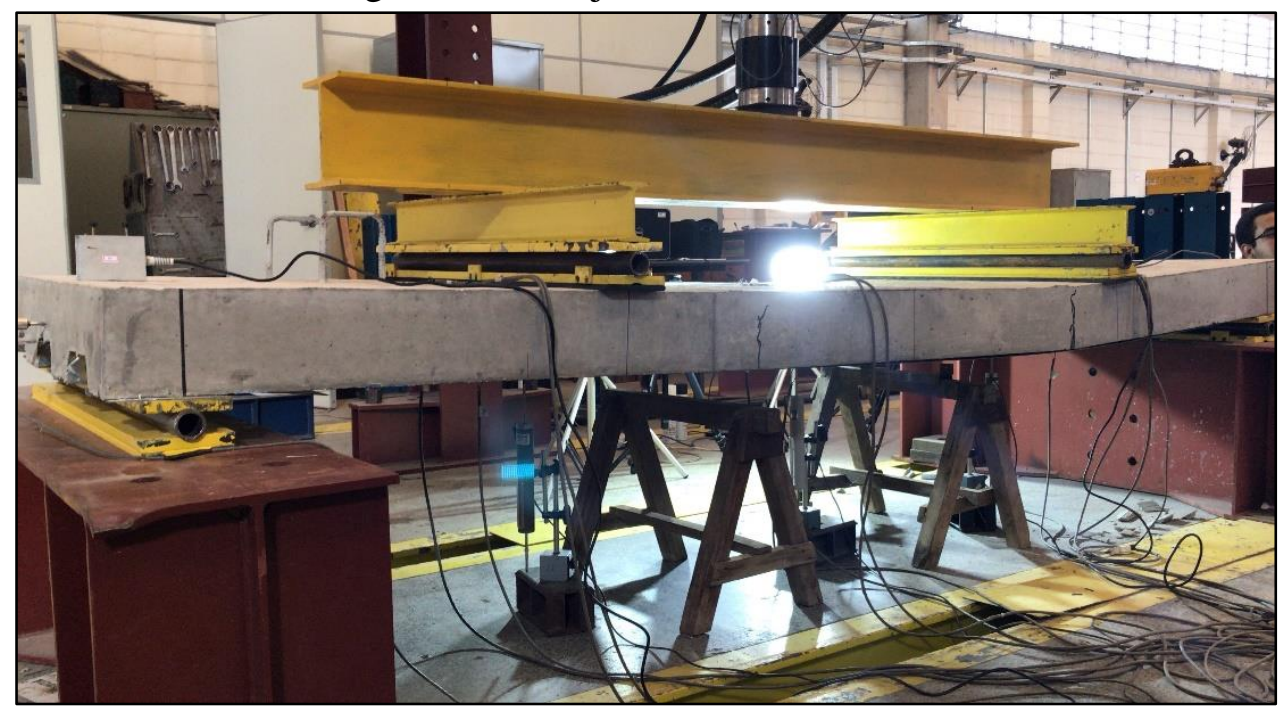

Figura B.5 - Situação final da Laje 1

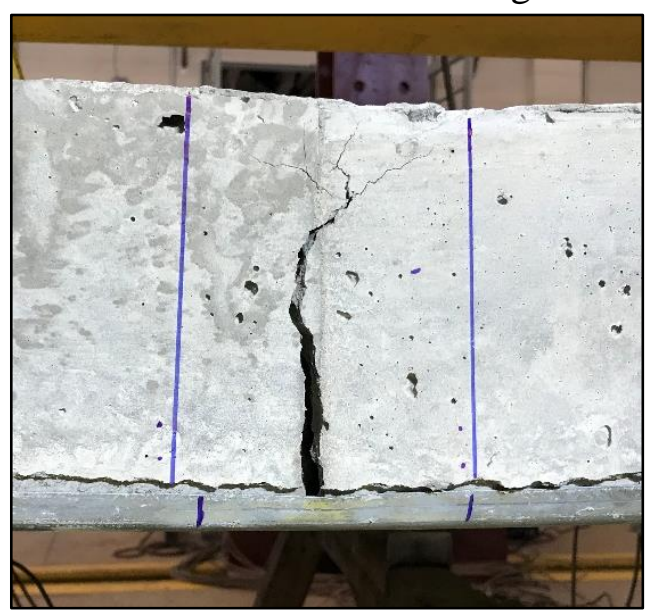

(a) Fissura principal

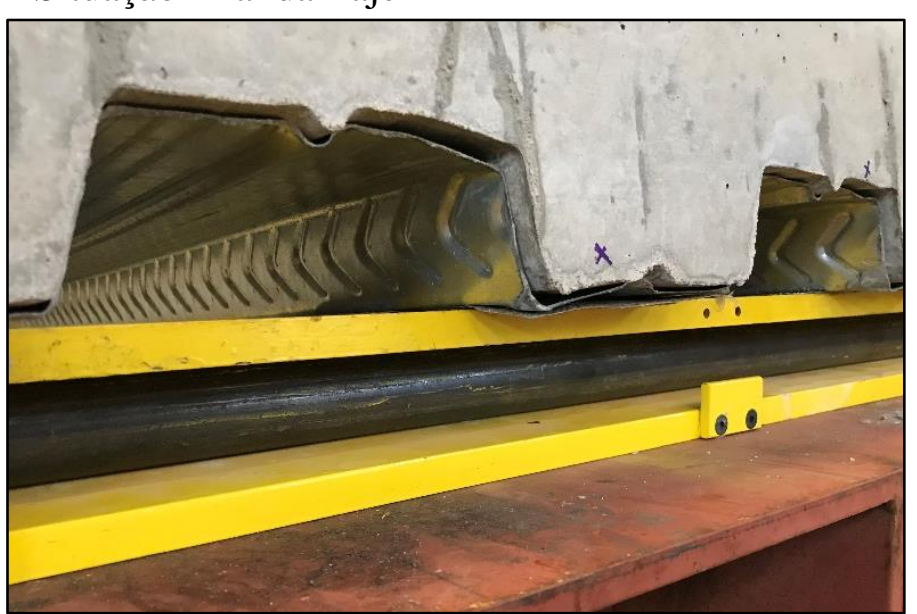

(b) Deslizamento de extremidade

Fonte: Autor 


\section{APÊNDICE C - RESULTADOS NUMÉRICOS DO MODELO DO ENSAIO SLIP-BLOCK}

Neste apêndice são apresentados os demais gráficos da Força Horizontal $\left(F_{\mathrm{H}}\right)$ versus Deslizamento $(s)$ da análise da influência dos parâmetros $k_{n}$ e $k_{t}$.

Figura C.1 - Análise da Influência de $k_{t}$

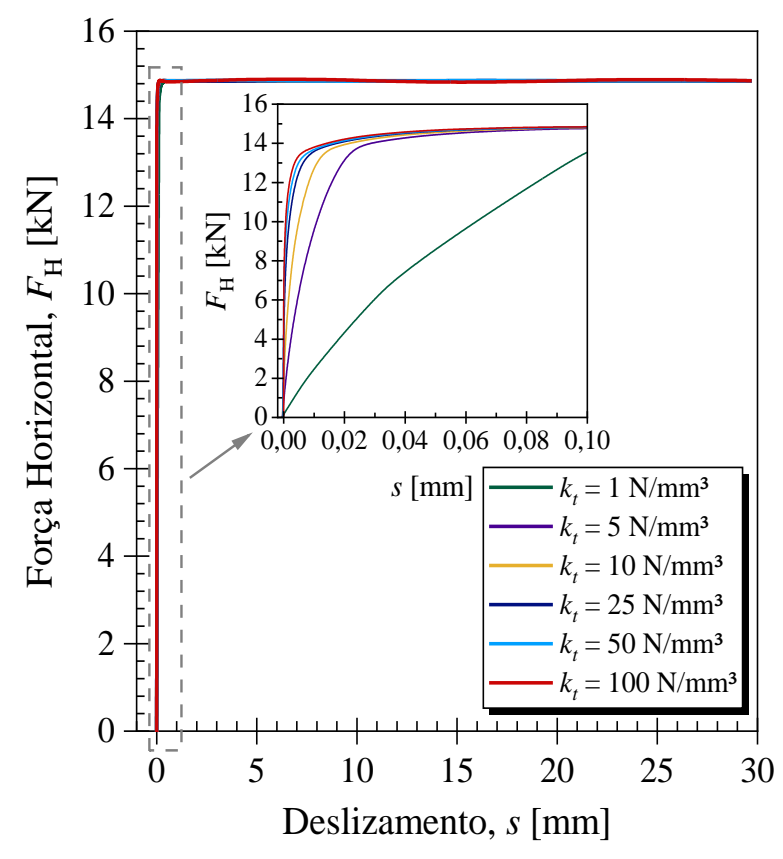

(a) $k_{n}=1 \mathrm{~N} / \mathrm{mm}^{3}$

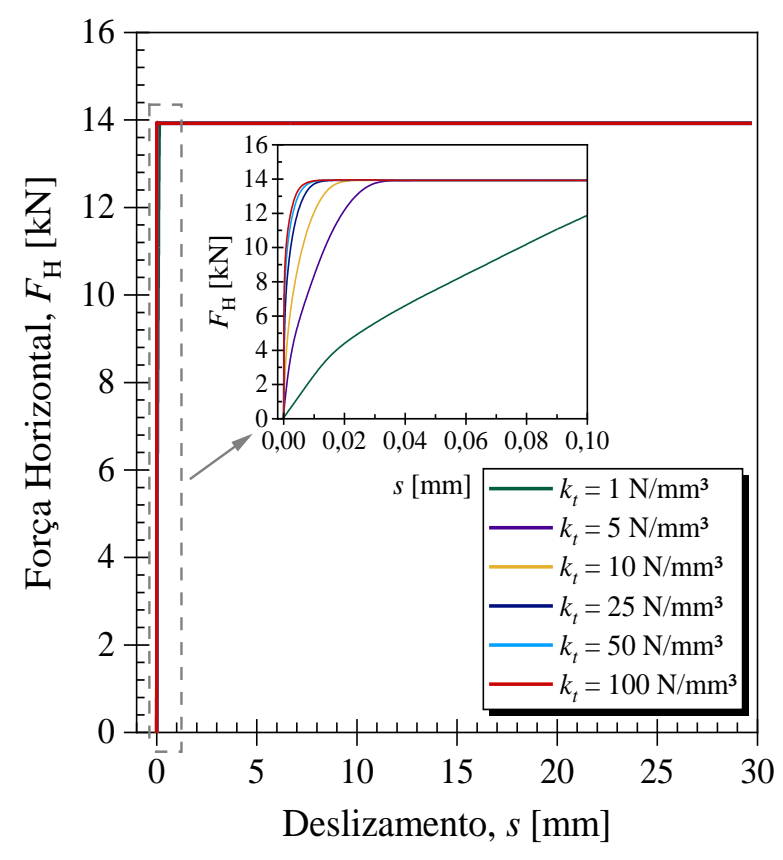

(c) $k_{n}=25 \mathrm{~N} / \mathrm{mm}^{3}$

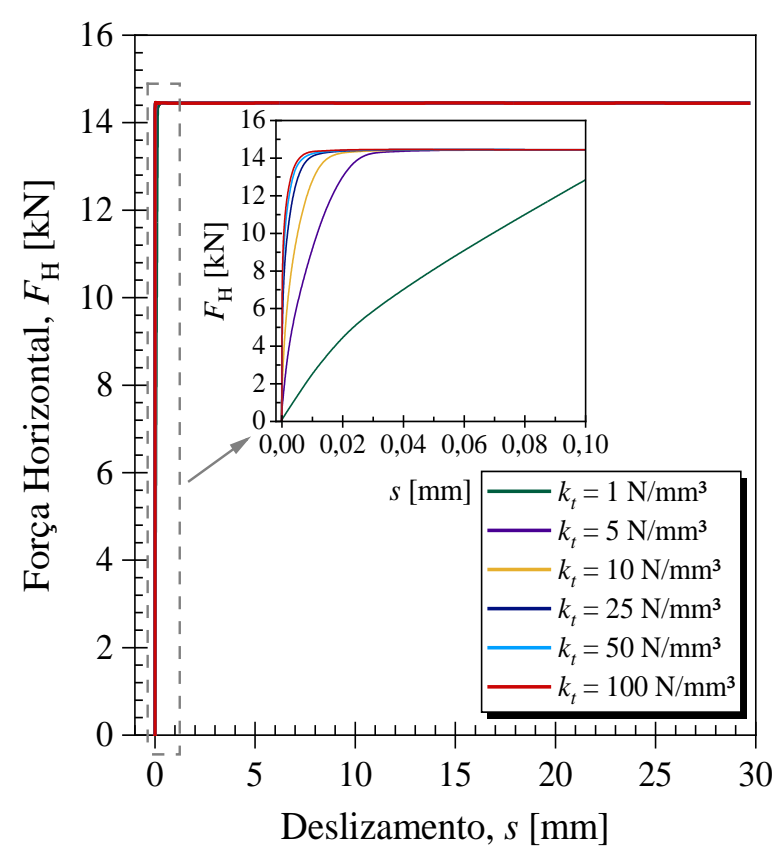

(b) $k_{n}=5 \mathrm{~N} / \mathrm{mm}^{3}$

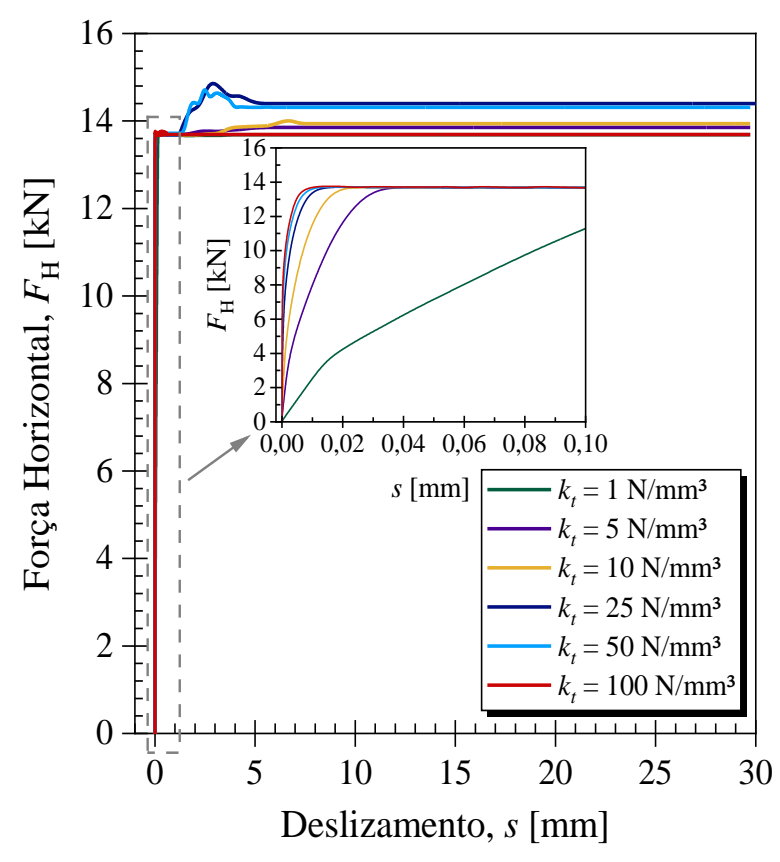

(d) $k_{n}=50 \mathrm{~N} / \mathrm{mm}^{3}$ 
Figura C.2 - Análise da Influência de $k_{n}$

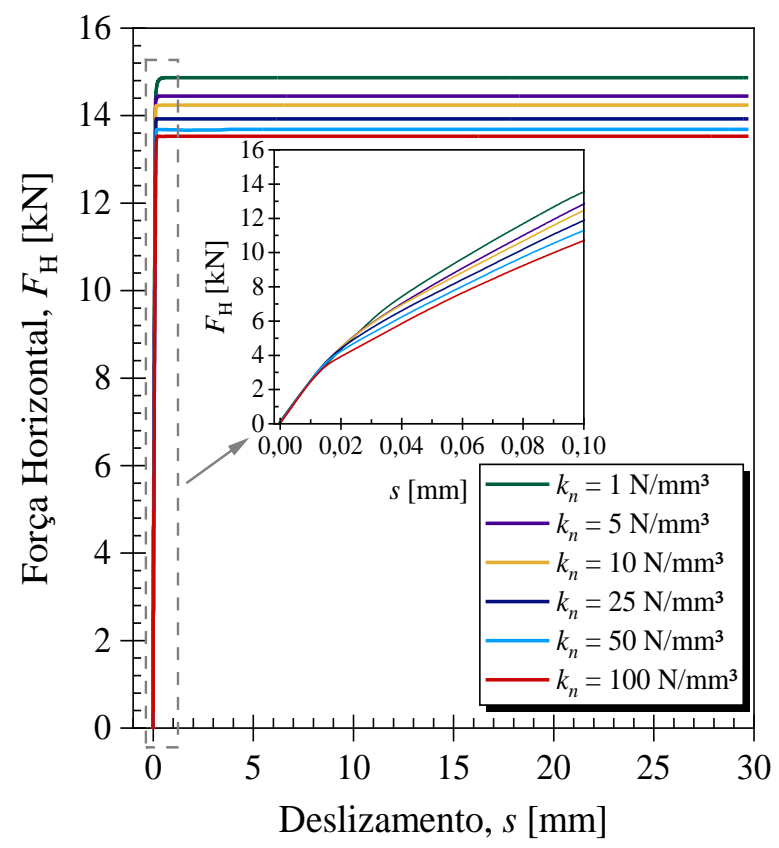

(a) $k_{t}=1 \mathrm{~N} / \mathrm{mm}^{3}$

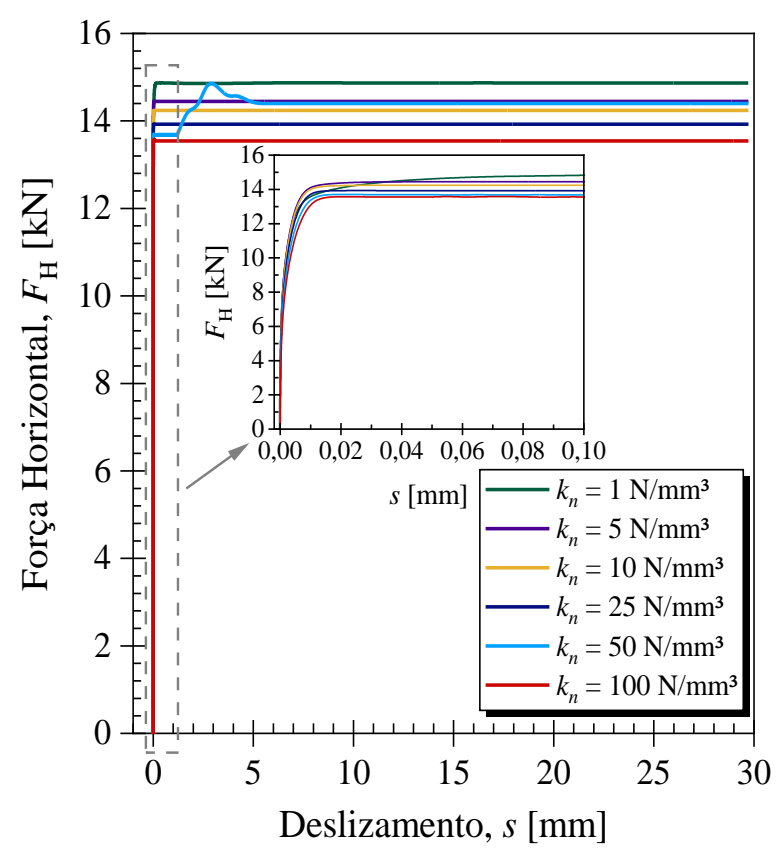

(c) $k_{t}=25 \mathrm{~N} / \mathrm{mm}^{3}$

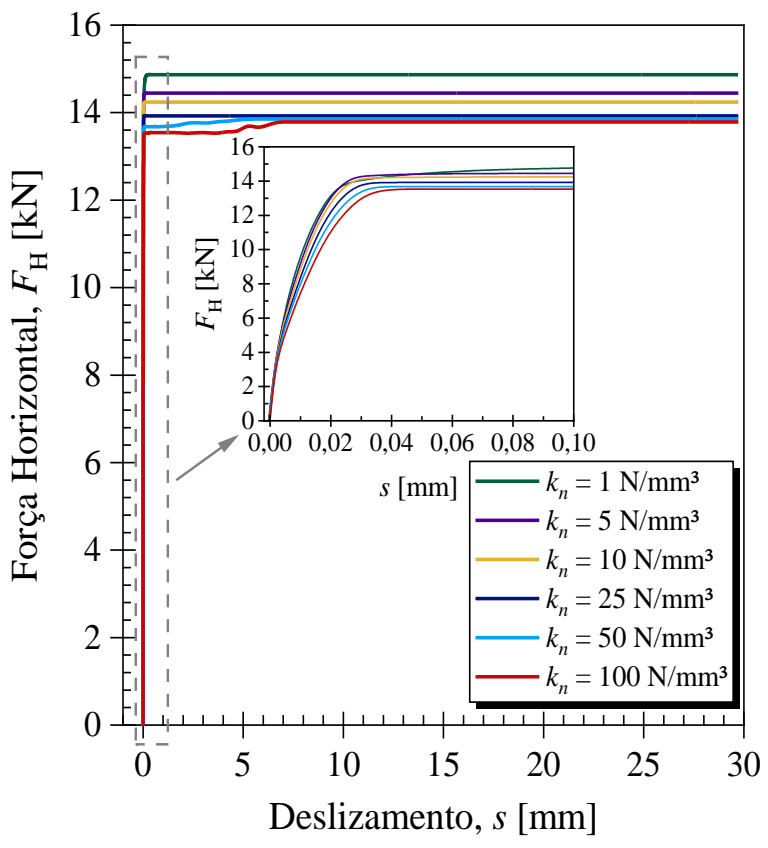

(b) $k_{t}=5 \mathrm{~N} / \mathrm{mm}^{3}$

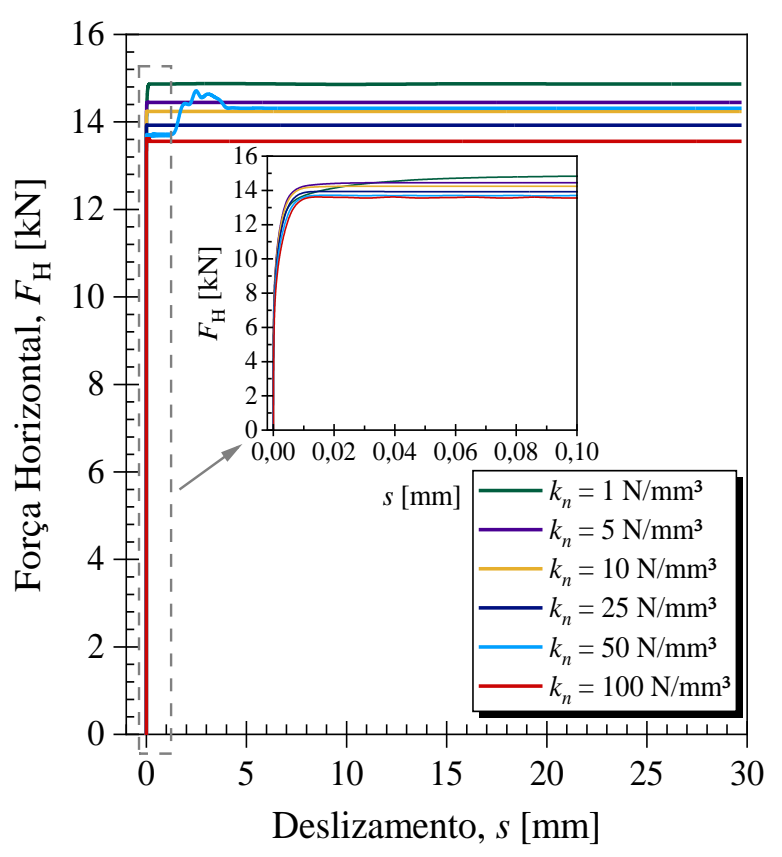

(d) $k_{t}=50 \mathrm{~N} / \mathrm{mm}^{3}$ 


\section{APÊNDICE D - RESULTADOS NUMÉRICOS DO MODELO INICIAL DA LAJE MISTA}

Os demais gráficos da Força $(F)$ versus Deslocamento vertical no meio do vão $(\delta)$ da análise da influência dos parâmetros $k_{n}$ e $k_{t}$ sobre o comportamento do modelo numérico inicial da laje mista são apresentados neste apêndice.

\section{D.1 Modelo de Interface de Comportamento Elástico Linear}

Figura D.1 - Análise da Influência de $k_{t}$ - Interface de comportamento elástico

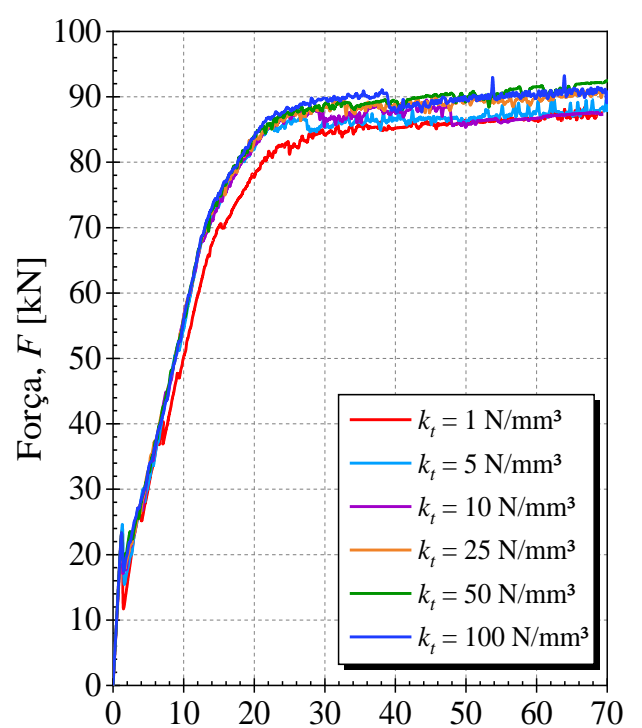

Deslocamento vertical no meio do vão, $\delta[\mathrm{mm}]$

(a) $k_{n}=1 \mathrm{~N} / \mathrm{mm}^{3}$

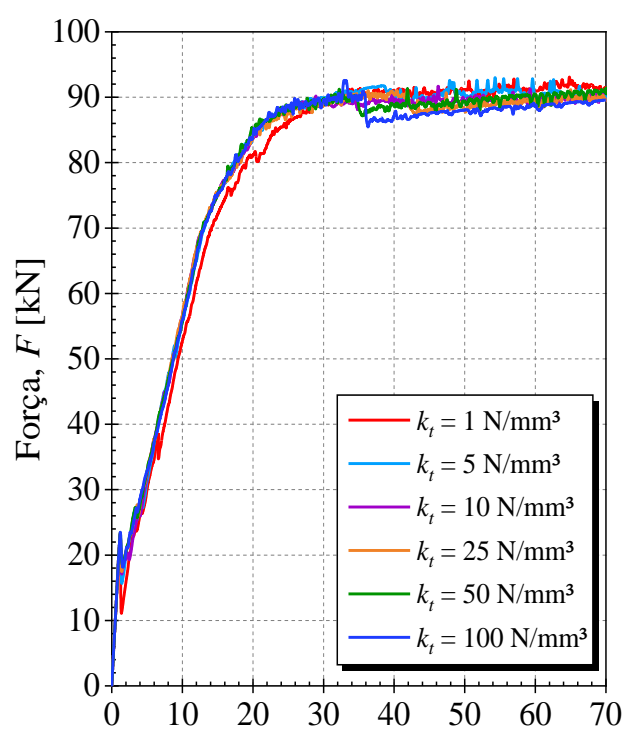

Deslocamento vertical no meio do vão, $\delta[\mathrm{mm}]$ (a) $k_{n}=25 \mathrm{~N} / \mathrm{mm}^{3}$

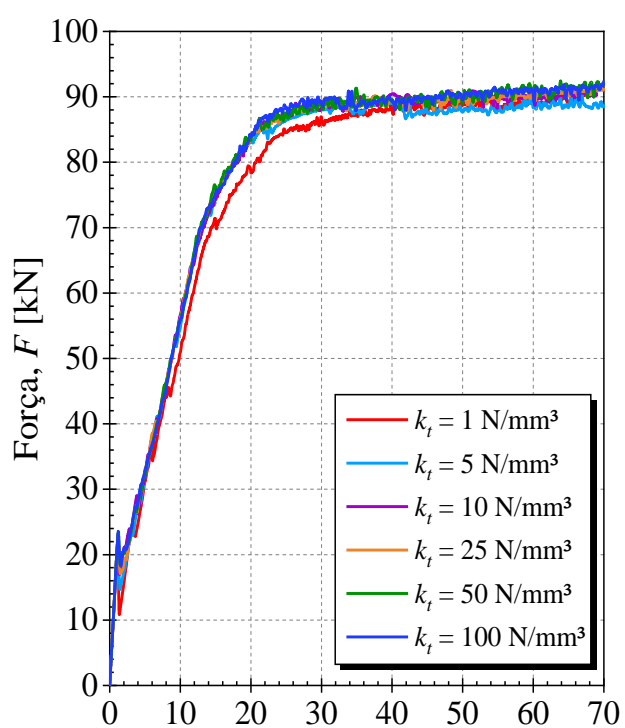

Deslocamento vertical no meio do vão, $\delta[\mathrm{mm}]$ (b) $k_{n}=5 \mathrm{~N} / \mathrm{mm}^{3}$

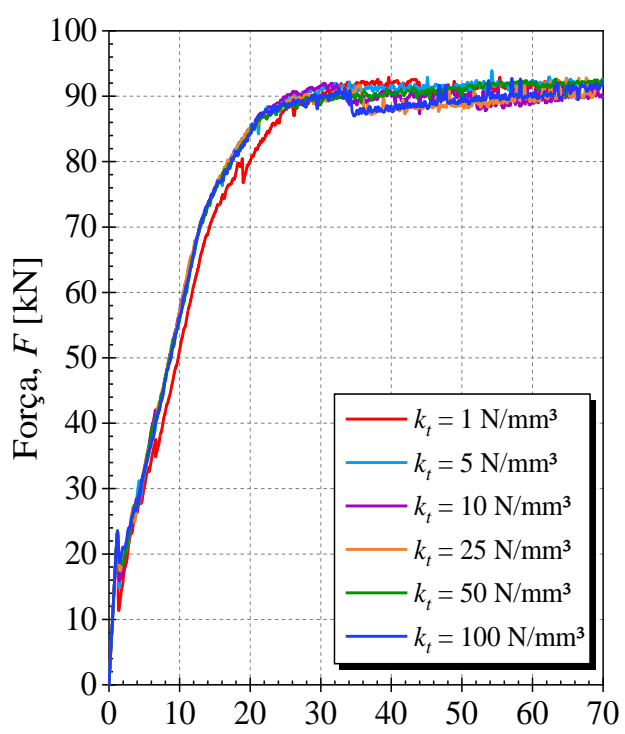

Deslocamento vertical no meio do vão, $\delta[\mathrm{mm}]$ (b) $k_{n}=50 \mathrm{~N} / \mathrm{mm}^{3}$ 
Figura D.2 - Análise da Influência de $k_{n}$ - Interface de comportamento elástico

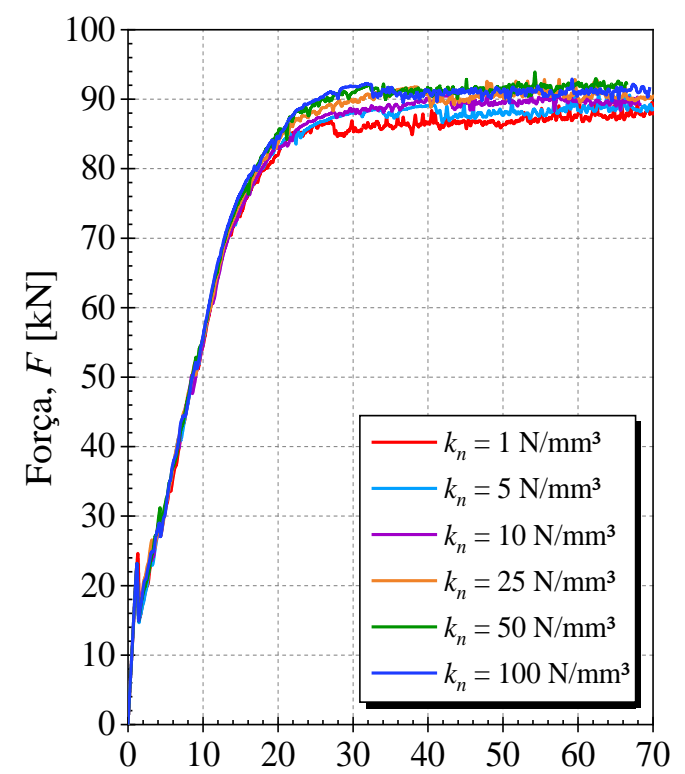

Deslocamento vertical no meio do vão, $\delta[\mathrm{mm}]$ (a) $k_{t}=5 \mathrm{~N} / \mathrm{mm}^{3}$

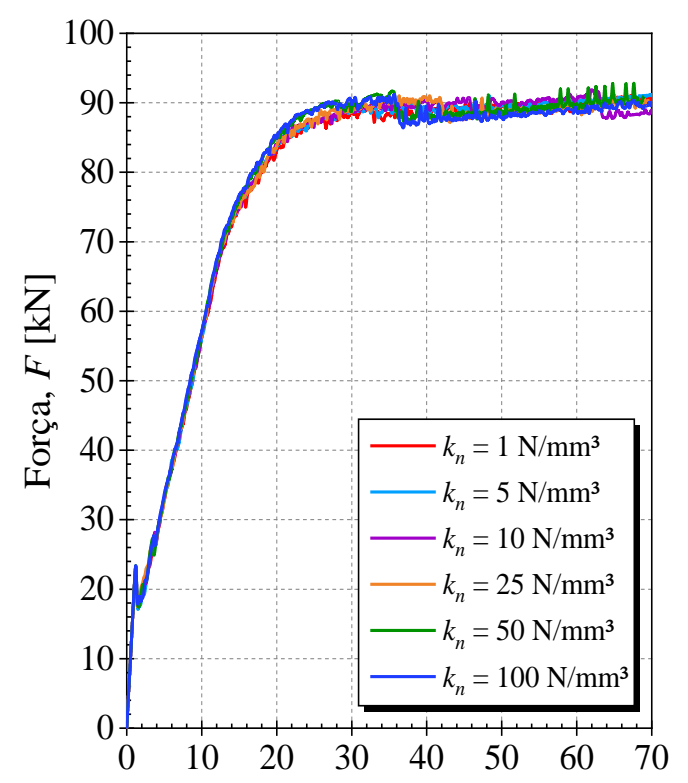

Deslocamento vertical no meio do vão, $\delta[\mathrm{mm}]$

(a) $k_{t}=25 \mathrm{~N} / \mathrm{mm}^{3}$

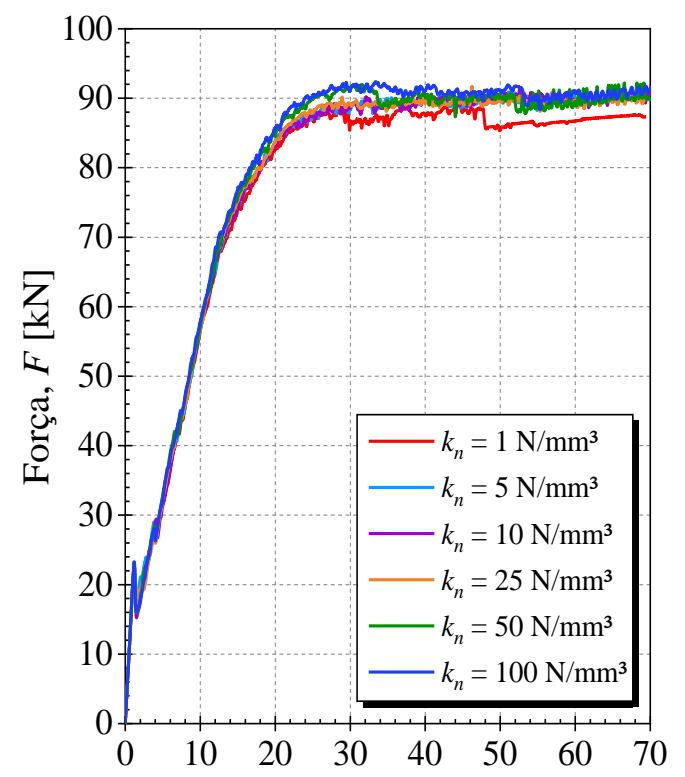

Deslocamento vertical no meio do vão, $\delta[\mathrm{mm}]$ (b) $k_{t}=10 \mathrm{~N} / \mathrm{mm}^{3}$

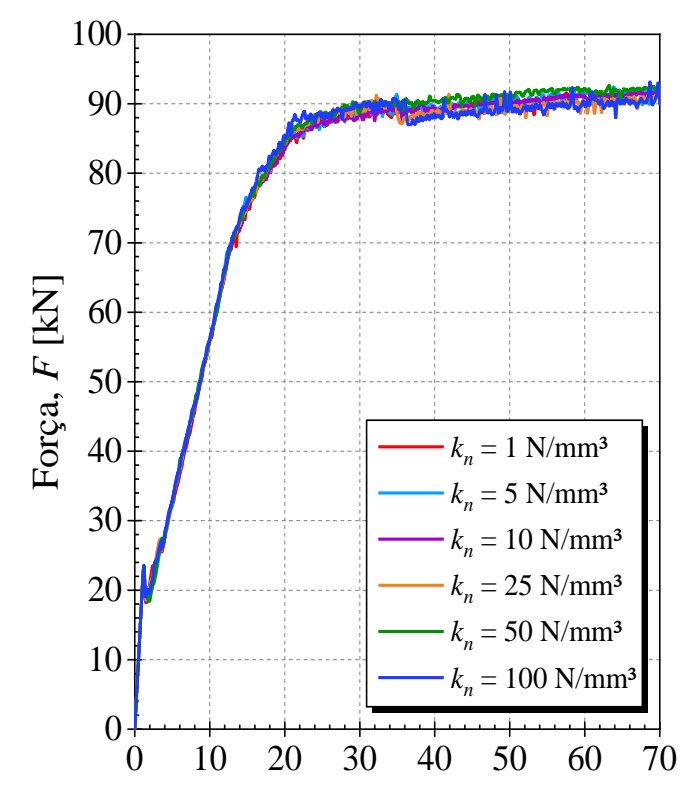

Deslocamento vertical no meio do vão, $\delta[\mathrm{mm}]$

(b) $k_{t}=50 \mathrm{~N} / \mathrm{mm}^{3}$ 


\section{D.2 Modelo de Interface Coulomb Friction}

Figura D.3 - Análise da Influência de $k_{t}$ - Modelo de interface Coulomb Friction

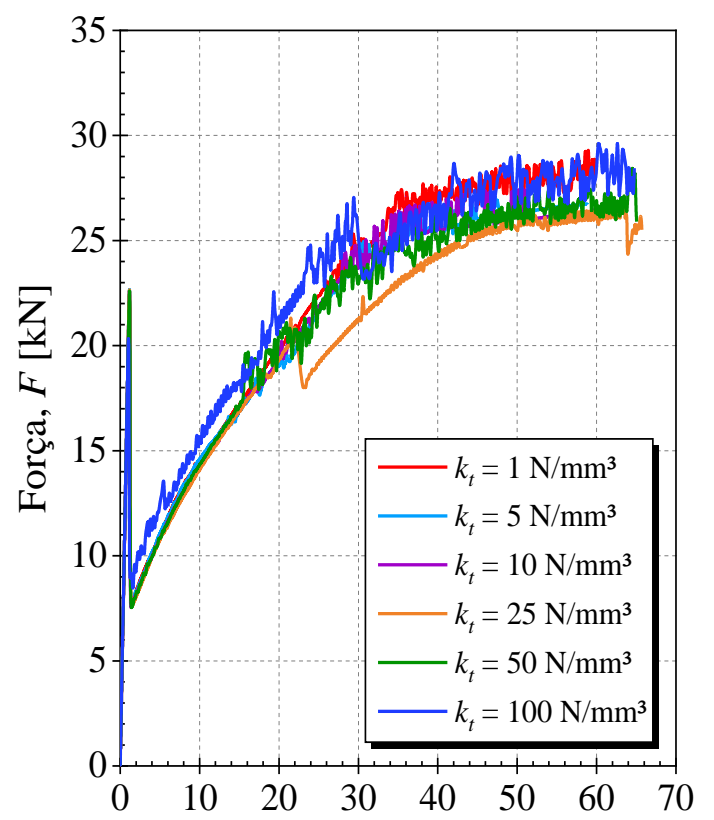

Deslocamento vertical no meio do vão, $\delta[\mathrm{mm}]$

(a) $k_{n}=1 \mathrm{~N} / \mathrm{mm}^{3}$

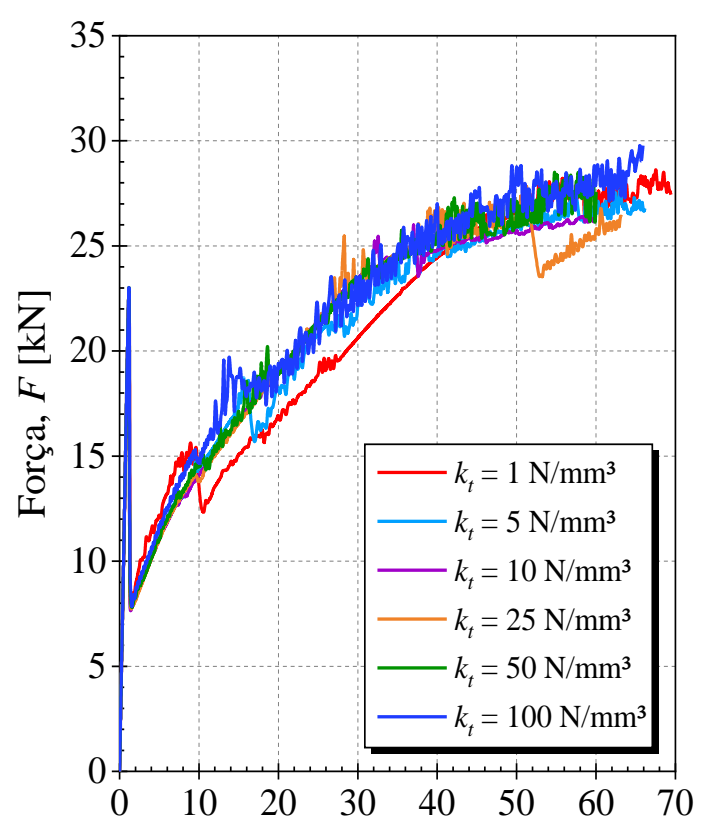

Deslocamento vertical no meio do vão, $\delta[\mathrm{mm}]$

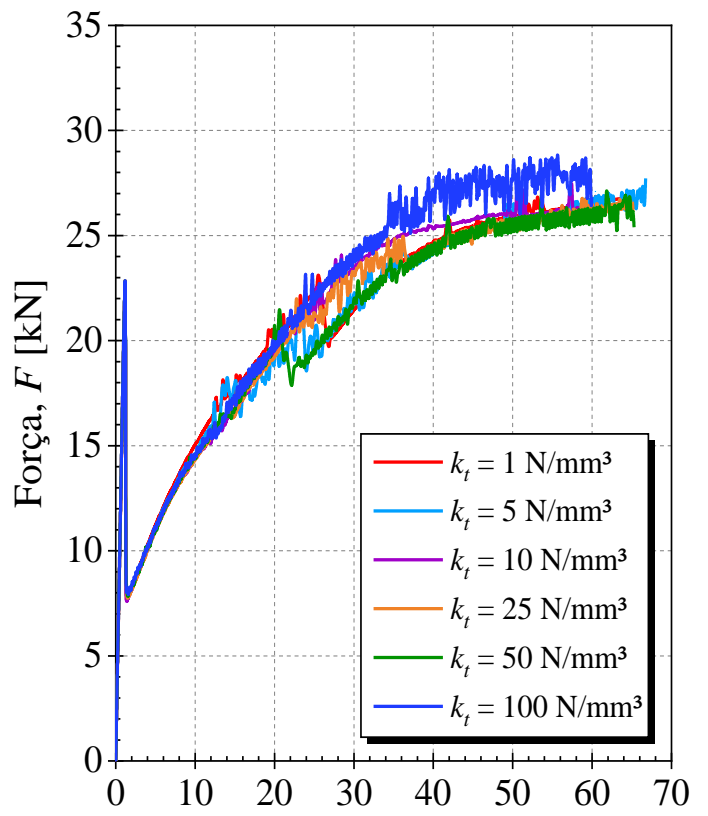

Deslocamento vertical no meio do vão, $\delta[\mathrm{mm}]$

(b) $k_{n}=5 \mathrm{~N} / \mathrm{mm}^{3}$

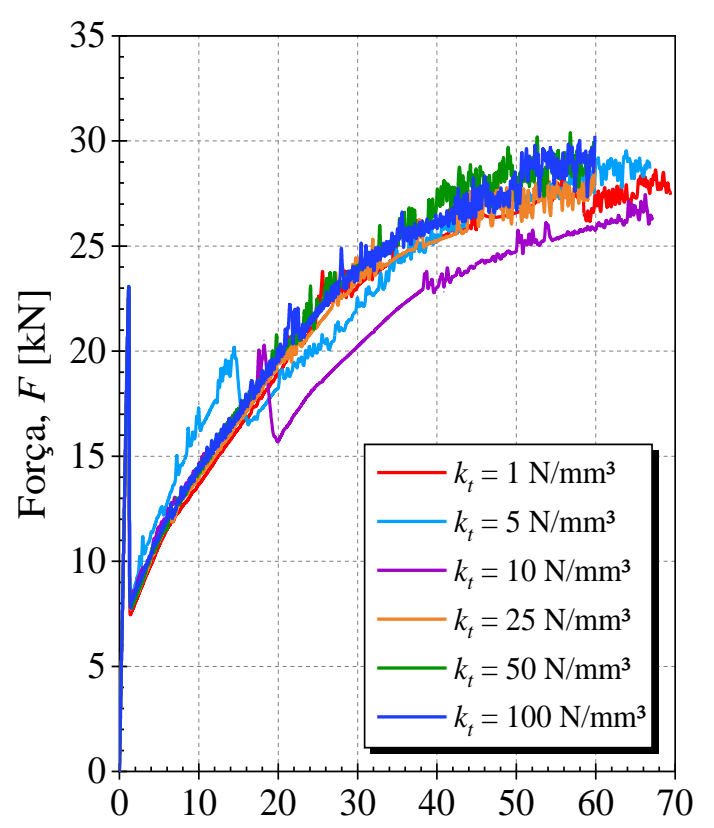

Deslocamento vertical no meio do vão, $\delta[\mathrm{mm}]$

(b) $k_{n}=50 \mathrm{~N} / \mathrm{mm}^{3}$ 
Figura D.4 - Análise da Influência de $k_{n}$ - Modelo de interface Coulomb Friction

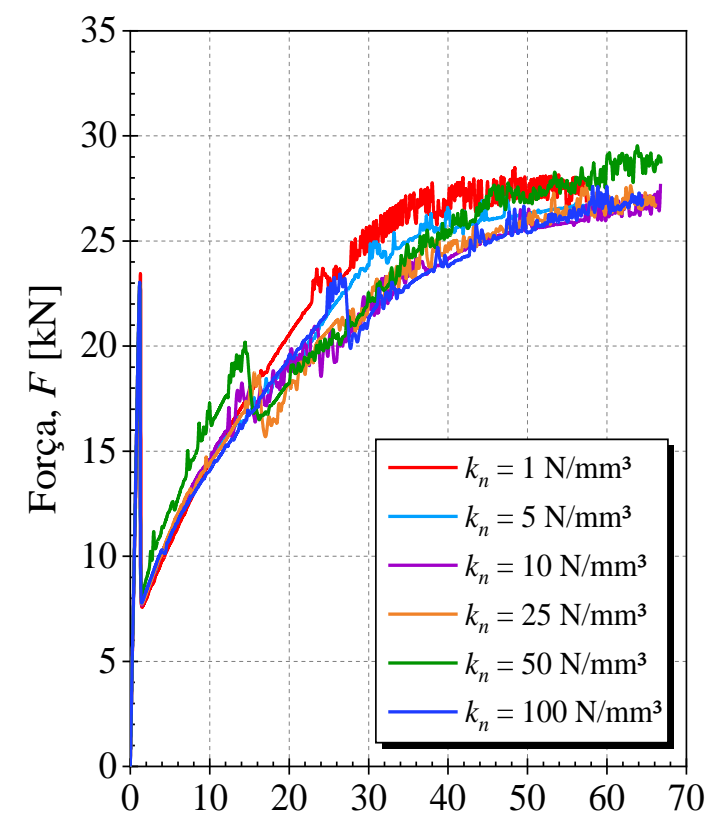

Deslocamento vertical no meio do vão, $\delta[\mathrm{mm}]$

(a) $k_{t}=5 \mathrm{~N} / \mathrm{mm}^{3}$

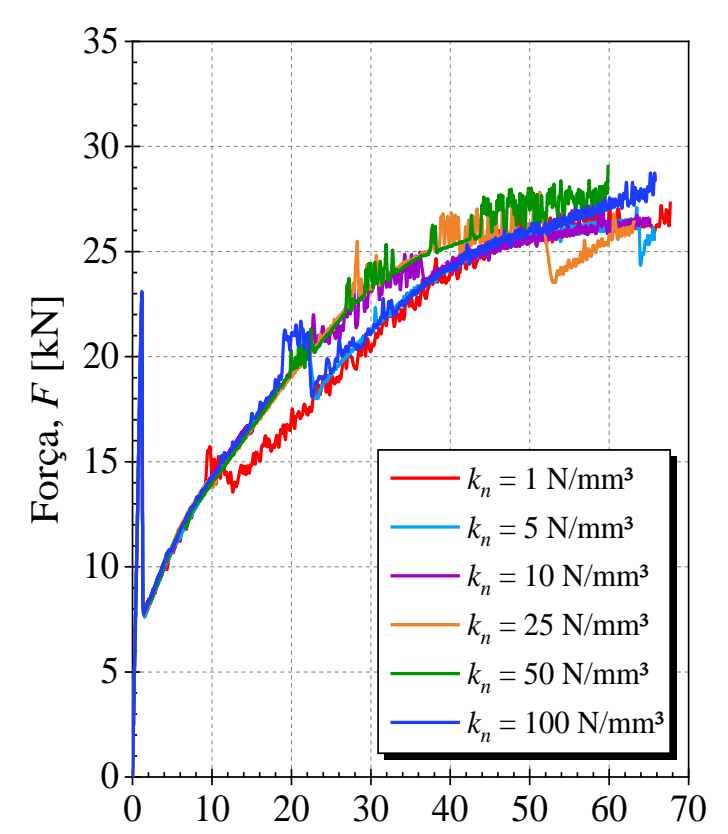

Deslocamento vertical no meio do vão, $\delta[\mathrm{mm}]$

(a) $k_{t}=25 \mathrm{~N} / \mathrm{mm}^{3}$

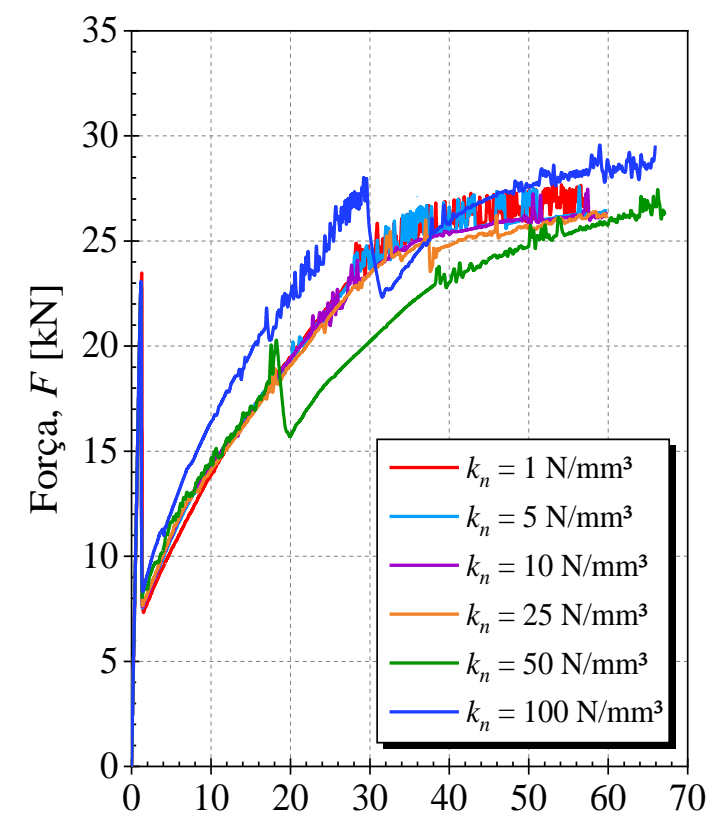

Deslocamento vertical no meio do vão, $\delta[\mathrm{mm}]$

(b) $k_{t}=10 \mathrm{~N} / \mathrm{mm}^{3}$

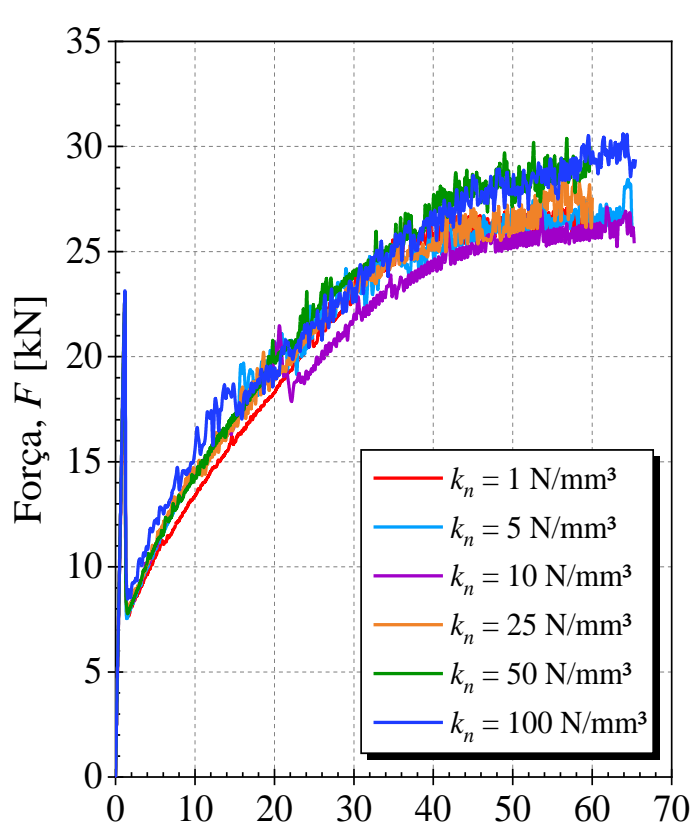

Deslocamento vertical no meio do vão, $\delta$ [mm]

(b) $k_{t}=50 \mathrm{~N} / \mathrm{mm}^{3}$ 